Małgorzata Sieradz

\title{
The Beginnings \\ of Polish Musicology
}

Volume 20

Eastern European Studies

in Musicology

Edited by Maciej Gołąb 
The book presents the history of the only strictly scientific Polish musicological periodical Kwartalnik Muzyczny. It shows how the editorial board of the periodical met with true approval and harsh criticism. The subject allows the author to present the beginnings of Polish musicology and its evolution through three epochs: the late partitioning period, the interwar period of Poland's independence, and the early years after the Second World War.

Dr Małgorzata Sieradz focuses her research on the Polish musical culture of the nineteenth and twentieth centuries, along with the history of music journals. 
The Beginnings of Polish Musicology 


\title{
Eastern European Studies in Musicology
}

Edited by Maciej Gołąb

\author{
Editorial board \\ Mikuláš Bek (Brno) \\ Gražina Daunoravičienè (Vilnius) \\ Luba Kyjanovska (Lviv) \\ Mikhail Saponov (Moscow) \\ Adrian Thomas (Cardiff) \\ László Vikárius (Budapest)
}

Volume 20 
Małgorzata Sieradz

\section{The Beginnings of Polish Musicology}

Translated by Lindsay Davidson 


\section{Bibliographic Information published by the Deutsche Nationalbibliothek}

The Deutsche Nationalbibliothek lists this publication in the Deutsche Nationalbibliografie; detailed bibliographic data is available online at http://dnb.d-nb.de.

\section{Library of Congress Cataloging-in-Publication Data}

A CIP catalog record for this book has been applied for at the Library of Congress.

The Publication is funded by Ministry of Science and Higher Education of the Republic of Poland as a part of the National Programme for the Development of the Humanities. This publication reflects the views only of the author, and the Ministry cannot be held responsible for any use which may be made of the information contained therein.

ISSN 2193-8342

ISBN 978-3-631-80958-7 (Print) · E-ISBN 978-3-631-82377-4 (E-PDF) E-ISBN 978-3-631-82378-1 (EPUB) · E-ISBN 978-3-631-82379-8 (MOBI) DOI 10.3726/b17067

\section{PETER LANG}
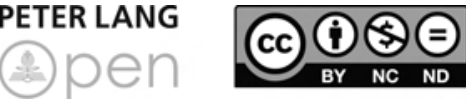

Open Access: This work is licensed under a Creative Commons Attribution Non Commercial No Derivatives 4.0 unported license. To view a copy of this license, visit https://creativecommons.org/licenses/by-nc-nd/4.0/

(c) Małgorzata Sieradz, 2020

Peter Lang - Berlin - Bern · Bruxelles · New York ·

Oxford $\cdot$ Warszawa $\cdot$ Wien

This publication has been peer reviewed.

www.peterlang.com 


\section{Contents}

Introduction 9

I Socio-institutional contexts of the establishment of Kwartalnik Muzyczny

1. Panorama of Polish musicological journalism until 1910 - Roman Chojnacki’s Młoda Muzyka and Przegląd Muzyczny - WTM and Henryk Opieński's Kwartalnik Muzyczny (1911-14) - collaboration with Adolf Chybiński clarification of the concept of a musicological quarterly university series

2. Societies, associations, institutes of the interwar period: 'Club of professional music press' - Polish Society for Contemporary Music - Polish Musicological Society Frederic Chopin Institute - Association of Early Music Lovers and Publishing Society of Polish Music as an institutional background to Kwartalnik Muzyczny

3. Music magazines of the interwar period: Lwowskie Wiadomości Muzyczne i Literackie, Poznańs Przeglad Muzyczny, Mateusz Gliński's Muzyka - other environmental and local musical magazines - controversies over the model of an expert journal of the milieu 
II Hopes of Polish musicology - Kwartalnik Muzyczny in the years 1928-1933

1. The idea of publishing a musicological quarterly preparatory work - establishing Kwartalnik Muzyczny: the periodical's concept - programme assumptions: the first editorial - reactions of the milieu

2. Musicological circles in Poland (Lviv, Cracow, Poznań, Warsaw) as addresses of the Kwartalnik socio-scientific contexts: ideas about the functioning of the musicological environment - main topics of interest - other possibilities of publishing musicological studies: academic publishing

3. Musicology among academic disciplines in the interwar period - systematics, discussions

4. Authors and subjects: historical-musical work - 'technical history' (Chybiński) versus 'live history' (Jachimecki); contemporary music as a subject for research; music theory and acoustics; philosophy, aesthetics, sociology; psychology, pedagogy; ethnography and musical folklore; themed editions

5. Muzyka Polska (1934-39) - Polski Rocznik Muzykologiczny $(1935,1936)$

III Difficult years - Kwartalnik Muzyczny in the years 1948-1950

1. New context of the functioning of the academic milieu and their publications - 'bourgeoisie musicology' 
2. Ideologisation of learning about music - conferences, conventions, congresses - Marxist musicology - Państwowy Instytut Sztuki - gradual radicalisation in academia

3. An attempt to continue the formula of the magazine - Adolf Chybiński and his collaborators (Zofia Lissa, Tadeusz Ochlewski, Józef M. Chomiński - scope of cooperation and organisation of editorial work) - new organisation of publishing work (PWM, PIS)

4. Authors and subjects as well as concepts, problems and work methods - continuation of the pre-war work - around the current issues of musical socialist realism - thematic projects

Conclusion

Premises of the publishing crisis - change of generation new publishing initiatives in the field of musicological periodicals: Muzyka, Studia Muzykologiczne, Rocznik Chopinowski

Afterword

Abbreviations 521

Bibliography 525

Secondary literature 
Primary literature

Archival collections

556

Index

557 


\section{Introduction}

At the beginning of the second decade of the twenty-first century, Polish musicology celebrated the centenary of the founding of the first departments at national universities - in 1911 at the Jagiellonian University under the direction of Zdzisław Jachimecki, in 1912 at the University of Lviv led by Adolf Chybiński. At the same time, though following the initiative of a musicologist not associated with any of these universities - Henryk Opieński - the activity of the first Polish music magazine which fulfilled the standards of an academic publication was inaugurated in Warsaw. In 1911 Kwartalnik Muzyczny started to appear. The periodical, which appeared for the first time exactly at the birth of Polish musicology, linked three epochs. For the first time, it accompanied the academic community at its dawn in enslaved Poland, for the second time - at the time of intensive development during the interwar period of free Poland and ultimately - in the time of the revival of academic structures during the difficult years of the communist regime of the 1950s. Three visions of the periodical appeared over a dozen or so years of its history. The first Kwartalnik, initiated as an organ of WTM, appeared in the years 1911-14. Closed as a consequence of the turbulence of history, it reappeared in 1928, this time as a magazine of the Warsaw SMDM and TWMP and functioned until the year 1933 (the tradition of the academic journal was sustained and continued in the pages of Polski Rocznik Muzykologiczny whose editorial survived until the first days of World War II). The third incarnation took place fifteen years later, in 1948, in the reality of the turn of the 1940s and 1950s, dominated by the new ideology. Adolf Chybiński, one of the fathers of Polish musicology, was connected to the journal from the very beginnings of its existence - first as its primary author and consultant on issues of merit, and later the editor-in-chief; he bridged all editions of Kwartalnik Muzyczny.

The only magazine addressed to the small group of Polish musicologists that was taking shape, as well as musicians and music enthusiasts eager to deepen their knowledge at an academic level, had to contribute to concentrating this young environment around the title and getting people to join initiatives undertaken by editors. On the other hand, it was also the source of disputes, which created groups of supporters and critics of this type of literature and of 'mummified' and 'paper' musicology (typical for 'technical history' based on building a base for musicological research through arduous archival and library inquiries and making detailed and tedious analyses supported by deep specialist theoretical 
knowledge that were the domain of the founder of the Lviv musicological school, Adolf Chybiński). The quoted terms appeared in the press from the group of supporters of the musicology proposed by the second founding father of Polish musicology, Zdzisław Jachimecki. Opposition to the Lviv methodology was 'living history' cultivated by the head of the department at the Jagiellonian University and by a group of journalists, mainly from Warsaw, associated, among others, with the editors of the popular monthly Muzyka which was founded and led by Mateusz Gliński. Its expression came in publications filled with interdisciplinary erudition and a beautiful literary narrative, the lack of scientific value of which was repeatedly criticised by Chybiński and his supporters.

The formulation of the title of this work in its final form imposed two perspectives from which to look at the topic: through the history of the journal and through the history of the environment. This dualistic approach, in turn, obliged me to expand the contexts - firstly - determination of the place of Kwartalnik Muzyczny against the background of the entire Polish music periodical history and - secondly - tracing the history of various institutions that musicologists of the first and second generation created. At the same time, the foreground was occupied continuously by Adolf Chybiński, a key figure, who was the foundation for the entire era encompassing the first four decades of Polish university studies of music.

The literature which has so far brought us closer to the history of this discipline in Poland is quite rich, but above all abounds in occasional reports and contributions. Therefore, the information contained therein had to be supplemented with reading and analysis of official documents surrounding the work of organisations and institutions from the scene - statutes, reports of activities, summaries from conventions and meetings (for example, WTM, PTMW, PTM, ZKP and others), often either completely unknown or unused. For the purpose of making the whole story below, the most significant were the collections of correspondence stored in several Polish libraries as well as - most importantly - those in private hands and never before accessible. This included the family archive of Józef Michał Chomiński containing the professor's legacy, including files with incoming and outgoing correspondence, the latter in the form of duplicate copies. In total from the period up to 1952 nearly six hundred documents, including from and to: Ignacy Blochman, Ludwik Bronarski, Mieczysław Drobner, Stanisław Golachowski, Włodzimierz Poźniak, Bronisław Romaniszyn, Marian Sobieski, Bronisław Edward Sydow, Zdzisław Jachimecki, Zygmunt Estreicher, Alicja Simon, Roman Palester, Roman Ingarden, Konstanty Régamey, Bolesław Woytowicz, Stefan Kisielewski, Zygmunt Mycielski, as well as representatives of Lviv's musicology - Hieronim Feicht, Stefania Łobaczewska 
and Zofia Lissa, and their common master - Adolf Chybiński. Amongst this group, there were also official writings - including from MKiS, with PWM, ZKP, PIS, the editorship of Ruch Muzyczny. Documents from the private archive of the Chomiński family were supplemented with funds collected in university libraries in Warsaw, Cracow and Poznań (archives of Adolf Chybiński, Zofia Lissa, Tadeusz Ochlewski, Ludwik Bronarski and others).

Though work on this monograph lasted for many years, it was by no means a 'path through torment.' It was the result of a continuous, ever-deepening fascination with the described matter. I also saw justification for this research in the kind of warm interest expressed in conversations with me by many representatives of the contemporary musicological milieu in Poland, often indicating to me the trails that were worth following. I pass this monograph to international readers with the hope of creating interest in four decades of the history of Polish musicology and Polish musicological journalism.

Małgorzata Sieradz 



\section{Socio-institutional contexts of the establishment of Kwartalnik Muzyczny}





\section{Panorama of Polish musicological journalism until 1910 - Roman Chojnacki's Młoda Muzyka and Przeglad Muzyczny - WTM and Henryk Opieński’s Kwartalnik Muzyczny (1911-14) - collaboration with Adolf Chybiński - clarification of the concept of a musicological quarterly - university series}

At the end of the third decade of the twentieth century the foundation of the first Polish periodical which could be described as musicological, entirely controlled by representatives of the academic community, was preceded by almost a hundred years of activity in the field by music critics and journalists, musicians and musically educated amateurs who laid the foundations for native scientific journalism. Already in autumn 1820, a prospectus announcing the first Tygodnik Muzyczny magazine appeared in several Warsaw bookshops and music shops. Karol Kurpiński was the creator, editor and primary author of the magazine. In his own words, it was supposed to contain a 'dissection of music in general, various information concerning music, remarks about works, about their performance and all antiquities and musical novelties. ... Moreover, [there were to be] exceptions from the life of famous composers and news about new musical works.' Kurpiński's greatest wish was to explain to the readers the 'grammar' of the language of music. He lamented that the average listener could only divide music into 'beautiful' and 'hideous, boring', having no basis and knowledge to explain why they like some music or not. Popular literary criticism at that time was based on an article, O klasyczności i romantyczności tudzież o duchu poezji polskiej ${ }^{1}$ [About classicism and romanticism and the spirit of Polish poetry] by Kazimierz Brodziński, which initiated a broad discussion and provided a powerful force and a kind of programme referring to all fields of art, and Rozprawa o metryczności i rytmiczności języka polskiego [Discourse about the metricism and rhythmicism of the Polish language] by Józef Elsner ${ }^{2}$ and Kilka rad dla

1 Pamiętnik Warszawski 1818 vol. 10 and 11.

2 Józef Elsner, Rozprawa o metryczności i rytmiczności języka polskiego, szczególniéy o wierszach polskich we względzie muzycznym. Cz. 1 / przez Józefa Elsnera; z przykładami 
piszacych poezje do śpiewania [Some advice for those writing poetry for singing] from Józef Dionizy Minasowicz, ${ }^{3}$ and an artistic exemplum of patriotic poems with the title Śpiewy historyczne [Historical songs] by Julian Ursyn Niemcewicz, which a group of composers set to music. Kurpiński undertook the task of bringing potential readers of his periodicals closer to texts primarily concerning the history of music ('Historia opery aż do opery polskiej' [The history of opera up to Polish opera], but also 'O muzyce dawnych Egipcjan' [About the music of ancient Egyptians]), aesthetic issues ('O skutkach muzyki' [About the effects of music], 'Czy potrzebna ludziom muzyka' [Do people need music?]) and theoretical ('Kilka słów o fudze' [A few words about fugue]). He mainly wrote himself, though, for example, he invited Minasowicz for the preparation of the 'Foreign news' section, Alojzy Żółkowski for the discussion of local news and opera reviews and a few other anonymous authors. He also tried to encourage cooperation with readers: 'Everybody in the country, as well as eminent amateurs and artists from overseas, are invited to give remarks, insights and thoughts, or send any discoveries regarding music to the editors of this weekly.4

The relatively slim milieu of musicians educated not only in playing instruments, but also prepared for the profession in the field of music history and theory, and the small circle of trained amateurs - aristocrats and townspeople - obliged the editor-in-chief to oscillate between ambitious intentions and the actual expectations of readers. Inviting them to cooperation, he pointed out that the "The style is to be clear and as far as possible easy for everyone to understand. We will try to avoid dissertations which are too-learned, as well as too long because it is not our intention to write for very learned in this art, but for all those who demand to discover its secrets. ${ }^{5} \mathrm{He}$ wanted to make his magazine stand out among the Warsaw press through its content and graphic design. Tadeusz Przybylski pointed out that compared to other contemporary publishing houses Tygodnik Muzyczny 'presented itself favourably with its neat and distinctive graphic layout,' ${ }^{\prime}$ but alas this did not help, because it only appeared from

rzecz objaśniaiacemi przez Kazimierza Brodzińskiego [A Dissertation on the metric and rhythmic qualities of the Polish language, with special focus on Polish poems from the perspective of music. Part I / by Józef Elsner; with poetic examples by Kazimierz Brodziński] (Warsaw 1818, Drukarnia S. Dąbrowskiego).

3 Printed in a four-volume edition Twory Józefa Dyonizego Minasowicza [Works of Józef Dionizy Minasowicz] (Leipzig 1844, Breitkopf und Haertel) vol. II.

4 From 'Prospekt,' which appeared before the first number of TM.

5 Ibid.

6 Przybylski 1980, 69. About the history of the journal, see also Strumiłło 1955. 
May to October 1820 and after a short break from December 1820 to June 1821 (after reactivation with the title Tygodnik Muzyczny i Dramatyczny). He finally experienced the fate that in the future for many music magazines became the norm: a short period in press, which could almost always be described with the formula used for the first time by Karol Kurpiński: 'for a too small number of subscribers, unable to maintain it, [the magazine] cannot be published anymore."7

Not only an excellent pianist, but also a brilliant literary journalist and music publicist, Maurycy Mochnacki, one of the most outstanding nineteenth-century music critics, remains somewhat on the margins of the history of Polish music magazines, one of the Warsaw 'young romantics', whose ties of close friendship linked him with Chopin, amongst others. His pen work was related only to the daily press, but he did not attempt to create a periodical for the musicians and enlightened dilettantes, as Kurpiński had earlier, and count Cichocki did a little later. He wrote at the turn of the eighteen-twenties and thirties in the journals he edited himself, Gazeta Polska and Kurier Polski. Although his texts focused primarily on performance and interpretative matters, his general erudition, literary culture and knowledge of musical issues allowed him to go beyond the context of a concert review towards polemical articles, supported by historicalmusical knowledge. While practising music criticism in the pages of popular newspapers, he knew that his texts would go to a very wide group of readers, not always musical, so as Stefan Jarociński put it, he was balancing between, 'music criticism in a broader sense ... [covering] all research or consideration of music with the intention of pronouncing opinions on its subject (value judgement), [and] in a narrower - similar action, but performed by a competent person, ${ }^{3}$ as was Mochnacki.

After several years of absence from the market of Polish music magazines, when news about concert and publishing life, sometimes information about musical events abroad or news from the life of leading composers and

7 TMD 1821/12 (27 June). Among the chief editors, only years later, Józef Sikorski and later, Henryk Opieński, broke away, both not through financial difficulties, but noting the historical situation as a reason for closing their editorial offices. Opieński wrote: 'the last [number of KM] came out in July 1914 a few weeks before the outbreak of the war, but not for lack of funds. The financial foundation for the quarterly was created by the late Konstanty Sarnecki ...; then, however, the subvention for each issue of the magazine that the following undertook to provide: Mianowski's estate (100 rb.) and Ordynat Zamoyski (100 rb.), made it possible to continue Kwartalnik,' see Henryk Opieński, [letter to the editor], Muzyka 1926/5, 240. Jarociński 1955, 7. 
virtuosos only appeared in the daily press and cultural magazines and papers 'for women, Józef count Cichocki, then known as a Warsaw animator and organiser of musical life, an amateur musician, activist of the Resursa Kupiecka [the Merchant Association], who served, among others, through the fact that he was one of the first to reach for Polish music 'antiquities,' publishing ten psalms by Mikołaj Gomółka, took up editing and publishing Pamiętnik Muzyczny Warszawski. Opening the first issue, he wrote: "When for a dozen years or even more, we have no separate magazine for the subject of music, when none of our artists and musical amateurs, despite their abilities, publish and seeing such a need, I undertook, until someone who is more zealous will appear, to publish Pamiętnik Muzyczny.'

Cichocki, although he was a zealous propagator of music and 'dilettante scholar' in this field (contrary to Kurpiński, an educated musician who had the ambition to deal with musical matter academically - according to his capabilities), his magazine was directed to undemanding recipients. Through various types of 'reports,' 'varia,' extracts from publishing catalogues, and also including musical scores brimming with a banal repertoire for piano or voice with piano, typically small salon compositions by Polish musicians, or original, little-known foreign artists, he wanted to bring the current sphere of musical life (concert, opera, publishing) closer to everyone. Apparently, however, he misjudged the target group of the magazine, because despite the lightness of the form of the Pamiętnik, the title did not gain readers and after a year, during which six numbers were published, it collapsed, despite announcing another year.

The first two Polish periodicals were generally heavily criticised by historians. ${ }^{9}$ In our opinion, however, one should agree with Dobrochna Strumiłło, who proposed a favourable evaluation of the magazines mainly due to the moment of their existence both in relation to the history of the European music press, and the time in the history of the Polish state and the realities of Warsaw in the 1820s and 1830 s. ${ }^{10}$

The next decades in the field of musical writing and music criticism were marked by the achievements of several of the capital's intellectuals and artists. The statements of a well-known journalist Józef Kenig, linked from 1843 with Gazeta Warszawska, were of an opinion-forming character, as were those of cellist and musicographer Maurycy Karasowski. As I wrote earlier elsewhere, at this time "Warsaw's bohemians," a group of young writers and artists, once

9 See, amongst others: Jachimecki 1948, 19-20; Jarociński 1959.

10 Strumiłło $1955,18-19$. 
again began to create a climate for reviving the cultural life of the Kingdom. The musical milieu used the pages of Gazeta Teatralna (a magazine dedicated to theatre, music and literature) published from February 1843 [with the fact that] in the Gazeta edited by Kiesewetter ... concerts and musical spectacles were only sporadically written about [mainly in the Grand Theatre] [and] for the already well-educated Warsaw music community, the magazine did not matter much.'11 Soon, however, news presented in a generally anecdotal form, a few cursory references to concerts, curiosities mostly drawn from French sources, critically evaluated by both journalists of the Warsaw press and historians involved in this field, were to be replaced by the father of modern Polish musical periodicals, Józef Sikorski.

Although Sikorski was still a representative of the second generation of romantics and did not join a positivist formation, which was then developing among intellectuals, in terms of stylistic writing, he completely broke away from the ubiquitous 'exalted' form of musical journalism (as described by Elżbieta Szczepańska-Lange ${ }^{12}$ in her wide raging sketch about Sikorski), and limited himself up to then mainly with concert reports: 'through destroying a certain order in relations between the music and journalistic circles of Warsaw, he brought about the restoration of shaky criteria for the evaluation of music and the revival of musical criticism ${ }^{13}$ absent in such a wide range since the times of Mochnacki.

The future creator of Ruch Muzyczny had all the basics to write at a high level of erudition. He studied at the Warsaw S.B. Linde Lyceum and through singing in the choir came into contact with Warsaw composers - Józef Stefani and Józef Elsner. Thanks to Elsner's protection in the years 1827-29 he took lessons in the Conservatoire. In time, he began to independently become acquainted with the writings of Adolf Bernhard Marx, Johann Nikolaus Forkel, Friedrich Wilhelm Schilling, Georg Wilhelm Friedrich Hegel. He taught himself French and German and broadened his interests in various directions. Already at the age of twenty, thirty he was a known music teacher in Warsaw; it seemed this was his calling: in 1846 he published the handbook titled Nowa szkoła na fortepiano [New school for piano] and six years later - a collection of music rules under the title Doręcznik muzyczny. Treściwe przedstawienie muzyki dzisiejszej ... ze słownikiem wyrazów muzycznych [Music handbook. A comprehensive presentation of today's music ... with a dictionary of musical words]. Earlier, however, in

11 Chechlińska/Guzy-Pasiakowa/Sieradz 2001, 299.

12 Szczepańska-Lange 1997, 31.

13 Ibid. 
1843 , at the time when one could only read about the musical field in the pages of the aforementioned Gazeta Teatralna that only ran for a moment, Sikorski linked up with the monthly Biblioteka Warszawska, in which at the beginning he gave the text ' $\mathrm{O}$ muzyce' ${ }^{\text {'14 }}$ [About music], and then he ran a regular column in Ruch Muzyczny. In the fifties, he also wrote for Gazeta Wielkiego Księstwa Poznańskiego, and in the sixties - for Tygodnik Ilustrowany. From the first essays, over the next several years (until 1858) Sikorski took a very in-depth look at subjects in the fields of history, theory and aesthetics of music, and also proposed his own concept of music criticism. Surrounding himself gradually with an everwider circle of educated artists and intellectuals, he was preparing to create a new editorial team.

The first edition of Ruch Muzyczny is dated April 1, 1857.

A group of activists and music critics became involved in cooperation around editing of the weekly - as the subtitle announced - 'artists and music lovers' Maurycy Karasowski, Apolinary Kątski, Oskar Kolberg, Stanisław Moniuszko, Józef Stefani, Józef Wieniawski and others. Such an editorial team ensured a high standard for the periodical and although the authors of the monograph about Ruch Muzyczny propose to treat the magazine as something which is 'not a professional magazine in the full sense of the word because it's goals are primarily education and popularisation, ${ }^{15}$ Jarociński compares the title to the European leader, François-Joseph Fétis’s Revue Musicale. ${ }^{16}$ Most of the space in the issues was occupied by reviews and criticism of current musical events, while articles about Liszt, Berlioz or Wagner became part of a discussion on new trends in European music. Aside from the current themes, the editorial team also attempted to print historical texts about both universal music, ${ }^{17}$ and also native. ${ }^{18}$ The multitude of interests of the group of journalists related to Ruch

14 Biblioteka Warszawska 1843/2, 665-673.

15 Krysmalska 1957, 14.

16 Jarociński 1959, 26-27.

17 See for example, the many parted series of articles titled 'Krótki rys historii powszechnej muzyki' [A brief outline of the history of music] published in the years 1859-61, 'Dramat i muzyka' [Drama and music] about the theory and aesthetics of opera (RM 1858/48, 377, 1858/49, 385-387, 1858/50, 393-395, 1858/51, 401-403), 'Przegląd kompozycji na wiolonczelę' [Review of cello compositions] by Maurycy Karasowski (RM 1861/45, 716-718).

18 Including, amongst others 'Notatki do historii muzyki polskiej' [A note to the history of Polish music] published in the years 1860-61 (including RM 1860/40, 646-651, 1860/41, 660-667), 'Stowarzyszenia muzyczne w Polsce' [Music societies in Poland] (RM 1858/12, 89-91, 1858/13, 97-99, 1858/16, 121-123). These publications were 
Muzyczny made it possible to publish materials from other fields of music scholarship: music theory, ${ }^{19}$ philosophy and aesthetics, ${ }^{20}$ pedagogy and psychology, ${ }^{21}$ acoustics and physiology of hearing, ${ }^{22}$ a number of articles in the field of organology and the history of instruments as well as musical folklore (including several articles from the ethnographer and composer Oskar Kolberg). ${ }^{23}$

The magazine gathered three hundred subscribers, primarily Warsaw music lovers, though of course not just, and they were given competent information

a continuation of Sikorski's interests and mission, which he began at the turn of the forties and fifties: discovering classics of Old Polish music, especially those remaining in church and monastic collections (amongst others in the archives and libraries of Pułtusk, Częstochowa, Piotrków and Łowicz). Detailed material on this topic along with extensive extracts from Sikorski's notebooks was published several dozen years later, in the first number of his Kwartalnik Muzyczny Adolf Chybiński (1928/29/1, 82-85), acknowledging priority to the editor of Ruch Muzyczny before the widely accepted precursor of such research, Aleksander Poliński, who was in possession of Sikorski's notes and without doubt made use of them.

19 Including: 'Kilka słów dotyczących elementarnych wiadomości o muzyce, nauce harmonii, generałbasie i kontrapunkcie' [A few words concerning elementary information about music, harmony, general bass and counterpoint] RM 1859/45, 385-387, 1859/46, 395-398, 1859/48, 411-412, 1859/51, 441-443, 1859/52, 450-452), 'Kilka uwag nad pismem muzycznym' [A few remarks concerning musical notation] (PMT 1862/20, 317-319), 'Tempo i metronom' [Tempo and metronome] (RM 1859/23, 203-204, 1859/24, 210-211).

20 See for example, 'Co to jest muzyka?' [What is music?] (RM 1858/7, 51-54, 1858/9, 65-67), 'Muzyka w stosunku do sztuk pięknych' [Music in relations to the fine arts] (PMT 1862/3, 42-44, 1862/6, 81-87).

21 'Arystoteles o muzyce i jej dzielności wychowawczej' [Aristotle about music and its educational valor] (PMT 1862/34, 529-532, 1862/35, 554-558), 'Muzyka i żałoba' [Music and mourning] (RM 1861/14, 209-215, 1861/15, 225-231, 1861/16, 241-248), 'O potrzebie książek teoretyczno-muzycznych i jak by przyjść do nich' [About the need for theoretical-music books and how to approach them] (PMT 1862/12, 189-192), 'Nauka muzyki w szkołach rządowych' [Music learning in government schools] (PMT 1862/31, 481-488, 1862/32, 497-501, 1862/33, 513-519).

22 For example, review of the work by Stanisław Przystański 'O akustyce sal przeznaczonych na liczne zebrania' [On the acoustics of halls intended for crowded meetings] (PMT 1858/20, 305-311), or the text 'Słuch muzykalny' [Musical hearing] (RM 1858/5, $35-36)$.

23 'Melodie ludowe w operze Jana Stefaniego Krakowiacy i Górale' [Folk melodies in the opera 'Cracovians and Highlanders' by Jan Stefani] (RM 1858/46, 361-363), 'Uwagi do redakcji Ruchu Muzycznego na temat zbierania melodii ukraińskich' [Remarks to 'Ruch Muzyczny’ editorial staff about collecting Ukrainian melodies] (RM 1859/22, 193). 
about significant music events in Poland and abroad, correspondence from the provinces was also published. A large part of the volume was taken up with articles from the areas of the history and theory of music, aesthetics, music pedagogy and reviews of compositions sent to the editorial office and catalogues of music available in Warsaw bookstores. The editorial team also carried out various social initiatives, the most spectacular being the collection of contributions for Karol Kurpiński's gravestone.

Despite the high content and editorial standards, Ruch Muzyczny struggled with financial problems, and after the suspension of operations during the January Uprising, the editorial office did not resume work again. Shortly later, in October 1865 Tomasz Le Brun (referring to the tradition of Ruch) published the first issue of the weekly Gazeta Muzyczna i Teatralna, but the magazine only survived until 29 March 1866. Among the authors related to the editors, whose short biographies were presented by Wanda Bogdany in a monograph devoted to magazine, ${ }^{24}$ it is worth mentioning August Jeske, ${ }^{25}$ F. Stevich, ${ }^{26}$ Le Brun, ${ }^{27}$ and the creator of 'A dozen materials for the history of music in Poland,' Kazimierz Łada. Unfortunately, after the closure of Gazeta, publicists and music critics linked with it (and other magazines) could only write for other cultural and social periodicals and the Warsaw daily newspapers.

Ten years after Józef Sikorski's debut in Biblioteka Warszawska Maurycy Karasowski began his career there as a critic and journalist, and in due course also as a historiographer. In 1858, he became associated with Ruch Muzyczny as a correspondent. An active musician, private music teacher, member of the orchestra of the Grand Theatre, he had a solid background in music history. This background not only allowed him to publish reviews of current concert and opera life, but also essays and journalistic texts both in the daily press and cultural artistic periodicals - in Biblioteka Warszawska, Ruch Muzyczny and, after

\section{Bogdany 1955.}

25 Author of the article 'Muzyka niemiecka w stosunku do francuskiej i włoskiej' [German music in relations to French and Italian music] (GMT 1865/6, 5-6), 'O zadaniu szkół muzycznych' [On the role of music school] (GMT 1865/1, 2-3, 1865/2, 4-5), 'O nauce śpiewu' [About learning to sing] (GMT 1866/24, 3-5, 1866/26, 2-3).

26 'Józef Elsner jako kompozytor muzyki kościelnej' [Józef Elsner as a composer of church music] (GMT 1865/10, 2-3, 1865/11, 3-4), 'Muzyka kościelna i jej zadanie' [Church music and its role] (GMT 1865/4, 2-3, 1866/20, 2-3).

27 Amongst others biographical materials and publications, - 'Koncerty i sale koncertowe w Warszawie' [Concerts and concert halls in Warsaw] (GMT 1866/15, 2-3), a presentation of the Warsaw piano factory Krall and Seidler (GMT 1866/21, 4). 
years, in Echo Muzyczne i Teatralne. In these journals he maintained permanent columns (when he was in place), he sent correspondence from foreign travels Prague, Paris, Dresden, and introduced the profiles of Polish composers. ${ }^{28}$ Karasowski was presented after his death in 1892 in the pages of Echo Muzyczne by the editor of the weekly, Jan Kleczyński, remembering his older friend as a person endearing himself to 'all hearts,' a person of 'good character and nice manner,' whose 'journalistic pen ... gave not inconsiderable service: his correspondence ... was written with rare tact, always interesting ..., though not sinfully lengthy. ${ }^{29}$

Kleczyński himself also had a thorough musical education, which he obtained in Paris, where he studied theory, composition and piano. He was not only an active musician, but also a teacher and community activist, one of the founders of the Warszawskie Towarzystwo Muzyczne [WTM], and first and foremost (from 1880) long-time editor-in-chief of the bi-weekly (later weekly) Echo Muzyczne, Teatralne i Artystyczne (from the year 1882 together with Aleksander Rajchman). The magazine initially appeared under the title Echo Muzyczne. It was conceived, as put by Włodzimierz Poźniak, in reference to the tradition of the Elsner’s periodical sheet music publication (the series Wybór pięknych dzieł muzycznych $i$ pieśni polskich [A Selection of beautiful works of music and Polish songs], which was published in a monthly cycle in the years 1803-05). In such a formula, however, under the supervision of the first director, Wincenty Kruziński, the publication did not have much success. Admittedly, the first changes - from sheet music publishing to a literary-artistic magazine - already took place under the leadership of Kruziński, but in the following months, the duties of the leader were taken over by his deputy, Jan Kleczyński. The size of the magazine increased, and the content was to be filled with materials from the fields of history, theory and aesthetics, and music criticism, in addition to the current correspondence and reports. Among the authors collaborating from almost the beginning of the new edition of Echo were great names amongst contemporary music critics, publicists and historians such as Aleksander Poliński, Józef Wieniawski, Władysław Żeleński, Zygmunt Noskowski, Maurycy Karasowski. The editor-in-chief himself, who previously published reviews and reports in the

28 See for example 'Jan Stefani' (RM 1857/27, 210-214, 1857/28, 217-219, 1857/29, 226229, 1857/30, 237-239), as well as sketches about J. Haydn, R. Schumann and W.A. Mozart published over the space of a few years on the pages of the monthly Biblioteka Warszawska.

29 Jan Kleczyński, 'Maurycy Karasowski' (EMTA 1892/448, 207-208). 
Warsaw Tygodnik Ilustrowany and the weekly Bluszcz, was one of the most prolific writers for the magazine. Małgorzata Woźna, the author of a biographical sketch about him, counted over seven hundred reviews, reports and articles that Kleczyński published in Echo in the years 1880-95, and all press publications that he wrote from 1867 to his death numbered nearly one thousand seven hundred and fifty. ${ }^{30}$ Reports and reviews were the primary forms of his writing, but he was also the author of many articles. Woźna divides Kleczyński's work into several areas: 1) popularisation of musical knowledge, mainly in the field of knowledge about opera (French, Italian and Polish) and making the profiles of Polish composers more familiar (Żeleński, Noskowski, Zarębski) as well as foreign composers (Liszt, Grieg, Tchaikovsky, but also Palestrina, Bach, and the Viennese classicists), 2) promoting the appreciation of Chopin and introducing interpretative issues connected with his work, 3) discovering Podhale folklore, which in the last decades of the nineteenth century became a new phenomenon for readers, and 4) 'the progressive trend in contemporary music', meaning Wagner's work.

Kleczyński's success as the leading cultural journalist at the time progressed along with the extension of the magazine's formula to other arts, which at the same time significantly increased the circle of collaborators. Many writers joined: Eliza Orzeszkowa, Maria Konopnicka, Henryk Sienkiewicz, Bolesław Prus, Teofil Lenartowicz; to name but a few. Apart from those already mentioned, Ignacy Jan Paderewski, Emanuel Kania, Ludwik Grosman and many others joined the music department. At the beginning of the new century, however, it gradually began to deviate from the interdisciplinary character of its content. The good fortune of the weekly, which lasted until Kleczyński's death and a few years later, gradually began to turn. Włodzimierz Poźniak saw two causes for this: 'premature decision to limit the range of Echo almost exclusively to musical matters' and the extra-editorial passions of the heir of the editorial chair, Rajchman, who in 1900 became the director of the Warsaw Philharmonic and was mainly devoted to that function. ${ }^{31}$ The last issue of one of the longestappearing cultural magazines (with an emphasis on musical culture) appeared in 1907.

Echo Muzyczne, Teatralne i Artystyczne was the periodical that foreshadowed a new era in the history of the native music magazine, slowly but steadily marked by a new generation of journalists and critics, often educated in

30 See Woźna 1976.

31 Poźniak 1965, Poźniak 1972; especially see Poźniak 1965, 17. 
European universities and conservatories. The new Warsaw periodical opened in the autumn of 1908 for the first Polish musicologists returning from foreign studies and critics associated with the new trend in Polish music, the 'musicalliterary bi-weekly', which de facto soon became a 'bi-weekly dedicated to music.' Roman Chojnacki initiated and led the journal, appearing up to the year 1914 and - after the war - in the short period in the years 1918-19 initially titled Młoda Muzyka, and from January 1910 as Przeglad Muzyczny (let us point out, ahead of the facts, that this had nothing to do with the journal of the same title directed in the 1920s in Poznań by Henryk Opieński). Along with the change of the title, the format and volume, as well as the list of cooperating authors, were also increased. The editor-in-chief was a young, but already well-known organiser and animator of musical life in Warsaw, a music critic and musician; particularly distinguished during the interwar period, when he was the head and artistic director of the Warsaw Philharmonic. In Przeglad another musician, conductor Romuald Haller, collaborated with him, and Stefan Gacki became the literary manager, after years the editor-in-chief of the avant-garde Almanach Nowej Sztuki.

The journal was created at a very fruitful moment for the musical milieu. The first years of the new century saw Warsaw brought to life by the activities of the new institution, the Philharmonic, whose directorate (after a few stormy years under Aleksander Rajchman) was taken over in 1908 by Henryk Melcer. Melcer was an outstanding personality in the musical world, an authority in the field of musical activity, a man who in a short time introduced into the concert repertoire compositions by the creators of a new trend in Polish music representatives of Young Poland. He soon invited to conducting cooperation, among others, one of the Young Poland activists - Grzegorz Fitelberg - and supporter of the formation, the musicologist debuting at the same time, Henryk Opieński. In order to deepen the atmosphere of understanding and openness to new trends in art in this favourable artistic situation, the idea of initiating a new title in the milieu met with interest, although in full generalities and platitudes the opening words to the first number did not hide the fact that there were no illusions concerning the fact that knowledge in the field of musical culture falls on fertile ground:

Bringing to life a new magazine devoted to a wide range of serious art, we mainly set ourselves the task of promoting art as the only beauty and raising our artistic culture in our society. We started work at a time when all serious creativity, having a basis in the inspiration of real art in all its manifestations, meets with a total lack of interest on the part of society, and young pioneers of art ... are condemned to eternal vegetation.... 
instead of spreading wings, we will encourage them to further work, raise their spirit, pour in faith and emphasise the good things with which we can expel the bad. ${ }^{32}$

After a few months of operation, although declaring, 'independence of judgement' and avoiding 'involuntary subservience to any existing musical cliques,' the editorial board, taking into account the opinions of the milieu, felt burdened with 'grateful duty to pay more detailed attention to the young musicians who, despite possessing serious knowledge and talent, still had difficulty taking a prominent place among the well-known and respected. ${ }^{33}$

To promote new art and new values in music in ideological solidarity with the members of the Young Composers' Association, the editors sought authors and correspondents in the circle of modern educated musicologists and critics sympathetic to the Berlin 'clique.' Hence from the names most frequently hosted in the pages of Młoda Muzyka and Przeglad Muzyczny over the years it was consistently possible to mention - apart from the editor-in-chief - Zdzisław Jachimecki, Henryk Opieński, Józef Reiss, Alicja Simon and only a few times or just at the outset of education in the field of musicology Stefania GerardFestenburg (Łobaczewska), who before the war managed to publish three articles, but above all - Adolf Chybiński. Anna Porębowiczowa, who in the already quoted 'Wstęp' [Introduction] to Volume VII of Bibliografia Polskich Czasopism Muzycznych [Bibliography of Polish musical periodicals] characterised Chybiński's achievements in Roman Chojnacki's bi-weekly thus:

In addition to scholarly articles in the field of early Polish music, informing readers about the state of research in Polish musicology, he writes biographical articles about Polish and foreign musicians, reviews from books and scores as well as critical articles. Thanks to him, the issue of musical ethnography appears in the pages of a music magazine for the first time. He is seconded by other intrepid people ... musicologists, writing articles, reports, reviews from various fields concerning music (history, aesthetics, psychology, music pedagogy, theory, musical culture, and others). ${ }^{34}$

In the first decade of the twentieth century, Chybiński, in addition to scholarly writing, at the same time dealt with criticism and journalism, already during his studies, he sent correspondence from Munich regarding current musical events. He cooperated with the Cracow Czas, Lviv Słowo Polskie, the monthly Krytyka, the Jesuit Przeglad Powszechny, with the weekly Świat. When in 1907, in the Warsaw-based two-year-old journal Nowa Gazeta - a journal on a high

32 MM 1908/1 ('Od Redakcji' [Editorial]). Full text also in: Porębowiczowa 1964, 9.

33 MM 1909/3 ('Od Redakcji').

34 Porębowiczowa 1964, 11. 
literary level and with grand ambitions in the field of cultural information - the supplement Literatura i Sztuka started to appear, texts were directed to it not only by Henryk Opieński, a collaborator from the beginning with Nowa Gazeta but also Chybiński. In the extensive, two-volume monograph on Polish music criticism at the turn of the century Magdalena Dziadek devoted a longer section to this chapter of the journalistic work of the then young adept of Munich musicology, from which we learn that '[The Supplement to] Przeglad Muzyczny, which was entrusted to Adolf Chybiński, was at first a review of musicological literature. The critic regularly discussed Polish and foreign textbooks and dissertations on music. As a reviewer of German books, he was submissive in relation to those musicological authorities. While reviewing Polish books, he let himself be carried away by a polemical temperament, the results of which Zdzisław Jachimecki experienced. The devastating assessment of Jachimecki's work Muzyka w Polsce ... gave rise to a passionate polemic between the two young authors, continued later in the pages of Gazeta Lwowska. ${ }^{35}$ At the same time the author also drew attention to the fact that 'Of more enduring significance are the musical dissertations advertised in Literatura i Sztuka, which have no ... highly articulated journalistic foundation ... Ruch renesansowy $w$ literaturze muzycznej [The Renaissance movement in music literature] (1907 No. 4) was one of the first Polish works synthesising the background and objectives of the movement for the revival of early music, and above all the works on Debussy, reporting the artistic foundations of the French artist based on his own writings. ${ }^{36}$

For Adolf Chybiński Przeglą Muzyczny became a convenient forum, appropriate for his education, for publishing the research results of the first years of independent activity - let us remember that in the same year, 1908, he obtained a diploma from the University of Munich on the basis of his work Beiträge zur Geschichte des Taktschlegens und des Kapellmeisteramtes in der Epoche der Mensuralmusik. ${ }^{37}$ His research activity was focused from the very beginning primarily on historical musicology and resulted in several dozen publications in Roman Chojnacki's Przeglą, and by following the yearbooks, we can see how wide his interests were apart from this, increasing this number by further positions. Most of the materials were created on the basis of music relics and documents

35 Dziadek 2002/1, 112; see also Dziadek 2002/2.

36 Dziadek 2002/1, 113; see also Dziadek 2004/1.

37 More on the subject of Chybińskis Munich studies later in this work. 
found by Chybiński in the Cracow archives. ${ }^{38}$ Here is where his first materials about the royal rorantists appeared ${ }^{39}$ and also on the subject of the Tabulatura Joannis de Lublin, ${ }^{40}$ supplemented with contributions restoring the awareness of biographies of Early Polish composers - Johannes Borimius and Jacek Różycki ${ }^{41}$ and many lesser, unknown musicians. In the field of the universal history of music of earlier ages, he presented a panorama of the European Renaissance, ${ }^{42}$ a series of articles devoted to the work of Johann Sebastian Bach (moreover, left unfinished due to the suspension of the magazine's activity) appeared in several editions from the year 1914. A considerable number of biographical materials from Chybiński's pen, however, referred to composers of less distant epochs. In the Chopin jubilee year, a sketch was made 'Chopin i jego wpływ' ${ }^{343}$ [Chopin and his influence], and several Moniuszko materials appeared in the post-war edition of the magazine ${ }^{44} \mathrm{He}$ made his contributions in occasional numbers: in the centenary of Liszt's ${ }^{45}$ birth, in the fiftieth anniversary of the birth of Debussy, ${ }^{46}$ he wrote about Mahler and Reger. At that time, however, his later fascination

38 For example 'Zbiory muzyczne na Wawelu' [Music collections in Wawel castle] (PM 1910/1, 1-4, 1910/2, 4-7); 'Z inwentarzy krakowskich 1550-1600, przyczynek do dziejów kultury muzycznej w dawnym Krakowie' [From Cracow inventories 1550-1600, a contribution to the history of music culture in ancient Cracow] (PM 1911/19, 9-12).

39 'Materiały do dziejów królewskiej kapeli rorantystów na Wawelu. Cz. II: 1624-1694' [Materials for the history of the royal band of Rorantists in Wawel. Vol. II: 1624-1694] (PM 1911/14, 1-5, 1911/15-16, 1-7, 1911/17, 1-5, 1911/18, 1-5, 1911/19, 8-9).

40 A contribution about Nicolaus Cracoviensis's compositions preserved in this landmark work: 'Z dziejów muzyki polskiej. Monogramista N.C. z XVI w.' [From the history of Polish music. Monogramist N.C. from the 16th century] (MM 1909/14, 1).

41 'Johannes Borimius-Borzymski. Nieznany polski kompozytor z XVI-XVII wieku' [Johannes Borimius-Borzymski. Unknown Polish composer from 16th-17th century] (PM 1910/1, 7-11); ‘Jacek Różycki, nadworny kapelmistrz i kompozytor Jana III’ [Jacek Różycki, Jan III's court Kapellmeister and composer] (PM 1911/4, 3-4, 1911/5, 3-5).

42 'Renesans w muzyce' [Renaissance in music] (PM 1913/9, 7-11, 1913/10, 1-3).

43 PM 1910/5, 1-4.

44 'Nieznane listy Stanisława i Aleksandry Moniuszków' [Unknown letters of Stanisław and Aleksandra Moniuszko] (PM 1918/1-2, 1-5); 'W setną rocznicę urodzin Moniuszki' [On the hundredth anniversary of Moniuszko’s birth] (PM 1919/11-12, 1-4); 'Problemy moniuszkowskie. I. Narodowy twórca w muzyce’ [Moniuszko problems. I. National artist in music] (PM 1919/13-14, 1-2, 1919/15-16, 1-3, 1919/17-18, 1-2).

45 'W sprawie kultu dzieł Liszta' [On the cult of Liszt's works] (PM 1911/21, 5-7).

46 'Klaudiusz Achilles Debussy. W 50-tą rocznicę urodzin' [Claude Achille Debussy. On the 50th anniversary of his birth] (PM 1912/20, 9-10, 1912/21, 1-2). 
with Grieg's works was not marked. An important part of Chybiński's publication for Przeglad were materials related to the figures of the contemporary Polish artistic milieu. Befriended by musicians of the young generation - composers, performers - he devoted many pages to their accomplishments: the creative work of the hero of his future monographs, Mieczysław Karłowicz, ${ }^{47}$ Ignacy Jan Paderewski, Henryk Melcer, Ludomir Różycki, Grzegorz Fitelberg, and Karol Szymanowski barely at the beginning of their careers. In addition he had articles on a cross-section of contemporary topics - about symphonic and song music by composers of Young Poland ${ }^{48}$ and piano music. ${ }^{49}$ He revealed his interests in musical ethnography, reporting amongst other things the deliberations of the international music congress in Vienna on 25-29 May 1910 and several times later, especially in the post-war edition of the magazine..$^{50} \mathrm{He}$ also commented on the popularisation of music and promotion of the 'high' musical culture in the article 'O wychowaniu muzycznym publiczności' [About the music education of the public] ${ }^{51}$ In this he wrote about various types of listeners, about musical intelligence and about the need to create a canon of the repertoire (quite an obvious selection from the works of Bach, Haendel, the Viennese classics, nineteenthcentury German composers, from Schubert and Mendelssohn, through Brahms, Bruckner and others), which would help educate conscious music lovers. This theme also includes articles by Józef Reiss, ${ }^{52}$ Henryk Opieński ${ }^{53}$ and the then starting out Stefania Gerard Festenburg (Łobaczewska). ${ }^{54}$

However, for musicology as a science and its place in the Polish university system the most important was the summary of the inaugural lecture published

47 'Mieczysław Karłowicz. Kilka wspomnień' [Mieczysław Karłowicz. A few memories] (MM 1909/7, 1-4); 'Mieczysław Karłowicz' (PM 1911/8, 6-8).

48 'Z najnowszej muzyki polskiej' [About the latest Polish music] (PM 1910/10, 4-5).

49 'Współczesna polska muzyka fortepianowa' [Contemporary Polish piano music] (PM 1914/8, 6-10).

50 'W sprawie zbierania instrumentów muzycznych na Podhalu' [On collecting musical instruments in Podhale] (PM 1919/11-12, 9-10); 'Ujemne wpływy na melodie ludowe' [Negative influences on fol melodies] (PM 1919/13-14, 5-8).

51 PM 1910/10, 10-12.

52 'Kultura życia muzycznego' [The culture of musical life] (PM 1911/8, 9-11, 1911/9, 3-4).

53 'Znaczenie opery dla rozwoju polskiej muzycznej kultury' [The importance of opera for the development of Polish music culture] (PM 1912/7, 9-10).

54 'Kilka słów o kulturze muzycznej XX wieku' [A few words about twentieth century music culture] (PM 1911/5, 8-10). 
by Chybiński at the beginning of 1913 during the opening of the new department at the University of Lviv. ${ }^{55}$

Although Chybiński dominated as an author in the pages of Przegląd Muzyczny, the editorial office never-the-less managed to maintain the character of a forum for scholarly discussion of the just emerging milieu and invite other musicologists to it as well. In the area of publications on research about Old Polish music, the bibliography of the magazine is supplemented in principle by two important names - Zdzisław Jachimecki, the author of, amongst others, the contribution about the band of Władysław IV $^{56}$ and the instrumental works of Adam Jarzębski ${ }^{57}$ and the monographic article about the song Chwała Tobie, gospodynie, ${ }^{58}$ and Józef Reiss, who twice presented materials ' $\mathrm{Z}$ dawnych kancjonałów' ${ }^{59}$ [From old cantionals]. Reading Jachimecki's other articles printed in Przeglad Muzyczny may indicate the direction - apart from old Polish music - his research interests will lead in the following years. Admittedly, his passions related to the work of the most important Polish composers of the nineteenth and twentieth centuries (Chopin, Moniuszko, Karłowicz, Szymanowski) were only just being formed. ${ }^{60}$ However, his fascination with French and German music was already visible at that time - as with the work of specific composers (Mahler, Debussy, Strauss and first and foremost Wagner), ${ }^{61}$ and also in the context of the confrontation of both of these cultures. ${ }^{62}$

Reiss was involved in newer creative works, especially in relation to European music, ${ }^{63}$ he shared an interest in the figure and work of Richard Wagner with

55 'Uniwersytet a muzyka' [University and music] (PM 1913/2, 1-5).

56 'Kontrapunkciści polscy w kapeli Władysława IV’ [Polish contrapuntal composers in Władysław IV’s band] (MM 1909/19, 3-5).

57 'Adam Jarzębski jako kompozytor koncertów i kancon' [Adam Jarzębski as a composer of concerts and canzone] (MM 1909/20, 8-11).

58 PM 1913/14-15, 8-10.

59 PM 1912/2, 1-2, 1914/1, 10-11.

60 See, for example, his reflections on Szymanowski's piano compositions (MM 1909/22, 6-8), or the article 'Chopin jako harmonista' [Chopin as a harmoniser] (PM 1910/5, 5-6).

61 He wrote about Wagner five times in the pages of Przegląd Muzyczny, including a presentation of his autobiography (PM 1911/12,4-7) and analysing the evolution of the composer's creativity (PM 1913/11, 4-6).

62 'Z muzyki dramatycznej w Niemczech i Francji' [From dramatic music in Germany and France] (PM 1911/22, 1-6, 1911/24, 1-4).

63 'Poematy symfoniczne Liszta' [Liszt's symphonic poems] (PM 1911/21, 5-7); 'Z dziejów romantyki muzycznej' [From the history of romantic music] (PM 1912/6, 1-5); 'O impresjonizmie w muzyce' [On impressionism in music] (PM 1918/1-2, 5-10). 
Jachimecki - in the occasional issue on the hundredth anniversary of the composer's birth they both included texts about the music of Bayreuth ${ }^{64}$ (a dozen or so Wagnerian items appeared in Przeglad, which distinguishes the character and activity of this musician from the background of interest in the work of other composers). He was occupied with the role of music in culture, which he expressed in several sketches, including in a publication about folk concerts ${ }^{65}$ or in the text mentioned above about the culture of musical life. He also revealed his interest in the history of music going beyond the ranges traditionally present in musicological studies, namely antiquity, ${ }^{66}$ while with the cycle ' $Z$ zagadnień estetyki muzyki' [From the riddles of musical aesthetics] ${ }^{67}$ he joined a small group of the first generation of musicologists working systematically in this field. In addition, he was one of the most prolific authors of reviews from the latest Polish and foreign musicological publications, as well as a translator of several foreign authors' materials published in the journal. ${ }^{68} \mathrm{He}$ himself also received reviews by both Chybiński and Jachimecki about his own article Melodie psalmowe Mikołaja Gomółki: 1580 [Psalm melodies by Mikołaj Gomółka: 1580]. ${ }^{69}$

The next 'university' musicologist invited by Chojnacki to the group of authors of the bi-weekly was Henryk Opieński. Opieński was soon to be the editor of the milieu's competing journal, Kwartalnik Muzyczny - the organ of the WTM. With his account of the first performance of Karol Szymanowski's Second Symphony

64 Józef Reiss, 'Ryszard Wagner. W setną rocznicę urodzin' [Richard Wagner. On the hundredth anniversary of his birth] (PM 1913/11, 1-4); Zdzisław Jachimecki, 'Ewolucja w twórczości Wagnera' [Evolution inWagner's work] (PM 1913/11, 4-6). In the case of Jachimecki, this was not the only Wagnerian material in the pages of Przeglad. He devoted a lot of studies to the composer's work, and above all a book (Lviv 1911), about which Reiss placed a review in Chojnacki's magazine (PM 1912/16, 10-13).

65 PM 1911/10, 6-8.

66 'O muzyce starogreckiej' [About ancient Greek music] (PM 1912/7, 1-6). He returned to the problems of theory in ancient treaties several more times, more on this subject in subsequent chapters.

67 PM 1919/3, 1-5, 1919/4, 1-5, 1919/5, 1-4, 1919/6, 1-4.

68 Amongst others the review of Die Musik als Ausdruck, Friedrich Hausegger's aesthetic treatise, which he wrote together with Chybiński was published in six issues in 1912 and after a break in seven episodes in 1914.

69 Chybiński's extensive review was published in parts, see PM 1912/19, 6-7, 1912/21, $6-8,1913 / 2,6-9$. For balance, the editors also published Jachimecki's review (PM $1912 / 20,16-17)$, which - as reported - was a reprint of an earlier publication from Biblioteka Warszawska. 
and the presentation of the work, he joined the group of people propagating the then young composer's work at that time. ${ }^{70}$ Concerning 'Old Polish' matters, he reminded everyone of the lutenist Jakub Polak, ${ }^{71}$ and he interested himself in the singing movement and published a methodology of teaching singing, 'reflections and wishes. ${ }^{72}$

Against the background of the four most important authors, both in terms of quality, and also 'productivity', the editor-in-chief of Młoda Muzyka and Przeglad Muzyczny, Roman Chojnacki, presents himself as an efficient organiser of the magazine and, above all, a chronicler of daily life. He was the author of short biographies in the regular column 'Współcześni muzycy polscy' [Contemporary Polish musicians], also a few obituaries and memories, and he also presented some of the most important European conservatories, ${ }^{73}$ but he did not, however, take up topics from music history or even the periphery of musicology, leaving this domain to pens already experienced in scholarly publications. Other collaborators for Przeglad were generally music critics or publicists, though, perhaps because of the Board's editorial declarations to cut themselves off from all cliques, the magazine did not attract the hottest names present in the daily and cultural press. A small amount of materials were submitted for printing by Piotr Rytel, who was freshly promoted at the Institute of Music in the field of composition and piano playing (in later years an active music critic) ${ }^{74}$ Having already experience as a journalist in Russian magazines and referring to his performed profession, Mateusz Gliński ${ }^{75}$ in 1919 made his debut in the Polish environment with an article in Przeglad. Correspondence was sent by practising musicians, such as pianist Aleksander Wielhorski ${ }^{76}$ or composer and conductor Ignacy Neumark dealing with German music, primarily from the second half of the nineteenth

70 PM 1911/9, 6-8.

71 MM 1909/19, 5-8. Zdzisław Jachimecki undertook a discussion about the details of fates of music presented in the dissertation (MM 1909/22, 9-11).

72 'O nauce śpiewu' [About learning to sing] (PM 1911/2, 4-5).

73 'Konserwatoria muzyczne’ [Musical conservatories] (MM 1909/6, 8-9, 1909/8, 3-4, 1909/13, 9-11).

74 In addition to the coverage of current musical life, he presented a critical analysis of Tchaikovsky's Pathetique Symphony (MM 1908,2, 10-12) and Puccini's Madame Butterfly (MM 1909/1, 5-7).

75 The historically considered cycle 'Szkice z dziejów sztuki kapelmistrzowskiej' [Sketches from the history of the Kapellmeister's art] was published in a few post-war issues of Przeglad Muzyczny.

76 See, for example, his article 'O muzyce rusińskiej' [About Ruthenian music] (MM 1909/19, 8-11). 
century (Reger, Wagner), although he also reached for Mendelssohn's legacy (in the centenary of his birth). Regional materials came from Russia - from the historian and music researcher Nikolai Findeisen who wrote about composers from the new Russian school, ${ }^{77}$ or from Czechia - from Jan Löwenbach writing about Prague as a focus of musical life. ${ }^{78}$ In addition, many translations of 'classic' readings appeared - Wagner, Berlioz, Liszt, Riemann. ${ }^{79}$

The magazine was not in debt to its most important authors. In correspondence and chronicles, information about their subsequent scholarly successes and new publications appeared. In the January issue of 1909 it was reported that Zdzisław Jachimecki 'was appointed director of the musical Conservatoire in Cracow', and 'Adolf Chybiński, music historian, a permanent collaborator of our magazine, received the degree of Doctor of Philosophy from the department of music at the University of Munich based on his thesis called Beitrage zur Geschichte des Taktschlegens und des Kapellmeisteramtes in der Epoche der Mensuralmusik. Mr. Chybiński is the third ${ }^{80}$ Pole, who has a doctorate in music and the first who achieved this degree in Germany. The newly decorated fellow countryman was invited to become a permanent member of the Polish music department in Dr Riemann's music encyclopedia. ${ }^{31}$

From the local chronicle, we also learn about scholarships awarded for research purposes (such as that granted from the funds of W. Orłowski to Adolf Chybiński at the beginning of 1910 'for academic-music research in foreign archives and libraries'), ${ }^{82}$ about appearances abroad by young musicologists

77 PM 1912/23, 1-9.

78 PM 1912/10, 5-7.

79 Riemann's system was presented in the pages of Przeglad Muzyczny by the experienced Warsaw (later Cracovian) pedagogue, publicist and critic Michał Julian Piotrowski (see 1918/1-2, 11-12, 1918/3, 10-12, 1918/4, 12-14).

80 Konrad Zawiłowski obtained the first diploma in musicology - studying under Guido Adler in Vienna - in 1902. Four years later, Zdzisław Jachimecki received his doctorate studying under the same promoter. Józef Reiss was also a graduate of the Vienna department, and Stefania Łobaczewska was a non-graduating attendee. Adolf Chybiński obtained his diploma in 1908 studying with Adolf Sandberger and Theodor Kroyer in Munich; Łucjan Kamieński graduated in 1910 in Berlin, under Hermann Kretzschmar and Johannes Wolf, and earlier, in 1907, another Poznanian, Wacław Piotrowski; Alicja Simon also studied there. Henryk Opieński attended the lectures of Hugo Riemann in Leipzig. Fr. Wacław Gieburowski undertook studies in church music in 1908 in Regensburg.

81 MM 1909/1 ('Kronika' [Chronicle]). Similar information appeared in the following year and this time involved the doctorate of Łucjan Kamieński.

82 PM 1910/3 ('Kronika'). 
(like Henryk Opieński’s readings on Chopin and Polish music in Prague in May 1910) ${ }^{83}$ and about the participation of Chybiński and Jachimecki in an international project about the creation of a Corpus scriptorum de musica (together with Adler, Sandberger, Wagner, Wolf and others). By not being limited to cooperation with authors from Warsaw, the editorial office could count on a wide reception in the country. This is also how it was. From time to time, flattering reviews about Przeglad Muzyczny which appeared in the capital and in the provincial press were cited. However, after the war break, it failed to return to its thriving activity from the turn of the first and second decade. Roman Chojnacki undertook different activities in the interwar years. He was almost continuously the artistic director of the Warsaw Philharmonic and was also a professor of music theory at the Warsaw Conservatoire. The title of the magazine itself appeared in Poznan in the 1920s, but the publication to which it was given did not refer in any way to the Warsaw bi-weekly.

The only link between the magazines seems to be Henryk Opieński, who was one of the most active authors of the bi-weekly. Later, for a short time, he was the editor of the Poznan Przeglad Muzyczny. In the first decade of the century, he was very much connected with the Warsaw milieu, primarily the environment of the local Musical Society. This gave him the opportunity to create a journal in competition to that made by Chojnacki, addressed primarily to readers well educated in the field of music knowledge, but dealing with issues of current musical life in a limited way. Until now, all music magazines, including those with the most ambitious profile, with editors-in-chief of such great erudition as Józef Sikorski or Jan Kleczyński, may have been occupied with both lesser and more educated music lovers, sometimes only music enthusiasts who are eager for information about current curiosities from musical life. Kwartalnik Muzyczny was supposed to stand in opposition to them, called into existence as an organ of the WTM. A short history of the Society is worth recalling here.

Already in 1869 in the pages of Kłosy (number 232), a weekly dedicated to literature, science and art, Warsaw music critic and pedagogue Władysław Wiślicki, presented a project to create a 'literary and artistic club' independent of the Instytut Muzyczny [Music institute] and the Warsaw Opera. The fate of the initiative was considered during 1870, and finally, in mid-January 1871, the WTM was established. ${ }^{84}$ The founders and the first members of the society were, amongst others, music journalists and musicians: Władysław Wiślicki, August

83 PM 1910/11 ('Kronika').

84 About WTM see for example, Spóz 1980; Spóz 1973. 
Freyer, Emanuel Kania, Jan Kleczyński, Józef Sikorski, Adam Münchheimer, Stanisław Moniuszko, Ignacy Krzyżanowski, Józef Wieniawski; Sergiusz Muchanow became the president, and Aleksander Zarzycki became the Musical Director. As part of its activities, WTM fulfilled, amongst others, the missions to popularise creative work and maintain the memory of the most important Polish composers - Frederic Chopin and (following his death) Stanisław Moniuszko. The Society's constitution contains basic assumptions and tasks that included, among others, regular organisation of concerts, popularisation of Polish musical creativity (including through publication), announcing composition competitions, supporting a system of scholarships for musically talented youth, organising amateur music groups; in the mid-1880s, a music school was established alongside WTM. In these initial assumptions, there was no question of leading and supporting scholarly activity.

Gradually, noticing the necessity of separating and dedicating its primary and basic tasks, the most exertive activists of the institution, started to draw out further Sections. On the initiative of the well-known linguist and ethnographer, Jan Karłowicz, the Stanisław Moniuszko Section was established at the end of 1891 to collect manuscripts and music prints and memorabilia of the composer, as well as publishing his works. The Church Music Section was founded in 1894 and five years later - this time at the initiative of the doctor and composer Henryk Dobrzycki - the Frederic Chopin Section. In 1905 Mieczysław Karłowicz became Musical director of the WTM, and shortly after that, in 1906, proposed the establishment of two new sections: Collective Music and Scientific. In the annual report the WTM reported that 'On the 21 December last year the Committee confirmed the regulations governing the Society's newly established Scientific Section ... The aim of this Section will be to encourage research and historical-scholarly research, as well as comparative studies in the field of music and related sciences and mutual learning, and finally the dissemination of Polish knowledge and musical art at home and abroad ....85

After the period of its initial organisation, the actual work of the Section restarted in the second half of 1907. The honorary president was Fr. Józef Surzyński and the Board was comprised of Henryk Opieński (chairman), Lucjan Marczewski (secretary, treasurer), Mieczysław Surzyński (librarian) and a few members, including amongst others Roman Statkowski and Felicjan Szopski. This was the formation that joined the International Music Society

85 Sprawozdanie Komitetu Warszawskiego Towarzystwa Muzycznego za rok 1906 [Report of WTM Committee for the year 1906] (Warsaw 1907), 3. 
as representatives for the Polish Section, and in order to strengthen contacts with European musicology, they subscribed to Sammelbände der internationalen Musikgesellschaft and Zeitschrift der internationale Musikgesellschaft (which was also noted in the annual report). At the beginning of the activity, the Board proposed a series of readings, the first of which was in November 1907, 'about early Polish dances of the sixteenth and seventeenth centuries', given by Henryk Opieński. ${ }^{86}$

After his arrival in Warsaw in 1901, Opieński immediately became involved in various activities in the musical milieu of the capital. ${ }^{87} \mathrm{He}$ already became interested in music criticism during the time of his studies in Berlin: he became - after taking over the task from Karłowicz - one of the correspondents for Echo Muzyczne, Teatralne i Artystyczne. While Opieński's own periodical remained as a plan for the time being, he spent the years of the first decade of the twentieth century passing between Warsaw and Leipzig, though, as Wojciech Jędrzejczak wrote in his memoir about him, 'throughout this period he did not neglect ... his pen - he wrote reviews, discussed concert programmes ..., he printed an article on Chopin (1909) and his works ..., he published the history of common music in outline (1912), worked on a doctoral dissertation about Bálint Bakfark. ${ }^{98}$ He was one of the authors working since 1905 on the initiative of the Academy of Learning in Cracow by Stanisław Estreicher ${ }^{89}$ Encyklopedia polska [Polish encyclopaedia]; on this occasion, he even coordinated the editorial team's cooperation with other musicologists - Chybiński and Jachimecki. Sometimes he 'scandalously' - as he himself wrote - neglected '... many things;

86 'the work - as explained - was based in studies of early prints and manuscripts (mostly tablature), see Sprawozdanie Komitetu Warszawskiego Towarzystwa Muzycznego za rok 1907 [Annual report WTM. . 1907] (Warsaw 1908), 15.

87 Opieński was a restless spirit, a real European. He was a friend of Stanisław Wyspiański, Józef Mehoffer and Stanisław Estreicher, see Sieradz 2017/1. Starting from the year 1884 (he was born in the year 1870) he gained knowledge and artistic skills in Cracow, Prague, Paris, Berlin and Leipzig; he visited Munich, where he met the young Chybiński for the first time. In time, he formed links with Switzerland, Warsaw and Poznań, where he spent some time in the twenties, but these were merely temporary stops on his life journey.

88 Jędrzejczak 1981/1, 5; see also Jędrzejczak 1981/2.

89 Stanisław Estreicher (1869-1939) was a legal historian, literary historian and bibliographer. He was a representative of a well-known Cracow family of scholars, associated for all his life with the Jagiellonian University. In various years he was the dean of the Faculty of Law, as well as the vice-rector and rector of the university, and a member of the Academy of Learning. He was an admirer of the work of the composers of the Young Poland group. 
now I must play "horribile dictu" with an orchestra for 10 days for the gramophone - to earn some extra money!'90 One of his most important plans, however, was the establishment and conduct of the first scientific journal of a strictly academic character, and the opportunity soon came.

Apart from reporting the events of the previous year, the WTM Report for 1907 presents the aims of the association's activities: 'concentrating the work on the history of Polish music, pedagogy and the theory of music in general, [the Management Board wishes] to fill a tangible gap in these areas .... One of the first activities of the Board is work on gathering and preparing material for the "Leksykon polskiej muzyki" [Lexicon of Polish music], further plans include a monograph on Moniuszko ... and setting up a professional music journal of a purely scholarly nature. ${ }^{91}$ Therefore, towards the end of 1909, Opieński began to send letters to well-known musicians, music critics and, above all, the few, but already functioning Polish musicologists. In the first place, he turned to Adolf Chybiński, who was well-known for his first serious achievements, presenting in the letter planned obligations for the editor on the one hand and expectations as to the nature of ordered material on the other hand:

Well, the question is coming to bear of Kwartalnik [emphasis H.O.] from 1910 (the first issue comes out in March) - of course the first thing is that I turn to you Sir with a request for collaboration - namely, for dissertations in the field of history and aesthetics - they may have musical examples and illustrations, of course from the outset our conditions are modest, so only 20 roubles paid by the page - maybe you have some work ready - maybe from the areas mentioned in the list (if such a facsimile were possible, it would be wonderful) ... would be perfect for the first number right away. Of course, we want to keep ... the tone very objective - very calm and non-aggressive, like in a scholarly quarterly. ${ }^{92}$

Despite the plans of Opieński and the Committee of WTM, ${ }^{93}$ the 'expert magazine' still had to wait a little longer. In March 1910, the future editors continued

90 Opieński to Chybiński from Warsaw 30 XII 1907, AACh-BJ, box 6, O-2/7.

91 Sprawozdanie Komitetu WTM 1907 (Warsaw 1908), 15.

92 Opieński to Chybiński from Warsaw 9 XII 1909, AACh-BJ, box 6, O-2/18.

93 In Sprawozdanie Komitetu WTM 1909 (Warsaw 1910) it was written: 'At the beginning of 1910, thanks to private help, the Section [scientific] will start the publication of Kwartalnik Muzyczny, devoted to historical and aesthetic-theoretical works; the editor will be Roman Statkowski; heads of both departments Messrs. Henryk Opieński and Felicjan Szopski' (p. 24). It should be added here that the editor-in-chief was to be Opieński himself, however, since he was an Austrian citizen, not a Russian citizen, he could not perform managerial functions in Warsaw. 
seeking permission from the authorities which was necessary to operate, and which was finally granted on April 26. It was decided to wait until September with the publication of the inaugural number, which meant that the materials should have been ready for publication at the end of July. Unfortunately, already at that time the editor of the new periodical realised that in the future he would often face delays due to reasons beyond his control: 'the deadline depends only on us, or rather on me; and I depend on the honourable co-workers, of whom nobody has yet sent an article on time. ${ }^{94}$ At the beginning of November, he asked Chybiński for a manuscript or even the title of an article for the edition which had already gone to press. The material finally arrived in the middle of the month, but Kwartalnik only appeared at the beginning of 1911, and the event was announced by a leaflet presenting the contents of the edition illustrated with a facsimile of a card from the Tabulatura Joannis de Lublin and a photograph from the collection of Mieczysław Karłowicz depicting Marcin Groblicz's violin.

According to the words of the first editorial, when preparing to publish Kwartalnik, the editors strictly defined their mission and target recipients, wanting to

fill the gap that prevails in our musical literature, without possessing an organ that would be able to devote its columns to more strictly professional articles and dissertations in the field of the history of music aesthetics and theory, and to gather relevant historical materials for further research. We would like to fulfil those needs indicated by the increasing number of Polish musicological works in recent times, and we want to do this through publishing Kwartalnik Muzyczny, which, aside from all 'directions' in art, excluding all personal sympathies and antipathies, will combine in its columns the views of the most diverse shades in accordance with the principle that from a serious juxtaposition of different judgements and views on art, conclusions as close to true as possible can be drawn.

The editorial office's message can be supplemented by the words of one of its members, Felicjan Szopski, who in his article about 'pedagogy' published on the following pages of the inaugural edition mentioned that 'Desiring in articles of our Kwartalnik to penetrate into all the most important factors, being a catapult for the musical movement, the development of musicality and musical knowledge, we will pay close attention to the state of musical pedagogy. ... We will devote the pages of our magazine to these matters from time to time, willingly

94 Opieński to Chybiński from Morges 9 VIII 1910, AACh-BJ, box 6, O-2/26. 
posting rational opinions of experts, founded on knowledge, experience and wider views. ${ }^{.95}$

For a time, it seemed that the fate of the periodical would proceed undisturbed. From the very beginning, Konstanty Sarnecki, a well-known Warsaw music lover and patron of the arts, provided strong financial support; Opieński probably wrote about it at the beginning of 1908 to Chybiński: 'a debate has started about a specialist monthly - because there is someone who can give money. ${ }^{96}$ Unfortunately, the benefactor died soon thereafter, in the middle of 1911, and the editorial office remained without material support for one and a half years. After this time, it was reported that 'Kwartalnik Muzyczny thanks to the support of Mianowski's estate and private subsidy from Count Zamoyski, Juliusz Herman, Piotr Wertheim and Miss Elżbieta Zalewska, has current survival guaranteed [100 roubles to each number]. Apart from additions to individual numbers, the editors of the quarterly will separately publish older and newer compositions exclusively Polish or having direct contact with Polish music.97

The next three years brought somewhat irregular publications, as in previous years, and they proceeded with continuous skirmishes with the unreliable printing press on the one hand, and on the other - with authors forever being late with their work. Opieński complained quite emphatically, saying that 'for each number of Kwartalnik it is always necessary to use forceps and a cesarean section. ${ }^{38}$ The Sprawozdania written in 1915 for the previous year reported that only two editions were published, and the next editions were constantly presented as the main goal. In 1914 we read that the 'Scientific Section, as in previous years, limited its activity exclusively to publishing a music quarterly. ${ }^{99}$ Unfortunately, the last two editions appeared in 1914, and the set of publications only covers two years: year I - numbers from January 1911, April 1911, October 1912 and a number from January 1913 (though indicated as year II); year II edition from October 1913 and from May 1914. In the summary of the year 1915 the Committee of WTM reported on the difficulties resulting from the wartime hostilities and forced absences from Warsaw of Henryk Opieński, an Austrian subject, who was the 'soul and pillar,' 'most active member' of the Scientific Section: 'The activities of the Scientific Section due to the ... scattering of its

95 Felicjan Szopski, 'Z naszej pedagogii muzycznej' [From our musical pedagogy] (KM 1911/1, 79-84, 1911/2, 186-191, cit. p. 80).

96 Opieński to Chybiński from Warsaw 12 II 1908, AACh-BJ, box 6, O-2/8.

97 Sprawozdanie Komitetu WTM 1912 (Warsaw 1913), 19.

98 Opieński to Chybiński from Warsaw 5 VIII 1911, AACh-BJ, box 6, O-2/40.

99 Sprawozdanie Komitetu WTM 1913 (Warsaw 1914), 21. 
members, and above all the absence of its head, Mr Henryk Opieński, who from the moment of the outbreak of war to the last days was forced to stay abroad were temporarily suspended.' ${ }^{100}$

This situation also stretched into the next year. In the new historical reality, after the year 1918, Kwartalnik was not reactivated as an organ of WTM. Opieński, who left the country at the beginning of the war operations, stopped on the way for three weeks with Father Józef Surzyński in Kościan and then at some village in the Sieradz region, arriving then to Switzerland, from where he returned - first to Warsaw, afterwards to Poznan - in the year 1919. During his several-year stay in Poznań, he had a second editorial episode, when in 1925-26 he ran his own Przeglad Muzyczny, also important on a national scale.

Due to the interest of the then editor-in-chief as well as the 'profile' of the musicological milieu emerging at the time, the vast majority of the quarterly was filled with historical works, primarily in the history of Polish music. The first years of the twentieth century were a period when, in a short time, the first generation of well-educated Polish musicologists began to return from foreign studies at German, Swiss and Viennese universities, though not all - as some people noticed years later - deserved to be called well-educated. ${ }^{101}$

For the first issue of the new magazine, the editorial team invited the two musicologists who were best prepared to conduct academic research at that time - Adolf Chybiński and Zdzisław Jachimecki wrote an article for the first issue - Tabulatura organowa Jana z Lublina (1540) [Organ Tabulatura Joannis de Lublin (1540)] giving the opportunity to inaugurate the journal's work. ${ }^{102}$ In subsequent issues the alumnus of the University of Munich maintained the subject

100 Sprawozdanie Komitetu WTM 1915 (Warsaw 1916), 13.

101 Speaking about the tasks of 'historical musicology', Chybinski wrote: 'a number of Polish musicologists who received musicological preparation at foreign universities, abandoned academic work for practical work (artistic and pedagogical) ... I am inclined to recognise as academic musicologists only those individuals who constantly and systematically work academically, and present the results of their work to society in the manner adopted in science,' Chybiński 1930, 589.

102 KM 1911/1, 9-35, and continuation 1911/2, 122-141, 1912/3, 217-252, 1913/4, 297 336. This article was preceded only by a study prepared by Henryk Opieński himself and Stanisław Kętrzyński on the subject of the fifteenth century Hymn na cześć Krakowa [Hymn in honor of Cracow] by Mikołaj of Radom along with facsimile and transcription (pp. 3-8). Chybiński continued his studies in subsequent numbers (KM 1911/2, 122-131, 1912/3, 217-252, 1913/4, 297-336). 
of Old Polish themes ${ }^{103}$ and once organological material: he supplemented the edition of Mieczysław Karłowicz's notes on early Polish violins with his own contribution on the same subject. ${ }^{104}$ Jachimecki initially announced an article about Chopin's harmony for the first issue, but he only provided short material on 'Several incomplete polyphonic compositions by Polish masters from the sixteenth century. ${ }^{105}$ Other authors of articles and historical materials were: Aleksander Poliński, ${ }^{106}$ Jan Wilusz (co-author, along with Chybiński, of an edition of eighteenth-century musical inventories from the Podhorce castle), ${ }^{107}$ Teresa Panieńska, ${ }^{108}$ Piotr Maszyński, ${ }^{109}$ Mieczysław Skolimowski, ${ }^{110}$ Alicja Simon ${ }^{111}$ and two people recommended by Chybiński from the newly opened department of musicology in Lviv - Bronisława Wójcikówna ${ }^{112}$ and

103 'Notatki biograficzne o przełożonych Kapeli Rorantystów w XVII stuleciu' [Biographical notes about the superior of the Rorantist band in the seventeenth century] (KM 1911/2, 142-146); 'Krakowskie inwentarze muzyczne z XVI w. (Przyczynek do historii muzyki w Polsce)' [Cracow music inventories in the sixteenth century (A contribution to the history of music in Poland] (KM 1912/3, 253-260); 'Kieycheriana' [Of Kieycher] (KM 1912/3, 261-262); 'Z dziejów muzyki krakowskiej' [From the history of music in Cracow] (KM 1913/1, 24-62, 1914/2, 91-108); 'O nieznanym zbiorze tańców polskich z r. 1622' [About an unknown collection of Polish dances from 1622] (KM 1913/1, 63-70); 'Z inwentarzy muzycznych zamku w Podhorcach' [From the musical inventories of the Pidhirtsi castle] (together with Jan Wilusz, KM 1913/1, 71-76).

104 Adolf Chybiński, 'Kilka słów o dawnych polskich skrzypcach' [A few words about early Polish violins] (KM 1911/2, 147), supplement to the notes about early Polish violins by Mieczysław Karłowicz (KM 1911/1, 39-47).

105 KM 1911/1, 36-38.

106 Aleksander Poliński, 'Nieznany skarb muzyczny' [Unknown musical treasure] (KM 1912/3, 263-268).

107 Jan Wilusz, Adolf Chybiński, 'Z inwentarzy muzycznych zamku w Podhorcach' [From the musical inventories of the Pidhirtsi castle] (KM 1913/1, 71-76).

108 Teresa Panieńska, 'Koncerty “spirituels” w Lesznie Wielkopolskim w roku 1785' ['Spirituels" concerts in Leszno Wielkopolskie in 1785] (KM 1913/1, 77-78); also 'Do historii muzyki w Poznaniu' [To the history of music in Poznań] (KM 1914/2, 109-113).

109 Piotr Maszyński, 'Eugeniusz Pankiewicz' (KM 1912/3, 287-288).

110 Mieczysław Skolimowski, 'Feliks Mottl' (KM 1912/3, 269-286).

111 Alicja Simonówna, 'Stosunek Sperontesa Singende Muse an der Pleisse... do muzyki ludowej polskiej' [The relationship of Sperontes' Singende Muse an der Pleisse... to Polish folk music] (KM 1911/1, 48-54).

112 Bronisława Wójcikówna, 'Tańce polskie Jana Fischera (1702)' [Johann Fischer's Polish dances (1702)] (KM 1914/2, 83-90). 
Stefania Łobaczewska-Festenburg. ${ }^{113}$ Texts touching theoretical and aesthetic issues appeared sporadically and were signed twice by Józef Rosenzweig ${ }^{114}$ and Adolf Gużewski ${ }^{115}$ and Felicjan Szopski, leading the 'theoretical' section, signed under the above-mentioned communique about 'our [Polish] musical pedagogy’ As stated, along with Kętrzyński, Opieński himself prepared material about the fifteenth-century hymn Cracovia civitas and - independently - an edition 'Notatki o dawnych polskich skrzypcach' [A note about early Polish violins] by Mieczysław Karłowicz, who died tragically two years earlier ('as an expression of remembrance about him and his work, so important and comprehensive for Polish arts $\left.{ }^{116}\right)$. In the fourth edition, Opieński undertook a 'musical dissection' of Symphony in B minor by Ignacy Jan Paderewski ${ }^{117}$ which gave rise to an entire series of 'Paderewskianas' written by him and heralded a deep, many year, almost lifelong attachment to the Master from Riond-Bosson. Some selected materials also appeared in separate copies of the Kwartalnik: piano transcriptions prepared by Opieński from lute and organ tablatures, Chybiński's first article, or the preludes for organ from the Tabulatura Joannis de Lublin. Chybiński was also a frequent contributor to the reporting department of the magazine. ${ }^{118}$

Judging from the frequency of the publication of the articles by Chybiński, it can be assumed that Opieński highly valued him as a musicologist, believing him equal to the level of education, erudition, meticulous research of the best European models. One cannot forget, however, that the remaining authors also acquired knowledge of foreign centres in the field of history or theory of music. Józef Rosenzweig, lawyer, writer, pianist and musicologist, who spoke several languages, alongside law studies at the University of Warsaw, attended lectures in musicology given by Hugo Riemann in Leipzig. When in 1900 he settled in Warsaw, he undertook music journalism, and cooperated, amongst others with

113 Stefania Łobaczewska-Festenburg, 'Przyczynki do dziejów humanizmu w muzyce' [Contribution to the history of humanism in music] (KM 1913/1, 3-23).

114 Józef Rosenzweig, 'Przyszłość estetyki muzycznej' [The future of musical aesthetics] (KM 1911/1, 72-78); also, 'Reforma w ustaleniu tonów z punktu widzenia estetycznego' [Reform in establishing tones from an aesthetic point of view] (KM 1911/2, 148-185).

115 Adolf Gużewski, 'Schopenhauer o muzyce. Studium filozoficzne' [Schopenhauer on music. Philosophical studies] (KM 1911/1, 55-71).

116 KM 1911/1, 39-47, here p. 39.

117 KM 1913/4, 341-352.

118 Opieński jokingly commented on this fact: 'Thank you very much for the reports. But you, Sir, are waving it!', see Opieński to Chybiński from Warsaw 28 IV 1910, AACh-BJ, box $6, \mathrm{O}-2 / 23$. 
Echo Muzyczne, Teatralne i Artystyczne, periodical Słowo and Kurier Poranny. He taught classes on the history and aesthetics of music in the WTM music school and in the F. Chopin Music Institute (and after years, according to the Polski Stownik Biograficzny, from 1923 he also lectured on the history of music at the University of Warsaw). ${ }^{119}$ In WTM he was a member of the Committee and from 1905 , secretary of the Society.

Mieczysław Surzyński, brother of Father Józef Surzyński, organist, conductor and pedagogue, gained education in Berlin in the field of music theory and composition. In Poznań, where he lived in the eighteen-nineties, he founded the Musical Society; after settling in Warsaw, he became associated with the Instytut Muzyczny [Musical Institute] and the WTM Music School. He gained experience as an author of historical-musical works by co-editing the magazine Spiew Kościelny, in which he also published his own articles. ${ }^{120}$

Adolf Gużewski and Piotr Maszyński, composers, organisers of musical life, both, although at different times, studied composition with Zygmunt Noskowski, and were associated with the circles of WTM. Maszyński joined WTM already in the year 1880, and at that time, he began to write reports from Warsaw's musical life in Gazeta Polska; Gużewski, a composer and pianist, sympathised with the circle of musicians of the Young Poland movement and was - apart from Karłowicz and Opieński among others - one of the signatories of the protest against the management of the Warsaw Philharmonic not allowing the performance of Young Polish composers to the concert repertoire. He devoted himself to pedagogy, but he also dealt with musical-aesthetic issues. ${ }^{121}$

As can be seen, Opieński made available the pages of Kwartalnik to tested, personally known researchers, musicographers and people of the pen, although he did not close himself to contacts with his opponents, such as Aleksander Poliński (the author included material 'Nieznany skarb muzyczny' [Unknown musical treasure] in the third number of Kwartalnik about sources discovered in the Gdańsk City Library), with whom he repeatedly battled polemics, sometimes even dealing with civil lawsuits. ${ }^{122}$ Establishing a journal with scholarly aspirations, he realised from whom he could find the greatest support: the milieu was still very small, as was said, the first musicologists - and authors and

119 Gajkowska 1991.

120 Mądry 2009.

121 Lissa 1990; Przybylski 1975.

122 Opieński wrote to Chybiński from Warsaw in a letter of 6 VI 1909 about his desire to sue Poliński, AACh-BJ, box 6, O-2/17. 
potential readers - were just returning from studies and scholarships abroad. However, limiting the programme - through a consistently implemented 'academic' profile of the magazine - the circle of readers in this small, newly formed group, the editors condemned Kwartalnik to a short life. It is hard to disagree with Kornel Michałowski, who, in excessive ambitions and material problems, sought a mere few-years-long vegetation of the title, ${ }^{123}$ differently than Opieński himself, who was convinced that closing the periodical was influenced by not low reception or financial problems, but current events.

As to the content of the magazine, it can be stated that even a cursory reading of the publication draws attention to the phenomenon of the writing dominance of Adolf Chybiński in the first edition of Kwartalnik Muzyczny. For the future founder of Lviv musicology, it was a perfect moment to 'anchor' himself permanently in the history of the journalistic milieu, and his privileged position on the list of authors without a doubt - apart from the great scholarly fertility of the young researcher - was related to the familiarity that connected him with Opieński. The beginnings of their acquaintance reached back to the 'Munich' times, dated a few years earlier. During his foreign studies, Chybiński began to acquire his first honours as a correspondent and rapporteur in the field of events related to Polish music in Zeitschrift der Internationalen Musikgesellschaft (from the year 1905) and in Allgemeines Litteraturblatt and Neue Zeitschrift für Musik (from the year 1906), he also collaborated with the editors of the Riemann dictionary. At the same time, he also made contact with a group of young Polish musicians staying in Berlin. ${ }^{124}$ Several times in 1906 and 1907 Mieczysław Karłowicz, whom he met in Zakopane, and who belonged to this artistic formation, visited him in Munich. Chybiński ${ }^{125}$ himself thought that it is probably from him that Opieński got the Munich address, as he stayed in the city temporarily, getting acquainted with the Hofbibliothek with Bakfarek's lute compositions (and making copies of them), which was part of his research work related to the

123 Kielanowska-Bronowicz/Michałowski 1963.

124 Members of the Spółka Młodych Polskich Kompozytorów [Company of Young Polish Composers] included Grzegorz Fitelberg, Ludomir Różycki, Apolinary Szeluto and Karol Szymanowski, also joined by Mieczysław Karłowicz and Henryk Opieński, and a sympathetic position was shown by Emil Młynarski. Although each of them had their own original view of new music, they were linked by their desire to break with the 'old.' Chybiński evaluated the initiative enthusiastically: 'we have opened a "clique," in which Karłowicz was the most critical mind, and the greatest enthusiast - me, see Chybiński 1959/2, quote p. 10.

125 Ibid. 
subject of a doctorate written under the guidance of Hugo Riemann in Leipzig. ${ }^{126}$ They met many times, and their acquaintance in the following years moved from a purely social plane to a strictly professional, involved in musicological activity in its various aspects.

Even before they started cooperation on Kwartalnik, in May 1909 Opieński together with Chybiński and Jachimecki went to Vienna for the third session (after the reorganisation of the International Musicological Society in 1904) of the academic conference. He was only an observer there, but two representatives from Cracow (Chybiński, a Cracovian born and bred, and at the time still living there, Jachimecki, a Lvivian who had already moved) gave papers in Vienna, and in addition - as reported - 'Dr Chybiński participated in the deliberations of the international music and bibliographic commission, which prepared a great bibliography of old prints and music manuscripts, in which Polish music will be included.127

Contacts on both private and professional grounds between the two young musicologists were cordial, though never, until the death of Opieński in 1942, went beyond the usual conventions. Having known each other for so many years, they never spoke to each other by their first names. Years later, Chybiński recalled that: '[Opieński was] rather versatile, well-listened, well-read, very cultured and intelligent, knowing lots of music, accustomed to the musical relations in France and Germany, not to mention Poland. ... he was a nice sociable man, and I spent many hours chatting with him in Munich ... Until the year of the Second World War, I was with him in constant, even quite frequent correspondence.'128

In the short period of operation of the first Kwartalnik Chybiński filled its pages with several positions - studies and reviews, overtaking other authors in terms of numbers as well as - on the whole - the level of publication; if he did not publish an essay, he was at least noted in the Chronicle as the author of materials currently announced elsewhere. This is in contrast to Zdzisław Jachimecki, who

126 According to Chybiński, Opieński, although he wrote and submitted his thesis, did not obtain a doctoral degree, because he failed to publish his dissertation, which was then an obligatory condition, see ibid.

127 MM 1909 no. 11, 'Kronika.'

128 Chybiński 1959/2, pp 8-9. The correspondence of Opieński to Chybiński is preserved in the archives of the Lviv professor in the Jagiellonian Library (PWM collection), whereas letters in the other direction - in the archives of Opieński currently belonging to the Fribourg collection of Fondation Archivum Helveto-Polonicum, see Sieradz $2017 / 2$. 
only sent his works two or three times to the Scientific Section of the WTM: in the journal he appeared as the author of the aforementioned work on polyphonic compositions by Polish masters of the XVI century (along with the catalogue), ${ }^{129}$ and also critically referred to the mentioned materials on Tabulatura Joannis de Lublin. ${ }^{130}$ Whereas for Chybiński, however, Kwartalnik became the main forum for exchanging musicological thought at the academic level in the Polish language, Jachimecki already had such a forum in the centre where he was just establishing the first Polish musicological department - at the Jagiellonian University. In Cracow, where the Academy of Learning was thriving, many dissertations and contributions could be published in the pages of Sprawozdania $A U$ [Reports of the Academy of Learning] and Rozprawy Wydziału Filologicznego $A U$ [Discourses of the Philology Faculty of the Academy of Learning]. In addition, for several years he was strongly associated with the main organs of the Galician conservatives Czas and - most of all - Przegląd Polski, established by Stanisław Koźmian, Józef Szujski, Stanisław Tarnowski and Ludwik Wodzicki as a scientific-literary monthly with long-standing traditions.

Besides - referring here to the activity of the Academy of Learning (AU) - both musicologists still had the opportunity to present their works at the meetings of the Faculty of Philology of AU and publish them through the Academy in the period before private docenture at the Cracow and Lviv universities; in later years for a long time they were also the only musicologist-member correspondents with the AU: Chybiński was appointed in 1929 and Jachimecki was called a year later. Chybiński presented his studies on the Tablature Joannis de Lublin (which was the property of the Academy) to the members of the Academy on 10 January 1910 and three times more in the years 1911-12 (as mentioned, the text was published in the journal Kwartalnik Muzyczny); in later years he did not feel so closely related to AU and its series (Sprawozdania, Rozprawy), and instead he collaborated with the Ethnographic Commission as part of the framework of Prace i Materialy Antropologiczno-Archeologiczne i Etnograficzne and after years presented two texts: 'Instrumenty muzyczne ludu polskiego na Podhalu' [Musical instruments of the Polish people in Podhale] (1924) and 'Dzwony pasterskie na Podhalu' [Shepherd's bells in Podhale] (1925). He also had a significant role in preparation for publication under the auspices of PAU of Pieśni

129 'Kilka niekompletnych kompozycji', op. cit.

130 'Na marginesie Tabulatury Jana z Lublina' [On the margin of Jan of Lublin's tablature] (KM 1913/4, 337-338). In response to this polemic, Chybiński published 'Glossy do marginaliów' [Glosses to the marginals] (KM 1913/4, 339-340). 
ludowe polskiego Śląsk [Folk songs of Polish Silesia] from Jan Tacina's collection, for which edition he was musical editor. ${ }^{131}$

Jachimecki was much more strongly connected with this Cracow scientific body - for him, it was the primary platform for presenting the results of his own research. Already on 15 April 1907, he presented the work Mikołaj Gomótka i jego stosunek do współczesnych kompozytorów psalmów [Mikołaj Gomółka and his relationship to contemporary psalm composers] in front of the Academy staff, and less than three years later (15 November 1909) he presented his habilitation thesis Wplywy włoskie w muzyce polskiej [Italian influences in Polish music]. ${ }^{132}$ In the years 1911-14 at the Cracow forum he gave a number of papers documenting work on the history of Polish music, posting their summaries in Sprawozdania AU, while in Rozprawy Wydziału Filologicznego $A U$ he published materials concerning organ tablature from the library of the Monastery of the Holy Spirit in Cracow and music at the court of King Władysław Jagiełło in the years 1424-30. In the interwar period, he presented his work twice - in 1927 and 1934.

In 1913 Józef Reiss also first gave the results of his research in the Rozprawy of the Faculty of Philology with the text of his dissertation Melodie psalmowe Mikołaja Gomółki 1580 [Psalm melodies by Mikołaj Gomółka]. After the war, until 1924 he repeatedly presented and published his works at the Faculty meetings. He did this one more time in 1934, and then only after a break of many years and in completely different conditions, in the autumn of 1945: then at the Faculty of Philology, he presented his work 'O materiałach do polskiej kultury muzycznej' [About materials for Polish music culture], whereas in the announcements he indicated a translation with commentary of Plutarch's treatise and - as Jachimecki said - 'a very rich collection of jottings and notes about music taken from all kinds of Polish prints and numerous manuscripts. ${ }^{133}$ Until 1939, several musicologists presented their research in the Cracow series: Stefan Śledziński wrote about the history of the Warsaw symphony, Zofia Lissa

131 On this subject see also Rostworowski 1974, particularly: Stachowska 1974. The Musicological Commission of PAU was created only after the war, in 1948 (and in practice functioned from 1949), but from the beginning of the creation of the foundations of Polish musicology within the broadly understood national culture, this field was present in the sphere of the scholarly and publishing activities of Academy, see chapter III.2.

132 The work was released by the publishing house of PAU in 1918, while a summary of it in German appeared in 1911 in the Academy's Bulletin International.

133 Jachimecki 1948, 53. 
wrote an essay 'O komizmie muzycznym' [On musical comicality], ${ }^{134}$ while Helena Windakiewiczowa directed her 'Wzory ludowej muzyki w mazurkach Fr. Chopina. Studium muzykologiczne' [Folk music patterns in Fr. Chopin's Mazurkas. Musicological study] ${ }^{135}$ to Rozprawy AU (1926).

Analogically to the Cracow situation, the Sprawozdania Towarzystwa Naukowego we Lwowie [Reports of the scientific society in Lviv] were published to meet the needs of the Lviv circle, and compact publications were announced within Archiwum Towarzystwa Naukowego we Lwowie [Archives of the scientific society in Lviv] as in the case of the Cracow series, access to their columns was restricted to a limited circle of researchers, primarily those connected to scholarship on a daily basis.

134 Printed in Kwartalnik Filozoficzny 1938/1, 1-22.

135 In the series: Rozprawy Wydziału Filologicznego PAU vol. 61, number 7 (Cracow 1926). 


\section{Societies, associations, institutes of the interwar period: 'Club of professional music press' - Polish Society for Contemporary Music - Polish Musicological Society - Frederic Chopin Institute - Association of Early Music Lovers and Publishing Society of Polish Music as an institutional background to Kwartalnik Muzyczny}

The change in Poland's political situation after 1918 and the freedom to consociate in various associations including creative, resulted in numerous initiatives in the world of music in a short period of time. Local music societies and singing associations that focused on musicians, music lovers and connoisseurs, who formed an ever-wider community focusing on the promotion of this art in its various aspects, continued to operate for years with varying degrees of intensity. Soon, these were joined by projects of musicologists and young artists that were often inspired by similar international initiatives - Société Internationale de Musicologie or Société Internationale pour la Musique Contemporaine. Several of them, associations, clubs and various institutions of varying area of influences and a selection of tasks, especially those of a nationwide scope, created a background for the relatively small music and musicological community - the Polish branch of the Musicological Society or the TMW [Society for contemporary music], the SMDM, the IFCh, or associations that associate with musical issues at various levels of the people of the pen. The societies - those mentioned, with a national range, and some industry and local ones - constituted the necessary organisational and personal facilities for the history of Polish musical periodicals. Lists of members of these assemblies often were filled with names of artistic and scientific individuals, such as Chybiński, Jachimecki, Opieński, Gliński, Kamieński, Stromenger, often outstanding people, were not always able to cooperate with each other. The resulting conflicts often caused concern for the parties involved in the controversy. Looking at it from today's perspective we can see how they significantly colour the view of these years.

Already in 1924, in order to meet the expectations of the environment, composer and conductor, and at the same time a critic and journalist, Mateusz Gliński, in the first monthly magazine Muzyka, pointed at the need to create 
a professional organisation that would focus on 'creative forces in the field of music criticism'136 - journalists, chroniclers of everyday cultural life, writers, as well as musicologists focused on scientific research. At the time he wrote that 'perhaps the most appropriate form would be to create a great club of artistic rapporteurs, where music critics would be one of the sections. ${ }^{137}$ He repeatedly returned to this subject, and finally, after five years, the idea of the 'club' would be finalised. He sought the support for this initiative not among musical critics but musicologists and journalists that had scientific aspirations.

At the beginning of 1929 Gliński, at that time a great admirer of Adolf Chybiński who was then an authority both in the musicological and musical environment, sent a message to Lviv about a group formed in Warsaw of writers who focused in the daily newspapers on - as they identified - 'rapporteur.' It is worth citing here a longer fragment from this letter.

Now, I would like to confide ... in a very important and urgent matter. Counsellor of the Disciplinary Commission of the Presidium of the Council of Ministers, Mr. Władysław Fabry, together with the Minister of Ministry of Communications, Mr. Jan Głowacki (both are avid music fans and write reviews in Polska Zbrojna and PolakKatolik), initiated the Union of Daily Scriptwriters under the name 'Group of Music Rapporteurs'; organised a Board which was already functioning in an ad hoc mode (and for many of us a very strange mode), to which the following were invited: messrs. Wieniawski ${ }^{138}$ (president), Rytel, ${ }^{139}$ Binental, ${ }^{140}$ Zmigryder; ${ }^{141}$ vice-president is

136 Muzyka 1924/1, 21-22, the column 'Impresje muzyczne' [Musical impressions].

137 Ibid., p. 21.

138 Adam Wieniawski (1876-1950), composer, conductor, musical rapporteur. He was secretary of the Polish Section of the MTMW, co-founder of SKP (ZKP) (secretary and long-term president), co-initiator of IFCh, member of the artistic council of the opera in Warsaw.

139 Piotr Rytel (1884-1970), composer and music critic, teacher among others of harmony and composition at the Warsaw Institute of Music, in the interwar period, and also after 1945, a columnist and columnist for capital newspapers and social and cultural periodicals. In the field of music critics, like Adam Wieniawski, he presented a conservative option in the music journalism of the interwar period.

140 Leopold Binental (1886-1944), violinist, publicist, and Chopinologist. He was one of the initiators of establishing the Frederic Chopin Institute. The exhibition of Chopin's documents and memorabilia organised in 1932 in Warsaw was preceded by the Chopin album, published in 1930 (On the 120th birthday. Documents and memorabilia).

141 Stanisław Zmigryder (1877-1930), pianist, pedagogue, reviewer, publicist. He studied at the Music Institute in Warsaw as well as in Berlin and Paris. He ran a piano playing school in Warsaw. He also lectured at the Stanisław Moniuszko Music School in Warsaw. He was the secretary of the Union of Musical and Theatrical Rapporteurs. 
Fabry. ${ }^{142}$ Mention is already made in the 'related' press. The union is aimed at professional interests, but at the same time aims to 'coordinate ideological differences, etc.' In other words, an organisation is formed which, in the mode of this very creation and personal composition, brings to mind the birth of the 'Contemporary Composers' Section. ${ }^{143} /$ I asked Wieniawski a delicate question yesterday, why I was not asked to attend an organisational meeting; the answer was that I am the rapporteur and editor of the professional magazine, and so far nobody thought of professional magazines just yet. ${ }^{144}$

This situation prompted Gliński to react immediately and establish a competitive association - 'Club of professional music press'- and invited the group of members of the organisational committee. Apart from Chybiński, who was also acting as the secretary of the editorial office of the already reborn new form of Kwartalnik Muzyczny, these included Kazimierz Sikorski, Bronisław Rutkowski who was the president of the SMDM (whose organ was the Kwartalnik), ${ }^{145}$ and Stanisław Wiechowicz, the head of the Poznan Przeglad Muzyczny. At the same time, he hoped for the professor's quick permission for cooperation, so that in the next magazine of Muzyka some 'concrete things' could be given. On 9 February 1929, after the meeting, which took place two days earlier, he wrote a letter to the editors of music magazines (including Chybiński), in which he presented the principles of the initiative sponsored by the monthly magazine, of which he was the editor-in-chief.

At the initiative of Muzyka, a nationwide Club of Professional Music Press is established with headquarters in Warsaw./The club will aim primarily to bring the Polish professional magazines closer together and to establish lasting contact with similar publishing houses abroad. In addition, the Club will have the purpose of providing professional

142 Władysław Fabry (1888-1946), Warsaw critic and publicist, music reviewer for journals Śpiewak, Polska Zbrojna. He was (together with Adolf Chybiński, Mateusz Gliński, Teodor Zalewski, Łucjan Kamieński, Janusz Miketta, Tadeusz Czerniawski and Zbigniew Drzewiecki) member of the jury of the state music award granted by the Ministry of Religious Denominations and Public Education in Warsaw.

143 The Association of Music and Theatre Speakers has been active since 1925; its co-organiser and vice-president in 1925-33 was Piotr Rytel, who at the same time in the years 1925-35 served as a member of the Board of the Polish Contemporary Composers Association. Apparently, in 1929, Fabry and others decided to narrow down the group of 'musical rapporteurs' to 'rapporteurs of everyday newspapers.'

144 Gliński to Chybiński from Warsaw 4 II 1929, AACh-BJ, box 6, G-5/91.

145 We will return to the history of SMDM below. 
support to all those working in both special and general press bodies, and to mitigate any opposition of professional and comradely nature that arise in the music press./The club will aim to bring together all professionals who work professionally in the field of journalism and music criticism in order to play the role of a serious opinion-giving institution in the musical movement of the country and exert a positive influence on the development of our musical movement./The club aims to fill a serious gap that is so far the lack of an organisation that brings Polish musical thought together. This gap is not filled by the established Association of Musical Rapporteurs, because 1) it aims only to defend professional and economic interests and 2) it was created without the participation of professional press, representing only general, daily and periodical publications. The Professional Press is not in any way to interfere with the Association of Musical Rapporteurs; on the contrary, the principles of cooperation with this organisation in the future are discussed already at the present stage./Assuming that my Dear Friend understands the importance of our efforts, want to support them with your participation, I am asking you to accept the dignity of becoming a founding member of the Professional Club of Music Press. ${ }^{146}$

Next, there were several formal questions and information about the date of the organisational meeting, February 14, in the accelerated ... mode due to the arrival in Warsaw for a short time of Prof. A. Chybiński, who already promised his cooperation in the course of the organisation. ${ }^{147}$ Chybiński himself did not appear; however, he learned the exact report from the meeting from a letter from Kazimierz Sikorski:

we talked about the 'Club.' We have come to the conclusion that the idea of associating the editors of music magazines could hardly be carried out due to the small number of actual editors and inability to invite such people who are not editors but would be desirable to us (e.g. Szymanowski, Szopski, etc.). Therefore, we propose with Rutkowski the name: 'Association of professional music magazines.' I think that we can lower ourselves to other magazines that are only 'professional' and will never be academic, otherwise, we would never be able to unite with anyone because there is no doubt that a new academic music magazine will not be created soon, equal to the level of Kwartalnik. It will only be about creating a strong organisation of music magazines for outside appearances. There is no way we can let Mr Gliński rule himself; if he thinks so, he's deeply mistaken. I think that we can agree to this form of cooperation with other music magazines and try to 'mother' them all. The future accession to the association was declared by: Muzyka Kościelna, Muzyk Wojskowy and Przegląd Muzyczny, that sent a plenipotence in the name of the professor (in Mr Gliński’s possession). We have

146 Gliński to Chybiński from Warsaw 9 II 1929, AACh-BJ, box 6, G-5/92.

147 Ibid. Letters of the same content were sent to many representatives of musicologists and music critics. 
not decided anything for now, and wait for your reply regarding Gliński's conditions (changing its name). As Rutkowski is leaving for a few weeks soon, Stanisław Furmanik will be replacing him at organisational meetings (head deep). I am asking for further instructions on how to deal with this matter. ${ }^{148}$

It is not known how this question was answered by Chybiński, we only know that at the end of February the Secretary of Kwartalnik was explaining himself to the - perhaps - reluctant attitude of the professor: '... In the latest Muzyka, ${ }^{149} \mathrm{Mr}$. Gliński announced the club of professional music as a fact already made, considering our visit as an organisational meeting. This is not true: I explicitly stated that we were speaking privately and after communicating with you, I will give an answer as what to do next. Fortunately, he did not announce the names and titles of magazines that joined this "Club," however, he acted like Herzenstein, ${ }^{150}$ not like Gliński. I told him a lot of unpleasant things about his attitude towards SMDM and the publishing house, but apparently not enough.' ${ }^{151}$

As for the details provided (or not given), Sikorski was wrong, because in the same notebook of Muzyka, just a few pages away, under the heading 'Variety. Current news', there is a note 'Consolidation of the music press' (p. 105), in which the names of founding members, 'editors of professional magazines' appeared next to Mateusz Gliński from Muzyka and Adolf Chybiński from Kwartalnik Muzyczny, and Bronisław Rutkowski and Kazimierz Sikorski, representatives of the SMDM Board, whose governing body was Kwartalnik, also: Władysław Gołębiowski (secretary of the Musicians-Pedagogues Union, editor-in-chief of the monthly magazine called Lwowskie Wiadomości Muzyczne i Literackie), Eugeniusz Dawidowicz (editor-in-chief of Grudziądz biweekly magazine, Muzyk Wojskowy), Zygmunt Latoszewski (in the years 1925-28 editor-in-chief of the Poznań monthly Muzyka Kościelna), Stefan (erroneously given: Stanisław) Marian Stoiński (editor-in-chief of the Katowice monthly magazine Śpiewak) and Stanisław Wiechowicz (from 1927 editor in chief of the Poznan Przeglad Muzyczny).

In connection with this note, there was a sharp conflict between the two associations on the line 'professional press'-'musical rapporteurs.' At the end of March, Adam Wieniawski, acting in the name of Władysław Fabry, was offended

148 Sikorski to Chybiński from Warsaw 15 II 1929, AACh-BJ, box 4, S-10/24.

149 See Muzyka 1929/2, 88, section 'Musical Impressions.'

150 In the correspondence between Chybiński and his trusted associates and friends, one can often hear the name 'Herzenstein,' which was the family name of Mateusz Gliński.

151 Sikorski to Chybiński from Warsaw 26 II 1929, AACh-BJ, box 4, S-10/21. 
by the words that allegedly fell in the March edition of Muzyka, ${ }^{152}$ sent an official letter to Gliński. He announced that the Board of the Union of Musical Rapporteurs, at the request of the publicist, designated him (Wieniawski) and Piotr Rytel as arbitrators to explain the contradictions in the relations concerning the details of establishing the 'Club.' On March 28, 1929, the newspaper Kurier Poranny published the article 'O czym powinien wiedzieć p. Gliński' [What should Mr Gliński know about], in which his author, Warsaw critic and rapporteur Zbigniew Domaniewski, recalled the words of Adam Wieniawski. Wieniawski, citing conversations with Sikorski and Chybiński, argued that: 1) they did not wish to give their names in the list of 'founders' given by Gliński as founding members of the Association, 2) they were surprised by the content of the aforementioned press reports and 3) they were firmly protesting against this situation.

In respect of these 'unjustified' charges, as Gliński claimed, he decided to report this situation to the arbitration court, relying on Juliusz KadenBandrowski and Stefan Bereza as arbitrators in the case. His representatives were Wacław Karczewski and Jerzy Gaszyński.

An open letter from the editor-in-chief of Muzyka and the minutes from subsequent acts of arbitration proceedings were published in the monthly magazine in April. ${ }^{153}$ We learn from the writings, that Kazimierz Sikorski during the meeting on 8 April with those acting in accordance with art. 60 of the Honorary Code [Władysław] Boziewicz'154 Karczewski and Gaszyński, stated that on February 14 'he declared his ideological accession, accepted the dignity of the

152 In the above-mentioned column 'Wesołe i smutne' [Happy and sad] in March 1929, we do not find any controversial statements about Fabry. Unruly jokes about the achievement of sexual maturity, which does not go hand in hand with the critical maturity of another 'rapporteur, Zbigniew Domaniewski, were to be found earlier in the February issue (p. 108); perhaps these remarks became one of the catalysts of the upcoming dispute.

153 Muzyka 1929/4, 177-181. Earlier, because in the numbers under the date of 10 April (Muzyka appeared on the twentieth of each month), Gliński also publicised the matter via two capital dailies - Kurier Polski and Epoka.

154 The honorary code based on traditional rules concerning Polski kodeks honorowy [Polish code of honor] (Cracow 1919), publication on honourable conduct, including duelling. Section 60 of the Code read: 'Unless it is certain whether the insulting person was actually going to insult the defiant, he should ask for one, if possible, mutual friend who would ask the insulter to explain the words or dubious acts. If the intention is stated, the 24-hour time allowed to the offended person to the challenge counts from the moment that the mutual friend informs him about it.' 
founding member and continues to participate in the organisational work of the "Club ..." 'and, in addition, representing 'on behalf of prof. A. Chybiński ... never protested against the alleged abuse of his name' and 'never asked anybody for advice or asked for intervention in order to protest against the given fact.' He also told Gliński that Chybiński 'withdraws all reservations, marked by letter. ${ }^{155}$ The only objection he had was to replace the verb 'arose' with his imperfective form ('arises') because in the middle of February the initiative was merely a proposal and was only implemented. On the other hand, Sikorski claimed that 'having arrived at Wieniawski's office, he expressed his surprise and indignation because of Mr. Gliński's note ... about the fact of the establishment of "Club of Professional Music Press" and asked Mr. Wieniawski, in what form "The Union of Musical Rapporteurs" could protest against this fact.'

According to one of the attached documents, Karczewski and Gaszyński went to Adam Wieniawski to clarify the case, but they did not find him that day (April 7) or the next, and therefore they wrote only the report of their efforts, passing it to arbitrators. The consequence of these activities was Wieniawski's letter, in which, as the chairman of the Union of Musical Rapporteurs, he stated that: 'Not being subject to the arbitration court ruling, based on customary rules unknown to the Board, we declare readiness to become acquainted with the evidence in the possession of the principal of the honourable gentlemen and those who may, in his opinion, completely display the matter - that is why we invite the honourable gentlemen, as the plenipotentiaries of Mr Mateusz Gliński, to the meeting of the Board of the Union of Musical Rapporteurs on 26 April of the year. ${ }^{156}$

Finally, assuming that Gliński had grounds to include the names of Chybiński and Sikorski among other names of supporters of the new organisation, the matter was considered clarified and settled, although - perhaps as a result of Chybiński's suggestion - Sikorski, however, filed on 12 April 1929 the dignity of the member-founder, which was also reported in the pages of Muzyka in the April edition. ${ }^{157}$

155 The fact that Chybiński favoured the initiative was also to be proved by the words about the many years of fruitful cooperation between the Warsaw editorial office and the professor. Gliński wrote: 'I think it is advisable to add that prof. Chybiński is a co-founder and one of the most active co-editors of Muzyka, where from the bright and efficient co-operation the scripture is used until the last moment,' see Epoka 1929, 10 April, 6.

156 Letter of the Board of the Union of Music Speakers from 23 IV 1929, quote from Muzyka 1929/4, 180.

157 Muzyka 1929/4, 181. 
Despite the described circumstances, work on the organisation of the 'Club' gradually progressed more and more efficiently, also thanks to the fact that the majority of members of the Statute Committee lived in Warsaw and were in constant contact with each other. In the following months, it was decided that the organisation could gather not only editors and collaborators of music magazines but all those who wrote about music. ${ }^{158}$ Initially, the organisation's assumptions were included in a few simple guidelines: 'focusing professional Polish musical thought, establishing mutual communication between employees in this field, representation of professional magazines both in the country and abroad, establishing close contact with the entirety of our musical movement.'.159 The formula of the organisation over the next few months reached and changed, evolving to a significant extent, which can be read from Gliński’s following letters. It was established, among others, that:

1. Not only editors and collaborators of music magazines can be members, but all who write about music, regardless of whether their activities are professional or connected with a permanent position of a music commentator./ 2. The basic condition for admission will be the possession of appropriate professional and ethical qualifications./ The new organisation encompasses slightly wider goals than those initially intended by the initiators of the 'Club of professional music press' and will strive not only to bring the journalists closer together but also to create the most favourable conditions for the development of music press and raise the level of criticism./ The new organisation's wide range of goals encouraged the founders to change the name ([from] 'Club of Professional Music Press') to 'Music Press Union' and to base their activities and reason to be in the constitution. Creation of the constitution was entrusted to the Commission, made up of the following members: prof. $\mathrm{dr}$ Łucjan Kamieński, prof. Stanisław Niewiadomski, dr Alicja Simon, Karol Stromenger ad editor Mateusz Gliński. ${ }^{160}$

Of course, he also invited (perhaps even above all) Chybiński ${ }^{161}$ to the Statute Commission. Unfortunately, the professor ignored this invitation, although previously he had undoubtedly expressed his opinion on matters related to details, including even the name of the group - he had reservations about the

158 See Muzyka 1929/6, 346.

159 'Konsolidacja prasy muzycznej' [Consolidation of the music press] (Muzyka 1929/2, 105-106).

160 Gliński to Chybiński from Warsaw 19 VIII 1929, AACh-BJ, box 6, G-5/102.

161 See Gliński to Chybiński from Warsaw 6 VII 1929, AACh-BJ, box 6, G-5/101. 
term 'press,' ${ }^{162}$ he considered it obligatory to add the term 'Polish.' In general, the editor of Muzyka appreciated all the remarks, though, as it turned out, he did not follow all the suggestions. For the moment, however, he emphasised how grateful he felt that 'thanks to the professor we left our intentions in the wider field and became a more serious organisation than the one we initiated previously.' ${ }^{163}$

Eventually, the Association of Music Writers ${ }^{164}$ and Critics was registered on 12 October 1929, and members of the temporary board were entered into the Association's statute, including members of the statutory committee: Mateusz Gliński, Łucjan Kamieński (who, incidentally, according to Gliński’s words, supported him most during the months pre-registration), Stanisław Niewiadomski, Karol Stromenger and Alicja Simon. The goals of the activity were presented: 'focusing on working in the field of Polish music literature, creating the most prosperous conditions for its development, striving to maintain a high professional and ethical level, defending the interests of those working in its scope and providing them with both moral and material support.' ${ }^{\text {'65 }}$

The means to achieve these goals were defined very broadly and not always precisely. The creation of sections and local branches was planned, organising reading rooms and discussion clubs, conferences, lectures, music programmes, magazines and newsletters, 'publishing all kinds of publications', cooperating with similar associations abroad, representing members of the Association in official situations, resolving conflicts within the environment, awarding various types of scholarships and awards, and - which seems particularly vague 'establishing contact with publishers, in order to fill important institutions in the music literature by qualified forces.' ${ }^{\prime 66}$ In the letter addressed after registration

162 'in the event that the name "Press" seemed so wrong that in the event of its maintenance, the Professor would not consider it possible to remain a founding member of the organisation, I am asking for immediate notification. Clara pacta [claros] faciunt amicos; we would avoid all misunderstandings,' see Gliński to Chybiński from Warsaw 24 VII 1929, AACh-BJ, box 6, G-5/103.

163 Ibid.

164 For the term 'Music Writers,' Gliński himself had reservations previously, 'it seems to me that the word "Press," although inaccurate, will eventually last, even though we all understand the meaning of the Professor's remarks. How else to write: "Publicists"? wrong ... "Musical writers" - even worse. It seems, however, that this compromise name will not hurt, because in fact today, with the Kwartalnik uprising, all those who write about music are part of an active press army', ibid.

165 Statut Stowarzyszenia Pisarzy. . . [Statute of the Writers' Association], Warsaw 1929 (without pagination).

166 Ibid. 
to Chybiński and sent to Lviv, the Association Board, anticipating the likely objections of the professor (and possibly also the editors of other periodicals), emphasised:

The ideological bases of the statute were based on the fundamental theses, referred to in the above-mentioned journal editor of Muzyka; ${ }^{167}$ the only change that we have allowed to introduce is the change in the name of our organisation, made as a result of the opposition of several founders (including Prof. A. Chybiński and Prof. Ł. Kamieński) and due to some objections in this regard from the Commissariat of the Government. Because this change had to be made in such a short time, the possibility of a letter agreement with the honourable Mr Editor was completely excluded. We ask politely whether the change of the name of our 'Association' will not cause an objection from you, sir, and whether you will not change your relationship to a new organisation, which on the basis of past cooperation counts you, sir, [to] the group of its co-founders. To avoid any misunderstanding, please kindly inform us immediately if there are any objections in this regard. ${ }^{168}$

In the following months, relations between Gliński and Chybiński clearly deteriorated; although they still corresponded with each other, it was not as often as before. The professor expressed 'disinclination for the publishing house $[M u z y k a]$ and its editorial staff,' ${ }^{169}$ accusing them of treating musicology improperly on the pages of the monthly magazine. Gliński defended himself by saying that he is not a musicologist, but he has respect for music. It should be added here that this unrelenting exchange of opinions resulted indirectly from the fact that there were ongoing polemics between the heads of two Polish musicological centres, especially on the subject of priorities in Polish musicological research and poor relations in the environment, polemics, whose arena was, amongst others, Myzyka: Chybiński expected loyalty, but Gliński - according to always verbalised rules - considered it natural also for Jachimecki ${ }^{170}$ to use the impartial pages of the magazine.

In a few letters from 1930 there was a kind of 'cease-fire': In July, congratulations were sent from Warsaw to Lviv in connection with the professor's jubilee and a memorial book published on this occasion, less than two months later, Chybiński's new article, 'O zadaniach historycznej muzykologii w Polsce' [On the tasks of historical musicology in Poland ${ }^{171}$, came to the editorial office. Towards

167 See the previously quoted letter from July 19, 1927 (note 25).

168 Gliński to Chybiński from Warsaw 12 X 1929, AACh-BJ, box 5, S-5/1.

169 See Gliński to Chybiński from Warsaw 7 III 1930, AACh-BJ, box 6, G-5/109.

170 See Jachimecki 1931.

171 Muzyka 1930/10, 587-595. 
the end of 1930, two resolutions were published in Muzyka; the Association of Polish Composers and the Association of Musical Writers and Critics. In the second one, it was stated openly that the National Culture Fund should support and 'maintain close and friendly contact with the entire Polish musical world', rather than 'to only focus on one field and be closed within one circle of any chosen organisation,' implicitly - beyond the control of public opinion on the distribution of financial resources. ${ }^{172}$ At the same time, the Ochlewski contra Stromenger case went to the arbitration court of the Association due to the dispute over unequal financing of private institutions from the National Culture Fund - at that time, a large part of the Warsaw music community was convinced about the cronyist relations between the founders of the SMDM and Stanisław Michalski, the director of the Fund, and openly criticised it. Ochlewski's strong reaction was a result of Stromenger's offensive publication about $\mathrm{SMDM}^{173}$ written on the pages of Gazeta Polska on November 1. In the article Stromenger talked about unclear accounts of the Association's finances, providing unjustified foreign scholarships from the FKN and other irregularities. The President of SMDM referred to these and other allegations in an official letter to the author of the article. ${ }^{174}$ On the subject of WDMP: it is necessary to read about what professionals and educated musicians are writing about this publication before writing articles without knowing things about these matters. To question the necessity of publishing valuable old Polish works, manuscripts that can be found in foreign libraries - can be only the enemy of Polish culture'; about the work of the SMDM Board: 'Any jokes about "feathering, which was supposed to be proof of their work" towards the Board of SMDM, that eagerly and selflessly devoted to work on this neglected episode - are an ordinary filth that cannot touch us'; about the 'pillars' of the Association: 'About prof. Chybiński, a highly deserving Polish scholar, valued by the scientific world in Europe and about prof. Sikorski, a musician of high education, they should not take on a cheap joke, given voice by dilettantes for whom the level of the Kwartalnik Muzyczny is too serious and professional. All the more, after the fact where we have discredited ourselves of any content with dilettante article ... about Bach's Brandenburg concertos'; ${ }^{175}$

172 Muzyka 1930/11-12, 698.

173 Stromenger 1930/1.

174 Ochlewski to Stromengera from Warsaw 2 XI 1930 (copy), AACh-BJ, box 1, O-1/46 (attachment).

175 See Karol Stromenger, 'O koncertach brandenburskich J.S. Bacha' [About J.S. Bach's Brandenburg concertos] (KM 1930/5, 14-18). Just a few months earlier, Chybiński adopted Stromenger's text at Ochlewski’s explicit request, as can be read in Zalewski 1977 (p. 11). 
finally, as a summary: 'You can fight to defend your ideas and criticise impartially, but losing ethics based on lies, slander and falsehood is probably enough reason for me to forget about my relationship with you. You can slander what is better - after all, it's your profession. Mine is of a different kind. So I hope we will not meet. ${ }^{317}$

And so, the earlier publication of Stromenger and the above words by Ochlewski (as a representative of the group of SMDM members) meant that any cooperation between the earlier supporters of the idea of the 'Club of professional music press' became impossible. The dispute continued to develop against the thinking of SMDM, as they wrote to Chybinski: 'The Board of the SPKM rejected the impartial court of arbitration proposed by Mr Ochlewski and only allowed Mr Ochlewski to send his representative to the court for explanations. Of course, we did not find such a proposal acceptable. ... In the current state of affairs, we have decided to authorise our president to take a court injunction against the author of a slanderous article. ${ }^{177}$

Gliński did not officially approve of either side, and Chybiński probably expected such a declaration. That was the reason why at the turn of 1930 and 1931 the conflict between them was already deep enough, or maybe the professor with his uncompromising character - decided to sharpen it, ${ }^{178}$ that he gave his membership card back to Gliński, who was the president of the Association of Writers and Music Critics, with the message of resignation from membership. By signing up on behalf of the Board, Alicja Simon and Stanisław Niewiadomski confirmed the receipt of the ID 'delivered via the editorial office of the journal Muzyka' and informed in the return letter about the deletion of the professor from the list of members on January $24 .{ }^{179}$ Gliński also took note of this decision, which he informed the professor in writing. In the same letter, he loyally warned about the planned publication of the correspondence sent from Cracow by Zdzisław Jachimecki, constituting another voice in one of many sharp discussions (this time about the principles in Polish musicology ${ }^{180}$ conducted in the interwar period between the 'fathers' of Polish musicology: In the January issue there will be a replica of prof. Jachimecki, which is an answer to your article

176 Ochlewski to Stromenger from Warsaw 2 XI 1930, ibid.

177 SMDM to Chybiński from Warsaw 20 XI 1930, AACh-BJ, box 5, S-3/11.

178 One should always take into account Chybinski's chauvinistic views, which in those years seemed to intensify.

179 Association of Musical Writers and Critics to Chybiński from Warsaw 28 I 1931, AACh-BJ, box 5, S-5/2.

180 Jachimecki 1931. 
on Polish musicology. Anticipating the effects of this article, I have been holding up presenting it for a long series of months, then, after making some changes in it, I asked to soften some of the content; I received a response that I can print it on the author's total responsibility, i.e. Mr Professor's. Therefore, currently granting, under the total impartiality of Muzyka, to Mr Jachimecki, who also speaks with his article "on his own responsibility," I consider it advisable to ensure that I personally completely withdraw from this musicological "exchange of views," but with all my loyalty, I will put your answer to prof. Jachimecki's accusations. I have no preconceived judgements, no sympathy, no obligations and no goals or personal interests in this case. ${ }^{181}$

After this letter, the correspondence between two editors - Kwartalnik Muzyczny and Muzyka - actually froze, also in matters related to the activity of the Association, and we do not have other reports regarding the achievements of the institution itself in the following years. In the archives of Chybinski that were kept in the Jagiellonian Library, eight letters from Gliński from the prewar period are preserved, in which his distance to the conflict is striking and, nevertheless, respect for the man who for many years was his authority. After the war Gliński, as we mentioned, refreshed his contact in 1950 when he wrote to the professor 'after long years of pause ... under the fresh impression of the beautiful volume of Chopin's Analyses sent here [to Instituto Internazionale Federico Chopin in Rome] by PWM.'182

At least some of the people associated in the 'Club, or related to the case in different ways, had already been engaged in the project, which was supposed to support the achievements of young Polish artists and combine the most progressive part of the music and musicological community with the European avant-garde. This is about PTMW (based in Warsaw), whose registration took place even before the fifth anniversary of Poland's regaining its statehood, in 1923. Let us remember that in the summer of 1922, after a series of contemporary repertoire concerts organised in Salzburg by Universal publishing house, Rudolf Réti and Egon Wellesz proposed on the international forum to set up a company with the primary aim to promote the latest trends in music. Music festivals were to become the platform for the confrontation of current European and American music. At the first of them, in Salzburg in 1923, Karol Szymanowski was invited to perform on the festival stage and sent two of the Hafiza Songs. A few months

181 Gliński to Chybiński from Warsaw 28 I 1931, AACh-BJ, box 6, G-5/118.

182 Gliński to Chybiński from Rome 3 II 1950, AACh-BUAM, fol. D-J, p. 209 (see also the letters under the date 16 VIII (p. 214) i 4 X 1951 (p. 215)). 
earlier, a letter from Stefania Różycka, wife of Ludomir Różycki, was sent to Adolf Chybiński, in which the author of the note communicated: 'I do not know if you know that an international music committee that has appointed all the nations of the world to form a national committee, has been created in London. ... Every year there will be a congress and music festival in different cities, each section must send its delegate. ... from London, they ask me to send the widest possible material about the latest creations of Polish music. ${ }^{383}$ Redirecting this information to Karol Szymanowski, Chybiński, in a typical biting tone, wrote to the composer: 'I want to hear your opinion immediately. Answer me immediately, because one day's lateness can make a difference. You must enter the Polish committee, as long as Poland's good is in your heart. I am offering you a praesidium for your sake and your relations abroad. Do not pay attention to that monkey (between us!) who wants to do something on his own!'184

When the ISCM festival was held in Prague a few months later, he was already present in the group of 'delegates' - next to, among others Szymanowski and Grzegorz Fitelberg - as was Mateusz Gliński, a young musician and music critic at the time, and soon the founder and long-time editor-in-chief of Muzyka, and a musicologist from Poznań, a graduate of the University of Berlin, soon the head of a new musicological centre in the capital of Wielkopolska, Łucjan Kamieński. During the festival, the participants of this trip formed the Polish Section of the Society, and the creator of Stabat Mater ${ }^{185}$ became (for now) informal president in the provisional management of PTMW; Gliński was the secretary. Immediately after group was formed, from Prague, with the date of June 1, its founders addressed Adolf Chybiński as a well-known and recognised head of one of the first two Polish musicological centres, and a letter that contained information about this fact and an invitation to participate in the Executive Committee was signed by Gliński and Kamieński:

On June 1, 1924, at the general meeting of representatives of Polish music, present at the festival of the International Society for Contemporary Music, held under the chairmanship of prof. dr. Łucjana Kamieński, the Polish section of ISCM was established. The Section Board was composed of: KAROL SZYMANOWSKI - chairman, prof. FELICJAN SZOPSKI, prof. dr ŁUCJAN KAMIEŃSKI, deputies, MATEUSZ GLIŃSKI,

183 Różycka to Chybiński from Warsaw 5 III 1923, see Szymanowski II / 1, 529-530 (attachment in note 2 to the letter of Adolf Chybiński to Karol Szymanowski from Lviv from 8 III 1923).

184 Chybiński to Szymanowski from Lviv 8 III 1923, see Szymanowski II / 1, 528.

185 On the presence (and absence) of works created by Polish composers at MTMW festivals see Chłopecki 2007. 
secretary. Position of the treasurer - vacant. Both the organisation of the Section and the election of the Board were held in close consultation with the ISCM Headquarters and the Delegates present at the festival.... By notifying the above-mentioned Dear Sir, I turn to him at the same time, in accordance with the resolution, adopted at the organisational meeting on 1 VI of this year, with a warm request to support the action that has already started, by kindly taking part in the Executive Committee of the Polish Section of the ISCM. Knowing the sympathetic attitude of Dear Sir to ISCM, which could be proved by Mrs Poraj-Różycka, resignation of the Dear Sir to the temporary organising committee, we believe that the Dear Sir will not refuse his support, which may be of great importance for the Polish contemporary music movement. ${ }^{186}$

The temporary management board decided to organise the first General Assembly of the Section. Adolf Chybiński, probably as one of many potential future members, received a letter dated September 20, 1924:

The Secretariat of the Polish Section of the INTERNATIONAL SOCIETY FOR CONTEMPORARY MUSIC hereby informs the Honourable Gentleman, that the first General Meeting of the members of the Section will be held at the CONSERVATOIRE OF WARSAW (Meeting Room) on September 29 at 4:00 PM on the first date and at 4.30 $\mathrm{PM}$ on the second date (valid for every number gathered). Because of the importance of matters to be discussed, the presence of all members is highly desirable. This notice serves as an entry card. ${ }^{187}$

During these first sessions, after Karol Szymanowski presented the history of the initiative, and through Mateusz Gliński's report on the previous several-month activity, it was decided to approve the previously prepared Statute and to construct a new Management Board. Its members included: Karol Szymanowski as the president, Felicjan Szopski and Łucjan Kamieński as vice-presidents, Mateusz Gliński as secretary, Zbigniew Drzewiecki as treasurer and Adolf Chybiński and Emil Młynarski as deputies of the Board members; in addition, Grzegorz Fitelberg, Henryk Melcer, Henryk Opieński and Ludomir Michał Rogowski took part in various Commissions. ${ }^{188}$ With time, on the occasion of the next General Meetings, the Boards were changing: first of all, from 1930 Szymanowski became the honorary president, and Zbigniew Drzewiecki held his place until 1939, with the exception that Stefania Łobaczewska was there for one term of office. Almost to the end of this period, Mateusz Gliński sat in the close circle of the Society's members.

186 Gliński and Kamieński to Chybiński from Prague 1 VI 1924, AACh-BJ, box 5, S-1/1. 187 Gliński to Chybiński from Warsaw 20 IX 1924, AACh-BJ, box 4, G-5/1.

188 Muzyka 1924/1, 46-47. 
Over the next two years, contemporary music enthusiasts acted informally, although work in the section was ongoing: Polish compositions were submitted for the next editions of the festival, delegates from Poland took part in the proceedings of the national sections, they were elected to international bodies Szymanowski was invited to the international jury deciding on the program of the Zurich festival, Gliński became a member of the committee of the newly created ISCM newsletter. Moreover, for the first few years regularly, and from 1928 many times - with only sporadic exceptions - Gliński was a delegate of the Polish Section for annual international festivals. Finally, however, the situation of the Polish Section had to be formalised and in the autumn of 1926. Chybiński, in a note to one of the letters from Warsaw, received the message: 'PS. More news. We legalise the Polish Society for Contemporary Music urgently, and we will probably develop intense activity. It would be good for the Professor, a member of the Board, to think in advance about the people of Lviv, from which the Lviv section of the Society will be organised.'189

The association was incorporated into the register of associations and unions on February 21, 1927. According to point 2 of the paragraph, its founders were: Zbigniew Drzewiecki, Mateusz Gliński, Felicjan Szopski and Karol Szymanowski, whose main aim was to 'support contemporary music' (paragraph I point 4). To achieve this goal, the Society could conduct educational and propaganda activities, participate in international musical life in the field of activities similar to its own, and also 'publish music and books and magazines, support and distribute its own publications as well as foreign' (paragraph I point 5.). ${ }^{190}$ The recruitment and selection of real members seemed a very delicate matter, which Gliński, in confidence, explained bluntly to Chybiński: 'PTMW has not yet started the correct "recruitment" of members. This issue is very irritating due to the necessity of applying appropriate criteria and limit access to the Society for the "mobs." The elite of contemporary Polish musicians cooperates with us together about 20 musicians. ${ }^{\text {.191 }}$

When, after a few years, the Society entered a period of marked crisis and stagnation of the number of 'music lovers' interested in contemporary music in general, and being part of the Polish Section ${ }^{192}$ in particular, an action was launched

189 Gliński to Chybiński from Warsaw 1 IX 1926, AACh-BJ, box 4, G-5/53.

190 See Statut PTMW 1927.

191 Gliński to Chybiński from Warsaw 22 VII 1927, AACh-BJ, box 4, G-5/67.

192 I am talking about supporting members that could have been all those who would like to declare a specific annual contribution to the Association. 
to popularise the new creativity under the slogan 'Mobilizacja Miłośników Muzyki' [Mobilisation of music lovers]. New members were actively sought. The membership card authorised many discounts in the field of current cultural life, and the upcoming ranks could additionally count on a copy of the Muzyka monthly. ${ }^{193}$

Muzyka, a monthly magazine founded and run by Mateusz Gliński in exactly the same moment in the middle of 1924 when the decisions on the separation of the Polish branch of ISCM from the international structures were developing. It was - at least in the first years of cooperation - to some extent an informal part of the Society, although the editors stipulated that 'the monthly ... seeks to join all healthy currents of our musical life under the slogan of culture and progress. It does not belong to any camp, to any party or coterie. The interest in modern musical trends is combined with pietism for the past and respect for every serious artistic effort, ${ }^{194}$ and the secretariats of both institutions for some time acted under the same private address of the editor and secretary as one person.

In the mid-1930s, fulfilling the Statute on the promotion and dissemination of publications, PTMW cooperated with the thriving TWMP, even moving its headquarters to the address of the publisher. As part of the reorganisation, as one of several, a publishing section was preparing a newsletter called Contemporary Music. Cooperation with the publishing house also in the organisation of the current musical life resulted in the revival of stage activity, concert halls were filled with listeners (which resulted with good reviews from contemporary music concerts in the Warsaw press), and also the first editions of works by young Polish composers. ${ }^{195}$ At that moment, Mateusz Gliński both in the structures of PTMW, as well as in terms of the contents of the magazine he had edited for over ten years, clearly began to place himself on the edge of the environment associated with new music. This was maybe because, on the one hand, he could not sufficiently mobilise the provinces to work for the Society, and on the other hand, he did not develop enough loyal back-up facilities in the local circles that undertook the work. To the question about the branch's activities that was asked by Chybiński several years earlier, in one of the letters he replied: 'PTMW has no branches in the provinces. There was only an initiative taken in Vilnius in this

193 More on this subject in Muzyka 1932/12, 329, 'Kronika' [Chronicle].

194 'Od Redakcji' [Editorial] (Muzyka 1924/2, cover).

195 In 1937 TWMP published scores for the symphonic poem Żolnierze [Soldiers] by Michał Kondracki (1932) as well as Taniec $z$ Osmoły [Danse from Osmoła] by Roman Palestra (1932). 
direction (Tadeusz Szeligowski), even one concert took place under our emblem. The Lviv section will be the first section, which I think corresponds to the level of modern music culture in Lviv. I must add that I informed the Headquarters about the establishment of the Lviv section at a meeting of delegates on the first of this month in Frankfurt and this announcement was met with great recognition.' ${ }^{396}$

Among the 'people of Lviv' there was a large group, which in a relatively short time managed to organise a thriving centre, with initiatives that were equal to almost the activities of the headquarters in Warsaw. On February 28, 1930, the chairman Zbigniew Drzewiecki attended the constitutional meeting of the branch of the Lviv-based PTMW. The following people were elected to the local Board: musician and musicologist, director of the Lviv PTM and conservatoire Adam Sołtys (as president), two local musicology graduates Stefania Łobaczewska (vice president) that was a secretary and treasurer - Zofia Lissa, and members - Seweryn Barbag (composer and musicologist, formerly a pupil of Guido Adler), Józef Koffler (also a 'Viennese' musicologist and composer as well as a music journalist), Zofia Kozłowska (pianist and singer, pedagogue in vocal studies) and outstanding pianist Leopold Münzer. As Łobaczewska wrote in Muzyka, 'Creating [the Lviv branch] has long been an urgent need of the cultural spheres of our city, deprived of constant contact with new art, the best proof was the great interest in the first broadcast of the Lviv Branch of the PTMW on the fifth of this month.'197

Just a year later, the next general assembly of the Lviv branch elected the new Board, lead by Łobaczewska, and in addition to the re-elected Münzer and Barbag, it also included: Zofia Drexler-Pasławska, Janina GrzegorzewskaLachowska, Tadeusz Majewski and Adam Szmar. However, the issue of honorary presidency seems unclear. In 1930, this title was given to Adolf Chybiński, from the accounts of 1931, we learn, however, that Adam Soltys was honoured this time. Could this dignity not be given forever? There is no doubt that Chybiński did not want to get involved in the works of the Lviv committee, but perhaps he was expelled from the circle of the Lviv Society by the younger generation, which would be painfully felt. In any case, the trace of his assessment of the situation can be found in the words strongly emphasised in one of the letters to Ludwik Bronarski: 'There are different young and the youngest musicologists of various religious denominations and various public testimonies, that are for setting

196 Gliński to Chybiński from Warsaw 22 VII 1927, AACh-BJ, box 4, G-5/67.

197 Stefania Łobaczewska: [correspondence] 'From opera and concert halls. Lviv' (Muzyka 1930/4, 244). 
up the section of the contemporary music Association in Lviv. Let it be! ... Actually, I would support this interest, but it is these founders who are simply demonstrating against earlier music, despite having - thanks to studying under me - theses from earlier music, and they are supposedly advertising these theses whenever, wherever they like.' ${ }^{198}$

Similarly, he reacted to another invitation, this time four years later, to the next local association, whose animators were, among others, enthusiasts Lissa and Łobaczewska who were actively acting on various fields in the Lviv environment, focusing particularly on contemporary music. They were prominent representatives of the Chybiński school, but through their emancipated (in scientific terms) attitude conflicted with their master. Moreover, as often happened in the professor's case, the decision was influenced by his chauvinistic beliefs, which pierces almost every word of his: 'In Lviv, a "Society of Composers, Performers and ... Musicologists" is being established. For this reason, I have nothing to do with it, because such "cooperation" seems to me illusory and consists of some confusing concepts: art and science - like Warsaw's model. These various musicological madams here, "chasing after the feather," as someone has said, always establishing something new. ${ }^{199}$

For the work of Adolf Chybiński, these ideas, more or less successful, no longer had much significance, first of all, because for him, the synonym of 'contemporary music' was the work of composers who began their creative career at the beginning of this century. On the subject of the latest trends, the works of Honegger, Hindemith, and composers of the Viennese school, he did not undertake a scientific discussion, and it seems that he was closer to opinions similar to those expressed in a letter to him from Łucjan Kamieński, reporting his impressions from the musicological congress in Vienna:

Every [composer] discovers America, but in his imagination. Instead of tonics, a falsehood will be written, he will divide the scale into a quarter or 78 semitones and then is considered a genius. Learn? for what! I was also at some opera of this Hindemith or what the Jew is called. Think about it, the bandmaster waving and waving with a truncheon, people are waiting, and this rabble in the orchestra tunes and tunes and cannot tune in properly. The singers roar their kilometre long coloraturas ... they roll their arms and legs, and here - nothing; they keep tuning, and after two hours they finally reach the tonic - and the end! What a worry those poor atonalists have, to get to what our grandparents already know in diapers. ${ }^{200}$

198 Chybiński to Bronarski from Lviv 15 III 1930, AACh-BUAM, Bronarski's archive, p. 34. 199 Chybiński to Bronarski from Lviv 4 V 1934, AACh-BUAM, Bronarski’s archive, p. 112. 200 Kamieński to Chybiński from Poznań 25 IV 1927, AACh-BJ, box 6, K-3/35. 
Soon, after the lovers of contemporary music began to act institutionally, Polish musicologists also began to think about joining a separate association, which was somehow the result of initiatives taken in international societies. In the spring of 1927, during the Beethoven congress in Vienna, after several years of a break, the Internationale Musikgesellschaft resumed its activity, so a few months later they could adopt a less artistic and more scientific perspective under the name, Internationale Gesellschaft für Musikwissenschaft/Sociéte Internationale de Musicologie. As part of this organisation, the Slavic Musicological Union emerged, in which Łucjan Kamieński, then-current head of the Department of Musicology in Poznań showed his interest by founding the Polish Section. ${ }^{201}$ As described by Kamieński, the Slavic section was formed in the act of protest against the marginalisation of musicologists from outside the main European centres - German and French - placing their speeches at the end of the debate. On the initiative of Czech musicologists, the representatives of the then Yugoslavia, Russians and two Poles - Kamieński and Opieński joined the organising committee and the provisional board of the new association, the second one - as he lived permanently in Switzerland - with the proviso that he would pass his mandate to somebody else (implicitly - due to the respect he was given and the position of the Nestor among musicologists - Adolf Chybiński). The president was the founder of the first Czech department of musicology (in Prague) Zdeněk Nejedlý. The plans for the new organisation included publications of 'monuments' and the editorial office of the quarterly. The first Slavs' meeting was to take place in May 1928 in Poznań. On the other hand, relations with an international society were to depend on the course of the talks: 'As for the Polish section of the "Slavic Society," I really think that it should be considered primarily as the "Towarzystwo Muzykologiczne Polskie" [Polish musicological society], and

201 Zdzisław Jachimecki, Adolf Chybiński and Maria Szczepańska also planned to go to the Beethoven congress, but this did not happen. However, Henryk Opieński was there. After returning from Vienna, Kamieński criticised the course of the congress very critically, and it can be seen that he had at least a cautious attitude to the new research methodologies presented there. He wrote: 'it was poor. A few of the elders, like Mr. [Peter] Wagner, did indeed give something positive, but mostly - and the majority were young people - feuilleton fairy tales. ... I believe that not only music but also musicology has fallen ill with war psychosis. They are doing something there, some spiritism, dialectics, revisions of bricked, unshakable methods - dung, dung, without justification or accuracy. It's not science anymore. Everyone discovers America, but in his imagination ..., see Kamieński to Chybiński from Poznań 25 IV 1927, AACh-BJ, box 6, K-3/35. 
whether it will adhere to the "Sociéte" at all, may depend on the relationship of Nejedlý, which I will demand. ${ }^{202}$

Over the next few months, Nejedlý managed to win one place for the Union Slave member of the Directorate of the international society, which in the meantime he took. As is clear from the accounts, he 'fiercely fought' for the postulates of all Slavs. However, it soon turned out that cooperation between the members of the Union was not going well. A group of several musicians quite quickly invited to talks by Kamieński from Polish branches, decided at the first meeting in February 1928 to establish an independent, Polish National Musicological Society (PTM), so that in the international arena the interests of the Polish environment could be represented without pressure from foreigners.

On February 4, 1928, a meeting took place at the Warsaw headquarters of the Institute for Supporting Science - the Józef Mianowski Fund, or rather a meeting of musicologists during which PTM was established. ${ }^{203}$ This fact was even reported by the daily press: 'The newly formed [musicological] society is the first attempt at organising Polish musical knowledge, knowledge represented by three university departments and a whole range of serious employees, who at the time of lack of a proper environment, their efforts had to be distracted by various other scientific corporations or popular publications, with obvious detriment to the development and influence of musicology itself. The centring of these efforts is, therefore, a significant fact, not only from a scientific point of view but also for the whole musical and cultural life in Poland. ${ }^{204}$

The Polish Section of Internationale Musik-Gesellschaft was supposed to connect the communities of the main national science and music centres. According to published announcements, 'The Statute of PTM [put first] in the organisation of strictly scientific work (in the form of publishing houses, scientific meetings, conventions) and representation of Polish musicology on the international forum, and also [to] include in the Society's tasks "to intensify the influence of musicology on practice, education and writing in the Polish-Lithuanian Commonwealth”'. ${ }^{205}$ Eucjan Kamieński wanted to encourage

202 Kamieński to Chybiński from Poznań 3 XII 1927, AACh-BJ, box 6, K-3/42.

203 Details of three years of PTM's activity can be found in the letters from Eucjan Kamieński preserved both in AACh-BJ and AACh-BUAM (folder with PTM materials, here, among others, a notary certified statute with the signatures of the aforementioned persons (p. 3-5), a list of active members dated June 1929 (p. 21), applications to the PTM Court (p. 22)). See also Michałowski 1979.

204 Przegląd Muzyczny 1928/2, 11 ('Różne' [Varia]); see also Kurier Poznański 1928/72, 8. 205 Ibid. 
and invite musicologists working not only in the academic circles of musicological centres - Cracow, Lviv and Poznań - but musicologists from all over Poland to cooperate with him. Only three people came from Lviv to meet on 4 February: Seweryn Barbag, Bronisława Wójcik and Maria Szczepańska (arriving with friendly but abstemious support for the initiative from Adolf Chybiński). Although initially Chybiński himself referred to Kamieński’s idea sceptically, in time both he and his associates in the Society were actively working (Chybiński even became one of the vice presidents).

The following signed under the Association's Statutes: Bronisława Wójcikówna, Seweryn Barbag, Maria Szczepańska, Melania Grafczyńska, Wacław Piotrowski, Łucjan Kamieński and (on behalf the Circle of Students of Musicology in Cracow) Maria Chmielikowska. A date was also made for the second meeting - February 14 of that year - during which the composition of the Board was chosen in absentia. This group includes all three leaders in Polish musicology: Łucjan Kamieński (Poznań) - president, Adolf Chybiński (Lviv) vice president, Zdzisław Jachimecki (Cracow) - vice president; Bronisław Wójcikówna (Lviv) became the secretary, Wacław Piotrowski (Poznań) - treasurer; in the Audit Committee and Court of the Society, Fr. Wacław Gieburowski and Kazimierz Zieliński (both from Poznań) and Lviv, Seweryn Barbag and Stefania Łobaczewska.

The fact that the members of the Board represented such geographically distant centres strongly hampered running communication and daily functioning of the Society, which may have provoked Chybiński to try to dominate the group and become more involved in the launch, already in the middle of March, of the Lviv branch: Adam Sołtys became his deputy, Maria Szczepańska secretary. Meanwhile, in the Statute as the headquarters of the institution declared Poznań, as did the court registration (incidentally completed more than a year later, on June 12, 1929). ${ }^{206}$ But almost from the beginning, there were doubts about this location. On March 8, 1928, only three weeks after the formation of the Board, Bronisław Wójcikówna wrote to Maria Szczepańska: 'In the last letter, our President, prof. Kamieński, wrote that together with other Poznań musicologists they came to a consistent conviction that the headquarters of the Polish Musicological Society should be in Lviv. They have their reasons, which cannot be denied apart from one maybe, that if we start our publications this

206 The registration formalities stretched out for many months. The first letters to potential members were sent over half a year earlier, in October 1928 (notary public M. Koszewski to Chybiński from Poznań on 11 X 1928, AACh-BUAM, from K- $€$, p. 6). 
year (either separate academic papers or academic journals), they will naturally emerge in Lviv as a place where a current secretary resides and is the one who will run the publishing agencies. ${ }^{207}$ Two years later, president Kamieński saw this situation slightly differently: 'Bronka [Wójcikówna] thinks that the president is sitting too far from ... Lviv. Oh what! At the assembly meeting, I was against such a scattering of the board, especially in the organisational period, - well, when Wójcikówna herself pushed through the current combination, believing that her energy would overcome all difficulties resulting from the dislocation of power.'208

When Bronisława Wójcik wrote about 'our publications' in March 1928, it was not about the Kwartalnik Muzyczny where the idea was rising at the same time, but in another group altogether. Wójcikówna's words referred to one of the Society's first goals: 'work on the development and scientific progress of musicology in the Polish-Lithuanian Commonwealth, on strengthening the position of Polish musicology on international science, and ... on increasing the influence of musicology on practice, upbringing and musical writing in Republic. Among the measures leading to the achievement of this goal, he lists the statute amongst other publishing of scientific papers in the field of musicology and artefacts of Polish artistic and folk music in an academic and practical form.' At the end of the quoted letter, the question was asked: 'Is the scientific work that has already been prepared or is currently being prepared by dear Sir, and would you like to publish it in the scientific publications of our Society? ... The same concerning musical artefacts that could find their place in "Monumenta Musices". ${ }^{209}$

As for the editions, the Board of Directors, for its part, proposed to develop and publish a long list of both musical and theoretical works included in the artefacts of Polish music history, from the Middle Ages to Chopin, and also by creators, as Kamieński described them, 'from the periphery' (foreigners creating in Poland). With regard to Chopin's compositions, it was planned to prepare a critical edition, which was to be directed by the Polish musicologist Ludwik Bronarski who lived in Switzerland, together with Bronisław Wójcik. Questions

207 Wójcikówna to Szczepańska from Lviv 6 III 1928, AACh-BUAM, Szczepańska’s archive, p. 44.

208 Kamieński to Chybiński from Poznań 2 II 1930, AACh-BJ, box 6, K-3/60.

209 From an invitation letter from 8 III 1928 to potential members of PTM, in this case to Ludwik Bronarski in Geneva (for information, among others, Adam Sołtys, Józef Koffler, Józef Reiss, Henryk Opieński, Hieronim Feicht, Alicja Simon, Helena Dorabialska, Helena Windakiewiczowa), preserved at. AACh-BUAM, folder with PTM materials, p. 23. 
regarding possible publishing plans were addressed to each of the potential active members of the Society, where the Statute said that 'that any musicologist of Polish nationality who has an academic diploma in the field of musicology (doctorate or magisteriate) can become a member ... someone who can show at least one printed academic work in the field of musicology. ... It is the duty of the active member to present at least every three years one academic work at the branch or the Society's meetings. ${ }^{210}$ In addition, 'a supporting member who has undertaken deserving academic musicological work, although he does not have an academic degree, may exceptionally become an active member of the Society.'211

On June 1929 lists of the Society's active members were, along with the addresses, the names of twenty people: from Lviv - Seweryn Eugeniusz Barbag, Adolf Chybiński, Józef Koffler, Stefania Łobaczewska, Maria Szczepańska, Bronisława Wójcik, Adam Sołtys, from Cracow - Melania Grafczyńska, Zdzisław Jachimecki, Józef Reiss, Helena Windakiewiczowa, from Poznań - Wacław Gieburowski, Łucjan Kamieński, Wacław Piotrowski, Kazimierz Zieliński, from Warsaw - Helena Dorabialska, Hieronim Feicht, Alicja Simon, and staying outside Poland Ludwik Bronarski (at that time in Geneva) and Henryk Opieński (in Morges). Being under numerical pressure from Lviv musicologists, the members of other communities were not too keen to engage in social work on the Board. First, Wacław Piotrowski wanted to resign from the function of the treasurer, who offered his function to Bronisława Wójcik, who, however, due to personal issues - her recent marriage - also decided to withdraw from the activities of PTM. She was replaced by Kazimierz Zieliński from Poznań, and so far, Piotrowski also remained.

In mid-1929, a group of active members (musicologists with published scientific achievements) decided to publish the PTM Bulletin, including works in the field of musicology. Unfortunately, difficult relations between the vice presidents - Chybiński and Jachimecki, the divergence of priorities as to the main directions of the Society's activity, Kamieński's proposals - unacceptable for Chybiński - to take over of subsidies granted by the Ministry of Religious Denominations and Public Education and the University of Lviv to publications that are already in the process of developing in WDMP (patronised and led by the professor), complicated the situation and actually prevented smooth cooperation. As Michałowski writes, 'Earlier, in January 1929, Łucjan Kamieński

210 Statut PTM, $₫$ II-7, print extant at AACh-BUAM, folder with PTM materials, pp. 7-10.

211 Ibid., $\$$ II-8. 
proposed to Adolf Chybiński, as the editor of the Kwartalnik Muzyczny, that this journal would be published together ... as the organ of the SMDM and the PTM - with Chybiński as "a delegate" of the Society to the editorial office of Kwartalnik - which, however, did not take place on account of Chybiński's objection.'212

It can be surmised that Chybiński, at this point as the editor-in-chief of the first de facto musicological journal, Kwartalnik Muzyczny for a few months now in its second incarnation, would have been reluctant to see competition for academic publications in the pages of the PTM periodic organ. PTM, however, turned out to be a weak organisation that posed no threat to Kwartalnik. It also did not provide an academic background for the magazine. Having been in constant contact with Łucjan Kamieński for years, Chybiński perhaps promised him that he would help join the activities of the Warsaw group and very active Poznań. This supposition could be inferred from the words of the President of the Society, who reminded that the professor 'the matter of PTM's relation to Kwartalnik was to be raised at the next "music lovers" meeting. ${ }^{213}$ The professor did not settle this matter, perhaps because he did not have a high opinion of representatives of other (than Lviv) musicological milieus. On the other hand, a little later, as the editor-in-chief, he complained that, contrary to his intentions and efforts, Kwartalnik was not a nationwide journal. In December 1929, he wrote to Ludwik Bronarski on the occasion of preparing the next issue of the periodical: 'It's already coming to my ears that Kwartalnik is a magazine of Lviv musicologists ... But why, despite my hot and polite requests, the malcontents do not send their or their student's work, or if they do send something, it is to the wastepaper basket, I do not know. I would sit quietly in such cases or send scientific revelations.214

The conviction about the insufficient level of academics from other centres and the conflict between leaders from Lviv and $\mathrm{Cracow}^{215}$ lasting for years did not help cooperation in the implementation of the plans set out at the beginning

212 Michałowski 1979, 25. See also Kamieński to Chybiński from Poznań 18 I 1929, AACh-BJ, box 6, K-3/52, where the question is being asked: 'How is it with "Kwartalnik"? I am asking you for prompt information on what to do about PTM joining the publishing house.'

213 This was about members of SMDM, which was created almost simultaneously in Warsaw, and whose history will be presented below. Quote: Kamieński to Chybiński from Poznań on 4 II 1929, AACh-BJ, box 6, K-3/53.

214 Chybiński to Bronarski from Lviv 11 XII 1929, AACh-BUAM, Bronarski’s archive, p. 26.

215 This conflict is known today mainly thanks to the edition of correspondence between Chybiński and Jachimecki prepared by Krystyna Winowicz, see Troski i spory 1983. 
of the activity by the Board. In addition, during the 1930s a sharp dispute arose between professors against the background of different positions in the book 'Do historii polskiej muzyki świeckiej w XV stuleciu' [To the history of Polish secular music in the fifteenth century] by Chybiński's pupil Maria Szczepańska, ${ }^{216}$ who even found herself 'on trial' in the Society's court, where the aggressive and excessively ironic form of the charges from Cracow against the researcher were negatively rated..$^{217}$

Despite constant conflicts between the centres and in the absence of support for his efforts from colleagues, Kamieński consistently made further attempts to unite the environment and, regardless of the bad atmosphere, tried to organise a conference of musicologists. None of his efforts, however, succeeded in breaking the existing animosities. In a large feuilleton published in the first edition of Muzyka in 1931, its editor-in-chief, Mateusz Gliński, analysed the lack of success in implementing the idea of a nationwide association:

In the small group of employees representing our musicology, the most bizarre relations have been established: here we find outstanding individuals walking on their own, working in complete isolation from their colleagues, we find groups and circles closed within their work, pushing away the participation of other companions. Time and again

\section{KM 1929/5, 1-10.}

217 By the way, it can be mentioned that not only Jachimecki polemicised with Szczepańska on the interpretation of Breve regnum and with Chybiński as the editor-in-chief of Kwartalnik Muzyczny on the admission to publication of a text containing false conclusions in the academic journal. In Wiadomości Literackie (1930 / 51-52, 8), a feuilleton by Karol Stromenger appeared entitled 'Mumifikacja muzyki' [Mummification of music], in which we read: 'A certain young music researcher announced an essay on a abecedarian's song from the fifteenth century, sponsored by the National Cultural Fund in Kwartalnik Muzyczny.... The author puts a bold hypothesis that the song refers to Kazimierz Jagiellończyk. [For a misinterpretation] the author of the essay lost so much time and effort, and Kwartalnik Muzyczny devoted so much space to introduce the reader to an obvious complete error using the "strictest" scientific musicological method, with a number of references to professional literature to support the researcher's deductions.' Here was an extensive quote from the polemical Jachimecki's booklet called Na marginesie pieśni studenckiej z XVw. [On the margins of a student song from the fifteenth century] (Cracow 1930) and further words of Stromenger's comment: 'Here, finally, is the voice of reason about musicology, detached from music, about musicology of the kind that the Kwartalnik Muzyczny cultivates. Paper pedantry, mummification of music ... it would ultimately be purely university affairs, if it wasn't for the clear pretensions of musicologists to pope in every musical matter, even on the bureaucratic ground of the capital.' We will return to this polemic in subsequent chapters. 
we are witnessing violent controversies between the most prominent representatives of the science of music, the scandals, the scandalised confusion of professional-scientific issues with personal matters. Such relations preclude any possibility of peaceful, systematic work.... When the Polish Musicological Society was established a few years ago, we welcomed them enthusiastically, linking with the fact of its creation the possibility of healing relations in the field of musicology. Reality has lied to these predictions: for several years of existence, the Society has failed to hold a single board meeting due to personal frictions between some of its members.... Can this state of affairs be reconciled with logic and the artistic and scientific interest of our country? ${ }^{218}$

There were also no plans for teamwork integrating the environment, for which special privileges were reserved in one of the points of the Statute (point 20): 'If the need to make a certain collective scientific work required the joint action of a larger number of Society members, then in the Society as a whole, and in individual departments, special sections may be established with the consent of the Board, governing their own regulations under these statutes.' The bad atmosphere in the environment and the lack of any causative power to implement even some projects from the beginning of the Society's existence caused an issue with organising the first Congress of Polish Musicologists planned for the end of May 1931, and the activities for PTM ceased for several years.

We learn about the next idea of resurrecting the PTM from one of Chybiński's letters, written almost ten years later to Ludwik Bronarski: 'Under the beautiful auspices of the Poznań convent, a new "Musicological Society" designed and also founded by the author of the attached article [Łucjan Kamieński] therefore, of course, a cultural parasite and a social pest like me (and my co-workers) will not want to push where such lofty slogans and noble ideals are spoken and cultivated to which we have not grown up to at all ... The organisers hope to win over state coffers for their "socially-useful" works. ${ }^{219}$

Representatives, or coordinators of individual centres, were supposed to be: the instigator of this initiative, Łucjan Kamieński in Poznań, Zdzisław Jachimecki in Cracow, Stefania Łobaczewska in Lviv and Stefan Śledziński in Warsaw. The first congress was planned in Warsaw in January 1938, another one in Cracow

218 Muzyka 1931/1, 29-30. A few years later, Gliński, commenting on Chybiński’s replica for his polemic, analysing the poor condition of the discipline, the article " Zmierzch nauki" w dziedzinie muzycznej' ["Twilight of science" in the musical field] (Muzyka 1934/5, 217-218) he wrote about the Lviv professor as the founder of the 'infamous vegetating Society of Musicology' (Muzyka 1934 / 6-7, 272).

219 Chybiński to Bronarski from Lviv 11 XI 1938, AACh-BUAM, Bronarski’s archive, p. 170. 
in June. According to Julian Pulikowski, a young and new musicologist in the milieu, a trusted Chybiński man who referred these messages to the professor, the Society's goal was to be, among others 'Exchange master's theses, circulars in various matters, ... taking back the editorial staff of the Musicological Yearbook from the Professor and transferring this editorial office to the Society!!!"220 All subsidies and funding from FKN would also be directed at the Society. In order to achieve success in the circles of the nationalistically marked leadership of the FKN, the initiative 'imposed a coat of anti-Semitism and introduced an Arian paragraph. ${ }^{\prime 221}$ Pulikowski, known at that time in the community for his anti-Semitic convictions, a few months earlier, in the middle of August 1938, tried to convince Chybiński to participate in the congress using such arguments:

it is supposed to be a meeting of POLISH musicologists only.... If we Poles do not stick together and for example, on such an occasion as the [organisation] of the "POLISH Music Week," and if we gather together for purely demonstrative purposes, only Jews will win. I am a supporter of this even a formally bizarre reunion, for all POLES to gather at least ONCE WITHOUT JEWS.... If Mr Professor is not be persuaded by me ... at least send Dr Szczepańska, Dr Dunicz, etc.! The LVIV School MUST be represented, by as many if possible! ${ }^{222}$

Nevertheless, a month later, Pulikowski resigned himself, arguing that it is not the time to create a Musicological Society, which instead of uniting all older and younger generation of musicologists in cooperation, it would only exacerbate the current relations and perpetuate them ${ }^{223}$ and suggested, that no one from Lviv would participate in the congress. However, not everyone, especially the representatives of the youngest generation of the students of the Jan Kazimierz University, negatively judged this event. For beginner musicologists, it was an opportunity to present their first research, recognise the environment and contact with numerous live music performances during the festival that was taking place at the same time. Jan Józef Dunicz, a recent graduate of Lviv musicology, shared his doubts with Chybiński:

I received, already announced by Mr Professor, an invitation from Poznań to be part of a musicological meeting which will take place on 2-5th October current year,

220 Pulikowski to Chybiński from Warsaw, October 1938, AACh-BJ, box 3, P-28/190.

221 Pulikowski to an undefined (maybe fictional?) professor from Warsaw [October] 1938, AACh-BJ, box 3, P-28/189.

222 Pulikowski to Chybińsk from Warsaw 17 VIII 1938, AACh-BJ, box 3, P-28/168.

223 Pulikowski to Zygmunt Latoszewski from Warsaw 15 IX 1938, AACh-BJ, box 3, P-28/170 (copy). 
and requested - if possible - a short talk about one of the topics I am working on. They ask for an answer, will I come ... I'm in a difficult position now. I must admit that I am interested in the congress, especially since it is connected with a rich concert programme (Harnasie, Straszny dwór [The haunted manor] in a new staging, Father Gieburowski's choir, etc.). ... If I were to take part in the congress, I would probably like to give a talk, and here I was informed about this with such short notice ... I really do not know if I will make it.... I will probably be forced to deny myself the pleasure of travelling and participate in this unusual event in Poland. ${ }^{224}$

In a very similar tone, though with a different dilemma, one of his students turned to the professor, Józef Chomiński, who said:

I am asking you, Professor, for kind advice on a certain matter. I received a letter from Dr Zygmunt Latoszewski with an invitation to a meeting of musicologists in Poznań, which will be held on the occasion of the "Polish Music Week" on October 3-5 this year. In addition, Dr Latoszewski ${ }^{225}$ asks me to present a paper there. Although I am not a good speaker, I could prepare a talk and ultimately deliver it. ... Currently, with my salary (PLN 138), it is very ... difficult for me to go to Poznań ... I do not know how and what I should write back to Dr Latoszewski. Does the "Lviv school" participate in this congress? If not, it would be all right, because my presence would be superfluous there. ${ }^{226}$

The congress eventually took place in a small group, and the next meeting of delegates from all musicological centres (including the emerging unit in Warsaw) was planned for January 1939 in the capital and for June the same year in Cracow. Before September 1939, no major initiatives in the Society were taken, but after the war, the musicologists focused as a separate section within the Polish Composers' Union.

Strongly chauvinistic, nationalistic and racial issues disturbed the work of the musicological society, divided the environment also at the launch of the Frederic Chopin Institute. Chopin's cult in the field of connecting enthusiasts of his work, of course, had a long tradition. Recall that after the Section named after Stanisław Moniuszko was spun out in 1891, and the Church Music Section six years later, in 1899 the Frederic Chopin Institute started its activity at the

224 Dunicz to Chybiński from Lviv 15 IX 1938, AACh-BJ, box 3, D-13/58.

225 Latoszewski was an active musician - from 1933 he was the conductor of the Poznan Opera Orchestra - as well as a musicologist. He was one of the first graduates of the department at the University of Poznań, obtaining his doctorate in 1932 based on the dissertation Pierwsze opery polskie Macieja Kamieńskiego [First Polish operas by Maciej Kamieński].

226 Chomiński to Chybiński from Warsaw 14 IX 1938, AACh-BJ, box 5, C-10/73. 
Warsaw Music Society, which, following the Moniuszko model, dealt with the collection of manuscripts and music prints, and memorabilia of the composer, which in turn was to give a basis for the creation of the composer's museum. This initiative was a natural consequence of the cult of Chopin, which from the moment of his death was present in various forms in the social and cultural life of the country. ${ }^{227}$ One of the main tasks of the Section was to conduct publishing activity, which was meant to be the result of systematic research on the work and the figure of Frederic. Although the publishing projects included planned translations of Chopin monographs, such as Frederick Chopin as a man and musician by Friedrich Niecks (London 1888), this was not yet the moment when the music historians and critics community would be ready to publish their own periodical dedicated to the composer.

In the twenties and thirties, various committees and societies began to form, including those taking care of Chopin's home in Żelazowa Wola or organisation of occasional 'days.' The Chopin Section at WTM still dealt only with the protection of the existing collections, and there was no question of research or scientific activity. This aspect was to be taken care of by the Frederic Chopin Institute initiated by a group of artists, politicians, organisers of musical life and enlightened music lovers. ${ }^{228}$ Although the date of establishment of IFCh is assumed to be April 1934, Grażyna Michniewicz in her article on the history of the Institute ${ }^{229}$ recalls that already in the autumn of 1933, the Ministry of Religious Denominations and Public Education received a bill of association, prepared by Mieczysław Idzikowski, ${ }^{230}$ signed by the Organising Committee made up of: Leopold Binental, ${ }^{231}$ Karol

227 About the cult of Chopin in Poland during the partitions and after the state gained independence, a number of works were created, see e.g. Szczepańska-Lange 2010.

228 It is worth mentioning surnames Emil Młynarski, Stanisław Niewiadomski, Józef Beck, Janusz Jędrzejewicz, Mieczysław Idzikowski, Karol Szymanowski, and August Zaleski.

229 Michniewicz 1983.

230 Mieczysław Idzikowski (1898-1974), Warsaw bookseller, publisher, one of the co-founders of IFCh.

231 Leopold Jan Binental (1886-1944), an ardent propagator of Chopin's cult. He was the author of many articles about Chopin in the pages of mainly the Warsaw press (Kurier Warszawski, Muzyka monthly). He collected souvenirs of Chopin. He organised the exhibition on the twentieth anniversary of the composer's birth. He is the author of the monograph Chopin, życiorys twórcy i jego sztuka [Chopin, biography of the creator and his art] (Warsaw 1937). 
Stromenger, ${ }^{232}$ Maurycy Mayzel, ${ }^{233}$ Zofia Jaroszewiczowa ${ }^{234}$ and 'as the owner of the everyday magazine and great music lover ${ }^{235}$ Mieczysław Łubkowski. The beginning of the initiative can be found even in $1932 .{ }^{236}$

Among the founding members, along with the signatories of the project were Karol Szymanowski, Ferdynand Hoesick, Stanisław Niewiadomski, Władysław Zawistowski, Henryk Opieński, Eugeniusz Morawski, Emil Młynarski, Juliusz Kaden-Bandrowski, Adam Wieniawski, and Witold Maliszewski; after a short time, Bronisława Wójcik-Keuprulian and Jarosław Iwaszkiewicz also joined this group. Even before the information gathering in April, the association received an approved Statute, in which the aims and objectives of the Institute were to 'promote ... cult for Frederic Chopin ... by publishing a permanent organ dedicated to Chopin.' The composition of the selected Board was severely criticised by the permanent columnist of Muzyka Polska, Jan Olcha (used by Bronisław Rutkowski), who pointed to the propagandistic character of this 'amateur-musical institution, and casting of figures such as Karol Szymanowski and Eugeniusz Morawski on less prominent positions of the board - only in the conciliation court or the audit committee, and to the distinction of people who were not so accomplished in the cause of Polish Chopinology, such as Zofia Jaroszewiczowa (against other, much more prominent Polish pianists), or Leopold Binental and

232 Karol Stromenger (1885-1975), music critic, publicist, pedagogue, composer. In 1909-13 he studied musicology in Vienna (where he also studied law). In the 1920s, when he already lived in Warsaw, he became the first critic of the Kurier Polski, later the Tygodnik Ilustrowany, the Kurier Poranny, he wrote to Muzyka, Wiadomości Literackie. He was involved in organisational work, including in the Association of Music Writers and Critics, see Dmitrowicz/Sowa 2006-07.

233 Maurycy Mayzel (1872-1940 (1941?)), social activist, chairman of the Jewish kehillah, very active in the self-governmental structures of Warsaw; Vice-president of the City Council of the city in the years 1927-34. In addition to many functions in trade associations, he was also an extraordinary member of the Union of Polish Stage Artists, see Fuks 1975.

234 Zofia Jaroszewiczowa was the wife of Władysław Romuald Jaroszewicz, an activist of the Piłsudski camp, who from 1926 until the beginning of September 1939 served as the Government Commissioner for the capital city of Warsaw, which meant that he was the 'head of the administrative authority of the second instance, in the rank of voivode. He was subjected, among others, to police, press censorship, etc.', see Żarnowski 1964-65.

235 Chopin 1937/1, 50.

236 Idzikowski wrote in Muzyka about the creation of the idea of founding the Institute, see Idzikowski 1934. 
Karol Stromenger (against the background of authors more experienced in research on Chopin). ${ }^{237}$

The financial situation of the Institute, as in many similar cases of societies and associations, was very uncertain. Theoretically, the funds for activity should flow from the state coffers, but the subsidies from the Ministry were small and sporadically directed, and the subsidies received from the National Culture Fund were intended entirely for the implementation of the main project - the National Edition of Chopin's Works. ${ }^{238}$

Ludwik Bronarski already in 1934 considered the plan for the preparation of the National Edition as justified by all means, even (or maybe: all the more) considering the fresh edition, the so-called Oxford, Édouard Ganche ${ }^{239}$ edition, which, of all his (Bronarski) expectations, did not satisfy even by the fact that 1) that it did not include the complete works, only piano compositions, 2) that the publisher relied only on the first French edition in his edition, not including German and English, and at the same time 3) is not deprived of numerous (significant) typographical errors. ${ }^{240}$ In the article on the new Polish critical edition of Chopin's works, ${ }^{241}$ he proposed, as we say today, a 'road map' of all activities that should accompany the beginning of work on a complete set of Chopin works and their conduct - from the collection of a competent editorial team to editorial details aimed at the maximum approaching the composer's artistic intentions. $\mathrm{He}$ also thought it is important to decide if the new publication would only be

237 Jan Olcha [Bronisław Rutkowski], 'Refleksje' [Reflections] (MP 1937/2, 143).

238 As it is known, Ludwik Bronarski was also soon invited by the editorial office of the National Edition. In the spring of 1934, however, when the Institute had just begun, and its statute (and the words about the new edition of Chopin's works) had already been approved, and the principles of activity announced, this musicologist, in a letter to Adolf Chybiński, expressed his surprise: 'Apparently an "Institute for Chopin" has been established in Warsaw, which for one of his tasks has set itself a monumental edition of Chopin's works. As I put forward the "postulate" of such a publication the end of my review of the Oxford edition, maybe the Professor will find it appropriate to provide this review with an appropriate "Comment from the Editor" with an allusion to the Institute that did not exist at the time of writing,' Bronarski to Chybiński from Geneva 28 II 1934, AACh-BJ, box 6, B-26/93; Bronarski's review was published in the first volume of the PRM published in 1935 (pp. 144-149).

239 The Oxford original edition of Frédéric Chopin edited from the original edition and the manuscripts by Edouard Ganche, London 1932.

240 See Bronarski's review in the PRM (op cit.).

241 Ludwik Bronarski',W sprawie nowego wydania dzieł Chopina' [On the new edition of Chopin's Works] (MP 1934/3, 191-195). 
a 'scientific-historical reconstruction' or serve pedagogical purposes, while he was inclined towards the non-instructional character of the publication, with any minor additions described in the commentary. The argument of 'national pride, which should have an impact on making decisions about works on publishing, fell several times in the article, also by comparison to the so-called Sejm edition of Mickiewicz's works. ${ }^{242}$ At that time, the plans were finished after the war with the edition of Chopin's Complete Works under the editorship of Ignacy Jan Paderewski, Ludwik Bronarski and Józef Turczyński (Cracow 1949-61), as established in the 1930s.

They could not count on full financial support for the Institute's other projects. One of the victims of the material problems of the institution was the previously mentioned organ - the Chopin magazine, which was initially conceived as a quarterly, with time to be a monthly, but appeared only twice in a cycle similar to a quarterly. August Zaleski, president of the IFC Board, wrote in a text from the editorial office that 'the Institute wants to fill the gap in the Polish literature that was the result of lack of a magazine that would serve as a reflection of the current state of research in the field of Chopinology.243 The editorial committee of the journal was formed in March 1936 and consisted of three people: Bronisława WójcikKeuprulian was responsible for academic editing, Stanisław Niewiadomski had the general department, and Leopold Binental - historical, 'artefacts.' It soon turned out that despite the letters addressed to potential authors experienced in Chopin (including members of the association) - Bronarski, Opieński, and also Lissa, Pulikowski, Jachimecki and others - materials were not delivered in significantly large numbers. The ones that were received by the editorial staff from other authors and correspondents did not meet expectations especially in terms of academic level. ${ }^{244}$ Postponed from month to month, the volume came

242 Adam Mickiewicz, Dzieła wszystkie [Complete works], Artur Górski, Stanisław Pigoń (ed.), vol. I-VIII, Warsaw 1933-36.

243 It is worth noting that the discussion that had already taken place in the mid-twenties over the spelling of the composer's name was resolved, and the Polonised version of 'Szopen' gave way to the French version.

244 A letter inviting authors to work also came to Adolf Chybiński. August Zaleski informed him that 'The Management Board of the IFCh in Warsaw has the honour to make it known that in fulfilling its objectives set out in the statute, in 1937 will issue its own organ, which will be a quarterly dedicated entirely to Chopin. The Board wants the quarterly to become a focus of all academic and literary works related to the life and work of Frederic Chopin, and also give a full picture of the Chopin cult in the country and abroad, and through the articles published therein expanding and deepening the cult of Chopin.... Deeply convinced that Dear Sir fully shares the need 
to fruition only in June 1937, and the subject matter of the texts of the first edition - except for the dissertation on Chopin's youthful compositions by Zdzisław Jachimecki ${ }^{245}$ - oscillates mainly around matters related to Chopin: contributions about the history of Żelazowa Wola, ${ }^{246}$ the history of the Institute, ${ }^{247}$ the history of the Chopin competition. ${ }^{248}$ In addition, the issue included a report 'Fryderyk Chopin w Polskim Radio' [Frederic Chopin on Polish Radio] and memories of the recently deceased Emil Młynarski, Stanisław Niewiadomski and Karol Szymanowski - also members of IFCh.

The Chopin edition was definitely different from the number one inaugural edition. Although the publication had to wait another few months, this time the authors were musicologists, not publicists or music critics. Furthermore, everyone was literally or indirectly connected with the Lviv mainstream of interwar musicology. The students of the Jan Kazimierz University - Zofia Lissa, ${ }^{249}$ Stefania Łobaczewska ${ }^{250}$ and Bronisława Wójcik-Keuprulian ${ }^{251}$ published their texts here; moreover, so did the leading Polish Chopinologist of the time, Ludwik Bronarski, ${ }^{252}$ a Lvivian by birth, who had been in close contact with Adolf

and purpose of such a publication, the Management Board is honoured to ask for kind cooperation by sending his dissertations or articles related to the life, work and worship of Frederic Chopin,' see IFCh to Chybiński from Warsaw 22 X 1936, AACh-BJ, box $5, \mathrm{I}-2 / 1$.

245 Zdzisław Jachimecki, 'Kompozycje Fryderyka Chopina z okresu dziecięctwa i lat chłopięcych' [Compositions of Frederic Chopin from the period of childhood and boyhood], Chopin 1937/1, 25-41.

246 Kazimierz Hugo-Bader, 'O dawnej i nowej Żelazowej Woli' [On the old and new Żelazowa Wola] (Chopin 1937/1, 2-10).

247 Witold Maliszewski, 'Historia powstania Instytutu' [History of the establishment of the Institute] (Chopin 1937/1, 50-51).

248 Jerzy Żurawlew, 'Jak powstały konkursy chopinowskie' [How the Chopin competition came into being] (Chopin 1937/1, 42-43); Adam Wieniawski, 'Z okazji III Międzynarodowego Konkursu Chopinowskiego' [On the occasion of the III international Chopin competition] (Chopin 1937/1, 44-48).

249 Zofia Lissa, 'O pierwiastkach programowych w muzyce Chopina' ['About Programmatic Elements in Chopin's Music'] (Chopin 1937/2, 64-75).

250 Stefania Łobaczewska, 'Problemy wykonawcze w muzyce Chopina' [Performance problems in Chopin's Music] (Chopin 1937/2, 82-93).

251 Bronisława Keuprulian, 'Co winniśmy Chopinowi' [What do we owe Chopin?] (Chopin 1937/2, 94-97).

252 Ludwik Bronarski, 'Muzyka Chopina a muzyka salonowa' [Chopin's music and salon music] (Chopin 1937/2, 76-81). 
Chybiński for years, as well as a friend of Chybiński and Henryk Opieński ${ }^{253}$ who exchanged his editorial experience with him.

Unfortunately, even such an excellent team of the authors of the second issue failed to mobilise the rather small number of scholars interested in the work and character of Chopin, too few for the needs of the magazine. Problems with the academic level of materials and delays in the preparation of the edition caused changes in the editorial board: after a temporary resignation, the function of the academic editor was maintained by Bronisława Wójcik-Keuprulian, who, however, soon died. Julian Pulikowski was responsible for organising the editorial work, supported informally by Bronarski; they were also joined by Konstanty Régamey (who at more or less the same time worked with the team of another Warsaw periodical, Muzyka Polska), and Stanisław Golachowski (who dealt with the chronicle of Chopin events). The new Editorial Committee proposed that Chopin be transformed into a yearbook, but the magazine did not appear again before the war, even in such a formula.

Chybiński, as it often happened, was irritated by the establishment of an institute that had the main task of conducting scientific and research activities (this time concerning Chopin) in a situation when he himself, away from Warsaw, somehow stood on the sidelines of this initiative.

They write to me from Warsaw as follows: 'We are impressed here by the creation of the Chopin Institute, organised under the auspices of MWRiOP. The Board of this institution was constituted not long ago .... It seems that the only "Chopinologist" in this company is ... Mr Binental. At the first general meeting of the Institute, the lecture "O uskutecznieniu w Polsce zbiorowego, naukowo-artystycznego wydawnictwa dzieł Chopina" [Making the collective scientific and artistic publishing of Chopin's works in Poland effective] was given by Mr Idzikowski ... the owner of the local bookshop and music printer"- Is there not a man who would show the whole absurdity of similar actions? In the corridors, they say that the patronage of the Institute is to be taken over by the master Paderewski. I do not want to believe it. No comment!!! But a question for your friend: is his last message essentially the truth? It would be unbelievable! ${ }^{254}$

Finally, at the beginning of 1937, he decided that since both Bronarski and the Master (Paderewski) agreed to cooperate, he could 'sign himself up as a member.' Commenting on the planned National Edition of Chopin's Works, he remarked that 'Warsaw residents ... must be constantly monitored.... The same applies to publishing works in the Chopin quarterly. It is understood that this publication

253 Henryk Opieński, 'Czy Chopin jest romantykiem?' [Is Chopin a romantic?] (Chopin 1937/2, 57-63).

254 Chybiński to Bronarski from Lviv 3 V 1934, AACh-BUAM, Bronarski’s archive, p. 110. 
deserves support, but only in this case, when Mr Binental (known for his arrogance and hysteria) will not put his two cents in.255

Chybiński himself was soon (in the war years) involved in a project prepared together with the management of TWMP (and personally Tadeusz Ochlewski) of the series of Analizy i Objaśnienia Dzieł Wszystkich Fryderyka Chopina [Analysis and explanation of all of Frederic Chopin's works], which - in the new reality only two volumes appeared: Mazurki prepared by Janusz Miketta (Cracow 1949) and Preludes by Józef Michał Chomiński (Cracow 1950).

In the meantime, however, he did not undertake major Chopin initiatives, especially since he had been dealing with another group of music activists from the capital for several years. None of the previously described associations was for Adolf Chybiński and his plans - both in the field of science and publishing such support emerged in the mid-1920s in Warsaw among a few local young musicians. In 1926, three graduates of the Warsaw Conservatoire, Tadeusz Ochlewski, Teodor Zalewski, and Bronisław Rutkowski returning from his scholarship in Paris, having already had their first experiences of making music together, created a project to popularise the early music repertoire in the form of regular chamber presentations. In order to formalise these activities, at the request of Zalewski, the group decided to form a 'registered association, and for this purpose - for formal reasons - two more people had to be involved. Adolf Chybiński and Emma Altberg, a pianist and journalist, a bit later for a number of years (1931-39) a writer associated with the Warsaw Express Poranny, where she wrote reviews, were invited to participate in the project. In the early years of the twentieth century, Altberg studied philosophy and social sciences in Switzerland, but then she devoted herself above all to playing the piano. She studied in Paris and St. Petersburg, after that she took (in 1926 and 1928) master classes in interpretation of early music with Wanda Landowska and Paul Brunold (this contact soon allowed Chybiński to recruit Brunold as the author of as many as four organology dissertations published in Kwartalnik Muzyczny, mainly about keyboard instruments $\left.{ }^{256}\right)$. She also became a pedagogue - a professor of piano and harpsichord, a specialist in teaching methodology of playing the piano. She was invaluable, on the one hand, in establishing contacts with the Warsaw cultural and intellectual circles in which she was involved. These contacts were needed

255 Chybiński to Bronarski from Lviv 14 I 1937, AACh-BUAM, Bronarski's archive, p. 154.

256 'Fortepiany Chopina' [Chopin's pianos] (KM 1928/1, 50-54); 'Dawne instrumenty klawiszowe' [Early keyboard instruments] (KM 1930/6-7, 167-184); 'Pianoforte' (KM 1930/9, 9-18); 'O lirze' [About the lyre] (KM 1932/16, 659-664). 
for young musicians to be successful in their activities. On the other hand, she was invaluable as an excellent harpsichordist - on the stage of the Association; collaborating with Kwartalnik; she was also a translator of Brunold's texts.

Reading the memoirs of Teodor Zalewski, ${ }^{257}$ one can probably get the impression that in 1924-25 he became an instigator of the situation, which soon resulted in artistic and publishing ideas important for the musical milieu, not only in Warsaw but also nationwide. At that time, Zalewski lived in Brwinów near Warsaw, as did Tadeusz Ochlewski's parents. The close neighbourhood encouraged both musicians to play chamber music together. However, before this relationship was strengthened, Zalewski's fate was full of turmoil connected with the historical events of the first decades of the twentieth century.

The Zalewski family - professional musicians - stayed in Rome in the 1890s then moved to Moscow. It was there that Teodor began to learn to play the piano with the Gniesin sisters; shortly before the outbreak of the war, he joined the Law Faculty of the Moscow State University. The independence of Poland prompted the Zalewskis to make a decision to return to their country - their repatriation journey lasted from September 1918 to April 1920. When the family finally arrived in Warsaw, Teodor, in connection with the Bolshevik war, was mobilised, but for a short time: first, he was transferred to the Ministry of Military Affairs, and in April 1922 he was completely released from service. Back in 1921, he returned to the law studies interrupted in Moscow, this time at the University of Warsaw, and at the same time, he began to take theory lessons with Piotr Rytel. He also joined the amateur symphony orchestra at WTM, whose conductor was Józef Śliwiński, and his deputy Mateusz Gliński. After demobilisation, in the autumn of 1922, he joined the Warsaw Conservatoire conducting class and thus gradually penetrated the musical milieu of Warsaw: he met Michał Kondracki, Piotr Perkowski, Jan Maklakiewicz, Kazimierz Wiłkomirski and Szymon Laks.

$\mathrm{He}$ met with both Rutkowski and Ochlewski at the conservatoire: Before leaving for a scholarship in Paris, Rutkowski recommended him as the manager and conductor of the musical ensemble in Leon Schiller's theatre complex, with Ochlewski - a violinist - he had a joint diploma exam during which he conducted the orchestra accompanying the soloist (June 1925, less than a year later he graduated from the Law Faculty and began training three years later also a lawyer $\left.{ }^{258}\right)$.

\section{Zalewski 1977.}

258 After the Second World War, legal powers allowed him to become a legal advisor in the Union of Polish Stage Artists. He soon left the bar, however, to devote himself to 
A native of the Vilnius area, Bronisław Rutkowski, left home at the age of seventeen to take up music studies in St. Petersburg. After four years, however, he moved to Vilnius, to study at the Stefan Batory University at the Faculty of the Humanities (Polish Studies), and after another two to return to music education: this time at the Warsaw Conservatoire he studied the organ with Mieczysław Surzyński, theory with Piotr Rytel and Roman Statkowski, and conducting with Henryk Melcer. After graduating, in Paris, he perfected the organ playing with Louis Vierne and studied aesthetics with André Pirro, and after returning to the country, he took the organ class at the Warsaw Conservatoire. For several years he was an organist in the capital's cathedral and also gave concerts in Poland and abroad, he cooperated with the radio, preparing regular cycles that popularised music, in the summer months he organised and led the Music Holiday Centre at Krzemieniec High School. ${ }^{259}$ As far as artistic activity is concerned, he made invaluable contributions to Polish organists and organs. He was not only a virtuoso of this instrument but also an excellent teacher and activist of the organist community. It is worth recalling that at the end of the 1920s he edited the Pismo Organistowskie, to which he invited Adolf Chybiński as an author. At the beginning of 1928, he wrote to Lviv: 'Thank you most cordially for the submitted article for Pismo Organistowskie, which will be published in the February issue.... I was afraid that you would not send your valuable work to such a small publishing house. For the time being, Pismo Organistowskie is a very modest publishing house. I edit it out of necessity because in Warsaw no one wants to take care of this important matter. ${ }^{260}$ For musicology, however, his decision to cooperate with Zalewski and Ochlewski in the organisation of SMDM became more important, and he became the president and - as Zalewski said - the 'minister of foreign affairs ${ }^{261}$ of the group, delegated to contacts with governmental and academic authorities.

teaching: in 1952-69, he was a professor, deputy rector and finally - in 1966, he took over Kazimierz Sikorski's function - the rector of the PWSM in Warsaw. In 1947-49 he was also the director of the Warsaw Philharmonic.

259 During the war, he conducted a similar activity in the underground. After the war he held similar functions as Teodor Zalewski, except that in Cracow he was a professor, dean, vice-rector and rector of the PWSM there, for a short time the artistic director of the Cracow Philharmonic, he lectured in Gregorian chant at the Faculty of Theology of the Jagiellonian University, he led Ruch Muzyczny for two years, he started cooperating with the Polish Radio again. He was active in various fora of the milieu, for which he received recognitions and awards many times.

260 Rutkowski to Chybiński from Warsaw 17 II 1928, AACh-BJ, box 4 R-19/1.

261 Zalewski 1977, 89. 
Another responsibility fell to Tadeusz Ochlewski, whose task was to select the concert repertoire, and, in this connection, also obtaining music materials for both performances and new co-performers. Like other musicians, he was simultaneously supplementing his artistic education with another field of study, but - which was rare - in his case, it was not a humanistic study field, but more scientific, as he studied electromechanics at the St. Petersburg Polytechnic Institute. As a young man, however, he also performed as a violinist, and he decided to improve this skill - first at the Conservatoire in St. Petersburg, and after the war, from 1921 at the Warsaw Conservatoire and in 1929 with Wanda Landowska during courses of interpretation of early music in Paris. At all times he was a member of various music ensembles, both orchestral and chamber music - the Trio-Sonata and the Polish Quartet. In 1927, he became a professor at the Warsaw Conservatoire, and for over a dozen seasons he was also a teacher at the Music Holiday Centre at Krzemieniec High School.

Ochlewski's passion, shared with other colleagues from SMDM, was to promote and popularise musical culture. After the first years of regular Warsaw concerts, the group decided to go with their idea to the provinces. The result of this idea was the initiation in 1934 of the Music Movement Organisation (ORMUZ), which Ochlewski directed to the outbreak of World War II. The statistics turned out to be impressive: fifteen symphonic concerts took place in Warsaw, four opera performances, and in the provinces, there were 624 concerts, moreover over two and a half thousand school programmes all over the country (more than half outside the capital).

From 1937, Ochlewski was appointed manager in TWMP, which had been established by SMDM activists in 1930. However, he is most associated with PWM. In 1945, at the request of the Minister of Culture and Art, he undertook the establishment of PWM on the remains of the pre-war institution, and he ran this until $1965 .{ }^{262}$ He was given prizes and awards many times.

In mid-December 1926, a group of enthusiasts of a new artistic idea met for the first time to select the first board of the Association. ${ }^{263}$ It was obviously

262 In the war years, as well as colleagues, he took part in the underground musical life of Warsaw, he participated in the Secret Musicians' Union, organised underground home concerts, but also performed in the Café Salon Sztuki [Art salon] run by Bolesław Woytowicz. After the war, he moved to Cracow.

263 Information about this fact can be found in the press chronicles as early as in January 1927: 'On the initiative of T[adeusz] Ochlewski and Br[onisław] Rutkowski, the Association of Early Music Lovers was founded in Warsaw to cultivate the works of unknown and forgotten creators of the past,' see Muzyka 1927/1, 39. 
formed by group initiators, of whom the 'functionaries' were: Rutkowski as president, as secretary - Ochlewski, as treasurer - Zalewski; in addition to the five founders, pastor August Loth, ${ }^{264}$ Zdzisław Dziewulski ${ }^{265}$ and Wacław Kochański ${ }^{266}$ joined the board. On some of the magazines, there is also a signature of a pianist and harpsichordist, an educator of the Warsaw Conservatoire, Margerita Trombini-Kazuro. ${ }^{267}$

Initially, SMDM focused on concert activities - chamber music evenings that took place every two weeks from January 1927, in which other musicians participated as well. They were concentrated in the room given to this purpose by Rector Melcer, in the building of the Conservatoire, an increasing number of people added to the list as part of the Association, on which there were - as Teodor Zalewski recalled - 'many pedagogues of various levels - from professors of higher education to public school teachers, some doctors and lawyers, a wide variety of so-called white-collar workers and a fairly large group of academic youth. ${ }^{268}$ Two years after the initiation of the activity, the Association had about five hundred members. For a long time, the performers, and even more so the members of the Board, did not derive any material benefits from their activities and only financial support from the FKN allowed for the development of further plans. The group could not count on ministerial subsidies, because young musicians were outside the circle of influence of MWRiOP officials - head of the Music Department of the Department of Art, Felicjan Szopski, professor of the competing music school - the Frederic Chopin Higher Music School of the WTM, and his successor, Janusz Miketta, also associated with the school at WTM. It was only in 1934 - according to some circles, 'as a result of a complicated, very cleverly run campaign against prof. Witold Maliszewski' ${ }^{269}$ (in

264 August Karol Loth (1869-1944), Evangelical clergyman, social activist, organiser and president of the Society of Polish Evangelical Youth. For nearly 45 years, he was associated with the parish of the Holy Trinity in Warsaw.

265 Music lover, counsellor of the Supreme Audit Office.

266 Wacław Kochański (1878-1939), violinist, educator, he studied, among others with J. Joachim in Berlin. From 1923, he was a professor at the State Conservatoire of Music in Warsaw, in various years he was also associated with music schools in Lviv (including the school of Sabina Kasparek and the Lviv Conservatoire).

267 See for example, the SMDM Board to Chybiński from Warsaw 16 April 1928, AACh-BJ, box 1, O-1/116.

268 Zalewski 1977, 92.

269 See 'Klika czy nie klika? W odpowiedzi na "w odpowiedzi”" [Clique or not a clique? In response to the 'answers'] (Muzyka 1937/3, 85). 
the years 1927-34 acting as the head of the music section in the Ministry of Religious Denominations and Public Education) - the position of music referent in the Ministry was awarded to Stefan Śledziński, SMDM's 'man' (slightly later criticised in connection with entrusting him with department of musicology in Warsaw Conservatoire).

From the beginning, the protector of the Association's activities was Stanisław Michalski, an educational activist, academic and science organiser, editor of Nauka Polska, creator of libraries and reading rooms, but first and foremost the head of the science department of the Józef Mianowski Fund during the entire interwar period and director of the FKN in 1928-39 (also a co-creator of the creative work home in Mlądz near Otwock, the so-called Mądralin). Michalski's great managerial talent allowed him to build the funds coming from everywhere - not only from intellectual and academic circles but also from the working class - donations that, in turn, were deliberately and rationally allocated for subsidies of scientific research, publications, scholarships and prizes. Subsequently, Ochlewski and his colleagues began to seek subsidies from the 1927-28 season.

Broad information about SMDM was published, among others in the chronicle of the first edition of Kwartalnik Muzyczny - it was explained what the Association was and what its tasks were, a report was added from the next, third general meeting of members, which took place on 15 October 1928, and there was also information about the selection of office bearers along with the definition of the scope of duties, the activities of the choir and the library, a list of previous programmes and concerts (also coming announcements), and about the goals and characteristics of the new series. ${ }^{270}$ SMDM's new plans included intensifying concert activity, initiating the work of WDMP and setting up a music magazine. For these purposes, in 1928, the Fund granted PLN 25,000, in the following years an annual fixed amount of PLN 10,000 was established, which without unnecessary formalities, was sufficient to settle accounts with attached copies of the publication of the publishing house. Thanks to the funds provided, the nature of the concerts changed. While they had previously only been chamber concerts, from 1928 , they included symphonic concerts (also with the choir).

From the beginning, the concert activity of the Association met with considerable enthusiasm from music critics and music lovers. After the group's first concerts, Mateusz Gliński, wrote a few kind words about the new initiative in Muzyka: 'Music lovers were reminded of a series of unknown and forgotten 
compositions through the interesting and useful concerts by the "Society of Early Music," held on Mondays in the hall of the conservatoire; they effectively fill the gap in our musical life, which until recently was very painful. ${ }^{271}$ Unfortunately, with time, friendly reactions and comments began to give way to criticism, most often on the line SMDM-editors of Muzyka, mainly from the editor-in-chief of the monthly. After the concert organised on the occasion of the tenth anniversary of the Association, the section 'Musical Review. Musical life in the capital' included a polemical report signed by Mateusz Gliński, in which the author asked, among others the question about the advisability of running a business that popularises musical culture in the form adopted by the members of the Society:

There is no doubt ... that early music can give many deep emotions and beneficial stimuli. But only music which is very good and very well performed. Meanwhile, SMDM, using the special care of FKN and MWRiOP, has developed an action that is completely disproportionate in relation to the essential needs of our concert life. An excess of concerts has caused dilution to programmes of secondary importance, sometimes simply uninteresting, schematic. ${ }^{272}$

Such unfavourable opinions appearing more frequently with the years, however, did not affect the achievement of the Association's main goals, that is, propagation of early Polish music - in addition to concert activity, also by providing them in printed form as part of WDMP, to which musical artefacts were directed - or previously found, or continuously obtained from archives and libraries penetrated by the next generation of young musicologists, that were better prepared for this kind of exploration and preparation of discovered materials. Initially, the compositions of the fifteenth and eighteenth centuries were considered, with time they were expanding this repertoire with works from the nineteenth century. Together with the first issue of WDMP, the SMDM Management Board issued a statement informing about the assumptions of the series, in which, amongst others, it could be read:

In the area of SMDM's activity in Warsaw, it is the dissemination of early Polish music. One of the means of this activity is the publishing of works by early Polish masters, which are a testimony that Poland has been involved in the development of European musical culture since the Middle Ages. The WDMP that is being started with this book, it is not aimed solely at academic but rather - and above all - practical and performance goals. The aim of SMDM is to publish all those artefacts of Polish music that undoubtedly are characterised by an outstanding and lasting artistic value, not just historical....

271 Muzyka 1927/3, 122, column 'From opera and concert halls.'

272 Muzyka 1937/1, 24. 
The SMDM Board hopes that the Publishing House will be embraced by the loving care of the Polish musical community, which has not yet had the opportunity to learn about old native music to the same extent as works of art and fine arts. ${ }^{273}$

For the credibility and raising the prestige of the series, in May 1927, the Board of the Association invited Adolf Chybiński by letter. It was known that Chybinski, from the time of his studies in Munich and throughout his scientific activity, devoted himself primarily to the recognition of the history of Polish music - mainly the Renaissance and Baroque periods, and debuted with the work of Bogurodzica pod względem historyczno-muzycznym [Bogurodzica from an historical-musical perspective] (Cracow 1907). At the end of the 1930s, Hieronim Feicht counted more than one hundred contributions, notes and materials about monuments and figures from the Polish musical past by his promoter ${ }^{274}$ who, penetrating mainly Cracow's archives, brought to light and brought to order many musical artefacts, previously forgotten and completely absent from the repertoire.

For musicians with solid practical education and ambitious plans to promote high-level musical culture, such as the founders of SMDM - Ochlewski, Rutkowski, Zalewski - but not sufficiently prepared to implement these plans in scientific terms, the consent of the professor of the Jan Kazimierz University, head of one of the three Polish musicological centres specialising in the history of early music, for them to cooperate, was an indispensable condition for the implementation of this idea. In the spring of 1927, duly encouraged by earlier contact with the professor regarding the preparation for one of Mielczewski's canzonas by the musicians, they wrote to Lviv:

Dear Professor, At the beginning of the current year [SMDM was founded in Warsaw], of which we send short information, wanting to interest you, Honorable Sir, and gain his valuable knowledge and experience for our purposes. The matter of the Association's activity is of great importance: the elaboration and possible publishing of Polish early music. We understand that in this area, without the help of you, Honorable Sir, it would be difficult for us to do anything.... We would like to seek the advice and guidance of you, Honorable Sir, in a whole range of matters (publishing houses, preparations of old Polish compositions and texts etc.), which are difficult topics to talk about via letter. ${ }^{275}$

273 See Stanisław Sylwester Szarzyński, Sonata a due violini e basso d’organo, ed. by Adolf Chybiński and Kazimierz Sikorski (WDMP 1) (Warsaw 1928).

274 Feicht 1937.

275 SMDM to Chybiński from Warsaw 16 V 1927, AACh-BJ, box 5, S-3/1. 
Undoubtedly, Chybiński himself, in the past notorious for undertaking excessive obligations, many of which he was unable - for reasons of time - to fulfil, could not reject this proposal particularly on account of his own interests. In any case, many times - also in the press - he encouraged other centres to take part in Warsaw initiatives. In 1930 he wrote: 'The Association's aim is to ensure the artistic and scientific cooperation of all Polish music environments. Currently, the Warsaw, Lviv and Poznań forces are already cooperating, though not fully yet.... It would be a good thing for the research on early Polish music, which is very desirable so that other Polish milieus - each in their own scope - will join similar publications.'276

For him, working with sources was a passion, and the possibility of using them for purposes, alongside scientific and artistic ones, had to give additional satisfaction. Chybiński was the author or co-author of most WDMP editions that appeared before the war (as well as the first post-war editions released from materials prepared in the 1930s). As Zalewski recalled, 'he put a lot of work into the Publishing House and did not take a penny for it, accepting our principle of work "for an idea," unpaid, purely social, without objection.'277 The professor mainly dealt with the scientific context of the journal, compiled comments, notes on composers, and revised the musical text. When, after many years, on the occasion of the tenth anniversary of the existence of SMDM, the President was receiving numerous expressions of appreciation for his activity, Deputy Minister of the Ministry of Religious Denominations and Public Education, prof. Józef Ujejski, a historian of Polish literature, an outstanding expert in Romanticism, sending a congratulatory letter to the whole team, he also wrote warm words 'in recognition of merit' for Adolf Chybiński, thus proving that in the broadly understood humanist milieu, the Lviv professor was a well-known and respected figure, and the scientific achievements of the Association were identified with him.

While discussing the first issues of WDMP - S.S. Szarzyński's Sonatas and Concerto Deus in nomine tuo by M. Mielczewski - the editorial staff of the Poznań Przeglad Muzyczny, who were friendly with the group of Warsaw music lovers, published an extensive commentary in the magazine:

The activity of the SMDM in Warsaw marked last season not only giving concerts, but also a lasting memento: the publication of the above-mentioned Polish works Fortunately, they are individuals in the younger generation of our musicians who have

276 Chybiński 1930, 592.

277 Zalewski 1977, 105. 
not only vitality and willingness to work, but also the ability to achieve their goals.... one should not overlook the names of these activists: B. Rutkowski, K. Sikorski, T. Zalewski, T. Ochlewski. ... Intending to join the publishing house, the management of SMDM entrusted the leadership to Adolf Chybiński, professor of musicology at the University of Lviv; it was difficult to find a better choice, because knowledge, thoroughness and accuracy in the application of research are known, diligence and knowledge of early Polish literature of this scholar. ${ }^{278}$

Kazimierz Sikorski was invited to help with the realisation of the figured bass and to prepare the performance edition of the WDMP publication. Sikorski was a graduate of the Frederic Chopin Higher School of Music at WTM, where he studied composition with Felicjan Szopski in the years 1911-19, theoretical subjects were taught by the writer of the words above, Henryk Opieński. ${ }^{279}$ At the same time, in the years 1915-21, Sikorski also attended the Philosophy Department (philosophy and law) of the University of Warsaw. After graduating, he left for Lviv to become a student of Chybiński, but rather soon pragmatic considerations dictated he had to abandon musicological studies and start to work in one of Lviv's private music schools. In the same year, 1921, Sikorski started a pedagogical career lasting several dozen years - he lectured (depending on the institution) harmony, counterpoint, composition, solfege, musical forms and instrumentation successively at the Helena Kijeńska-Dobkiewicz Music Conservatoire in Łódź (1921-25), the State Conservatoire Music in Poznań (1926-27), the State Conservatoire of Music in Warsaw (1927-39); ${ }^{280}$ he was also one of the lecturers at courses for teachers at the Music Holiday Centre in Krzemieniec. ${ }^{281}$ In the meantime, he benefitted from the MWRiOP scholarship

278 Przegląd Muzyczny 1928/7, 7.

279 A lot of information about Kazimierz Sikorski's life and activities can be found in PeretZiemlańska 1995, Peret-Ziemlańska 1999, Kowalczyk/Jaraczewska-Mockałło 1995.

280 During the Second World War (1940-44), Sikorski ran the Staatliche Musikschule in Warsaw, an institution opened with the approval of underground authorities. (Adolf Chybiński informed Ludwik Bronarski at the end of 1941 in a letter from 19 December: 'Our music colleagues in Warsaw give some advice. Sikorski runs a music school. Others play in cafes', see Chybiński to Bronarski from Lviv 19 XII 1941, AACh-BUAM, Bronarski's archive, p. 159). After the war, in 1945-54, he began working at the PWSM in Łódź, where he was first the dean of Faculty I, then the rector. At the same time, from 1951, he lectured at the PWSM in Warsaw, which he eventually chose and in which from 1957 until his retirement in 1966 he was the rector, and in 1975 he received the honorary doctorate degree of this university.

$281 \mathrm{He}$ expressed his pedagogical passion by preparing a series of textbooks for learning harmony, counterpoint and instrumentation. 
twice, and in 1925 and 1930 he studied with Nadia Boulanger in Paris. Already in the interwar period, he was an active member of various creative unions: a founding member of SKP (from 1932 a member of the Board), deputy president of the Polish Section of MTMW (1928-30). ${ }^{282}$ In the Society named and initiated after the death of Karol Szymanowski, Sikorski, as a great admirer of the work of the author of Harnasie, became president. Even before the war, he received his first awards and distinctions, including the Polonia Restituta Order, 1937, and after the war the Golden Cross of Merit, 1952, the Jurzykowski Foundation Award, 1981, and awards from the milieu. An important episode in Sikorski's life for the system of music education in Poland was his participation in the preparation of the reform of music education. (Works under the System and Programme Committee at MWRiOP, including, among others, Karol Szymanowski and Janusz Miketta, chaired by Adolf Chybiński.)

As mentioned above, it was originally intended to limit the publishing plans to items covering the Polish musical renaissance and baroque, to works - as Chybiński himself declared - of not only historical but also artistic value. ${ }^{283}$ Publishers wanted to provide a wide range of genres and types of works both for scientific and performance purposes - also as an offer for foreign centres - by Pękel, Różycki, Gorczycki or works extracted 'from total oblivion by Jarzębski, Mielczewski, Szarzyński, first of all previously unknown or known from other editions, but revised due to perceived imperfections and inaccuracies against the original. The professor also dreamed about publishing further works of 'great in value and size ${ }^{284}$ - Szarzyński's Litanies and Completorium or compositions by Zieleński. ${ }^{285}$

282 After the war, he was the president of the Polish Composers' Union (1954-59), chairman of the Polish Music Council (1960), president of the TiFC board (1972-80, since 1980 an honorary president), co-organiser of the first Warsaw Autumn.

283 Dunicz 1937.

284 Ibid, 11.

285 Feicht 1937, 8. Before the war, seventeen editions were published as part of the series: S.S. Szarzyński, Sonata a due violini con basso pro organo (1707), ed. A. Chybiński, K. Sikorski (WDMP 1 Warsaw 1928); M. Mielczewski, „Deus in nomine tuo": Concerto a 4, ed. A. Chybiński, K. Sikorski (WDMP 2 Warsaw 1928); J. Różycki, Hymni ecclesiastici: quatuor vocibus concinendi, ed. A. Chybiński, B. Rutkowski (WDMP 3 Warsaw 1928); B. Pękiel, Audite mortales, ed. H. Feicht, K. Sikorski (WDMP 4 Warsaw 1928); S.S. Szarzyński, Pariendo non gravaris: Concerto a 3, ed. A. Chybiński, K. Sikorski (WDMP 5 Warsaw 1928); M. Mielczewski, Canzona a 3, ed. A. Chybiński, Z. Jahnke (WDMP 6 Warsaw 1928); G.G. Gorczycki, Missa Paschalis ed. A. Chybiński (WDMP 7 Warsaw 1930); Anonimus, „Duma” na 4 instrumenty, ed. M. Szczepańska, 
Just over a year from the establishment of SMDM, in March 1928, another organisation was founded based on the personal 'pillars' of association - Towarzystwo Wydawnicze Muzyki Polskiej (TWMP; Polish Music Publishing Society). Representatives of the newly educated group of musicians knew how much young composers lacked a publishing house which would undertake the publication of new native art, and they were also aware of the lack and shortcomings of pedagogical literature. Only the very few could afford the editions of the European publishing houses (only a few - Karol Szymanowski, Józef Koffler) had contracts with Universal Edition at that time. Artists from the generation born at the end of the nineteenth century concentrated around TWMP who were close both 'ideologically and with age ${ }^{328}$ to the founding members of the new publishing house. The instigators of the project declared that the publishing programme should serve various factions 'often standing at extremely different artistic positions and representing various creative trends, ${ }^{287}$ including the achievements of past eras, which, moreover, did not always appeal to young musicians. As a result, TWMP's offer included both compositions by Jan Maklakiewicz, Eugeniusz Pankiewicz, Piotr Perkowski, Bronisław Rutkowski, Kazimierz Sikorski, Tadeusz Szeligowski, as well as Roman Statkowski, Henryk Melcer, Feliks Nowowiejski, Stanisław Moniuszko and Juliusz Zarembski, and this is also an incomplete list. The publishing plans grew rapidly and, as Zalewski recalls, three lithographs for the production of music were used; for the graphical side of the covers - unified

T. Ochlewski (WDMP 8 Warsaw [1930]); Wacław z Szamotuł: „In te Domine speravi” (Psalmus XXX...), ed. M. Szczepańska, H. Opieński (WDMP 9 Warsaw 1930); S.S. Szarzyński, „Jesu spes mea.” Concerto a 3 de Deo, ed. A. Chybiński (WDMP 10 Warsaw 1931); A. Jarzębski, „Tamburitta” a tre voci, ed. M. Szczepańska, K. Sikorski (WDMP 11 Warsaw 1932); M. Zieleński, „Vox in Rama.” Communio, ed. A. Chybiński (WDMP 12 Warsaw 1933); P. Damian [Stachowicz] P.S., „Veni Consolator.” Concerto a 2, ed. A. Chybiński (WDMP 13 Warsaw 1934); G.G. Gorczycki, „Illuxit sol.” Motetto de Martyribus, ed. A. Chybiński (WDMP 14 Warsaw 1934); A. Jarzębski, „Nova Casa.” Concerto a 3 Violini e Cembalo, ed. M. Szczepańska, K. Sikorski (WDMP 15 Warsaw 1936); J. Różycki, Magnificemus in cantico, ed. A. Chybiński (WDMP 16 Warsaw 1937); B. Pękiel, Missa pulcherrima, ed. H. Feicht (WDMP 17 Warsaw 1938).

In the 1930s TWMP, founded and led by members of SMDM, also opened the Polish Choral Song series, in which choral compositions of contemporary Polish composers were published, including Tadeusz Mayzner (booklet I), Jan Maklakiewicz and Władysław Raczkowski (booklet II), Tadeusz Szeligowski (booklet III), Stanisław Kazuro (booklet IV), Bronisław Rutkowski (booklet V) and others.

286 Zalewski 1977, 115.

287 Ibid. 
for all publications - responsibility was held by Edward Manteufel, a graphic designer who had already designed the cover of the flagship title of the publishing house - Kwartalnik Muzyczny. At one point organising the production of music in the flat at 16 Zurawia Street obliged the Management Board of the Society to formalise contacts with creators, elaborate the principles of taking over copyright and transferring fees to composers according to contracts developed for this purpose. The publishing house could settle into routine work also thanks to the changes that took place in the government when Wojciech Jastrzębowski was promoted to the new publishers as the director of the Department of Art. As it turned out; unfortunately, they received less support from the Department of Music, which was managed by Janusz Miketta. However, they could always count on the help of FKN and its head Stanisław Michalski.

The new TWMP statute, approved on December 20, 1934, indicates its primary goals, valid since the beginning of the Society's activity: 'supporting Polish musical creativity, strengthening its position and significance as one of the manifestations of the cultural life of the Polish nation, spreading love for music among broad layers society and cooperation of Polish musicians on the promotion of musical culture in Poland. ${ }^{288}$ In addition, in agreement with MWRiOP, the Society organised a collection of manuscripts by Polish composers, in which the works submitted from the departmental subsidies for this purpose were written out in parts and made available in such a form for a fee. Less than three months later, in March 1935, a new Board was elected: Teodor Zalewski became the president, board members - Kazimierz Sikorski (secretary, chairman of the Publishing Committee), Tadeusz Ochlewski (chairman of the ORMUZ Committee), Feliks Łabuński ${ }^{289}$ (chairman of the Contemporary Music Committee); the treasurer and chairman of the Propaganda Commission (being at the same time the editor of the Muzyka Polska quarterly, which was launched in 1934), was Bronisław Rutkowski, and the deputies were Roman Palester and Julian Pulikowski.

In the next few years, the only music publisher so widely conceived at that time realised its plans including both music publications, as well as books and

288 MP 1935/5, 88

289 Łabuński first studied music in Warsaw, and from 1926 in Paris with Nadia Boulanger (composition and counterpoint) and from 1928 with Paul Dukas (orchestration). In 1926 he also undertook musicology studies with Georges Migot. He was a co-founder of the Association of Young Polish Musicians (including secretary in 1927-29, vicepresident in 1929-30 and chairman in 1930-33). After returning to Poland in 1934, he was among others the head of the classical music editorial office at Polish Radio and a member of the TWMP Management Board. 
magazines. Its organ was the aforementioned Muzyka Polska; The Society also dealt with the printing and compiling of the next periodical for musicologists Polski Rocznik Muzykologiczny (PRM) - transformed from Kwartalnik Muzyczny, and Gazetka Muzyczna - a magazine for the youngest generation. In 1935 the TWMP also published an excellent monograph by Ludwik Bronarski, Chopin's Harmony, probably in this respect the first analytical oriented dissertation in Polish on issues related to research on Chopin's work, and also the first such a serious publication on the Society's list of titles.

In Warsaw, the opinions about the 'clique' of the 'Music Lovers' were obviously not unambiguous. On the part of the milieu focused in particular around Muzyka, allegations were made to take over the lion's share of state subsidies for musical purposes, similarly as regards funds from FKN. An anonymous publicist of Muzyka, perhaps the editor-in-chief, Mateusz Gliński, posted the text 'Clique or not a clique? In response to the "answers", 290 Zalewski's replica of the defence of SMDM, replete with irony, was published in Muzyka Polska, ${ }^{291}$ (this, in turn, was the answer to the anonymous column in the section 'Musical impressions' entitled 'Apology and apologists of ancient music'). ${ }^{292}$ Zalewski's arguments that 'The scope of work of these institutions [SMDM and TWMP] is indeed quite wide: permanent concerts in Warsaw, music notes and music book publishing house, magazine, organisation of musical movement in the province, programmes for school youth, ${ }^{293}$ were reminded with a comment that the members of the Association 'made energetic efforts to include the Warsaw Opera, the Warsaw Music Society, the Directorate of concerts at the Conservatoire'294_ conclusion: they wanted to take control of the entire musical life of the capital. The tone of the note was, of course, overly ironic and resulted from the animosities that divided the Warsaw music community in the fight for public funds, but it gives an image of how strong the Zalewski-Ochlewski-Rutkowski group and colleagues team was, full of new ideas implemented in larger and larger areas of culture.

The creators of SMDM and Adolf Chybinski had a special intimacy. The professor and Warsaw musicians set themselves the goal for their association's activity: to discover, announce and save from oblivion - through performances

290 Muzyka 1937/3, 84-86.

291 Zalewski 1937.

292 Muzyka 1937/, 21-22.

293 Zalewski 1937, 98.

294 Muzyka 1937/3, 84. 
and editions - artefacts of Polish music. Everyone did the best they could. Chybiński was almost a full generation older than the rest - in the 1920s, when they started their cooperation, the Lviv musicologist released his subsequent group of graduates, Zalewski, Rutkowski and Ochlewski had only just received their diplomas, so for them he was also a kind of master and guide in the musical Old Polish literature. They were impressed by his personality. Zalewski recalled: 'I met with prof. Chybiński quite often and received much cordiality and kindness from him. Personally, I liked him very much and appreciated him immensely, ${ }^{295}$ and then presented such a personality characterisation of the professor's personality: 'erudite, a bookworm, a pedantic and meticulous researcher - in his research he was characterised by accuracy, the ability to use all sources in a comprehensive manner and a great sense of responsibility in formulating conclusions. ... introverted, somewhat mysterious, hardly communicating outside, always hidden somewhere .... He had something of a Benedictine monk in his posture. ${ }^{296}$

In those years, Chybiński was the dean and vice-dean of the Faculty of Humanities at the Jan Kazimierz University, chairman of the faculty's examination committee, vice-president of the PTM, chairman of the Opinion Committee of the Music School System, member of the composition competitions committee. Despite all these duties, he had to welcome the invitation to participate in a project involving the promotion of early music, which came from Warsaw, with great satisfaction. Not only was he chosen as the leading authority in Poland, which must have been flattering for him but the invitation itself opened before him completely different possibilities of 'organising' his own research passions. Zalewski and colleagues counted on the inflow of a new repertoire for their broadcasts - at last the professor could hope that he would be able to show his musical discoveries to the world in a manner he thought fit.

He had a very sceptical, ironic and unwilling attitude towards the Warsaw environment, and even to the city itself as a cluster of people. We do not know the correspondence he directed to the members of the Association's Board, but in letters to Ludwik Bronarski, he repeatedly mentioned 'manifestations of Warsawism,' 'Warsaw's conduct' or 'Warsaw's cunning' as a synonym of deviousness. He complained: 'I have a real "Warsaw poverty" with Kwartalnik.... I cannot bring "Warsaw" to order. I will probably go one day to give someone an ultimatum.297 And other times: 'I am kindly asking to inform me about

295 Zalewski 1977, 104.

296 Ibid.

297 Chybiński to Bronarski from Lviv 21 III 1929, AACh-BUAM, Bronarski’s archive, p. 14. 
possible Warsaw insubordination, which sometimes becomes my bone in my throat. Warsaw's mess has its own style, and because there is a "Stylish" theatre and a "Stylish" cinema in Warsaw, the magazines must be "stylish" as well.298 It even seems that due to various misunderstandings, at some point a split could have occurred in the SMDM Board. Anticipating some information about Kwartalnik Muzyczny itself, it is worth mentioning that at the turn of 1929 and 1930 disputes continued about the profile and content as well as the definition of the 'target group' of the magazine's readers. From two subsequent letters to Bronarski, we find out what Chybiński was going to Warsaw with and what he returned with:

... On Sunday I have a meeting of the board of the SMDM. It will be hot there because the board is not fired up by 'musicology' and therefore is not happy with the direction of Kwartalnik. They would like more 'news.' I do not oppose it, yes, but who will write it?... Of course, I know that the SMDM board will be beaten and at least helpless. But let's just get a resolution that Kwartalnik will live until the end of his second volume, and I will not grieve at all, because then, on the model of Switzerland, we will create a yearbook only that it is no longer musical but musicological. Support from governmental factors will be certain, we will receive the money. Then the whole ballast of various headings and reports will fall off, and no one will cramp us with anything or anybody. There will be a lot of news and news, but for more serious people. ${ }^{299}$

And two weeks later:

We have not changed in Warsaw. In my own way, I hit the argument with whatever fist I hit the table and I saw (or maybe it just seems to me that I saw) how they put their ears down. The most important was my query, or rather two questions: 1. Is the Kwartalnik to be changed into Muzyka of Mr. Herzenstein-Gliński? 2. What other collaborators are proposed by the Association's management? Because 'no' came as an answer, I found the matter settled. I also threatened the yearbook. ${ }^{300}$... As it was, it will be. ${ }^{301}$

Among the members of the SMDM-WDMP group, surely the most intimate contact was between Chybiński and Kazimierz Sikorski for several reasons. First of all - they knew each other before; at the beginning of the 1920s, for a short time, Sikorski was his student at Lviv musicology. Although the plans - as it turned out soon - were different then, as mentioned above, he devoted himself

298 Chybiński to Bronarski from Lviv 3 VI 1930, AACh-BUAM, Bronarski’s archive, p. 39.

299 Chybiński to Bronarski from Lviv 24 I 1930, AACh-BUAM, Bronarski’s archive, k. 30.

300 The issue of the shape of the magazine and the idea for the year came back three years later and ended with the separation of the team into two editorial offices - a quarterly (with the bi-monthly and monthly periodical) Muzyka Polska and PRM, below.

301 Chybiński to Bronarski from Lviv 10 II 1930, AACh-BUAM, Bronarski’s archive, p. 31. 
to pedagogy there, but it was known that he came to the UJK especially for classes with the professor. Secondly, they shared their common tasks within the Association: running Kwartalnik Muzyczny, in which Sikorski became a secretary. Even though Chybiński, as seen, often complained about cooperation with Warsaw, they trusted each other. Above all, however, Sikorski was an excellent theoretician, which in Chybiński's eyes was his great asset. According to the professor, a real musicologist should absolutely have their skills deepened in the field of learning harmony and counterpoint, which he repeatedly emphasised. Although Sikorski did not claim to be a musicologist, he nevertheless perfectly suited Chybiński's expectations when it came to the academic treatment of the musical matter, which they dealt with together.

Less is known about the relations between the professor and Rutkowski and Zalewski, apart from the brief reflection of the latter cited above. On the other hand, he often corresponded with Ochlewski before the war, mainly on a professional basis. Their contacts tightened strongly after 1945, when he became director - created on the basis of pre-war structures - of the state-owned music publishing house, which also included the executive editing of the post-war edition of the Kwartalnik Muzyczny and in which the various pre-war publishing plans were resumed. From the large amount of correspondence between Chybiński and Ochlewski from 1944-52, on the only 'war' card, Chybiński turns to Ochlewski with a formula 'Dear and beloved Colleague,' but in the letters there are only very cordial phrases 'My Dear and Dear Tadziu,' 'Dear Tadzieńku,' 'Dear Teddy' The professor probably wrote one of his last letters to Ochlewski, revealing intimate details related to his health. The then director of PWM wrote the opposite, probably almost as often, always starting with the heartfelt phrase 'Dear Dolek', but it seems that due to his function and duty as the head of the publishing house he tried to keep some distance; he often drew his friend's attention to his imperfections as an author and editor, although he always tried to do so gently - once he turned the situation into a joke, another time patiently lecturing.

In the mid-1930s, Chybinski's contacts with the founders of SMDM and WDMP became colder, mainly due to the changes that took place in the field of publishing politics, and marginalisation of the position of the professor to the role of a one-man editor in the PRM - a newly created journal, admittedly academic when it comes to for content, but more niche in terms of reception than the previous Kwartalnik. At the same time, the group of associates of the Association was growing, and the functions in the structures of institutions were passed into the hands of new members. In the spring of 1938, for example, after another change in the TWMP Management, Kazimierz Sikorski from the old 
circle became the president, Tadeusz Szeligowski was already the secretary, and the treasurer was the composer and conductor Michał Jaworski, and members Stanisław Wiechowicz and Piotr Perkowski. Muzyka Polska in 1937-39 was edited by Konstanty Régamey. Pulikowski, who shortly after arriving in Warsaw was admitted to all 'formations' of 'Lovers' - SMDM, WDMP and the editorial board of Muzyka Polska, a new organ of the group - after the fuss that took place at the turn of 1937/38, which was associated with the person acting as the secretary of the editorial office of the monthly Stefan Kisielewski, ${ }^{302}$ he left the Association. The details of these events will, however, be the subject of further chapters.

From the above brief sketch outlining the panorama of the main environmental associations and societies of the interwar period, it is clear that Adolf Chybiński, who was never an initiator of establishing these organisations, was usually engaged in their works by being invited to a close group of boards, or even taking over the chairman function. From the first years of the new century, he was one of the central figures of the nascent Polish musicology and, with time, its Nestor, around whom the opinion-forming part of the musical community was focused. Unfortunately, his unstable nature, irritability, and the tendency to contest the actions of other circles than his friends meant that, with time, he gave up on work that would benefit further organisations or led to situations in which he was marginalised. Mieczysław Tomaszewski, writing about Chybiński in the context of his difficult contacts with Jachimecki, stated that the first of them 'he did not sin with openness, he was easily offended and often withdrew. ${ }^{303}$ This brief, but very accurate description can be related to the collaboration of Chybiński with almost the entire environment operating in these years, although - paradoxically - it is difficult to imagine the life of this environment without the professor. After the war, this sphere of activity - an activist and organiser - was continued by his pupils and the next generation of Polish musicologists.

302 Pulikowski did not reveal his chauvinistic tendencies at the time, preferring anti-Semitic beliefs to professional cooperation. Kisielewski, accused by Pulikowski of communism, was ready to pursue his rights in court, see letter of 4 IV 1938, quoted in Pulikowski to Chybiński from Warsaw in April 1938, AACh-BJ, box 3, P-28/197.

303 Tomaszewski 2004, 185. 



\section{Music magazines of the interwar period: Lwowskie Wiadomości Muzyczne i Literackie, Poznań's Przegląd Muzyczny, Mateusz Gliński's Muzyka - other environmental and local musical magazines - controversies over the model of an expert journal of the milieu}

In the uncertain conditions of the first years of independent Poland, musicologists active in the country looked for any opportunity to announce the results of their work. After the years of the Great War, the few previously functioning musical journals were slowly coming back to life. However, the time was not favourable for such activities; public funds were cautiously granted, directed primarily toward rebuilding the state apparatus. Nevertheless, efforts were made in academic centres to revitalise scientific writing; these efforts were also present in the activities of the broadly understood musical environment, including Polish musicology of the time. The main dramatis personae were Zdzisław Jachimecki, Henryk Opieński, Łucjan Kamieński and a large group of musicologists from Lviv with Adolf Chybiński at their head, who, as has already been presented earlier, had for years held ambitions to actively participate in giving shape to the writing in the field of his discipline.

Just after the war, though for a short period (in the years 1918-19), the Warsaw Przeglad Muzyczny was reopened, still under the editorship of Roman Chojnacki, in an unchanged graphic layout. The opening edition was prepared by Adolf Chybiński, featuring the letters of the Moniuszko spouses from the Ossoliński ${ }^{304}$ Library's resources. Gazeta Muzyczna, edited by Stanisław Niewiadomski, operated in Lviv a little longer (until the year 1921). In the capital, after Przeglad Muzyczny closed, in 1922 Stanisław Kazuro attempted to fill the gap, producing Kultura Muzyczna, in 1925, Edward Wrocki's Wiadomości Muzyczne started activities. In other centres there were editors of local and specialised interest music magazines, such as Muzyk Wojskowy published in Grudziądz as a biweekly (later a monthly), in Poznań Śpiewak (which was a reactivation in 1918, but in

304 'Nieznane listy Stanisława i Aleksandry Moniuszków' [Unknown letters of Stanisław and Aleksandra Moniuszko] (PM 1918/1-2, 1-5). 
the face of constant financial problems transformed into Przeglad Muzyczny, also published in the capital of Greater Poland and edited by Opieński), in Katowice Śpiewak Ślaski (which turned out to be the most viable music journal, as it was in print until the year 1939, although like other similar writings it did not play a nationwide role $)^{305}$ and a number of minor, ephemeral publishing houses. In these circumstances, a significant and opinion-leading role, not only at the regional level, was played by Lwowskie Wiadomości Muzyczne i Literackie (further LWML), led by the violinist and teacher Władysław Gołębiowski. Appearing from autumn 1925 to May 1934, with a break between July 1931 and October 1932, the monthly was an organ of the Związek Muzyków-Pedagogów [Union of music teachers] in Lviv. Its wide editorial circle above all included musicians, musicologists and music critics (as well as literary figures) - including Adolf Chybiński and the composer and conductor (also a critic with musicological training) Adam Sołtys, professor of the Conservatoire, Franciszek Neuhauser, composer and lecturer (in Lviv and Katowice) Adam Mitscha, Father Hieronim Feicht, Bronisława Wójcik-Keuprulian.

For Lviv's relatively large musical-musicological environment, the LWML became a convenient, near (geographically) address, to which were directed as with other similar titles - chronicles of current events as well as lengthy dissertations, often extending outside the framework of common popularisation. It was established at a similar time as Warsaw's Muzyka and Poznańs Przeglad Muzyczny and was consistent with them in terms of content, authors' letters and the frequency of editions (considering of course certain figures active only locally in each of the cities as well as the 'fidelity' of certain names to one of the titles to a larger degree than others). Historical sketches were written, as well as articles devoted to the work of earlier and contemporary composers, often on particular occasions such as birthdays and anniversaries. ${ }^{306}$ Surprisingly rich for

305 Fojcik 1985/1986.

306 Chronologically speaking - starting from the four hundredth anniversary of Palestrina's birth (Zofia Pohorylesowa, 'Palestrina,' LWML 1925/6, 1), through two hundred years from Gorczycki’s death (Adolf Chybiński, 'Grzegorz Gerwazy Gorczycki,' LWML $1934 / 84,1$ ), the fiftieth anniversary of Wieniawski's death (an emotional article by Józef Reiss demanding the restoration of a supposedly worthy place in the history of Polish music as a somewhat forgotten composer: 'Czy to nie wstyd?' [Is this not a disgrace?], LWML 1930/7-8, 1) and a whole range of other contributions to commemorate or honour important figures of musical life. This group of materials includes a comprehensive biography devoted to Chybiński, which the editorial team prepared in connection with the fiftieth anniversary and twenty-fifth anniversary of his academic work (LWML 1930/11, 1-2). 
the organ devoted only (?) to 'matters of musical culture', articles moving around theoretical and aesthetic issues were represented, supplemented with the themes of practical musical modernity. On the one hand, this was fueled by a comprehensive discussion of new trends in music dynamically developing in the first decades of the twentieth century (considered at the level of straightforward information and reports about concert life, as well as in-depth musicological considerations), and on the other, new media as well (radio and cinema that supported the dissemination of music on a new, previously unknown scale). A few regular authors wrote these subjects appearing in LWML. One of the fundamental goals of publications by Józef Reiss, Zofia Lissa or Stefania Łobaczewska was to somehow make the contemporary listener aware of what was changing in the work of the new generation of composers with regards to previous traditions; how to listen to new music appreciating these changes, how the listener should be prepared to receive the new music. ${ }^{307}$ To support his actions in propagating avant-garde art, the editors came up with a series of articles by an outstanding musician and writer from Arnold Schöberg's circle, Erwin Stein, who brought the question of compositional work into not only the latest era of music history, but also the role of the audience in modern times. ${ }^{308}$

The group of theoretical-aesthetic texts may be complemented by materials referring to the dissemination of music and musical culture, in which sociological issues were of considerable importance. In this case, Józef Reiss also turned out to be one of the primary authors dealing with the sociology of music, as he himself stated, not based so much on strict scientific foundations, but as issues for discussion, a stimulus for independent consideration.' ${ }^{309}$ The author, otherwise known mainly and primarily from his achievements in the field of historical research, even undertook such polemical topics as music inside prison walls ${ }^{310}$

307 Here see for example, the reprint of Józef Reiss's extensive lecture given to the LiteraryArtistic Circle in Lviv called 'Ideologia dzisiejszej muzyki' [Ideology of today's music] (LWML 1929/12, 2, 1930/1, 1-2, 1930/2, 2), or Zofia Lissa’s article 'O słuchaniu "nowej” muzyki' [On listening to 'new' music] (LWML 1930/26, 2, 1931/1, 1-2), and that of Stefania Łobaczewska, 'Problemy współczesnej estetyki muzycznej' [The problems of contemporary musical aesthetics] (LWML 1931/2, 1-2).

308 Erwin Stein, 'Muzyka współczesna a publiczność' [Contemporary music and the public] (LWML 1928/3, 1-2); 'Melodia w muzyce współczesnej' [Melody in contemporary music] (LWML 1928/7-8, 2); 'Co to jest muzyka atonalna?' [What is atonal music?] (LWML 1929/5, 2) (all texts translated from German into Polish).

309 Józef Reiss, 'Socjologia muzyki' [Sociology of music] (LWML 1928/5, 3).

310 LWML 1928/9, 1. 
or gender studies - as we would say today - the theme of women's musicality, their perception of women mainly as performers and not as creators, the traditional equation of music with the figure of a woman. ${ }^{311}$ In turn in the article 'Jak mówić i pisać o muzyce?' [How to speak and write about music?] he abandoned the sociology of music in favour of discussions about music criticism, ${ }^{312}$ and his considerations were completed in the following months by publications by Łobaczewska ${ }^{313}$ and Chybiński. ${ }^{314}$

Regarding the number of publications on the pages of LWML, Stefania Łobaczewska decidedly surpassed other authors, and it should be emphasised that she filled her texts mainly with reviews of musical and musicological literature, discussing books as well as studies and articles announced in journals (often published in the form of offprints). ${ }^{315}$ Thanks to Lobaczewska, readers could get to know the latest work of her university colleagues - Bronisława Wójcikówna (for example, Problem formy w muzyce romantycznej [The problem of form in Romantic music]. Lviv 1929), ${ }^{316}$ Maria Szczepańska (amongst others Nowe źródło do historii muzyki średniowiecznej w Polsce [New sources for the history Medieval music in Poland]. Cracow 1930), ${ }^{317}$ Zofia Lissa (O harmonice Aleksandra Skriabina [About Alexander Scriabin's harmony]. Warsaw 1930, Zarys nauki o muzyce [Overview of music principles]. Lviv $1934^{318}$ and others), with the

311 LWML 1928/6, 1. We are talking about shared music and love of the sensual element, about identifying a melody with a woman, rhythm with a man, singing as a woman's domain, and playing an instrument - a man's; Reiss derived all of these claims from sociological and psychological conditions.

312 LWML 1929/6, 1.

313 'O celach i zadaniach krytyki muzycznej' [About the goals and tasks of music critics] (LWML 1929/12, 3-4).

314 'O kilku problemach krytyki muzycznej' [About a few problems of music criticism] (LWML 1930/2, 1, 1930/3, 1).

315 At the same time, Łobaczewska was also a regular reviewer, columnist, reporter and critic in Gazeta Lwowska Magdalena Dziadek, who years ago presented a lengthy study on the subject of the music critic activity of the Lviv musicologist (Dziadek 2004/3), stated: 'Łobaczewska wrote much on various matters, which resulted from her duties as a regular critic at a daily newspaper, as well as from the prevailing confidence of the musicologists, who considered themselves competent enough to discuss music of all cultures and periods. However, she did express her thoughts at a professional level, giving evidence of her knowledge of European cultural life' (ibid., 91-92).

316 LWML 1930/1, 4.

317 LWML 1931/1, 3.

318 LWML 1931/1, 3-4, 1934/84, 4. 
new Kwartalnik Muzyczny $y^{319}$ and editions appearing under the framework of the $\mathrm{WDMP}^{320}$ series, as well as new compositions (including amongst others works by Jan Maklakiewicz, Kazimierz Sikorski and Szymon Walijewski). ${ }^{321}$ However, Łobaczewska announced only a few pieces from the field of music criticism and music aesthetics. In the feuilleton 'O kult muzyki współczesnej' [About the cult of contemporary music] she joined the group of authors who explained where current musical creation was and the task before the propagators of the newest works - in this case, institutions such as the restored activity of the Lviv section of the TMW. ${ }^{322}$

Within LWML, Łobaczewska twice raised public controversy with her recent preceptor, Adolf Chybiński. One of the disputes concerned the legacy of Grzegorz Gerwazy Gorczycki which, in her (Łobaczewska's) assessment, deserved attention not because of its artistic value, which - according to her - was not great, but because it contributed to the narrow body of preserved monuments of Polish baroque literature. ${ }^{323}$ This critical assessment of the work of the cathedral Kapellmeister is surprising since the same reviewer accepted with praise the edition for Gorczycki's Missa paschalis prepared by Chybiński, also raising the artistic qualities of this composition, as part of the WDMP series. ${ }^{324}$

Among the surnames outside the strictly musicological group of Lviv, mention can be made of Wiktor Brumer, a theatrologist and theatre critic who also had his own writing episode in Kwartalnik Muzyczny, or Stefan Śledziński, who spoke about methods of teaching singing in general schools, and Arnold Schönberg or his student Hans Eisler (in the future one of the leading ideologues of socialist realism in communist Germany), whose articles in the field of music theory were published in translations. ${ }^{325}$

Occasionally, the editors of LWML decided to organise monographic numbers. The May issue of 1928 was partly themed and was devoted to the philosopher, the representative of messianism, Józef Hoene-Wroński, on the occasion

319 LWML 1926/6, 2-3.

320 LWML 1930/7-8, 4.

321 Ibid.

322 'O kult muzyki współczesnej' [About the cult of contemporary music] (LWML $1932 / 68,3)$.

323 The polemics between Chybiński and Łobaczewska took place in LWML 1933/731933/75, passim.

324 See LWML 1930/7-8, 4.

325 Fragments of Harmonielehre in LWML 1927/11, 1; 'Co należy wiedzieć z teorii muzyki?' [What should one know of music theory] (LWML 1928/10, 3). 
of the one hundred and fifty years of his birth. At that time, amongst others, the introduction to Christian Cherfils's study Un essai de religion scientifique 'Introduction à Wronski philosophe et réformateur' (Paris 1898) was published (in translation) and Paulina Chomicz's large sketch 'Hoene-Wrońskiego filozofia muzyki ${ }^{326}$ [Hoene-Wroński's philosophy of music]. On the other hand, number $80^{327}$ from January 1934 was dedicated to Ukranian music. ${ }^{328}$

Among about fifty titles of academic journals, which appeared in general in Lviv in the years 1918-39 (most often related to the activities of scholarly societies - Polskie Towarzystwo Filologiczne [Polish philological society], Polskie Towarzystwo Ekonomiczne [Polish economic society], Polskie Towarzystwo Filozoficzne [Polish philosofical society], Polskie Towarzystwo Historyczne [Polish historical society], Polski Związek Entomologiczny [Polish entomological association] and others, whose headquarters were located at UJK), LWML is of course absent, because it is not an academic journal (despite many 'university' authors). Grażyna Wrona, press historian, while running queries and studies at the National Archive of Lviv Oblast (within the documents of the Lviv County, Press Office 1925-39), amongst others, recorded and entered into her catalogue 'writings on the registration of a Polish scientific [emph. MS] magazine Chopin' (fond 110, description 3, case 285). ${ }^{329}$ This 'Popular musical monthly', founded and run by the singer and pedagogue Władysław Świeży, appeared only for the last four months of 1932. On behalf of the editors Świeży wrote for the inauguration: 'In memory of "Chopin Days" in Poland we began publishing Szopen, a monthly magazine serving as a popular read for all those interested in music ... The editorial office invites all musicians for cooperation in order to give the magazine the assumed popular character.

Although the journal had indeed presented mainly news of lesser significance, poetry, musical chronicles, obituaries, reviews of concerts and opera performances, there were also articles and reports written by members of the Lviv musicological community. The very first issue started with an article by Bronisława Wójcik-Keuprulian on Chopin, followed by a text by Stefania Łobaczewska on the Chopin Piano Competition. The second issue began with an

326 LWML 1928/5, 2, 3.

327 Initially, the journal was marked with a double numbering system - according to the year and in continual numbering. After the break, from the last issues of 1932, only continual numbering was used.

328 Wasyl Barwinski’s comprehensive review study: LWML 1934/80, 1-2, 1934/81, 1-2, 1934/82, 2-3.

329 Wrona 2003, p. 178, see footnote 6. 
article by Zofia Lissa 'Młodzież a życie koncertowe' [Youth and concert life] and most of the columns were filled with a text by Świeży on Edward Grieg. The third issue was published under the slogan 'Dni chopinowskie we Lwowie' [Chopin days in Lviv] and included discussions on the works of Chopin by Seweryn Barbag and Jerzy Freiheiter as well as texts by Zofia Lissa and Stefania Łobaczewska. Finally, the fourth issue included a monograph by Maria Szczepańska entitled 'O kolędzie polskiej' [On the Polish carol]. Nonetheless, Chopin had no chance for longer existence. It was issued on poor-quality paper and - like many times before in similar cases - thanks to funds from the chief editor. Despite a benevolent group of authors, it was unable to break through as a 'mandatory organ for music students in Poland' (in the notes from the editor's found in the first issue).

For not much longer - from September 1936 till March 1937 - 'a monthly dedicated to the musical culture of Lviv' was also published in Lviv - Echo, whose editor-in-chief was a graduate of Viennese musicology, Józef Koffler, and the responsible editor was Wacław Töpfer. Contrary to Szopen's 'popular direction,' from the beginning the editors of Echo defined the ambitious profile of the magazine. The intention was 1) to educate an aware music lover, 2) to develop and sharpen the sense and awareness of quality which is the foundation for a real musical culture, 3) fight all harmful influences (but which? we do not know), 4) check the activity of factors responsible for music culture.

Also, in this case, the editors were able to invite musicologists and music critics active in the city - Adam Sołtys, Seweryn Barbag, Wiktor Hausman, Zofia Lissa, Stefania Łobaczewska - to collaborate. However, it needs to be stressed that for the widely perceived musical circles of Lviv, the primary forum for discussion and musical criticism in the two-decade inter-war period was above all LWML, which, though it boasted many eminent names among its authors, maintained the character of a local periodical.

It was different in the case of the Warsaw monthly Muzyka, founded merely a year earlier and led by Mateusz Gliński. Encouraged by the state of affairs, also cultural, that reigned in the short time after Poland's regaining independence, the young editor, active as a conductor and music critic, decided to establish and publish a regularly appearing magazine of an informational character. He had the ambitious concept of collaborating not only with critics and music journalists but also with leading musicologists of the first (and soon also second) generation.

Gliński, born in Warsaw in 1892, began learning to play the violin as a seventeen-year-old with Stanisław Barcewicz and theory with Roman Statkowski and Mieczysław Surzyński at the Warsaw Conservatoire. Before finishing his studies, he was engaged by Fitelberg to join the Philharmonic Orchestra. After 
four years, in 1913 he left to study conducting in Leipzig under Artur Nikisch, thanks to whom he was even a member of the Gewandhaus Orchestra for a short time. At the same time, he studied composition under Max Reger at the Leipzig Conservatoire and attended lectures by Hugon Riemann, Artur Prüfer and Arnold Schering in the musicology department of the local university. In view of the deportation from Germany, which he was subject to in connection with the outbreak of war, he decided to continue his musical studies in St. Petersburg (theory and conducting). As a conductor, he made his debut the following year during a short visit to Warsaw, leading an outdoor concert in the Swiss Valley square.

In 1914, he began to contribute criticism and music reports for the Russian press, and he was active in this field in Warsaw from the first moments following his return in 1918. Soon, it was journalistic and organisational activity that dominated Gliński's professional life. He was the creator or co-creator of several circles of initiatives already described above, important for the musical life of the Warsaw and nationwide, such as the establishment in 1926 of Stowarzyszenia Pisarzy i Krytyków Muzycznych [Association of music writers and critics] (originally as Klub Fachowej Prasy Muzycznej [Club of professional music press], see chapter I.2). The legal training Gliński obtained in the meantime allowed him many times to support non-profitable cultural and publishing activities through profits gained from his legal practice.

The plan to open a new environmental title dedicated 'not only to professionals, but to all those who admire beauty and are interested in the development of both Polish and foreign art, ${ }^{3}{ }^{30}$ was devised at a time when there have already been at least several music magazines, which, though admittedly often featured educated musicologists, usually had a small range, a local character, and were rather shortlived. On the other hand, Gliński assumed that thanks to his mission he would receive acclamation. He spoke more about his goals in the programme note, full of pathos, and the editorial guidelines:

The musical life of Poland, until now immersed in lethargy, will awaken and set itself on the road to progress only when the whole of society takes part. It is already paying much attention to other, related fields of art; only regarding music has it shown great indifference so far. There is thus a tragic gulf that separates the activity of our leading musical institutions and the work of outstanding individuals in this area from the broad layers of Polish society. Therefore, a fundamental goal of our activities will continue to be awakening and stimulating healthy musical instinct, combatting illiteracy and disorientation in the field of music.... The fundamental character of the journal will continue to

330 'Od Redakcji' [Editorial], Muzyka 1924/2, no page numbers. 
combine serious content with a lightness and accessibility of form, allowing broad layers of our society to have living contact with Muzyka. ${ }^{331}$

Despite this pretentious form, the editors clearly defined the content of the magazine as of a popularising, informative and educational character. As we shall see later in the work, at the stage of formulating the editorial - referring to the tradition of similar programme notes, many other journals of the milieu, which (also from pure pragmatism and for saving finances) wanted to find readership - Muzyka stood in opposition to the idea of publications of a scientific nature, choosing 'lightness and accessibility of form, appropriate for the assumptions of popularising knowledge about music, and avoiding any ideology. In the further part of the declaration of the programme, we read:

Our journal strives to combine all the healthy currents in our musical lives under the slogans of culture and progress. It does not belong to any movement, any party or clique. Interest in modern musical trends is combined with regard for the past and respect for every serious artistic effort resulting from a sincere love of art. Striving to bring the musical life of Poland closer to European artistic movements is combined with real care for the development of Polish national art and the preservation of its independent ethnographic elements in their pure state.... Muzyka strives to bring music closer to other fields of the fine arts: poetry, painting, sculpture, dance, theatre. ... It must not speak for any combative movement, nor proclaim any creative ideology based on excessive individualism. ${ }^{332}$

The popular character of this publication was perceived by some contemporary critics and publicists, as well as advocates of such music literature, as a basic value, writing that "there is no place for "scientism" that would be dry, boring and appeal just to a few people. Reliable musical truth, based on solid ground, is provided in a smooth, engrossing and available manner,' ${ }^{333}$ or elsewhere: 'It [the journal] is not intended for a closed group of experts; to the contrary - its task is to popularise the art of music among the broadest circles of society. That is why each issue has eclectic content designed to meet all tastes and demands, as well as an exquisite external layout, ${ }^{334}$ and years later: 'It is a magazine which can be adjusted to suit general needs, to serve popularisation. It is based on strictly scientific principles, but the content is provided in a form that is accessible and comprehensible for all. ${ }^{335}$

\section{Ibid}

332 Ibid.

333 Felicjan Szopski in the pages of Kurier Warszawski, quotation after: Michałowski 1967, 11.

334 Wiadomości Literackie [Literary news] 1925/7, quotation after: ibid.

335 Kurier Warszawski 1933 from 12 February, quotation after: ibid. 
Gliński began as editor along with the prevalent wave of fascination with contemporary music, which also in Poland had outstanding representatives, even on a European scale, as was the case with the internationally recognised Karol Szymanowski. The journal's first issue appeared in November 1924, just a few months after the Prague ISCM festival, during which its Polish section was formed, and its interim board included both Szymanowski and Gliński. ${ }^{336}$ It was assumed that the periodical would serve the popularisation of music among (as it was termed in the prospectus mentioned above) 'broad layers of society' For this reason, lengthy materials of a scientific character were not accepted for publication: the editors designated 18-20 pages for printed articles, not foreseeing anything 'to be continued.' There were, of course, many diversions from this principle: the editor-in-chief himself, a few months after the premiere of Szymanowski's King Roger, disagreeing with its cool reception among the public and critics, devoted lengthy material to this opera, in which he analysed the current situation regarding opera theatre and the influence of the Wagnerian opera tradition, increasingly unsuitable to contemporary expectations, with examples in the work of Hindemith and Křenek. ${ }^{337}$ Over the next years, approval for larger texts was also received, for example, by Adolf Chybiński, ${ }^{338}$ Zdzisław Jachimecki, ${ }^{339}$ Hieronim Feicht, ${ }^{340}$ and Stefania Łobaczewska. ${ }^{341}$ It was therefore clear that work 'in episodes' was generally written by professional musicologists presenting the results of their current research, discussed in a methodological

336 More about this theme in chapter I.2 dedicated to associations operating in those twenty years.

337 Muzyka 1927/1, 18-20, 1927/2, 60-64, 1927/3, 110-113.

338 See for example, the text which is very important because of the approach to the clash of cultures 'Wschód i Zachód w muzyce' [East and West in Music] (Muzyka 1929/1, 18-20, 1929/2, 74-78, 1929/3, 134-136).

339 'Nokturny Chopina' [Chopin's nocturnes] (Muzyka 1926/10, 520-523, 1926/11-12, 591-594) were fragments of Jachimecki’s monograph Chopin. Rys życia i twórczości [Chopin. An overview of his life and work] which was published the following year in Cracow's Drukarnia Narodowa.

340 The article 'Polska muzyka kościelna w epoce barokowej (od Zieleńskiego do Pękiela)' [Polish church music in the Baroque period (from Zieleński to Pękiel)] (Muzyka 1928/10, 437-439, 1928/12, 573-576), similarly to Jachimecki's sketches mentioned above, was an 'exception from a larger whole.'

341 She published exceptions from the item being prepared for printing Ogólnego zarysu estetyki muzycznej [A general sketch of musical aesthetics] (Lviv 1938) in the two-part essay 'Co jest treścią dzieła muzycznego?' [What is the content of a musical work?] (Muzyka 1935/8-9, 103-104, 1935/10-12, 214-216). 
manner going beyond the formula of journalism and popularisation, despite the limited scientific apparatus enforced by the editors.

Regarding the nature of the materials published in Muzyka, Kornel Michałowski calculated that about thirty-six per cent of the contents were biographical items, over twenty per cent referred to musical news, similarly - to historical texts (in total for the whole history of music, along with - then - latest history); seventeen per cent contained issues in the field of musical practice, eight per cent covered theoretical and aesthetic considerations. Materials were divided between regular columns, which over the years - due to the diversity of materials and for clear arrangement - developed into a dozen: articles, studies, outlines, etc. formats regarding the theory, aesthetics, history of music (also in relation to the current musical movement); the 'Artists' tribune' section that featured opinions of musicians, launched in response to a survey carried out by the editors; ;42 'Musical impressions,' or in other words comments (mostly made by the editor-in-chief) on the hot topics concerning not only the music community, but also musicologists; ${ }^{343}$ the 'Radio and mechanical music' section, which reflects on the importance attached to the opportunities granted at that time to music and music culture through this new medium. Additionally, 'Korespondencje z kraju i zagranicy' [Domestic and foreign correspondence], 'Przegląd pedagogiczno-muzyczny' [Pedagogical-musical review], 'Sylwetki i profile' [Silhouettes and profiles], 'Rozmaitości' [Varia], 'Komunikaty' [Announcements], 'Spotkania i wywiady' [Meetings and interviews], 'Listy do Redakcji' [Letters to the Editor], and a satirical section. In 'Kronika bieżąca' [Current chronicle] already in the first edition, apart from concert current affairs, a 'musicological' note appeared: information

342 For example, on the subject of the spelling of the name of Frederic Chopin (Muzyka 1926/1 and following, passim), romanticism in the modern era (Muzyka 1928 / 7-9, 91-140) or musical talent (amongst others Muzyka 1927/2).

343 This section included the brief but trenchant criticism of these circles written by Seweryn Barbag ('Przykre sprawy muzykologii polskiej' [Unpleasant affairs in Polish musicology], Muzyka 1935/1-2, 18-19). A few years earlier, the editor-inchief Mateusz Gliński, who was also a regular writer in this section, on its pages (Muzyka 1930/11-12, 683-684) took on the defence of the attitude of Adolf Chybiński, presented previously by the professor in an article on the state of musicology at the time and priorities in musicological research ('O zadaniach historycznej muzykologii w Polsce' [On the tasks of historical musicology in Poland], Muzyka 1930/10, 587595). Jachimecki, in a sense called on to take a position in this matter, replied with a lengthy, polemic article 'Polska muzykologia i polscy muzykologowie' [Polish musicology and Polish musicologists] (Muzyka 1931/1 24-27). More about the subject of disputes concerning the shape of Polish musicology in chapter II-3. 
was included about a 'substantial work (141 pages)' by Adolf Chybiński with the title Instrumenty muzyczne ludu polskiego na Podhalu [Musical instruments of the Polish people in Podhale], and a month later it was stated that 'Dr Zdzisław Jachimecki, professor of musicology at the Jagiellonian University, gave a series of valuable propaganda lectures about Polish music at Italian universities, ${ }^{344}$ and another time, that 'Our own compatriot Dr Alicja Simon, known in the field of musicology, took the prestigious position of Director of the Music Department of the Library of Congress in Washington' and reminded everyone, amongst others, of the 375th anniversary of the death of Guido of Arezzo, 'creator of the contemporary music notation system. ${ }^{345}$ In 'Press Review, the editors tried to present news from leading European music magazines - La Revue Musicale, Die Musik, Le Courrier Musical, Zeitschrift für Musik, Listy Hudební Matice. It was possible to persuade 'hot surnames' from abroad to cooperate in obtaining materials for current boxes - from Czechia, Austria, Italy, Germany; this was similar in terms of articles: Gliński published translations of works (or their fragments) of such authors as the composer, pianist, but also the creator of the monthly dedicated to contemporary music Musica d'Oggi Alfredo Casella, ${ }^{346}$ composer (a former student of Arnold Schönberg) and musicologist (from Guido Adler's school) Egon Wellesz, ${ }^{347}$ the French Chopinologist Édouard Ganche, ${ }^{348}$ freshly promoted in Berlin by Wolf, Sachs and von Hornbostel, Otto Gombosi, ${ }^{349}$ Hugo Leichtentritt, ${ }^{350}$ the Czech pianist, composer and musicologist Boleslav Vomáčka and many others. Comments were published (sometimes authorised, sometimes perhaps not $^{351}$ ) on the topic of contemporary music or illustrious characters

344 Muzyka 1924/2, 101.

345 Muzyka 1925/1, 43.

346 Including: 'Zagadnienia harmonii nowoczesnej' [Issues of modern harmony] (Muzyka 1925/11-12, 71-78), 'Myśli o postępie w muzyce' [Thoughts on progress in music] (Muzyka 1927/1, 15-17).

347 'Uwagi o współczesnej twórczości muzycznej' [Notes on contemporary music creativity] (Muzyka 1925/2, 64-66).

348 Including: 'Nieznany utwór Chopina' [Unknown work by Chopin] (Muzyka 1925/4-5, 146-148); 'O polskość Chopina' [About Chopin’s Polishness] (Muzyka 1929/1, 14-17); 'Życie muzyczne Fryderyka Chopina w Paryżu' [The musical life of Frederic Chopin in Paris] (Muzyka 1932/7-9, 31-43).

349 'Walenty Bakfark w Polsce' [Walenty Bakfark in Poland] (Muzyka 1929/6, 299-306).

350 Correspondence from Berlin in Muzyka 1924/2, 86-89.

351 Jerzy Waldorff voiced doubts about the authenticity of some of the statements published in Muzyka in a short article in the magazine Prosto z Mostu (1937 no. 26). 
remarking on their own works, such as Richard Strauss, ${ }^{352}$ Ferruccio Busoni, ${ }^{353}$ Igor Stravinsky, ${ }^{354}$ Sergei Rachmaninoff,, ${ }^{355}$ and for example, in the survey under the slogan 'Romanticism in the contemporary age' opinions were quoted from Sergei Prokofiev, Manuel de Falla, Paul Dukas, Edward Elgar, Maurice Ravel, Ernst Křenek, Vincent d'Indy. ${ }^{356}$ Those are only some of the names, which should be supplemented with a list of all the Polish composers of the time, with Szymanowski at the forefront. Throughout the years, he was treated in a special manner by the magazine editors: a dissertation on the composer (supposedly to be written by Adolf Chybiński, but finally completed by Jarosław Iwaszkiewicz) was to start the monograph cycle Biblioteka Muzyczna [Musical library] initiated at the beginning of Gliński's term as editor of Muzyka (mentioned below); in 1937 a memorial issue was also devoted to him. ${ }^{357}$ The musician continued his collaboration with the office until his death, passing his public statements for disposal, such as the foreword at the Warsaw Philharmonic during the Chopin celebrations of 1924 'Fryderyka Chopina mit o duszy polskiej' [Frederic Chopin's myth of the Polish soul] ${ }^{358}$ (this text inaugurated the existence of the magazine), or the 'Chopin' speech at the University of Warsaw given on 9 November 1930, 359 fragments of the speech at the doctor honoris causa ceremony at the Jagiellonian University, ${ }^{360}$ or original articles, as for example, the piece on Ravel on the 50th anniversary of his birth. ${ }^{361}$

The editorial team was focused on engaging the most 'professional' authors representatives of university centres. The first name to appear was AdolfChybiński, the author of the article about piano mazurkas by Karol Szymanowski. ${ }^{362}$ In the

352 Considerations on his own creativity: 'O stylu operowym' [About operatic style] (Muzyka 1925/1, 8-12).

353 'Mój testament muzyczny' [My musical testament] (Muzyka 1932/3-4, 77-79).

354 'O mych ostatnich utworach' [About my last works] (Muzyka 1924/1, 15-17); 'Moja spowiedź muzyczna' [My musical confession] (Muzyka 1934/2, 56-57).

355 'Z mych przeżyć' [From my experiences] (Muzyka 1930/6, 369-370).

356 Muzyka 1928/7-9 special edition called Romantyzm w muzyce [Romanticism in music], 91-140.

357 Muzyka 1937/4-5.

358 Muzyka 1924/1, 3-5.

359 Muzyka 1932/7-9 (special number with the title Szopen), 7-12.

360 Muzyka 1931/1, 8.

361 Muzyka 1925/3, 94-96.

362 Muzyka 1925/1, 12-15, 1925/2, 61-64. Already in the second edition of the first year, Łucjan Kamieński made his debut, not with a musicological text, but a review from the Poznań staging of the Legendy Bałtyku [Legends of the Baltic] by Feliks Nowowiejski. 
spring of 1925, Alicja Simon presented an outline of Józef Hoene-Wroński’s philosophy of music, ${ }^{363}$ Zdzisław Jachimecki submitted his reflections on the contemporary culture in Italy under the title 'Pokłosie muzyczne z podróży po Italii' [Musical aftermath of a trip to Italy], ${ }^{364}$ and a few months later, Hieronim Feicht gave a spacious, by the standards of Muzyka, article on Giovanni da Palestrina, in which he considered, amongst others, the impact of the composer's works on early Polish music. ${ }^{365}$ Gradually, almost all the other Polish musicologists joined the group of authors of the magazine: Seweryn Barbag, Ludwik Bronarski, Jerzy Freiheiter, Melania Grafczyńska, Józef Koffler, Zofia Lissa, Henryk Opieński, Stefania Łobaczewska, Józef Reiss, Adam Sołtys, Bronisława Wójcik-Keuprulian. However, the names of Chybiński's most loyal students were missing - Maria Szczepańska, Jan Józef Dunicz and Józef Chomiński.

Thematically focused, mostly double or triple editions, which were planned several months in advance turned out to be a handy manoeuvre by Gliński. ${ }^{366}$ On the one hand, monographic numbers were in a way complementary to the current theme undertaken by Muzyka, and on the other hand, they facilitated

363 Muzyka 1925/3, 99-103. Sketches from the field of the theory of acoustics authored by Hoene-Wroński were published in the pages of Muzyka three years later $(1928 / 10,482)$.

364 Muzyka 1925/4-5, 171-174. He continued the Italian thread with the essay 'Związki muzyki italskiej z Polską' [Links between Italian music and Poland] (Muzyka $1925 / 10,4-8)$.

365 Muzyka 1925/1-2, 61-66.

366 Monographic editions should not be confused with the monographs issued and edited by Gliński, for they functioned as a completely independent entity, even though managed by the same editor. Gliński introduced a detailed plan for a cycle presenting composers' monographs and other topics compiled in a series entitled Biblioteka Muzyczna to Chybiński in autumn 1925 (Gliński to Chybiński from Warsaw $12 \mathrm{X}$ 1925, AACh-BJ, box 4, G-5/21). Previously, he agreed with the professor that the cycle will open with Chybiński's publication on Szymanowski, whereby the goal of the Warsaw publisher was that 'these [monographs - MS] were not too heavy so as to be able to combine "professionalism" (mostly in general aesthetic terms) with the brilliance and literariness of the form' (Gliński to Chybiński from Warsaw 1 I 1925, AACh-BJ, box4, G-5/13). Finally in 1928, issued by publishers Gebethner \& Wolff the following monographs were added: Adam Wieniawski, Ludomir Rózycki; Stanisław Niewiadomski, Stanisław Moniuszko; Felicjan Szopski, Władysław Żeleński; Karol Stromenger, Franciszek Schubert; Henryk Opieński, Jan Ignacy Paderewski; André Coeuroy, Dzieje muzyki francuskiej [History of French music]). Five years later, Biblioteka was supplemented by a monograph by Mateusz Gliński on Alexander Scriabin. 
editorial work during the holiday season and made it possible to circumvent the organisational discomforts of the summer heatwave ${ }^{367}$ safely.

Besides 'vacation' monographs, thematic issues also appeared throughout the year. These were especially numerous in 1926 when along with a triple 'July-September' issue, three special editions were published. First of all, a 'Czechoslovakian issue was prepared (1926 no. 2), which may undoubtedly be explained by the seemingly strong contacts with Czech and Slovak musicologists and journalists (let us not forget the common activities organised by the Slavic Musicological Union initiated by Czechs at the IMS). The editors explained the choice of the music and musical culture of Czechoslovakia for the first thematic presentation in the following way: 'In recent years, longing for a national ideal in our musical lives, we more often turn with our hearts and thoughts to the music of the brotherly Czechoslovak nation, full of vigour and racial purity. The exchange of information is becoming increasingly relevant, allowing the two nations to come closer and get to know each other better in the musical arena. ${ }^{368}$

The volume began with a historical presentation of Czech-Polish relations in music (pp. 45-48), written by Zdeněk Nejedlý, who played a rather shameful role in post-war Czechoslovak musicological history, though he was one of the leading figures of the musicological world in the twenty-year inter-war period, at least in this part of Europe. An article on the most important figures of the Czech national school - Smetana, Dvořák and Fibich (pp. 54-57) - as well as information on journal writing (pp. 63-64) was prepared by one of the leading representatives of the new music in Bohemia, the composer, conductor and teacher Karel Boleslav Jiřak (1891-1972). The composer and musicologist Vladimir Helfert (1886-1945) discussed the creative ideas in Czech music (pp. 49-53), while the critic and music writer (as well as lawyer) Jan Loewenbach (Löwenbach, 18801972) presented the main currents in contemporary Czech music (pp. 58-60) and sketched an image of the local publishing movement (pp. 65-66). This was all complemented by reports on the Czechoslovak section of the ISCM by Josef Loewenbach (Löwenbach, pp. 67-68) and on musical education in Czechoslovakia by Jan Branberger (pp. 61-62).

367 In total, eleven monographs appeared as (double or triple) numbers of Muzyka, including: 1926 Muzyka współczesna [Contemporary music], 1927 Muzyka polska [Polish music], 1928 Romantyzm w muzyce [Romanticism in music], 1929 Instrumenty muzyczne [Musical instruments], 1930 Nowa muzyka [New music], 1931 Taniec [Dance], 1932 Szopen [Chopin], 1934 Opera [Opera]; a few others, for example, Radio i gramofon [Radio and grammophone], remained in the sphere of plans.

368 'Od Redakcji' [Editorial] (Muzyka 1926/2, [no page numbers]). 
The continuation of cooperation with the Czechs was to be a 'Polish' edition published shortly thereafter as a special issue of the Prague magazine Listy Hudební Matice.

A month later, the opportunity arose to dedicate an edition of Muzyka to Mieczysław Karłowicz (a non-round date, the seventeenth anniversary of his death, but the fiftieth anniversary of his birth). There were no detailed analyses of the composer's works, apart from a brief sketch by Chybiński containing an outline of characteristics (pp. 100-106). After Władysław Zahorowski’s biographical introduction (pp. 97-99), later on, a memoir text by Stanisław Barcewicz (pp. 106-107) and Grzegorz Fitelberg's reflections about the Epizod na maskaradzie [Episode at a masquerade] were printed full of personal reflections (pp. 108-109). The edition closed with selected letters from Karłowicz to Chybiński (pp. 110-114).

In autumn the 'Chopin' edition appeared, which

was a modest reflection of those feelings and thoughts associated with the unveiling of the Chopin monument. ${ }^{369}$ Not to be distracted in detail [the editors] wanted to give ... a synthesis of the life and work of the immortal Master ... a modest wreath of words, thoughts and feelings, which we put with humble reverence at the foot of the pedestal, which will stand for centuries to honour the brilliant figure of the beloved Master. ${ }^{370}$

For the needs of this edition, Gliński managed to obtain material prepared by music critic, translator and publicist Bernard Szarlitt - fragments of

369 Discussion as to the proper spelling of the name Frédéric/Fryderyk Chopin/Szopen was carried on for a few years in the inter-war period on the pages of $M u z y k a$; in a few issues of 1926 in the form of a survey in which musicologists, musicians, journalists, literary experts and historians were invited to take part: Stanisław Niewiadomski, Adolf Chybiński, Feliks R. Halpern, Bolesław Busiakiewicz, Tadeusz Boy-Żeleński, Jan Baudouin de Courtenay, Ferdynand Hoesick, Zdzisław Jachimecki, Adam Kryński, Ludomir Różycki, Piotr Maszyński, Bernard Szarlitt, Stanisław Pereświet-Sołtan, Tadeusz Szeligowski, Aleksander Michałowski, Henryk Opieński, Emil Młynarski. The editorial staff summarised the survey in the June issue of Muzyka (1926/6, 273-274). Only Busiakiewicz, a music critic and radio journalist, categorically supported the polonised spelling, referring to the spelling used by the authorities - Paderewski and Przybyszewski. The vast majority of the survey participants treated the problem with flexibility (for example, the use of the spelling 'Szopen' in publications intended 'for less enlightened masses'). A completely different view was presented by Chybiński, who even suggested that an apostrophe should be used for the declination of the name to highlight its foreign origin. Gliński himself preferred the Polish version and even named one of Muzyka's 'holiday' collective monographs of Szopen (1932/7-9); Stanisław Niewiadomski also referred there to the question of 'Ch czy Sz' [Ch or Sz] (pp. 88-90).

370 'Od Redakcji' [Editorial] (Muzyka 1926/10, [no page numbers]). 
Chopin's letters, in which opinions about music and music are given (pp. 524526), memories of the history of the design and construction of the Chopin monument noted by its creator, Wacław Szymanowski, starting from the year 1903, in which the idea was conceived, up until its unveiling (pp. 526-527), impressions of Chopin written by Stanisław Niewiadomski (pp. 511-514), fragments of the monograph prepared for publication by Zdzisław Jachimecki Fryderyk Chopin. Rys życia i twórczości [Frederic Chopin. An overview of his life and work $]^{371}$ - here about the nocturnes (pp. 520-523). Two eminent names supplemented the list of authors - Ignacy Jan Paderewski - the number opened with fragments of his speech delivered years earlier (in Lviv on the centenary of the composer's birth) - and Édouard Ganche, who at the invitation of Gliński sent an original, polemical article-challenge 'Chopin na Wawel' [Chopin at Wawel] (pp. 515-519).

That issue must have left him feeling hungry for more because several years later Gliński decided to dedicate one of the 'summer' monographs to the great composer, which in that case included thirteen papers in total - analytical, literary, problem-oriented ones. As for an introduction, the editors used a speech provided by Karol Szymanowski given two years earlier at the University of Warsaw (pp. 7-12). It was followed by the articles of all the leading musicologists, journalists and critics, to whom the study of Chopin's life, work and legacy was particularly close - again Édouard Ganche, and in addition Bronisława WójcikKeuprulian, Stefania Łobaczewska, Aleksander Michałowski, Henryk Opieński, Leopold Binental, Jarosław Iwaszkiewicz, Stanisław Niewiadomski and Mateusz Gliński himself.

One should also note further topics undertaken by the editors - an article on Beethoven, generously filled with literary materials (on the centenary of his death, Muzyka 1927/4, and in it, among others, reflection by Hugo von Hofmannstahl on the works of Beethoven (p. 146), translations from Romain Rolland (pp. 153154) and Guido Adler (pp. 162-166) as well as a selection of letters written by Beethoven prepared by Władysław Fabry (pp. 167-171) along with articles by Stanisław Niewiadomski (pp. 147-152), Łucjan Kamieński (pp. 157-161), and fragments of prose by Witold Hulewicz (pp. 155-156), or the jubilee, 100th issue of the monthly including the 'studies, outlines and fragments of the greatest artists of our day, organised in three blocks: 1) 'voices on the essence of music' (Ignacy Jan Paderewski, Gabriel d'Annunzio and Karol Szymanowski, pp. 3-4),

371 Cracow 1927. 
2) 'voices on the principles of the development of music,'3) 'voices on the forms of its incarnation.' As it is written in the foreword, 'in the abundance of these works the reader will find much material already published on the pages of Muzyka ... mostly reprints of works that are nowadays inaccessible to a wider base of readers due to exhaustion of the relevant issues. ${ }^{372}$

Coming back to the origin of the idea behind the monographs, the 'summer' special issue of 1926 called Muzyka Wspótczesna [Contemporary music] had been on Gliński's mind at least since mid-1925, as this is what he wrote around that time to Adolf Chybiński: 'I would be very glad, Professor, if you could provide us with an analytical "introduction" to the basics of the new music (new forms, new harmony etc.). Such an introduction would be even more appropriate as all the articles, no exceptions, steer clear from theoretical problems. It would simply be a first-class accomplishment to introduce the readers in a professional yet friendly manner to purely musical issues. ${ }^{373}$

Indeed, the volume consisted of twenty-six, generally very brief and very essential reviews of the current creative output of European countries (only sometimes, in case of papers concerning Poland, Czechoslovakia, Russia, France and Germany - slightly lengthier ones) and 'America' (which included a paper outlining music in the United States supplemented with information about the creative output of countries from South America). Whereas in the introductory essay Chybiński mainly put emphasis on the speed of changes taking place in contemporary art, on the parallel operation of various '-isms', attempting to explain the 'linear technique' commonly found in the new music as the composers' response to 'harmonic Baroque' typical for the older ages, stressing that a lack of melody is only an illusion and that 'any attempts to negate melodiousness are a result of looking at it from another epoch's perspective and thus - an example of disloyalty in criticism.' Whereas the critical issue in his opinion was to find the 'new form,' avoiding 'the need to repeat motifs and architectural symmetry that seems forced and schematic.' Even though in Chybiński's essay one can see his complete acceptance and understanding of the current trends in music, it seems that a moment was approaching when yet another generation of musicologists was to create Avant-Garde among the connoisseurs of the latest musical creations.

The material gathered in this volume was described in the next issue of Muzyka by the editor himself as 'an encyclopaedia of contemporary music, [in which] there is a clear and transparent picture of contemporary trends in musical

372 'Od Redakcji' [Editorial] (Muzyka 1933/2, [no page numbers]).

373 Gliński to Chybiński from Warsaw 27 VII 1925, AACh-BJ, box 4, G-5/21. 
thought in all European countries.' And not resting on his laurels, in connection with new ideas, he began to send invitations to other writing musicians and musicologists, encouraging them to take part in subsequent collective monographic publications.

Thanks to the indisputable passion behind Mateusz Gliński's work, and later also thanks to various initiatives which he continuously employed to enrich the magazine, Muzyka met with great interest from the very first issues. According to the editors, the main reason for this success lay in the right assumptions of the adopted programme: combining interest in the latest music with pietism and respect for the past, placing Polish musical culture in Europe on the one hand, but also caring for the purity of national art and its self-contained ethnographic and racial elements ${ }^{374}$ on the other. To substantiate the good opinion enjoyed by the publication, nearly every issue featured 'news from the press', which always said: 'very well edited magazine,' 'publication in a purely European style,' 'excellent editorship,' 'an example to follow for every magazine' in terms of both contents and editorship; it should be stated that without a doubt the editors chose the quotes subjectively, but - of course - the publication certainly deserved good feedback. The publishers' efforts were recognised, among others, by Adam Wieniawski, a publicist working for Rzeczpospolita, who in the past had got in a serious conflict with Gliński over actions connected to the establishment of the 'Klub fachowej prasy muzycznej' [Club of professional music press]. ${ }^{375}$ Meanwhile, however, he wrote: 'Finally, on a Thursday, the long-awaited publication edited by Mateusz Gliński - the monthly magazine Muzyka - was released. The need for such a publication could be easily felt with increasing activity in music. The monthly magazine was a brand new publication. No other existing music publication had such a wide-scale, professionally, skilfully and objectively developed plan. Perfectly edited, presented in a visually pleasing manner just like foreign publications of a similar type, discussing clearly and without pedantry the whole activity in the world of music in Poland and abroad...., ${ }^{376}$ and later: 'The most noticeable feature is the sophisticated appearance of every issue, in a better taste than many other well-known foreign publications of a similar type. The quality of the whole contents of the magazine is very high thanks to the competence of the impressive range of collaborators working on the magazine, including the best-known composers, musicians and musicologists, both Polish

374 'Od Redakcji' [Editorial] (Muzyka 1924/2).

375 I write about this in more detail in chapter I.2.

376 Quote in Muzyka 1924/2, 100. 
and foreign. The editors also showed great skill in being able to balance and maintain great objectivity. ${ }^{377}$

After a few years it seemed that everyone continued to favour the works of the editorial team: 'One can safely say about this publication, which appears second to none abroad, that it brings great honour to its initiator, editor Mateusz Gliński' (Tygodnik Ilustrowany), 'Muzyka monthly under the editorship of Mateusz Gliński has maintained an excellent European level. It is interesting, lively, abundant in information, knows how to keep in touch abroad' (Sztuka i Życie). ${ }^{378}$ Alas, neither the good opinion of both the community and the readers nor the editors' efforts to increase the attractiveness of the magazine through new publishing ideas - further regular columns, thematic editions, a growing number of authors - none was able to protect Muzyka against crisis. In view of the financial troubles after the subsidies received from MWRiOP were reduced by half, the editor-in-chief founded the Circle of Friends of Muzyka. The aim of the association was to secure the financial basis and 'support the newspaper particularly in the field of propagating music in the widest circles of Polish society and representing it abroad.' The only requirement to become a member was to make a one-off payment (250 PLN) or declare in favour of 4 PLN monthly contributions. According to lists published in consecutive issues of Muzyka, the group of members increased from month to month - here we find the names of Emil Młynarski, Eugeniusz Morawski, Adam Wieniawski, Karol Szymanowski, Władysław Skoczylas, Jan Kiepura, members of the Tyszkiewicz and Szembek family, and many others - however, among them there are no representatives of musicology who at that time (1934), despite their cooperation with Muzyka, did not regard it as a forum for the exchange of scholarly ideas, but only one of the possibilities to publish their minor works (contributions, messages). Seeking support (and endorsement) from the state coffers while planning themed editions, in 1935 Gliński - in connection with the death of Marshal Józef Piłsudski, published an issue under the slogan Józef Pitsudski and his Legions, the profile of which went astray from the first issues of the journal. In any case, after a collapse in 1933, when he published only four books (none was published in the second half of the year), only a dozen volumes (respectively: eight, five and two) were prepared in the following period 1934-36. Although six issues were published again in 1937, Kornel Michałowski claimed that 'the magazine's "revival" of 1937 was ostensible, its assurance of "independence and intransigence" sounded

377 Rzeczpospolita 1926 from 29 May, quote in Muzyka 1926/5, no page numbers.

378 Rzeczpospolita 1926 from 29 May, quote in Muzyka 1926/5, no page numbers. 
more hollow and false than ever, and the hope for stabilising the publication was nothing but vain. ${ }^{379}$ The publication concluded with the only double issue with the date ' 1938 . 380

Stefan Jarociński saw the failure of Muzyka in the editor-in-chief's type of conformism, allowing him 'to gain readers and financial resources necessary to run the magazine or be a good advertisement for him,' defining Gliński as 'a typical faceless critic', though 'skilful' and not devoid of 'ingenuity.381 It seems that in over thirteenyears' worth of history of the periodical one can find plenty of evidence that there was a need for such a publication as Muzyka: perhaps less so among publicists, critics or musicologists (there were at least several or around a dozen other local and trade publications at that time, where they could publish their papers), and more so among readers interested in the current life of the music community, and at the same time in historic knowledge about music culture or in theoretical issues explained in a quite reader-friendly way. From the very start, Gliński himself stressed that Muzyka was not aimed at filling the niche created by a lack of a purely professional trade magazine. 'Our aim is to promote music, and we have to make sure at any reasonable cost that the rather strong relationship which we have already established with society does not become weaker even for one moment. ${ }^{382} \mathrm{~A}$ few years later, Gliński wrote even more bluntly:

I am not and will never be a musicologist, so I can say with complete confidence that I have respect, first of all, for music. Despite that, I can definitely say that with regard to musicology, Muzyka plays a very important and current role. It is Muzyka, rather than any other publication, that presents society with the results of musicological research, moving them from a laboratory research platform into the open world and disseminating them among the educated population. However, to be able to play that role, it has to ensure that everything it says is indeed being read rather than sharing the fate of other publications, only published for the use of a small number of specialists. ${ }^{383}$

In spite of the dissonance which could be felt at the turn of the 1920s and 1930s in the contact between Gliński and Chybiński, it was the Lviv leader of musicology who appeared most often as an author in the Warsaw periodical. His articles were usually of a monographic nature: 'Kolęda w dawnej muzyce polskiej'

379 Michałowski 1967, 15.

380 The exact combination of numbers, along with information about the format, volume, printing houses, magazine prices, etc. can be found in Michałowski 1967, 18-20.

381 Jarociński 1955, 481.

382 Gliński to Chybiński from Warsaw 1 II 1926, AACh-BJ, box 4, G-5/31.

383 Gliński to Chybiński from Warsaw 7 III 1930, AACh-BJ, box 4, G-5/109. 
[Carols in early Polish music], ${ }^{384}$ 'O muzyce górali tatrzańskich' [About the music of Podhale highlanders], ${ }^{385}$ 'O instrumentach muzycznych ludu polskiego' [About musical instruments of the Polish people]. ${ }^{386} \mathrm{He}$ departed from popularisation in the lengthy dissertation ' $Z$ dziejów muzyki polskiej do 1800 roku' [From the history of Polish music to the year 1800] ${ }^{387}$ written for the needs of one of the monographs, although this work was also construed to bring a history of Polish music and musical culture in an interesting way to the average reader of the monthly. On several occasions he provided the editorial office with materials from his favourite research on Karłowicz: in the aforementioned special number, apart from the composer's profile, he prepared an edition of several of his letters from the years 1904-08 from his own archive. ${ }^{388}$

For the milieu of musicologists, but also journalists and music critics, the polemics in which Chybiński repeatedly appeared in Muzyka were very significant. One of them, on the subject of differences in assessment of significance and evaluation of the value of research on medieval music, and concerning Stefania Łobaczewska’s controversial (according to the professor) column in Lviv's Słowo Polskie. ${ }^{389}$ Chybiński entered the discussion in defence of his beloved research on early music and early musical culture, the German musicological school and his own activities in various fields of music scholarship, using the magazine's pages several times. He published his views on the obligations of music historians in a comprehensive article 'O zadaniach historycznej muzykologii w Polsce ${ }^{330}$ [On the tasks of historical musicology in Poland]. The starting point for the opinions formulated in the text (and at the same time the conclusion) was the thesis that 'research on the history of music and musical culture in Poland must be the focal point of the work of a Polish musicologist-historian,391 and 'the study material' within 'polish music' - its history and ethnography (presuming - as could be expected - historical and ethnographic sources) and the author develop his reflections in this direction. The thesis presented in this form does not seem controversial, but some musicians were upset by several phrases which clearly defined the 'pattern' of musicological activity according to Chybiński. For

384 Muzyka 1927/12, 559-564.

385 Muzyka 1926/11-12, 584-588.

386 Muzyka 1929/6, 307-310.

387 Muzyka polska. Collective monograph edited by Mateusz Gliński, 31-72.

388 Muzyka 1926/3, 100-105 i 110-114.

389 Łobaczewska 1933.

390 Muzyka 1930/10, 587-595.

391 Ibid., 595. 
example, he wrote that 'only research and papers which comply with scientific methods and lead to results valuable for science can be considered musicology' (p. 590), which should be pursued 'not only in the scope of music scores but also archive materials' and 'the task of a musicologist-historian in Poland is not only to study the history of our music, but also to disseminate such works' (p. 591), which should be achieved, for example, through an initiative such as WDMP, which combined the efforts of 'Warsaw's, Lviv's and Poznańs resources' (p. 592).

Such phrases could not go unnoticed by the second 'father' of Polish musicology, who held a rather different position on research. In the polemical article published shortly later in $M u z y k a^{392}$ Zdzisław Jachimecki, predictably, criticised the fact that 'prof. Chybiński emphasises the importance of archival research such ... as if only archivists had the right to be called "scientifically working musicologists"' ${ }^{393}$ It seems that he was affected by claims regarding the musicologists' promotional activities, often reckless and careless, a result of rattling the work off. As an example of popularisation, he gave the publications of Henryk Opieński - La musique polonaise ${ }^{394}$ [Polish music] and the monograph Stanisław Moniuszko. Życie i dzieła ${ }^{395}$ [Stanisław Moniuszko. Life and works] which Chybiński also highly recommended; he also disagreed with Chybiński's division of musicologists into 'scientific' and 'former', in which the main criterion would be the frequency of publishing the results of scholarly research.

The editorial team of Muzyka did not engage in the described polemics between the chiefs in Lviv and Cracow. Otherwise a few years later, when a strong reaction of Chybiński was triggered by the words of Mateusz Gliński in the short 'impression' “"Zmierzch nauki” $w$ dziedzinie muzycznej' [The twilight of education in music]. ${ }^{396}$ This alluded to the suspension of Kwartalnik Muzyczny, run by Chybiński, and the purposefulness of running a somehow niche magazine that absorbs funds in abundance, and all this due to the stagnation that started to overwhelm the community. The professor was most agitated by the comment indicating the handful of readers. Responding to this objection, he pointed to forty-seven, as he calculated himself, names of 'workers', potential readers of scholarly texts (with the provision that it was definitely not all of them). $\mathrm{He}$ also stressed that there was no collapse of the magazine, since, at the same time,

392 Jachimecki 1931.

393 Ibid., p. 24.

394 Paris ${ }^{2} 1929$.

395 Lviv 1924.

396 Muzyka 1934/5, 217-218. Chybiński’s letter titled 'W obronie muzykologii polskiej' [In defence of Polish musicology] (Muzyka 1934/6-7, 270-271). 
there was the new, strictly academic Polski Rocznik Muzykologiczny (further PRM [Polish musicological yearbook]) in place of the periodical, which - in his words - never was one. In the following, malicious reply to Chybiński's letter, the editor used, and in a perverse manner, quotes from the above-described polemics of 1930, amongst others on recognising as 'scientific musicologists only [those individuals], who continuously and systematically perform scientific work and present the results of it to the public in a form adopted in science ${ }^{3997}$ using such a principle, it would be difficult to speak of close to fifty professionally active musicologists listed by the professor. (A few months later, Chybiński once again published another controversial text in Muzyka Polska, this time focusing on the Karłowicz theme. As it referred to a dissertation published a few years earlier Rozwój kultury muzycznej w Polsce [Development of musical culture in Poland] (1913), its author, Zdzisław Jachimecki, answered with a pamhplet Pod jakim kątem patrzy prof. dr Adolf Chybiński na kwestię wplywologii muzycznej (wyjaśnienie enigmatyczności artykułu 'Do kwestii wplywologii muzycznej') [From what angle is Prof. Dr. Adolf Chybiński looking at the issue of musical influence (Explanation of the enigma of the article 'To the question of musical influences')]. ${ }^{398}$ )

The editors of the monthly could not restrain themselves from their own comment and presented another dispute on the Cracow-Lviv line, again not sparing the professor from Lviv, in one of the press reviews. ${ }^{399}$ Then, for several years, Gliński and Chybiński remained in conflict. As we remember, it was not always this way. In the first period of their acquaintance, their contacts were more than courteous, letters from Warsaw to Lviv indicate the admiration and respect of the leader of Muzyka for the leading authority in the field of musicology. In the autumn of 1924, Gliński, who had previously had correspondence with Chybiński in connection with the activities aimed at establishing the PTMW, asked the professor to 'as soon as possible send the promised: article about "New Music" and the books by Weismann and Reiss ${ }^{300}$ and supplement - apparently

397 (mgl) [Mateusz Gliński]: [no title], Muzyka 1934/6-7, 272.

398 Cracow 1935. The discussion was continued, amongst others in the form of another booklet by Jachimecki Jeszcze trochę o 'Wplywologii muzycznej' w oświetleniu prof. dra Adolfa Chybińskiego [A little more about 'musical influence' in the light of prof. dr. Adolf Chybiński] (Cracow 1935).

399 Muzyka 1935/1-2, 39-40.

400 Gliński to Chybiński from Warsaw 4 XI 1924, AACh-BJ, box 4, G-5/7. Józef Reiss's review of the monograph 'Skrzypce. Ich budowa, technika i literatura' [Violins. Their construction, technique and literature] in: Muzyka 1924/2, 91-94. In the case of 
sent earlier - to the chronicle of musical life in Lviv. Along with this letter, a package with twelve copies of the first issue of the magazine went from Warsaw asking Chybiński to mediate in giving these free copies to the representatives of the local music community at his own discretion - the best musicians - and selected editorial offices (a prospectus was also attached for them). Gliński also expected the target list of the Lviv recipients. The first edition, of course, was also addressed the professor, adding another letter asking for an opinion: 'I am much interested in the opinion it [Muzyka] evoked. Mr Professor, have you noticed any deficiencies that could be eliminated? I kindly ask you Mr Professor, please give me any tips before the release of the second issue. 401 The expected, though unspecified 'administrative guidance' came probably from Lviv. This included reservations of a personal nature, which, however, the Warsaw editor refuted with words taken almost explicitly from the editorial, speaking of 'free tribune for all the outstanding employees of the musical realm, regardless of their beliefs. ${ }^{402}$

Gliński enjoyed the animated correspondence between Warsaw and Lviv, feeling 'goodwill for the magazine and lively creative enthusiasm in his [Chybiński's] letters. ${ }^{303} \mathrm{He}$ would share his publishing concerns and problems, and at least for some time, he was hoping to intensify or maybe even formalise the cooperation, calling the musicologist the editor of Muzyka rather than just a co-worker or author. Many times he wanted to 'confer' by drawing up and consulting plans for subsequent issues of the magazine and accompanying Biblioteka Muzyczna volumes. He confided his desire to dissolve cooperation with Adam Soltys and Witold Friemann as correspondents, and at the same time asked for help in pulling Stefania Łobaczewska 'into our circle"404 - a successful idea as for years Łobaczewska was one of the most prolific authors of the monthly. When in 1925 Chybiński planned a visit to Warsaw, he immediately received a letter from Gliński with an invitation: 'I am very glad that I will see you, Professor, in a few days in Warsaw. I have lots of plans that we will discuss personally.... I would be very happy if you could agree to "step" into my editorial office, where we will be

the second review, perhaps this concerned Adolf Weissmann's monograph Chopin (Leipzig 1910).

401 Gliński to Chybiński from Warsaw 8 XII 1924, AACh-BJ, box 4, G-5/10.

402 Gliński to Chybiński from Warsaw 16 XII 1924, AACh-BJ, box 4, G-5/11.

403 Gliński to Chybiński from Warsaw 28 XII 1924, AACh-BJ, box 4, G-5/12.

404 See for example, Gliński to Chybiński from Warsaw 17 V 1926, AACh-BJ, box 4, G-5/44. 
happy to welcome you. We do not have extraordinarily comfortable facilities to host you, but we will welcome you with all our hospitality.' 405

Unfortunately, the correspondence in the other direction is no longer extant, but it seems that, apart from words of appreciation and encouragement, it also had to include criticism, which, moreover, was received by Gliński for a long time with humility: 'you must be certainly annoyed, Professor, with the superficiality of our requirements and our criteria. Oh well. Sometimes, I too feel that we are gliding on the surface, avoiding going into any serious "depth," both in theoretical and empirical terms. Sadly, that is the way it has to be and the way it will remain.'406 Almost from the beginning, Gliński's patience was repeatedly put to the test. Time and again, Chybiński's vice came to the fore: failing to deliver work to the editorial office as promised. Any delays in the completion of the announced texts might just turn against the author of the would-be publications, were it not for the fact that the delays resulting amongst others from stopping the uncompleted material for composition and printing lead to adverse repercussions that encumbered publishers, usually financially, but not only. In addition, the professor 'reserved' a number of topics for himself - in one of Gliński's letters there is mention of even twenty ${ }^{407}$ volumes of the aforementioned Biblioteka Muzyczna: apart from Szymanowski and Karłowicz, there were also 'carols and pastorals' and 'Polish dances' and 'a few French themes', and it turns out he also counted on works about Bach, a theme entrusted to Zdzisław Jachimecki. ${ }^{408}$

At a certain point another issue was the question of Chybinski's loyalty, as he published his works, among others, in Warsaw's Wiadomości Muzyczne (the organ of the Warsaw Musicians' Association), whose editors (the chief editor was a collector and music critic, Edward Wrocki) were in a serious conflict with Gliński. But even though year by year the tone of the letters from Warsaw to Lviv was becoming colder and colder, towards the end of the 1920s Muzyka's editor still sought advice from Chybiński on editorship-related matters and the professor accepted another request, this time to write an organology article for the next special issue entitled Instrumenty muzyczne $e^{409}$ [Musical instruments].

405 Gliński to Chybiński from Warsaw 16 IV 1925, AACh-BJ, box 4, G-5/18.

406 Gliński to Chybiński from Warsaw 1 II 1926, AACh-BJ, box 4, G-5/31.

407 See Gliński to Chybiński from Warsaw 11 I 1928, AACh-BJ, box 4, G-5/84.

408 Gliński to Chybiński from Warsaw 24 XII 1926, AACh-BJ, box 4, G-5/53.

409 Chybiński, as usual, was late with the delivery of the text. His article 'O instrumentach muzycznych ludu polskiego' [About musical instruments of the Polish people] appeared not in a special number of Muzyka (1929 no. 5), but in the next issue (pp. 307-310). 
A serious source of misunderstanding was Gliński's initiation of the activity of the 'Club of professional music press', the idea of which (and putting it into practice) Chybiński did not accept for a moment. ${ }^{410}$ Despite that, he received an invitation from Warsaw to take part in the sessions of the organisationalstatutory committee of the Association. He did not accept that invitation, only presented several organisational suggestions, for example, concerning the name of the Club. From that moment on the period when the editor of Muzyka pursued a close collaboration with the Head of Lviv's musicology was reaching an end. Only one more time, in 1932, Gliński asked Chybiński about the possibility of writing an article on Bach's impact on Polish music for a planned special issue of the Parisian Revue Musicale. A year later an official request came to Lviv to write an opinion on the magazine in relation with its 100th jubilee issue, and several months later, in connection with the letter from Stefania Łobaczewska to the editors quoted above, Gliński once again confirmed his loyalty to the professor, as he wrote:

taking into account the long-standing cooperation between you, Dear Professor, and your excellent moral and professional assistance while launching the magazine and throughout the first few years of its existence, and remembering your long-standing pleasant and kind attitude to the editors and their chief, the attitude that sadly, as a result of some misunderstandings has changed slightly in the recent years - I believe it to be my moral obligation to present you, Dear Professor, with a copy of Dr Łobaczewska’a statement before publishing it and to express my complete readiness to publish a copy of your statement next to it, Dear Professor. ${ }^{411}$

Further cooperation between Gliński and Chybiński was no longer possible. In the 1930s, apart from the letter presented in Łobaczewska's matter, Chybiński only twice sent his texts to Muzyka - either he caused controversy and prompted polemics, as in the case of the aforementioned article 'O zadaniach historycznej muzykologii w Polsce' [On the tasks of historical musicology in Poland], or he answered it - as an already former editor of Kwartalnik Muzyczny - to the allegations made by others about the purposefulness of the magazine (as just discussed).

Mateusz Gliński, for whom, at the beginning of his publishing experience, Chybiński was a mentor and consultant for editorial work, for years, consistently but with great difficulty, tried to acquire the Professor's work for Muzyka, like for example, some of his special projects, such as an edition entitled Muzyka

410 A short history of the club is already described in chapter I.2.

411 Gliński to Chybiński from Warsaw 9 XII 1933, AACh-BJ, box 4, G-5/121. 
wspótczesna [Contemporary music] from 1926, based on the authority of the professor, giving him introductory articles to edit. Following the correspondence of Gliński to Chybiński, we repeatedly encounter solicitations and strong requests from Warsaw for further texts, for example, 'some fragment (at your own discretion) of the material about Karłowicz, such as you already have prepared at the moment. I would be so personally and editorially infinitely grateful for such an honour on Karłowicz's Anniversary ${ }_{2}^{312}$ and, in requesting texts, he was ready to make numerous concessions. ${ }^{413}$ Quite quickly, though reluctantly, he had to accept the fact that Chybiński also submitted his writings to other magazines.

Such a publication, which Chybinski gladly worked with at that time, in the late twenties, was Poznańs Przeglad Muzyczny. It appeared on the music publications market around the same time as Lviv' Lwowskie Wiadomości Muzyczne i Literackie and Warsaw's Muzyka. Even though initially a lot of space in Przeglad was occupied by news dedicated to the vocalist community, it soon became (which was without a doubt an accomplishment achieved by its chief editor, musicologist Henryk Opieński, who had studied under the wings of Hugo Riemann) one of such periodicals where many critics, publicists and academics active at that time wanted to present their articles, arguments and inputs, and probably the only (until 1928) publication which so skilfully catered to the community's need for news and at the same time pursued academic ambitions. Even though initially the editors sought popular materials, it was mainly aimed at encouraging the readers with lighter contents and gaining loyal fans. ${ }^{414}$ It was called into life as a bi-weekly, but from 1926 to the end of 1931, he appeared only once a month.

The idea to publish a periodical in a more extensive form than just a bulletin for vocal music lovers through the Poznańs vocalists' association was born

412 Gliński to Chybiński from Warsaw 22 I 1926, AACh-BJ, box 6, G-5/32.

413 'I would even be willing to move "Highlander Music" to the leading place of the first post-vacation number,' see Gliński to Chybiński from Warsaw 20 VII 1926, AACh-BJ, box 6, G-5/32. Article with the title 'O muzyce górali tatrzańskich' [About the music of Podhale highlanders] published in Muzyka 1926/11-12, 584-588.

414 During the preparation of the first editions, Opieński explained to Chybiński the wording he used in a letter (unknown to us today) to Bronisława Wójcik: 'If I wrote "popular" to Wojcikówna, it was because initially I would like to draw the audience in with an easier read, but at the same time give them a taste of more exact and professional things,' see Opieński to Chybiński from Poznań 11 XII 1924, AACh-BJ, box $6, \mathrm{O}-2 / 73$. 
in 1924 or even maybe slightly earlier. While staying in regular contact with Chybiński, Opieński wrote to him towards the end of the year:

My letter has a special purpose. The Vocalist Club Association of Wielkopolska, which I preside, is starting a biweekly magazine on 1 January: Przeglad Muzyczny, under my editorship; it should replace or rather fill the gap that exists in the Polish music community which does not have a serious periodical. The aim we need to have: teaching a blind man about colour. - ... So please, if you may, send us something for issue no. I (by15 XII).... Perhaps something in the area of highlander folklore would be most convenient for you? Please!! ${ }^{15}$

Three weeks later, in his typically colourful and emphatic manner, he presented the assumptions and purpose which were to guide the editorial staff and himself: 'the motto of our Przeglad is development - evolution of Polish music.... I will be very glad if in two corners of the Polish Republic fires of Polish music culture burn brightly; judging by your own work - Lviv is already a significant centre for musicology - here we mainly have to work from scratch., ${ }^{416}$

In the first years of Przeglad, Chybiński was present in almost every edition; he opened many of them; when he was invited to collaborate as an author, he immediately responded by sending an article in the field of musical ethnography, this time addressing this department of musicological research from the side of methodology. As years earlier, this time Opieński again showed particular trust and respect to Chybiński, placing the first part of this text which for the norms of the magazine was very extensive, almost at the opening, ${ }^{417}$ right after the programme article of his own authorship, 'Muzykalność a estetyczna kultura' [Musicality and cultural aesthetics], in which he described the tasks to be undertaken by the newly established journal in order to support the spreading of musical culture throughout the community, with an attempt to characterise and assess its level. ${ }^{418}$ Immediately after the first article which was extremely important then for the folklore research, Chybiński began to overwhelm the editorial staff of Przeglad

415 Opieński to Chybiński from Poznań 13 XI 1921, AACh-BJ, box 6, O-2/72.

416 Opieński to Chybiński from Poznań 3 XII 1924, AACh-BJ, box 6, O-2/77.

417 Adolf Chybiński, 'Wskazówki zbierania melodii ludowych' [Tips for collecting folk melodies] (PM 1925/1, 6-12, 1925/2, 1-9). Opieński wrote enthusiastically about Chybiński's article with hope for a response from the milieu: 'is perfect for us and I hope that consequently it will be of interest to various provincial musicians (let alone those from the capital),' see Opieński to Chybiński from Poznań 15 XII 1924, AACh-BJ, box 6, O-2/74.

418 Henryk Opieński, 'W miejsce programu. Muzykalność a estetyczna kultura' [In place of the program. Musicality and aesthetic culture] (PM 1925/1, 2-6). 
with 'Old Polish music.' As late as 1925, he presented four contributions, the first of which, 'On a number of putative, known and unknown Polish composers from the seventeenth and eighteenth century, ${ }^{419}$ caused - not without exception in the pages of the Poznań magazine - an argument with Zdzisław Jachimecki. ${ }^{420}$ The Lviv professor made the unfair allegation that the Cracow adversary had disregarded his contribution in undertaking historical research around the name of the seventeenth-century composer Sebastian Antoni Kaszczewski. The second of the polemics took place three years later and referred to the assessments of the figures of Marcin Leopolita and Mikołaj Gomółka, and it was preceded by a discussion of the issues published in 1913 by Józef Reiss about Gomółka’s Melodie na psatterz polski ${ }^{421}$ [Melody on the Polish psaltery].

In the next annals - 1926-28, and even 1929, when he was already leading a scholarly journal ${ }^{422}$ - Chybiński presented a dozen or so dissertations and reviews (often extensive enough to encourage the editors to divide them and print them in installments), mainly concerning the history of music and musical culture until the end of the eighteenth century, but also newer music, as for an example article on the 'problems of national style and folklore in the work of

419 PM 1925/13-14, 1-7, 1925/15-16, 1-7.

420 Zdzisław Jachimecki, 'Konieczne sprostowanie. Z powodu rozprawy Adolfa Chybińskiego' [Necessary correction on account of Adolf Chybinski's essay] (PM 1925/17-18, 9-10), and Chybiński's polemic titled 'W sprawie dawniejszych kompozytorów polskich' [On the matter of early Polish composers] (PM 1925/20, 6).

421 See Henryk Opieński's review in nr. 3 from 1928 (p. 10) and the polemics in PM: Adolf Chybiński, 'O rehabilitację Mikołaja Gomółki' [About the rehabilitation of Mikołaj Gomółka] (PM 1928/9, 4-7); Zdzisław Jachimecki, 'Kto ma prawo do rehabilitowania Mikołaja Gomółki' [Who has the right to rehabilitate Mikołaj Gomółka] (PM 1928/10-11, 17-18); Adolf Chybiński, 'W sprawie Marcina Leopolity i Mikołaja Gomółki' [In the matter of Marcin Leopolita and Mikołaj Gomółka] (PM 1928/12, 10-12; next to the continuation of the dispute concerning Gomółka, an additional polemical commentary on Jachimecki's article 'Spuścizna artystyczna M. Leopolity w muzykologii polskiej' [The artistic inheritance of M. Leopolita in Polish musicology], PM 1928/10-11, 13-17); Zdzisław Jachimecki, 'Profesorowi Drowi Adolfowi Chybińskiemu w sprawie Leopolity i Gomółki wyjaśnień kilkoro’ [To Professor Dr Adolf Chybiński in the case of Leopolita and Gomółka, several explanations] (PM 1929/2, 12-13; continuation of skirmishes for meritorical arguments and more).

422 It should be noted here that in the meantime he sent a fragment of the article to Poznań 'Do dziejów muzykologii w Polsce' [To the history of musicology in Poland] prepared for the requirement of KM (1928/1, 82-85): reprint of fragments under the title 'Do bibliografii dawnej muzyki polskiej' [To the bibliography of early Polish music] in PM 1929/11, 7 . 
Polish composers of the nineteenth and twentieth centuries' - 'Sny o "pieśniach o ziemi naszej" ${ }^{423}$ [Dreams about songs of our land]. In addition to the already mentioned work on ethnographic issues inaugurating the first issue of Przeglad, he addressed folklore two more times: firstly - writing recollections about Bartuś Obrochta, ${ }^{424}$ the second time - preparing a review about the monumental study Puszcza kurpiowska w pieśni [Kurpie Forest in songs] by Father Władysław Skierkowski. ${ }^{425}$ In turn, in the periodical Henryk Opieński reviewed Chybiński's ethnographic works: Instrumenty muzyczne ludu polskiego na Podhalu [Musical instruments of the Polish people in Podhale] (Cracow 1924) and O muzyce górali podhalańskich [About the music of Podhale highlanders] (Zakopane 1927). ${ }^{426}$

After changes in the editorial office, the professor responded in the following years to the new needs of the journal by sending several works on the dissemination of choral music, combining academic knowledge with practical aspects of the problem and assessing the current work on vocal ensembles. ${ }^{427}$

The Old Polish compilation, published in Przeglad by the Lviv professor, was complemented by dissertations by his young assistant, Maria Szczepańska. In one of these $\mathrm{e}^{428}$ the Lviv musicologist enriched the then 'state of possession' in the field of Polish fifteenth-century polyphonic song with a third work, O nadroższy kwiatku panieńskiej czystości [About the dearest flower of maiden purity], known, as the author pointed out, from the reproduction included by Aleksander Poliński to his Dzieje muzyki polskiej [History of Polish music], but not previously analysed by anyone. She had an opportunity to get to know the historical piece from her own experience; she performed a 'palaeographical analysis' which not only made a discussion about the music layer possible but also facilitated an attempt to reconstruct the text. Szczepańska maintained an interest in similar pieces and the culmination of her work on another fifteenth-century song

423 PM 1926/4, 5-6, 1926/6, 7-9.

424 'Śp. Bartłomiej Obrochta z Kościeliska' [The late Bartłomiej Obrochta of Kościelisko] (PM 1926/6, 15-16).

425 PM 1928/9, 11-12.

426 PM 1925/11, 18-19, 1928/1, 9.

427 For more about the place of the singing community and the activities of choirs see in PM for example, 'O wyższy poziom zespołów chóralnych' [About the higher standard of choral ensembles] (1927/9, 1-5, 1927/10, 1-4), 'O potrzebie odrodzenia twórczości chóralnej w Polsce’ [About the need to revive choral creativity in Poland] (1929/1, 2-5).

428 Maria Szczepańska, 'Do historii polskiej pieśni z XV wieku' [To the history of Polish songs of the fifteenth century'] (PM 1927/5, 6-8, 1927/6, 1-5). 
originating from sources preserved in Polish archives was an extensive monograph of the hymn to Saint Stanislaus, which the researcher sent to the editors in Poznań a year later. ${ }^{429}$ She also wrote several reviews for the magazine, and to celebrate Chybiński's fiftieth birthday, probably at the editors' request, she prepared a list of musicological works written by the professor, which accompanied an extensive report by Henryk Opieński on a commemorative book prepared by his students and friends. ${ }^{430}$

Stefania Łobaczewska contributed to the pages of Przeglad Muzyczny first and foremost as a trusted reviewer of musicological publications. She published two original works - both focused on issues in the field of theory, particularly contemporary music, which at that time interested her in the highest degree. ${ }^{431}$

Having known Chybiński for many years and his 'school', Opieński, from the first weeks of work for the Przeglad Muzyczny, also sought texts from Bronisława Wójcik, counting on her 'like on Zawisza',432 and Fr. Hieronim Feicht, in the midtwenties, one of the most experienced musicologists of the young generation. Perhaps using the professor's mediation, he commissioned Feicht to publish a treatise on sources for hymn Bogurodzica [Mother of God] (along with notes and text prepared by the author based on a seventeenth-century manuscript found in Lviv), and immediately, in December 1924, he sent it to print. ${ }^{433}$ In the following years, he wrote regularly for Przeglad. Already in 1925 he signalled his interest in the figure and work of Bartłomiej Pękiel, ${ }^{434}$ and also participated in a discussion

429 Maria Szczepańska, 'Hymn ku czci św. Stanisława z XV w. (Przyczynek do historii średniowiecznej muzyki w Polsce)' [Hymn in honour of Saint Stanislaus from the fifteenth century (A contribution to the history of medieval music in Poland)] (PM 1928/7, 1-5 ff.).

430 PM 1930/11-12, 4-5.

431 See sketch 'Podstawy rytmiki i metryki muzycznej' [Basics of rhythm and musical metrics] (PM 1926/9, 4), and a monographic article on the work of Schönberg and his place in contemporary music 'Problemat atonalności i Arnold Schönberg' [The problem of atonality and Arnold Schönberg] (PM 1926/11, 4-5, 1927/1, 4-8, 1927/2, 5-7, 1927/3, 8).

432 See Opieński to Chybiński from Poznań 15 XII 1924, AACh-BJ, box 6, O-2/74.

433 Hieronim Feicht, 'Historyczno-muzyczne uwagi o lwowskich rękopisach Bogarodzicy' [Historical-musical remarks about the Lviv manuscripts of Bogurodzica] (PM 1925/2, 10-14, 1925/3, 5-8 and sheet music supplement).

434 Hieronim Feicht, 'Bartłomiej Pękiel. 1.Zarys biografii. 2. Twórczość. 3. Charakterystyka kompozytora' [Bartłomiej Pękiel. 1. Biographical sketch. 2. Creativity. 3. Characteristics of the composer] (PM 1925/10, 1-5, 1925/11, 5-10, 1925/12, 1-3). 
on the revival of the practice of Gregorian chant and the choral movement in Poland. ${ }^{435}$

In turn, Wójcikówna, despite the efforts of the editorial board, only sporadically collaborated and only in the first period of Przeglad's activity. In one of three texts, a short feuilleton 'O pewnym nieporozumieniu, ${ }^{\text {'36 }}$ [About a certain misunderstanding] commented on the wording of the well-known Chopinologist, James Huneker (duplicating the current opinion also held in German literature), talking about the 'Asianness' of Chopin's music, preventing full understanding of the master's works by the 'western' listener. The second of the texts was of a different character - 'O "gamie" w muzyce współczesnej' [About the 'scale' in contemporary music'] $]^{437}$ - in the journal's bibliography it was assigned to the section of 'Theory, aesthetics, psychology', being, however, just a popular lecture, explaining to laymen the goal of modern composers' search for new 'sound' environments, not limiting their creative intentions in the field of musical material.

With a good knowledge of the musicological community, which back then was obviously still quite small, the editor of Przeglad mainly sent his invitations to Lviv, where the most 'academic' papers were written. His collaboration with colleagues from Cracow was much less frequent, and he was not really hoping for any papers from Poznań. Even though the respectable group of German musicologists, who gained their qualifications still before the war, included the 'respectable' Łucjan Kamieński, who settled in Wielkopolska's capital after the war, so he was only a stone's throw away, but sadly in Opieński's opinion he was 'so painfully slow that it was a real art to get something from him.'438 Over the years, he was known as an efficient organiser in various fields - we can remember here that living for almost ten years in Königsberg (1909-18) he write the music column for the Königsberger Allgemeine Zeitung, and already was the director of the touring operetta in Poznan, then the deputy director of the local State Music Academy (later Conservatoire), and in 1922 he was entrusted with organising the department of musicology at the University, which he led until the outbreak of war and where in the meantime (in 1930) he founded a phonographic

435 PM 1925/24, 6-7. He preceded his speech with an article-report about the cultivation of early music in choral practice 'Kult Palestriny u pierwszych odnowicieli polskiej muzyki kościelnej' [The cult of Palestrina and the first revivers of Polish church music] (PM 1925/24, 4-6).

436 PM 1925/3, 11-12.

437 PM 1925/10, 5-9.

438 Opieński to Chybiński from Poznań 15 XII 1924, AACh-BJ, box 6, O-2/74. 
archive. For the whole musicological milieu, he became a key figure when in the years 1928-31 he took up organisation of and then running the PTM. He published much in German - still during his studies in Berlin, and also after the war in Archiv für Musikwissenschaft, Allgemeine Musikzeitung, and in Polish in Poznańs university publishing houses and in the Sprawozdania Poznańskiego Towarzystwa Przyjaciót Nauk [Reports of the Poznań Society of Friends of Sciences], he was a reviewer of Kurier Poznański. Music magazines where his works can be found include the local Życie Muzyczne $i$ Teatralne which appeared only for a few months of the 1934/35 season and in which he posted the article 'Folklor a kultura muzyczna' [Folklore and musical culture], the Warsovian Muzyka and PRM, led by Chybiński, in the first volume of which he published 'Monografia pieśni zmówinowej z Kaszub południowych'339 [Monograph about chant song from southern Kaszuby]. However, it was not possible to persuade Kamieński to become an author cooperating with Przeglad Muzyczny.

Of course, these few names of musicologists should be supplemented with the names of journalists and music critics who filled Przeglad Muzyczny with both reports and information addressed to the main readers of the magazine members and activists of singers' circles - as well as attempts to disseminate knowledge about the history of music and musical culture, or discuss performance issues. Among regular columnists and reporters was vocalist and pedagogue Roman Heising (in the 1930s he completed his education also with musicological studies), composer, conductor and activist of the singing movement Stanisław Kwaśnik, or above all, one of the journal's editors, Stanisław Wiechowicz, composer, conductor, music critic.

Henryk Opieński formally led the magazine until mid-July 1927, although he left Poznań already on 27 VI 1926 to the Swiss home of his newly wed (1925) wife Lidia. ${ }^{40}$ However, he intended to keep in touch both with the Związek Kół Spiewaczych [Union of Singers' Circles] and the editors of Przeglad Muzyczny, although he planned to have peace from direct contact with people for two years, and if health allows, work on compositions. ${ }^{341}$ In fact, we have evidence that for many of the following months he certainly received news from Poznan and personally intervened with authors, even if already known from not meeting

439 PRM 1935/1, 107-131.

440 Lidia Barblan-Opieńska (1890-1983), Swiss singer and composer. Studied in Fribourg, Paris and Basel, she taught singing in Fribourg, Basel, Poznań and Lausanne. She was a co-founder and member of the 'Motet et Madrigal' ensemble led by Opieński. She is also the author of piano variations and cantatas.

441 Opieński to Chybiński from Morges 9 VII 1926, AACh-BJ, box 6, O-2/93. 
their original commitments, like the head of Lviv musicology, whom he asked for: 'They whine from Przeglad in Poznan that they have received nothing from you for a long time. Sir Professor, if you would be so generous to look kindly toward them and send them something from your portfolio." ${ }^{342}$

Mirosława Stempniewicz ${ }^{433}$ probably rightly points out that the duties of the editor-in-chief to date had been performed by another musician and theoretician from Warsaw, Kazimierz Sikorski, who - let us add - studied theoretical subjects at the Higher School of Music at WTM years earlier under Opieński. His name does not appear on the pages of the journal, but only in a small note informing about the acquisition of the editorial position by Wiechowicz. ${ }^{444}$ Sikorski had adequate preparation (let us remember that in addition to a diploma in the field of theory and composition, he also studied philosophy at the University of Warsaw and started, but quickly abandoned, studies with Chybiński in Lviv). Sikorski was ambitious to keep the profile of the publication as given by the first editor, and thus not limit it to the activities of singer unions, but also carefully propagate more thorough knowledge of music. Soon, less than a year later, he could solidify his first editorial experience by accepting an offer from the reactivated Przegląd Muzyczny.

Together with the new editor Wiechowicz, who was primarily a practising musician, whose passion included choral creativity and performance, he transformed the profile of the magazine: to a greater extent editions concerned the musical culture of choral communities and performance practice, yet still included - although much less frequently - historical materials, most often related to issues of vocal music.

Adolf Chybiński, his constant and most productive colleague, was asked to write a special text on the occasion of the magazine's fifth anniversary. Chybiński primarily spoke of a 'friendly gate' that Henryk Opieński, the first editor - whom he referred to as 'a professional musicologist' - opened for musicological works entering a higher level at that time. He did not fear the inconsistency of his decisions with the assumptions and goals of any organ of singing associations, because in Chybiński's understanding the duty of every music magazine (also

442 Opieński to Chybiński from Morges 19 XII 1926, AACh-BJ, box 6, O-2/ 94.

443 Stempniewicz 1966, 14.

444 PM 1927/7, 16. Indeed Sikorski himself wrote to Chybiński about his nomination: 'A few days ago I took over the editorial office of Przeglad Muzyczny .... Seeing that you, Sir, are a regular contributor to Przeglad, I respectfully request you continue to supply this magazine with your valuable articles, see Sikorski to Chybiński from Poznań 12 XI 1926, AACh-BJ, S-10/2. 
popular) is propagating in one form or another, the history of our native music among wide-ranging groups of singers', the more so that 'a considerable number of musicological works [published here] concerned earlier choral music and early choral culture. ${ }^{345}$ Summing up the activities of the editorial staff to date, he pointed out that thanks to the adopted programme, Przeglad Muzyczny also inspired other magazines to take on a greater interest in historical issues, and its content etched in the annals of music press forever. Regarding his experience as an author, he wrote: 'I would say both now and in the future that I will deem the years of cooperating with Przeglad Muzyczny the nicest and most productive years. Moreover, when I think of the line of development of Przeglad Muzyczny, I see that thanks to the ideology and perseverance of publishing and editorial factors, Przeglad Muzyczny is shaping up for a very real future filled with broad perspectives.' ${ }^{446}$

The last words were rather polite. While two years earlier, in 1928, seven of Chybiński's articles (in eleven editions) were published in Przeglad, along with two pieces by Wiechowicz, Opieński, Kwaśnik and Jachimecki each, and one by Feicht, Reiss (in three editions), Szczepańska (in four editions) and several other authors (and I mention only musicology texts here), a year later from the author-musicologists only Chybiński (five essays in six editions) and Opieński (four titles in seven editions) remained; the remaining content consisted of materials on current issues relevant to the singing environment. Never-the-less, when Chybiński reminisced about his 'most productive' years, he did not refer solely to his collaboration with the Poznań-based Przeglad Muzyczny.

Analysing his 'contributory' writing on this occasion and taking into account the bibliography in this period until $1939,{ }^{447}$ three periods can be observed, characterised by a special intensity of 'small' forms, both scholarly and popularising knowledge about the history of music and musical culture. The first period stretches from 1910 to 1912, when he submitted his works - let us remember - generously to columns of the Warsaw-based Przeglad Muzyczny run by Roman Chojnacki (nearly thirty items). Moreover, he sent his texts to the ethnographic quarterly $L u d$ (run by dialect-specialist Szymon Matusiak) and to the Warsaw artistic, literary and scientific magazine Sfinks (the creator and editor of

445 Adolf Chybiński: [text on the occasion of the fifth anniversary of PM] (PM 1930/1, 3). 446 Ibid., 4.

447 Kornel Michałowski prepared the most complete bibliography of Chybiński for the needs of the second memorial book dedicated to the professor 'on the occasion of his seventieth birthday' (Ksiega pamiątkowa 1950, 26-43) and again as a supplement to the edition of Chybiński’s memoirs (Chybiński 1959/1, 210-257). 
which was the poet, journalist and literary critic Władysław Bukowiński). First and foremost, he was then one of the pillars of Kwartalnik Muzyczny, the organ of WTM, and also published abroad. ${ }^{448}$

Another peak of his activity that made him a matchless role model for authors of contributions falls in the second half of the 1920s. At that time, he associated himself simultaneously with several magazines, whose editorial staffs operated in various centres of the reborn Poland. On the pages of Muzyka, until the collapse of cooperation between Warsaw and Lviv, there appeared a total of twenty smaller and larger articles and reviews. Thus, the editor of the monthly had to rapidly, though reluctantly, accept the fact that Chybiński submitted his essays to other magazines as well. 'Yesterday I read, and with high interest, Sir Professor, your excellent piece in Przeglad Muzyczny', he wrote at that time, 'Why on earth have you sent us absolutely nothing for many weeks? Have you ceased to consider MUZYKA as your organ? ... I could not and would not impose anything on you Mr Professor. Please believe me that everything the Professor will send will be accepted with sincere joy. ${ }^{349}$ In turn, he published both independent, original articles and comments in Opieński's Przeglad Muzyczny in the running columns: 'Letters,' 'Current news', 'Reports on notes and books' - more than thirty essays, reviews, comments, and reports by Chybiński appeared there over six years. At the same time, he was still publishing in the Poznan Muzyka Kościelna, the Warsaw Wiadomości Muzyczne, the Cracow Kurier LiterackoNaukowy, the Tarnow monthly Hosanna, and Muzyk Wojskowy $y^{450}$ published in Grudziądz. However, a special place among these titles was occupied - albeit briefly for less than a year - by the monthly Myśl Muzyczna [Musical thought] given the subtitle Dodatek Muzykologiczny do miesięcznika Śpiewak (Śpiewak Ślaski) [Musicological supplement to the monthly singer (Silesian singer)]. Already in 1927, the professor associated his exiguous career with this literary and musical periodical, which was an organ of the Zjednoczenie Polskich Związków Śpiewaczych i Muzycznych na Śląsku [Union of Polish singer and musical

448 On the subject of 'small forms' in the form of reviews and polemics emerging for the cooperation of Chybiński with numerous literary and cultural journals, etc. see chapter I.1. Here, let us only add that in the 1920s and 1930s, or even from the moment of dedicating himself to a university career, he basically gave up musical criticism for musicological criticism, and the 'small forms' he wrote were always the results of academic research, not journalistic polemics.

449 Gliński to Chybiński from Warsaw 5 VIII 1925, AACh-BUAM, fol. D-J, p. 208.

450 I refer to the aforementioned bibliography prepared by Kornel Michałowski (see footnote 144). 
associations in Silesia]. Evidently, he found a valuable partner for scholarly discussion and a faithful and grateful recipient of his dissertations in his founder and editor-in-chief, Stefan Marian Stoiński, a former student of Leichtentritt and Fleischer. ${ }^{451}$ In 1928, several years of collaboration resulted in the idea of developing a musicological supplement, in which the index of authors' names came down de facto to two positions: Stoiński and Chybiński, with a quantitative - and qualitative - dominance from the latter. Six articles and reports by the supplement's editor and twelve of the professor's publications were issued in nine volumes; this set was supplemented by a dissertation by Maria Szczepańska about unknown Polish 'lamentations' from the end of the fifteenth century. ${ }^{452}$

In fact, the bulk of Chybiński's publications in Katowice was based on results as usually in his case - of many years of research conducted on archives, mainly from Wawel. In Myśl Muzyczna he published material on the instrumental canzone of Marcin Mielczewski, the biography of Walentyn Bakfark, the founding and the early years of the St. Mary's band in Cracow, the biography of Wacław of Szamotuły, Jan Fabrycy of Żywiec, the history of music in Wawel Cathedral in the fifteenth and sixteenth centuries, the issue of Italian influence in the sixteenth century Polish music, the biography of Sebastian of Felsztyn, motet works of Marcin Mielczewski as well as inventories of musical requisites and instruments of the Jesuit bands in Cracow in the eighteenth century. The historical sketch 'Muzykologia wśród nauk uniwersyteckich' [Musicology among university sciences $]^{453}$ was important for disseminating knowledge about the history of the discipline. The article brought attention to the clue to propagating early music through source publications 'Renesans dawnej muzyki polskiej' [Renaissance of early Polish music] referring to the first volume of the new WDMP series just

451 Stefan Marian Stoiński (1891-1945), Polish ethnographer, conductor and composer. He studied at the Julius Stern Conservatoire in Berlin and privately studied musicology with Hugo Leichtentritt and Otto Fleischer. After World War I he settled in Silesia; in the years 1922-24 was the head of the Opera in Katowice, in 1925 he founded the Instytut Muzyczny [Institute of Music] there, in the years 1926-39 he edited the monthly Śpiewak Śląski (later Śpiewak). In 1931 he became president of the Związek Śląskich Kół Śpiewaczych [Union of Silesian singing circles]. He was an organiser of the singing movement in Silesia, founder of the Secondary Music School (then PSM) in Bytom in 1945. PSB reports that in the pages of Spiewak, Przeglad Muzyczny, Polonia and other magazines, he published nearly one hundred articles, see Wypych-Gawrońska 2005.

452 Myśl Muzyczna (suplement to the monthly Śpiewak) 1928/8, 49-51.

453 Myśl Muzyczna 1928/2, 9. 
released and from the end of the nineteenth century Father Surzyński's monumental series about sacred music, Monumenta Musices Medii Aevi in Polonia. ${ }^{454}$

As mentioned, there were nine supplements to Śpiewak, all published in 1928. During the last quarter of that year Chybiński devoted all his creative force to prepare for the release of the first Kwartalnik Muzyczny, which was to become the primary platform for his scholarly writing. This did not mean however that the smaller formats - contributions, messages, and materials, were not published in friendly publications. Let us trace Chybiński’s bibliography from 1928.

Kornel Michałowski, in the set attached to Ksiega pamiatkowa takes into account thirty-seven titles during this period, which could be supplemented with at least a few more positions, for example, articles whose printing, begun in 1927, continued in editions during the next year, ${ }^{455}$ and reports, probably not always included by Michałowski. Many of them were published in parts, so that the frequency of appearance of the professor's name was, in fact, even higher. On the other hand, some of the materials were used by various publications, although reprints generally did not occur simultaneously. Such a solution was by no means a rarity: to complete their portfolios, editors often sought to obtain each and every name found in the narrow circle of writing musicologists, critics and musicians; this bothered neither the authors nor the readers. Publications from the interwar period generally constituted either local or environmental projects, usually reaching to a limited and specific range of readers - the amateur singer movement, church musicians, organists, members of musician trade unions, a wide group of music lovers. In order to raise the prestige of such publications,

454 A note on the planned publication also appeared in Przeglad Muzyczny: 'Monumenta musices medii aevi in Polonia. Later that year, the Faculty of Musicology of Lviv University released the first volume, which included the monuments of Polish music from the Middle Ages towards the end of the fifteenth century. The publication remained under the direction of Prof. Dr Adolf Chybiński and the editorial committee, consisting of: X. Dr Hieronim Feicht (Freiburg), Dr Maria Szczepańska (Lviv) and Dr Bronisława Wójcikówna (Lviv). Volume 1, containing several dozen 2- and 3-voice pieces was compiled by Dr Maria Szczepańska and included, among others, compositions of the great Polish composer - Mikołaj of Radom. The publication will consist of several volumes and will be exclusively of a scientific nature' (PM 1928/5, 15-16).

455 See for example, 'Kult muzyki Orlanda di Lasso w dawnym Krakowie' [The cult of Orlando di Lasso in early Cracow] (Muzyka Kościelna 1927/11, 213-215, 1928/3, 49-50); 'Lutnia, lutniści i tańce w poezji polskiej XVII wieku' [The lute, lutenists and dance in Polish poetry of the XVII century] (Śpiewak 1927/11, 105-107, 1927/12, $117-120,1928 / 1,2-5,1928 / 2,19-22)$. 
it was worth to invite the established authorities from time to time. Alas, due to lack of either time or original themes, but also on special requests from the editorial staff, they often duplicated their essays.

In the case of Chybiński and in relation to the year 1928, the reprint issue probably concerns six works. It would appear that the two titles included in the monthly Muzyka were published almost in parallel and 'with permission' in other periodicals due to the importance that Chybiński attached to the matters that he discussed in them. The article 'Renesans dawnej muzyki polskiej' [Renaissance of early Polish music], ${ }^{456}$ the problem of which was close to him, has been discussed above. This is a short presentation of all attempts to identify the Old Polish repertoire and bring it closer to the contemporary audiences; amongst others publication of Śpiewy kościelne by Józef Count Cichocki, publication of sources of old Polish music in the pages of Kwartalnik Muzyczny by Henryk Opieński, Józef Reiss editing Lilius's composition for the magazine Muzyka $i$ Spiew works included as examples in monographs, for example, in Jachimecki's Wpływy włoskie w muzyce polskiej [Italian influence in Polish music] (Cracow 1911). To continue this tradition, Chybiński joined from the beginning of his academic career, and at this point, in 1928, he managed to lead to the opening of a new source series.

For the third time, Chybiński intensified his 'contributing' creativity in the mid-1930s. He strengthened his contacts with the editors of Ilustrowany Kurier Codzienny and its supplement entitled Kurier Literacko-Naukowy he prepared profiles of composers, essays on early music, columns about Tatra and highlander themes, and his favourite music by Norwegian composers.

As for other representatives of the first generation of Polish musicologists, their activity in the pages of musical periodicals of the 1920s and 1930s looked different. As is known, Zdzisław Jachimecki led his academic career in a manner entirely different from Chybiński. For him, the time came in the twenties for the publication of syntheses and monographs: Historia muzyki polskiej (w zarysie) [History of Polish music (An overview)] (Warsaw 1920), Stanisław Moniuszko (Warsaw 1921), the extended edition Wagner. Życie i twórczość [Wagner. Life and work] (Warsaw 1922), he was undoubtedly already preparing Fryderyk Chopin. Rys życia i twórczości [Frederic Chopin. An overview of his life and work] (Cracow 1927). As for the smaller forms, after 1915 a clear break can be seen in his activities lasting until the mid-twenties, when he began to publish more contributions, articles, polemics, reviews, mainly in Muzyka, Muzyka Kościelna, 
the Poznań Przeglad Muzyczny, or the series of the Akademia Umiejętności [Academy of Learning]. It should not be forgotten that during all these years his articles were also published in foreign publications: The Musical Quarterly, ${ }^{457}$ La Revue Musicale, ${ }^{458}$ the entry in A Dictionary of Modern Music and Musicians (London 1924) and Das neue Musiklexikon (Berlin 1926).

Józef Reiss, connected to Cracow, indeed regularly included his works in the Sprawozdania Polskiej Akademii Umiejętności (for example, 'Wielogłosowa pieśń religijna w XVI wieku w Polsce' [Polyphonic religious songs of the sixteenth century in Poland], 1920, vol. 28; 'Jan Brożek-Broscius jako teoretyk muzyki' [Jan Brożek-Broscius as a music theorist] 1923, vol. 29). In the twenties Reiss also published articles in Zeitschrift für Musikweissenschaft (amongst others 'Georgius Libanus Lignicensis als Musiker' and 'Zwei mehrstimmige Lieder aus dem 15. Jahrhundert,' both texts in the years 1922/23), and amongst the Polish music magazines - in Muzyk Wojskowy and Orkiestra - and also in Ilustrowany Kurier Codzienny.

Before 1918 Alicja Simon was only sporadically ${ }^{459}$ a guest writer in the pages of the music magazines - Kwartalnik Muzyczny and Przeglad Muzyczny. Living abroad for years - in Berlin, Geneva and finally in the years 1924-28 in Washington - she worked professionally and published much there. After the war but still before returning to Poland she sent an article about the philosophy of Hoene-Wroński ${ }^{460}$ to Muzyka; in the thirties, she started cooperation among others with Polski Rocznik Muzykologiczny. ${ }^{461}$

Henryk Opieński, while occupied with running the 'Motet et Madrigal' choir that he organised in 1917 in Lausanne, was still involved in conducting historical research: his work La musique polonaise was published in Paris in 1918 followed by the monograph Stanisław Moniuszko. Muzyka i dzieła, issued a few years later (in 1924) in Lviv. In one of the few post-war editions of the Warsaw Przegląd Muzyczny edited by Roman Chojnacki he included a text about Hugo Riemann ${ }^{462}$ (after which, as described, a few years after the closure of the

457 For example, 'Polish Music' in the year 1920, 'Karol Szymanowski' in the year 1922.

458 'Deux opéras polonais sur Napoleon' in the year 1924.

459 'Stosunek Sperontesa Singende Muse an der Pleisse... do muzyki ludowej polskiej' [The relationship of Sperontes' Singende Muse an der Pleisse... to Polish folk music] (KM 1911/1, 48-54); 'Kilka notatek muzycznych z gazet pisanych' [A few musical notes from written gazettes] (PM 1911/1, 8-9).

460 Muzyka 1925/3, 99-103.

461 'Życie muzyczne w świetle Pamiętnika Józefa hr. Krasińskiego’ [Musical life in the light of count Józef Krasiński’s diary] PRM 1935/1, 91-106.

462 PM 1919/17-18. 
magazine, the title was taken by a periodical operating in Poznań under the auspices of the Zjednoczenie Polskich Związków Śpiewaczych [Union of Polish singing unions]). In the absence of Opieński's publications from the period before 1925, fragments of his few letters sent to Chybiński sound rather striking. Therein, he agrees to the Lviv proposals to prepare material for (maybe - this we still do not know) the new musicological periodical planned by the professor. At the beginning of 1920 Opieński wrote from Łódź: 'Regarding the collaboration, I will be glad to include a little work in the annal [?] - just as you suggested - on the Bakfark project, along with some of his letters and messages on his hitherto unknown manu[scripts] and Polish compositions - Agreed?', ${ }^{363}$ and after a few months: 'For the work ordered by you [?] I will get started in November after returning from Switzerland, from where I am leaving for concerts in midOctober; I will also use it to see what new materials to look for abroad, ${ }^{364}$ and a year later: 'Of course, I agree [to your proposal] by agreeing to the terms.... Please, just kindly specify the exact number of lines on the page and the number of syllables in the line, and at the same time the deadline by which I have to provide the manuscript.' ${ }^{365}$

The mentioned material about Bakfark's letters appeared only years later. ${ }^{466}$ Meanwhile, however, Opieński, as has been said, initiated the edition of a new journal in 1925, in which he himself published various materials on a number of occasions: historical articles, texts on musical culture and dissemination of music and current affairs, occasional notes on the singing movement, polemics, posthumous recollections. Beginning in 1926, he regularly wrote for Muzyka, and from 1928 he became a trusted and reliable author cooperating with Adolf Chybiński in Kwartalnik Muzyczny.

It should also be asked what was the attitude - at least in some cases - of Chybiński's students and colleagues towards other magazines from the musicians' and musicologists' environment. A wealth of information on this topic can be found in the next chapter. In this case, one has to conclude that their activity was enormous, which is not surprising because in those years such publications were probably a major supplement for the scholars' budgets. Having this in mind, we cannot be surprised that young people submitted their texts not only to their

463 Opieński to Chybiński from Łódź 11 II 1920, AACh-BJ, box 6, O-2/67.

464 Opieński to Chybiński from Miłosław 3 VIII [1920], AACh-BJ, box 6, O-2/68.

465 Opieński to Chybiński from Poznań 7 VII 1921, AACh-BJ, box 6, O-2/69.

466 'Sześć listów lutnisty Bakfarka' [Six letters by Bakfark the lutenist], ed. Henryk Opieński (KM 1930/6-7, 158-167). 
mentor-editor of the most significant music journal but to other addresses as well, including the more 'hostile' ones. Bronisław Wójcik-Keuprulian clearly presented her arguments, who addressed these words to her mentor ${ }^{467}$ in the spring of 1930:

In my opinion, the interests of Kwartalnik in no way collide with the interests of Muzyka. Kwartalnik is a scientific journal, Muzyka - a popular music 'magazine' and these journals cannot compete with each other, nor should they. ... with regards to the completely different purposes of the two magazines, I see no good reason why the collaborators of Kwartalnik should not also write in Muzyka from time to time. To the contrary, I would consider it wrong, as then there would be a lack of expertly written articles in Muzyka, which would be harmful to Polish writing on music in general. Therefore, I do not refuse collaboration with Mr Gliński, and if I find enough time, I'll always write some little article for Muzyka. I emphasise: 'article'; as for 'scientific dissertations,' fortunately, we now have Kwartalnik. ${ }^{468}$

The religious periodicals are surprisingly numerous in the interwar period. Remigiusz Pośpiech, who briefly undertook the characterisation of the editor of the Theological Department at Opole University's half-yearly Liturgia Sacra ${ }^{469}$ citing, among other things, the bibliography collated by Father Zygmunt Zieliński and bibliographies by Michałowski and Pigła, ${ }^{470}$ on this occasion indicates more than twenty titles that interest him. The majority consists of organist publications, while others are devoted to church singing and liturgy. Poznan was traditionally rich in musical life associated with religious practice. That is where Fr. Wacław Gieburowski had run his magazine - Vademecum dla Muzyków Kościelnych [Vademecum for church musicians] - for two years (1923-24). In the period between 1918 and 1939 six periodicals were issued in Warsaw. They were published generally at intervals not more than two to three years, although the monthly Hosanna - dedicated to matters of religious and church music, first edited by Fr. Wojciech Orzech and afterwards by Fr. Henryk Nowacki, had been published from 1926 until the outbreak of World War II, for the final ten years in Warsaw. Likewise, Muzyka Kościelna - from the [Organists' Association of the Archdiocese of Gniezno-Poznań] - also enjoyed a long life. Its permanent authors (at least in the early years) included Fr. Wacław Gieburowski, Adolf Chybiński, Fr. Hieronim Feicht, and a musicologist from Poznań - Kazimierz Zieliński. In the years 1927-28, Bronisław

467 Wójcikówna was Chybiński’s first student, and quickly also became his first assistant. 468 Wójcik to Chybiński from Lviv 9 IV 1930, AACh-BJ, box 4, W-24/92.

469 Pośpiech 2009.

470 Zieliński 1981; Michałowski 1955; Michałowski 1964; Michałowski 1978; Pigła 1991. 
Rutkowski, a representative of the SMDM also led a journal which belonged to this same trend, Pismo Organistowskie. Miesięcznik poświęcony wiedzy fachowej $i \dot{z y c i u}$ organistów, and directed it as if it was a side issue and independent of the editor's musical and organisational activity. In a letter he wrote to the professor during the first months of acquaintance with Chybiński: 'Thank you very much for the article submitted to Pismo Organistowskie, which will be included in the February edition. ${ }^{471}$... I was afraid that you wouldn't want to send your valuable work to such a small publishing house. Pismo Organistowskie for now is a very modest publishing house, I edit it out of necessity, because in Warsaw, no one wants to deal with this important matter. ${ }^{3472}$

In view of the rich and diversified periodical press offer available in the interwar period, there is a somewhat humorous story of the unfulfilled plans of a young musicologist - Julian Pulikowski - whose activities in various fields left a significant imprint, especially on the capital-based circles (elaborated further in chapter II). It should be emphasised that one of his desires was to take up editorial work, which he was able to partly realise in Muzyka Polska (the quarterly, bi-monthly and monthly which emerged in 1934 after the division of Kwartalnik Muzyczny) - that is where Adolf Chybiński patronised the ambitious, new to the Warsaw environment, protege of Guido Adler and Egon Wellesz in Vienna, amongst others. Even then, exchanging letters with the professor, he misread his words about the 'co-redaction' of the simultaneously planned Muzyka Polska annals and 'with sincere joy and with all his heart' gave thanks for the honour he dreamed of. ${ }^{473}$ Unexpectedly, after four years, in autumn 1938, he presented his own idea for a magazine. Referring to the proposal of an unspecified professor at the University of Warsaw, he began to weave plans to initiate a new title 'for cultured spheres, for "intellectuals" (and therefore not only for professional musicians) $)^{374}$ - not a strictly musicological journal, but something of the type 'Zeitschrift für polnische Musikkultur, Zeitschrift für die gebildeten Stände. Works on music, music culture, etc., etc., in scholarly terms, but for broad cultural layers. ... Everything at the highest level strictly scholarly, but accessible to a

471 Chybiński published two articles in Pismo Organistowskie: 'Organista jako współpracownik naukowy' [The organist as a scholarly collaborator] (1928/2) and 'Organista a pieśń ludowa' [The organist and folk song'] (1928/4).

472 Rutkowski to Chybiński from Warsaw 17 II 1928, AACh-BJ, box 4, R-19/1.

473 Pulikowski to Chybiński from Warsaw in mid-September 1934, AACh-BJ, box 3, P-28/69.

474 Pulikowski to Chybiński from Warsaw 29 X 1938, AACh-BJ, box 3, P-28/191. 
normal educated reader. ${ }^{275}$ The magazine was to be a quarterly (with the perspective of being bi-monthly), perhaps with the title Wiedza o Muzyce. Pismo poświęcone polskiej kulturze muzycznej' [Knowledge about music. A magazine devoted to Polish musical culture], or perhaps Kultura Muzyczna. Kwartalnik dla miłośników muzyki' [Musical culture. A quarterly for music lovers]. Considering Pulikowski's research interests, we can assume that it was probably for his own initiative for which he wanted to gain Chybiński. Although no editorial office was yet formally working, he commissioned the professor to write articles (with a request to state their size), for example, on the theme of 'Niezrozumialstwo w muzyce i muzykologii' [Misunderstanding in music and musicology], 'Renesans muzyczny ${ }^{347}$ [Musical renassaince]. He needed ready texts in order for the first edition to be 'totally druckreif, to start to establish [the magazine], receive funds, etc. ${ }^{377} \mathrm{He}$ even suggested a separation of functions in the editorial committee, in which 'should be a musicologist, a musician, or a music enthusiast who would serve as a link between music and "gebildete Stände" for whom the magazine is to be published. As for now, we can see only two names: the name of Mr Professor as the musicologist and Mrs Prof. [Cezaria] Jędrzejewiczowa, an expert in folk music and a highly cultural music enthusiast.... Furthermore, Professor Schumann [Stefan Szuman] from Cracow, who is a great music aficionado, was mentioned as well. But rather as a loose remark. The name of general Stachiewicz also appears... I kindly ask you Sir Professor for your consent on a Membership of such a committee. ${ }^{478}$

I think we can assume that Pulikowski, who had previously suggested to Chybiński that he collaborate in editing the PRM, sought to create his own magazine, a matter in which he did not succeed, and the planned title remained in the realm of dreams. His accounts of the course of work on the inauguration of editorial work sounded quite credible, but it seems that everything depicted in the lists of events were just figments of his imagination. In any case, the periodical did not appear before September 1939, and thus did not become competition either for PRM, or for other contemporary titles.

475 Pulikowski to Chybiński from Warsaw 29 X 1938, AACh-BJ, box 3, P-28/191.

476 Pulikowski to Chybiński from Warsaw 4 XI 1938, AACh-BJ, box 3, P-28/193.

477 Pulikowski to Chybiński from Warsaw 24 XI 1938, AACh-BJ, box 3, P-28/176.

478 Pulikowski to Chybiński from Warsaw 20 XII 1938, AACh-BJ, box 3, P-28/195. 

II. Hopes of Polish musicology - Kwartalnik Muzyczny in the years 1928-1933 



\section{The idea of publishing a musicological quarterly - preparatory work - establishing Kwartalnik Muzyczny: the periodical's concept - programme assumptions: the first editorial - reactions of the milieu}

Excluding the first Kwartalnik Muzyczny - the organ of WTM - whose goal was the planned, statutory activity of the management Board announced in the annual report of the Towarzystwo, ${ }^{1}$ all nineteenth and most twentieth-century music magazines were (at least in their original intent) one-man initiatives of their editors (we should exclude from this periodicals that were created as organs of the scene, such as publications of singing unions or various foundations and religious associations). This is also how Adolf Chybiński wanted to see 'his' quarterly/annual, and he shared this idea with his musicologist friends. Let us remember that Henryk Opieński already wrote in 1920 about publishing his little work in an unspecified edition of Chybiński's yearbook. ${ }^{2}$ Without doubt, the professor was thinking about his own journal for years. He was strongly associated with each of the editors to whom he directed the results of his research he appeared not only as an author, but he also served as an adviser and through the great intensity of his contributions, which filled the pages of the music and socio-cultural-literary press in a profound manner, he had already previously given a scientific tone to several titles: from the period before the Great War Kwartalnik Muzyczny, Młoda Muzyka, the Warsaw-based Przeglad Muzyczny, and from the twenty year interwar period - the Poznań Przeglad Muzyczny, Myśl Muzyczna, Muzyka (at least in those columns devoted to historical and theoretical issues).

The editors of these magazines probably realised that they were not ambitious enough for the expectations of the most elite readers - a new class of musicologists - their profile, when (generally) for pragmatic reasons (the expectations of the bodies appointing them, finances) they published publications for a wide range of music amateurs, and therefore for everyone and for no-one ${ }^{3}$. The

1 Sprawozdanie Komitetu WTM 1909 1910, 24.

2 Opieński to Chybiński from Łódź 11 II 1920, AACh-BJ, box 6, O-2/67.

3 See for example, the already cited letter from Gliński to Chybiński from Warsaw from 1 II 1926, AACh-BJ, box 4, G-5/31. 
first generation of musicologists educated at foreign universities realised that they owed it to society not only to study, but also to popularise music, even if this did not always coincide with their professional ambitions. Łucjan Kamieński, albeit with apprehension, once accurately spoke of the threats connected with activities in the field of journalism, criticism and music education. He was not an advocate of frittering away time and academic knowledge in favour of popular literature, while in musicological studies he saw the possibility of developing new, qualified, early career specialists prepared to undertake professional activity other than strictly scientific - as publicists, music activists, and educators:

It must be better that we do it, rather than dilettantism takes over all musical education, but, of course, then studies and research suffer, because ... leaving aside wasted time, writing for the community scientifically demoralises, the scientific and feuilletonistic psyches (even if the feuilleton covers 3 columns or 12 sides) are so different, it always takes me much effort to change from one to the other. ... It will be better if our circle is multiplied and after graduation our students are specialised, some in certain directions of academic work, others in journalism and popular literature, still others in practice. ${ }^{4}$

Perhaps not all representatives of musicologists considered such a division necessary and justified, and some (sometimes by choice, sometimes against themselves, out of necessity forced by life situation) successfully practised popularisation and scholarship together; at the same time, however, the need to set up a scholarly journal smouldered in the community.

In 1925 a reporter in Przeglad Muzyczny signed with the monogram 's' mentioned in the information provided about the newly-created periodical - the varsovian Muzyka - and other local publishing initiatives that 'in Lviv publication of Kwartalnik Muzyczny is being planned. ${ }^{5}$ Let us also recall here the words of Henryk Opieński about including in the nearly unknown yearbook 'a little work ... from Bakwark, a few of his letters and information about his previously unknown Polish manuscripts.6 Some organisational work took place, because the gentlemen returned to a specific conversation about the publication with Chybiński, probably the following summer, when Opieński agreed to the proposed offer, and he began to work in autumn, after returning to Switzerland from his artistic journey.

4 Kamieński to Chybiński from Poznań 12 I 1926, AACh-BJ, box 6, K-3/27.

5 PM 1925/2, 15.

6 Opieński to Chybiński from Łódź 11 II 1920, AACh-BJ, box 6, O-2/67.

7 See Opieński to Chybiński from Miłosław 3 VIII [1921], AACh-BJ, box 6, sign. O-2/68. 
Evidently, nothing came of these plans at the dawn of the twenties - at that time, Chybiński still lacked the facilities that could support him financially. The country had just been revived, it was difficult (amongst many other urgent needs of the resurrected state) to find sponsors to support new low-profit initiatives, such as scholarly activities in niche specialisations, to which the then young and little-known Polish musicology belonged. For sure, however, there were still discussions among active musicologists about the necessity of opening an editorial office for a 'professional' journal, with a strictly academic profile, not a potpourri combining serious presentations of the state of academic research with current affairs of music or musical journalism, magazines that would not limit the authors to short forms, popularising music. ${ }^{8}$

Almost at the same time as Chybiński’s first plans appeared, in Poznań Łucjan Kamieński raised the idea for a monthly or biweekly, which he wrote about extensively in a letter to Lviv:

So now I will tell you confidentially about a particular project, about which I counted a priori on your support, the more so because you encouraged me to do something similar.... And so: a musical monthly, or eventually a biweekly, is being made ... and I will take over the chief editorship. We will rely on this rag ... Muzyka i Śpiew, but we will change the title and its whole scope.... The actual management, however, must be entirely in my hands, along with the right to choose professional staff .... I am asking you then, my beloved colleague, to support us with your cooperation and also to inspire the 'younger brothers' of Lviv, that is, your helpers and mature students, to cooperate.... Apart from me, from Poznan there will be Gieburowski, Piotrowski, and after the fait accompli and in any case Henio [Opieński], from Cracow I will ask Jachimecki and Reiss; from Lviv I count, apart from you sir, on Wójcikówna and Father Feicht. But how now with Warsaw? I want to strictly aspire to a serious level, something like Berlin's Musik - but from that Warsaw mob, perhaps only one Binental could write for such a journal. Also, at the same time, I would like to give the thing a Christian profile... Ergo?

8 We should appreciate those editors who did not avoid extensive dissertations of authors that are most important for the history of music (and related fields). There are many examples of such publications printed 'in sections' in the pages of Przeglad Muzyczny, Myśl Muzyczna, Muzyka Kościelna, Lwowskie Wiadomości Muzyczne $i$ Literackie and a number of other titles already referenced in chapter I. But for example, already the editors of Muzyka refused greater size even to such an authority as Chybiński: 'MUZYKA cannot place larger works due to technical reasons (we currently assign a maximum of 18-20 pages for articles. Further continuations are almost categorically deleted). Therefore, despite the most sincere intentions, I could only reflect on a fragment of 5 pages from the study about which the Professor writes in his letter.... If not, then please, dear sir, think about a new article for MUYKA, see Gliński to Chybiński from Warsaw 1 I 1925, AACh-BJ, box 4, G-5/13. 
I will further invite Kromalicki and Landowska ${ }^{9}$ (o Moses!), also Alicja Simon. I would also like ... to have correspondents relating from abroad, in Berlin, Paris, London, Rome, Milan. Could you, sir, advise me in this regard? ${ }^{10}$

One can see from this letter that Kamieński wanted to break with the current practice used by most music press publishers, of combining various types of historical sketches with popular feuilletons and with concert hall and opera critics. He suggested creating a magazine after the form of the 'Berlin Musik, referring with this comparison to the one published since 1901 (we can add that it lasted until 1943), the German bi-weekly led by conductor and publisher Bernhard Schuster, in which magazine we can find the texts of Boris von Schloezer, Theodor W. Adorno, Franz Schreker, Curt Sachs, Ferruccio Busoni, Karl Geiringer and many other outstanding music historians and theoreticians. A small group of educated Polish musicologists may not have been able to meet such ambitious plans at once, but the direction was indicated, and the names mentioned by Kamieński did indeed guarantee the highest possible level for the 'expert' periodical. ${ }^{11}$

However, these were only the first projects whose realisation turned out to be not so obvious. Just a few months later, Kamieński spoke not about a bi-weekly, but only about an annual publication, ${ }^{12}$ but he was soon busy with the organisation of the next Polish branch of musicology in Poznań, and left aside his 'editorial' plans, perhaps with the hope that Lviv would organise the 'annual'

9 Wanda Landowska (1879-1959), an outstanding pianist and harpsichordist, to a large extent contributed to the renaissance of the music of J.S. Bach. She was also the author of many works devoted to the performance of early music.

10 Kamieński to Chybiński from Poznań 21 V 1921, AACh-BJ, box 6, K-3/2.

11 It should be added that Kamieński, modelling himself on the plans for the Berlin Die Musik, was thinking primarily of the quality, not the layout, of the content. In Shuster's bi-weekly there were - apart from the work of the most outstanding musical pens of the time (and archival texts) - also reports on the contents of German and foreign musical journals, reviews of books and musicalia, including those of a lighter genre, concert reviews, a chronicle of current events and announcements of new publications, reports on the matters of musical societies. In principle, all larger Polish periodicals corresponded to such an arrangement in this time - Muzyka, Przeglad Muzyczny (Lwowskie Wiadomości Muzyczne i Literackie, further LWML) printed in newspaper format, the content was also similar).

12 'Time now for a musicological annual. Remember that [the Poznań publishing house] Św. Wojciech once told me they were ready to publish it. Well, I think I will use it. You have something, send it,' see Kamieński to Chybiński from Poznań 9 XI 1921, AACh-BJ, box $6, \mathrm{~K}-3 / 11$. 
publication. Meanwhile, the leader of Lviv musicology patiently waited for any kind of 'publishing' opportunity, which finally appeared in 1927. Let us remember that at this time Chybiński was invited by young Warsaw musicians - Ochlewski, Rutkowski and Zalewski - to the group of founding members of SMDM established by them (see chapter I-2). The Association's planned activities included, amongst others, apart from organising concerts, the launch of the WDMP sheet music series and the creation of a music magazine, for which a subsidy from the FNP was obtained. The first attempts to select the appropriate printing press (led by Zygmunt Łazarski) took place before these decisions, in November 1927. In the following months, the cover design and detailed budget were agreed, and in June 1928 a meeting was held with the professor and the local group in Warsaw (Kazimierz Sikorski, who was invited to act as the responsible editor and was supposed to arrive in Warsaw in September).$^{13}$ The editorial team was two people - Chybiński-Sikorski - and the official address they used was ul. Okólnik 1 in Warsaw (the Conservatoire building), then also (as 'administrative' headquarters) Świętokrzyska 16 apt. 8, and private addresses: Chybiński's Lviv home at ul. Kalecza 20 and Sikorski's Warsaw flat at ul. Korzeniowskiego 6 apt. 25. (We also know for sure, that as the third one, as a volunteer and as a person for special assignments in works requiring special care, the editorial team were sometimes supported by Bronisława Wójcikówna, for example, in the case of proofreading articles by Ludwik Bronarski, held in such high esteem by the editors.)

Kwartalnik Muzyczny in its second incarnation was an organ of SMDM, and the idea was a consequence of conversations held in the Warsaw circle of musicians gathered around the Association, but in accepting the invitation from its Board to cooperate and to lead the journal, the professor's own academic personality dominated the journal completely. The members of the SMDM however, despite the fact that they targeted the magazine to a wide group of musicians, accepted this 'scholarly' domination, being aware (based on their own

13 In addition to engaging in the work of various associations and unions, including editorial work, Kazimierz Sikorski was first and foremost a composer and theorist as well as a teacher. He existed as an author thanks to theoretical works written for the needs of music schools - his textbooks for harmony, instrumentation and counterpoint are still the basis of music education at the secondary level. Despite his close cooperation (before the war) with Chybiński, he did not offer Kwartalnik Muzyczny a single text for publication, his participation in the organisation of work in the editorial team was invaluable. 
experience) of the importance of musicological research for responsibly undertaken workmanship. ${ }^{14}$

The enthusiasts expressed the motives for opening the scholarly journal in an editorial at the beginning of the new title: 'The necessity for us of the existence of a scholarly magazine is too much visible in present times. Today the evaluation of our musical culture is marked by musicians belonging to certain musical groups, their official influences and relations. An objective assessment of our musical achievements from the earliest times to the contemporary era is not only desirable, but also necessary. ${ }^{\prime 15}$ Fully sharing these beliefs signed by the Board under their editorial, Chybiński immediately started organising the first number, the work of which was primarily devoted to musicologists belonging to his immediate circle and proven in previous cooperation - Henryk Opieński, Feliks Starczewski, Maria Szczepańska, Heronim Feicht. In acquiring an article about Chopin's pianos by the French musicologist, organist and harpsichordist Paul Brunold, as already mentioned, he was probably helped by Emma Altberg, co-founder of SMDM, putting the editorial team in contact with this French musician. Through the Warsaw circles of Kwartalnik Muzyczny, the first number also included material from the field of acoustics by Gabriel Tołwiński and the essay 'O kulturze muzycznej w Polsce' [About musical culture in Poland] by Stanisław Furmanik. Chybiński himself published an essay on Marcin Mielczewski's vocal-instrumental concerts and short remarks on the history of musicology in Poland. With the beginning of work on Kwartalnik, the acquaintance of Adolf Chybiński and Ludwik Bronarski became stronger and so began the long-standing history of their fruitful cooperation in the pages of Polish musicological periodicals. In the autumn, directed to Bronarski in Switzerland, independently by Bronisław Rutkowski from Warsaw and by the professor on his

14 I have written about the differences which began to emerge at the turn of 1928 and 1930 regarding the different perception of the 'target group' of readers of Kwartalnik Muzyczny by Chybiński on the one hand and the Warsaw editors on the other in chapter I-2. It is then that the professor wrote to Bronarski, elaborating his further publishing plans: 'But let only [the Board of SMDM] adopt a resolution that the Kwartalnik will survive until the end of its second volume, and I will not grieve at all, because then we will create an annual based on the Swiss model - just that one that it is no longer musical, but musicological.' Writing about the Swiss annual, he had Schweizer Jahrbuch für Musikwissenschaft/Annales Suisses de Musicologie/Annuario Svizzero di Musicologia in mind which appeared from 1924, see Chybiński to Bronarski from Lviv 24 I 1930, AACh-BUAM, Bronarski's archive, p. 30.

15 KM 1928/1, III. 
own behalf and that of the Secretariat of SMDM from Lviv, a 'request to send a piece titled Harmonika Fryderyka Chopina [Frederic Chopin's harmony]. ${ }^{16}$ The author did not provide SMDM with the requested article - as is known, the work Harmonika Chopina, conceived on a much grander scale, appeared in the year 1935 in Warsaw published by TWMP - but he prepared a different text for the first number of Kwartalnik, discussing issues of a collective and critical edition of Chopin's works. With his studies and reports, he was present in nearly all the pre-war editions.

The first issue of Kwartalnik was released in the final days of December 1928. Chybiński wrote the editorial to it, however - as Zalewski himself admitted - the text was significantly modified by the Warsaw part of the editorial team (unfortunately, it is difficult to say in which regards). ${ }^{17}$ It is known, that reading the contents of the 'editorials' and notes 'From the editors', it is usually possible to follow the current moods accompanying the editorial work on the following numbers, the motives for the decision to open or close the title, the mood of the editors and representatives of the superior authorities.' In the first editorial of Kwartalnik, it is possible to sense much enthusiasm. This enthusiasm raised the tone accompanying the founding of a journal with such a serious profile: 'SMDM, spreading the passion for musical masterpieces of the past and striving for a deeper knowledge of them, organised ongoing concerts and programmes, brought to life WDMP, and now undertakes to publish Kwartalnik Muzyczny. ... This will be a magazine intended primarily for musicians, a magazine that deals with extensive musical issues in a serious, factual and expert manner. ${ }^{18}$ These words were extended with a statement about the desirability of supplementing musical knowledge, where 'talent ... and technical skills are not enough if they are not supported by knowledge and thorough education,' and the country needs 'seriously educated musicians with broad horizons and established views on all phenomena in the field of art.'

With awareness of the notion growing in general opinion of a 'lack of more serious interest for art [and] the proverbial non-musicality of ... society', the Board of the Association expressed its belief that 'by associating with the past, taking from it values that have survived for centuries, examining the life and works of old masters, penetrating the essence of their creative spirit, we create strong foundations on which talent, skill and work will build an edifice of

16 Chybiński to Bronarski from Lviv 20 IX 1928, AACh-BUAM, Bronarski’s archive, p. 9.

17 Zalewski 1977, 108-109.

18 This and further quotes from the editorial in KM 1928/1, [I-III]. 
contemporary creativity. Without these lasting foundations, the music culture of our country cannot develop normally.' Moreover, according to the signatories, society 'understands the importance of art, [hence] it is the duty of every musician to tirelessly extract and intensify this passion.' This duty was to be served, amongst others, by 'scholarly research on music in recent decades [which] has produced serious results, establishing a number of facts and displaying many musical issues.' Next came the explanation of the decision to establish a new journal: 'Polish musical knowledge is not well known to the wider public, or even musicians due to the lack of extensive publications and professional magazines. Already more than once we have tried to publish music magazines of a scholarly nature: unfortunately, obstacles of various natures interrupted their existence. In this way, a very serious gap has appeared in our life that SMDM wants to fill in by publishing Kwartalnik Muzyczny.'

The programme mainly dealt with promoting the idea of resurrecting early music (through planning the repertoire of concerts or setting up a series of WDMP), and the Board felt obliged to explain to readers that indeed in the case of Kwartalnik this principle will not apply and the journal 'will deal not only with early music, but to an equal degree with later music up to and including contemporary music. ... usually in placing early music in contrast to contemporary, they are characterised as two opposite poles, one is said to fight the other, and they are never combined with each other. In our opinion, this view is mistaken. We are sincere admirers of early music, but we do not tear it away from the present times. ... Putting the question this way, we liberate music from the clusters of passing historical phenomena and give it a characteristic of eternity.... This is also why we do restrict the content of Kwartalnik Muzyczny only within the boundaries of early music. We want to give a magazine dedicated to music, not just the history of music. ${ }^{19}$

19 We can find an extension of this idea a year later in the note 'From the Editor' closing the first period of editorial work. 'a magazine published in the form of a quarterly, can only take into account works in the field of contemporary music which have a more permanent value and are not a product of a temporary vein of writing, or ... are a product of "ephemeral" current trends. ... With the greatest willingness we will always show hospitality to work whose content is addressed to the most up to date moment and to "music of the future" - we do not demand that these are strictly scholarly works; however, we do demand that these works have material value and be free of phraseology concealing emptiness of thought. We do not in any way give priority to purely scholarly works; it is also desirable to have accessible works which are characterised by an original view of themes known or not touched by our musical journalism,' see 'Od Redakcji' [Editorial] (KM 1929/5, I-II). 
In practice, the break with the formula of all other music magazines, filled with numerous departments and columns, to which almost every submitted text could be assigned - whether that be an article or a chronicle note, or thoughts poured onto paper from connoisseurs of music, professionals and amateurs ${ }^{20}$ influenced the decision for a simplified content structure of Kwartalnik. This time Chybiński modelled on the 'classics' of European journalism - the German Zeitschrift für Musikwissenschaft and French Revue de Musicologie, where most of the volume was filled with articles and reports from musicological publications and important sheet music editions, and information about the most important periodicals and current news, e.g. from the activities of leading music societies, such as Société Française de Musicologie, were only an essential addition.

In essence, four columns were established in Kwartalnik Muzyczny. The main part, of course, was filled with articles that followed 'Historical material' (depending on the content, also known as 'Materials for the history of Polish music, 'Documents and materials for the history of Polish music,' and 'Materials and documents for the history of music in Poland'). 'Materials' were complementary to the part which was made of articles, and were directed to this section because of their documentary content or small size (though sometimes also due to the subjective opinion of the editor-in-chief concerning the theme of such a publication) and distinguished by their two-column layout and a smaller font, like in the case that followed them, 'Reports' (although at the end of the edition, the two-column system was abandoned); followed by further 'Chronicles' and usually also a chapter on 'Polish musical magazines' (taking in to account information about the contents of the magazines: Hosanna, LWML, Muzyka, Muzyka Kościelna, Muzyka w Szkole, Orkiestra, Śpiewak). A surprisingly large number of

20 For example, in $M u z y k a$, in addition to the section with articles opening monthly, over the whole range of the magazine edition there were a dozen or so headings, appearing with different frequency: 'Impresje muzyczne' [Musical impressions] (in which the editor himself, Mateusz Gliński, was a permanent columnist), ' $Z$ oper i sal koncertowych' [From operas and concert halls], 'Trybuna artystów' [Artists' tribune], Nowe wydawnictwa' [New publications], 'Przegląd prasy' [Press review], 'Rozmaitości' [Varia], 'Kronika' [Chronicle], 'Dział informacyjny' [Information section] (which contained advertisements for other magazines, publications, etc.), 'Korespondencje' [Correspondence], 'Listy do redakcji' [Letters to the editors], 'Wesołe i smutne' [Funny and sad], 'Przegląd pedagogiczno-muzyczny' [Pedagogical-musical review], 'Wiadomości radiofoniczne' [Radiophonic news], which later evolved into the column 'Radio i muzyka mechaniczna' [Radio and mechanical music]. In such an arrangement, articles usually took up a smaller part of the monthly. 
reviews were included in 'Reports' (both books and sheet music), which I will return to discuss in chapter II-4; 'Chronicle' was an information corner about the activities of SMDM - here concert programmes and music programmes were given as well as notes about realisations (finished and planned) of the WDMP series; the third of the mentioned headings was sometimes expanded with a column ' $Z$ czasopism muzycznych zagranicznych' [From foreign musical magazines], in which reprints from publications on the achievements of Polish musicologists were published, and in practice - about editions in the framework of WDMP. ${ }^{21}$

A novelty against the background of all previous musical publications was to include also a table of contents in French in the book, through which Chybiński signalised the potential international reach of the journal.

Each number usually ended (only sporadically started) with notes 'from the editor,' in which the editorial resources of the portfolio were presented. Several times the editorial staff prepared a wider commentary, as in the fifth number, which opened the second year of work. Chybiński sustained the magazine's programme assumptions there, regretting that the lack of an abundance of sufficiently scholarly musicological creativity did not allow full realisation of the intended plans for broadening knowledge about the history of Polish music. In turn, in the ninth number, he announced further expansion of the areas not yet sufficiently exploited and planned thematic numbers, to participate in which on account of the 'niche' character of the themes - he decided to invite authors from outside his known circle of scholars (sociologists, music psychologists and pedagogues, and also ethnographers and folklore researchers). ${ }^{22}$

Chybiński planned one more column, which he wrote about to Ludwik Bronarski: 'for a long time I have been planning a column in Kwartalnik ..., and it's titled "Miscellanea" (after "Historical Material" and before "Reports"). If you sir, my friend, have some material for this column, then I will try for still another so that we can create this column starting from number $14 .{ }^{23}$ The next idea was born less than a year later - this time Chybiński planned a column for 'Actualia' [Current affairs],

in which the authors, signed or unsigned, will deal with current matters, but not in the sense of sensations or some brief news, but ... permanent current affairs. I want to bring

21 For example, reprint of the review by L.M. Pereyra and Paul Brunold included in Revue de Musicologie from the first four numbers of WDMP (KM 1929/5, 98-99), or Hugo Leichtentritt in Die Musik about numbers 1 and 2 WDMP (KM 1931/10-11, 341-342).

22 See notes 'Od Redakcji' (KM 1931/10-11, 348, 1931/12-13, 480).

23 Chybiński to Bronarski from Lviv 2 XI 1931, AACh-BUAM, Bronarski’s archive, p. 71. 
our Kwartalnik to life at all costs. If you sir, my friend, have something 'troubling you' and it would be worth giving it a more general meaning, then exploiting your innate sense of tact and taste and ability for deep reflection, you would sir, my friend, serve many good causes. Maybe something about "Polish music abroad" etc.? You have at your disposal all matters of art, science, knowledge, culture etc. ${ }^{24}$

A magazine thus conceived, very strict in its structure and not giving the opportunity for current journalism and criticism in its pages, but only pure scholarship, on the one hand, aroused enthusiasm among (some) Polish researchers of music history and related fields, and on the other hand it quickly became an object of criticism. This criticism resulted from both a different approach to musicology and purely pragmatic motives (for example, personal conflict or the issue of uneven distribution of finances by the state institutions appointed for this). Shortly after the appearance of the first issue, Henryk Opieński, one of its authors, wrote: 'I was very happy with Kwartalnik; after all, finally a Christian - truly scientific and honest journal. I was writing the other day to Rutkowski - although it is rather to you, dear sir, to whom congratulations should be given. As for the vignette, it is good as it is - you know, sir, that only now (that is after your letter) looking at the vignette of Sebastian that I saw German text there - I also wrote to Rutkowski that I regretted that there was no memory of the deceased "Kwartalnik I" in the preface, as they are from one family, though a descendant - as befits a free Poland - more robust in serious materials. ${ }^{25}$

In turn, in one of the February numbers of Kurier Warszawski, in the column 'Z wydawnictw muzycznych' [From music publishers], Felicjan Szopski's ${ }^{26}$ review appeared. The publicist, briefly recalling the history of Polish music magazines, associated the new quarterly with success associated with even the fact that it was not - in contrast to its predecessors - under political pressure. Szopski very highly rated the contents of the first journal published under the auspices of SMDM, and also praised the preparation of the publication from a technical viewpoint. At the same time, he addressed the activists of the Association with words of appreciation for their full initiative and energy which helped establish

24 Chybiński to Bronarski from Zakopane 29 VII 1932, AACh-BUAM, Bronarski’s archive, p. 79.

25 Opieński to Chybiński from Morges 14 (finished 19) III 1929, AACh-BJ, box 6, O-2/103.

26 Felicjan Szopski, 'Kwartalnik Muzyczny. - Muzyka' (KW 1929/45 from 15 II, evening edition, 12). 
'the basics of musical knowledge and healthy love for music budding from the seed of highly interesting concerts and publications. ${ }^{27}$

From Kamieński from Poznań however, there were questions about the possibility of taking over the title from the custody of SMDM and under the wing of PTM, led by him. The members of SMDM also often expressed their satisfaction with the publications prepared by Chybinski with gratitude: 'We were all impressed with number 6-7 of Kwartalnik: it looks beautiful outside and inside it is exceptionally interesting. We congratulate the Professor - and thank him. ${ }^{28}$

Not everyone, however, supported such hermetic literature as represented in the pages of Kwartalnik. In 1930/31, a discussion about the culture of 'paper musicology' practised in Lviv swept through the circles of journalists and music academics and the sense of producing such publications for a handful of readers. The Warsaw group of critics, with Karol Stromenger at their head, sympathised with Zdzisław Jachimecki, in the criticism of 'technically' treated musicological research, and put forth his views in the pages of the capital's journal, mercilessly highlighting mistakes made in the scholarly narrative (also in the pages of Kwartalnik Muzyczny) and ridiculing misguided research interpretations. ${ }^{29}$

Mateusz Gliński, in turn, tried not to comment on the achievements of the 'competition,' although in this period he often wrote to Chybiński. In his letters, he said little about his impressions after the appearance of Kwartalnik, but in January he noted the first number in Muzyka. ${ }^{30}$

We can find the most information about the Warsaw-Lviv contacts in the abundant, often cited correspondence between Adolf Chybiński and Ludwik Bronarski. It is from the pages of these letters that we have the opportunity to get to know the creative process over subsequent editions, the editor's remarks about events related to the work on the contents of the editorial portfolio, and the many detailed reports about editorial life was written up almost 'day by day.' In one of the letters, for example, the editor explained the rather unfortunate practice of dividing essays into episodes:

In this annual [avoiding division] was ... almost impossible, because the material with which I started publishing the magazine consisted, with few exceptions, of excerpts from longer works, not very digestible in extenso by readers of Kwartalnik. I also wanted to

27 Ibid.

28 Rutkowski to Chybiński from Warsaw 12 VI 1930, AACh-BJ, box 6, R-19/17.

29 Maria Szczepańska’s publications, amongst others, mercilessly ridiculed by Jachimecki and Stromenger, served as an example of such a scholarly 'false start,' which we will be talking about later while discussing the contents of Kwartalnik (chapter II-4).

30 'Przegląd prasy' [Press review] (Muzyka 1929/1, 43). 
help Polish historical musicology and to print at least parts of 'heavy' works. For the next year, I will place whole works (even longer ones). I am already introducing this principle by printing the extensive work of Father Dr Feicht about Pękiel's 'Cantata.' Of course, in the fourth number already we have the end of 'further parts' (completion). My remarks go mainly to my closest employees and me, as the authors of printed works, because the separation of anyone's work into two numbers happens everywhere and in every publishing house. ${ }^{31}$

Of course, there were more editorial problems: almost from the very beginning, there were problems with completing the numbers and keeping the deadlines for editorial work, the shipment from Lviv with the texts to 'number one' did not contain all the necessary materials and plates, and therefore the letter sent to Chybiński by Ochlewski is one of dozens similarly filled with reminders, such as accompanied the Kwartalnik publications (also after the war). ${ }^{32}$ In October the following year, a question was asked about the 'July' edition, in November delivery was expected of the complete set of materials to the 'fifth' as soon as possible, in February 1930, there was a constant lack of texts to fill the double edition scheduled for the first half of the year. Also, on the other hand, not much later, Chybiński even thought about increasing the frequency of the publication of the magazine: 'I have a sincere desire to convert the Kwartalnik into a bimonthly, but these are dreams only. Let's stay ahead, what we gain with difficulty, trying to achieve a higher and higher standard of the whole. ${ }^{33}$

The tardiness at the editorial office also overlapped with problems with the printing press. The Board of the SMDM alerted: 'The technical side is failing - we must battle with the printers, and we don't know how. We often telephone and from time to time confer with Mr Lazarski, he always promises and assures us that we will not have difficulties with his press. We are seriously wondering if we should not change the printers. ${ }^{34}$ With these delays (less often from an excess of accepted materials) the decision to combine numbers was taken $(6 / 7,10 / 11$,

31 Chybiński to Bronarski 20 IV 1929, AACh-BUAM, Bronarski’s archive, p. 15. Chybiński decided to publish Maria Szczepańska's article 'O utworach Mikołaja Radomskiego (z Radomia) (Wiek XV)' a few years later in volume II of PRM (pp. 87-94). In the post-war edition of Kwartalnik Szczepańska's article 'Studia o utworach Mikołaja Radomskiego (wiek XV). Zagadnienia form' [Studies on the works of Mikołaj Radomski (15th Century). Issues of form] (KM 1949/25, 7-54, 1950/29-30, 64-83) appeared.

32 Ochlewski to Chybiński from Warsaw 13 IX 1928, AACh-BJ, box 6, O-1/33.

33 Chybiński to Bronarski from Lviv 12 III 1931, AACh-BUAM, Bronarski's archive, p. 59.

34 Rutkowski to Chybiński from Warsaw 11 I 1930, AACh-BJ, box no. 6, R-19/12. 
$12 / 13,14 / 15,17 / 18,19 / 20$; adhering to the principle of not linking journals falling between the years, no common number 5/6 was issued, as initially planned).

Finally, after months of quarrelling about further plans for press publications of the Association, a delegation from Warsaw announced a visit to Lviv in late autumn $1933 .{ }^{35} \mathrm{~A}$ few of the people most loyal to Chybiński expressed their opinion in connection with the decision to close Kwartalnik. Bronisława Wójcik-Keuprulian, the author of many foreign publications, wrote: 'I cannot restrain myself ... from expressing sincere regret on account of the closure of the publishers of Kwartalnik. Whoever understands European periodical publications in the field of musicology must state objectively and impartially that Kwartalnik stood at the highest scholarly level, which was not matched by any musicological journal, not even the German Zeitschrift für Musikwissenschaft with such a long scholarly tradition behind it. Undoubtedly this character of Kwartalnik was an obstacle in achieving material successes, but for all that Kwartalnik could be proud of the fact that it served reliable research work and grew our scholarly culture. ${ }^{36}$

At the announced meeting and as a result of conversations amongst the Board of SMDM it was proposed to create a division into two periodicals: 1) closer to the formula of Muzyka (that is, next to historical or theoretical publications of a lighter nature, full of musical current affairs) a quarterly (over time, a bimonthly and monthly magazine) Muzyka Polska (initially, at least formally, with Chybiński as a co-editor), and 2) the strictly scholarly Polski Rocznik Muzykologiczny run independently (and alone) by Chybiński. The histories of the inauguration and the activities of both periodicals will be presented below (chapter II-5). However, in order to find out how much the scholarly musicological quarterly was needed in those years and how the 'expert' milieu gathered around it, it is worth becoming familiar with the outline of the contemporary history of musicological departments and discussions about the form of the young field practised in Polish universities (chapters II-2 and II-3).

35 Rutkowski to Chybiński from Warsaw 3 XI 1933, at AACh-BJ,box no. 6, sign. R-19/35.

36 Wójcik-Keuprulian to Chybiński from Lviv 30 I 1934, AACh-BJ, box 4, W-24/126. 


\section{Musicological circles in Poland (Lviv, Cracow, Poznań, Warsaw) as addresses of the Kwartalnik - socio-scientific contexts: ideas about the functioning of the musicological environment - main topics of interest - other possibilities of publishing musicological studies: academic publishing}

At the threshold of the second decade of the twentieth century, Adolf Chybiński, who was educated in the German university ways and the structures not just from Munich but also from the institutes of Vienna or Berlin, tried to create a centre based on similar principles when he took on the newly created department in his Alma Mater in Lviv. The Lviv musicology group was not the first in the history of the science in Polish lands - for a year a department had been led by Zdzisław Jachimecki at the Jagiellonian University. However, from the point of view of, in particular, the history of scholarly musical journalism, through the person of the head of both the institution and the main nationwide (at least in principle) musicological periodical, it became a nursery for musicological writing activities. Therefore, I propose to open a review of Polish academic centres, which had the largest influence on the form of the literature with a short snapshot of the history of the environment of what was on one side of the academic, and on the other, artistic capital of Galicia.

The turn of the nineteenth and twentieth centuries was a period of prosperity for Lviv. Even in the 1860s-1870s, numerous industrial, economic and social institutions began to emerge (Pedagogical Society, Colleges' Society, Loan Bank).$^{37}$ During this time, at the University of Lviv, from the Congress of Vienna until 1918 operating as the Franciscan University, the fight to increase the number of lectures conducted in Polish started. Already in 1882, the University was partially polonised, and the number of Polish-language lectures grew from a dozen or so to nearly two hundred at the beginning of the twentieth century, when the university became the largest Alma Mater of Galicia, just before the First World War, with nearly five thousand students.

37 More on this subject for example, Sołtys 2008. 
The Lviv University was called Jan Kazimierz a year after Poland regained statehood, in November 1919, and soon thereafter also gained a new location the building of the former Sejm Krajowy [National parliament] ${ }^{38}$ and a dozen other facilities in Lviv. It could be mentioned that it was difficult to house musicology at the same address as other humanities departments: its first, modest home was at Mikołaja street, in time, it was changed to a three-room office at Długosza street 27, in rooms occupied by the university's Department of Physics, and in the twenties it was headquartered at Mickiewicza street 5, where there were four rooms for use. ${ }^{39}$

As Jan Draus wrote in the monograph of the university, the Lviv University 'experienced a scientific apogee in the interwar period, ${ }^{30}$ which created - but not always in accordance with the expectations of the musicologists' environment a potentially favourable field for the development of the centre led by Adolf Chybiński. In the academic atmosphere of Lviv during this time masters created their own centres: historians Franciszek Ksawery Liske, Tadeusz Wojciechowski, historian of diplomacy and political science Szymon Askenazy, historians and art theorists Jan Bołoz-Antoniewicz and Karolina Lanckorońska specialising in Italian Renaissance and Baroque, philosopher Kazimierz Twardowski, Oswald Balzer - creator of the school of Polish law, anthropologist Jan Czekanowski, mathematicians - Stefan Banach, Hugo Steinhaus, Leon Chwistek and many other outstanding intellectuals and researchers, and among the creators of Lviv 'schools.' Draus also mentions - as the father of the Polish musicological school Adolf Chybiński, ${ }^{41}$ who found a friendly group of academics from the beginning of his stay in Lviv, as evidenced by his memories of musical evenings in the house of Kazimierz Twardowski, in which he often took part. ${ }^{42}$

Unfortunately, despite such huge intellectual potential, the University sometimes - and not only in the first years of the existence of the young state succumbed to the pressure of current affairs, and politics influenced the activities of cultural and scientific institutions in various ways. The situation inside the Lviv university was complicated by the city's multiethnicity - similarly to the (also borderland) Vilnius Stefan Batory University - which to a lesser extent

38 One-chamber provincial parliament operating in Galicia in 1861-1918.

39 Much detailed information on the organisation of the department in the first period of its existence (and later) can be found amongst others in the publications of Hrab 2007, Hrab 2009, Piekarski 2014, Piekarski 2017.

40 Draus 2007, 9.

41 Ibid, 31.

42 Chybiński 1959/1, 163-166. 
touched the teaching staff, but to a greater extent the students, which became particularly evident in the first months after Poland gained statehood. The sixmonth Polish-Ukrainian open conflict and battle for Lviv (from Novemeber 1918 to June 1919) resulted amongst others with a complete ban on admission to the University for young people who could not prove Polish citizenship (though not necessarily Polish nationality) and certify participation in military service during the Polish-Ukrainian war (or present legitimate reasons for not participating in these events). Through the decision of MWRiOP from March 1920 the previously utraquist school became a completely Polish-speaking institution. Ukrainian lecturers were removed, which led to legal and shortly after secret attempts to organise university and technical courses and lectures by the academic Ukrainian community. Thus, two universities of a national nature were established in Lviv: Secret Ukrainian University and the secret High Technical School. At the same time, however, protests from Ukrainian creative and scientific associations, also in the international arena, aimed to bring about considerable relaxation of the restrictive regulations at local universities within a few years, and the UJK Senate with commented on the plans to establish a public Ukrainian university in Lviv in the 1920s in a spirit of goodwill, stressing that they were always ready to support the aspirations of that nation to cultivate its own culture and achievements in the field of science. ${ }^{43}$ Restrictions were gradually abolished, including admitting people without Polish citizenship to the student body; the situation began to return to normal after 1923, when 'after the Council of Ambassadors recognised the eastern borders of Poland ... access to study for Ukrainian youth was successively eased'; ${ }^{44}$ by 1925 , secret universities in Lviv discontinued their activities. ${ }^{45}$

The second wave of conflicts that afflicted the academic community in all Polish universities was related to the reform of Janusz Jędrzejewicz in 1933, introducing limitations on the independence of the universities, including the possibility of top-down removal of departments. The changes in the UJK resulting from these regulations brought about protests by the teaching staff and student strikes, and from Minister Jędrzejewicz's side, failure to approve subsequent

43 The quite complicated fate of the Lviv academic milieu and activities of the University of Lviv in the months of the Polish-Ukrainian conflict and the Polish-Bolshevik war, as well as the turbulent period associated with the introduction of a government law regarding the strengthening of the role of the minister of WRiOP relating to university (1933) described by Jan Draus (op. cit.). See also Mękarski 1970.

44 Draus 2007, 60.

45 Much more on this theme ibid., 17-19. 
candidates for Rectors presented by the Senate and assigning a commissioner to the University. The situation in this respect de facto stabilised only four years later, when Wojciech Świętosławski, an opponent of previous reforms, became the new Minister for WRiOP.

Fortunately for the milieu of the University of Lviv, at no critical moment was the university closed. Classes were however suspended, but without the need to repeat semesters or re-recruit students (which happened several times in the thirties at the University of Warsaw and the Stefan Batory University in Vilnius) and the university library was also closed periodically.

Chybiński always tried to remain on the sidelines of current events, but often mentioned the protests in letters to Bronarski: 'University troubles again in Warsaw. I wonder if the echo will resonate in Lviv and elsewhere. Unfortunately, it seems so, and soon. How I do not like this!! It seems to me that the new law on academic associations will not remove the disturbance. 46

More important to the life of the University were disruptions in the course of classes arising against the background of Polish-Jewish conflicts - starting with the introduction of the numerus clausus rules by successive departments at the beginning of the 1920s, through the 'bench ghetto' and attempts to push through the so-called numerus nullus in the late thirties. At that time, unlike a few years earlier, when the majority of the academic community - both students and the academic staff - supported one side against state interference in the internal affairs of the university, there was also a division line within the conflict. Although the main core of the academic staff were sympathisers of the then National Democracy, a large group of Lviv academics had progressive and democratic views, sometimes even leftist. In such a situation, the collision of these two elements in the local Alma Mater was unavoidable, which could again result in suspension of classes.

In anticipation of the history of the Lviv Department of Musicology which will be presented below, it should be mentioned that the ethnic melting pot was also typical of the entire university. In connection with the wave of anti-Semitic student riots in the autumn of 1937, Chybiński was concerned above all for the situation of his pupils and the course of their studies. He wrote: 'I am very concerned about the state of affairs at the university. I have had several students since last year, whom I came to like for their diligence, reliability (I won't mention the exceptions) and whom I value for usually being capable as well as intelligent and passionate people. Nevertheless, my best intentions are paralysed by

46 Chybiński to Bronarski from Lviv 26 X 1933, AACh-BUAM, Bronarski’s archive, p. 94. 
fighting, hindering systematic pedagogical work. On the other hand, without exception they are all people who are calm and slow to wrangle. ${ }^{37}$ And further:

We'll see if we can save this trimester. Despite all things, me together with Mrs. Szczepańska and Mr. Dunicz mustered our students so that they do not lose any of the exercise material for this year, even if the trimester is lost on the order of the rectorate or even the ministry, due to the constant suspensions of lectures and without any fault on the part of my students. If it is cancelled, then I shall grant them the double number of hours on the colloquial testimonies for the exercises in the second trimester. ${ }^{48}$

On the other hand, Chybiński's nationalistic and chauvinistic beliefs were repeatedly to be seen in those years. Opinions expressed in private at that time did not prevent him, after many years, in a different historical situation, from maintaining contacts with former students of Ukrainian or Jewish descent. Inclined, as we know, to conduct rich correspondence, during the war, in 1942, Chybiński responded to letters originally from Vienna, and after the war, from Utrecht, from one of his former students, Myrosław Antonowycz ${ }^{49}$, who was known after the war as an outstanding musicologist (he also studied with A. Smijers), researcher and publisher of the work of Josquin des Prés, specialist in the field of Orthodox Ukrainian music, creator and long-time leader of the Utrecht Byzantine Choir. I will have the opportunity to write about the strong, permanent cooperation with representatives of the Lviv minorities - Józef Chomiński or Zofia Lissa - after 1945.

It was in such realities of political skirmishes and national animosities - that the formation of one of the main musicological centre in Poland took place in the twenty-year-long interwar period. Let us not forget, however, that the Lviv department was important, but not the only circle in the city in which musicological thought could reach fertile ground, and the group of local musicologists, also graduates of foreign institutions, could realise their calling and use the education gained in this field in a variety of ways. For years, other institutions had been active in the city, gathering music lovers and people interested in knowledge about music - the opera house, the philharmonic, music schools, the scientific and musical society, magazines.

47 Chybiński to Bronarski from Lviv 9 XI 1937, AACh-BUAM, Bronarski’s archive, p. 162.

48 Chybiński to Bronarski from Lviv 27 XI 1937, AACh-BUAM, Bronarski’s archive, p. 164.

49 Twenty-seven letters from Chybiński to Antonowycz from the years 1942-52 (supplemented with four letters - also additions by - Maria Szczepańska) were published by Jurij Jasinovskij, see Jasinovskij 2003. 
The tradition of music associations in Lviv dates back to 1826, when Franz Xaver Mozart - son of Wolfgang Amadeus - founded the Society of Saint Cecilia, which patronised concert performances of church and secular music. After fuctioning for a short time as the Towarzystwo Wykształcenia Muzyki w Galicji [Music education society in Galicia] (1857-58), finally (in 1853-54) the movement assumed the name Galicyjskie Towarzystwo Muzyczne [Galician music society], and after 1919 as the Polskie Towarzystwo Muzyczne [Polish music society] and in this form survived until 1939. In the years 1887-99 it was directed by Chopin's student, Karol Mikuli, and for the next forty years by other well-known Lviv musicians: Mieczysław Sołtys in the years 1899-1929, and in the years 1929-39 his son, Adam. The Society and its orchestra had a special significance for Lviv, especially in the 1930s, when the standard of music production in the city, which was previously well-renowned for this cultural field (here we can point to the rich history of the Lviv opera, especially at the turn of the century) was clearly falling and the Society's conservatoire this was also a difficult period. As evidence we have, recalled by Maria Ewa Sołtys, a quotation from the quarterly Muzyka Polska: 'It is difficult to talk about the musical life of Lviv nowadays. It is rather a slow but continuous decline of the musical movement in our "most musical" - ironically! - Polish city. A praiseworthy exception has been the interesting and valuable programme of a well-prepared inaugural concert [musical society] (conducted by Adam Sołtys). ${ }^{50}$

Both Sołtyses were first and foremost conductors. Mieczysław, after studying law and philosophy at the University of Lviv for a year, was also a student at the University of Vienna, where he attended, among others, classes with Robert Hirschfeld, a student of Eduard Hanslick. However, Mieczysław's deepening of university knowledge did not result in activity in this field, although it may have influenced the new 'Plan of learning' he initiated in 1911, which was adopted for the Society's Conservatoire, according to which the theory and composition were given a thorough, eight-year course, and counterpoint was a compulsory subject. ${ }^{51}$ (This was not without significance for the parallel development of Lviv musicology, because its leader, Adolf Chybiński, set high demands in this area, which were difficult to meet, and for young people the local Conservatoire of the Polish Musical Society was one of the few institutions where such skills could be gained at the right level). In any case, in his professional life Mieczysław focused on conducting, composing and teaching.

50 MP 1935/6, 149, quote also in Sołtys 2008, 142.

51 Sołtys 2008, 52. 
It was different for his son Adam, educated in the direction of music from an early age (he played the violin, the piano, attempted composition, and began conducting internships at an early age). However, when he went to Berlin in 1911, he studied composition privately with Robert Kahn, he also became a musicology student at the University of Berlin, taking part in the seminars of Johannes Wolf, Hermann Kretzschmar and Karl Stumpf. He finished his Berlin studies after the war - in 1921 he defended his dissertation titled Georg Österreich (1664-1735). Sein Leben und Werke. Ein Beitrag zur Geschichte der norddeutschen Kantate. Both practical music and university education allowed Adam to pursue two types of activities in parallel: he was a very active conductor, and at the same time he was a music critic, author of articles and reports, mainly on current affairs, in music magazines - the Warsaw Muzyka, ${ }^{52}$ Kurier Lwowski, Lwowskie Wiadomości Muzyczne i Literackie, ${ }^{53}$ for which he was a member of the editorial committee, and in Józef Koffler's Orkiestra; in 1928 he became Chybiński's deputy in the Lviv chapter of the PTM, and at the beginning of 1930 president of the new branch of the PTMW established there. While devoting himself mainly to artistic work, he did not conduct any research.

Apart from the Konserwatorium Galicyjskiego (Polskiego) Towarzystwa Muzycznego [Conservatoire of the Galician (next Polish) Music Society] and among many smaller institutions with different levels of teaching, the Lviv Institute of Music played an important role, especially in the second half of the nineteen twenties. From 1931 it was renamed (at the request of its owner, Anna Niementowska and with the consent of the proposed patron) to become the Lwowskie Konserwatorium Muzyczne im. Karola Szymanowskiego [Karol Szymanowski Lviv Music Conservatoire]. It was important for the musicological milieu that several representatives of this discipline were among its lecturers: Seweryn Barbag, Zofia Lissa, Stefania Łobaczewska, Józef Reiss, Vasyl Barvinski.

Another base for the Lviv musicological school - apart from the local Alma Mater - was the Towarzystwo Naukowe [Scientific society] founded at the beginning of the twentieth century by Oswald Balcer (at the time as the Towarzystwo dla Popierania Nauki Polskiej [Society for supporting Polish science]), which focused the intellectual fora of the Lviv elite. As part of the Society, there were

52 Correspondence and letters to the editor and a statement about the conductor's role in the survey 'Niewidzialny dyrygent' [Invisible conductor] (Muzyka 1928/2, 70-72).

53 Already in the first he included the text 'O solistach i o publiczności koncertowej' [About soloists and concert audiences] (LWML 1925/1, 2). 
three departments: philological, historical-philosophical, and mathematicalnatural sciences, and the Section of History of Art and Culture, independent of them. Musicology was represented in the first of the departments: a local active member was Adolf Chybiński, after time Bronisława Wójcik (elected 9 II 1925), Father Hieronim Feicht (from 1 III 1926) and Maria Szczepańska (from 18 III $1929)^{54}$ became coopted members; Chybiński was also an additional member of the Section. The activities of the institution were financed on the one hand by membership fees, on the other by MWRiOP funds and all kinds of private donations. These funds covered the needs related, amongst others, with publishing activity: in the years 1921-39 Sprawozdania Towarzystwa Naukowego we Lwowie [Reports of scientific society in Lviv] (three books in the year) appeared, compact publications were announced as part of the series Archiwum Towarzystwa Naukowego we Lwowie [Archive of scientific society in Lviv]. The pages of both the magazine and the open series were not only for members of the group. Apart from, for example, Adolf Chybiński's information about his own research in Podhale,$^{55}$ we can find summaries of his public presentations of other works in the field of musicology. For example, at the meeting of the Society on May 2, 1921, the professor presented two items: by Father Wacław Gieburowski, 'Trzy dokumenty neumatyczne $\mathrm{z}$ Biblioteki seminarium duchownego w Poznaniu' ${ }^{56}$ [Three neume documents from the seminarium library in Poznań] and Witold Chrzanowski about Frederic Chopin ${ }^{57}$ rondeaus, and a few years later Seweryn Barbag's essay about Chopin's ${ }^{58}$ songs.

Seweryn Barbag himself was one of the most active musicologists in Lviv. ${ }^{59}$ In addition to his law studies at his home university, in 1924 he graduated in musicology from Vienna where he studied with Guido Adler with a dissertation

54 This information is in Sprawozdania Towarzystwa Naukowego we Lwowie 1937/3, amongst other sources.

55 Adolf Chybiński, 'Sprawozdanie z badań nad instrumentami i melodiami ludu podhalańskiego w latach 1920 i 1921' [Report on reserach into instruments and melodies of the Podhale people in the years 1920-1921] (Sprawozdania Towarzystwa Naukowego we Lwowie 1922/3, 122-124).

56 Sprawozdania Towarzystwa Naukowego we Lwowie 1921/3, 186. The work was published as part of the series Archiwum Towarzystwa Naukowego we Lwowie one year later (division I vol. 1).

57 Ibid., 186-187. Similarly, this dissertation was published in Lviv in the year 1922.

58 Ibid., 1926/2, 54-55. 'Studium o pieśniach Fryderyka Chopina' [Study of Frederic Chopin's songs] published in the series Archiwum Towarzystwa Naukowego we Lwowie (Lviv-Warsaw-Cracow 1927).

59 Even so, he is a relatively unknown character today, see Bristiger 2014. 
on the works of César Franck. After returning to the capital of Galicia, he professionally joined the local Conservatoire, taught privately, and was also occupied with music journalism, he also wrote numerous reviews, reports and articles in the local press - Lwowskie Wiadomości Muzyczne i Literackie, Echo, Szopen (where he popularised and brought the figures and works of classical masters closer to the public - Beethoven, Wagner, Wolf, Brahms, but he also dealt with issues from the borderline of psychology and pedagogy ${ }^{60}$ and sociology ${ }^{61}-$ as well as nationwide music press - Mateusz Gliński’s Muzyka and Kwartalnik Muzyczny. ${ }^{62}$ Particular attention in his work should be paid to the aforementioned study about Chopin's ${ }^{63}$ songs and one of the few attempts in the inter-war period to propose systematics of musicology. ${ }^{64}$ His main interests were, above all, issues related to new genres of creativity that emerged in connection with the new media - cinema and radio, ${ }^{65}$ and musical education and didactics. ${ }^{66} \mathrm{In}$ connection with these interests and activities for education, he was appointed, among others, to the Opinion Committee of the MWRiOP on the system of

60 'Mnemonika muzyczna (kształcenie pamięci muzycznej)' [Musical mnemonics (developing musical memory)] (LWML 1925-26/12, 1); 'Żywa muzyka jako źródło wychowania muzycznego' [Live music as a source of musical education'] (LWML $1931 / 5,1-2)$.

61 'Publiczność jako problemat kultury muzycznej' [The audience as a problem of musical culture] (LWML 1925-26/11,2).

62 See for example, his essay about Polish artistic song (Muzyka 1927/7-9, 91-107).

63 Michał Bristiger makes the comment that in this work Barbag tackles the 'ethical' aspect of Chopin's songs - a category that he considered in his future proposal of the systematics of musicology as one of the related sciences; this direction of thought is illustrated by the sentence from Studium: 'All the songs have ... an undeniable ethical value due to the pure and honest and sometimes touching reflection of personal experiences', see Bristiger 2014, 4.

64 Barbag 1928. The dissertation was also published in a dozen or so episodes starting with number 10. LWML from 1927. We will return to the author's conclusions contained in this thesis.

65 'Radio i film - czy estrada i scena' [Radio and film - or stage and scene] (Echo 1936/3, 7-10).

66 See amongst others published paper presented during the meeting of the Opinion Committee MWRiOP 'Projekt reformy szkoły muzycznej niższej' [Project of reform of music primary schools] (Muzyka 1929/2, 110-112, 1929/3, 169-170, 1929/4, 235-236), and the paper 'Praca wyższej szkoły muzycznej' [The work of higher music schools] (KM 1931/10-11, 208-215). 
music education. He also spoke about contemporary music, ${ }^{67}$ and an especially interesting text related to the (then) newest music was the article 'Semper idem' about turning points in the history of music and against this background about the latest breakthrough brought about by the music of Schönberg, Stravinsky, Debussy and R. Strauss. ${ }^{68}$ His text 'Przykre sprawy muzykologii polskiej ${ }^{3}{ }^{9}$ [The sad affairs of Polish musicology], in which he presented his - let's add: very critical - point of view on conflicts within the environment echoed widely throughout the musicological world.

In the first period of World War II, he became one of the musicology lecturers at the newly renamed Lviv State Conservatoire, launched after the annexation of Lviv by Soviet Russia. Due to his state of health and progression of tuberculosis from 1942 to death in autumn 1944, he was in Otwock near Warsaw.

At about the same time as Barbag, Józef Koffler also studied musicology at Vienna University. Although he began his studies a little earlier, but as a result of war activities and the resulting mandatory (and in his case also voluntary) service, it was not until 1923 that he obtained his doctoral degree on the basis of his dissertation on instrumentation in Mendelssohn-Bartholdy's symphonic compositions. Also educated in the field of playing the piano, harmony, counterpoint and conducting, after returning to Lviv he joined the conservatoire of the Polskie Towarzystwo Muzyczne [Polish musical society].

From the point of view of both music journalism and 'professional' musical writing, the character of Józef Koffler appears quite interesting. ${ }^{70}$ Firstly, due to his sudden and, in terms of quantity, very intense contribution to the 'media' market, and secondly - his rather ambitious attempts to manage musical periodicals. In 1926, the artist was soon to dedicate his piano variations to Schönberg (15 Variations d'apres une suite de douze tons Op. 9 'Hr. Arnold Schönberg zugeeigne'), he established cooperation with Eugeniusz Dawidowicz and the monthly published by him amongst the Grudziądz scene, Muzyk Wojskowy dedicated to musical culture in the Polish Army. In the sketches this included, he presented

67 'Bojkot nowej muzyki' [Boycott new music] (LWML 1933,79, 2); also a voice (together with Emil Młynarski, Michał Kondracki, Janusz Miketta, Stefania Łobaczewska, Józef Koffler and others) in the discussion about improving the health of the musical movement in Poland: 'Muzyka polska w niebezpieczeństwie' [Polish music in danger] (Muzyka 1934/6-7, 267).

68 LWML 1926/8, 1.

69 Muzyka 1935/1-2, 18-19.

70 Concerning his musical writing, see Madaj 1996; Gołąb 1995. 
the profiles of contemporary composers (Stravinsky, Schreker, Szymanowski), ${ }^{71}$ he brought closer the history of music in episodes, ${ }^{72}$ and with military ensembles in mind he prepared a cycle called ' $\mathrm{O}$ barwach orkiestrowych'73 [About orchestra colours]. In 1930 he founded his own popular science monthly 'devoted to the propagation of musical culture among orchestras and music societies in Poland' with the title Orkiestra. In comparison with other titles of this period, the long period the magazine was in print is surprising (1930-38). Having an idealistic goal and wanting 'above all, to serve musical art, ${ }^{34}$ the editor-in-chief consistently used the form of thematic cycles in a form which was almost like a course of lectures. In this way, he published over twenty episodes of 'lectures' about theory of music and composition, over thirty regarding instrumentation, similarly regarding harmony, also a multi-part 'Repetytorium z historii muzyki' [Repetitorium of music history] and 'Formy muzyczne"75 [Musical forms]. Katarzyna Madaj counted that 'more than half (about $61.5 \%$ ) of the contents of Orkiestra were articles in the form of lectures, thanks to which the monthly could almost replace the handy encyclopaedia of music ${ }^{76}$ and - let's add therefore, it was undoubtedly a sensation on the music market of the interwar period. An additional service of the editor was soliciting authors of such calibre as Adolf Chybiński, Zdzisław Jachimecki, Henryk Opieński, Stanisław Niewiadomski, Józef Reiss, Alicja Simon, Władysław Fabry, and representatives of the next generation - the extremely promising musicologists Jerzy Freiheiter, Włodzimierz Poźniak, Adam Sołtys. In the pages of Orkiestra Chybiński brought readers a closer view of composers such as Gustav Mahler ${ }^{77}$ amongst others, and sketched one of his favourite topics in a contribution 'Podhale we współczesnej muzyce polskiej ${ }^{78}$ [Podhale in contemporary Polish music], constituting a

71 MW 1927/11, 2-3, 1928/8, 8, 1928/1, 11-12. Apart from Barbag, a permanent author working in the years 1926-29 initially a biweekly, later monthly, was also Józef Reiss, and Juliusz Adamski, the editors also frequently used translations of publications by European musicologists - Hans Mersmann, Ernst Křenek and others.

72 'Historia muzyki w zarysie' [A sketch of music history] (MW 1927/4-6, 9, 14-20, $1928 / 2,4,9)$.

73 MW 1928/10, 12, 16, 18.

74 'Od Redakcji' [Editorial] (Orkiestra 1930/1, 1).

75 Detailed information on this subject can be found in the bibliography of Józef Koffler's studies prepared by Katarzyna Madaj (Gołąb 1995/1 268-274); see also Gołąb 1997.

76 Gołąb 1995/1, 129.

77 Orkiestra 1936/7-8, 100-103.

78 Orkiestra 1931/5, 68-69. 
kind of historical sketch of 'playing in a highlander style' and issues related to 'mountain culture' - both in general cultural contexts (the personage of Tytus Chałubiński, Tatra threads in literature), as well as the work of young Polish composers - Szymanowski, Maklakiewicz, Kondracki. He also gave Koffler the text of his speech about Frederic Chopin delivered to the academy ceremony at the Grand Theatre in Lviv on November 16, 1931. At the end of 1932, in one of the episodes of the regular column 'Co każdy muzyk wiedzieć powinien' [What every musician should know], which was a form of a small encyclopaedia of music in episodes, he also prepared an extensive biography of the professor as one of the following entries. ${ }^{79}$

In Orkiestra Henryk Opieński shared his many years of memories and experiences as a conductor, ${ }^{80}$ and in one of the first notebooks in the chronicle, information about his sixtieth birthday was published along with the biographical note. Stanisław Niewiadomski was the author of a multi-episode cycle 'Szkice historyczne' [Historical sketches], in which he introduced the history of music, in chronological order, beginning in ancient times. ${ }^{81}$

In 1931, Zdzisław Jachimecki presented the figure of Władysław Żeleński (in the tenth anniversary of his death), ${ }^{82}$ almost two years later, returning to his work, when in the pages of Orkiestra he straightened out his misinterpretation of style in the composer's Piano Sonata op. 5, drawing inspiration, as Jachimecki saw after some time, from Beethoven's works. ${ }^{83}$

In addition to these names, there were however, not just from the sidelines of musicology but also of journalism and music criticism, names of local music activists and pedagogues who were interested in instrumental and orchestral music: Julian Adamski from Rohatyn, Leon Solski, Adam Czerwiński from Stryj, Faustyn Kulczycki from Katowice, M. Papermann from Jarosław, Tomasz Szyfers

79 Orkiestra 1932/10, 166.

80 Amongst others 'Ze wspomnień osobistych. O słynnych i mniej słynnych dyrygentach' [From personal memories. About famous and not-famous conductors] (Orkiestra 1933/2, 24-25, 1933/3, 38-41, 1933/4, 59-61, 1933/5, 77-80); 'Czy można się nauczyć dyrygować orkiestrą' [Can you learn to conduct an orchestra?] (Orkiestra 1931/7, 102-103).

81 The sketches appeared over many years, beginning with the booklet 1930/3.

82 Orkiestra 1931/2, 22-23, 1931/3, 36-37.

83 Orkiestra 1932/10, 154-155. The correction referred to the essay 'Muzyka polska od roku 1864 do roku 1914' [Polish music from the year 1864 to 1914] appearing in Polska, jej dzieje i kultura [Poland, its history and culture], ed. Aleksander Brückner, Warsaw 1930 vol. III, pp. 894-924, about the influences of Beethoven p. 903. 
from Lviv, R. Czerwiński from Warsaw, Ryszard Eblisiewicz from Gdańsk, Piotr Gromski from Warsaw - they are the authors of composers' silhouettes, articles on the history of music, instrumentology and organology, pedagogy and music education, and even music therapy or on the phenomenon of synaesthesia (as in the case of Gromski's text 'Czy barwy są słyszalne?' [Can colours be heard?]), ${ }^{84}$ maybe not revealing and not very original, but mainly because they were supposed to be communicative and through their simplified message were intended to interest the addressees of the magazine, i.e. members of the broadly understood environment of instrumentalists and conductors.

Having already had many years of experience as an editor, in the second half of the thirties Koffler decided to create his own magazine, which indeed was of a local character, but was important because it focused a small thriving group of Lviv musicologists acting in opposition to the traditionally understood historical musicology of the Chybiński school, and which was also linked to the local branch of the PTMW. Quite clearly, however, Echo. Miesięcznik poświęcony kulturze muzycznej Lwowa did not appeal with its ideological programme to many readers, as it ceased to appear after just a few monthly editions (from September 1936 to March the following year). In the editorial to the first edition the editors declared that it would develop conscious music lovers, educate and sharpen the sense and awareness of qualities that constitute the foundations of a true musical culture, combat all influences harmful to music and musical culture, and control the activities of the factors responsible for musical culture. Even in its assumptions, this periodical did not aspire to be a scientific journal. It had a social-cultural character and addressed current issues affecting the musical growth of society, but the names of the authors published in it could guarantee serious and valuable statements. In the inaugural edition of the magazine devoted to the musical education of children and youth, contributions came from, amongst others Adam Sołtys, Seweryn Barbag, Stefania Łobaczewska and Zofia Lissa; ${ }^{85}$ the last was also the author of an article on the role of radio in shaping musical culture. ${ }^{86}$

84 Orkiestra 1934/8, 119-120, 1934/9, 134.

85 A few years earlier she commented on a similar topic in the article 'Psychologia współczesna a wychowanie muzyczne' [Contemporary psychology in musical education] (Muzyka w Szkole 1932/7, 137-143) and in the lengthy dissertation 'Twórczość muzyczna dziecka w świetle psychologii i pedagogii' [Musical creativity of the child in the light of psychology and pedagogy] (Muzyka w Szkole 1933 no. 7 pp. 141-145, 1933/8, 165-174).

86 Zofia Lissa, 'Radio a kultura muzyczna' [Radio and musical culture] (Echo 1936-37/2, $6-7)$. The role of radio as a medium in the transmission of sound recording of music 
As an author, Koffler was invited several times to the pages of Kwartalnik Muzyczny: he prepared reports on books about conducting and instrumentation and presented his method of mastering the art of diatonic modulation. ${ }^{87}$ He wrote quite frequently for Muzyka. He joined a group of musicologists speaking in the press about the role of radio; ${ }^{88}$ he himself as a composer using twelve-tone technique, took up polemics on contemporary music with Stefania Lobaczewska; ${ }^{89}$ he sent correspondence and reports from Lviv, he participated in surveys on current issues affecting the music community, led by the editor of Muzyka, Mateusz Gliński.

Along with the above-mentioned active representatives of musicology in Lviv (Sołtys, Barbag, Koffler), the 'field' environment was mainly made up of graduates of the new musicology centre with their master at the forefront. The history of establishing the Faculty (Department) of Musicology at the University of Lviv is known ${ }^{90}$ : the instigators of the opening of this direction in the capital of Galicia were two local professors: Jan Bołoz-Antoniewicz, art historian, head of the department at the university, and Wilhelm Bruchnalski, literary historian, dean of the Faculty of Philosophy, both convinced of the necessity of introducing this field into the structure of the faculties of the local Alma Mater. From Bruchnalski in 1907, even before receiving his doctorate (which took place in 1908) Chybiński, first a student at UJ, and at that moment, the University of Munich in the field of musicology, classical philology and German studies, was asked if he would be interested in conducting music history classes in Lviv. $\mathrm{He}$ recalled this years later: 'I was already writing my $\mathrm{PhD}$ thesis, having collected the materials for it, when I received an inquiry from Prof. Bruchnalski, dean of

and the significance of this medium for the public was already of interest to Lissa, see 'Radio we współczesnej kulturze muzycznej' [Radio in contemporary musical culture] (KM 1932/16, 643-659).

87 'Modulacja diatoniczna. Nowa metoda nauczania' [Diatonic modulation. A new method of teaching] (KM 1931/10-11, 275-286).

88 'Problemy muzyczne $\mathrm{w}$ radio' [Musical problems on the radio] (Muzyka 1932/1-2, 23-25); 'Radio a kultura muzyczna' [Radio and musical culture] (Muzyka 1935/10-11, 225-228).

89 Józef Koffler, Stefania Łobaczewska, 'O muzyce dwunastotonowej. Dwugłos polemiczny' [About twelve-tone music. Two-voice polemic] (Muzyka 1936/1-6, 20-22).

90 See for example, Hrab 2009, and above all, the recollections of the father-founder of the department (Chybiński 1959/1). 
the philosophy department in Lviv, asking me when I was going to graduate from university to be able to... habilitate as an assistant professor of musicology at the University of Lviv as soon as possible. ${ }^{.1}$

Over the next few years, establishing an independent department was not possible, as in order to fulfil formalities, it was necessary for Chybiński to attain habilitation, giving him venia legendi, or the right to conduct lectures. Although the candidate Bruchnalski was a native Cracovian, had begun his higher studies here and had also been keenly involved in research with Cracow collections for years (the UJ library and Wawel archives), he could not count on a position at his alma mater as this was proposed to Zdzisław Jachimecki. Jachimecki, in turn, of Lviv origin, after four years of musicology studies with Guido Adler in Vienna, defended his doctorate based on a dissertation on the Psalms of Mikołaj Gomółka in 1906 in Cracow, and gained his habilitation there four years later on the basis of the work Wplywy włoskie w muzyce polskiej od roku 1540 do 1640 [Italian influences in Polish music from 1540 to 1640]; he became an associate professor and was able to join the organisation of classes as part of the Jagiellonian University History and Music Theory Seminar.

We learn the most about the years of education, first in Cracow, then in Munich, and finally in the crossings between these two cities from Adolf Chybiński's own memoirs. ${ }^{92}$ Let us only recall here only the most important moments for him at the beginning of his musicological path.

Born and raised right under Wawel Castle, Chybiński, having been educated musically not only in piano playing but also with a solid theoretical foundation obtained under Professor Jan Drozdowski of the Cracow conservatoire, began studying humanities - classical philology and German - at Jagiellonian University in the year 1898. In the 1901/02 academic year, he went to Munich, where he quite soon decided to direct his primary interests in the area of musicology, while continuing classical studies at the same time. After a two-year break, in 1904 he returned to Bavaria in order to continue studies at LudwigMaximilians-Universität under Adolf Sandberger and above all his assistant Theodor Kroyer, as well as composition under Professor Ludwig Tuilly of the local conservatoire. The young Cracovian - in the future, a medievalist, ethnographer,

91 Chybiński 1959/1, 145. It is worth remembering here that already in 1903 the young Chybiński was invited by Felicjan Szopski, then professor of the Music Society Conservatoire in Cracow, to give a lecture in Lviv about Richard Strauss.

92 Ibid. 
music critic, expert in the Young Poland music movement, thus became the first Polish student studying at a German university (the first Polish musicologists Konrad Zawiłowski, Józef Reiss and Zdzisław Jachimecki studied in Vienna, and others in German centres - Łucjan Kamieński in Berlin, or Henryk Opieński in Leipzig - but these were a few years later).

The Musicology Department in Munich, where Chybiński decided to take on studies, had operated at that university since 1894 under the direction of Adolf Sandberger. This German musicologist, interested above all in studying the works of Orlando di Lasso, collected at the local Hof- and Staatsbibliothek, provided a clear direction for research conducted at his institute. The study of old musical prints and manuscripts became its main objectives. The faculty's students, engaged in work on volumes of 'Denkmäler', prepared them in the areas of musical history and theory, as well as harmony, counterpoint and paleography. As a teacher he passed on this passion for palaeographic research to the next generation of his pupils, who included, amongst others Theodor Kroyer (after Sandberger, the second Munich 'master' of young Chybiński), Thrasybulos Georgiades, Ernst Bücken, and Ludwig Schiedermeier; also Adolf Chybiński. In students, Sandberger aroused fascination with artefacts of European music and deepened access to rich collections of sources documenting the creativity of works of the rank of the legacy of notable people such as Pierre de la Rue, Nicolas Gombert, Adrian Willaert, Guido of Arezzo and Franchinus Gaffurius, which have been preserved in the collections of these libraries.

From Munich, Chybiński brought back to Poland not only research interests and the necessary scientific methods, but also - which would soon turn out to be helpful in carrying out the tasks given him - profound knowledge of the system in which German universities worked, where students, choosing classes individually and according to their own interests in philosophy, philology, major subjects, and with the possibility of constant contact and consultation with the professor, obtained an education providing substantial erudition and a broad, humanistic perspective on knowledge. It was on these principles that Chybiński based his didactic activities and contacts with students throughout his teaching career, first in Lviv, and in his last years in Poznań. In addition, Uljana Hrab, author of works on the history of Lviv musicology and its creator, ${ }^{93}$ draws attention to the fact that he managed to implement and continue this classic European methodology and the organisation of musicological studies as a discipline being an element in the system of university sciences (let us add - in opposition to the

93 See Hrab 2005, Hrab 2007, Hrab 2009, Hrab 2010. 
practice of placing musical-historical trends in the structures of conservatoires, as was the case, for example, in Soviet education) despite the changing geopolitical realities: until the year 1918 Lviv and his Alma Mater belonged to AustriaHungary, during the next twenty years to Poland, from the start of World War II to 1941 the city was under Soviet occupation then German. ${ }^{94}$ During his last months in Lviv and before he left for Zakopane, where he spent the rest of the Second World War, the professor was no longer active as a musicologist (at least officially - he was working then as a translator). However, in Soviet Lviv, transferred to the Mykola Lysenko State Conservatoire, he was appointed Director of the musical history section, part of the theoretical department led by Zofia Lissa.

Before he became a creator and one of the pillars of the new Polish discipline, in 1908 he finished his Munich dissertation on the history of conducting, ${ }^{95}$ and then returned to Cracow, where for the next four years he conducted an intense penetration of local archives and libraries: the Wawel, municipal, and Jagiellonian libraries. ${ }^{96}$ These researches and studies enabled him to gather materials for many subsequent years for research and publishing. At the same time, in 1905, he associated himself with the capital of Galicia as a local reviewer of Gazeta Lwowska, in which he repeatedly promoted the achievements of the composers of Young Poland and contemporary, progressive European artists, contrasting their work to the conventional achievements of the composers of the older generation. ${ }^{97}$

94 Hrab 2009, p. 54.

95 Beiträage zur Geschichte des Taktschlegens und des Kapellmeisteramtes in der Epoche der Mensuralmusik, 1908.

96 This activity was formally supported by the creation of a musical section within the Towarzystwo Miłośników Historii i Zabytków Krakowa [Association of friends of the history and monuments of Cracow], which included: the art historian and historic building conservator Stanisław Tomkowicz as president, the composer and conductor Bolesław Wallek-Walewski, the Cracow composer Bolesław Raczyński, and the recently graduated musicologist Adolf Chybiński as its secretary. In the chronicle in varsavian biweekly Młoda Muzyka a note appeared which read: 'The commission is to occupy itself with forming a catalogue of all the musical works (practical and theoretical), found in private and public libraries, archives and monasteries of Cracow. The main emphasis was placed on music from the earliest times up to the nineteenth century.... After finishing this work, the collaborators intend to involve themselves with the collections of Western Galicia (monasteries, private libraries, etc.)' (Młoda Muzyka 1909/11, 13).

97 Magdalena Dziadek wrote the following about this period: 'At the beginning of Chybiński's collaboration with Gazeta Lwowska, there was a cycle of his correspondence on the subject of Wagner celebrations in Munich. Soon afterwards, a number of 
From the first months of the formation of Chybiński's Lviv school of musicology, it was characterised - in the words of Uljana Hrab - by a humanistic worldview, research on musical phenomena from a wide historical perspective, acceptance of a common methodological approach, perfect mastery of scientific research methods, both in the area of musicological study as well as those characteristic of widely-understood humanities studies, objectivism and criticism in relation of the studied material, and striving towards self-learning. ${ }^{98}$

At this point, referring to the words of Adolf Chybiński himself, we should verify the beginning of musicology at the University of Lviv as being in the year 1912, which is the correct date from a formal viewpoint: the decree of the MWRiOP of 30 October 1912 gave the recently promoted docent the opportunity to organise a new faculty and regular work at the institution from 31 November. The year 1912 was given by Zdzisław Jachimecki in his summary of the achievements of Polish musicology included in a 'report' prepared for the PAU, Muzykologia i piśmiennictwo muzyczne w Polsce [Musicology and musical literature in Poland]. ${ }^{99}$ However, he evidently attached more importance to the actual facts rather than formal records, since in 1938, inaugurating the series of Lwowskie Rozprawy Muzykologiczne, he wrote that 'The Faculty was established in 1913 with the support of the then Academic Senate of the University of Lviv and has simultaneously received the right to use a private musicological library..., and further: 'However, the Faculty's administration hopes that from this year on, with 25 years of the actual existence of the Department, good fate will be bestowed on the publication of works and that the Faculty of Musicology of the Jan Kazimierz University will be able to continue to render its service for the good of Polish science.100

This would explain why, in the register of lectures of Lviv University, the classes conducted by Chybiński, preceded by his inaugural lecture 'University and music, ${ }^{\prime 101}$ only appear in the summer semester of 1913, but rather earlier than in

his articles appeared in Gazeta Lwowska dedicated to the matter of modernist music Polish and foreign. One may consider as his "keynote address" a text discussing the Berlin concert of Young Poland in 1906, in which he recognised that the achievements of Szymanowski, Różycki and Fitelberg surpass those of Debussy,' see Dziadek 2005, 97.

98 Hrab 2007, 31.

99 In the series: Historia Nauki Polskiej w Monografiach [History of Polish science in monographs] 23 (Cracow 1948, 35).

100 Chybiński 1938, [no page numbers].

101 As mentioned above, an abbreviation of the lecture was published in PM 1913,2, 1-5. 
the summer (Maciej Gołąb mentioned this in his sketch 'Początki muzykologii na uniwersytetach we Wrocławiu (1910) i we Lwowie (1912)' [Beginnings of musicology at the Universities of Wroclaw (1910) and Lviv (1912)], ${ }^{102}$ because the inaugural lecture itself took place at the beginning of the year, and the first lectures, including about 'musical notation' (mensural and tablature) immediately after. ${ }^{103}$ In addition, this semester was filled with lectures and exercises concerning topics that he undoubtedly considered a canon in the field of musicology: on the history of polyphonic music of the fifteenth and sixteenth centuries, theory of counterpoint in the sixteenth century, analysis of Beethoven's ${ }^{104}$ sonatas.

Less than two years after the opening of the department, its development was put into question due to the progress of hostilities. As before and after Chybiński spent the vacation of 1914 in Zakopane. It was there that he received the first reports from Bronisława Wójcik, about the atmosphere in Lviv, filled with uncertainty about the future of the city, the university and the department itself: 'The Faculty stands silent, empty, and it seems as though no one visits it besides me I doubt that the institution at Długosza street 27 was to be used for military purposes - I think that this only applies to the main building and the government institutes ... I believe, however, that you may find out more by writing to the university office - in my opinion, everything can remain as it is - and you can rest assured that books and musical items are secure. ${ }^{105}$

The most important for the institution was to preserve the still small, yet diligently collected library books and music at Długosza street. ${ }^{106}$ Bronisława

102 Muzyka 2012/4, 6.

103 On the subject of the newly opened department, see also an enthusiastic anonymous letter, 'List ze Lwowa' [Letter from Lviv] (PM 1913/18, 11-14).

104 Detailed information on the activities conducted from the inauguration until 1940 will be omitted, as they can be found in at least two works: Hrab 2009, 143-158 and Ochwat 2007; see also Mazepa/Mazepa 2003, 258-269.

105 Wójcik to Chybiński from Lviv 22 VIII 1914, AACh-BJ, box 4, W-24/5.

106 Let us refer to the data collected by Uljana Hrab which concern the contents of this collection as of the academic year 1914/15: there were seventy titles on the history of music, thirty on aesthetics, fourteen on ethnography, fifty-five on the universal history of music, twenty-two on the history of musical instruments, thirty-eight on the history of the Eastern Orthodox Church music, sixteen on the history of opera and oratorio, and thirteen on musical paleography, in total 568 titles in 847 volumes (Hrab 2009, 58). Shortly before the outbreak of the Second World War, the catalogues listed as many as 2145 items. Hrab also mentions the donation made to the Department after the death of Bronisława Wójcik-Keuprulian (about 1500 books and music scores). 
Wójcikówna was involved in the library from the beginning of her cooperation with the professor. For many following months of 1914/15, she reassured the absent boss that the collections remained in complete order in the meantime; for her herself - it seems - her working conditions could not be better. An introvert by nature, she assessed 'internal and external conditions' so well, 'that it is harder to do so - since December I work every morning (10 [a.m.]-1 [p.m.]) in the library ... in the afternoon, in the evenings at home.... I expect Fischer to be able to stand with his own strength. ${ }^{107}$

It is known that, starting from the first period of hostilities, Lviv musicology classes, just like in the whole university, were suspended in the academic year $1914 / 15$. At the end of the summer of 1915, there was hope of activating the university, and thus also of the return of the teaching staff, but Chybiński extended his stay in Zakopane. At the beginning of October, information about lectures was given, but from the sixth of this month, Wójcikówna was still by herself to welcome new students in the institute. Eventually, however, the head of the Department returned with his family to the city and to his didactic duties. Only from the academic year 1922/23 is it possible to speak of full stabilisation, when the Lviv university began to return to the ordinary mode of work, initially in the four-faculty structure (faculties of philosophy, law, theology and medicine), in the next academic year it was transformed into a five-faculty institution. The Faculty of Philosophy, as part of which the Musicology Institute functioned, ${ }^{108}$ was divided into two sections, Mathematical-Physics and Humanities, to which musicology belonged to the end of the interwar period and whose dean in the academic year 1928/29 was Adolf Chybiński, professor at this university since 1920. The department functioned in this form and within the framework of the structure described until the end of December 1939. At the beginning of 1940, the Soviet authorities incorporated it into the Lviv State Conservatoire (along with all movable property - collections, library, instruments), which in turn was created from the Conservatoire of the Polish Musical Society, the Lviv Karol

107 Wójcikówna to Chybiński from Lviv 30 I 1915, AACh-BJ, box 4, W-24/6. We should recall that during this time she was working on her dissertation about Johann Fischer from Augsburg.

108 The nomenclature related to the institution's structure was somewhat ambiguous, as the terms 'department,' 'institute' and 'faculty' were all used in the same manner. Uljana Hrab noted that in the twenty-year inter-war period, it operated as a 'department' in the period of 1919-25 and in 1933-39, as an 'institute' in the years 1925-33, and proposes that musicology here be referred to synonymously with the terms 'department' and 'faculty' (see Hrab 2009, 47). 
Szymanowski Conservatoire of Music operating from 1931 and the Mykola Lysenko Musical Institute.

The material condition of the Musicology Department itself and its teaching staff - first of all Chybiński himself, and over the years also his assistants (nearly from the beginning - Bronisława Wójcik, in 1925/26 Fr. Hieronim Feicht, from 1926 Maria Szczepańska, later together with Jan Józef Dunicz) - was poor through most of the period of its existence. During its first few years, the Department did not receive any subsidies for its activities, and Chybiński, as a so-called private docent, did not receive a salary (which was provided only to professors), only a honorarium for conducted lectures (four hours a week, from the $1916 / 17$ academic year - five). ${ }^{109}$ In the late autumn of 1918, Chybiński was appointed an associate professor, still without a fixed salary, and finally, from April 1921, a full professor with a designated salary. He continued to supplement the collections of the Institute's library from private resources for years - books, catalogues, scores - using his contacts, including foreign ones, ordering review copies, sporadically making exchanges, and obtaining publications directly from the authors; he partially co-financed the purchase of the piano for the institution, he also tried to obtain subsidies for phonographs for conducting field research.

Concerning didactics, Chybiński strictly followed the patterns observed in Munich. He recalled: 'I never allowed any literary phrases in my lectures. Contrary to the advice of my older colleagues, I chose old music to be the topic of my lectures instead of recent music. Therefore, my practical classes dealt with music palaeography and strict counterpoint ..., I taught the history of music theory, and in the second year of my university work the lectures revolved around Bach. ${ }^{110}$ Monographic lectures could be divided into two groups: those devoted to the history of instrumental forms (within different genres and in the work of various composers), ${ }^{111}$ and the history and theory of polyphonic forms (vocal and instrumental) of the baroque period. ${ }^{112}$ In addition, Edward Grieg's

109 To supplement his household budget and a more stable, yet still rather unfavourable financial situation, from the beginning of his stay in Lviv Chybiński also taught at the Music School headed by Sabina Kasparek and, most importantly, he was very productive when it came to publishing.

110 Chybiński 1959/1, 158.

111 For example: History of the piano sonata (in the 1916/17 academic year), Theory and history of imitative forms $(1920 / 21,1021 / 22)$, The symphony and overture since the times of Ludwig van Beethoven (1915/16), The symphonic works of Franz Liszt and his school (1935/36).

112 Amongst others: The Organ and Piano Music of Johann Sebastian Bach and Georg Friedrich Haendel (1915/16), The history of the sonata and concerto until the 
compositions occupied a special place in Chybiński's work, as did Scandinavian music in general with a special focus on Norwegian creations, subjects to which he returned several times. ${ }^{113}$ In addition to monographic lectures, exercises and seminars also took place where the students worked independently, solving analytical, theoretical and practical tasks, from palaeography, counterpoint and harmony. The titles of the works of younger groups of students of the first years cited by Hrab indicate the focus of interest on the history of Polish music from the sixteenth and eighteenth centuries (over time, the spectrum of topics grew, and the audience focussed on a wider range). ${ }^{114}$

Until 1925, Bronisława Wójcikówna was the only assistant (let's add - as a volunteer) and the closest collaborator with the head of the Lviv department. Although she had already received her doctorate in July 1917 - as the first student of the Polish musicological centres - it was two years before her boss had the opportunity to create the post of assistant for his Department and offered her for this position.

Wójcikówna, who had earlier studied philosophy and mathematics at Lviv University, was one of the first students in the newly-created Faculty of Musicology, accompanying Chybiński nearly from the first moments of his career at her Alma Mater in Lviv; however, in contrast to her successors in the position of assistant, she shared research interests with the professor to a small extent and mainly at the beginning of her scientific career, writing her $\mathrm{PhD}$ dissertation on a subject chosen by her promoter - the compositions of Johann Fischer of Augsburg (Jan Fischer $z$ Augsburga (1646-1721) jako kompozytor suit [Johann Fischer from Augsburg (1646-1721) as a composer of suites]). Chybiński, always full of new ideas, infected the young doctoral student with enthusiasm and, despite years of her own scholarly and didactic experience, she emphasised the desire to collect individual achievements on her account (this independence of thought and action in the future was to result in a fairly serious conflict between the then mature researcher and her Master ${ }^{115}$ ). Meanwhile, however, she wrote:

mid-eighteenth century (1926/27), Instrumental works of Johann Sebastian Bach and Georg Friedrich Haendel (1936/37).

113 In the year 1934/35 he presented: Edward Grieg's Work (with an introduction to the history of Norwegian music, in 1935/36 the second part of this lecture, and for 1939/40 a lecture on the music of the country of his beloved composer, the creator of Solveig's Song, was announced.

114 More about the theme of Hrab 2009, 64-68.

115 For more about the relations between Adolf Chybiński and Bronisława Wójcik see Muszkalska 2012 and Sieradz 2018. 
During these two months of correspondence you've had so many new and interesting thoughts, ideas, projects and plans for further work that even a year would not be enough to discuss them in part, and I am filled with admiration, anxiety and enthusiasm for work.... And when we get on with the planned vade mecum [?], I will do all the dictionaries and bibliographies, so that even you - Dear Master - would not be ashamed of such pedantry - But that's only a contribution; I need to have a share in more interesting parts - bon? - I seem to have grown fond of collective work now.'116

Together with the professor and under his guidance she taught - similarly to her successors in subsequent years - classes on analysis, counterpoint, palaeography, and mensural notation. For the next few years she supported Chybiński in teaching young musicologists in Lviv and creating a new academic community. However, at the turn of 1925 due to personal reasons she had to make the decision to give up her academic career, at least for some time. ${ }^{17}$ She knew that she also had well-prepared successors in her place - Father Hieronim Feicht and Maria Szczepańska, who in turn (in the years 1925-26 and 1926-39) took over her responsibilities. In 1926 she decided to re-engage in the Department, but only to a limited extent, for example, to undertake what she called 'ethnophonic' ${ }^{\text {'118 }}$ work.

In the summer of 1929, the relations between Chybinski and his first doctoral student deteriorated significantly. The professor, due to his reservations about the student's knowledge and skills in the fields of counterpoint and instrumentation, strongly opposed her habilitation (in any case, not in the field of full musicology), which she eventually received from UJ, while delivering a lecture Stanowisko muzykologii w systemie naukowym [The position of musicology in the scientific system] (this suggestion of the systematics of musicology evoked numerous comments not only from Chybiński, which will be mentioned later).

116 Wójcikówna to Chybiński from Lviv 16 IX 1916, AACh-BJ, box 4, W-24/33.

117 In this time, she cooperated with the Lviv branch of Książnica-Atlas. In the summer of 1924, she wrote to Chybiński: 'Knowing how my cooperation with you at the university is supposedly something I've been doing "on the side" has been bothering me for a long time now, very strongly at times. Currently, the thought that in a few weeks' time I would again be active in this "side occupation" has become unbearable to me. That's why I decided to straightforwardly and honestly let you know of my intention to give up my assistant's position. ... Maintaining the status quo, i.e. sharing my time between my bookstore profession and my assistant duties (in relation: $80 \%-20 \%$, hence to the detriment of the Faculty) completely prevents me from pursuing my scholarly work. ... Were I to "follow my heart" - I would choose my assistant's duties. Life is hard, however, and one needs to go on ..., Wójcik to Chybiński from Lviv 15 VIII 1924, AACh-BJ, box 4, W-24/48.

118 Wójcik to Chybiński from Lviv 16 VIII 1926, AACh-BJ, box 4, W-24/61. 
The researcher commented on the opposition and criticism flowing from UJK in a comprehensive letter in which she defended herself with words: 'If I were a careerist, then following the "tenor" of your letter, I would soon be choosing a topic from the history of earlier Polish music, I would be hard at work and submit a thesis that would fit your likes and wishes. But I will not do this. I do not recognise scholars "made to order," I hold them in highest contempt, and I expect too much of myself to take the path of compromise or one of the least resistance.' She also made an assessment of the levels of subsequent cohorts of students from the Department: 'However, I sincerely wish you that the theses of students closer to you due to their choice of topics, achieve the best results, so as to allow you to choose your University associate from among your students. ... For the time being, I still do not see any real historical talent capable of bold historical constructs.'119

She got her first experience in the field of publication even before the First World War, when - no doubt following the professor's recommendation - she sent an article about materials for her doctoral thesis to the already-active Kwartalnik Muzyczny in Warsaw run by Henryk Opieński. ${ }^{120}$ After the war, she additionally wrote for LWML, ${ }^{121}$ the Poznań Przeglad Muzyczny and also for the capital's cultural monthly Przegląd Warszawski and for Mateusz Gliński’s Muzyka, as well as foreign magazines - the aforementioned Zeitschrift für Musikwissenschaft, La Revue Musicale, Slavische Rundschau. ${ }^{122}$ In the Lviv Gazeta Muzyczna already in 1918 presented a sketch about musicology as a science within the framework of university studies ${ }^{123}$ - she returned to the considerations on the systematics of musicology after many years, preparing (and publishing) the above-mentioned habilitation lecture Stanowisko muzykologii w systemie nauk [Position of musicology in the system of sciences]. ${ }^{124}$ Over the following years, she more and more devoted her works to themes involving Chopin considered in various

119 Wójcik to Chybiński from Lviv 8 VIII 1929, AACh-BJ, box 4, W-24/85.

120 'Tańce polskie Jana Fischera' [Johann Fischer's Polish dances] (KM 1914/2, 83-90). A few years later, fragments of the dissertation were also published abroad, see Bronisława Wójcikówna, 'Johann Fischer von Augsburg als Suitenkomponist' (Zeitschrift für Musikwissenschaft 1922/23, 129-156).

121 Amongst others: 'O typowych postaciach melodii Chopina' [About typical figures of Chopin's melody] (LWML 1925-26/4, 1).

122 A bibliography of the researcher's works amongst others in Dahlig 2012/1.

123 Wójcikówna 1918.

124 Lecture published in Rozprawy i Notatki Muzykologiczne 1934/1, 1-14. More concerning the views given by Bronisława Wójcik in chapter II-3. 
aspects: from strictly musical issues to the presence of Chopin in literature. ${ }^{125}$ She was also very happy to accept the invitation to join the group of authors who opened the activities of Kwartalnik Muzyczny.

Despite the fact that Bronisława Wójcik opened a list of active students of Polish musicology, it turns out that she was not a pioneer among the authors of the new generation. On the pages of the Polish music journal with scientific aspirations - the first Kwartalnik Muzyczny - she was preceded by Stefania Łobaczewska, initially signing with her maiden name Gérard de Festenburg. In 1911, before she began her studies at the newly established department of musicology, she sent to the editorial office of Kwartalnik Muzyczny her article 'Kilka słów o kulturze muzycznej XX wieku' ${ }^{126}$ [A few words about musical culture of the twentieth century] in which the history of music is presented in the context of musical culture (thus including the subject matter into the trend of articles published also at that time by Józef Reiss ${ }^{127}$ or Henryk Opieński ${ }^{128}$ amongst others), and shortly after, an essay dedicated to the questions on the origins of music. ${ }^{129}$ After a short break, in 1912, she also published a sketch in the same magazine 'Schopenhauer o muzyce' [Schopenhauer about music]. ${ }^{130}$ All three works were so interesting that, as it turned out later, they initiated Łobaczewska's many years of fascination with the issues of aesthetics and philosophy as well as the sociology of music.

The first materials arose while the author was studying piano at the Lviv Conservatoire, while in the area of musical knowledge she was basically

125 See amongst others: 'O czynnikach stylu Chopina' [On the factors of Chopin's style] (Muzyka 1932/7-9, 52-65); 'Z literatury francuskiej o Chopinie' [From French literature on Chopin] (Przeglad Warszawski 1922/7, 147-150). As a result of her research work in 1930, she published a monograph in Lviv Melodyka Chopina [Chopin's melodics], which predated by five years the second such position in Polish Chopin literature, Ludwik Bronarski's work Harmonika Chopina [Chopin's harmonics] (Warsaw 1935). She also published a collection of essays Chopin. Studia - krytyki - szkice [Chopin. Studies - criticism - sketches] (Warsaw 1933). A few years later, in 1937 she became editor of the journal Chopin, which was an organ of the IFCh. Research and organisational activities were stopped her premature death in 1938.

126 KM 1911/5, 8-10.

127 'Kultura życia muzycznego' [The culture of musical life] (PM 1911/8, 9-11, 1911/9, 3-4).

128 'Znaczenie opery dla rozwoju polskiej muzycznej kultury' [The importance of the opera for the development of Polish musical culture] (PM 1912/7, 9-10).

129 KM 1911/11, 6-10, 1911/12, 1-4.

130 PM 1912/4, 1-5. 
self-taught. Right after the opening of the new department at the University of Lviv, she decided to attend the lectures of Adolf Chybiński. She then took part in classes as an unenrolled student, much as in the years 1914-18 in Vienna, when she explored musicology with Guido Adler in a similar manner. She returned to study at her Alma Mater in Lviv once more in the years 1925-29, this time with the intention of finishing her $\mathrm{PhD}$ dissertation, which, notabene, had been made impossible for some time because of her lack of school-leaving exams. Łobaczewska (who obtained general knowledge in her youth under private teachers) finally passed these exams in 1929 , in order to immediately apply for doctoral examinations.

Being one of the professor's first students, she was involved as a volunteer in the activities of the Department, including illustrating the history and music literature classes on the piano. In his memoirs from the years of Lviv, Chybiński wrote: 'In addition to Wójcikówna, Stefania Łobaczewska and Helena Paygertówna (later Mrs. Świeżawska) deserve a mention from that time. They also participated in illustrating my university lectures.'131 At the same time, more importantly for us, almost from the beginning of the first decade of the new century, she was very active as a reviewer and promoter of music, activities about which Magdalena Dziadek devoted a broad sketch. ${ }^{132}$ Following this author, it can be admitted that in this field, the field of music criticism '[Łobaczewska's] eclectic vision of creativity "beefed up" with democratic ideology has, like all of [her] pre-war writings ..., many shallow waters, sometimes approaching dangerously close to naivety, but all in all, it is a document of an ideologically crystallised attitude - quite common among music critics of the interwar period, although rarely declared with such impetus and stubbornness. ${ }^{133}$ Perhaps the rhetoric which she adopted simply fit in with the general discourse on musical culture of that time and she repeated the views held by a group of creators and publicists to whom she was ideologically close. However, she cannot be judged so harshly when it comes to her academic papers in which she followed the good example of the Lviv musicological school. In this field, in addition to the articles already mentioned, she earlier took on the subject of Chopin, ${ }^{134}$ to which she returned several times in later years, assisting, amongst others, magazines

131 Chybiński 1959/1, 160.

132 Dziadek 2004/3.

133 Ibid., 110.

134 'Chopin jako muzyk i jako człowiek' [Chopin as a musician and a man] (Lirnik 1910/9). 
dedicated to the composer - the Lvivian Szopen and organ of the IFCh Chopin. ${ }^{135}$ However, nearly from the beginning of her activities, her main interests were in the direction of the wider context of musical function: sociology, psychology, philosophy, aesthetics. This is evident in the mentioned two texts printed by Przeglad Muzyczny (in the first, original sources of the phenomenon of music are indicated, while the second presents the history of music in the context of widely understood musical culture), as well as in an article published just a few months later in the same Przeglad Muzyczny, this time in the area of musical aesthetics, ${ }^{136}$ to which the researcher devoted many of her important works. ${ }^{137}$ What is important for our considerations, a few of them came to life - years later - in the pages of Kwartalnik Muzyczny.

It seems that it was not unusual that the editor-in-chief - Chybiński - invited his pupil to co-operate as an author; it can be often seen that he repeatedly supported his pupils and colleagues in this area. ${ }^{138}$ When it comes to Stefania Łobaczewska (and Zofia Lissa, as discussed below), this attitude could have been opposed due to the professor's antipathy towards the research interests and academic paths chosen by the young researchers. The professor (an avid historian and archivist) did not approve of the fact that they sometimes departed from purely historical reflections and ventured on the periphery of musicology. In one of the letters to Ludwik Bronarski, we find the professor's opinion, for example:

It is a peculiar thing: there are those, who would not want to deal with musical works or music even with my encouragement, but would rather beat around the bush, and they think that they are dealing with the 'essence of music.' They do not get music. They'd rather write very wise things about something that is not the fruit of creativity, but supposedly the 'creativity itself' which, of course, they do not deal with at all. Nerves, nerves!! Chasing after sensational news, etc., as if current affairs were excluded from the sphere of musical interests of those who also deal with music's past. And when one starts to talk about things that are absolutely music-related, technical or stylistic, then again,

135 'Echa konkursu chopinowskiego' [Echo of the Chopin competition] (Szopen 1932/3, 1-3); 'Problemy wykonawcze w muzyce Chopina' [Performance problems in Chopin's music] (Chopin 1937/2, 82-93).

136 'Schopenhauer o muzyce' [Schopenhauer about music] (PM 1912/4, 1-5).

137 Let us first and foremost recall the dissertation Ogólny zarys estetyki muzycznej [General sketch of musical aesthetics] (Lviv 1938).

138 It is worth recalling here that in an article published in the monographic journal Muzyka polska titled $Z$ dziejów muzyki polskiej do $1800 \mathrm{r}$. [From the history of Polish music up to 1800] Chybiński repeatedly mentions the work of his students in the references: Maria Szczepańska, Hieronim Feicht, Stefania Łobaczewska, Erazm Łańcucki, Maria Ramertówna (Muzyka 1927/7-9, 31-72). 
the nerves of these people cannot hold out. Psychology, aesthetics, sociology, etc., everything but musicology in sensu stricto. Neither music nor musicology, but something else, brought to the sphere of music. I hunt down such individuals in the Institute. ${ }^{139}$

Chybiński, in spite of personal animosity and a critical view of his pupils' activities (here thinking of Łobaczewska and Lissa), appreciated their writing experience and scientific potential, and he eagerly printed materials addressed to the editor of Kwartalnik Muzyczny. Łobaczewska did not share the professor's interest in the area of musical history, at least not in reference to early music: the only text in which she discussed the main issues of Lviv musicology was her two-part article in the Kwartalnik on the works of Sebastian of Felsztyn. ${ }^{140}$ However, she was one of the forerunners of the research of (contemporary) creativity, both universal and Polish - first and foremost the works of Karol Szymanowski. ${ }^{141}$ Chybiński planned to use these interests and publish her article about the piano works of the creator of Król Roger [King Roger], ${ }^{142}$ but this idea however, was not realised. Although many of her articles about the latest music appeared in the thirties in the pages of Mateusz Gliński's Muzyka, Muzyka Współczesna and LWML, ${ }^{143}$ for Chybiński, however, she was, above all, the author of numerous reports on the latest publications in the field of literature which she found interesting (she also constantly wrote reviews for Gazeta Lwowska). ${ }^{144}$

Unfortunately, in the middle of 1930s a bitter conflict broke out between the master and his student. It was caused by her worldview, a perception of

139 Chybiński to Bronarski from Lviv 27 II 1933, AACh-BUAM, Bronarski's archive, p. 86.

140 Stefania Łobaczewska, 'O utworach Sebastiana z Felsztyna (XVI wiek)' [About the works of Sebastian of Felsztyn (XVI century)] (KM 1929/3, 227-245, 1929/4, 346-365).

141 See for example, 'Geneza stylu Karola Szymanowskiego' [The genesis of Karol Szymanowski’s style] (Muzyka 1934/1, 8-11); 'Twórczość pieśniarska Karola Szymanowskiego' [Karol Szymanowski’s song writing] (MW 1937/4-5, 4-6). Research on the work and figure of Karol Szymanowski resulted in monographs written after the war in the 1940s Szymanowski. Życie i twórczość [Szymanowski. Life and work] (Cracow 1950).

142 See Chybiński do Bronarskiego from Lviv 10 II 1930, AACh-BUAM, Bronarski’s archive, p. 31.

143 See amongst others 'Problem formy w muzyce współczesnej' [The problem of form in contemporary music] (Muzyka 1930/5, 11-21); 'Drogi rozwoju współczesnej muzyki polskiej' [The course of development of contemporary Polish music] (MW 1939/3-4, 1-6).

144 On the subject of the achievements of the Lviv researcher see also Markuszewski 2005. 
musicology as a science which was different than that of Chybiński, and the attempt to appropriate a field of activity belonging to musicologists in Lviv, reflected for example, in the activities of the Lviv branch of TMW led by the members of the younger generation (apart from Lobaczewska, also by Zofia Lissa and Józef Koffler). According to the professor, they also sympathised with the communist movement, which disqualified them in his eyes. Until the outbreak of the war, this conflict was making it considerably more difficult for the professor and his student to engage in academic activities together. When it comes to the relationship between Chybiński and Łobaczewska in subsequent years, it needs to be noted that after the war, in the new political and scholarly reality, their conflict was completely forgotten. Chybiński began supporting the activities of his graduates who had taken over new (and old) Polish musicological establishments.

The above-mentioned Zofia Lissa first studied piano playing and theory at the Lviv Conservatoire; then after finishing the school, she began her musicology studies at the University of Lviv in 1924. One should remember that she also studied philosophy, psychology and art history at this institution, and each of these subjects (doubtlessly also due to the presence of the professors that Lissa then met - Roman Ingarden, Kazimierz Twardowski) had a significant influence on the direction of the musicology research that she later devoted herself to: she had a fascination with the sociology of music, psychology, aesthetics and pedagogy. Among the pre-war aesthetic essays, mention should be made of the text presented at the PAU forum in Cracow, O komizmie muzycznym ${ }^{145}$ [About musical comicality], which after the war became the basis of her 1947 habilitation thesis. To a much lesser degree, similarly to Łobaczewska, she was interested in historical research, and if so, regarding the latest music: in 1929 she defended her doctoral thesis O harmonice Aleksandra Skriabina [About Aleksander Scriabin's harmony], and fragments of this work - already traditional for graduates of Lviv - appeared in Kwartalnik Muzyczny. ${ }^{146}$ She began intensely publishing

145 Published in Kwartalnik Filozoficzny 1938/1, 23-73.

146 1929-30/8, 320-355. One should also remember that Lissa took on historical subjects several times after the war, preparing together with Józef Chomiński the landmark volume Muzyka polskiego Odrodzenia [Music of the Polish renaissance] (Warsaw 1953), in which however, 'the accuracy of certain observations was countered by the avoidance of facts and one-sided evaluations put forward in the language of anticlericalism and the class struggle' (Witkowska-Zaremba 2006, 270). In the following years, dissertations were predominantly about the works and profiles of Frederic Chopin and Karol Szymanowski. 
around 1930, and her texts of the next nearly ten years may be divided into two thematic groups: theoretical, analytical and methodological work (and here is one of her most important pre-war essays 'Politonalność i atonalność w świetle najnowszych badań' [Polytonality and atonality in view of the latest research]) ${ }^{147}$ as well as the already mentioned thesis bordering on musicology.

Even though Chybiński did not really value Lissa as a person (when it came to her views, he used to lump her together with Łobaczewska and pointed out her Semitic descent), he always admitted that her intelligence and erudition were remarkable. However, this was not enough to keep her in the department. In this situation, Lissa found employment at Lviv's Szymanowski Conservatoire, and a few years later also in the local Institute of Psychology, where she continued research in the area of musicality with groups of children and youth; on topics of psychology and pedagogy she had earlier managed to publish a few texts, including amongst others in Kwartalnik Muzyczny, Muzyka Polska, Gliński’s Muzyka, LWMP and in the specialist magazine Muzyka $w$ Szkole. ${ }^{148}$ During the period of the Soviet Union's occupation of Lviv, she performed the function of Dean of the Theory Department at the M. Lysenko State Conservatoire, at the same time participating in Adolf Chybiński's seminar conducted as part of the Musicology Department transferred to this institution.

In the inter-war period, Lissa was strongly interested in music in the new mass media - radio and film, which is evident in her studies and articles from this period: apart from the quite extensive dissertation Muzyka i film. Studium $z$ pogranicza ontologii, estetyki i psychologii muzyki filmowej ${ }^{149}$ [Music and film. Study from the border between ontology, aesthetics ad psychology of film music], at that time, she published a number of articles on this subject, including

147 KM 1930/6-7, 192-237.

148 Amongst others: 'Z psychologii muzycznej dziecka' [From childhood musical psychology] (KM 1931/10-11, 173-207); 'O postęp w pedagogice muzycznej' [On the progress of musical pedagogy] (LWML 1931/4, 1); 'Twórczość muzyczna dziecka w świetle psychologii i pedagogiki' [Musical creativity of the child in the light of psychology and pedagogy] (Muzyka w Szkole 1933/7, 141-146, 1933/8, 165-174, 1933/910, 192-203); 'Badania muzykalności a wychowanie muzyczne' [Measuring musicality in musical education] (MP 1934/3, 216-221); 'Cudowne dziecko w świetle psychologii' [The wunderkind in the light of psychology] (Muzyka 1937/1, 13-16). Muzyka w Szkole was an organ of the Związek Nauczycieli Śpiewu i Muzyki [Association of Teachers of Singing and Music] in state and private schools in Katowice, published from 1929 (from 1932 in Warsaw.

149 Lviv 1937. 
the texts 'Jak słyszymy muzykę w radio' [How we hear music on radio] ${ }^{150}$, 'Radio we współczesnej kulturze muzycznej' [Radio in contemporary musical culture] ${ }^{151}$, 'Radio a kultura muzyczna' [Radio and musical culture]. ${ }^{152}$ Above all, however, she was interested in music in a sociological context and in connection with her publications in this field she collaborated with the Lviv monthly Przeglad Społeczny (editor in chief Leon Weinstock) ${ }^{153}$ and the Poznan quarterly of the Polski Instytut Socjologiczny [Polish Sociological Institute] Przegląd Socjologiczny (editor-in-chief Florian Znaniecki). Elżbieta Dziębowska, author of the entry for Zofia Lissa in the Encyklopedia Muzyczna PWM, ${ }^{154}$ wrote that the researcher 'treated music not as a sound phenomenon, but primarily as a cultural phenomenon, a historically-conditioned artistic creation, addressed to a specific recipient. ${ }^{155}$ Her approach was rather detached from the nature of research conducted by the head of Lviv musicology and had nothing to do with using archives to get to know the musical culture of the past centuries. As has already been noted, Lissa did not extend her sphere of interests to the realm of music history (such as the works of Chopin and Szymanowski) until after the war.

Chybiński's relations with Hieronim Feicht differed somewhat from those with Łobaczewska and Lissa. Through his research interests, Feicht soon became one of the students closest to Chybiński at the Institute. Similarly as with another student, Maria Szczepańska, from the beginning he tended toward research of 'ancient' music, especially Polish (or that connected to Polish culture), also having the solid preparation in the fields of music theory, harmony and counterpoint so desired by Chybiński. ${ }^{156}$

150 Muzyka 1936/1-6, 16-19.

151 KM 1932/16, 643-659.

152 Echo 1936-37/2, 6-7.

153 See for example, 'O społecznym znaczeniu muzyki w historii ludzkości' [About the collective significance of music in the history of humanity] (Przegląd Społeczny 1930/4, 128-133, 1930/5, 180-186); 'U podstaw kultury muzycznej. Z zagadnień socjologii muzyki' [At the core of musical culture. From the issues of music sociology] (Przeglad Społeczny 1937/9-11 and others published in this monthly).

154 Dziębowska 1997/1.

155 Ibid., 370.

156 In Chybiński's correspondence we can find many comments concerning the level of knowledge of harmony amongst the Lviv students: 'In fact, only two of them: Feicht and Szczepańska, have a very wide knowledge of harmony and counterpoint (and all technical aspects in general); Łobaczewska and Lissa have fairly good knowledge, while Keuprulian is quite poor in the matter; meanwhile, Freiheiter, whose short 
Feicht as a young priest, shortly after leaving the seminary of the missionary fathers, and also after music studies with Bolesław Wallek-Walewski ${ }^{157}$ (Cracow) and Mieczysław Sołtys (Lviv), began his music studies in 1922 in the Lviv department. Deeply prepared in the fields - as Zofia Lissa put it - of 'gregorianica and liturgica, ${ }^{158}$ interested in the music of earlier ages, mainly church, he perfectly fit in the profile of the professor's research and personal preferences. Therefore, when in 1925 Bronisława Wójcik, the professor's first assistant, made the decision to finish work for the department, she indicated Feicht (and Szczepańska) as her potential successors, worthy of trust and well prepared for classes with students. ${ }^{159}$ In the same year, the priest obtained a doctoral degree based on a dissertation about religious compositions by Bartłomiej Pękiel. ${ }^{160}$ He was Chybiński’s assistant in the years 1925/26, after which he went on to study musicology in Swiss Fribourg, where he attended Peter Wagner's lectures. ${ }^{161}$ After returning to the country, obligations towards his congregation sent him to various places: in the years 1929/30 he was in Cracow, where besides his religious duties he conducted classes in music history, musical forms and Gregorian chant; later in Warsaw (where for a certain time, in the years 1930-32, he taught history and musical theory at the Conservatoire), Bydgoszcz, Łysków in the Słonim district and again in Cracow, where he took on the Chair of Church History and Patrologia at the missionary Theological Institute, again collaborating also with the local Conservatoire. In spite of these migrations, he remained one of the pillars of the

dissertation on Grieg's harmonics is printed in Norwegian, has excellent knowledge' Chybiński to Bronarski from Lviv 5 VII 1932, AACh-BUAM, Bronarski's archive, p. 77.

157 Let us remember that in the thirties he dedicated articles to his teacher: 'Bolesław Wallek-Walewski jako kompozytor religijny' [Bolesław Wallek-Walewski as a composer of religious music] (Muzyka Kościelna 1931/10-11, 132-135), 'Requiem, kompozycja Bolesława Wallek-Walewskiego' [Requiem, a composition by Bolesław Wallek-Walewski] (IKC 1936/303).

158 Lissa 1967.

159 'I decided to simply and honestly announce to the Professor my intention of resigning from the assistant position. ... X. Feicht was already finishing [his PhD], Szczepańska was showing promise, so the Professor would find someone to replace me,' see Wójcikówna to Chybiński from Lviv 15 VIII 1924, AACh-BJ, box 4, W-24/48.

160 He used the material from this work in the article 'Bartłomiej Pękiel' (PM 1925/1, 1-5).

161 Peter Wagner (1865-1931) was an outstanding medievalist, a specialist in the field of Gregorian chant, mensural notation, and paleography. From 1893, he conducted classes in the history of music (especially church) at the University of Fribourg, where he was a professor, and in the years 1920-21 also rector. 
Lviv musicology school, always associating himself with the research style preferred by its founder.

We can consider the year $1925^{162}$ as the actual date of Feicht's debut in music literature. At that time his articles appeared in several periodicals: in the Warsaw Muzyka he tackled the character and creative work of Giovanni Pierluigi da Palestrina, ${ }^{163}$ he continued the Palestrina theme, writing about the cult of this composer in the Poznań Przeglad Muzyczny; ${ }^{164}$ he also published material on the theme of his discovery in Lviv of a version of Bogurodzica ${ }^{165}$ on the pages of Przeglad. Initially interested in Polish baroque music, he soon occupied himself with renaissance and medieval work, publishing before the war a few more articles on these periods in the Warsaw and Poznan periodicals, ${ }^{166}$ though above all with Chybiński: in Kwartalnik Muzyczny he placed the lengthy 'Przyczynki do dziejów kapeli królewskiej w Warszawie za rządów kapelmistrzowskich Marka Scacchiego' [On the history of the royal ensemble in Warsaw under its kapellmeister Marco Scacchi] ${ }^{167}$ as well as articles on Pękiel, Leopolita and (for the second volume of the PRM) on Gorczycki. ${ }^{168} \mathrm{He}$ also continued to collaborate with the

162 Earlier, at the beginning of the second decade of the twentieth century, in the quarterly of the missionary priests from Cracow, Meteor, he took a closer look at Haendel's profile and oratorios and commented on the performance of Giovanni Pierluigi da Palestrina's Missa 'Papae Marcelli.'

163 Muzyka 1925/11-12, 61-66.

164 'Kult Palestriny u pierwszych odnowicieli polskiej muzyki kościelnej' [The cult of Palestrina among the first restorers of Polish church music] (PM 1925/24, 4-6).

165 'Historyczno-muzyczne uwagi o lwowskich rękopisach Bogarodzicy' [Historicalmusical comments about the Lviv manuscript of Bogurodzica] (PM 1925/2, 10-14, $1925 / 3$, 5-8). This publication was presented to the members of the Lwowskie Towarzystwo Naukowe [Lviv Scientific Society] by his mentor (Adolf Chybiński); Bogurodzica was published by Hieronim Feicht after the war in collaboration with Jerzy Woronczak (general editor) and Ewa Ostrowska (linguistic introduction) (Wrocław 1962).

166 See for example, 'Wojciech Dębołęcki, kompozytor religijny pierwszej połowy XVII wieku' [Wojciech Dębołęcki, religious composer of the first half of the seventeenth century] (Przegląd Teologiczny 1926/2, 113-143), 'Polska muzyka kościelna w epoce barokowej' [Polish church music in the baroque era] (Muzyka 1928/10, 437-439), 'Źródła śpiewu gregoriańskiego w Polsce' [Source of gregorian chant in Poland] (Muzyka 1929/11-12, 481-484).

167 KM 1928/1, 20-34, 1929/2, 125-144.

168 More on this subject in other chapters of this work. These and other texts by Feicht were published by Zofia Lissa in two volumes Opera musicologica Hieronymi Feicht: vol. I Studia nad muzyką polskiego średniowiecza [Studies about Polish medieval music] 
journals of church circles, including Muzyka Kościelna, in which he dealt with both historical and current topics. ${ }^{169}$ In the 1930s, he also began to focus his research interests towards later centuries: he discussed Stanisław Moniuszko's ${ }^{170}$ Pamiętnik do nauki harmonii [Summary for studying harmony] and he toll an interest in Karol Szymanowski; ${ }^{171}$ this tendency persisted and even influenced the theme of his habilitation thesis from 1946 titled Ronda Chopina [Chopin's rondos] far distant from the Gregorian chant and liturgical matters.

The contacts between Feicht and Chybiński lasted through the war years and the following period. Many people emphasise that with time the studentteacher dependency that connected them had changed into more friendly relations, which is evident in the rich correspondence maintained in the Chybiński Archives at Poznańs University Library.

The second person that played a significant role alongside Chybiński not only in Lviv but also after the war in Poznań, was Maria Szczepańska, the next assistant professor after Feicht recommended by Bronisława Wójcik. For years she was unconditionally devoted to her Master, with whom she above all shared interests and even a fascination with the music of former centuries: 'She examined in detail ... the basic repertoire, including such important artifacts as manuscript 52 of the Krasiński Library [present sign.: BN, ref. III 8054], manuscript $378 \mathrm{BN}$ in Warsaw (missing), based on which she developed the works of Mikołaja z Radomia; furthermore, the subject of her research included the sixteenth century manuscript of Cracow lute tablature ... Polish sources for polyphonic Magnificat and religious polyphonic songs. ${ }^{.72}$

(Cracow 1975), vol. II Studia nad muzyka polskiego renesansu i baroku [Studies about Polish music of the renassaince and baroque] (Cracow 1980).

169 Amongst others: 'Muzyka kościelna we Lwowie' [Church music in Lviv] (Muzyka Kościelna 1926/5-6, 77-81); 'Dzieje reformy muzyki kościelnej w Polsce' [History of the reform of church music in Poland] (Muzyka Kościelna 1926/11-12, 190-197); 'Znaczenie radiofonii dla propagandy liturgii kościelnej' [The importance of radio broadcasting for the propaganda of church liturgy] (Muzyka Kościelna 1927/6, 121123, reprint Muzyka 1927/10, 510-511).

170 PRM 1936/2, 42-52.

171 'Karol Szymanowski. Wspomnienia i impresje' [Karol Szymanowski. Reminiscences and impressions] (MP 1937/4, 185-203); 'Nad trumną Karola Szymanowskiego' [By Karol Szymanowski's coffin] (MP 1937/7, 219-224). A complete bibliography of the publication of Father Hieronim Feicht, prepared by Danuta Idaszak, was attached to Opera musicologica Hieronymi Feicht (vol. I, op. cit., 22-39).

172 Morawska 2007. 
Due to the subjects that she studied, regarding the earliest history of music (with the often-used chronological order of articles giving it first place in the journal), and perhaps also thanks to her position in the Faculty, she received the privilege of opening the first issue of Kwartalnik Muzyczny with her dissertation on arrangements of Marian hymns, and turned out to be one of the journal's most prolific authors (alongside Chybiński himself and Ludwik Bronarski). ${ }^{173}$

A few years ago, based on archival materials filed at the University Library in Poznań, Bożena Muszkalska devoted a broad biographical sketch to Szczepańska in connection with the International Musicological Conference organized in 2005 by the Institute of Cultural Studies of the University of Wroclaw. ${ }^{174}$ Born in 1902, Szczepańska studied piano at the Conservatoire of the Polish Musical Society. At the University of Lviv, along with musicology she also attended archaeology classes, following the interests of her father in the areas of archaeology and philology. Not much of the researcher's pre-war correspondence has survived, but from the letters, including those mentioned by Muszkalska, it is clear that even before receiving her doctorate in 1926, she was recommended by Chybiński to befriended editors: to cite the professor's words from a speech in Wroclaw about losing the works of Dukas 'about which you must write an article for Przeglad Muzyczny,'175 translated into publication as 'Paweł Dukas. (W 60-letnią rocznicę urodzin)' [Paul Dukas. (On the 60th anniversary of his birth]. ${ }^{176}$ In addition, she wrote several reviews for this Poznań magazine. In the next two years she also recorded international successes: she became a correspondent member of the Société Française de Musicologie, and her paper was received at the Beethoven Conference (although it should be noted that it was not published in the conference book, contrary to the presentations by Alicja

173 The extent to which Chybiński appreciated his pupil is evident in his words: 'I feel quite at home in the sixteenth, the seventeenth and somewhat the eighteenth centuries; I don't know the fifteenth century so well, less than my present assistant, with whom I'm afraid to talk on this matter. She's well-read like some foreign musicologist. She doesn't really show off her knowledge until the last section of "Marian hymns," and I'm really glad of her work on Mikołaj z Radomia (in the second year of the Kwartalnik), as she's discovered remarkably interesting things. She's an incredibly hard-working being. As an assistant, she shames me with her dutifulness. It's really she who directs my Institute. She's also a very good teacher, and in some areas even excellent,' Chybiński to Bronarski from Lviv 7 II 1929, AACh-BUAM, Bronarski's archive, p. 12.

174 Muszkalska 2005.

175 Chybiński to Szczepańska from Milanówek 23 VIII 1925, AACh-BUAM, Szczepańska’s archive, fol. I, p. 112.

176 PM 1925/21, 8-10. 
Simon, Łucjan Kamieński, Henryk Opieński and Melania Grafczyńska). ${ }^{177}$ The decline of the twenties brought about the intensification of her contributing work. Szczepańska started to publish regularly in the recently opened Kwartalnik Muzyczny, Polski Rocznik Muzykologiczny, in the monthly Hosanna (organ of the Society of Liturgical Music), she was also the author of the article in the journal completely monopolised by Stefan Marian Stoiński (editor in chief) and Adolf Chybiński, the monthly Myśl Muzyczna. ${ }^{178}$

In the periodicals edited by Chybiński, the young musicologist presented a total of seven dissertations ${ }^{179}$ and a number of reviews and two bibliographies of Polish music literature for the years 1927-28 and 1929-30. Publications outside of the main current of Szczepańska's work were published in studies edited by Chybiński; on the centenary of Bellini's death, the article 'Hexameron, Bellini and Chopin' (Lviv 1935). All of Szczepańska's texts, as with the priest Feicht, were characterised by the passion typical for the Lviv musicology school for using source materials and taking on discussion with the richest literature (also European), though devoid of literary rhetoric. Such methods of musicology were prone to attack, though mainly from the circle of music reviewers, not 'academics.' Unfortunately, Szczepańska did not avoid mistakes in her analyses. Her dissertation on the subject of Breve regnum, ${ }^{180}$ which she recognised as a song dedicated

177 See Beethoven-Zentenarfeier Wien, 26. bis 31. März 1927. Veranstaltet von Bund und Stadt, unter dem Ehrenschutz des Herrn Bundespräsidenten Dr. Michael Hainisch. Internationaler Musikhistorischer Kongress (Vienna 1927).

178 ,O nieznanych lamentacjach polskich z końca XV wieku' [About unknown Polish lamentations from the end of the XV century] (Myśl Muzyczna 1928/8, 49-51).

179 'Wielogłosowe opracowania hymnów mariańskich w rękopisach polskich XV wieku' [Polyphonic arrangements of Marian hymns in Polish fifteenth-century manuscripts] (KM 1928/1, 1-19, 1929/2, 107-125, 1929/3, 219-227, 1929/4, 339-345); 'Do historii polskiej muzyki świeckiej w XV stuleciu' [To the history of Polish secular music of the XV century] (KM 1929/5, 1-10); 'Do historii muzyki wielogłosowej w Polsce z końca XV wieku' [To the history of polyphonic music in Poland of the XV century] (KM 1930/8, 275-306); 'Do historii wielogłosowego „magnificat” w Polsce' [To the history of the polyphonic magnificat in Poland] (KM 1930/9, 6-9); ' Z folkloru muzycznego w XVII w.' [From musical folklore in the XVII century] (KM 1933/17-18, 27-34); 'O dwunastogłosowym Magnificat Mikołaja Zieleńskiego z r. 1611. Do historii stylu weneckiego Polsce' [About the twelve-voice magnificat by Mikołaj Zieleński from 1611. To the history of the Venetian style in Poland] (PRM 1935/1, 28-53); 'O utworach Mikołaja Radomskiego (z Radomia) (Wiek XV). Wstęp' [About the works of Mikołaj Radomski (from Radom) (XV century). Introduction] (PRM 1936/2, 87-94).

180 'Do historii polskiej muzyki świeckiej w XV stuleciu' [To the history of Polish secular music of the XV century], op. cit. 
to the real king, not the briefly nominated king of Cracow students, was met with sharp criticism by part of the musicological circles, especially by Zdzisław Jachimecki, who published two brochures sharply polemicising with the author's conclusions. ${ }^{181}$ He bluntly wrote: 'It has been a long time since we last dealt with a "scientific" dissertation so erroneously posed, so naïvely and falsely carried out and crowned with such absurd results.'182

Printing a dissertation on the pages of a new, and at that time, only strictly academic journal, to which access was generally limited to a small circle of authors befriended with the chief editor, stirred the ire of his opponents. It also gave rise to criticism of musicology in general, in the manner in which it was cultivated by Adolf Chybiński: detailed, arduous work on composition and meticulous analysis of sources. In the Warsaw Wiadomości Literackie the Warsaw critic Karol Stromenger had a column ridiculing both Szczepańska’s achievements and the legitimacy of 'paper' musicology. And though Stromenger cited Jachimecki's words ("Kwartalnik Muzyczny devoted so much space to introduce the reader to an obviously completely mistaken use of the "strictest" scientific methodology in musicology, with the help of a number of references to professional literature to support the researcher's arguments. ... The most far-reaching meticulousness in making the various details of a musical work "book-compatible"... means nothing for a musicologist who only sees notes, without embracing their musical union ${ }^{183}$ ) as a 'the voice of reason about musicology detached from music, about musicology of the kind cultivated by Kwartalnik Muzyczny. Paper pedantry, mummification of music, ... a huge machine of knowledge as an aim in itself,' ${ }^{184}$ summa summarum it neither reduced the evaluation of Szczepańska's achievements nor changed the paradigm of the Lviv form of musicology.

A figure forgotten today, and one of the most important, when it comes to the academic potential of the students of the Lviv department, was Jerzy Freiheiter. Chybiński appreciated Freiheiter's extremely solid preparation in theoretical

181 Na marginesie pieśni studenckiej z XV wieku. Wyjaśnienie utworu „Breve regnum erigitur" z rkp. nr 52 Biblioteki Krasińskich w Warszawie [On the margins of student Songs from the XV century. Clarification of the work Breve regnum erigitur from MS no. 52 of the Krasiński Library in Warsaw]. Cracow 1930; Na drugim marginesie pieśni studenckiej z XV wieku „Breve regnum erigitur.” P. dr Marii Szczepańskiej odpowiedź rzeczowa [On the second margins of student songs Breve regnum erigitur from the XV century. Material answer to dr Maria Szczepańska]. Cracow 1931.

182 Zdzisław Jachimecki, Na marginesie pieśni studenckiej, op. cit., 7.

183 Ibid., 14-15.

184 Stromenger 1930/2. 
terms and had a lot of appreciation for his knowledge in the field of harmony, counterpoint and compositional technique; he spoke of him as 'a man who knows more about harmony than the entire city of Lviv. ${ }^{185}$ And although in this case, he did not forget about the Semitic origin of his student, he wrote thus about his doctoral thesis (here we should remember that Freiheiter was one of the students who chose to write his dissertation about the work of Chybiński's beloved composer Edward Grieg, writing about his harmony): 'It was printed in Oslo in Norwegian, but I want to print it in Polish as well, so that the Polish bibliography does not fall out in favour of the Norwegian bibliography. The whole thing may never see the light of day, which is a pity, because it is the best work in the field of harmony I have: What other students only know some part of in the theory and practice of harmony, Freiheiter has at his fingertips.'186

Chybiński directed an abbreviated version of this work to be published in Kwartalnik Muzyczny. ${ }^{187}$ In the same year of 1932, in the Lviv magazine Szopen, among lectures given on the occasion of the local Chopin Days, there also appeared the short form of a lecture by the young musicologist. ${ }^{188}$ In general, though, he was concerned with rather 'hot' topics: he wrote about contemporary composers, ${ }^{189}$ cooperated in writing with the editors of Muzyka Polska, sending numerous reviews and a few articles for print, including his view on a subject often present in writing on music of the twenty-year inter-war period - the importance of radio for musical culture. ${ }^{190}$

As emphasised many times by Uljana Hrab, ${ }^{191}$ Adolf Chybiński is also treated by Ukrainians as the father of musicology. Beginning with the first classes, over

185 Chybiński to Bronarski from Lviv 27 II 1933, AACh-BUAM, Bronarski's archive, p. 86. In the 1930s, Freiheiter even proposed a three-year harmony course, see 'O umuzykalniającą naukę harmonii' [About the musicalising science of harmony] (MP 1934/3, 222-229).

186 Chybiński to Bronarski from Lviv 3 X 1932, AACh-BUAM, Bronarski’s archive, p. 81. See also Łopatowska-Romsvik 2016

187 'O harmonice Edwarda Griega (1843-1907)’ [About Edward Grieg's (1843-1907) harmony] (KM 1932/16, 716-744).

188 Szopen 1932/3, 17-22.

189 'Józef Koffler' (Muzyka” 1936/7-8, 85-86); 'Alban Berg jako nauczyciel' [Alban Berg as a teacher] (MW 1938/2,1-3).

190 'Opera w radio - nowym polem pracy dla kompozytorów' [Opera on the radio - a new field of work for composers] (MP 1935/1, 29-32); 'O drogę do nowego słuchacza (z problemów socjologii radia)' [About the road to the new listener (from the problems of the sociology of radio)] (MP 1935/4, 286-289).

191 Hrab 2009, passim. 
his entire Lviv period he educated many Ukrainian students and - as far as we know - valued them very much for their diligence and hard work. In 1932 Borys Kudryk defended his doctoral thesis Historia muzyki ukrainskiej w latach 1829-1873 od założenia chóru katedry grecko-katolickiej w Przemyślu do śmierci J. Lawrowskiego ${ }^{192}$ [History of Ukrainian music in the years 1829-1873 from the founding of the choir of the Greek catholic cathedral in Przemyśl until the death of J. Lawrowski], in 1931 Jakiw Kozaruk completed his Masters (Poczatki i zakończenia utworów polifonicznych $w$ XIII i XIV wieku [Beginnings and endings of polyphonic works in the XIII and XIV centuries]), five years later Jaroslava Kolodij (who also devoted her work to Edward Grieg, writing on the subject of Liryka fortepianowa Edwarda Griega [Edward Grieg's piano lyrics]); the Professor's favourite pupil, as Jurij Jasinowśkij maintained, referring to the memories of Chybiński himself quoted by Myrosław Antonowycz, ${ }^{193}$ was Nestor Nyzankivskij, who began to attend classes in the newly created department already in the spring of 1913, at the same time taking private lessons in the field of counterpoint and harmony from Chybiński; ${ }^{194}$ other students included Maria Bilynśka, Jarosław Marynowycz, Myrosław Antonowycz (about whom more below) ${ }^{195}$ began studies in 1936. And although articles sometimes appeared in the local Lviv press written by Ukrainian authors who also came from outside the circle of UJK, ${ }^{196}$ however, despite the interesting results of the work of Ukrainian

192 At this time Kudryk was already an author of articles and reviews, mainly in the Ukrainian press, and his writing activity was continued in Polish Lviv until the war broke out. Natalia Tołoszniak, author of a text on the reporting and reviewing accomplishments of Kudryk, summarised that in his publications, along with discussing the work of Western European composers (from Haendel and Bach to Brahms and Wagner), the musicologist revealed his interest in Ukrainian church music and Ukrainian folk songs. He collaborated above all with the journals Meta, Nova Zorâ and Dilo. Unfortunately, among the over a hundred titles mentioned by the author, not a single Polish text has been found, see Tołoszniak 2008.

193 Published in J. Bułka, Nestor Niżankivśkij (Lviv 1997). Cited after: Jasinowski 2005, see footnote 4 .

194 As the professor himself remembered, he was 'most undoubtedly the most "European" and the highest-educated,' see Adolf Chybiński, Pamiętnik z lat 1880-1944 i dziennik z lat 1944-45 [Memorials from 1880-1944 and diary from 1944-45] at AACh-BUAM, section 'Lviv and Zakopane 1912-1944,' c. 99.

195 See also Hrab 2010.

196 For example, the editors of LWML prepared a special 'Ukranian' number in 1934, for which authors of that ethnicity were the main contributors of material (1934/80, and completion of some publications 1934/81, 1934/82). 
students and graduates, their texts were only sporadically published in the pages of Polish music and cultural magazines, while in Chybiński's Kwartalnik Muzyczny - almost never. ${ }^{197}$

Wasyl Barwinśki, author of the lead article in the aforementioned 'Ukranian' number of LWML, ${ }^{198}$ worked has a pianist, musicologist, music critic. He studied at the Lviv Conservatoire and musicology at Prague's University under Zdeněk Nejedlý. In Lviv, he took on the position of director of the Lysenko Music Institute. He collaborated with the monthly Ukrainśka Muzyka. At the same time, another Ukrainian musicologist, Stanisław Ludkewycz (1879-1979), also a composer, conductor and folklorist, was active in the Lviv area. In the first years of the twentieth century, apart from studies in the philosophy department of Lviv University and composition studies under Mieczysław Sołtys, he was a student of Guido Adler in Vienna (where he obtained his $\mathrm{PhD}$ in musicology), as well as Hugo Riemann in Leipzig. In the years 1910-14 he fulfilled the function of director of the M. Lysenko Higher Musical Institute, at which, through the whole twenty-year inter-war period (under Barwinśki's direction) he lectured in theoretical subjects. Both Barwinśki and Ludkewycz were members of the commission for the reform of musical education led by MWRiOP. In the field of publication on the pages of the Polish music and musicological press, they rather did not assimilate with the Polish community.

The only but significant exception among Rusyn students who quickly and permanently bound their scholarly path to the Polish circle of the Lviv music school, was Józef Michał Chomiński. Chybiński, despite his reservations about his origin, held high hopes for him. He wrote: 'I am also afraid that the best of my historians will not be a Pole but a Rusyn, Chomiński. ${ }^{199}$

197 It should be noted, however, that Ukrainian musicologists worked extensively with the editors of Ukrainian journals, see Piekarski 2010/1, particularly pp. 93-100). Following this author, let us say that, in addition to the 174 periodicals mentioned above, published in Ukrainian there were additionally: Muzičnij Listok under the editorship of Stanisław Ludkewycz, Bojan (ed. Wołodymyr Solczanyk), the quarterly Bogolłovija (whose editor was Archbishop Josip Slipyj), Muzičnij Vistnik (edited by Ivan Hryniewecki) and Ukrainśka Muzyka, the monthly of the Związek Ukraińskich Muzyków Zawodowych [The Union of Ukrainian Professional Musicians], and other socio-cultural and educational journals.

198 Wasyl Barwiński, 'Muzyka ukraińska' [Ukrainian music] (LWML 1934/80, 1-2, 1934/81, 1-2, 1934/82, 2-3).

199 Chybiński to Bronarski from Lviv 3 X 1932, AACh-BUAM, Bronarski's archive, p. 81. 
Chomiński, a few years younger than the first graduates, was one of the first to be obliged to obtain a master's degree preceding a doctoral dissertation. The essential short form of his master's thesis on imitational technique of the thirteenth and fourteenth centuries nearly completely filled the last pre-war issue of the Kwartalnik, ${ }^{200}$ after which Chomiński began preparations for a second text based on his previous research. A lengthy analysis of the organum quadruplum Sederunt by Pérotin, in which Józef Chomiński continued a presentation of his earlier interests in the history of medieval music, opened the first volume of the Polski Rocznik Muzykologiczny (pp. 1-27). As I have already mentioned in an article on the history of the magazine, ${ }^{201}$ although we have access to a fairly extensive corpus of correspondence between the professor and his recent student from before the war, the letters about work on this particular article, unfortunately, have not survived. However, we have accounts of his rather poorly progressing preparations to study the work of Karol Szymanowski, from which one may assume that Chomiński had a very critical view of his activities. The first study (and a report on work on Stilwende der Musik by Ernst Pepping, of which he informed the editors in September 1935, intending to provide the texts within a month ${ }^{202}$ ) was prepared for the second volume of the Rocznik, ${ }^{203}$ while the continuation was to be published in the next one. In the summer of 1936, he wrote: 'I do not know ... whether I would be able to finish the second part of the harmony (Impressionist) by September, because the material begins to resist me. These are more difficult issues, after all. What makes them all the more difficult is the fact that we do not actually have a theoretical system yet that would provide a good basis for scientific investigations in this regard. ${ }^{204}$

200 KM 1933/19-20, 113-157; due to the large scale of the study, the editors in the journal only further included one paper by Bronisław Romaniszyn, 'Głos dziecka i jego kształcenie’ [The child's voice and its education] (pp. 157-172) and reviews.

201 Sieradz 2011.

202 Chomiński to Chybiński from Werchrata 13 IX 1935, AACh-BJ, box 5, C-10/7.

203 Józef Chomiński, 'Studia nad twórczością K. Szymanowskiego. Cz. I: Problem tonalny w Stopiewniach' [Studies on K. Szymanowski's creativity. Part I: The tonal problem in Słopiewnie] (PRM 1936/2, 53-86).

204 Chomiński to Chybiński from Werchrata, 24 VII 1936, at AACh-BJ, box no. 5, sign. C-10/10. It must be remembered that at exactly this time, as he was working on Szymanowski, he was finishing writing his dissertation on the subject Zagadnienia konstruktywne w pieśniach Edvarda Griega [Structural issues in Edward Grieg's songs], which he defended in July 1936. We know that Chomiński was working earlier on another issue, which the professor appraised with enthusiasm: 'My student, Chomiński (Rusyn) is writing a dissertation about Liszt's harmonies, a wildly talented man, whose 
He also provided the editors of Rocznik with reviews from Chopin's Harmonics [Harmoniki Chopina] by Ludwik Bronarski, recently published by the TWMP: for Chybiński it was important to have a review worthy of the book itself, and as mentioned above, among his students he highly valued Freiheiter and especially Chomiński for their knowledge of harmony and music theory, thus the choice of reviewer. Apart from this, he did not publish much, mainly for the editors of Muzyka Polska, especially in the second half of the 1930s, when he was able to move to Warsaw and become involved in the circles of the TWMP. He was a quite frequent author on the pages of the monthly, along with his Lviv colleagues, Łobaczewska, Lissa, Freiheiter and the youngest of them, Jan Józef Dunicz.

Dunicz is one of the most prominent graduates of Lviv musicology; the professor placed high hopes in him, as in the case of Chomiński, the more so given that the student closely shared his master's interest in the music of the Polish Baroque: 'My second volunteer assistant, Mr. Dunicz, is starting to shape up. He goes in the historical direction, and I am glad, because a number of my students have moved away from this direction, prompted by agitation on one side, which even in its valuable work has failed to be convinced that no composer can be suspended in air, since he was not living in the Sahara from birth to death. ${ }^{205} \mathrm{He}$ studied violin at the local conservatoire and Polish language at UJK. He was an assistant in the Lviv Institute (initially, as the professor mentions in the letter, as a volunteer, and then in 1934 he received a full-time position), and his dissertation Adam Jarzębski i jego „Canzoni e Concerti” [Adam Jarzębski and his Canzoni e Concerti] was published as the first work in the series newly founded by Chybiński Lwowskie Rozprawy Muzykologiczne. ${ }^{206}$ Also, he wrote articles directed primarily to two editorial offices: to periodicals led by Chybiński

skill is also admirable. ... I do not know how much truth there is in it, but Chomiński claims that Kurth's work on romantic harmony [Ernst Kurth: Romantische Harmonik und ihre Krise in Wagners 'Tristan.' Bern 1920] is full of inaccuracies and historical errors, which he will have to hunt down one by one. Sure - whoever does not consider Chopin as harmonic (as seen in "Romantic harmony"), cannot inspire unreserved confidence. In any case, I consider Chomiński to be a very strict man who does not blab to the wind. Besides, my friend, you will have the opportunity to view his work on the development of imitation in the thirteenth and fourteenth centuries. There he points out a number of horrible errors to the fugue historian Müller-Blattau,' see Chybiński to Bronarski from Lviv 30 XII 1933, AACh-BUAM, Bronarski’s archive, p. 96.

205 Chybiński to Bronarski from Lviv 27 II 1933, AACh-BUAM, Bronarski's archive, p. 86. 206 Lviv 1938. 
and the sister Muzyka Polska led by a group friendly with the professor clustered around $\mathrm{SMDM}^{207}$ (he also wrote a few entries for the Polish Biographical Dictionary and a few radio programs for the Lviv station). The first of his texts in Kwartalnik was a short report about Franciszek Brzeziński’s book about Bedřich Smetana. Later, however, there were extensive material studies, ${ }^{208}$ which in terms of form duplicated good models of Chybiński's publications and those of his favourite students - Szczepańska, Feicht. Dunicz was proud of his first achievements and grateful to the professor for his support. Unfortunately, his promising scholarly career did not have the chance to develop in the face of upcoming historical events and the musicologist's tragic premature death.

Wójcik-Keuprulian's earlier related evaluation of up-and-coming Lviv musicology, questioning the existence among the students of real historical talents, was certainly too harsh. While it is true that eight years had passed from her doctorate in 1917 to the closure of the next doctoral studies, from 1925 onwards nearly every diploma made an important contribution to the institution's image. The subjects of the dissertations and master's theses could be divided into three or four groups. The first were works concerning the history of Polish music (Maria Szczepańska on manuscript 52 of the Krasiński Estate Library, Hieronim Feicht on the religious works of Pękiel, Erazm Łańcucki on church music in seventeenth- and eighteenth-century Poland, Helena Kasparek on Polish a cappella masses from the turn of the eighteenth century, Jan Józef Dunicz on Canzonie Concerti by Adam Jarzębski), the second - the work of European composers of the nineteenth and twentieth centuries (Zofia Lissa on Scriabin's harmonics, Stefania Łobaczewska on Debussy's harmonics, Anna Hornung on the solo songs of Franck, Chausson and Duparc), the third - works of Chybiński's favourite composer, Edward Grieg (a double perspective on matters related to the composer's solo songs - presented by Maria Ramert and Józef Chomiński, and also Jerzy Freiheiter on Grieg’s harmonies and Jarosława Kołodij on his Lyrische Stücke). In spite of Chybiński's personal interest in folklore and matters of musical ethnography (folk art forms, matters related to folk instruments), not many diplomas in this area were obtained in the period (Dunicz's master's thesis on the polonaise

207 There he was also the rapporteur of the musical movement in Lviv, replacing Jerzy Freiheiter in this function.

208 'Z badań nad muzyką polską XVIII w. Cz. I: Kasper Pyrszyński (1718-1758)' [From research on Polish music of the eighteenth century. Part 1. Kasper Pyrszyński (17181758)] (PRM 1935/1, 54-75); 'Z badań nad muzyką polską XVIII wieku. Cz. II: Jacek Szczurowski (ur. 1718)' [From research on Polish music of the eighteenth century. Part II. Jacek Szczurowski (born 1718)] (PRM 1936/2, 122-139). 
in the nineteenth century, Tadeusz Głodziński on the krakowiak, Wilhelmina Bagarówna on the oberek). ${ }^{209}$ The others were concerned with the broadly understood subject of early music: Zbigniew Liebhardt wrote on progression in early Medieval music, Irena Spiegel on the history of the madrigal in Italy, Maria Bilińska on Bach's sarabande, Jakiw Kozaruk on polyphonic works of the thirteenth and fourteenth centuries, Antonina Wozaczyńska on homophony in polyphonic works of the fourteenth and fifteenth centuries, Anna Kolischer on the work of Gilles Binchois. Borys Kudryk wrote a dissertation on the history of Ukrainian music in the nineteenth century. However, not a single dissertation arose on the subject of German symphonics (to which Chybiński devoted a few cycles of monographic lectures from various perspectives), the work and person of Frederic Chopin (though he couldn't imagine running his journals without material on Chopin), or the life and work of Mieczysław Karłowicz, Karol Szymanowski and other young Polish composers.

Chybiński organised the study programme so that students, on the one hand, would master the scientific canons, while on the other hand, they developed individual interests. He supported them in their choice of various paths of musicology, even when he was not in total agreement with these. Indeed, when following the department's history and getting to know the professor's opinions on the choices of specialisation and the mature activity of certain students, we notice that he selected the closest collaborators according to a sort of scholarly loyalty and the suitability of their interests to his. On the other hand, however, he also appreciated the potential and intellect of those students who diverted far from the main current of Lviv musicology, as was the case for example, with Zofia Lissa (with whom he was particularly professionally dependent after the war). ${ }^{210}$ In fact, although sometimes he complained about the hardships of 'pedagogy', he was extremely connected with his department and its students: 'In fact, our Lviv-based musicology has a sympathetic ambience and everyone is aware of their tasks; I support the works, sometimes bringing publications for my institute, which more closely correspond to other directions than the work I had

209 Chybiński planned to publish extracts from these three diploma theses in the 17-18 KM journal, along with two articles by Julian Pulikowski, dissertations by Henryk Opieński and Helena Windakiewiczowa and, perhaps, also some article by Ludwik Bronarski (see Chybiński to Bronarski from Lviv 24 III 1932, AACh-BUAM, Bronarski's archive, p. 73). In fact neither in this 'ethnographic' edition (nor the following) none of the materials mentioned here by the young adepts of the department appeared.

210 We will return to the post-war cooperation of Chybiński and Lissa later in this work. 
chosen. I devote a lot of time to pedagogy and to assess the work of my pupils (even former ones), though they also help me in my pedagogical activities.211

Similarly, his disciples were attached to the master, which they expressed by giving him a memorial book published by their own means for on the occasion of his fiftieth birthday and twenty-fifth anniversary of academic work. ${ }^{212}$ They repeated a similar gesture years later, in 1950, by preparing another congratulatory volume for the professor's seventieth birthday. ${ }^{213}$

It should be emphasised that the new centre enjoyed great popularity. Among the twenty or thirty people who applied on enrolment days, after conversing with the professor there remained a group of several people, whose number was further reduced over the first months of study. Thanks to the strict enrolment criteria and evaluation during the course of studies, Chybiński - making use of his undoubted pedagogic and didactic talent - built an academic environment to rival the German centres, where each student, entirely devoting himself to learning, could count on the master's support and constant contact with him. Over the years one can also follow the promotion of certain people through the publication of their achievements in journals conducted by the professor (and his acquaintances). The earlier described dramatic events that occurred in the twenties and thirties at Polish universities, fortunately, did not disturb the course of teaching in a manner that would threaten musicology - here the attitude of the professor and his assistants was helpful, as they called on their students to concentrate on their studies. However, Chybiński's department at the University of Lviv fell under the burden of other historical events - the war's beginning and the Soviet army's entrance into the city. The new authorities decided to direct all the local 'powers and funds' in the area of higher musical education to Lviv's State Conservatoire created on the foundation of the Conservatoire of the Polish Musical Association. The new centre was provided with part of the property and staff of the Mykola Lysenko Musical Institute and the Karol Szymanowski

211 Chybiński to Bronarski from Lviv 28 II 1929, AACh-BUAM, Bronarski's archive, p. 13.

212 Ksiega pamiatkowa 1930. From outside the strict university circle, the authors of the book were Ludwik Bronarski, Wacław Piotrowski, Witold Friemann and Julian Pulikowski. Apart from them, the following announced the results of their research here - Maria Szczepańska, Father Hieronim Feicht, Bronisława Wójcik-Keuprulian, Helena Windakiewiczowa, Stefania Łobaczewska and Zofia Lissa.

213 Ksiega pamiątkowa 1950. This time, the list of authors was longer, and the whole was supplemented with an article presenting the professor's profile, a bibliography of his works and a list of graduates' names who completed musicology studies with diplomas (master's or doctoral) under Chybiński's supervision. 
Conservatoire. The University structures, from then on named after Ivan Franko, were also deprived of musicology, which - on the model of Soviet schooling was to become part of the artistic school. To the new centre, the university as an institution and Chybiński personally lost a large section of the movable property which had been gathered, often with private money, since 1913: books, musical scores, photocopies, instruments. As we know, Chybiński managed to save part of the collection as a private library and archive, which Tadeusz Ochlewski offered to help move from Lviv to Warsaw during the war; finally, however, the professor decided to transfer the materials to Cracow, where they were under the care of Chybiński's friend, the singer Bronisław Romaniszyn.

Among the musicologists active in Lviv, a few were given administrative functions in the new Conservatoire. Let us remember that the vice-director for scientific and didactic matters as well as the Department of Composition was Józef Koffler, the dean of the Department of Conducting (and section director) Adam Sołtys, the Department of Composition and Department of Music History - Zofia Lissa (and within it the director of the Music History section Adolf Chybiński), while the director of the Music History section was Stanisław Ludkewycz; besides them, lecturers at the school included Seweryn Barbag, Maria Szczepańska, Jerzy Freiheiter and Borys Kudryk. The Conservatoire ceased to function at the time of German aggression against the Soviet Union. The teaching staff was scattered, and the lecturers met various fates - some, such as Łobaczewska and Lissa, left the city, while others, including Chybiński and Szczepańska, remained and occupied themselves with various jobs as office clerks or translators, sometimes giving private music lessons. After liberation, work was again undertaken in the reactivated Conservatoire by Barwinśki, Ludkewycz, Sołtys and Szczepańska, among others. Adolf Chybiński spent the last period of the war in Zakopane, from which he moved to Poznan as he accepted the offer from that university to take on the organisation and direction of the new department of musicology. He was never to return to Lviv.

$$
* * *
$$

Referring to the archival documents of the Jagiellonian University, Fr. Tadeusz Przybylski recalled that the first attempts to initiate classes in the history and theory of music were made by the university at the turn of the nineteenth and twentieth centuries: twice, in the years 1899 and 1900, the Austrian authorities were asked to appoint Władysław Żeleński, then director of the Cracow Conservatoire, ${ }^{214}$

214 For more about the history of Cracow musicology see Dziębowska 1987/2, and particularly Dziębowska 1987/1, Przybylski 1987. 
as honorary professor at the Jagiellonian University and twice Vienna refused. When in June 1911 the habilitation took place of Zdzisław Jachimecki, a graduate of Vienna's musicology and student of Guido Adler, which resulted in Jachimecki as a 'private docent of musical skills' (Privatdozent) attaining venia legendi, the conditions had arisen to again apply to open a department of studies. This time the university authorities obtained agreement and after confirmation of this first habilitation in Polish musicology in October of that year, preparations were begun for classes conducted in the winter semester of 1911/12 by the new docent - a monograph lecture entitled Zasady i rozwój dramatu muzycznego [Principles and development of musical drama].

Just like in the soon-opened institutions in Lviv and a few years later in Poznań, at the beginning of its activity, Cracow musicology did not have the characteristics of a fully organised seminary. For a number of years, the group of students was scarce. According to Przybylski, no more than 10-12 people took part in all the classes on a yearly basis: in individual rooms of quite random locations (Institute of Zoology, Jagiellonian University Department of Chemistry), with one piano and a board with staves, with a laboriously collected library, which officially began its activity only in 1922. By around the same time, the musicological seminary saw only two people obtain a diploma: in 1921 Władysław Kalisz based on his work on multi-voice church music among Italians in Poland in the first half of the seventeenth century, and in 1923 Helena Dorabialska completed a dissertation on Józef Damse and his operatic comedies. In the following years, thanks to the didactic cooperation (though not full-time) of subsequent docents - Józef Reiss in 1922 and (considerably later, in 1934; classes in the 1935/36 academic year) Adolf Chybiński's student in Lviv, Bronisława Wójcik-Keuprulian - as well as the gaining of a full-time position for the assistant Włodzimierz Poźniak ${ }^{215}$ preparing a doctorate under Jachimecki's supervision - Cracow's Seminary of Music History and Theory (known from 1938 as an Institute) really began to develop and in the thirties regularly promoted its subsequent graduates, some of whom made a lasting mark on the discipline's history with their research, journalistic and pedagogic activities: Stanisław Golachowski, Aleksander Frączkiewicz, Stefan Śledziński-Lidzki, Alina Nowak-Romanowicz, Mieczysław Drobner.

Jachimecki's monographic lectures were thematically related to his current academic interests. ${ }^{216}$ In the following years, they were classes on musical drama, history of opera from 1600 to 1750, Mozart's operas, profiles and works

215 For some time during 1934/35 this function was fulfilled by Stanisław Golachowski. 216 Przybylski 1987; Drobner 1980. 
of nineteenth-century Italian composers - Rossini, Bellini, Donizetti, Verdi, the creative work of Wagner, Bach, Beethoven, Chopin, Haendel. ${ }^{217}$ Gradually, although the creator of the institution was a supporter of independent education of students, he complemented the monographic presentations with course activities in harmony and counterpoint, musical forms, paleography, and instrumentation.

The analysis of Jachimecki's enormous musicological heritage, both his monographs and contributions, would take many pages of this work; Barbara Przybyszewska-Jarmińska devoted her attention to the 'monographic' work of the professor during the conference on the centenary of Polish and Cracow musicology. ${ }^{218}$ Here it suffices to say that, although he just as eagerly published in the press as in monographs (he also did public readings and cooperated with radio), with regards to the frequency of announcing partial results of his own research, he was overtaken by his antagonist from Lviv. This can be seen at a glance when leafing through the pre- and interwar period Przeglad Muzyczny, the 'first' Kwartalnik Muzyczny, Muzyka, as well as local magazines and magazines of the milieu - Hosanna, Spiewak, Muzyk Wojskowy. His style, heavy on literary emphasis, especially in texts from the two-decade inter-war period, in various reviews and reports from concert life, better served the popularisation

217 Włodzimierz Poźniak recalled: 'The members of our Department were involved with both the history of old Polish music, going back as far as the eleventh century, as well as more recent and contemporary music. ... They also entered into the fields of sociology, aesthetics, acoustics and, satisfying the rather modest needs of society then, published many works of popular science,' see Poźniak 1967, 449.

Jachimecki's interests included subjects related to antique Polish music of the sixteenth century and earlier; however, most of the work on this topic was done by around 1915. Later he returned to the theme less frequently, at times provoked by publications of other musicologists, as for example, in the case of the above-mentioned discussion aroused by Maria Szczepańska's dissertation To the history of secular Polish music in the 15th century (op. cit.), whose mistaken theses were commented in the mentioned brochures (see note 181), or the exchange of opinions with Adolf Chybiński related to the dissertation of the Lviv professor 'On several supposed, known and unknown Polish composers of the seventeenth and eighteenth centuries' (PM 1925/13-14, 1-7; Jachimecki's correction in PM 1925/17-18, 9-10), as well as the equally emotional polemics between them on the subject of research on the legacy of Mikołaj Gomółka and Marcin Leopolita (PM 1928/9, 4-7, 1928/10-11, 13-17, 17-18, 1928/12, 10, $10-12,192 / 2,12-13)$.

218 Przybyszewska-Jarmińska 2016; see also Wilk 2000/4 and Wilk 2000/1, Wilk 2000/2, Wilk 2000/3. 
of music on the pages of general culture and society magazines, such as Cracow's Ilustrowany Kurier Codzienny and his literary-scientific section, Echo Muzyczne, Dziennik Polski, Kurier Poznański, than the documentation of musicological research.

To the lecture programme drawn out by the department head, Józef Reiss added classes in the area of aesthetics and the history of theory (ancient history and medieval music theory, theoretic-musical concepts of the Renaissance, reading of theoretical treatises, Friedrich Nietzsche's opinions on music, and others) and the sociology of music. He gladly made use of the series of Cracow's Akademia Umiejętności [Academy of Learning] to announce the results of his research: his first dissertation 'Psalmic melodies of Mikołaj Gomółka, 1580' was published in the Rozprawy Wydzialu Filologicznego [The dissertations of the Philological Department] under its auspices, and in the 1920s he made use of the pages of the Sprawozdania Akademii Umiejętności [The reports of the Academy of Learning] several times, the series of which we will later mention. Before the war, he appeared several times as an author for the Warsaw Przeglad Muzyczny; after the war, Reiss's materials appeared several times in the Poznan edition of the magazine of the same title: the many-part article 'Stanisław Moniuszko i jego posłannictwo'219 [Stanisław Moniuszko and his mission], 'Św. Augustyn w muzyce'220 [St. Augustine in music], he also published a reprint of his lecture on oratorio, originally printed in Muzyk Wojskowy. ${ }^{221} \mathrm{He}$ wrote for Ilustrowany Kurier Codzienny, Orkiestra, Kwartalnik Filozoficzny. He collaborated with Mateusz Gliński, by forwarding to Muzyka amongst others, the material 'Postacie i dzieła' [Characters and works] to the monographic edition Romantyzm w perspektywie historycznej [Romanticism in historical perspective], ${ }^{222}$ 'Dzieje symfonii w Polsce'223 [History of the symphony in Poland], 'Orkiestra symfoniczna w perspektywie historycznej'224 [The symphony orchestra in historical perspective], the one-off text about Ignacy Jan Paderewski, ${ }^{225}$ and additionally, he released a number of compact publications and monographs.

After associating with the Cracow department, using her earlier research announced in the essay about Chopin’s melody, Bronisława Wójcik-Keuprulian

219 PM 1928/3, 8-10, 1928/4, 8-10, 1928/5, 5-7.

220 PM 1930/9-10, 3-5.

221 PM 1927/11, 6-8.

222 Muzyka 1928/7-9, 26-50.

223 Muzyka 1927/7-9, 131-142.

224 Muzyka 1929/5, 29-40.

225 Muzyka 1935/10-12, 117-120. 
prepared two series of lectures: about melodic issues (theoretical, historical, comparative) and about issues of Chopin's style, and was the first to introduce classes in musical ethnography (general issues in this field, about Armenian folk and religious music), but this did not affect the students' decisions about the subjects they chose for their diploma theses - no ethnomusicological thesis was written in Cracow before the war. ${ }^{226}$ Wójcik-Keuprulian's activities in the pages of the 'expert' press were quite substantial (as mentioned earlier in connection with the review of achievements of the Lviv circles), but only once was she involved with the series of the academic local environment, announcing her controversial work 'Stanowisko muzykologii w systemie nauk'227 [The position of musicology in the scientific system] in Rozprawki i Notatki Muzykologiczne (more about this below). The dissertation became the subject of harsh criticism, such as Julian Pulikowski ${ }^{228}$ placed in Muzyka Polska (signing - as he often used to do - with the monogram T.K.).

The broadening of the subjects of monographic lectures beyond the interests of the head of the seminar had no influence on the topics of research undertaken by young adepts of Cracow musicology. All diplomas were supervised by Jachimecki, whose interests were also shared by his students. Hence, a whole series of works on the history of music, mainly concerning the nineteenth century, sometimes with trips to the eighteenth century (also sporadically the seventeenth century) or the the most recent creations, and therefore the legacies of Józef Damse, Karol Lipiński, Juliusz Zarembski, Karol Kurpiński, Ignacy Feliks Dobrzyński, Antoni Stolpe, Henryk Wieniawski, Józef Elsner, Józef Brzowski, Stanisław Niewiadomski, Karol Szymanowski, Eugeniusz Pankiewicz, Władysław Żeleński.

226 Shortly after the liberation, still in 1945, Jachimecki was the supervisor of Piotr Świerc's diploma thesis Najstarszy zbiór melodii śląskich pieśni ludowych Juliusza Rogera [Juliusz Roger's oldest collection of Silesian folk songs]; Świerc, however, was not connected with Cracow musicology before the war.

227 Rozprawy i Notatki Muzykologiczne 1934/1, 1-14. The polemics around WójcikKeuprulian - letter to the editor of the magazine - appeared in MP 1935/5, 70-74, together with Włodzimierz Poźniak’s voice referring to Pulikowski's criticism and also his article 'Romans wokalny w twórczości M.Kl. Ogińskiego' [Vocal romance in the work of Michał Kleofas Ogiński].

228 Pulikowski extensively described the details of this episode in a letter to Adolf Chybiński, see Pulikowski to Chybiński from Warsaw 3 II 1935, AACh-BJ, box 3, P-28/113. 
Some of the students of the department published the results of their first research work before they received their diplomas. Marceli Liebeskind, who in 1930 defended his thesis on the work of Mieczysław Karłowicz, sent a summary of the fragments of the work he prepared for the Cracow seminar to Muzyka;229 the case was similar with Antoni Wieczorek, author of a dissertation on Karol Kurpiński's operatic works in the years 1811-20, who published materials on the subject of Kurpiński in Mateusz Gliński’s monthly magazine two years before his diploma, ${ }^{230}$ and after receiving his doctorate he sent fragments of the dissertation to the Poznan Przeglad Muzyczny. ${ }^{231}$

The Cracow milieu, which, apart from a small group of employees and alumni of the department, was made up of local critics, publicists and musicians penning their opinions, mainly on current affairs, wrote in the pages of the magazine Czas and the monthly Muzyka i Śpiew, above all in the Ilustrowany Kurier Codzienny, in which the weekly supplement Kurier Literacko-Naukowy historical materials and reports about contemporary creations were published not only by Cracovians Zdzisław Jachimecki and Józef Reiss, but also - with particular intensity especially in the years 1933-36 - Adolf Chybiński, however, the young musicologists who tried to keep up with them writing mainly reviews and concerts - Włodzimierz Poźniak, Mieczysław Drobner, and the music populariser, organiser of musical events (such as the festival of Polish music in Prague in 1927), one of the founders of the PTM, Melania Grafczyńska. The pages of social and cultural magazines, however, could not be sufficient for strictly scholarly publications, hence the alternative to this kind of local press and nationwide music magazines in the years of establishing the first departments, both Cracow and Lviv, were the AU publications. It is worth mentioning briefly why this institution was so important for documenting musicological achievements.

Rich in centuries-old tradition, the scientific milieu of Galicia's second city after Lviv had the potential to develop an institution covering all partitions, also open to intellectual circles abroad, on the basis of the Jagiellonian University (in the nineteenth century, the main university of a national character) and the local Scientific Society. The AU was established in these foundations in 1872

229 Marceli Liebeskind, 'Utwory fortepianowe Mieczysława Karłowicza' [Mieczysław Karłowicz’s piano works] (Muzyka 1926/11-12, 571-576).

230 Antoni Wieczorek, 'Karol Kurpiński. Próba charakterystyki' [Karol Kurpiński. An attempt at characterisation] (Muzyka 1938/4-5, 147-151).

231 Antoni Wieczorek, 'Karol Kurpiński. I. Życie, działalność, człowiek. II. Opery’ [Karol Kurpiński. I. Life, work, man. II. Operas] (PM 1931/2-3, 1-5, 1931/4-6, 1-7, 1931/7, 1-3). 
(from 1919 PAU). Its goal was to 'support and facilitate creative scientific work in Poland, manage it and, if possible, reward, organise scientific undertakings, and also maintain communication between Polish science and the scientific communities abroad.'232

The first president of PAU after the World War was prof. Kazimierz Morawski, historian and classiscal philologist. ${ }^{233}$ Although after 1919 the Academy was closely related to the scientific policy of the new Polish state, in the interwar period it became an independent and free institution in all its aspects, and these years cover the period of its greatest prosperity. From the ideological point of view, conservatism and ideology of national democracy, popular among Cracow's academics, dominated the present humanistic thought. Fortunately, Cracow, including its scientific-intellectual circles, did not feel the effects of the world war. Research, publishing and the whole organisation of life at the University and within the Academy continued undisturbed. This convenient situation strengthened the position of the Cracow community - and in time that of Lviv, which was also closely personally related to it - in relation to other Polish centres, and despite the declared openness, caused a kind of monopolisation and local profile of the institution: representatives of other universities and research centres on the Board of the PAU were in the minority, and this meant that the initiatives of that body played a specific and important role in the local - intellectual and cultural - life of Cracow.

In the first years of the free state, money for financing PAU was difficult to obtain. At the same time, other scholarly societies were active in the country: Lviv, Poznań and Vilnius, and TPN in Warsaw. In 1924, however, rescue arrived in the form of a donation given to the Academy by the pro-Polish Archduke Karol Stefan Habsburg. The so-called Żywiecki's estate - 1/5 of the magnate's wealth in the form of income-generating forests and farms - became a material guarantee for the Cracow institution. At the same time the subsidies from MWRiOP and the centrally functioning FKN increased. Although the world crisis of 1929 also affected Polish science and it was only possible to speak of financial stability around 1937, the comfortable situation associated with the Habsburg estate, around the turn of the twenties and thirties, allowed Cracow to take on the role of animator of Polish scientific life from the Warsaw Scientific Society, which, moreover, at the same time, was preparing to be transformed into a similar Cracow-like nationwide formula - Akademia Nauk [Academy of Sciences].

232 Semkowicz 1938, 29.

233 More about PAU: Piskurewicz 1998; Rostworowski 1974; Stachowska 1974. 
One of the main provisions in the draft constitution of 1924 was the statement that 'PAU is the chief scientific institution in Poland, established to cultivate all skills.' Finally, in the constitution approved in 1927, the Academy is defined as an 'institution established to nurture science,' also through the publication of research results carried out in various Polish centres.

The Academy was made up of three Faculties: of Philology, History-Philosophy, and Mathematics-Natural Sciences, and from 1930 the Medical Faculty, within which, in turn, there were Commissions and Committees. All ordinary members and correspondents (domestic and foreign), who numbered close to one hundred and twenty at the end of the 1930s, were entitled to attend meetings of all faculties and commissions, for which the scholars from beyond the Academy were also invited to present their works and research reports. In the interwar period only Adolf Chybiński was chosen from among musicologists as a correspondent member, in 1929, and Zdzisław Jachimecki a year later. ${ }^{234}$ Both of them, even before the private docenture at the Cracow and Lviv universities, had the opportunity to present their works at the meetings of the Faculty of Philology of the AU and publish them through the publishing houses of the Academy. Jachimecki was much more strongly connected with this Cracow scientific body - for him it was a natural forum for presenting the results of his research. Let us remember that on April 15, 1907, in Cracow he presented the assumptions of the dissertation Mikołaj Gomółka i jego stosunek do wspótczesnych kompozytorów psalmów [Mikołaj Gomółka and his relationship to contemporary psalm composers]. At the end of 1909, he presented his habilitation thesis Wplywy włoskie w muzyce polskiej [Italian influences in Polish music], published in 1911 by the Academy of Learning Publishers (a summary in German appeared in Bulletin International of the Academy in 1911). In the years 1911-14 members of the Academy had the opportunity to listen to Jachimecki several times, for the dissertations Tabulatura organowa $z$ biblioteki klasztoru św. Ducha $w$ Krakowie z roku 1548 [Organ tablature from the Library of the Holy Spirit Monastery in Cracow from the year 1548] and Muzyka na dworze króla Władysława Jagiełty: 1424-1430 [Music at the court of king Władysław Jagiełł: 1424-1430] were released by the

234 In the year 1951 Chybiński received the dignity of being made an honorary member of PAU. The third musicologist in the group of correspondents was Ludwik Bronarski in 1948, but due to the fact that he was constantly abroad, he did not actively participate in the activities of the institution. For a short history of the Academy during the difficult years after World War II, more information in chapter III-1. 
$\mathrm{AU}^{235}$ publishing house; reports on these and summaries of his other works on the history of Polish music were published in Sprawozdania AU and Rozprawy Wydziału Filologicznego $A U .{ }^{236}$ Later, in the interwar period, Jachimecki gave papers about his work to PAU only twice; after the war, his 'report' Muzykologia i piśmiennictwo muzyczne w Polsce [Musicology and musical writing in Poland] appeared in 1948 as part of the series Historia Nauki Polskiej w Monografiach [History of Polish science in monographs].

As mentioned earlier, Chybiński's studies on the tablature of Joannis de Lublin (which was owned by the Academy and is now in the PAU/PAN Library) were discussed on January, 10, 1910 and three more times in the years 1911-12 (he published the printed text on this subject in the pages of the 'first' Kwartalnik Muzyczny ${ }^{237}$ ); in later years, he did not feel so closely linked to the Cracow institution and its organs, although he still cooperated with the ethnographic commission ${ }^{238}$ and within the framework of Prace i Materiaty AntropologicznoArcheologiczne $i$ Etnograficzne [Anthropological-archeological and ethnographic studies and materials] years later, he announced two texts: 'Instrumenty muzyczne ludu polskiego na Podhalu' [Musical instruments of the Polish people of the Podhale] (1924) and 'Dzwony pasterskie na Podhalu' [Podhale shepherds' bells] (1925). He also played a large role in preparation for publication of Pieśni ludowe polskiego Ślaska [Folk songs from Polish Silesia] from the collections of Jan Tacina, which was a result of the work of the Komitet Wydawnictw Sląskich [the Silesian Publication Committee], in which edition Chybiński was the music editor. ${ }^{239} \mathrm{He}$ was also foreseen as one of the authors for entries concerning ethnographic articles in the encyclopaedia planned by PAU (vol. II dedicated to

235 See Rozprawy AU: Wydział Filologiczny series III vol. VIII 1916, 1-58) and Rozprawy AU: Wydział Filologiczny vol. LIV 1915; see also 'Twórczość Marcina Mielczewskiego, kompozytora XVII w.' [The work of Marcin Mielczewski, composer of the seventeenth century] (Sprawozdania AU 1913/6, 3-5).

236 A bibliography of the works of Zdzisław Jachimecki in: Woźna-Stankiewicz 2012.

237 See chapter I footnote 102.

238 Within the Academy, apart from the 'faculty' committees, there were also units independent of the faculty structure. This included amongst others the Ethnographic Commission and the Silesian Publication Committee established in 1932, with whom musicologists also cooperated.

239 About this theme first and foremost see Rostworowski 1974. The PAU Musicological Commission was established only after the war, in 1948 (practically it operated from 1949). However, it should be emphasised that from the beginning of the founding of Polish musicology within the broadly understood national culture, this field was present in the Academy's academic and publishing activities. 
ethnography), however, this plan was not implemented due to the outbreak of World War II.

Other musicologists were also invited to cooperate with the Academy. As already mentioned before, Józef Reiss's 'Melodie psalmowe' [Psalm melodies] was announced in the pages of Rozprawy Wydziatu Filologicznego in 1913. In the years 1919-34 he reported his work several times at Faculty meetings; in Sprawozdania $A U$ he published 'Spór recenzentów warszawskich o Paganiniego w roku 1829' [The Warsaw reviewers' disputes about Paganini in the year 1829], 'Wielogłosowa pieśń religijna w XVI wieku w Polsce' [Polyphonic religious songs of the sixteenth century in Poland], 'Jerzy Liban z Legnicy jako muzyk' [Jerzy Liban from Legnica as a musician], the essays 'Jan Brożek-Broscius jako teoretyk muzyki' [Jan Brożek-Broscius as a music theorist] and 'Pauli Paulirini de Praga Tractatus de musica (ca 1460).240 Just after World War II, in November 1945 he presented the subject 'O materiałach do polskiej kultury muzycznej' [About materials for Polish musical culture], and in his plans for publication he had a translation of Plutarch's treaty On Music and 'a very rich collection of records and notes about music, taken out of all kinds of Polish prints and numerous manuscripts. ${ }^{241}$ Before 1939 there were also presentations to the Cracow milieu by Stefan Śledziński (he spoke about the history of the Warsaw symphony) and Zofia Lissa ('O komizmie muzycznym' [About musical comicality] ${ }^{242}$ ).

The open and well-known conflict between the heads of the first two musicologies, practically closing the doors of Kwartalnik Muzyczny editorial office to the Cracow group, made Jachimecki seek his own possibilities for publishing the results of his seminar, in addition to the AU publishing house. Under the auspices of the Musicologists' Club at Jagiellonian University and the Club's curator, Jachimecki himself, two volumes of the Rozprawy $i$ Notatki Muzykologiczne [Musicological dissertations and notes] appeared. Right in the foreword, the editor explained that its 'modestly restricted volume' and 'modest external form' were caused by a lack of subsidies and foresaw a lack of consistency in the issuing of subsequent journals. It seems, however, that he went a little too far by writing that he "wishes ... to fill the immense gaps, appearing in all areas of - so far still very meager - Polish musicological literature.243 After all,

240 Respectively: vol. XXIV 1919/2, 8-9, vol. XXV 1920/7, 5-10, vol. XXVI 1921/5, 5-6, vol. XXVIII 1923/8, 3-4, vol. XXIX 1924/3, 4-7.

241 Jachimecki 1948, 53.

242 Text published in Kwartalnik Filozoficzny 1938/1, 23-73, 1938/2, 95-107.

243 Zdzisław Jachimecki: 'Od Redakcji' [Editorial] (Rozprawy i Notatki Muzykologiczne 1934/1, no page numbers). 
he wrote these words in October 1934, when the still small environment of music historians and theoreticians had already read twenty lengthy issues of Kwartalnik Muzyczny; an edition of the PRM was planned, intended for strictly scientific dissertations; for historical materials of a somewhat lighter weight, new pages of Muzyka Polska were opened. All the time Gliński’s Muzyka was in print, in which the content may have been mediocre at times, though it was well edited. ${ }^{244}$ With the conflict lasting for years between the leaders of the Lviv and Cracow centres, when one of them was linked to most of the 'professional' editors, the second was forced to create the next, independent title. It does not seem, however, that Jachimecki was in his element with editorial work. He had no ideas for the shape and plan of publication. In two journals, he included randomly selected texts that he happened to have available: in the first, Bronisława Wójcik-Keuprulian's above-mentioned habilitation lecture (pp. 1-14), the first part of Józef Reiss's larger dissertation on the division of the monochord (according to Euclid's treatise, pp. 15-31 $1^{245}$ ), Włodzimierz Poźniak’s article 'Romans wokalny w twórczości Michała Kleofasa Ogińskiego' [Vocal romance in the work of Michał Kleofas Ogiński] (pp. 32-59), and a summary of Stefan Śledziński-Lidzki's dissertation 'Dzieje symfonii warszawskiej w pierwszej połowie XIX wieku' [History of Warsaw symphony in the first half of the nineteenth century] (pp. 60-66). Due to Jachimecki's publishing initiative in the second volume of Rozprawy i Notatki in 1936, Alina Nowak was able to publish her diploma thesis on the sonatas of Józef Elsner, filling the entire issue. In view of the nearly two hundred-pages PRM, prepared and published at the same time by Chybiński, Jachimeckis journal looks very modest and it is difficult to understand that it could be compared with the yearbook and positively evaluated by the environment, if we are to believe the words of Julian Pulikowski, who reported to Chybiński: 'It is a pity that you did not hear what Mr. Rutkowski said about the Rocznik yesterday evening. He compared the Rocznik with Cracow "notes"! And how "serious," how "reliable" this Rocznik is compared to the Cracow rag!'246

For a certain time, it was also possible to include Fr. Hieronim Feicht, who learned musicology in Lviv, among the Cracow community: at the turn of the

244 According to words from a somewhat later letter from Pulikowski to Chybiński from Warsaw 10 II 1937, AACh-BJ, box 3, P-28/143.

245 The expected continuation did not appear. However, Reiss took on ancient Greek treatises two more times: after the war, he published his translation of the Dialogue of Plutarch of Chaeronea on music (Cracow 1946) and the Dialogue on dance by Lucian of Samosata (Warsaw 1951).

246 Pulikowski to Chybiński from Warsaw 22 IV 1935, AACh-BJ, box 3, P-28/93. 
twenties and thirties and in the second half of the thirties he was 'posted' by his order in the Cracow home of priest missionaries, on this occasion he undertook lectures on the history and theory of music at the Cracow Conservatoire. ${ }^{247}$ As far as musicological publications are concerned, he consistently cooperated, above all, with his Lviv mentor, though, as mentioned, his articles also appeared on the pages of Warsaw's Muzyka and the Poznan Przeglad Muzyczny and in magazines for the church and catholic circles such as for example, Przeglad Teologiczny.

In the 1930s the Cracow musicological circle was formally and briefly joined by Stefan Śledziński, connected with Warsaw's musical environment. When in connection with his planned naming as one of the lecturers of the 'musicology department' to be established at the capital's Conservatoire, he was obliged to obtain a doctorate within two years, he decided to turn to Zdzisław Jachimecki as his supervisor. An abstract of the dissertation printed in Rozprawy i Notatki was the result of the successful completion of his doctoral proceedings. It seems, however, that for Śledziński this fact was more a formality than an inner need. His passion was in teaching. For years Śledziński not only worked in musical education but also fulfilled the role of supervisor of musical institutions as an officer of the MWRiOP - and although he taught music history at the Conservatoire, he was not generally involved in scholarly research.

After the war of 1914-18, there was a chance to develop a third domestic musicological centre. After obtaining statehood, in May 1919, the inauguration of the University's activity took place in Polish Poznan. For the first three consecutive years, the programme of the Faculty of Philosophy was led by a student of Otto Kinkeldey in Wroclaw and Hermann Kretzschmar and Johannes Wolf in Berlin, Fr. Wacław Gieburowski. He gave classes in music theory and history: lectures on the origins of polyphonic music, the history of the oratorio, the history of medieval music theory. Shortly after, in a newly created institution, he would lead classes in palaeography and the history of Gregorian chant. Almost simultaneously, in 1920, in the capital of Greater Poland, the conservatoire started to operate, with Henryk Opieński, appointed earlier as director, travelling between Warsaw and Switzerland. His deputy Łucjan Kamieński was also educated by the already mentioned Kretzschmar and Wolf; the group of musicologists at the school was supplemented by another: a graduate of Berlin

247 In a letter to Ludwik Bronarski, Chybiński wrote: '[Feicht] pretends to be a Cracovian, born in Mogilno in Greater Poland, musically raised in Lviv and Fribourg, and residing in Cracow. There is no way!', Chybiński to Bronarski from Lviv 3 XI 1929, AAChBUAM, Bronarski's archive, p. 23. 
musicology, Wacław Piotrowski and the aforementioned Father Gieburowski. ${ }^{248}$ Despite not arranging all the formalities linked to habilitation, in the next year, Kamieński was given the task of organising the university's Musicological Seminary, which eventually began functioning in May 1922, and after ten years was transformed into a Department. The chief of the Poznan facility was a professor from autumn 1937, in the years 1938-39 also fulfilled the function of Dean of the university's Faculty of Humanities. At the same time that the Senate of Poznan University made the proposal, he made efforts towards attaining a position at the University of Warsaw, though this matter was unsure, as in order to take on a position there he made the problematic demand that the institution provides accommodation. Moreover, a decision had not actually been taken (and would not be for many years) to establish a musicological department in the capital. He therefore remained in Poznań: 'Three days ago, the Poznań faculty informed me that it "entrusts" lectures to me. The dean asks for a conference regarding presenting me "as a professor of musicology at the Poznań University." Well, let's see what that means ... It seems that they offer me a professorship N.B. without habilitation. ... Since Warsaw has not addressed me to this day, I will accept.'249 A year later he was still hoping to be called to Warsaw, even considering who could replace him in the faculty. The opinions that he expressed in one of his letters to Chybiński offer interesting evidence of his real evaluation of colleagues "in the business"

Father Gieburowski, a reliable and serious employee, seems to be too one-sided to preside at the department of musicology 'in all extent' ... There is Piotrowski, who received his doctorate only a year ago, and has yet to present a professional publication; besides, he's a man of rather plain mind, though quite righteous and noble .... On the other hand - what do you think of - do not get scared, Wójcikówna? How is her habilitation going? ... As far as I think, she, too, is not yet ripe for the department, but maybe something good will come of it in a few years. ... If you had not emphasised so enthusiastically that you have to stay in Lviv, and if there were better library conditions, etc., I would most gladly - remembering your special sympathy to the Western Borderlands - invite you in the event of my resettlement to Warsaw from

248 The history of musicology at the University of Poznań; see Jabłoński/Jasińska/ Stęszewski 1999, and especially Michałowski 1999 and Tatarska 1999. See also Muszkalska 2011/2, where the author, basing on the publications and correspondence of Kamieński, presents his then pioneering methods of ethnographic research, which allowed him as department head to create a modern centre for research on folklore, leading in the field.

249 Kamieński to Chybiński from Poznań 6 I 1922, AACh-BJ, box 6, K-3/12. 
the Poznań 'capital' ... What of it, if it's not doable... And I regret passing this seminar of mine to just anyone - to you I would pass with pleasure. . $^{250}$

Although he did not officially resign from his efforts for Warsaw, he preferred to have support in place. In the first years of the seminar, lectures and exercises were conducted by Wacław Gieburowski, due to his interest being focused on historical and aesthetic issues while after the priest left the department, Kamieński himself continued them. From the beginning of February 1922 Kamieński began lectures ( 4 hours) and exercises ( 2 hours) and discussions about basso continuo. ${ }^{251}$ The facility was equipped very poorly; however, the new, young leader immediately displayed initiative: 'without a seminar office, I only have a cabinet with a few books borrowed from the university's library. But "fear not"; I have already submitted applications, I am also collecting private donations. ${ }^{252}$

To help in the presentation of theoretical issues (harmony, counterpoint, figured bass) the head of the institution asked his colleague from the conservatoire, Wacław Piotrowski, whose duties were assumed a few years later by the first local doctoral graduate, Kazimierz Zieliński. At the turn of the 1930s, classes in the area of musical ethnology were brought in (Łucjan Kamieński); in the years 1933-35 lectures in laryngology, which were to be conducted by the eminent otolaryngologist working at the University of Poznań, prof. Alfred Laskiewicz. In the mid-thirties Zygmunt Sitowski and Marian Sobieski became assistants, having been informally connected with the department earlier, while at the end of the twenties and soon after a group of young graduates took on collaboration on a voluntary basis with the Regional Phonographic Archives, ${ }^{253}$ founded by Kamieński at the University, further discussed below. Two years before the outbreak of the war, the list of lectures was supplemented with acoustics, which was entrusted to the newly promoted Marek Kwiek, one of the six local graduates who managed to obtain his $\mathrm{PhD}$ in his native Alma Mater. ${ }^{254}$

250 Kamieński to Chybiński from Poznań 12 IV 1923, AACh-BJ, box 6, K-3/19.

251 See Kamieński to Chybiński from Poznań 18 I 1922, AACh-BJ, box 6, K-3/13.

252 Kamieński to Chybiński from Poznań 10 II 1922, AACh-BJ, box 6, K-3/14.

253 Bożena Muszkalska named the whole group of 'musicological' youth who participated in field trips: Bożena Czyżykowska, Marek Kwiek, Roman Padlewski, Bożena Stelmachowska, Maria Pleussówna (Turczynowicz), Hanna Rudzińska (Kruszewska), Zygmunt Sitowski, Konrad Pałubicki, Jadwiga Pietruszyńska (Sobieska), Marian Sobieski, see Muszkalska 1999.

254 Kamieński spoke about Kwiek extremely flatteringly: 'Kwiek, the most talented one, set about developing temperatures. I expect a lot from him in the area of comparative musicology. A great physicist and mathematician, who may one day push our learning into the natural sciences. That is the material for a full-on professor, see 
The pre-war history of Poznańs musicology includes nearly twenty master's theses; these were all defended after 1934 (the remaining students entered in the university archives did not obtain a diploma; for some, musicology studies were only an episode, others continued their studies after the war), while until the mid1930s only historical topics were undertaken. Kamieński, who in his own dissertation took on the subject of the oratorios of J.A. Hasse, ${ }^{255}$ mainly continued with historical subjects in his research activity until the late-1920s. Nor did he completely leave them in the following years: of particular interest to us are his polemics referring to the composer of the national anthem Mazurek Dąbrowskiego, which took place on the pages of Muzyka between him and Stanisław Zetowski, ${ }^{256}$ and also material published in 1928 on the subject of eighty-six polonaises from the second half of the eighteenth century that he had found. ${ }^{257}$

The information that we find while reading Kamieński's correspondence with Adolf Chybiński is also of interest from the viewpoint of the history of musical writing. It is a matter of his plans related to establishing his own editorial office, or else a 'take-over' from the hands of Warsaw's SMDM and co-editing Kwartalnik Muzyczny ${ }^{258}$ with the Lviv professor. However, despite many years of good contacts with Kamieński and their shared views on many issues concerning the vital problems of the musical and musicological milieu, Chybiński did not have enough confidence in him to decide on this 'union' between Lviv and Poznań. In this situation, he was collaborating as an author with the leading music periodicals. In his youth, during his stay in Berlin, later in Königsberg, but also in later years, he published a lot in German (in Sammelbände der

Kamieński to Chybiński from Poznań 6 IV 1934, AACh-BJ, box 6, K-3/72. Marek Kwiek (1913-62) was also a graduate of the Faculty of Mechanics of the Warsaw University of Technology. After the war, in 1945 he habilitated at the Faculty of Humanities of the UP, where he became an associate professor and head of the Department of Acoustics and Vibration Theory.

255 Hasses Oratorien im musikhistorischen Zusammenhange. Published with the title Die Oratorien von J.A. Hasse. Leipzig 1912.

256 Łucjan Kamieński, 'Czy Ogiński był rzeczywiście autorem naszego hymnu narodowego' [Was Ogiński really the author of our national anthem] (Muzyka 1934/4, 162); 'Kto był kompozytorem naszego hymnu narodowego?' [Who was the composer of our national anthem?] (Muzyka 1934/6-7, 245-249, 1934/10-12, 347-357); Stanisław Zetowski, 'A jednak Ogiński jest twórcą naszego hymnu' [But Ogiński really is the composer of our national anthem] (Muzyka 1935/1-2, 10-17).

257 Łucjan Kamieński, 'O polonezie staropolskim' [On the old Polish polonaise] (Muzyka 1928/3, 99-103).

258 See chapter I-2. More on this subject see also Michałowski 1979, 25. 
Internationalen Musikgesellschaft, Archiv für Musikwissenschaft, Allgemeine Musikzeitung). When he had become immersed in Poznańs academic environment, a few times he made use of the pages of Sprawozdania [Reports] of the local Association of the Friends of Science (TPN) ${ }^{259}$ to print his materials. However, he was above all quite a regular writer in the capital's Muzyka, where he provided texts of a popularising, reporting or review character, as well as taking on scholarly discussion; altogether he appeared on the pages of Muzyka a dozen or so times. ${ }^{260}$ However, it is surprising how weak his contacts were with the local Przeglad Muzyczny and Życie Muzyczne i Teatralne, where his name can only sporadically be found. ${ }^{261}$

It can be seen from this that writing did not absorb him too much - it seems that he preferred to focus on his main interests and their realisation. In the second half of the twenties, he developed his second passion - researching and immortalising folk art on phonograms. Lectures given in the years 1924-25 on the morphology of folkloric songs and instruments, ${ }^{262}$ the gradual gathering of sound documentation during myriad travels around various regions of Poland, and finally the financial support of the MWRiOP allowed realisation of the idea which came when familiarising oneself with the activities of the PhonogrammArchiv in Berlin: opening the Regional Phonographic Archives (RAF) at Poznańs Department of Musicology. This became the primary representative of comparative musicology in Poland, and in response to Poznańs project - let us stress that it was the only one, though there was a concept of establishing a network of such regional collections - a few years later a Central Phonographic Archive was organised by Julian Pulikowski at the National Library in Warsaw in

259 Amongst others: 'Z badań nad folklorem muzycznym Wielkopolski' [From research into musical folklore of Greater Poland] (Sprawozdania Poznańskiego Towarzystwa Przyjaciół Nauk 1932/3, 52-55); 'Diafonia ludowa w Pieninach' [Folk diaphony in the Pieniny] (Sprawozdania Poznańskiego Towarzystwa Przyjaciół Nauk 1933/1, 5-7).

260 Apart from the discussion with Stanisław Zetowski about Dąbrowskis Mazurka mentioned elsewhere, see for example, 'O polonezie staropolskim (z nieznanych źródeł)' [About the early Polish polonaise (from unknown sources)] (Muzyka 1928/3, 99-103); 'Eros i Psyche Ludomira Różyckiego' [Ludomir Różycki's Eros i Psyche] (Muzyka 1930/2, 86-93).

261 See 'Folklor a kultura muzyczna' [Folklore and musical culture] (Życie Muzyczne i Teatralne 1934/2, 3-4).

262 More on this topic Tatarska 1999. 
1935. The Poznan collection, numbering about four thousand phonograms, was completely destroyed by fire during the war. ${ }^{263}$

Work on completing the sound collections affected the profile of the entire Poznań department, as its extensive research in the area of musical ethnography distinguished it from the other musicology centres where this type of activity was almost absent. Here we should remember that in Cracow musical ethnography was taught only briefly by Bronisława Wójcik-Keuprulian, while in Lviv it was not until the 1939/40 academic year that Chybiński - himself always passionate about folklore, author of numerous dissertations and monographs in this area planned a lecture on the folkloric music (but also professional) of Scandinavia and precisely that of Norway. ${ }^{264}$ Thus, Kamieński was able to find a niche in musicological research, giving the Poznań centre a clear profile; unfortunately, though, he did not carry out the idea of publishing gathered materials in the form of a yearbook of Poznańs phonographic archives. ${ }^{265}$ In a short time, however, several diplomas were created, in which the Archive's collections were used. ${ }^{266}$ This activity, however, did not translate in any particular way into publications

263 For the contemporaries, Kamieński's collections were the main and the only argument that distinguished the Poznan centre from among three Polish musicologies. In the aforementioned feuilleton 'Przykre sprawy muzykologii polskiej' [The sad affairs of Polish musicology] Seweryn Barbag wrote: 'Prof. Kamieński’s latest success in the recording of hundreds or even thousands of Pomeranian songs on records makes up for the long-term scientific silence of Poznańs musicologists, especially considering how the Lviv and Cracow musicologists have been publishing a few to a dozen works per year from various fields.... Prof. Kamieński's studies are not finished yet; the most important part will involve a synthetic and comparative study of the entire material,' Barbag 1935.

264 Let us emphasise once again that Norway as a country, with its magnificent landscapes, with its somewhat mysterious culture, and especially Grieg's music, was repeatedly idealised and glorified by Chybiński.

265 See Kamieński to Chybiński from Poznań 29 II 1930, AACh-BJ, box 6, K-3/65.

266 Jadwiga Pietruszyńska, Dudy wielkopolskie [Greater Poland bagpipes], 1935; Konrad Pałubicki, Monografia pieśni ludowej 'Na Podolu biały kamień' [Folk song monograph. Na Podolu biały kamień], 1937; Bożena Czyżykowska, Wiwaty wielkopolskie [Greater Poland salutes], 1938; Maria Turczynowicz, Metoda pracy Oskara Kolberga w pierwszych trzech tomach Wielkiego Księstwa Poznańskiego seria 9-11 'Ludu.' Ankieta Poznańskiego Towarzystwa Przyjaciół Nauk [Oskar Kolberg's working method in the first three volumes of the Grand Duchy of Poznan series 9-11 of the 'Lud.' Survey of the Poznań society of friends of sciences], 1938; Witold Kandulski, Monografia pieśni ludowej 'Wyjechał pan z chartami w pole' [Folk song monograph. Wyjechał pan z chartami w pole], 1939. 
in the music press. Admittedly, Kamieński's students - Hanna Rudnicka, Marian Sobieski, Zygmunt Sitowski and others - cooperated with various magazines, mainly in the area of reports and concert and publishing reviews. Among the young musicologists from Poznań, Zygmunt Latoszewski distinguished himself in this respect, who, apart from numerous accounts, published, amongst others, two historical texts in Muzyka: still before gaining his doctorate - 'Dzieje opery polskiej'267 [History of Polish opera] and a few years later - 'Początki opery polskiej (wiek XIX-XX)'268 [The beginning of Polish opera]. A few in Poznań were involved with Chybiński's periodicals, Kwartalnik and PRM, but only Kamieński and Marek Kwiek published dissertations ${ }^{269}$ through their publications, while Father Gieburowski and Marian Sobieski remained with book reviews. Bożena Czyżykowska published a few texts in the Greater Poland press ('Fonograf zbiera pieśni' [The Phonograph collects songs], ${ }^{270}$ 'Muzykalność ludu wielkopolskiego' [Musicality of the Greater Poland people] and 'Na wesele do Domachowa' ${ }^{271}$ [For a wedding to Domachów]), but they were not of an academic nature.

Over time it was clear that the most significant contribution to the continuation of Poznańs folklore research was made by two of Kamieński's students - Marian Sobieski and Jadwiga Pietruszyńska, after their wedding in 1936 - Sobieska. (After the war, following the assumptions of their teacher, the Sobieskis developed the All-Poland Campaign for the Collection of Folkloric Music, during which, thanks to the more modern devices available, they were able to gather incomparably more recordings, nearly fifty thousand compared to four thousand collected during Poznańs pioneer exploration.) It was Sobieski himself who made the first field recordings in the Kujawy region with the faculty leader; Pietruszyńska went to Mazowsze, with which she had a family connection: she was from Warsaw, studied at the University there (art history) and at the Conservatoire (violin playing), though she chose the young centre in Poznan for musicology studies. In the mid-1930s, she also had a short but significant

267 Muzyka 1927/7-9, 109-128.

268 Muzyka 1934/8-9, 7-17.

269 Łucjan Kamieński, 'Z najnowszych badań nad fizjologią gry fortepianowej”[From the latest research about the physiology of playing the piano] (KM 1929/5, 62-66); 'Monografia pieśni zmówinowej z Kaszub południowych' [A monograph of chant song from southern Kaszuby region] (PRM 1935/1, 107-131); Marek Kwiek, 'Czynniki rezonansowe w barwie dźwięku' [Factors of resonance in the colour of sound] (PRM 1936/2, 35-41).

270 Tęcza [Poznań] 1933/3, 50-53.

271 Both are published in Kronika Gostyńska (1934/8, 114-117, 1935/4, 49-56). 
'press' episode: for a time she was the secretary to the editorial office of Muzyka Polska, but on account of personal plans left the team after a few months. In Adolf Chybiński's rich 'Cracow' archive there are nearly fifty letters from 1936 regarding the then contacts of the professor with TWMP and Muzyka Polska signed by Teodor Zalewski and Jadwiga Pietruszyńska (Sobieska). When it comes to contributing achievements from the period before 1939, the results of the Sobieskis' works - let us also add those that go beyond the folklore themes, such as the presentation of Cztery motety Kopernikowskie [Four Copernican Motets] op. 19 by Tadeusz Kassern ${ }^{272}$ - they jointly published many times.

Returning to the matter of the "specialisation" of Poznańs musicology, one should indicate the second "niche" that Kamieński managed to perceive and make use of - acoustic research. This research was closely linked to developing the activities of the Regional Phonographic Archives (RAF) and the laboratory in which increasingly modern devices for recording were collected as well as for the analysis of recordings. The centre's chief, himself highly interested in theoretical matters and modern technological capabilities for research on sound, rather quickly educated a student who was to soon become an authority in this field. Marek Kwiek, two years after his master's degree on the subject of development paths of musical scales, obtained a PhD in 1936 based on his dissertation Zależność między własnościami fizycznymi dźwięku a jego styszalnościa [The relationship between the physical properties of the sound and its audibility]. It should be added that in this field this was pioneering work at Polish universities and, according to Kamieński's review, cited by Helena Harajda, in general 'Poland's first major contribution in psychological musicology ... [although research] by nature is carried out using phisico-mathematical methods. ${ }^{273}$

(By the way, it is worth mentioning that Bronisława Wójcik-Keuprulian's systematics raised the particular role of acoustics within the whole field; however, her approach to the subject was strictly theoretical and not in any way connected to the Poznan centres activities, which were oriented more towards practice than

272 Muzyka Kościelna 1938/4, 48-52.

273 Harajda 1999, 103. It seems that at that time, the only partner for scholarly discussion in this area was Gabriel Tołwiński who worked in the Conservatoire in Warsaw, who in Chybiński's Kwartalnik in the years 1928-31 published two articles in the field of acoustics. He was also a member of a group of several people, who in 1934 were entrusted with classes within the 'musicological department' formed at the same university (see below). He was the author of the handbook Akustyka muzyczna published by TWMP (Warsaw 1929). 
theory. As for the controversy that arose in regards to the researcher's proposals, we will return in chapter II-3)

Certain statements suggest that in the mid-twenties an idea was born to make a kind of 'pooling' of the Poznań cathedral (and others?) in Warsaw, which provoked strong opposition and indignation of the head of the Wielkopolska branch. Kamieński bluntly expressed his opinion on this subject:

Every Department has its regional significance as a centre of work and of education. Lecturers visit the province, developing regional materials from Warsaw, for example, would be very troublesome. ... And the students! I know you have a lot of them. Here too, activity has been growing gradually, so that I now have 23 members of the seminary and the studies ... are prospering. So what will happen to my group? To Warsaw? Bah! Many can go there! In Poznań, one is staying with one's relatives, not far from home ... and before one would go to the 'congress', one would rather go study law, gynecology, the devil knows what, but one will stay in Poznań. As a result, Wielkopolska would virtually be left completely stripped of musicology; the provincial musical culture would suffer a great deal. ${ }^{274}$

In the context of music publications of the Poznan environment, it is also worth mentioning the figure Stanisław Wiechowicz, who was above all a composer and conductor but was also involved in the musical press for many years not only as an author, but also as editor. Along with reviews, he wrote articles on musical life, musical education and the dissemination of music - in Poznańs Śpiewak (Singer), Kurier Poznański, in Muzyka Polska, and above all in Przeglad Muzyczny, where he was editor after Henryk Opieński (and the short term of Kazimierz Sikorski in this position) from 1927; ${ }^{275}$ in 1929 he also became a founding member of the 'Professional Music Press Club.' Intimate contacts with Adolf Chybiński dating back to the years of the magazine's functioning, his frequent consultations regarding the shape and content of the periodical, are testimonies to Wiechowicz as a man caring not only for a high level of live music but also knowledge of music. He repeatedly sought Chybiński as an author, also when the singing community asked the editorial office to move away from the too-academic nature of the texts and was grateful for articles on topics that could be of vital interest to the environment, such as 'W sprawie kultu dawnej muzyki polskiej chóralnej"276 [In the matter of the cult of early Polish choral music] and 'O wyższy poziom zespołów chórowych' [About the high level of choral ensembles]. ${ }^{277}$

274 Kamieński to Chybiński from Poznań 12 I 1926, AACh-BJ, box 6, K-3/27.

275 See Mrygoń 1982, Mrygoń 1989.

276 PM 1930/9-10, 1-2.

277 PM 1927/9, 1-5, 1927/10, 1-5. 
The panorama of musicological centres in Poland during the twenty-year inter-war period is complemented by the short history of the Warsaw department, whose development was attempted under the auspices of the Conservatoire, as well as part of the University. The controversial fate of this initiative and its realisation can be followed in Chybiński's correspondence with Julian Pulikowski, who was engaged in the project himself; however, critical remarks were also made by other musicologists.

Although the decision to grant similar authority to musicology at the conservatoire as at universities was opposed by the deans of the Faculty of Humanities at Józef Piłsudski University in Warsaw, a section of the capital's conservatoire circles strongly supported this project from the beginning. Mateusz Gliński even intended to devote one of the special editions of his monthly magazine to musicology; he wanted 'to make quite a commotion in Muzyka regarding the musicology department in Warsaw' announcing ('for example') a survey and commissioning special articles. ${ }^{278}$ Creating the facility was fostered, among others by Zdzisław Jachimecki, whose 'people' belonged to the local teaching staff - Helena Dorabialska (who received a doctoral degree at the Jagiellonian University in 1925 based on her dissertation Józef Damse i jego komedie muzyczne [Józef Damse and his musical comedies]) and Stefan Śledziński (who defended his doctoral thesis in Cracow in 1932, Dzieje symfonii warszawskiej w1. połowie XIX wieku [Symphonic works in the first half of the nineteenth century]). The inauguration ceremony took place on February 20, 1934, noted amongst others in Muzyka Polska, ${ }^{279}$ and reports from this event were also published in the press beyond Warsaw; in the Przemyśl monthly Orkiestra (edited - let us remember by Józef Koffler) it was written:

On the twentieth of this month [February], the Faculty of Musicology had its grand opening in the Warsaw Conservatoire of Music. The ceremony took place in the morning hours in the Barcewicz's room, with the participation of government representatives, music and scientific communities. The president of the Council of Ministers, the Minister of WRiOP [Wacław] Jędrzejewicz also came, ${ }^{280}$ accompanied by the Deputy Minister Rev.

278 See Gliński to Chybiński from Warsaw 18 VI 1927, AACh-BJ, box 4, G-5/64. Paul Nettl's text mentioned in this letter by 'Musikwissenschaft und neue Musik' was never published in $M u z y k a$, and also Stefania Łobaczewska's article anounced there 'Muzykologia polska' [Polish musicology] was published in a special number of Muzyka with the title Muzyka polska (1927/7-9, 143-151).

279 MP 1934/1, 80 (Kronika).

280 Just four days earlier, Wacław Jędrzejewicz picked up the minister's portfolio at the WRiOP, replacing his brother, Janusz Jędrzejewicz. 
[Bronisław] Żongołłowicz. ${ }^{281}$... The introductory words were given by the rector of the Conservatoire, the well-known composer Prof. Eugeniusz Morawski. The Rector raised the important scientific significance of the newly created faculty, above all for the Polish musical community. Prof. Morawski announced close cooperation with the Warsaw Conservatoire and the University in the field of musicology. Then, Mr. Witold Maliszewski spoke on behalf of the Art Department of the Ministry of WRiOP, raising the importance of musicology for the development of musical culture. Professor Zdzisław Jachimecki from Cracow joyfully greeted the creation of such an important music institution. Following these introductory speeches, the head of the musicology department Prof. Dr Stefan Śledziński gave a lecture on the subject 'Indications of Warsaw musicology.282

Jachimecki's speech probably aroused controversy, given that Kamieński conveyed the reports he heard about the events of the ceremony as follows: 'if what I was told is true, namely that only one student has entered this "faculty," then this soap bubble will probably soon burst. All the more so because the favour of the university for this compromise item has gone haywire thanks to the help of the arch-clever speech by our friend patron [Jachimecki]; you probably know about the fact that the rector left the hall ostentatiously during this speech, and that the Warsaw Senate sent a letter to J[achimecki] requesting an explanation. ${ }^{283}$

From the beginning, the already mentioned Julian Pulikowski made strong efforts to obtain a place in Warsaw's musicology didactic team, as after settling in the capital he sought worthy employment for himself. Born in 1908, Pulikowski grew up in Hanover, which was not without significance in the further course of his life: in Poland he was perceived as a foreigner from Germany, sympathetic to the nation, and this, combined with his complicated and controversial personality, and probably also his imperfect use of the Polish language, put him in the position of an outsider not accepted by a large part of the milieu, especially during the few years of the war, when he decided to continue his work in library structures, under the authority of the occupying forces. Under these circumstances, his death, which took place during the Warsaw Uprising during the digging of the insurgents' fortifications, is all the more dramatic. ${ }^{284}$

281 Rev. Bronisław Żongołłowicz was a Deputy Minister at the WRiOP resort in the years 1930-36.

282 Orkiestra 1934/2, 32 (Kronika [Chronicle]).

283 Kamieński to Chybiński from Poznań 6 IV 1934, AACh-BJ, box 6, K-3/72.

284 More about Julian Pulikowski see Bartkowski 2009, Dahlig 2012/2. 
Returning however to the career path of Pulikowski, one should remember that he studied philosophy, art history and musicology at the Vienna University, the latter subject under Alfred Orel, Wilhelm Fischer and Robert Lach. ${ }^{285}$ Additionally, at the beginning of the 1930s, he went to Hamburg, where had the chance to work in the phonetic laboratory of Wilhelm Heinitz, a specialist in the field of comparative musicology and psychology. When he came to Poland in 1934 and settled in Warsaw, he had already maintained contact with Adolf Chybiński for a few years, who in 1929 began sending reports from foreign publications - from the fifth issue of Kwartalnik Muzyczny his reviews appeared regularly in nearly every issue. Already then, in December 1929, he referred to his forthcoming article 'Pieśń ludowa i muzykologia' [Folkloric songs and musicology ${ }^{286}$, which did not appear in print until 1936 in the second volume of the PRM. Besides, he did not publish much, and generally in magazines outside the musical trend. Although he tried at all costs to avoid becoming pigeonholed as an ethnomusicologist, he often dealt with issues in this field, but mostly in a broader context - historical, sociological, and general-cultural. ${ }^{287}$ Piotr Dahlig emphasises that Pulikowski 'sought to coordinate historical and systematic musicology ... postulated taking into account all musical culture, including folk and peasant music.'288

285 The interests of these researchers undoubtedly influenced the future specialisation of Pulikowski: for years, Orel was the director of the music department at Vienna's Stadtbibliothek and also worked in the library of that city's musicology institute. Lach, apart from being in charge of the music collection of Vienna's Hofbibliothek, was also involved in cataloguing recordings in the local Staatsbibliothek, and as far as his interests were concerned, concentrated above all on matters of musical ethnography.

286 See Pulikowski to Chybiński from Vienna 12 XII 1929, AACh-BJ, box 3, P-28/7. Chybiński must have had serious reservations towards this text, which may explain why its publication date was so delayed. During work on the second volume of the PRM, Pulikowski agreed to 'stylistically concentrate' and 'supplement' the article - and perhaps - to explain the difference between his use of the terms 'volkstümlich' ('of the people') and 'volksläufig' ('of mass appeal'). He then asked Chybiński if he liked the article. see Pulikowski to Chybiński from Warsaw 30 XII 1934, AACh-BJ, box 3 , P-28/79.

287 See for example, titles such as ‘Sześć polskich pieśni ludowych z roku 1819’ [Six Polish folk songs from the year 1819] (Zaranie Ślaskie 1931/2, reprint in KM 1933/17-18, 34-36), 'Zagadnienie historii muzyki narodowej' [The issue of national music history] (Źycie Sztuki 1935/2, 56-68), 'Dlaczego zajmujemy się muzyką ludową?' [Why do we deal with folk music?] (Gazetka Muzyczna 1937/5, 1), 'Ratujmy pieśń i muzykę ludową' [Let's save a song and folk music] (Tygodnik Ilustrowany 1937/10, 196).

288 Dahlig 2004. 
In July 1934 Pulikowski was given work in the Music Department of the National Library. At the same time Janusz Miketta, then a bureaucrat in MWRiOP, making use of his competences, proposed opening the Institute for the Study of Folk Songs [Instytut Badań Pieśni Ludowych], the Board of which consisted of (apart from Pulikowski) Chybiński, Kamieński, Cezaria Baudouin de Courtenay Ehrenkreutz Jędrzejewiczowa, ${ }^{289}$ Kazimierz Moszyński, Eugeniusz Frankowski, Kazimierz Nitsch, Zdzisław Stieber, Witold Doroszewski. According to the prepared statute of the Institute, CAF was to be created, which, as is known, Pulikowski successfully organised in a short time; by the outbreak of the war, about twenty thousand Polish folk songs were found in the collection of the archive. Unfortunately, they were destroyed during the war. ${ }^{290}$

In the meantime, however, he was also searching for other tasks. At that time, the 'musicological department' was planned at the State Conservatoire. This idea and attempts to implement it over the next few years involved some of the musicologists' milieu, while another part (including Chybiński and his collaborators) were shocked. Talks continued about whether the course should not be run by UJP. It was unclear what kind of education and what knowledge bases would be accepted for potential students - whether the youth in the vocational school, such as was the conservatoire, would be as well educated as the students of university studies? All of the proposed lecturers had doctorates, but none of them obtained venia legendi by way of habilitation, which was a sine qua non condition for the establishment of a scientific institution. In this situation, the opinion of the musicologists' community was unambiguous. Seweryn Barbag wrote at the beginning of 1935: "The latest creation of the "faculty" of musicology at the Warsaw Conservatoire speaks volumes of how even in professional areas, not everyone is aware of the seriousness of musicology. The administration of each new musicological school should be handled by outstanding

289 Cezaria Baudouin de Courtenay Ehrenkreutz Jędrzejewiczowa (1885-1967), ethnologist, ethnographer and cultural historian. She founded and ran ethnography departments first at the University of Vilnius (1927-35), then at the Józef Piłsudski University in Warsaw (1935-39). The author of works devoted to rituals and artistic folk art and researcher of folklore of the Vilnius Region. Privately she was the wife (from 1933) of Janusz Jędrzejewicz, the Prime Minister and almost simultaneously the minister in the department WRiOP, creator of education reform (known as the Jędrzejewicz reform). Pulikowski sought good contacts with Jędrzejewiczowa due to their similar specialisation and because of the prestige associated with the proximity of the government spheres.

290 About this subject see Dahlig 1993. 
and academically experienced individuals. We expected that a highly deserving professor will be appointed as head of the musicological department in Warsaw, such as Prof. Dr Reiss from Cracow, or Dr Wójcik-Keuprulian from Lviv. ${ }^{291}$

Meanwhile, the entire teaching staff was to be based only on the conservatoire's lecturers, but they had not followed the necessary scholarly path to be able to conduct classes of an academic nature. Indeed for this reason, it was not possible for the department to be included in the University's structure in order, as written by Magdalena Dziadek, 'to carry out courses on humanities and diploma exams equal in rank to university master's degrees. ${ }^{292}$ In relation to the conservatoire, however, plans to launch the faculty were made, and was described by Pulikowski thus: 'The "musicological department" [of the Warsaw Conservatoire] has 13 hours allocated: 2 for Miss [Helena] Dorabialska on "the history of musical forms," 2 for Mr. [Henryk] Rydzewski on musical aesthetics, ${ }^{293}$ 5 for Mr. [Stefan] Śledziński on "the history of instruments" and "the general history of music," and 4 for me on "ethnography." How I fill these 4 hours, is up to me.294

The new organisation was ceremonially inaugurated at the beginning of 1934. However, in the adopted formula, without a titled leader who could create a department, it did not meet with approval from the majority of 'university' musicologists and was ostracised by other centres - Lviv (with Chybiński) and Poznań (with Kamieński), except for Cracow and Zdzisław Jachimecki. Jachimecki, who - according to the words of the editorial office of the monthly Muzyka - 'invited by MWRiOP to take care of this new music learning institution, ${ }^{295}$ not only spiritually supported Warsaw lecturers. Years before, he had supervised Helena Dorabialska, just two years earlier, he led Stefan Śledziński's

291 Barbag 1935, 19.

292 Dziadek 2011, 466, see also Dziadek 2016.

293 Magdalena Dziadek has determined that Henryk Rydzewski went to the Conservatoire under the rectorship of Karol Szymanowski together with a group of several other people (amongst others with Stefan Śledziński, Kazimierz Sikorski, Jan Maklakiewicz). At the school he conducted classes in pedagogy.

294 See Pulikowski to Chybiński from Warsaw 25 VIII 1934, AACh-BJ, box 3, P-28/67. The acoustician Gabriel Tołwiński complemented the didactic team of the new 'faculty'. We also know that Pulikowski applied for the position of assistant for Józef Chomiński, who was trying to find an opening in the capital on account of the lack of positions in UJK, amongst other places (Pulikowski to Chybiński from Warsaw 29 X 1938, AACh-BJ, box 3, P-28/191).

295 Note from the editor in Jachimecki 1934. 
doctorate, and also proposed the Jagiellonian University as the place of habilitation for both of them. Śledzinski also suggested to Juliusz Pulikowski to conduct the habilitation procedure there (he kept his close contact with Chybiński and the fact that he prepared the habilitation thesis somewhat under his supervision a strict secret). The Cracow professor was one of the honorary guests at the opening ceremonies of the 'faculty', and fragments of the text of his speech were published by Mateusz Gliński in the pages of Muzyka. ${ }^{296}$ The didactic team of the 'musicological department, as already mentioned, did not meet the university requirements, although Magdalena Dziadek maintains that 'each of the three pedagogues lecturing at the Faculty of Musicology had several majors completed and doctoral degrees in musicology. ${ }^{297}$ Śledziński studied Polish philology and art history at the University of Warsaw as well as conducting and composition at the Warsaw Conservatoire of Music; then, however, for a number of years, he worked mainly as a conductor (military bands, among others) and fulfilled clerical functions. Helena Dorabialska studied piano in Moscow and Warsaw, and also a composition course in Warsaw, and in 1924 she completed, as already mentioned, her doctorate in musicology in Cracow, but worked primarily as a pianist, composer and teacher. As far as academic experience is concerned, each of them had only classes with the students of the Conservatoire, which did not create any university competencies. This gave contemporaries arguments for a severe judgement of these two lecturers. We know from Pulikowski's reports, that Rydzewski, who specialised in the field of psychology and pedagogy, and Tołwiński the acoustician did not have 'any complaints.' Unfortunately, concerning the others, he had the worst opinion: 'Neither Dorab[ialska] nor Śledz[iński] have the SLIGHTEST idea about neumes, Modal notation [sic], mensural notation, about tabulature! and THIS a music historian who cannot read old texts!' ${ }^{298}$ Interested in taking a lucrative position among the staff of musicology at the Conservatoire, Pulikowski wrote further: 'There was [on September $27,1934]$ a meeting of all "musicologists" of this "Musicological Faculty" at the Conservatoire. These included: Śledziński, Dorabialska, Tołwiński, Rydzewski and myself. Dear Professor, NEVER have I seen SUCH musicologists as Śledziński and Dorabialska ... and never thought that anything like this is even possible! A laity dilettante is a philosopher to them. Naturally: the "proseminar,"

296 Ibid.

297 Dziadek 2011, 468.

298 Pulikowski to Chybiński from Warsaw 28 IX 1934, AACh-BJ, box 3, P-28/73. 
the "seminar," exam this and exam that, systematics, level, etc., all this is merely "in der Luft schwirren."'299

As far as publications are concerned, none of the mentioned persons had many scientific works to their account, although Stefan Śledziński became a faithful author for Muzyka Polska from the beginning of its activity, with the fact that the subject of his articles usually revolved around current affairs music education and teaching methodology. or the degree of music literacy. ${ }^{300}$ Dorabialska wrote music reviews in the Warsaw Biuletyn Artystyczny, bi-weekly dedicated to art and culture, led in the years 1931-33 by the avant-garde artist Jan Dłużniewski, and the organ of the PPS, the daily Robotnik. Only sporadically do we find the names of other 'faculty' pedagogues in the pages of the music magazines journals: Henryk Rydzewski appears only once, in Muzyka, for which he prepared 'Kilka słów o metodzie wykładu literatury polskiej i powszechnej na terenie gimnazjum muzycznego ${ }^{\prime 301}$ [A few words about the method of lecturing Polish and universal literature in the music middle school], Gabriel Tołwiński, as already mentioned, appeared twice as an author in the pages of Kwartalnik Muzyczny.

To save - in his own conviction - the idea of musicology at the conservatoire, Pulikowski had his own project: 'If I could do that, I would set up such an "Arbeitsgemeinschaft" in line with the German formula: we could take an ethnologist, a phonetician, a theatrologist, an historian - in literature and art, etc. and make various lectures touching upon the topics of Grenzgebieten. ${ }^{302} \mathrm{He}$ also included similar 'revolutionary' ideas in the article 'Muzykologia - l'art pour l'art?'303, which was created almost in parallel to the moment of launching 'Warsaw musicology'; in it Dziadek finds the marks of a declaration of an agenda - probably accurately, because in this essay Pulikowski repeatedly emphasises the role musicology should play in shaping the musical life of society or help in the creative work of composers, critics, teachers - and so, corresponding to the location of the 'faculty', practical aspects to making use of musicological knowledge.

299 Ibid.

300 'Szkolnictwo muzyczne' [Musical education] (MP 1936/6, 379-382); 'Elle parle gauloi. (O fatalnej dykcji śpiewaków)' [Elle parle gauloi. About the terrible diction of the singers] (MP 1935/3, 224-225); 'Dyletantyzm i amatorstwo' [Dilletantism and amateurism] (MP 1934/4, 301-304).

301 Muzyka 1929/1, 52-54.

302 Pulikowski to Chybiński from Warsaw 28 IX 1934, AACh-BJ, box 3, P-28/73.

303 MP 1934/3, 201-209. 
The prolonged shortcomings of a formal and organisational nature caused that in reference to the principles of the new institution and the decision whether it should be an entity at the Conservatoire or at the University, there was no consensus for subsequent years. On December 4, 1936, a letter signed by the dean of the Faculty of Humanities, Stanisław Wędkiewicz, in which it was stated that: 'At its meeting of December 1, 1936, the Council of the Faculty of Humanities approved the organisation of full musicological study at the Faculty of Humanities at the Józef Piłsudski University in Warsaw. ${ }^{304}$

Unfortunately, a few months later it turned out that instead of musicology, plans were made to establish an anthropogeography department under the direction of Bogdan Zaborski. ${ }^{305}$ At this time, Pulikowski lectured in Jędrzejewicz's ethnography department on the systematics of musicology and an introduction to musicological literature and, hoping to lead the Warsaw department on his own, ${ }^{306}$ prepared a plan for studies, in which he did not consider it necessary to include theory, harmony, counterpoint and instrumentation, because these would be skills acquired in music schools; there would also be no need for the history of harmony and counterpoint, useful only to music historians, not for musicologists dedicated, for example, to musical education. ${ }^{307}$ Although there is no evidence for such a remark, this concept of musicological studies could not possibly have been accepted by Chybiński.

Although in 1937 and 1938 no one entered the 'faculty' efforts to maintain musicology within the framework of the conservatoire still continued. According to Pulikowski, neither Dorabialska nor Rydzewski had any students and to be able to satisfy the principle of 'tres faciunt collegium,' they organised casual listeners; Śledziński did not start courses at all. ${ }^{308}$ Finally, in the autumn of 1938, the Department of Musicology at the Faculty of the Humanities, entrusted to Pulikowski, was established at the University. However, he did not manage to fully develop the institution's activities before the war.

304 See Pulikowski to Chybiński from Warsaw 8 XII 1936, AACh-BJ, box 3, P-28/141.

305 See Pulikowski to Chybiński from Warsaw 28 IV 1937, AACh-BJ, box 3, P-28/146. Bogdan Zaborski (1901-85), a geographer, was a professor at Warsaw University (from 1928), after the war settled in Canada, where he lectured at the Universities in Montreal (from 1948) and Ottawa (from 1957). He conducted research in the field of social and economic geography and geomorphology.

306 He gained his habilitation in 1936.

307 Pulikowski to Chybiński from Warsaw 23 V 1937, AACh-BJ, box 3, P-28/150.

308 Pulikowski to Chybiński from Warsaw 4 XI 1938, AACh-BJ, box 3, P-28/193. 
Pulikowski, who was a generation younger than the other staff of the planned conservatoire faculty and, above all, a person who was new in the Warsaw and national musical world, could not win long term allies because - it must be mentioned - of his often excessive and controversial organisational and scholarly ambitions. The milieu, which, after the model of Lviv, Cracow or Poznań, was to have focused around the scholarly musicological group in Warsaw, due to its actual absence in the interwar period, did not exist. More or less educated in this direction, critics and music journalists, or writing musicians, were associated with institutions and societies operating in the capital city: the Conservatoire, WTM, SMDM and TWMP, IFCh, or with periodical editors, with Mateusz Gliński's Muzyka at the forefront, and Warsaw episodes in the activities of some musicologists promoted elsewhere (Bronisława Wójcik-Keuprulian, who wanted to continue her academic career at the capital's University and who was active in the IFCh; Father Hieronim Feicht, who in the years 1930-32 lectured on theory and history of music at the Warsaw Conservatoire; among the older generation, even Feliks Starczewski, who at the beginning of the century studied in Berlin with Oskar Fleischer and Max Friedländer, and after years of activity mainly as a musician, composer and journalist, also a writer of 'expert' texts, but with little experience as an academic teacher, and who was invited to the group of lecturers of musicology at the University of Warsaw in 1938) were not enough to create a platform for academic discussion here. 


\section{Musicology among academic disciplines in the interwar period - systematics, discussions}

Polish musicology has, already since the first period of its existence, seen several 'program declarations' given by its representatives, followed by summaries of the assessments of the previous and current state of this discipline, both in the press and in compact publications. Comments on this subject can also be found in private correspondence of the main characters from the erstwhile scientific community. They can be divided into two groups: one, which includes statements the authors of which aimed at explaining the specificity of musicology as a science and justifying its presence within the structures of universities as well as underlining the essence of cooperation between musicologists and other representatives of the world of culture and arts, and the importance of the work conducted by historians of music for the general education of the population. This topic was elaborated throughout the second, third and fourth decade of the twentieth century by the leading representatives - Chybiński, Jachimecki, Reiss, Pulikowski as well as music publicists - Gliński, Stromenger, many other anonymous authors. The second group consists of a small number, yet important for Polish music literature, attempts to either systematise this science or explain the specifics of some of its branches - Barbag, Wójcik-Keuprulian, Kamieński. One should also mention the periodical heated disputes about the differences in the perception and understanding of research methodology adopted by the representatives of musicology, or the assessment of the activities of associations of active musicologists, which took place in music, socio-cultural and environmental magazines. The catalyst for any discussion about this Polish scholarly discipline, new at that time, could be the decisions to open - almost in parallel two departments of music history at two Polish universities - in Cracow and Lviv, followed by the attempts to justify these decisions, and later on - the need to acquaint potential candidates with the study programme.

Musicology, like earlier in other European centres, grew in Poland from nineteenth-century historiography, a process not as banal as may seem with a mere cursory reflection. The thoughts formulated by Maria Ossowska and Stanisław Ossowski are adequate concerning Polish musicology, as they are in the case of the history of the development of other fields: 'Usually ... before the emergence of a new science, there are already issues that will constitute its 
framework, which have previously been assigned to other sciences.... It is only with the passage of time, when we become sufficiently accustomed to new frames and when new issues arise from borrowed issues, only then are we just starting to treat the issues of the new science as especially appropriate. 309

Katarzyna Morawska ${ }^{310}$ devoted her extensive sketch of the nineteenthcentury basis for the shaping of future musicological studies, and at the outset of her considerations noted that 'a relatively small interest in nineteenth-century [Polish] musical literature stems primarily from the conviction of its primitivism in comparison with the achievements of Western European musicography. ${ }^{311}$ Numerous examples of compact publications and contributions in the field of musical historiography, quoted by her in dozens of footnotes, indicate how rich the literature was and how the extensive her research had to be in order to present as full a review as possible.

Morawska considers the history of Polish historiography within the century from 1803 (a reading by Jan Paweł Woronicz on the patriotic songs presented at the meeting of the Warsaw TPN, and published in the yearbook of this Society, 1803 vol. II) to 1907, when Dzieje muzyki polskiej w zarysie [Sketch of Polish music history] was published by Aleksander Poliński in Lviv. Musical historiography, which had been dominant in the works of this period and the long-term subject of which had been early music, focused primarily on topics relating to - most frequently - works from the sixteenth century, with trips to the seventeenth and eighteenth century (more often), and - rarely - due to limited research - to medieval music. A lack of educated Polish music historians placed research in this area far below the achievements of foreign musicographers as well as local representatives of other historical scholarship - history of literature, history of art and general history, the critical scientific methods of which have been outlined already in the eighteenth century. Morawska reiterates the eighteenth-century 'unearthing of the monuments of Old Polish literature' or the attempts to organise the material in the field of visual arts. The field of music also gained through these initiatives, for as the author notes, 'antiquarian collectors ${ }^{312}$ included materials on the history of Polish music in a wide range of works. Music history also owes them a number of important discoveries and source information. ... however, the history of music

309 Ossowscy 1935, 7.

310 Morawska 1976. For more about the idea of development of historicism see Poniatowska 1993/2.

311 Morawska 1976, 8.

312 This term was used to identify any historical sources and artefacts found and collected at that time. 
was still marginalised, mainly due to the fact that it required the researcher to have additional special professional preparation. ${ }^{313}$

Following the example of Western European centres, detailed factual documentation had been collected to serve as the basis for considering the creativity and culture of the past, including music. The main form of historiographical discourse on the history of music were contributions, mostly of an anecdotal nature, rarely undertaking a critical evaluation of sources and monuments. Using the chronological breakdown of Polish music historiography, as proposed by Katarzyna Morawska, we can identify three periods. The first, chaotic in terms of organisation of activities, rich in material publications, was primarily the domain of general history researchers; ${ }^{314}$ the fledgeling Polish music periodical press, by meeting the expectations of a relatively small number of readers generally did not make any attempts to get closer to the scientific level. The author draws attention to the character and activities of Ambroży Grabowski, a Cracow historian. He was a collector and antiquarian, who, upon gathering 'ancient' materials of all kinds, came across a number of messages about music and musicians, among others, royal, aristocratic and urban (mostly Cracowbased) and passed them on both in compact publications, ${ }^{315}$ and minor forms. ${ }^{316}$

313 Morawska 1976, 15.

314 Zofia Helman links music historiography in terms of methodological issues not with general history (political, economic), but above all to the history of literature and art, 'and thus the fields that focus on works - especially products of human activity, aimed at inducing aesthetic experiences,' see Helman 2002, 115.

In her reflections, the author begins with indicating the bipolarity which characterised the beginnings of historical research on music: 'recognition of the history of music in historical and cultural associations, designated by the "zeitgeist" [here she indicates works by Johann N. Forkel and August Wilhelm Ambros], and isolation of historicalmusical process from general phenomena and treating it "in an autonomous manner" limited to issues of form and compositional technique' (in work of François-Joseph Fétis and Hugo Riemann) (ibid., 115-116). Her correct remark that their successors (Guido Adler, Ernst Bücken) also did not incline toward this dichotomy, but united these two methodological trends, we can relate - though with varying intensity - to the scientific outlooks of the representatives of the very first generations of Polish musicologists.

315 Amongst others: Dawne zabytki miasta Krakowa [Ancient monuments of the City of Cracow] Cracow 1850; Starożytnicze wiadomości o Krakowie [Ancient news about Cracow] Cracow 1852.

316 See for example, 'Okruszyny wiadomości z dziedziny sztuki i starożytności naszych' [Crumbs of news from the field of art and our antiquity] (Biblioteka Warszawska 1854). 
Admittedly, as Morawska underlined, 'he did not take care about the exact systematisation and segregation of the material, ${ }^{317}$ however, the searches he undertook to find archives and the analysis of historical works of Old Polish literature anticipated the methodology that became the basic means of scholarly investigation of a large part of Polish musicology in the twentieth century. Another nineteenth-century musicographer, Maurycy Karasowski, author of several books, including the monograph Rys historyczny opery polskiej [Historical sketch of Polish opera] (Cracow 1859), in 1855 published in Biblioteka Warszawska ${ }^{318}$ an article 'Przegląd muzykalny' [Music review]. This article, in turn, can be regarded as important due to the much more synthetic description of history than earlier historiographic publications, and its task was to 'illustrate the role and importance of music in the intellectual culture and social life of the country... [the author] does not collect a large number of factual messages, but using selected examples tries to show the systematic and continuous development of music in Poland, and news about folk music, music at magnate's and royal courts, musical associations and others illustrates the presence of this art among all estates and in many circumstances. ${ }^{319}$ Already at that time, he drew attention to Czech and, later, Italian influences, so in Karasowski's achievements, we can see the second of the underlying trends of future musicological research - showing musical phenomena against a broad historical and cultural background.

The future, most-favourite subject of analysis and investigation amongst the first generations of musicologists - issues of monody and Gregorian chant were not touched upon in local publications in the absence of prepared Polish researchers. Furthermore, the issue of the history of universal music was also rarely raised. On the other hand, importantly, this period provided Polish musical studies with at least a few reasonably reliable publications of a lexicographical nature - alongside the admittedly controversial and differently assessed Stownik muzyków polskich [Dictionary of Polish musicians] published in Paris (1857) by Wojciech Sowiński, and the earlier Słowniczek wyrazów polskich znaczacych narzędzia muzyczne niegdyś w wojskowym i pokojowym używaniu będace [A glossary of the Polish words meaning musical tools used to be in military and peaceful use] (1828) developed 'from a manuscript of Adam Czartoryski' for the Lviv-based Czasopismo Naukowe Ksiegozbioru Publicznego imienia Ossolińskich ${ }^{320}$.

317 Morawska 1976, 20.

318 Biblioteka Warszawska 1855/4, 302-310.

319 Morawska 1976, 38.

$3201828 / 2,81-88$. 
The second period in the development of nineteenth-century Polish musical historiography indicated by Katarzyna Morawska were the years from the 1850s-1870s, dominated by the activities of Józef Sikorski and people from the circle of Ruch Muzyczny. It seems that during this period interest in historiography or 'antiquities' diminished significantly, whereas contemporary creativity and musical life became the focus of attention. Sikorski himself, creator and editor of Ruch, was heavily involved in current criticism and music journalism, but it should not be forgotten that it was him who devised a plan of action regarding work with materials that were previously unavailable. Sikorski appealed to the clergy to open archives and monastic and church libraries in order to enable researchers and music historians to describe artefacts and documents of the past stored there and contribute in this way to a gradual enrichment of knowledge about (particularly) religious music and musical culture of past centuries. Sikorski's activities - both through personal journeys to provincial centres and contributory achievements created on the basis of the achievements from these journeys - gave the first Polish musicologists a legacy that cannot be overestimated. ${ }^{321}$

In the subsequent study by Katarzyna Morawska on the nineteenth-century studies of early music in Poland, two features of the second period of this study have been outlined: 'explicit clarification of the scientific goal of the detailed documentation tasks. The chief task is to develop the history of Polish music, which should be made from the point of view of the present and considered as a whole as a lasting achievement of Polish musical culture,',322 and an 'attempt to incorporate Polish music in the development of universal music history. $^{323}$ (As can be told from reading numerous articles and contributions, the emphasis placed on prioritising the issues related to the history of Polish music was also verbalised by the two founding fathers, Chybiński and Jachimecki, even at the time of their acute confrontation regarding different choices of manners of scholarly discourse). There are also the first major syntheses, which were an important point of reference for those interested in studying the past of Polish music: in Ruch Muzyczny Sikorski announced, in fragments, part his Krótki rys powszechnej historii muzyki [Brief history of common music] ${ }^{324}$, he also planned

321 Let us remember that Adolf Chybiński presented extensive material about Sikorski's visits to the libraries and archives of Pułtusk, Częstochowa, Piotrków and Łowicz, with reference to excerpts from his notebooks, several decades later (KM 1928/1, 82-85).

322 Morawska 1976, 45-46.

323 Ibid., 47.

324 For detailed bibliographic information see Bogdany/Michałowski 1957. 
a similar synthesis in relation to the history of Polish music, Maurycy Karasowski published Rys historyczny opery polskiej [An historical sketch of Polish opera], ${ }^{325}$ Kazimierz Łada, a trained violinist and composer, published the Historia muzyki [History of music] ${ }^{326}$ - these are just a few titles, which reliably, although still without the support of academic activities, laid the foundation for the next generation of historiographers.

As a period in the Polish study of music, the end of the century brought the years immediately preceding the birth of Polish musicology. At that time, both the number and the level of 'professionalism' of the publications grew, and Morawska observed the sources of this, among others in the increased access to professional European literature. As she wrote, 'important features of Polish musical writing of this period include ... the transition from writing a chronicle of history to the discussion of particular issues, dividing the history of music into smaller periods, centres, problems. Monographic musical writing was beginning to develop. On the other hand, the "history of history," which had been so popular in the past, was almost disappearing.... There is an awareness of the difference between the description of historical events regarding music and the study of musical creation itself.'327

325 Maurycy Karasowski, Rys historyczny opery polskiej poprzedzony szczegółowym pogladem na dzieje muzyki dramatycznej powszechnej [Historical outline of Polish opera preceded by a detailed review of the history of universal dramatic music] (Warsaw 1859). Furthermore, one can also add that Karasowski was an admirer of the works of Frederic Chopin (author of the book Młodość Fryderyka Chopina [Frederic Chopin's youth]. (Warsaw 1869) and Friedrich Chopin. Sein leben und seine briefe. (Berlin 1878), trans. to Polish Fryderyk Chopin - życie - listy - dzieła [Frederic Chopin - life - letters - works] (Warsaw 1882) and thanks to his work he is remembered as one of the first researchers from the field of Polish Chopinography and Chopinology.

326 Warsaw 1860.

327 Morawska 1976, 59-60. It can said that one of the examples of this type of research on music history was the still highly-regarded monograph by Ferdynand Hoesick (a Warsaw bookseller and publisher, literary expert and intellectual, and at the same time a passionate musicologist and propagator of the cult of Chopin) - Chopin. Życie i twórczość [Chopin. Life and work] (vol. I-III Warsaw 1910-11). Hoesick continued the above-mentioned monograph tradition, through his actions giving value to works based on striving to faithfully reproduce the originals and gather reliable documentation, as Irena Poniatowska also argues in an extensive biographical sketch devoted to Hoesick, see Poniatowska 1993/1. 
Still, however, musicology did not exist as a university study in Poland. Further ordering and cataloguing the library resources was undertaken by subsequent researchers of the musical past - Jan Kleczyński, Aleksander Poliński and Father Józef Surzyński. This time, they headed for the collections held in Cracow - the Wawel archives, Jagiellonian and Czartoryski libraries - resources that soon, based on modern methodologies known for studies abroad, were studied in-depth by the first Polish musicologists. Unfortunately, the lack of a fully professional preparation and unfair treatment of historical material brought Poliński an abundance of critics among the young blood educated in the West, contrary to the research works conducted by Father Surzyński, which were repeatedly, even after years, highly appreciated Adolf Chybiński, mainly for his initiative in editing music from the past (publication of compositions by Zieleński, Wacław of Szamotuły, Gorczycki and Pękiel in his own cycle Monumenta Musices Sacrae in Polonia). As we know, in the future Chybiński was the co-founder of another series of this kind (WDMP), and he regarded his editorial activities as one of the principal duties of a musicologist. Morawska devotes a separate section within her outline to this type of publication, indicating the two breakthrough positions for Polish musical editing, including the Śpiewy kościelne na kilka głosów dawnych kompozytorów polskich [Polyphonic church songs by early Polish composers] prepared by Józef Count Cichocki (1838) and the afore-mentioned Monumenta by Father Józef Surzyński.

The evolution of historical research (including the history of music), which could be traced in the nineteenth century, continued in the next century. Among several manifestations of historicism typical of the twentieth century, to which Irena Poniatowska drew attention in her speech during the jubilee tenth MAEO Congress in Bydgoszcz in 1994, ${ }^{328}$ for music historians, particularly those working in the first decades of the century, the closest was to pursue it as 'the need for knowledge, acquaintance with the past, or some of its manifestations for the purposes of historical synthesis'; ${ }^{\prime} 29$ but the generation which several decades later would have to get through the hardships of scholarly activity in the complicated political realities of the period of socialist realism (and also a narrow but active group of sociologising and aestheticising musicologists/musicians

328 Among others definitions, we can understand historicism as 'the desire to cultivate, practice the art of the past, expand the repertoire' and 'seeking models in the past as a result of the need for creative inspiration' and 'idealising the past, flowing from criticism of the present day, see Poniatowska 1995, 120-121.

329 Ibid., p. 120. 
working in the interwar period - Lissa, Łobaczewska) already saw historical research through 'understanding of the ideas and mechanisms of change that led to the current situation in music or music culture. ${ }^{330}$

Zbigniew Skowron, starting in one of his treatises ${ }^{331}$ from the then accepted view concerning the relationship of nineteenth-century musical historiography with models of contemporary general history, he treated precisely historicism (and therefore the study of social phenomena and cultural products in a broad context of their creation and on the background of general historical processes) as one of the cognitive tools of historiography, whereas 'in the foreground he places metahistorical reflections; to a lesser extent he includes the subject of music history in the strict sense, i.e. factography.'332 Upon considering the thoughts of Carl Dahlhaus contained in his Grundlagen der Musikgeschichte, ${ }^{333}$ he asks the German musicologist a question: 'Does historiography mean assimilation of the past, or rather practising the criticism of tradition?', and stops on the issue of the difference between this criticism in the nineteenth and twentieth century. If, after Skowron, we quote Dahlhaus 'the greater the pietism in reconstructing the past ... rather than criticising it, the greater the suspicion towards the testimonies that it evidences, ${ }^{334}$ perhaps it will help us understand the existence of an entire group of 'works-in-progress' by Adolf Chybiński, announced, refined, created for years and often unperformed, sometimes giving his adversaries a pretext for attack.

A hundred years of efforts to further and popularise the knowledge of music history, frequently undertaken by amateurs and enthusiasts, was not enough to lay a solid foundation for the new field of science at Polish universities. Let us recall that the medieval quadrivium was held dear in German and Anglo-Saxon culture and until the eighteenth century, music was a mandatory subject. From the turn of the twentieth century, departments of music in those circles were often staffed by groups of teachers. In Poland, on the other hand, ever since the study of music became an academic discipline, its teachers had to stand up against a general misunderstanding of musicology as a branch of science and justify its presence within the walls of academia. History has shown that the efforts taken a century earlier by Józef Elsner to ensure that classes on the knowledge of music

330 Ibid., p. 121.

331 Skowron 2002.

332 Ibid., 146.

333 Köln 1977.

334 Skowron 2002, 149. 
(in the framework of the Warsaw School of Music ${ }^{335}$ ) which took place within the walls of the University of Warsaw, generally could not count on the support of the university authorities. It seemed, however, that over time, when in the last decades of the nineteenth-century musicology faculties were being launched at major European universities, also on Polish soil, the situation may change. Maciej Gołąb, in his brief, but extremely interesting, outline of the beginnings of Polish musicology, including in the Polish context of the University of Wroclaw, wrote that 'formation of musicology on the current territory of Poland - in 1910 at the Friedrich Wilhelm University of Wroclaw, in 1911 at the Jagiellonian University in Cracow and in 1912 at the Jan Kazimierz University in Lviv - was ... the ultimate consequence of the hundred-year-old process of institutionalisation ... of the studies on music; a process that began in the history of European culture at the beginning of the nineteenth century.'336

However, this process was not over yet. Even ten-odd years after the inauguration' in Cracow and Lviv, in a different epoch and a different social, political and academic reality, when an organisational chart of Polish universities was being prepared at the Faculty of Philology in the University in Warsaw at the beginning of the 1920s, it was suggested that musicology should be excluded from higher education curriculum. Zdzisław Jachimecki reminded everyone of this a few years later during his speech at the opening of the Musicological Faculty at the State Conservatoire of Warsaw, a speech from which extensive fragments were published in the monthly Muzyka. ${ }^{337}$ According to him, over ten years of presence of this major at Polish universities was not enough to stop the representatives of Warsaw university from devising a project which stated that musicology 'should be excluded from higher education in Poland because it is not up to academic institutions to teach girls how to play dance music. ${ }^{338}$ The

335 On the subject of this first higher level music institution, see Dziadek 2011, 57-67, and also Chechlińska/Guzy-Pasiakowa/Sieradz 2001, 289-291.

336 Gołąb 2012, 3. It is also worth recalling a letter of Jan Józef Dunicz to Chybiński, as quoted by Gołąb, certifying that, for example, contact between libraries of the 'bor derland' universities was a day-to-day basis: 'I returned Zieleński's old print, according to the wish of Sir Professor, immediately to the Univ[ersity] Library so that it can be sent to Wroclaw' (Dunicz to Chybiński from Lviv 24 VII 1933, AACh-BJ, box 3-D 13/6). The idea which was controversial, in the context of the universities of Lviv and Wroclaw, of 'borderland' was tackled by Maciej Gołąb in the indicated article (Gołąb 2012 footnote 31 ).

337 Jachimecki 1934.

338 Ibid., 113. 
lack of widespread awareness of the scientific discourse about music - both in academic circles and in popular opinion - was also discussed around the same time by Seweryn Barbag in his short column on 'today's day' of Polish musicology: 'Polish musicology is still regarded as a mysterious field of science in the opinion of an enlightened citizen, whose awareness of the diverse phenomena and issues of musical knowledge is disproportionately primitive compared to his knowledge of history and literary criticism, about the problems of visual arts and theatre. This is not to mention the non-humorous, but simply outrageous sentiment of cultural spheres on the essence and the tasks of musicology. ${ }^{339}$

Adolf Chybiński had already tried to justify the purpose of the presence of musicology in the area of academic sciences in his inaugural lecture at the opening of the department entrusted to him in 1912 in Lviv. ${ }^{340}$ In the opening, he expressed the conviction that universities should not be treated only as institutions preparing students for public functions, but first and foremost as 'the highest scientific institutions' that give listeners 'higher academic knowledge.' Concerning musicology, one should not confuse theoretical and historical musical knowledge taught in the university classes with the improvement of practical skills, which is the purpose of conservatoires and music schools. However, practical preparation for musicological studies is necessary, unlike even in the case study of the visual arts or poetry, in which the researcher's practical skills are not nearly needed at all either to follow the development of the entire history of the discipline or to analyse the selected examples. At the same time, it must be understood that musicology often uses more exact methods than many of the humanities. It is impossible to conduct research on the historical development of music without knowledge of the theoretical basics. Also, vice versa - the lack of historical knowledge and knowledge of past eras means that 'proficiency in theoretical subjects of music does not go beyond the artisanal routine. ${ }^{341}$ Going further, one can neither 'judge' nor 'understand' a musical

339 Barbag 1935. He had already written in a similar tone in the past: 'The word "musicology" is, in the spheres of Polish intelligence, a term for a strange university study, the aim of which no one understands: it is kind of "black magic," available only to musicians who do not play an instrument, do not sing, do not compose nor orchestrate', see Barbag 1928, 108.

340 A comprehensive summary, prepared by Chybiński for the purposes of the publication entitled 'Uniwersytet a muzyka' [University and music], was published by Roman Chojnacki in Warsaw's PM (1913/2, 1-5 and supplementary text published there in PM 1913/19, 15).

341 Ibid., 2. 
work without knowledge of the epochs that both preceded and followed it, so that the basis of knowledge of music is, as indicated by Chybiński, the knowledge of its history in its various aspects: 'One of the most significant aspects of musical skills is the history of music, which gives us a view on the development of musical forms and styles, compositional techniques, recognised as the quality and manner of using melody, harmony, polyphony, vocal and instrumental texture. Here is the place where historical method and theoretical knowledge come together.... The subsequent relationship between theory and history is the mutual interaction of these areas of musical knowledge. If the theory is essentially on a par with history and constitutes the first condition of scientific work, then, on the other hand, for music practice and its history, it is indispensable to know the history of music theory. ${ }^{342}$

Following this path, one must assume that historical knowledge ought to be complemented with a number of auxiliary studies and, in this respect, Chybiński recognised some points of contact with other fields of university studies - history, paleography, history of literature, theology, philosophy, philology as well as specialised areas such as historical chronology, diplomacy, library studies as well as biographical information and statistics - amongst the abundance of others which he indicated. He associated the history of musical instruments with iconography, and considered 'folkloric area' - musical ethnography - as a particularly important section, 'with which musical skills maintain an unbreakable bond. ${ }^{343}$ Another supporting group are the natural sciences (acoustics, physiology, psychology) and philosophical (logic, aesthetics), which, according to the Adlerian division, including ethnography, belong to systematic musicology.

Justifying the necessity of including studies on music within the university structures, in the inaugural speech cited in Przegląd Muzyczny Chybiński also stressed that 'musical skills also [offer] themselves as a source of knowledge capable of providing significant help to other fields of learning.' He wrote: 'We know that in the studies on poetic metre, songs, the history of culture as well as psychology, psychiatry, and even social economy ... musical knowledge plays a significant role. ${ }^{344}$ He personally was explicitly tied to archival exploration and research, one of the pillars of historical musicology. Furthermore, he was convinced that Polish music (considered in the context of musical culture) ought to comprise the primary research material, penetrated - as he lamented at that

342 Ibid., 3.

343 Ibid., 4.

344 Ibid. 
time - to a minimum. He prepared his most trusted students for this direction, placing meticulousness in the documentation of sources above all else.

Chybiński returned to the same topic many years later, upon publishing an extensive essay 'Muzykologia wśród nauk uniwersyteckich' [Musicology amongst university sciences'] $]^{345}$ in the Katowice-based Myśl Muzyczna. Starting with a concise presentation of the history of many centuries of music studies at European universities, he aimed at answering his own question: 'why do music studies have an inherent right to occupy a rightful place amongst the fields of scholarship taught at universities. He found an analogy in related sciences, pointing to archaeology, history of art (or, as he asserts - 'fine arts studies'), studies on belles-lettres. According to Chybiński, the lack of understanding for the study of music, which was manifested by many people, could have been caused by the 'immateriality' of the object of musicological research, that is music itself, which cannot be touched nor seen. He assumed that this was also why representatives of exact science who deal with abstract mathematics often admired this art form. The professor also proved that it is correct to apply the Polish term 'muzykologia' [musicology] to his field of study by making a reference to the same terminology in English, French and Italian, excluding German (which might be surprising given that since the very beginning, Polish musicology had been based on the German model). Chybiński announced the further part of his reflections, this time regarding the scope and purpose of musicology in light of the current state of our scholarship, ${ }^{346}$ but he did not, however, realise these announcements.

His style of work and the methodology that he adopted was appreciated even at the very beginning of his academic career. Printing the text of his lecture given in Lviv in 1913 was most probably the first attempt to present the basics of musicology to the Polish academic and music community. It cannot be ruled out that it became the impetus for discussion on the importance of exploring historical sources. Józef Reiss also spoke his mind and presented his views on music historiography in an article published in Przeglad Muzyczny at the same time. ${ }^{347}$ Reiss pointed to Chybiński's recent publications as examples of works fundamental for Polish historiography, as well as Jachimecki's dissertation. He stated: 'Between the historical-musical essays using ... the method according to which source material is subjected to material and close evaluation, the works of Dr Adolf Chybiński ... and Dr Zdzisław Jachimecki are in the foreground. These three

345 Chybiński 1928.

346 Ibid., 12.

347 Reiss 1913. 
works ${ }^{348}$ may form the foundation for a bright synthetic construction, for they summarise, with little leftover, the germinal form of all almost all significant manifestations in the music of the sixteenth century. ${ }^{349}$

He also stressed how ungrateful a task it is to promote knowledge about music: 'Papers based on academic sources, despite their high scientific value, cannot count on being disseminated among the general public. They are meticulously carved, tiny mosaic stones, but they gain importance only when they become parts of a sophisticated whole, the elements of one coherent organism. The general public wants to be informed and instructed by means of established views and precise results, acquired through skilful analytical work.'350

Returning to Chybiński's view on 'building from the foundations' for the music historian, it is possible to recognise that he realised that he would make Herman Kretzschmar's (who to the question 'what can university teach about music' answered that everything that contributes to a deeper understanding of music that music schools do not teach ${ }^{351}$ ) postulate, cited in the article cited above, a reality, it is necessary - within one centre - to divide the work, specialise and separate didactic duties between several 'scholarly' forces, so that all musicological knowledge could be received by students in every field at an equally high level of competence. ${ }^{352}$ The aim of the speech printed by Chojnacki was not to present a detailed classification of musicology. We need to remember that the speech was originally aimed at the university teaching staff. A large group of university teachers, as has happened more than once in history, did not understand the difference between practical musical education provided by conservatoires and strictly scientific instruction offered to graduates of this major. On the other hand, the speech was also aimed at young musicology novices, who often

348 Adolf Chybiński, Materiały do dziejów królewskiej kapeli rorantystów na Wawelu [Materials for the history of the royal chapel of rorantists at Wawel] (part I: 15401624, Cracow 1910); also, Teoria mensuralna w polskiej literaturze muzycznej pierwszej połowy XVI wieku [Mensural theory in Polish music literature of the first half of the sixteenth century] (Cracow 1911); Zdzisław Jachimecki, Wpływy włoskie w muzyce polskiej [Italian Influences in Polish Music] (part I: 1540-1640, Cracow 1911).

349 Reiss 1913, 8.

350 Ibid., 9.

351 Chybiński refers to Hermann Kretzschmar's reflections in his Musikalische Zeitfragen: Zehn Vortrage published a few years earlier (Leipzig 1903).

352 Almost a quarter of a century later in his Systematyka muzykologii [Musicological systematics] (Barbag 1928, 109) Seweryn Barbag wrote about the fact that 'specialisation in musicology is unavoidable.' 
failed to grasp the differences between attending a conservatoire and a university and opted for university education unaware of the in-depth knowledge that they would be expected to master. So what was expected of candidates applying for admission to musicology? Well: 'a thorough knowledge of harmony, counterpoint, and musical forms, at least a basic knowledge of instrumentation and score reading. No candidate applying for admission to this new department that year had any idea what a musicology professor may demand; that is why that year's students of doctor Chybiński had to fill knowledge gaps under his supervision and with huge effort on their own part.'353

Here it should be emphasised how different in this respect the situations of Lviv and the aforementioned Wroclaw were, as we learn from Agnieszka Drożdżewska's monograph about local musicology ${ }^{354}$ and the article by Maciej Gołąb already quoted. The department led by Otto Kinkeldey had its roots in Das Königliche Akademische Institut für Kirchenmusik, whose last leader was the outstanding music historian and collector of musicalia, Emil Bohn. Other Wroclaw music societies, which for decades had been gathering collections that cannot be overestimated for the work of academic institutions, provided not only artistic and intellectual support, but above all library and archival resources for musicologists: Verein für Kirchenmusik existing from 1819, Singakademie (from 1825), and functioning in the first decade of the twentieth century, the Philomusische Gesellschaft.

Neither Adolf Chybiński nor Zdzisław Jachimecki could rely on such source materials. They created their libraries from scratch, often using their own funds. Generally, they also could not count on the local community and its understanding of the essence of the majors they designed. The anonymous author of the words cited above was delighted with the fact that a musicological department was opened in Lviv and firmly believed that appointing Chybiński as associate professor of Lviv Alma Mater would make it clear to everybody that musicology is an academic discipline. He was all the more impressed with the fact that the activity of the department was supposed to be inaugurated with a monographic lecture on the hermetic and unpopular topic of 'mensural notation. For the record, let us recall that at the same time, Chybiński organised compensatory classes to help students catch up with the basics of music knowledge. In the first semester, he introduced lectures on more general topics (such

353 'List ze Lwowa (Kilka uwag o stosunkach muzycznych)' [Letter from Lviv (A few comments about musical relations'] (PM 1913/18, 11-14, see p. 13).

354 Drożdżewska 2012, particularly chapter II.1.; see also Drożdżewska 2011. 
as the history of the fifteenth- and sixteenth-century polyphony and theory of counterpoint in the sixteenth century) and classes devoted to the analysis of Beethoven's sonatas. In the next semesters, he added more lectures: on instrumental works by Bach, on symphonic poems by Liszt and Strauss, and a review of the development of the sonata (from Beethoven to Reger). In the following years, he managed to take up topics ranging from medieval music (e.g. medieval musical palaeography) to the works of nineteenth-century composers. ${ }^{355}$ Neither the programme of the Lviv department (focused mainly on the study of musical 'antiquities') nor other centres (Cracow with a focus on the history of music of the nineteenth century, Poznań developing a fruitful ethnomusicology programme) were able to fill the whole spectrum of musicological problems. Even a quarter of a century later, Seweryn Barbag still pointed to the gaps that still needed to be filled: 'Numerous branches of music scholarship do not have representatives in Poland.... And none of the above-mentioned Polish universities has any specialist for natural musicology (acoustics, psychophysiology, or instrumentology), only comparative musicology initiated by dr Wójcik-Keuprulian ... No one lectures the theory of composition in the framework of a systematic history of forms, nor aesthetics nor psychology; there are also no separate style studies, no one deals with the sociology of music.... In the musicological departments, there is almost only the history of music, especially Polish, and folklore is vastly expanded.'356

Several years of stagnation followed (starting from 1914 and ending with 1918, and even 1920) caused by war (to a lesser extent in Cracow, more in Lviv, where, for example, the classes in the academic year 1914/1915 were completely suspended). This stagnation hampered the development of Polish music studies at the very beginning of its existence. In such a difficult moment, just after entering into a new, independent reality (although at the beginning of another conflict, albeit local, Polish-Ukrainian War, and within it more than six months of the siege of Lviv), on the pages of the first issue of Gazeta Muzyczna, newlylaunched (and despite unfavourable circumstances) by Stanisław Niewiadomski, who had recently arrived, the sense and secrets of this poorly promoted new discipline, though present at universities for several years, were described by Bronisława Wójcikówna. In a short sketch titled 'Muzyka jako przedmiot studiów uniwersyteckich' [Music as a subject of study at university] ${ }^{357}$ at the outset she emphasised that 'learning music at the university is neither learning

355 We can find the full programme of activities in Hrab 2009, 143-158.

356 Barbag 1935, 19.

357 GM 1918/3, 21-22. 
composition nor does it deal with the education of performers [because] the aim of musicology is to examine the developmental process of music, and on this basis to learn the essence of this art. ${ }^{358}$ On the one hand, it is a historical branch of science which studies, for example, the history of musical notation, musical forms, and instruments (using a whole array of auxiliary sciences, such as diplomacy, biographical studies, linguistics, and plastic arts history, among others); on the other hand, 'as a philosophical science ... it only studies the musical matter, that is sound, in various combinations ...: it studies function, rhythm, melics ... and strives to justify the laws it discovers. ${ }^{359}$ According to Wójcik, the laws governing these relations influence the determination of the category of beauty in music, and this is already a matter which falls within the scope of aesthetic considerations, and furthermore - philosophy. The primary mode of action of a musicologist is analysis, which, subject to further generalisations, aims at forming a synthesis.

This brief statement by Bronisława Wójcik can be considered on the one hand a 'new opening' of musicology for the youth interested in studying in this field after several years of wartime trauma and in the free Polish state. On the other hand it can be treated as one the first presentations (very simply) on the Polish market of systematics of the musicological field; subsequent attempts, much more robust, were soon undertaken by other Polish musicologists, including the author herself and her colleague-peer from Lviv, Seweryn Barbag (more below).

Zdzisław Jachimecki approached the issue of presenting the field he was practising differently. He wrote about native musicology in the pages of Polska Wspótczesna, addressed to intellectual circles of the Cracow quarterly 'devoted to civic education. ${ }^{360}$ The article indicated, in a concise form, current achievements of Polish music historiography, with an emphasis on the achievements of modern (at that time) Polish musicology: the nineteenth-century 'dilettante attempts' by Józef Cichocki, 'encyclopaedic work' by Wojciech Sowiński, 'the history of opera' by Maurycy Karasowski and pre-1880 'monographic studies on Chopin' he opposed to publications of the founder, as he called him, of Polish music historiography of music - Fr. Józef Surzyński and then (poorly evaluated by the next generation of music historians) Aleksander Poliński. He emphasised that the activities of these musicographers in the next two or three decades were supported by modern knowledge from young musicologists educated at German

358 Ibid.

359 Ibid, 22.

360 Jachimecki 1923. 
universities - the author of these words - Zdzisław Jachimecki, Adolf Chybiński, Józef Reiss, Henryk Opieński, Łucjan Kamieński. They became the basis of new personnel in Polish institutions while being 'almost the only co-workers' of the most important music press titles (Przeglad Muzyczny and the first edition of Kwartalnik Muzyczny). Jachimecki stressed that 'the complicity of several musicologists became soon distinguishable in Polish music literature and Polish scholarship in general. ... An overview of works issued in the last five years ... will allow us to realise the tasks accomplished in this field. ${ }^{361}$

This task was not just to teach a small group of students attending musicological departments or to have a discussion with a growing group of music publicists, critics, and music lovers, but also to promote Polish music and Poland itself abroad. According to Jachimecki, this was evidenced by a paper written by Henryk Opieński La musique Polonaise, essai historique sur le développement de l'art musical en Pologne. ${ }^{362}$ Other publications being created in the form of textbooks, like the mentioned Historia muzyki $w$ zarysie [An overview of music history] by Józef Reiss, ${ }^{363}$ and monographs, also announced in the pages of musicological journals and series by Polish and foreign publishers, also had the value, that they effectively inhibited the influx of publications dedicated to our musical circles from European (and mainly German) sources, in which it is often possible to feel the stigma - today we would say - of colonialism.

According to the author of the article, 'for the time being, the fields of aesthetics and pure theoretical speculation present themselves poorly in Polish musicology. ${ }^{364}$ Let us remember that when he wrote these words in 1923, two graduates of the department in Lviv were about to start independent activity there - Stefania Łobaczewska and Zofia Lissa, both with a lively interest in systematic musicology; Łobaczewska, however, made her first attempts before the war with topics from the field of musical aesthetics in the pages of Przeglad Muzyczny, ${ }^{365}$ just like Zdzisław Jachimecki ${ }^{366}$ himself. The researchers successfully

361 Ibid., 126, 127.

362 Paris 1918.

363 Warsaw 1920.

364 Jachimecki 1923, 129-130.

365 Stefania Gérard de Festenburg [Łobaczewska], 'W kwestii pochodzenia muzyki' [In the question of the origins of music] (PM 1911/11, 6-10, 1911/12, 1-4); also, 'Schopenhauer o muzyce' [Schopenhauer about music'] (PM 1912/4, 1-5).

366 'Wyraz i technika kompozytorska w muzyce polskiej' [Expression and compositional technique in Polish music] (PM 1910/20, 11-14); also 'Stefano Arteaga i Ryszard Wagner jako teoretycy dramatu muzycznego' [Stefano Arteaga and Richard Wagner as theoreticians of music-drama] (PM 1912/11, 1-8, 1912/12, 1-6, 1912/14-15, 1-5). 
established the foundations for this branch of musicology (as well as philosophy, psychology and pedagogy) and in the future made a significant contribution to its development also in the international field.

Jachimecki's brief presentation in Polska Współczesna ended with a reflection on the lack of Polish musical journalism ${ }^{367}$ and monumental editions of Polish music artefacts, which did not even satisfy - according to him - the special publishing commission called up for this two years earlier in the Department of Culture and Art of MWRiOP. There was still hope that 'the staff involved in this branch of science, which is based on the most precise research methods possible and supported by a whole array of auxiliary measures, will be growing steadily to serve knowledge and society.' ${ }^{368}$

A few years later Chybiński once again presented the historian-musicologist's tasks in Poland. Nearly twenty years after the publication of the Lviv inaugural lecture from 1930, he presented his views on historical musicology in Muzyka. He wrote, amongst others, that: 'One can deal not only with Polish music, or even not deal with it at all. However, I think that there are many reasons to not deplete the research on the history of Polish music for the benefit of others, provided you have sufficient reverence for the development of native art.... While being, for example, a Polish music ethnographer, is it worth exploring the music of American Negroes, since Polish folk music remains almost completely unexplored? ... In any case - in my opinion - research on the history of music and musical culture in Poland must constitute a focal point of the work of a Polish historian-musicologist.'369

Extensive consideration on this subject was preceded by a reminder of the difficult beginnings of Polish music scholarship, when the work was not limited to 'scholarly creation,' but for the training of new academic workers, it was naturally necessary to take on the burden of organisational and pedagogical activity. ${ }^{370}$ Moreover, even those efforts did not yield entirely satisfactory results, because not all 'doctors in musicology' remained in pursuit of academic musicology and strictly scientific research. Once again, he argued that scientific research on both the creativity and musical culture 'must take place not only in terms of musical material but the archives as well. Only a synthesis of these studies

367 This was about scholarly musicological titles, because journalism and music criticism were quite good at that time, although not without significance, of course, was the interruption in the edition of press titles caused by several years of war turmoil.

368 Jachimecki 1923, 130.

369 Chybiński 1930.

370 Ibid., 588. 
can create a picture of music's historical reality. ${ }^{371}$ In addition, this should be accompanied by musicological works on editions of artefacts of early music, an example of which are the few publications, significant for Polish scholarship and culture, of the series Monumenta Musices Sacrae in Polonia by Father Surzyński, Melodie psalmowe edited by Józef Reiss, Stanisława Ferkówna and Roman Ferek, and initiatives new at that time - the editions of Wydawnictwa Dawnej Muzyki Polskiej [Publications of early Polish music] and Monumenta Musices Medii Aevi in Polonia prepared by a group of Lviv musicologists.

The academic work of a historian should be accompanied by 'desirable and necessary' activities which promote knowledge. However, it may also have 'a negative effect on scientific output.' 'Promotion of musicology in our country is currently ... an ad hoc activity, which can be effective only when it is preceded by precise research.... A mistake made in an academic paper does not bring about universal damage, whereas a mistake made in a work aimed at the general public does. ${ }^{372}$

For the musicological community, the innuendos hiding in these last sentences were clear. ${ }^{373}$ Together with the words about pseudoscientific snobbism spoken in the same text by Chybiński, they triggered the reaction of Zdzisław Jachimecki, who soon published a polemic in Muzyka, ${ }^{374}$ proposing 'agreeing on the basic postulates of Polish musicology and the manners in which to implement them. ${ }^{375}$ And the difference between these basic postulates between the Lviv and Cracow schools was primarily that under Wawel they did not consider that it was necessary towards archival research to sacrifice one's 'entire life force, ... to print dozens of pages with mechanical extracts from old inventories and to parade with this as if a scientific achievement. ${ }^{376}$ In the year 1931 Jachimecki was already the author of many monographs. ${ }^{377} \mathrm{He}$ complained of using archival

371 Ibid., 591.

372 Ibid, 594.

373 The diametrical difference in the treatment of historical musicology as a science by the Lviv and Cracow departments was well known, as well as the understanding of the functions and tasks of musical-historical publications by the heads of both departments. On the subject of Jachimecki's erudite, humanistic and interdisciplinary approach to musicological research, while avoiding excessive detail, see Przybyszewska-Jarmińska 2016.

374 Jachimecki 1931.

375 Ibid., 24.

376 Ibid.

377 Here we can mention Historia muzyki polskiej ( $w$ zarysie) [History of Polish music (An overview)] (Warsaw 1920), Wagner. Życie i twórczość [Wagner. Life and work] 
queries as the sole determinant of their formation almost from the beginning of his research activities. As to Chybinski's belief that it is impossible to create syntheses 'complete and free of gaps, ${ }^{378}$ before all the historical material is gathered, he replied with one sentence: 'the sense of history is not based on storing "everything," but on correct ordering of significant historical values. ${ }^{379}$ He defended his rich heritage especially in compact publications, opposing them to quite a few achievements of a similar type made by his adversary from Lviv, mentioning and not without irony - the long-announced monograph on Bach, the planned 'monumental collection of folk songs', the unpublished although signalled for years works on the methods of collecting and organising folk melodies, ${ }^{380}$ the organisation of work on folk melodies ${ }^{381}$ and on the tasks of Polish musical ethnography. ${ }^{382} \mathrm{He}$ completely agreed, however, with Chybiński as to the main task that ought to be fulfilled by every 'former,' 'semi-' and 'complete' Polish musicologist who 'has a passion for the work and the research subject, therefore for Polish music, and will be thus glad to continue studying our musical past in hope that by doing so he will contribute to the welfare of social culture. ${ }^{383}$

(Warsaw 1922), Fryderyk Chopin. Rys życia i twórczości [Frederic Chopin. An overview of his life and work] (Cracow 1927).

378 See Chybiński 1930, 590.

379 He recalled that Chybiński, before he researched 'everything', himself became the author of two syntheses: 'Muzyka kościelna w Polsce' [Church music in Poland]. Addition in: Karl Weinmann: Dzieje muzyki kościelnej [History of church music]. Ratyzbona/Raciborz [1906]), and the study 'Z dziejów muzyki polskiej do XVIII w.' [From the history of Polish music to the XVIII century'] (Muzyka 1927/7-9, 31-73).

380 This remark may be surprising, as already in 1907 Chybiński published an extensive dissertation on this subject: 'O metodach zbierania i porządkowania melodii ludowych'[About methods of collecting and organising folk melodies] (Lud 1907/13, 171-201), which Jachimecki did not remember (or perhaps did not know?). Years later he returned to the same theme, preparing 'Wskazówki zbierania melodii ludowych' [Indications on how to collect folk melodies] (PM 1925/1, 6-12, 1925/2, 1-9).

381 Adolf Chybiński, 'O organizację pracy nad melodiami ludowymi' ['About the Organisation of Work on Folk Melodies'] (Lud 1922/21, 29-39).

382 Chybiński published the two-part sketch 'O potrzebach polskiej etnografii muzycznej' [About the needs of Polish music ethnography] after WWII, in the pages of the newly establish quarterly Polska Sztuka Ludowa [Polish folk art] (part 1. 'Zagadnienia Kolbergowskie' [Kolberg's Issues], 1947,1-2, 16-19, part 2. 'Zagadnienia pokolbergowskie' [Post-Kolberg issues], 1948/1, 6-8).

383 Jachimecki 1931, 27. The source and the history of the long-term reluctance of both Nestors of Polish musicology can be traced in their correspondence, see Troski $i$ spory 1983. 
A kind of re-opening of wounds took place from time to time, sometimes with regard to matters that were already distant, such as Chybinski's polemic concerning the essay published twenty years earlier by Jachimecki, Rozwój kultury muzycznej w Polsce [Development of musical culture in Poland] (and the idea presented there by the author of Liszt's alleged influence on the work of Mieczysław Karłowicz), ${ }^{384}$ and Jachimecki's answer to this polemic. ${ }^{385}$ It did not put an end to the discussion. The swordplay concerning priorities in the approach to different research styles continued. Chybiński wrote that 'brochures and leaflets written by the professor from Cracow do not bring knowledge one step forward, but they are full of words which express dissatisfaction with those who ... cannot accept ... many views held by professor Jachimecki. ${ }^{386}$ Jachimecki answered with these words: 'Prof. Chybiński always tolls with great emphasis at the huge bell of "Science," when trying to convince the readers of his numerous forays into thinking against my views, into believing that they do not deserve trust as being void of any scientific basis. ... This science, to which Professor Chybiński is always referring, is indeed very small, written by the smallest " $\mathrm{s}$ "

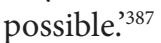

In a commentary on this dispute between the founding fathers Seweryn Barbag submitted a column to the editorial office of Muzyka, summarising the current situation of musicology as not the best, though promising, provided that the 'embattled disagreements' were discontinued in the face of a situation in which 'the fight is still valid, the hatred is seething, but neither victors nor losers can be seen' and considered one of the necessary requirements for 'the fully-fledged functioning of Polish musicology' to be the 'cessation of fruitless and harmful personal attacks. ${ }^{388}$ The 'unpleasant matters' of the Polish musicological environment had already been discussed openly for a long time. A few years earlier, in the monthly, its editor-in-chief, Mateusz Gliński wrote a short column called 'Musical impressions': 'Such relations exclude any possibility of calm, systematic work, and make it difficult, if not completely impossible, to introduce any healthy competition and fruitful exchange of ideas, which constitute a prerequisite for progress in any field. They paralyse the organisational

384 Chybiński 1934/1.

385 Jachimecki 1935/2.

386 Chybiński 1935.

387 Jachimecki 1935/1.

388 Barbag 1935. 
development of our musicology, discredit it in the eyes of Polish society and remarkably reduce our achievements in this field in the eyes of foreigners. ${ }^{3} 39$

The pleas, which Gliński put in his 'impressions', also gave rise to other similar expressions of opinion. From time to time there were words of criticism aimed at the discipline and actions of its representatives spewed by some journalists who questioned the sense and value of research that came down, in their understanding, to the collection and analysis of historical details useless for presenting the history of music to a wider audience. Here, Jachimecki's unwillingness to practice these kinds of studies on music was accompanied by voices of representatives of non-academic circles of Warsaw journalists and music critics, namely Leopold Binental and Karol Stromenger. There was a well-known controversy, raised and flared by part of Warsaw society at the turn of the 1920s and 1930s, concerning the futility of devoting funds from the FKN to such an ineffective (and inefficient) activity as scientific publications produced only for a handful of specialists. Allegations were made of supporting 'paper and pedantic tedium. ${ }^{390}$ The defence against both this type of writing and the meticulous, archival searches and analyses that took place in the comforts of offices and archives was undertaken by Mateusz Gliński, who saw at least part of the problem as resulting from the short history of the discipline and the small number of adversaries prepared for specialist discussion. He emphasised the analogies that join partial laboratory experiments typical of exact and natural science, marked with reports on these experiments abundant in numbers and symbols (which 'always has a somewhat non-public feature as it remains, despite being published, within the narrow limits of a small group of scholars united by kinship of undertaken topics'), with equally partial 'contributory' humanities research stages, perhaps uninteresting for the popularisation of universal studies on music, yet needed to move from analysis to synthesis. ${ }^{391}$

In the 1930s, Julian Pulikowski - enfant terrible of the Warsaw music and musicological society - decided to present his vision of musicology and solutions that link it to musical life. He exemplified his controversial ideas, amongst

389 Muzyka 1931/1, 29-30.

390 Stromenger 1930/2. At the same time, Karol Szymanowski, amongst others, criticised Chybiński's attitude, at the same time also supporting Jachimecki in the dispute: 'About Ch[ybiński] - this is really a grim matter for me - such "smallness" in a man ... What's worse: completely psychologically incomprehensible ... at the level of your tasks and works, he almost brushes against some paranoid psychosis!'; see Szymanowski III, part. 3, 511 .

391 Gliński 1930. 
others, by presenting a plan for organising musicology studies at the University of Warsaw, as already mentioned above at the presentation of musicological centres. He, in turn, saw the nature of the widespread misunderstanding of this field of studies in the lack of cooperation between musicologists and musicianpractitioners, while the latter should familiarise themselves with professional publications that would help them cultivate this art form with full awareness. Moreover, he quite imprecisely stated that musicology should 'enrich musical life; to simplify the task of musical creativity; rush to the help of a music performer; give the music lover the deepest possible experience; provide the music teacher a well-thought-out and proven basis for practical and theoretical education in music, music criticism should lead to an opinion which is justified and free from prejudices. ${ }^{392}$ Albeit, it is difficult to determine what he understood through all this. Pulikowski paid particular attention to music critics, who had the task of presenting the most competent assessment, based on a thorough musicological education (this refers less to criticism of performance, more to criticism of the piece, compositional technique, resulting from objective, scholarly criteria), which would help form higher and higher expectations amongst average listeners to the presented repertoire. At the end he demanded to use the term 'musicologist' only to persons thoroughly educated in this direction, acting on the floodplain of academic researchers instead of each and every author of a publication on music material, and serving primarily for popularising music.

As can be seen from the above-cited opinion, both musicologists and other persons to whom this subject was not inconsequential from time to time recalled in the debate about the shape of this young discipline on the floodplain of Polish humanities, that the image of musicology and expectations as to its shape, the nature of the research, teaching models, programmes of individual departments or rhetorics of professional publications appeared to be extremely diversified. It seems important, however, that such discussions took place at all, which might mean that in short time since the birth of this discipline in Poland it was not niche and managed to cause excitement throughout a wide group of academics, critics, journalists and artists. This notion is confirmed by the words of Mateusz Gliński that 'sometimes we talked about this with a number of colleagues who were also interested in ... the raised matter of musicological research and progress of works in this field. ${ }^{393}$

392 Pulikowski 1934, 204.

393 Gliński 1930, 683. 
In these years Stefania Łobaczewska and Łucjan Kamieński joined in the discussion about the principles of musicological research, preferred methodologies and the essence of this science. The latter prepared an article for Muzyka, which briefly describes in historical terms the achievements of Polish musical ethnography, including from before its university period. ${ }^{394}$ Let us note that he had a special mandate to draw such a conclusion: upon developing the department of musicology as entrusted to him by the authorities of the University of Poznan, on the one hand, he took into account his own interests, and on the other hand, the visible gaps in the area of studies on folklore in the existing centres in Cracow and Lviv. In the programme of studies he proposed, he placed great emphasis on this subject. Here we should also remember that in the area of Polish musicology he was the creator of the term 'ethnomusicology.'395

Stefania Łobaczewska, in turn, received an invitation from Mateusz Gliński to prepare material on the subject of musicology for the monograph edited by him under the title Muzyka polska. ${ }^{396}$ She began her outline with a brief estimation of the history of the discipline, paying attention to the presence of music theory in the golden period of the Jagiellonian University (15th-16th century) and the broad reception of all the most important European theoretical treaties throughout that time in the Cracow Alma Mater. Łobaczewska placed the next opening on the expertise on music around the mid-nineteenth century, recalling the figures and accomplishments of Józef Cichocki, Józef Sikorski, Fr. Józef Surzyński, Aleksander Poliński, Ferdynand Hoesick and - closer to her times - Opieński, Reiss and the founding fathers - Chybiński, Jachimecki as well as Kamieński, and further - musicologists of her generation - Bronisława Wójcikówna and Seweryn Barbag. In brief, she also characterised the profiles of

394 Kamieński 1934.

395 This is how he saw the transition from description to general considerations of scholarship about mankind and culture: 'I started to write a paper entitled "Nuta o Krzyżu" w śpiewnikach Jana Seklucjana [Note about the cross in the songbooks of Jan Seklucjan], a preliminary study of Polish musical ethnology. [...] By combining folklore with the study of hymnals and sequences, we can go from musical ethnography to ethnology' Kamieński to Chybiński from Poznań 24 VII 1926, AACh-BJ, box $6, \mathrm{~K}-3 / 28$.

396 Warsaw 1927. This publication, like several other collected monographs edited by Gliński (Muzyka współczesna [Contemporary music], Warsaw 1926, Nowa muzyka [New music], Warsaw 1930, Opera, Warsaw 1934 and others) was prepared by the Muzyka magazine and, as mentioned, filled the publishing year during the summer downtime. 
research conducted by Polish musicology centres. In 1927, when she prepared her brief outline of Polish musicology, she considered issues of national music monuments as one of the most important tasks for the representatives of this field of studies, while regretting that the issue of 'Pomniki muzyki religijnej i świeckiej w Polsce' [Monuments of religious and secular music in Poland], which was launched in 1921, still remained in planning while the prepared materials for the first issues of Monuments edited by dr. Chybiński at the department of Gebethner and Wolff in Warsaw await better times. ${ }^{397}$

At the turn of the twenties and thirties, when Polish musicology (despite material miseries) was already well-established in academic structures, Seweryn Barbag and (again) Bronisława Wójcik-Keuprulian - each separately - were tempted to 'organise' the field they dealt with. Barbag published his dissertation called Systematyka muzykologii [Musicological systematics] (both in the form of a compact publication, referred to here earlier and also - in parts - in the pages of the periodical ${ }^{398}$ ) in the magazine Lwowskie Wiadomości Muzyczne i Literackie. What induced him to write the paper was his conviction that 'the value of systematics lies in being aware of the organic connection that exists between individual phenomena, facts and issues and general knowledge, [whereas] each idea needs to be manifested in such a form so that it is possible to capture it logically as a representation. ${ }^{399}$ He put his thoughts in five parts: In the first, he took up the subject of musicology, in the second - 'the entirety of the material', followed by a review of German systems. Chapter four was an extract of mandatory bibliography to complete musicological studies (for practical purposes he even left blank pages for notes on the reading). Finally, all was crowned by 'Comments on musicological studies' which are a set of Barbag's loose remarks of this field of science.

Assuming that 'knowledge' is a broader term than 'science,' he began by saying explicitly: 'Musicology is knowledge about music. Its subject is all of the phenomena, facts and problems, scientifically and practically in direct or indirect relation to music combined. ${ }^{400}$ She explained how she understood these concepts on the first pages of the work. She devoted the preliminary considerations to the mutual complementarity of approaches towards 'the world of tones': perception of music in the context of science and art, division between musicology as

397 Łobaczewska 1927, 151.

398 See LWML starting from number 1927/10 from the year 1927 with breaks to 1929/11.

399 Barbag 1928, 18.

400 Ibid., 7. 
'cognition' in opposition to music as an 'object of cognition.' Here she mentions the names of German scientists - Handschin, Kretzschmar, Adler - which can be considered as an indication (and this is confirmed by other chapters of the essay) that Barbag also identified with the circle of German schools yet subjected them to criticism. For example, she noted that in his systematics Adler ignored music sociology (which was justifiable as sociology did not exist as an independent field of science at the time of the publication of Umfang, Methode und Ziel der Musikwissenschaft in 1885) and also attached insufficient weight to acoustics, 'tone-forming mechanics' and physiology of musical hearing, recognising them merely as auxiliary sciences. Finally, Barbag underlines the 'uniqueness' of Adler's assignment of the term 'musicology' only to research from the field of ethnography.

Barbag did not relate Riemann's Grundriss der Musikwissenschaft (1919) but rather recapitulated its assessment on the pages of Zeitschrift für Musikwissenschaft (1920/1) submitted by Arthur Wolfgang Cohn. Perhaps he valued, among others, Cohn's ideas such as the one in which he indicates philosophy, as a discipline representing a synthesis of all the special and distinct sciences, on the first and chief place before them. Bringing Cohn's original systematics a little closer, he stressed that the author of Die Erkenntnis der Tonkunst, Gedanken über Begründung und der Aufbau Musikwissenschaft (1919) himself 'created ... a very logical and consistent division of musicological knowledge' opposing general musicology against detailed musicology and dividing the 'intuitive' disciplines from 'inductive', whereas history occupied a special place in this systematics.

Barbag concluded his reasoning in this brief review of selected systematics and devoted the rest of the work to presenting a selection of bibliography from the existing European and Polish literature, mandatory for any student of musicology.

Barbag's Systematyka met with great interest throughout the musicologist community, an assertion confirmed in the pages of contemporary newspapers as well as personal correspondence. It was assessed in different ways. Łucjan Kamieński was sceptical towards this new publication. Shortly afterwards he wrote about his impressions to Lviv: 'What do you think about Barbag's Systematyka? Interesting thing. It seems to me, however, that it fails to sufficiently separate musicology as a science from the conservatoire based practical teaching of music [sic] (of this "knowledge" of Rytlów et consortium). It is unfortunately not suitable to serve as an introduction to musicology for beginners, just as Riemann's "Grundriss," and therefore I do not introduce it at all.'401 
Stefania Łobaczewska showed keen interest and expressed her opinion about the work twice. On the pages of Muzyka, she wrote that the adopted systematics deserved acclaim, and its main advantage was the fact that it treated the entire knowledge of music 'from the point of view of an organic and necessary connection of music as an art with science, and practice with theory.402 According to Łobaczewska, the task undertaken by the author was to standardise the relationships between individual fields which he had distinguished, such as philosophy of music, theory of artistic technique, music practice, natural musicology, sociomusicology and music history (along with auxiliary sciences). The reviewer also appreciated Barbag's erudition and the fact that he emphasised, 'the role of philosophy of music in the structure of musicological sciences', (which was close to her heart). ${ }^{403}$ Evaluating Systematyka in the pages of LWML, ${ }^{404}$ as the basic merit of the work, she considered putting music history on a par with fields taken into account by Barbag - philosophy of music, theory of artistic techniques, natural musicology, music sociology and a range of auxiliary sciences. According to Łobaczewska, another achievement in the field of discipline systematics was underlining the role of sociology and dividing philosophy of music from musical aesthetics and separating psychology from physiology. ${ }^{405}$

In the extensive review included in the pages of Kwartalnik Muzyczny Bronisława Wójcik-Keuprulian, ${ }^{406}$ similarly to Łobaczewska, as one of the basic values adopted by the author of the assumptions, recognised the emphasis of 'an inseparable connection between practice and theory, art and science, ${ }^{3} 407$ and as new and valuable - including questions quite specifically understood by Barbag, such as 'emphasising the importance of the philosophy of music and delimiting it from aesthetics, placing emphasis on musical sociology. ${ }^{2} 08$ Nonetheless, she also claimed that the author in the central part of the work only enumerates a series of musicological sciences, setting out their mutual relationships (including relationships with other humanities), which makes the whole resemble an 'introduction to musicology' rather than scholarly systematics. The second allegation

\section{2 Łobaczewska 1931.}

403 Ibid.

404 1930/7-8, 5.

405 For precision we should add that Barbag in general considered that "Aesthetics" as an interchangeable concept for the philosophy of art ... is an inaccurate term and irrelevant in its original meaning,' see Barbag 1928, 31.

406 Wójcik-Keuprulian 1931.

407 Ibid., 324.

408 Ibid., 325. 
relates to the not entirely consistent classification attached at the end of the said extensive bibliography. However, as a whole, it was assessed very positively with an indication of the particularly high educational value of the publications.

It is difficult to assess the extent to which Wójcik-Keuprulian had based her idea on systematics at that moment in time; it is enough to state that only a few years after the publication of Barbag's systematic, the musicologist published a habilitation lecture, which she had the opportunity to deliver at the Jagiellonian University on April 28, $1934 .{ }^{409}$ Starting from a cursory presentation of the history of the field, she posed the question of whether musicology is one science or a collection of sciences. ${ }^{410}$ Just like Barbag, she undertook to review and assess the selected systematics, and for her further considerations, she selected three areas belonging to the general study of music: acoustics included in the systematic field, palaeography as one of the historical studies and aesthetics as part of the philosophy of music. This choice allowed her to indicate a variety of research methods that can be used in musicology. The author devoted many pages to acoustics, which as a 'physical and mathematical' branch of science is not only directly related to sound, which is the object of its research, but also, as Wójcik wrote, 'does not break its ties with music as an art form, which means that by necessity it draws from other sciences related to musicology, such as music history, ethnography, psychology and aesthetics. ... music acoustics, which laid the foundation for the aforementioned fields, is a constituent of a vast and varied study of music, that is musicology, so it is not exclusively and solely a branch of physical and mathematical sciences.'111 To Julian Pulikowski this perception of acoustics seemed to overly distinguish this field of studies compared to other areas of musicology. Hiding under the acronym T.K., in Muzyka Polska he published a quite critical overview of Wójcik-Keuprulian's proposal, indicating, for example, her erroneous identification of musical aesthetics with the philosophy of music or assignment of acoustic music to the circle of humanities, for example, in the place where the researcher states that 'acoustic music is not a field of physics, but it is a branch of music studies.' Further, ${ }^{412}$ she stated, 'It cannot be treated like a field of mathematics and natural science, because its subject is not a creation of nature, but a creation of culture.' We know that Pulikowski, having

409 Wójcik-Keuprulian 1934. It should be recalled that her habilitation was opened on the basis of the monograph Melodyka Chopina [Chopin's Melodics] (Lviv 1930).

410 Wójcik-Keuprulian 1934, 2.

411 Ibid., 4.

412 Ibid., 12. 
experience in working in acoustic laboratories, could provide reliable feedback on the false assessment presented by the author of acoustic research conducted through the prism of methodologies typical for humanities. Nevertheless, it seems that the reviewer unnecessarily highlighted such 'acoustic' optics (with close attention to the mentioned competencies), in a manner disproportionate to the place which it occupied in the presented hierarchical structure of musicology. Through this Pulikowski managed to goad Wójcik into discussion. The authors submitted a reply to the next Muzyka Polska which primarily addressed the topic of the relationship between acoustics and other departments of musicology, defending the earlier theses on the superiority of the former over the latter if only for the reason that the subject of musicological research is 'musical work and this work, whatever it would be, wherever and whenever created, has and ought to have a sound form. ${ }^{313}$

A discussion of Wójcik-Keuprulian's systematics closed Pulikowski's extensive answer in the same edition of Muzyka Polska, ${ }^{414}$ which only sharpened the previous controversy and undoubtedly contributed to increasing the polarisation of positions and deepening the conflict between the 'Cracow-centered' and 'close to Lviv' musicological groupings.

Following the above-quoted statements, a conclusion comes into mind that the discussion on its shape, which arose at the beginning of the development of Polish musicology, was often not of a constructive character, except perhaps for purely informational publications. The arguments invoked in disputes regarding different perceptions of both the applied research methodology and organisation of studies were often of a personal nature, branded with a long-standing conflict between the heads of the two main musicological centres - Lviv and Cracow. Approaches on contentious issues taken by the persons concerned were full of invective and malice, and non-essential topics often prevailed over professional polemics. Was this reflected on the pages of the trade press? Sometimes editorials granted columns in a somewhat selective manner, guided by personal sympathies and interests (such as in the case of the weekly Wiadomości Literackie, always critical towards 'paper' Lviv musicology), while at other times they tried to take an objective stance, inviting different parties to exchange views (as was done loyally for many years by Mateusz Gliński in his Muzyka or by a group of artists from SMDM and TWMP in Muzyka Polska). The only scientific journal - Kwartalnik Muzyczny - despite

413 MP 1935/5, 71 (original emphasis).

414 MP 1935/5, 74-76. 
the repeated declarations of its head on its national character, broke the prevailing 'arrangement' reluctantly and was usually filled with publications from 'proven' and 'faithful' authors presenting their views on musicology converging with the attitude of the editor-in-chief. 


\section{Authors and subjects: historical-musical work - 'technical history' (Chybiński) versus 'live history' (Jachimecki); contemporary music as a subject for research; music theory and acoustics; philosophy, aesthetics, sociology; psychology, pedagogy; ethnography and musical folklore; themed editions}

At the beginning of 1928, Adolf Chybiński stated that 'I will succeed ... in establishing or renewing Kwartalnik Muzyczny ${ }^{3415}$ and in the spring started collecting materials for the editorial file. The launch of a new scientific title, which Kwartalnik Muzyczny would be - at least according to the editor-inchief - required names that would ensure continuous functioning and regular publishing of the magazine. According to forecasts, its content included a fairly broad panorama of topics and research interests as well as a provenance of invited authors. It seems that there had been many more plans than were actually realised throughout the upcoming few years: in the editorial advertisements published in a majority of booklets we read about, amongst others, an article prepared by Maria Remertówna, one of the students of Lviv musicology, on the Warsaw lute tablature of the seventeenth century, also about the work of the head of Poznań musicology Łucjan Kamieński 'on a certain Old-Polish melody and polonaises from the seventeenth and eighteenth century, about an article by Adam Sołtys on the symphonic and opera works of Karol Szymanowski, about an article by Jan A. Maklakiewicz on the studies of folk melodies, about an article by Heikki Klemetti, a Finnish composer, conductor and music critic, on a dance known in Finland as 'polska,' or about '[Eugène Marie Valentin] Borrel's article on the embellishments in the works of J. Tartini.' ${ }^{316}$

As a matter of fact, for Chybiński, there was no alternative methodology in historical research that he was willing to accept and that could replace the one he had acquired during his studies in Munich. He was also trying to instil this

415 Chybiński to Bronarski from Lviv 6 II 1928, AACh-BUAM, Bronarski’s archive, p. 8. 416 See various notes 'Od Redakcji' [Editorial] closing the editions of Kwartalnik Muzyczny. 
approach towards scholarship in his students. I have already written about the extent to which this scientific attitude ('paper musicology') was opposed not only by some music critics but by some musicologists as well. The professor had a passion for approaching his research material in a 'technical' way (which applied to both music sources and archival materials on past music), which was the exact opposite of 'living history', filled with literary narration and advocated by Zdzisław Jachimecki, who was Chybiński’s long-time antagonist. This passion not only determined the direction of the professor's academic career but also stamped its influence on the form of the Lviv musicological school which he developed and on Kwartalnik which he headed. As a result, it also influenced the choice of authors involved with the journal. Kwartalnik, through which the current state of knowledge was passed as small forms of academic literature (articles, contributions, reports, papers) ${ }^{417}$ was an ideal 'medium' for Chybiński, who penetrated archives and libraries, extracting information from countless readings he collected in both private and institutional libraries, and (in reference to 'folklore' themes) during ethnographic expeditions. He rarely crowned his activities with extensive monographs; in his bibliography, he had several hundred academic titles and materials published on the pages of music, cultural and literary periodicals. ${ }^{418}$

Already the contents of the first issue of the new magazine, based on classic designs from key European music periodicals, indicated the direction that the editors chose for the upcoming years: display of historical themes (though not limited to them), supplementing the basic, article content with smaller contributions and informing in many (if possible) reports about the novelties in both Polish and foreign literature. (Even at this stage of preliminary work, it was declared that the editorial team of Kwartalnik should avoid dividing publications between two volumes, which automatically meant that the desired materials had to be limited to relatively brief papers. ${ }^{419}$ In practice, it turned out that both in this edition of Kwartalnik and in its few post-war issues, this rule was continuously broken.)

417 More extensive dissertations (for example, by Maria Szczepańska or Hieronim Feicht), were published in parts, so - on any single occasion - they still did not exceed the size of the average article.

418 See Michałowski 1950; Michałowski 1959.

419 Sometimes Chybiński remained open to the possibility that 'certain exceptions will be made for important and valuable works which take up problems as significant as for example, "Chopin's harmony," see Chybiński to Bronarski from Lviv 20 IX 1928, AACh-BUAM, Bronarski's archive, p. 9. 
A natural source, from which the editors could draw original materials, was the Lviv musicological institute represented by a group of Chybiński's students, extremely prolific from an academic point of view. In the interwar period, most of them showed an above-average activity, compared to the musicological youth from Cracow or Poznań, in the field of publishing, both journalistic and popularising, and research. As can be seen from the previously outlined preview of the beginnings of the academic careers of local graduates, they wrote a lot and looked for every opportunity to print their works, yet they usually left their main theses for Kwartalnik Muzyczny. It should be noted, however, that Chybiński consistently restricted his selection to a few names associated with the department, even if he sometimes planned to expand this list. ${ }^{420}$ Statistics show that (if we also take into account articles written a few years later and submitted to PRM) while there were over seventy papers written by 'outsiders', another sixty were signed by Chybiński and several of his pupils: Feicht, Lissa, Chomiński, Dunicz, Freiheiter, Szczepańska, Wójcik-Keuprulian, Łobaczewska. At the same time, the professor was trying to show the full spectrum of research topics taken up by his pupils, even though privately he did not approve of all their choices. ${ }^{421}$ However, he could be sure of the reliable scientific skills of the graduates of the Lviv department, thanks to whom the magazine enjoyed a steady supply of studies and theses that met the high standards.

Out of this group, Chybiński invited his two assistants (Hieronim Feicht ${ }^{422}$ and Maria Szczepańska ${ }^{423}$ ) to contribute to the first issue of Kwartalnik Muzyczny,

420 Thinking at one point about a 'completely ethnographic' edition, he also considered original works or abbreviations of his graduates' diplomas: Dunicz on folk polonaises, Bagar on obereks, and Głodziński on the krakowiak, see Chybiński to Bronarski from Lviv 24 III 1932, AACh-BUAM, Bronarski's archive, p. 73. Of these three people, only Dunicz became an author for Chybiński.

421 See for example, a fragment of the letter to Ludwik Bronarski, in which he wrote about some of his pupils: "They preferred to take an interest in "general" problems rather than Polish music, for example, Debussy [Łobaczewska], etc. I basically do not find any difficulty in choosing such interest, but sometimes I already have too much of this liberalism,' see Chybiński to Bronarski from Lviv 27 VI 1930, AACh-BUAM, Bronarski's archive, p. 41.

422 'Przyczynki do dziejów kapeli królewskiej w Warszawie za rządów kapelmistrzowskich Marka Scacchiego' [Contributions to the history of the royal band in Warsaw under the leadership of band Master Marco Scacchi] (KM 1928/1, 20-34, finished in 1929/2, 125-144).

423 'Wielogłosowe opracowania hymnów mariańskich w rękopisach polskich XV wieku' [Polyphonic arrangements of Marian hymns in Polish manuscripts of the XV century] (KM 1928/1, 1-19, and 1929/2, 125-144, 1929/3, 219-227, 1929/4, 339-345. 
which was being prepared at that time. He also invited authors whom he had known before and of whose professionalism he could be sure: Feliks Starczewski, ${ }^{424}$ an experienced publicist and a music critic, and Henryk Opieński, ${ }^{425}$ his old friend. It was an opportunity for Chybiński to return a favour to Opieński, who made it possible for Chybiński to make his debut in the first edition of Kwartalnik Muzyczny and then continue his fruitful cooperation with this journal for the next few years when Opieński was its editor-in-chief. On the recommendation of the Warsaw part of the editorial team (or rather by its choice), the group of authors contributing to 'number one' was joined by Paul Brunold, ${ }^{426}$ Gabriel Tołwiński ${ }^{427}$ and Stanisław Furmanik. ${ }^{428}$ Another author who often appeared in Kwartalnik throughout its pre-war history was Ludwik Bronarski. ${ }^{429}$ Chybiński, as the host of the journal, also joined the group of authors. He submitted a paper on vocal and instrumental concertos of Marcin Mielczewski ${ }^{430}$ and a short text 'on the history of musicology in Poland.'431

Due to the interest of the editor-in-chief, one of the main thematic areas which focused a large group of authors and a large part of their articles in the interwar Kwartalnik was musical 'Old Poland' and 'antiquity' ('There is such an abomination of traditional Old Polish music that you have to maintain works in this regard almost tendentiously, ${ }^{432}$ wrote Chybiński), and the professor's favourite author in this field was his student and assistant, Maria Szczepańska.

424 'Pierwsze zaczątki metod umuzykalnienia' [The first beginnings of musicalisation methdology] (KM 1928/1, 85-86).

425 'Sonaty Chopina, ich oceny i ich wartość konstrukcyjna' [Chopin”s sonatas, their evaluation and structural values] (KM 1928/1, 59-72, 1929/2, 152-162).

426 'Fortepiany Chopina' [Chopin's pianos] (KM 1928/1, 50-54).

427 'Najnowsze badania nad akustyką sal teatralnych i koncertowych' [The newest research into the acoustics of concert halls and theatres] (KM 1928/1, 72-77).

428 'O kulturę muzyczną w Polsce' [About musical culture in Poland] (KM 1928/1, 77-81).

429 In the beginning, he published a polemic article ' $\mathrm{W}$ sprawie wydania pośmiertnych dzieł Fryderyka Chopina' [On the posthumous publication of Frederic Chopin's works] (KM 1928,1, 55-59).

430 'O koncertach wokalno-instrumentalnych Marcina Mielczewskiego (†1651)’ [On vocal and instrumental concertos of Marcin Mielczewski (d. 1651)] (KM 1928/1, 34-50, 1929/2, 144-152, 1929/3, 246-251, 1929/5, 10-14, 1930/8, 306-313).

431 'Do dziejów muzykologii w Polsce' [On the history of musicology in Poland] (KM 1928/1, 82-85). Moreover, he was the author of three reports, including an extensive review of an edition of Melodies for the Polish Psalter by Mikołaj Gomółka, prepared for publishing by Józef Reiss.

432 Chybiński to Bronarski from Lviv 7 II 1929, AACh-BUAM, Bronarski’s archive, p. 12. 
I have already mentioned her activity in the field of academic writing and contribution to Kwartalnik when I presented the achievements of musicology in Lviv in its heyday, in the 1920s and 1930s. I will just emphasise here that it was the name of this young scholar which appeared on the first page of the new Polish musicological journal. In the case of analytical theses, Szczepańska's works were characterised by a 'classical' narrative, detailed analysis which aimed to confirm the arguments set forth by the researcher, yet sometimes misguided - as in the aforementioned case of the contribution on, as Chybiński put it, 'a certain Polish political hymn from the fifteenth century." ${ }^{333}$ Without a doubt, her mentor favoured her as an author. Nevertheless, it turns out that not all papers submitted by her were accepted for printing straight away. This was the case with her extensive study entitled 'O utworach Mikołaja Radomskiego (z Radomia) (wiek XV)' [On the compositions of Mikołaj Radomski (Mikołaj of Radom) (15th Century)], ${ }^{434}$ which had already had its own story: due to the above-mentioned rule adopted by the editorial team, which limited the practice of printing continuations in several issues, the professor decided that this paper should be published as an independent publication. Nevertheless, it remained stuck in the editorial office and was not sent for printing. Its first part, 'Introduction,' was published a few years later in PRM, whose editor was also Adolf Chybiński (see chapter II-5). ${ }^{435}$

Besides Szczepańska another eulogist of 'Old Poland' appearing on the pages of the magazine run by Chybiński was Father Hieronim Feicht who, although sometimes directed his interest toward music from the twentieth century - the works of Karol Szymanowski - during the years of his cooperation with Kwartalnik dealt mainly with the Polish legacy of the sixteenth and seventeenth centuries. As often happened, in his case, the publications resulted from work on a doctoral dissertation. The 'Contributions' published in the first editions constituted material that Feicht gathered by the way, during his archival queries aimed at finding sources for Pękiel's biography. Referring to the existing literature - of Poliński, Jachimecki, Chybiński, and Max Seiffert or the lexicon by Eitner - and citing records from the Warsaw collections, the priest verified or documented an abundance of facts from the life of Marco Scacchi and other musicians of the Chapel

433 Chybiński to Bronarski from Lviv 17 IX 1929, AACh-BUAM, Bronarski’s archive, p. 19. 434 PRM 1936/2, 87-94.

435 Its continuation was planned for the third volume of PRM, which was never printed due to the dramatic events of the first days of the war. Chybinski returned to Szczepańska's work after the liberation, again taking up the duties of the editor-inchief of the reactivated KM (see chapter III-4). 
Royal, including those previously unknown. ${ }^{436} \mathrm{He}$ directly referred his dissertation to the essay about Audite mortales by Bartłomiej Pękiel. ${ }^{437}$ In this case, the starting point for the scholarly discussion was the only more substantial material previously devoted to this composition - the chapter on Pękiel in the book by Zdzisław Jachimecki Wpływy włoskie w muzyce polskiej [Italian influences in polish music $]^{438}$. However, when it comes to reading, he did not stop there and went on to analyse all musical elements of the work in detail. He moved freely between papers which had already been regarded as classics as that time (written by Guido Adler, Arnold Schering and Hugo Leichtentritt) and the most recent ones (written by Hugo Riemann, Albert Smijers and Hans Schnoor). (On a side note, this ease in discussing European scholastic literature and the discipline that governed how he presented his argument was characteristic of all students of Chybiński, who often accused representatives of other musicological centres of inadequacies in this respect).

Already in the following year, Feicht again presented his monographic dissertation in the pages of Kwartalnik, this time dedicated to Leopolita's Missa paschalis. ${ }^{439}$ Despite the lack of sources and the need to rely on Fr. Surzyński's often erroneous edition (Feicht preceded the analysis by a discussion on the differences between that edition and the preserved, incomplete copies of the mass preserved in Wawel), on several dozen pages, the author conducted an almost bar-for-bar analysis. This analysis included the text and music and justified the title as well. When it comes to the announcement concerning Gorczycki's biography, which has already been mentioned in a footnote, Feicht, who was involved with Congregation of the Mission in Cracow, relied on a little-known work by Father Stanisław Wysocki devoted to this congregation ${ }^{440}$ and completed the

436 He made a short contribution to verifying and supplementing information about another example of early Polish music several years later, publishing - this time in PRM (1936/2, 98-99) - the article 'Do biografii G.G. Gorczyckiego' [To the biography of G.G. Gorczycki]. These and other texts by Feicht were later edited by Zofia Lissa in two volumes: Studia nad muzyka polskiego średniowiecza [Studies on music of the Polish Middle Ages] (Cracow 1975) and Studia nad muzyka polskiego renesansu $i$ baroku [Studies on the music of the Polish Renaissance and Baroque] (Cracow 1980).

437 'Audite mortales Bartłomieja Pękiela' [Bartłomiej Pękiel's Audite mortales] (KM 1929/4, 366-396).

438 Cracow 1911.

439 KM 1930/6-7, 109-157.

440 Seminarium zamkowe w Krakowie, jego dzieje i ustrój [Castle seminary in Cracow. Its history and organisation]. Lviv 1910. 
unknown episodes from the musician's life. He also referred to the discoveries that had been made up to that time, for example, those of Adolf Chybiński, his mentor. The next two reports were a 'Baroque' essay entitled 'Do biografii G.G. Gorczyckiego' [On the biography of G.G. Gorczycki] and a 'nineteenth century' essay 'Pamiętnik do nauki harmonii Stanisława Moniuszki' [A guide to learning harmony by Stanisław Moniuszko]. These two were written after some time and were published in the second volume of PRM. ${ }^{441}$

The third person from the university department who closely cooperated with the professor was Bronisława Wójcikówna. Despite the aforementioned disagreements, which at the end of the 1920s led to her falling out with the professor, she was also among the regular contributors to Kwartalnik Muzyczny. She published four texts on Chopin, who dominated her research interests in the $1930 \mathrm{~s},{ }^{442}$ as well as a two-part article on the music of 'the Nearer East. ${ }^{343}$ As the first, she submitted the article 'O polifonii Chopina' [On Chopin's polyphony] for printing which, although sent in the first months of the editorial office's work, had to wait a while to be published. ${ }^{444}$ Moving to the subject of Chopin's works, almost untouched in Polish literature, she launched - like the earlier mentioned Feicht and Szczepańska - a discussion with European researchers: from Germany, France, and Great Britain. In subsequent years, remaining on the topic of Chopin, she met the editor-in-chief's expectations. In her article 'O literaturze chopinowskiej w Polsce odrodzonej' [About Chopin literature in revivalist Poland]. ${ }^{45}$ she referred to the most recent, post-war studies on Chopin, published both in Poland and abroad, and criticised the excessively literary style which characterised many of them. He emphasises that monumental works are not free of this, such as Ferdynand Hoesick's Chopin. Życie i twórczość [Chopin. Life and works], Fryderyk Chopin by Henryk Opieński, not to mention the publications of Witold Chrzanowski, Helena Windakiewicz or Zdzisław Jachimecki, as well as foreign authors - Hugo Leichtentritt or James Huneker. Next, entering into

441 PRM 1936/2, 42-52.

442 'O polifonii Chopina' [About Chopin's Polyphony], 'O literaturze chopinowskiej w Polsce odrodzonej' [About Chopin literature in revivalist Poland], 'Wariacje i technika wariacyjna Chopina' [Variations and Chopin's variation technique] and the material 'Chopin w opinii literata francuskiego' [Chopin as seen by French literati] (accordingly: KM 1929/3, 251-259, 1929/4, 412-428, 1931/12-13, 380-392, 1932/14-15, 598-601).

443 KM 1932/14-15, 573-593, 1933/17-18, 69-78.

444 KM 1929/3, 251-259.

445 KM 1929/4, 412-428. 
the scope of methodological considerations, she analysed the current literature on Chopin in terms of various musicological methods used by the authors. Thus, Wójcik's article is not a mere report on the publishing movement, but an example of the scientific discussion on the directions of research on the history of music represented by contemporary musicologists (indicating a higher value in cognitive terms of works of a purely analytical character).

When Chybiński was planning the ethnographic issue, ${ }^{446}$ he once again approached Wójcikówna and invited her to contribute to it because he had been aware of the second area of her research interests. As has already been mentioned, due to family connections with Polish Armenians, the researcher had for some time been promoting the history of this nation's music (she published numerous articles, for example, in Posłaniec św. Grzegorza, a magazine of Polish Armenians). This is why she submitted an extensive essay on this topic to Kwartalnik. She profiled Father Gomidas, an Armenian priest and a musicologist educated in Berlin, whose activities contributed to the revival of both the music of the national church and folk music. ${ }^{447}$ She supplemented this material with the second part of her study on the music of the 'Nearer' East. It was an essay on the theoretical foundations of Arabic and Turkish-Persian music. ${ }^{448}$ As noted by Bożena Muszkalska, further plans regarding other cultures from the Middle East were not pursued by the researcher, and her health problems as well as the "barriers she encountered trying to stand out as an academic in the world of competing men, did not allow for full implementation of her [other] ambitious plans.' ${ }^{449}$

Chybiński’s two 'favourite' pupils, Józef Michał Chomiński and Jan Józef Dunicz, were slightly younger than the three first assistant lecturers at the Lviv department. They did not make their debut in the professor's journals until the second half of the 1930s. Dunicz submitted his debut article to PRM, whereas Chomiński made it in time to publish an extensive paper on the history of medieval music ${ }^{450}$ in the last issue of Kwartalnik. The next two articles were published

446 The monographic issue on ethnography finally came out in 1933 as a double issue, numbered $17 / 18$.

447 'Muzyka Bliższego Wschodu. I. Muzyka ormiańska' [The Music of the Nearer East. I. Armenian Music"] (KM 1932/14/15, 573-593).

448 'Muzyka Bliższego Wschodu. II. Muzyka turecka' [The Music of the Nearer East. I. Turkish Music"] (KM 1933/17-18, 69-78).

449 Muszkalska 2012, 69.

450 'Technika imitacyjna XIII i XIV w.' [Imitative techniques of the XIII and XIV centuries] (KM 1933/19-20, 113-157). 
in PRM. The first article submitted by Chomiński was a summary of his master's thesis from 1931. It was an extensive synthesis presenting a two-century history of the imitative technique 'from the times of Pérotin to the times of Ciconia."451 Its construction and narrative, as well as the range of literature used, deserve recognition as a model example of an academic treatise, which is a result of research firmly embedded in the German-type musicology, taught by Chybiński to his students in Lviv. As such, he stood in one line with Feicht's detailed studies on the Easter Mass by Leopolita, or Szczepańska’s studies on Marian hymns. And although, as mentioned earlier, there is no correspondence between the student and his master from that time, the professor's impression from reading Chomiński's study did survive, however, in a letter to Bronarski: 'Master Chomiński, ... wrote an excellent work on the technique of imitation in the thirteenth and fourteenth century, beating the previous literature on this subject.'452

However, the article written by Jerzy Freiheiter, Chomiński's friend, did not deserve such an enthusiastic reception. His professional activity has already been mentioned when the university department was being discussed (Chapter II-2). However, it needs to be noted that despite Chybiński's aforementioned favourable opinion on Freiheiter's knowledge of harmony and theory, as well as his dissertation, its summary published in Kwartalnik ${ }^{453}$ was judged rather harshly. The text is filled with a series of detailed harmonic analyses, confirming the young musicologist's excellent proficiency in this area. However, it constitutes difficult reading even for someone who is well-prepared in this respect. In addition, due to pragmatic reasons, the number of musical examples illustrating the argument was significantly reduced, hence large fragments were merely descriptive, while typographical constraints also prevented the introduction of Riemann's symbols to the text, adopted by the author in the analyses conducted within the dissertation. It would be difficult to determine whether this unpleasant experience, associated with his first attempt as a contributing author of Kwartalnik, had a bearing on the fact that in the next years, Freiheiter wrote only a few reviews for Chybiński. In the 1930s, he published articles in Muzyka Polska, ${ }^{454}$

451 Ibid., 13.

452 Chybiński to Bronarski from Lviv 3 X 1932, AACh-BUAM, Bronarski’s archive, p. 81. The post-war correspondence between Adolf Chybiński and Józef Michał Chomiński was published in 2016, see Sieradz 2016/2.

453 'O harmonice Edwarda Griega (1843-1907)' [About Edward Grieg's harmony (18431907)] (KM 1932/16, 716-744).

454 'O umuzykalniającą naukę harmonii' [On the teaching of harmony which promotes the appreciation of music] (MP 1934/3, 222-229). 
$M u z y k a^{455}$ and most often in LWML. After reading the texts published in these journals, it is visible that Freiheiter's interests focused on theory and contemporary music. ${ }^{456}$ Most importantly, he was active as a musician, an educator and an organiser of music life. ${ }^{457}$

In a way, at the opposite pole to the achievements of the afore-mentioned students of Chybiński, already present on the pages of Kwartalnik, there also remained two other graduates of the department in Lviv - Stefania Łobaczewska and Zofia Lissa. They were linked (or rather divided) with the professor through frequent disputes, both methodological and ideological. Let us recall that it was the controversy with Łobaczewska, which afterwards moved from Lviv to the nationwide field through publications and newsletters, among others, in the monthly Muzyka, which nearly launched a community 'peer court' that was to decide which side is right in the dispute over the value of research on early music. The dispute flared up in 1933 and, as I wrote earlier, by the war it had already significantly reduced contacts between the teacher and his pupil. She, however, had previously made an important contribution to the content of Kwartalnik for the professor was able to appreciate the passion for research of his graduates as well as their academic workshop. Despite the differences of interests, he had repeatedly invited them to cooperate with Kwartalnik, relying on their scientific integrity no less than in the case of other students.

Even though Łobaczewska and Lissa rarely dealt with historical issues on a daily basis, each of them submitted historical studies to Kwartalnik Muzyczny. Łobaczewska was the author of two articles whose content was 'classical' (according to categories preferred by Chybiński), including a paper on the output of Sebastian of Felsztyn. Following the example of her colleagues from the same department, she analysed the works of this musician and was trying to determine their style against the background of his epoch. ${ }^{458}$ She showcased in-depth knowledge of the best examples of similar analyses and referred to rich European source literature devoted to this subject. An additional nod towards Chybiński

455 Amongst others material about Józef Koffler (Muzyka 1936/7-8, 85-86).

456 See for example, 'Problemu muzyki odtwórczej' [The problem of imitative music'] (LWML 1928/2, 3); 'Stylistyczne założenia muzyki współczesnej' [Stylistic assumptions of contemporary music] (LWML 1933/70, 2-3).

$457 \mathrm{He}$ also used these experiences for his publications, as in the case of the article on the reform of the teaching of harmony (LWML 1927/4, 2).

458 Stefania Łobaczewska, 'O utworach Sebastiana z Felsztyna (XVI wiek)' [About the works of Sebastian of Felsztyn (XVI century)] (KM 1929/3, 227-245, 1929/4, 346-365). 
was the point of departure for her reflections, that is 'Biografia Sebastiana $z$ Felsztyna' [Biography of Sebastian of Felsztyn] ${ }^{459}$ published by the professor.

Before Łobaczewska turned to sociology and aesthetics, which was visible in the next volumes, she submitted for print a summary of her doctoral dissertation entitled 'O harmonice Klaudiusza Achillesa Debussy'ego w pierwszym okresie jego twórczości' [On the Achille-Claude Debussy's harmony in the first period of his artistic work]. ${ }^{460}$ Despite the significant limitations of the original form of the dissertation (reduced number of musical examples from one hundred and twenty-three to just eleven, and reliance on only a few bibliographical entries from amongst more than a hundred), the work constitutes an exemplary, scientific analysis of contemporary music, using the newest, but also the classical at that time, European literature. ${ }^{461}$ These two historical publications by Łobaczewska were followed by a series of texts on psychology and the aesthetics of music, for example, 'O założeniach estetycznych i psychologicznych muzyki programowej' [On aesthetic and psychological assumptions of programme music] ${ }^{462}$ and ' $Z$ najnowszych badań nad psychologią i estetyką muzyczną' [From the most recent studies on psychology and the aesthetics of music] ${ }^{463}$ written with Zofia Lissa.

Lissa, unlike her older colleague, did not debut in Kwartalnik with a historical dissertation, but with a theoretical study on 'the changes taking place in its [music's] individual elements and the relationship between one another. ${ }^{364}$ From

459 See Myśl Muzyczna 1928/9, 57-59, 1929/2, 1-3.

460 KM 1929/5, 2-62.

461 Chybiński himself was aware that his students' dissertations (but also some other musicologists from Lviv), especially regarding the newest music, were of a high academic level: 'Works in the field of modern music, written by Łobaczewska, Lissówna, Koffler etc., which I will include in the current yearbook of Kwartalnik, which will be more and more "modernised," will be understood only by a few people because our state of musical preparedness is too low, and there are still terrible shortcomings, and these works require becoming accustomed to serious works and there is a lack of such in the area of newer music', see Chybiński to Bronarski from Lviv, 24 I 1930, AACh-BUAM, Bronarski's archive, p. 30.

462 KM 1930/9, 19-34.

463 KM 1932/14-15, 543. In fact, this title concealed reviews of four recently published books (which expressed the most recent research attitudes) written by European authorities on psychology and the aesthetics of music: Henri Delacroix, Ernst Kurth, Julius Bahle and Hans Mersmann.

464 Zofia Lissa, 'Politonalność i atonalność w świetle najnowszych badań' [Polytonality and atonality in the light of the latest research'] (KM 1930/6-7, 192-237, quote page 193). 
today's perspective what may seem interesting is the attitude towards the history of music and the elements defining its periodisation, which is different to the 'materialist' (from which Lissa is primarily known). The criteria to which she adhered at that time had a strictly musical character. For example, she wrote that 'the transformation of the division of music history into periods is ... a transformation of one, less frequently a whole group, musical style factors' ${ }^{365}$ and 'in the development of European music after Christ two main eras can be indicated ...: the era based on pure diatonic church modes ... [and] the era of major and minor tonality ${ }^{366}$ - and there is no mention of any stages in the development of societies, which Lissa assumed as a sine qua non of the progress in the history of music in the future. The complementation, as she asserts, of these two eras in the history of universal music is the growing (at the time of writing) atonality, and to be able to sufficiently describe the issue of atonality one must define in advance the concept of key and tonality. Lissa takes on the task and presents the latest results of research in this area conducted by the leading theorists in Europe. Her article is extremely erudite in this respect, built on reading dissertations by Kurth, Riemann, Capellen, Erpf, Grabner, Schönberg, Schenker, Schreyer, Lenormand, Deroux, Milhaud, Mersmann... - these are still not all the characters with whom the author took up discussion in her article.

Shortly afterwards, following the example of other Lvivians, she submitted a summary of her dissertation for print. It was an analytical monograph on contemporary European music, ${ }^{467}$ a subject which rarely appeared in Chybiński's journal. After that, she devoted herself completely to subjects which were the closest to her: music pedagogy and psychology, ${ }^{468}$ as well as research on the role of the radio, which at that time was a new medium. ${ }^{469}$

\section{Ibid., 193.}

466 Ibid., 194.

467 Zofia Lissa, 'O harmonice Aleksandra Skriabina' [About Alexander Scriabin's harmony] (KM 1930/8, 320-355).

468 'Z psychologii muzycznej dziecka' [On music psychology of the child' (KM 1931/1011, 173-207); 'Z zagadnień współczesnej pedagogii muzycznej' [On the problems of contemporary music pedagogy] (KM 1932/14-15, 504-523). The above-mentioned treatise combined with a review, entitled ' $\mathrm{Z}$ najnowszych badań nad psychologią $\mathrm{i}$ estetyką muzyczną' ['From the most recent studies on psychology and the aesthetics of music] (op. cit.) and prepared with Stefania Łobaczewska, served as a comment on the most recent publications on this subject.

469 'Radio we współczesnej kulturze muzyczne (psychologiczne, artystyczne, społeczne i pedagogiczne problematy radia)' [Radio in contemporary music culture (psychological, artistic, social and pedagogical problems of the radio)] (KM 1932/16, 643-659). 
Chybiński himself was a master of contributions. His achievements in the field of small forms of academic literature amount to hundreds of positions. Amongst the fourteen titles that appeared on the pages of the 'second' Kwartalnik, almost all consisted of contributions and sketches - mostly profiles of old Polish musicians enriched with information that Chybiński gathered over the years primarily in the archives in Cracow. ${ }^{470} \mathrm{He}$ dealt mostly with subjects which were the closest to him, namely those related to 'Old Polish' music from the sixteenth and seventeenth centuries, sometimes moving on to more recent history, that is the nineteenth century and the beginning of the twentieth century. ${ }^{471}$ The professor submitted papers to most of the fourteen volumes which he was preparing at the turn of the 1930s. One of these texts was broken down into as many as five volumes - his extensive monograph on vocal and instrumental concertos of Marcin Mielczewski, ${ }^{472}$ which confirmed the popular opinion that prevails until today and presents Chybiński as one of the most important pioneers of in-depth and detailed research on the artistic output of this early Baroque composer.

When it comes to his own papers which Chybiński published in Kwartalnik, he departed from historical research only two times. The second issue included his speech on teaching the history of music in conservatoires and music schools, which he had given at the II Conference of the Consultative Committee of the MWRiOP, devoted to the music education system in Poland. ${ }^{473}$ In 1933, he

470 The first of the materials referred to the Warsaw collections and the legacy of Aleksander Poliński ('Do dziejów muzykologii w Polsce' [On the history of musicology in Poland], KM 1928/1, 82-85). In addition, see 'Do historii muzyki we Lwowie'[To the history of music in Lviv] (KM 1928/1, 82-85); 'Do historii koncertów w Warszawie za Stanisława Augusta' [On the history of concerts in Warsaw under Stanisław August] (KM 1929/3, 297-302); 'Do historii włoskich muzyków w Polsce' [On the history of Italian musicians in Poland] (KM 1930/6-7, 237-238), and also the biograms: 'Wincenty Maxylewicz (1685-1745)' (KM 1929/5, 18-25); 'Jan Fabrycy z Żywca' [Jan Fabrycy from Żywiec] (KM 1932/16, 665-670), and the sketch 'Do biografii Wacława z Szamotuł (zm. 1572)' [To the biography of Wacław of Szamotuły (died 1572)] (KM 1931/12-13, 427-430); 'Do biografii Sebastiana z Felsztyna' [To the biography of Sebastian of Felsztyn] (KM 1931/12-13, 427-430); 'Do życiorysu Walentego Backfarka’ [To Bálint Bakfark’s Resume] (KM 1930/6-7, 158-167).

471 An edition of unknown letters of Stanisław and Aleksandra Moniuszko (KM 1930/6-7, 187-192) and the correspondence of Mieczysław Karłowicz (from letters to Grzegorz Fitelberg) (KM 1929/2, 162-167).

472 KM 1928/1, 34-50, 1929/2, 144-152, 1929/3, 246-251, 1929/5, 10-14, 1930/8, 306-313.

473 'Studia z zakresu szkolnictwa muzycznego' [Studies on the Music Education System”] (KM 1929/2, 167-180). 
published an article titled 'O źródłach i rozpowszechnieniu dwudziestu melodii ludowych na skalnym Podhalu' [On the sources and dissemination of twenty folk melodies in Skalne Podhale]. ${ }^{474}$ The latter article was quite controversial due to the author's thesis which stated that melodies from Podhale were not just a part of the legacy of this geographical area, but constituted a joint achievement of many ethnic groups.

The academic creativity, thanks to which Chybiński and his Lviv students went down in the history of the 'second' Kwartalnik, greatly influenced the quality and the level of the magazine. However, let us remember that it was not an organ of the department; given the frequency of this periodical, the residents of Lviv would not be able to fill its pages themselves. Hence the need to cooperate with other centres, which was often indicated (was it sincere?) by the editor-in-chief.

The only contributing author of Kwartalnik Muzyczny who was at that time involved with the musicological centre in Cracow was Stanisław Golachowski, a young assistant lecturer ${ }^{475}$ During the Second World War and after its end, he became known as a devoted collector of Karol Szymanowski memorabilia and archives. His determination earned him the recognition of the whole music community, including Adolf Chybinski. It was then, at the end of the 1940s, that he published a series of articles devoted to the author of Harnasie. ${ }^{476} \mathrm{He}$ also followed his interest in music acoustics, which he supplemented by continuing studies in mathematics and physics that he had taken up during the war. When it comes to music acoustics, he was one of the few researchers in this field. ${ }^{477}$ His musicological passion must have been noticed by the professor back before

474 KM 1933/17-18, 48-65.

475 At the initial stage of organisational work, the new initiative was communicated to representatives of all communities. However, for obvious reasons, the Cracow centre did not really respond to the invitation to join the group of authors: 'we have sensed that [Jachimecki] is not exactly happy with our publishing activity, even though in his letter he wished us luck, development, etc., etc.', see Rutkowski to Chybiński from Krzemieniec 18 VII 1928, AACh-BJ, box 4, R-19/3.

476 Amongst others: Karol Szymanowski. Warsaw 1948 (there were also several reprints and translations into German and Russian); 'Niedokończony koncert fortepianowy Karola Szymanowskiego' [Unfinished piano concerto by Karol Szymanowski], in: Księga pamiątkowa 1950, 263-274; 'Tablice chronologiczne do życia i twórczości Karola Szymanowskiego' [Chronological tables for the life and work of Karol Szymanowski], in: Józef M. Chomiński (ed.), Z życia i twórczości Karola Szymanowskiego [On the life and art of Karol Szymanowski] (Cracow 1960, 217-318).

477 Together with Mieczysław Drobner, he authored an instruction book on musical acoustics (Cracow 1953). 
the war, when despite his highly critical attitude towards the achievements of the whole Cracow environment, he decided to accept an essay entitled 'Missa pro defunctis Józefa Kozłowskiego (1757-1831)' [Missa pro defunctis by Józef Kozłowski (1757-1831)] ${ }^{478}$ for print. In fact, the work constitutes a somewhat schematic analysis of the piece, yet it meets the requirements of this type of dissertation set forth by Chybinski. It is also worth mentioning that while writing, Golachowski also used European literature, both archival and newest, and avoided colourful, literary rhetoric. The Professor soon had another chance encounter - certainly as a reader, perhaps also at the stage of editorial works with Golachowski's scholastic achievements, upon the publication in Muzyka Polska of a biographical sketch on Antoni Stolpe, ${ }^{479}$ whose creative work was the subject of a thesis written by the young musicologist, whereas the young resident of Cracow returned for cooperation with the editors of Kwartalnik only once to prepare a review of the latest szymanowskian piece for the first post-war booklet. ${ }^{480}$

Golachowski was one of the few members of the youngest generation of musicologists and representatives of university departments from outside Lviv who managed to meet the demands of the editorial team. ${ }^{481}$ Thanks to his first publication, he joined the group of authors specialising in the history of music, which was the dominant field of musicology in Kwartalnik. This group, which was the closest to Chybiński, was based on the Lviv centre and earlier 'press' contacts of the professor. One of the first authors that were fundamental for the functioning of this kind of magazine was Henryk Opieński; he belonged to the group of people closest to Chybiński throughout his career as a 'writing' musicologist. First of all, it should be noted that as a loyal, good companion for many years, he had sincerely seconded the professor from the first moment he learned about the new publishing initiative. He himself had huge experience in this field - he launched the first Kwartalnik Muzyczny, and in the mid-1920s he had run the Poznań-based Przeglad Muzyczny. From 1926, he had been living permanently in Switzerland, yet he maintained close and frequent contacts with the Polish music community, treating any new editorial challenges with

478 KM 1932/16, 671-685.

479 MP 1935/3, 169-185.

480 KM 1948/21-22, 280-282.

481 Another one was Marek Kwiek, who graduated in musicology in Poznań and made his debut in PRM. 
fond sentiment. ${ }^{482}$ He had already published his own texts with success and had written numerous press publications, syntheses and monographs. When it comes to non-serial publications, he focused on three figures: Chopin, Moniuszko and most importantly, Paderewski. ${ }^{483}$ However, when it comes to articles, he did not limit his research interests. This is also the case regarding texts which he sent to Chybiński.

In total, six texts appeared in Kwartalnik signed by Opieński (he submitted three more to Chybiński for use in the upcoming PRM). At the beginning, he provided a major study on the evolution in the assessment of Frederic Chopin's sonatas by critics and scholars, starting from the literary review by Robert Schumann, through Franz Liszt's reflection and the comprehensive analyses by Frederick Niecks, all the way to the scholarly discourse by Vincent d'Indy and Hugo Leichtentritt, and he decorated the review with selected fragments of source texts. Continuing this historical overview in the second booklet, he focused on the problem of confronting sonatas by Beethoven and Chopin by historiographers and musicologists, recalling facts confirming Frederic's fascination with the legacy of the great Viennese composer.

The Chopin topic, so close to Opieński, did not appear in his 'quarterly' texts any longer - on the basis of a casual glance at the subjects the author seems to be a 'restless spirit' starting with penetration of the history of music from ancient centuries all the way to current tasks of music 'pedagogy.' He returned, amongst others, to the hero of his dissertation - the sixteenth-century lutenist and composer Valentin Greff Bakfark, whose correspondence with Prince Albert of Prussia (with comments) was prepared for publication; ${ }^{484}$ still clinging to the

482 See for example, the letter quoted above in chapter II (footnote 25) Opieński to Chybiński from Morges 14 III 1929, AACh-BJ, box 6, O-2/103.

483 Amongst others already in 1909 he published the monograph Chopin in Lviv and continued his interest in Frederic's work, for two years later he published the work Chopin jako twórca. Objaśnienie jego utworów [Chopin as a creator. Explanation of his works] (Warsaw 1911). Together with Stanisław Rossowski, he wrote the monograph I.J. Paderewski. Zarys charakterystyki [I.J. Paderewski. An outline of his characteristics] (Lviv 1911) years later, already in Morges, he completed a few more Paderewski items published both in Poland and in Switzerland. Just before the First World War, the first of his syntheses appeared - Dzieje muzyki powszechnej w zarysie [The history of music in outline] (Warsaw 1912), and just after the war - the second (La musique polonaise. Paris 1918).

484 'Sześć listów lutnisty Bekwarka' [Six letters from the lutenist Bekwark] (KM 1930/6-7, $158-167)$. It is from this author's introduction to this edition that we learn that his doctorate, written under the guidance of Hugo Riemann and approved in 1913 by the philosophical faculty of the University of Leipzig, did not live to see a printed 
sixteenth century, he recalled the then common compositional practice of using all kinds of realistic 'imitations' - the sounds of battles, 'bird tales' - and the growing expressionist mannerisms accompanying the expansion of such naturalistic effects in music, which eventually went in two directions: 'church music began to take on the theatrical accents of a baroque flavour, whereas opera music entered a phase of pompousness. ${ }^{385}$ In this article, Opieński reached beyond the scheme of a mere historical work and provided a narrative with elements of aestheticism reminding of the theoretical and aesthetic ideas of Glarean, Ronsard, Zarlin accompanying the contemporary authors.

'Przyczynek do dziejów poloneza w XVIII wieku' [Contribution to the history of the Polonaise in the Eighteenth century $]^{486}$ turned out to be interesting material not so much as a reminder of one of the episodes in the "history of the polonaise, but primarily for the source, which was presented by Opieński, which had been passed to him in 1914 by Aleksander Poliński, a manuscript, which in 1820 was sent by an anonymous subscriber to Karol Kurpiński for use in the weekly Tygodnik Muzyczny. In this way, the nineteenth-century monument addressed to 'the first Polish professional magazine of its kind' ${ }^{487}$ finally found its place on the pages of the first Polish musicological magazine (moreover, Opieński limited himself mainly to a brief analysis of these simple compositions). A little earlier, the second of the 'eighteenth century' articles was published - 'description and analysis' of a few instrumental pieces from the collection of the Order of Cistercians in Obra, at this point kept in the library Archives of the Archdiocese of Poznań, among them the compositions of the little-known composer Wojciech Dankowski ${ }^{488}$ (whose name, recorded in sources in its historical form 'A,' 'Ad.' or 'Adal,' was deciphered by Opieński); the author became interested in the figure of this old Polish musician mainly after reading the letters of Józef Elsner to the publishing house Breitkopf \& Hartel, to which he had access due to courtesy of

version due to unfavourable events and the outbreak of World War I. Failure to meet the condition, which was the publication, resulted in lack of formal approval of the doctorate.

485 Henryk Opieński, 'Naturalizm i ekspresjonizm w muzyce XVI wieku' [Naturalism and expressionism in the music of the Sixteenth century] (KM 1931/12-13, 414-242).

486 KM 1933/17-18, 36-43.

487 Ibid., 36.

488 'Symfonie M. Dankowskiego i J. Wańskiego. Przyczynek do dziejów polskiej muzyki symfonicznej w drugiej połowie XVIII wieku)' [Symphonies by M. Dankowski and J. Wański. Contribution to the history of Polish symphonic music in the second half of the eighteenth century)] (KM 1932/16, 685-692). 
the management of the publishing house's archive. ${ }^{489}$ The presentation of a project about changes in the system of teaching music theory contained completely different topics. ${ }^{490}$ Opieński, being fully aware of the need for introducing such changes in view of the rapid evolution in compositional techniques and the use of sound materials, stressed that 'pedagogy, in principle, should be a conservative factor based on traditions; but the basis of these traditions can only be the essential, invariable truths about various senses utilised in relation to the needs of the era.'491

Feliks Starczewski, a writer and a music critic, but most importantly a teacher and a chamber musician, had also known Chybiński since their youth when they were both writing reviews and music reports for the Warsaw press. As a publicist, Starczewski contributed to Echo Muzyczne, Teatralne i Artystyczne, Nowości Muzyczne, Kurier Teatralny, Lutnista, Epoka, Młoda Muzyka, Teatr Ludowy, Wiadomości Muzyczne, Muzyka, Śpiewak, Chór, Chopin and other less known magazines. He published a few books; ${ }^{492}$ he was trying to tackle the problem of popularising music and documented the activity of Warsaw music institutions, such as the Music Society and the Music Conservatoire. ${ }^{493}$ As early as in 1910, his bibliographical note appeared in a series entitled 'Współcześni kompozytorzy polscy' [Contemporary Polish composers], ${ }^{494}$ which was being prepared by the editorial team of Przeglad Muzyczny. The note says, for example, that Feliks Starczewski was a thoroughly educated musician (a composer and a pianist). In Warsaw, he was a student of Antoni Sygietyński and Zygmunt Noskowski, among others, in Berlin his teacher was Engelbert Humperdinck, and in Paris he had classes with Vincent d'Indy. Years later, he became a teacher in the State Music Conservatoire in Warsaw. In Berlin, apart from music studies, he also started musicological studies. His teachers were Oskar Fleischer and Max

489 The letters themselves were the subject of the later article 'Józef Elsner w świetle nieznanych listów' [Józef Elsner in the light of unknown letters], already published in the pages of PRM 1935/1, 76-90.

490 'Zadania pedagogii wobec nowych prądów w muzycznej twórczości' [The task of pedagogy in the face of new trends in musical creativity] (KM 1931/10-11, 170-173).

491 Ibid., 172.

492 See for example, Działalność muzyczna J. Karłowicza, jej charakterystyka i ocena [Music activity of J. Karłowicz, its characteristics and assessment] (Warsaw 1907).

493 Konserwatorium muzyczne w Warszawie [Music conservatoire in Warsaw] (Warsaw 1937); after the war, he presented the history of the choir of the Warsaw Conservatoire throughout 75 years of its existence (Śpiewak 1948/1-5).

494 PM 1910/2, 7-8. 
Friedländer. In Paris, he broadened his knowledge of aesthetics by attending classes conducted by Lionel Dauriac.

He was an activist in the Warsaw musical environment and the co-founder of the WTM Chopin Section and, as mentioned before, a publicist in many of the capital's magazines. He belonged to the inner circle of the founders of SMDM, hence there is no doubt to his presence in the first issue, as well as several others in total, he published six historical articles, mainly of a material character. This was the case of the first text on a nineteenth-century report from Pamiętnik Muzyczny Warszawski about teaching music according to the modern method of St. André.$^{495}$ Soon afterwards, he presented a two-part article which was a 'report on a report' devoted to the music life of Warsaw. It was based on music news from the capital city published in the 1930s in Pamiętnik Muzyczny Warszawski, a periodical run by Józef Cichocki. ${ }^{496}$ Starczewski used Pamiętnik once again when he reminded readers of a translated review by François-David-Christophe Stoepel which had appeared in this magazine. Stoepel had reviewed a variation on La ci darem la mano and Chopin's Piano Concerto in E minor. Starczewski also devoted a long paragraph to this reviewer. ${ }^{497}$ Two years later, he once again based his paper on archival press, this time German Allgemeine Musikalische Zeitung from 19 December 1810. He presented an essay entitled 'O organizacji konserwatoriów muzycznych w Niemczech ok. r. 1810’ [On the organisation of music conservatoires in Germany c. 1810]. ${ }^{498}$ The culmination of his cooperation with the interwar Kwartalnik was a biographical sketch of the little-known composer Henryk Szopowicz, erroneously described by some nineteenthcentury historiographers (Kazimierz Łada) as a pupil of Chopin. ${ }^{499}$ Starczewski in his article confronts the available encyclopaedia sources and press releases of the era in order to underline a full and credible figure of the doctor-composer, also briefly discussing his artistic works (minor piano pieces). As can be seen, this and other articles were closed in terms of time in the nineteenth century and did not go beyond the form of contributions, valuable due to the approximation

495 Feliks Starczewski, 'Pierwsze zaczątki. ..,' op. cit.

496 'Muzyka w Warszawie w 1834 i 1835 roku' [Music in Warsaw in the years 1834 and 1835] (KM 1929/3, 302-213); 'Warszawska muzyka w roku 1835' [Warsaw music in the year 1935] (KM 1929/4, 428-439).

497 'Recenzja dwóch dzieł Fryderyka Chopina przez Franciszka Stoepel z Gazety muzycznej paryskiej' [A review of two works by Frederic Chopin written by Franciszek Stoepel for Gazeta Muzyczna Paryska] (KM 1931/12-13, 430-434).

498 KM 1931/10-11, 286-290.

499 KM 193319-20, 201-210. 
of unpopular and often difficult to access sources, and not because of the original interpretations.

Readers were also made familiar with historical subjects thanks to the publications of a few other contributing authors of Kwartalnik, who used short introductory articles and materials to address historical issues in the easiest way possible, simply by describing and reporting certain subjects. This was the case for Stanisław Zetowski, a publicist, a music critic and a literary researcher, whose stance on the authorship of Pieśni Legionów Polskich we Włoszech [Song of the Polish legions in Italy] (also known as Jeszcze Polska nie zginęta [Poland is not yet lost] mazurka) has until today remained one of the most widely discussed opinions on this matter. Zetowski submitted two texts to Chybiński. One was an article which talked not so much about the relation between music and words, but rather about the effect which music has on words (he wondered how Weber's music influenced the artistic attitude of Zygmunt Krasiński). ${ }^{500}$ The other was a short introductory article on Karol Kurpiński’s Dziennik podróży [Travel journal] and press reports on this journey (which was written based on the composer's correspondence). ${ }^{501}$ (It is interesting that the article about music by Weber also contained references to Kurpiński's report from a trip to Paris, including his Dresden meetings with the German composer; one can see that this source opened different directions worth investigating for the author). The 'Weberian' article did not boil down to a schematic analysis of works of one of the trinity of poets, but pointed to the gradual growth of the young Krasiński against a broad cultural background into the omnipresent, even in the musical life of the European provinces - the Polish borderlands - and the poetics of Freischütz. This resulted in a number of works - the novels Grób rodziny Reichstalów, Sen Elżbiety Pileckiej, Władysław Herman i dwór jego, Zamek Wilczki, as well as the excellent dramas - Nie-Boska komedia and Irydion. In the interwar history of Kwartalnik, Zetowski's text was probably the only example addressing the subject of relations between literature and music, and thus relations which seem to occur less frequently: the impact of musical works on literary works instead of imposing the literary programme to a musical composition. Upon analysing the numerous examples from Krasiński’s artistic legacy, the author confirmed his

500 'Muzyka Webera w twórczości Zygmunta Krasińskiego' [Weber's music in the creative work of Zygmunt Krasiński] (KM 1932/16, 692-704).

501 'Na marginesie podróży za granicę Karola Kurpińskiego w r. 1823' [On the margins of Karol Kurpiński’s travel abroad in 1823] (KM 1932/16, 753-754). 
thesis that 'Weber's music was then a major creative wake-up call for the poet ... and it made him [Krasiński] a poet above all poets. ${ }^{502}$

Chybiński did not know Zetowski in person and mainly had a 'second-hand' opinion about his works, but he was clearly pleased with his article submitted for Kwartalnik: 'I do not know [Mr] Zetowski in person, but his local colleagues told me this and that about him, but nothing neither important nor serious. I read some of his popular works here and there, and I was not moved with his tendency towards fantastic ideas or self-confident literary-musical syntheses. Works sent to me to Kwartalnik are good, yet in a sense more literary.503

A small contributory text was sent to Kwartalnik by the young Lviv historian Józef Skoczek. ${ }^{504}$ In his short text, he presented two documents referring to the musical life of Lviv in former times. ${ }^{505}$ Another author from Lviv - Seweryn Barbag - wrote a number of works on the history of music (including a dissertation on Cesar Franck's works, Studium o pieśniach Chopinach [A study on Chopin's songs] issued in Lviv in 1927, and a large number of published articles, such as 'Polska pieśn artystyczna' [The Polish artistic song] ${ }^{506}$ or 'Semper idem (problem ewolucji twórczości muzycznej na przestrzeni wieków)' [Semper idem (the evolution of musical creativity over the centuries)], ${ }^{507}$ but he devoted the bulk

502 Stanisław Zetowski, 'Muzyka Webera. ., ,' op. cit., 704.

503 Chybiński to Bronarski from Lviv 5 VII 1932, AACh-BUAM, Bronarski's archive, p. 77. 504 Józef Skoczek (1903-1966) avidly penetrated local archives, and his research resulted in numerous articles and monographs concerning the history of Lviv (and not only) from the Middle Ages till modern times (see for example, Lwowskie inwentarze biblioteczne w epoce renesansu [Lviv library inventories in the Renaissance era'], Lviv 1939, Polskość Sląska $w$ archiwalnych źródłach Lwowa [The Polishness of Silesia in archival sources of Lviv], Katowice 1936), 'an explorer of the history and culture of Lviv, he devoted a few monographs and articles to the topics of history and education, for example, large studies on the Lviv cathedral school and on upbringing in medieval Poland and in the courts of Jagiellonian and Vasa rulers. After the war, he lectured on the history of Poland and the history of culture and education at the Jagiellonian University, the Pedagogical School in Cracow and the Pedagogical Institute in Katowice. He published a critical work Wybór pism pedagogicznych Polski doby Odrodzenia [A choice of pedagogical works of Poland in the era of the Renaissance] and prepared Rozwój szkolnictwa w Polsce średniowiecznej [The development of the education system in Medieval Poland] for Historia wychowania [History of education] edited by Ł. Kurdybacha,' see Śródka 1999, 46.

505 'Cech muzyczny lwowski w XVI i XVII wieku' [Characteristics of Lvivian music in the XVI and XVII centuries] (KM 1929/2, 182-185).

506 Muzyka 1927/7-9 special edition with the title Muzyka polska, 91-107.

507 LWML 1925-26/8, 1. 
of his research to the issues of pedagogy, psychology, the popularisation of music, the organisation of musical life and education..$^{508}$ Barbag submitted such texts to Kwartalnik Muzyczny. This extremely well-educated musicologist (studied in Vienna under Guido Adler) and composer (disciple of Ludomir Różycki and Henryk Melcer) as well as a pianist and a graduate of law at the University of Lviv, was one of the most active 'writing' figures of the interwar period. I already had the opportunity to discuss his Systematyka muzykologii more broadly as well as his bold words on the condition of Polish musicology in terms of organisation of departments and the (lack of) cooperation between members of the environment. On the pages of magazines he frequently commented on the current problems - education of the recipients of musical culture, music education and artistic education, the presence and importance of new media (radio and cinema) for contemporary music. For the needs of Kwartalnik Muzyczny, he also took up the matter of organisation of science and curricula (concerning theory) in higher music education. For this purpose, he prepared an article (dedicated to Janusz Miketta, who performed various official functions in the interwar period, including ministerial councillor and chairman of the music and singing committee at MWRiOP) entitled 'Propedeutyka teorii muzyki jako zagadnienie dydaktyczne' [Propedeutics of music theory as a didactic issue].$^{509}$ An interesting matter - from today's perspective - found in this article is not so much the issue of agreeing, as Barbag wrote, to the 'traditionally divergent aspirations of theory and practice ... in connection with overvaluation of contemporary music education in Poland, ${ }^{510}$ as placing a sign of equality between government solutions and the state educational policy in contemporary Germany and Russia in the field of 'social development of musical culture.' He does not elaborate on this topic further, yet focuses mainly on identifying defects in the education system, including the poor preparation of young people at a basic level. In fact, Barbag's article is a compact, regular sketch of a model lecture on propaedeutics - in his words: 'the foundation,' which should begin the education of music theory (with an explanation of all the elements of a musical work - sound material, diatonics, diatonic scale, transposition, intervals, dynamics, agogics - these are just a few

508 See for example, 'Projekt reformy szkoły muzycznej niższej' [Project to reform the lower music schools] (Muzyka 1929/2, 110-112, 1929/3, 169-170, 1929/4, 235-236); 'Publiczność jako problemat kultury muzycznej' [The audience as a problem of musical culture] (LWML 19125-26/11, 2); ‘Żywa muzyka jako źródło wychowania muzycznego' [Live music as a source of musical education] (LWML 1931/6, 1-2).

509 KM 1931/10-11, 261-275.

510 Ibid., 261. 
of the many concepts necessary to explain the basis for study of music). He also goes back to the solutions presented a few years earlier in the said Systematyka. In the same edition, Chybiński decided to use another, earlier, text by Barbag his speech from the meeting of the Opinion Committee of the MWRiOP delivered in March 1929 on the system of music education. In this text, the author confirmed his organisational skills and his ability to take a 'visionary' view of the future of music education.

In his two 'quarterly' appearances, Barbag did not support himself with literature on the theory and methodology of music pedagogy - in this sense, his comments are not of an academic nature, as would be expected from publications in Chybiński's magazine. However, it was important that the draft came from under the pen of an outstanding active musicologist, which gave hope that the results would meet the expectations not only in terms of professional education of future musicians but also as to their learning in the field of the broadly and deeply recognised knowledge of music. In this sense - we can guess - Barbag had support for his ideas and the editor-in-chief (who, after all, next to academic duties at the Jan Kazimierz University, had been for many years associated with Lviv music teaching), and these young students of Chybiński (Łobaczewska and - especially - Lissa), for whom psychology and education were some of the main fields of research interests.

Another notable historian was Paul Brunold - a Parisian musicologist, an excellent organist and harpsichordist and also a conservator of these instruments (the future co-author of an anthology of French harpsichord virtuosos of the seventeenth century), who sent a few articles on the study of instruments and organology to Kwartalnik. The first of these articles - 'Fortepiany Chopina' [Chopin's pianos] ${ }^{511}$ - sketched the history of two instruments that were owned by the Pleyel company and the National Museum in Warsaw at that time. The remaining articles were intended as a cycle devoted to the history of keyboard instruments commissioned by the editors. ${ }^{512}$ From among other planned sketches (on the spinet, harpsichord, pianoforte or - exceptionally - on the lyre, whose sound is generated by scratching the strings, although admittedly it is not a 'keyboard' instrument), the last two were accomplished. ${ }^{513}$

511 KM 1928/1, 50-54.

512 Paul Brunold, 'Dawne instrumenty klawiszowe. [1.] Klawikord. [2.] Klawesyn' [Early keyboard instruments. [1.] Clavichord. [2.] Harpsichord] (KM 19281, 167-184).

513 Paul Brunold, 'Pianoforte' (KM 1930/9, 9-18); 'O lirze' [About the lyre] (KM 1932/16, 659-664). 
A separate group in the personal index of Kwartalnik included authors who were associated with music practice on a day-to-day basis, and who treated writing as an opportunity to share their experience supported by knowledge of the theoretical foundations of the profession, sometimes ranging with their statements from history towards musical aesthetics. At the top of this list was Karol Szymanowski, whose musical writings constitute a fascinating subject of analysis for researchers to this day. All his legacy comprises two thick volumes of writings - both musical and literary. ${ }^{514}$ The composer's name appeared on the pages of leading dailies and magazines particularly in the third decade of the twentieth century, when he fully developed his activity as a publicist, in which Zofia Helman, an excellent expert in Szymanowski's works and the author of an encyclopaedic entry about him, ${ }^{515}$ identified four motifs of his considerations, including the following topics: ' 1 . the national style in Chopin's music and tradition, 2. contemporary trends in music, 3. the tradition of Romanticism and 4. the role of music in society. ${ }^{516}$ In Przeglad Muzyczny, Kwartalnik Muzyczny and the Muzyka monthly appearing at the same time we can only find a few titles signed by him, but in general, they were not texts written 'exclusively', and it seems that every editorial would have been happy with the possibility of duplicating such texts. Such was, for example, the case of 'Wychowawcza rola kultury muzycznej $\mathrm{w}$ społeczeństwie' [The educational role of music culture in society] - a dissertation circulating between various press titles that was originally published in the literary monthly Pamiętnik Warszawski (1930/8) and subsequently used as a whole by Adolf Chybiński ${ }^{517}$ and in fragments a few years later by Wieńczysław Brzostowski, an editor of the Poznań monthly Życie Muzyczne i Teatralne. ${ }^{518}$ Szymanowski wrote another essay - 'O romantyzmie w muzyce' [On romanticism in music] - for the needs of Droga - a Lviv social and literary monthly run by an outstanding theatrical critic and stage designer Wilam Horzyca; ${ }^{519}$ in the same year, Chybiński included the text in one of his first issues of Kwartalnik ${ }^{520}$

514 Karol Szymanowski: Pisma [Karol Szymanowski: Writings], vol. 1 Pisma muzyczne [Music writings] collected and edited by Kornel Michałowski, introduction by Stefan Kisielewski, Cracow 1984, vol. 2 Pisma literackie [Literary writings], collected and edited by Teresa Chylińska, Cracow 1989.

515 Helman 2007.

516 Ibid., 295.

517 KM 1931/10-11, 129-156.

518 Życie Muzyczne i Teatralne 1935/7, 3-4.

519 Droga 1929/1, 72-81, 1929/2, 160-165.

520 'O romantyzmie w muzyce' [About romanticism in music] (KM 1929/3, 284-297). 
and a year later the fragments of the essay were included in Muzyka by Mateusz Gliński. $^{521}$

The only trace of contacts between Chybiński and Szymanowski on the publication of 'Romantyzm w muzyce' [Romanticism in music] can be found in an undated letter written by the composer, which refers to an unpaid fee. Teresa Chylińska had without a doubt accurately addressed this question to the Kwartalnik edition of an essay, which allowed her to hypothetically date the writing to April/May 1929.522 In the correspondence between Chybiński and Bronarski that has survived, where we can usually find frequent and systematic reports on editorial plans and works, there is no mention of Romantyzm by Szymanowski, and the content of the issue no. 3 (apart from continuations of articles from the previous issues) was to be 'connected with the Convention of Slavic Associations of Singers' to a large extent. The plans included: '7. An article by Dr [Josef] Hutter from Prague on Czech musicology and the cult of early music in Czechoslovakia, 8. An article by Dr [Dragan] Plamenac and Dr [Kosta P.] Manojlović on musicology and the cult of early music in Croatia and Serbia. 523

As it turns out, this time the selection of Szymanowski's essay was inspired (or even imposed) - in the absence of the aforementioned 'Slavic' texts - by the Warsaw part of the editorial office. This fact can be inferred from a letter by Kazimierz Sikorski to the professor: 'The Board of SMDM proposes to print Szymanowski's article "Romantyzm w muzyce," which appeared in booklet I and II of Droga monthly. Szymanowski agrees, if you, Sir Professor do not mind.... The article is very interesting and could bring something new and more contemporary. ${ }^{324}$ It proved interesting and valuable mainly due to the attitude declared by the composer, who alienated himself from 'less or more vague psychological considerations [and] ... failure to consider the issue of Romanticism profoundly. ${ }^{525}$ Like other texts by Szymanowski published in Kwartalnik, the essay on Romanticism ${ }^{526}$ was written in a beautiful literary style full of 'symbolic

521 Here with the title 'Dążenia i ideały nowej muzyki' [On the path to the new music ideals] (Muzyka 1930,5, 7-10).

522 See Szymanowski III, 141-142.

523 Chybiński to Bronarski from Lviv 21 III 1929, AACh-BUAM, Bronarski’s archive, p. 14. However, the plans concerning the 'Slavic' part were never carried out.

524 Sikorski to Chybiński from Warsaw 13 IV 1929, AACh-BJ, box 4, S-10/25.

525 Karol Szymanowski, 'O romantyzmie...,' op. cit., pp. 284-285.

526 Szymanowski appeared in Kwartalnik two more times, always in connection with 'academic' situations: the magazine published his rector's speech delivered on the day of opening the School of the State Conservatoire of Music in Warsaw (KM 1930/9, 
releases,' 'vicious circles,' 'creative self-will' and 'magical lanterns illuminating the gloomy interiors of the human soul permeated with emotions with their amazing glow. ${ }^{527}$ Among the authors of the magazine, nobody was a match for him in terms of style, because even if other materials went beyond the rhetoric expected by the editor-in-chief, typical for a scientific dissertation (or contribution), they did not come from the pens of so universally talented and outstanding artists with broad horizons and interests, day-to-day companions of the greatest artists of their age, including writers.

The group of authors from Kwartalnik Muzyczny, who were writers-composers just like Szymanowski, included Henryk Opieński, Feliks Starczewski, Michał Kondracki, Józef Koffler, Roman Palester and Czesław Marek. The last three authors also represented 'young blood' that Chybiński really wanted to work with since there were no experienced authors from the older generation. The most prolific author turned out to be Michał Kondracki, a promising composer and an excellent pianist. After his music studies in Warsaw and then in Paris, where he was a student of Paul Dukas, Paul Vidal and Nadia Boulanger, he came back to Warsaw in 1932. He devoted himself not only to music but also to organisational and journalistic activity (he was, for example, the co-founder of the PTMW). As Teodor Zalewski put it, he 'clung' to a group of members of the SMDM, who invited him to the meetings of the Management Board of the TWMP 'in an advisory capacity. ${ }^{528}$ Furthermore, he was an avid collector of folklore, which (also with other advantages) quickly won him the sympathy of Adolf Chybiński, who vividly described meeting with him: 'I met there [in Zakopane] ... a charming man, a young composer, whom your colleague may have had the opportunity to meet at Master Paderewski's house in Morges. That was Mr Michał Kondracki, a student of Vidal and Dukas. He explores Podhale by kilometres on a daily basis and is ecstatic about the region (also musically), and he has to be a good diplomat since so far no one has hit him with a Kulik at any wedding, party, or revelry. ${ }^{529}$

As regards Kondracki's composing achievements, Adam Mrygoń, the author of his entry in Encyklopedia muzyczna PWM [The music encyclopaedia of PWM] stressed that 'because of the strength of his talent, he was not an epigon

1-6) and printed from Wiadomości Literackie $(1930 / 48,2)$ and a speech entitled Chopin delivered during an academic ceremony held at the University of Warsaw (KM 1931/12-13, 357-362).

527 Karol Szymanowski, 'O romantyzmie...,' op. cit., passim.

528 Zalewski 1977, 137.

529 Chybiński to Bronarski from Lviv 3 VI 1930, AACh-BUAM, Bronarski’s archive, p. 39. 
of Karol Szymanowski or an imitator of the French school that had helped him master contemporary composing techniques.5 ${ }^{530}$ As an author, Kondracki collaborated with many periodicals, which may be suggested by the few hundred articles and reviews that Mrygon ascribes to him. For periodicals such as Muzyka, Muzyka Polska and, primarily, Kwartalnik Muzyczny, he wrote texts that were results of his works in his two main interest areas: contemporary music and folklore. ${ }^{531}$ In his debut in Kwartalnik, he presented himself as a glorifier of the genius of Igor Stravinsky, whom he called 'one of the greatest reforming minds, the creator of a new direction and a new music generation, ... who is the personification of music in the broadest sense. ${ }^{532}$ Kondracki regarded the path that Stravinsky had chosen to make use of folk themes in his compositions as a model of artistic adaptation. He recognised similar tendencies in works of some other European composers: Ravel, Poulenc, de Falla, Granados, Prokofiev, Bloch and in Szymanowski's work. He also joined their attitudes with a common idea of modernism, which, as he asserted, is not everything 'that is new or simply fashionable,' nor is it 'music of dissonances. 'The essential feature of modernism is its polytonality (and the resulting atonality), both in terms of harmony and counterpoint. ${ }^{533}$ Kondracki's fascination with Stravinsky and the stylisation of folk themes (on the examples of works of the great Russian composer, also Bela Bartók and Maurice Ravel) was confirmed also by another article 'Muzyka ludowa jako materiał dla twórczości muzycznej' [Folk music as material for musical creation], ${ }^{534}$ and (in a different context: the evaluation of early music and

530 Mrygoń 1997.

531 See for example, 'Współczesna technika kompozytorska' [Contemporary composing techniques] (Muzyka 1931/1-2, 19-22); 'O kierunkach współczesnej muzyki polskiej' [On trends in contemporary Polish music] (MP 1937/6, 267-273); 'Muzyka Huculszczyzny' [The music of Hutsulshchyna] (MP 1935/3, 186-202).

532 Michał Kondracki, 'Modernizm i moderniści' [Modernism and modernists] (KM 1930/9, 34).

533 Ibid., 36.

534 KLM 1931/12-13, 406-413. On the occasion of this article Chybiński, who had been a eulogist of contemporary Polish music since youth, betrayed his weakness towards artistic souls, which sometimes led him to accept the non-academic materials delivered to Kwartalnik: 'I still have an article by Kondracki about folk melodies as material for creators, and there is much talk about Chopin in it. Admittedly, it is a... very artistic article, but can KWARTALNIK ignore the artist's desire to speak? On the contrary, I address our composers with such proposals, only that I am, unfortunately, in such situations, a lout, and the artist is usually a model... At least generally!', see Chybiński to Bronarski from Lviv 14 III 1931, AACh-BUAM, Bronarski’s archive, p. 60. 
its comparison to contemporary music) in the sketch 'Muzyka dawna i dzisiejsza' [Early and modern music]. ${ }^{535} \mathrm{He}$ took up the subject of folk music as such a description and analysis of the practice of musicians from mountainous regions - in the article 'Współczesna muzyka góralska na Podhalu i Żywiecczyźnie’ [Contemporary Polish highlanders' music in Podhale and the Żywiec Region]. ${ }^{536}$

From the very beginning of his career, Roman Palester divided his creative potential between composing and writing. Like many representatives of the artistic community, he had a university and artistic education. After an initial period of studying in Cracow and Lviv, he studied music at the Music Conservatoire in Warsaw and took up art history at the University of Warsaw. For a short period of time, he received instruction in theory from Piotr Rytel, but then he moved on the class of Kazimierz Sikorski. Thanks to his contacts with this musician, he soon got close to activists from the TWMP and authors who regularly published in Muzyka Polska. In the contemporary music press, he expressed his opinions only on contemporary works, but it needs to be noted that his texts were based on in-depth knowledge of both theory and the history of theory. They referred to notions related to the aesthetics of music. This was also the case with a publication whose aim was to make the Polish music community familiar with the first volume of Hindemith's theoretical work Unterweisung im Tonsatz (1937), in which the composer provided an interpretation of his theoretical system. Palester, just like Kondracki, admired the works of Stravinsky and Hindemith. ${ }^{537}$ Being active in the Polish section of the ISCM (also as its deputy president shortly before the war), he spoke 'in defence of new music' several times, presenting it as a natural consequence of systematic development of a few centuries of functional harmony until Scriabin put the "dot above the "I"' in the entire process ${ }^{538}$.

The article entitled 'Kryzys modernizmu muzycznego' [The crisis of music modernism], which Palester submitted to Kwartalnik Muzyczny ${ }^{539}$ preceded the above-mentioned works and was a reaction to Michał Kondracki's appeal. Even though the author accused Kondracki of using naive phrases and of some shortcomings in addressing theoretical issues, he fully sympathised with his opinion on the responsibility of musicians for the presence of contemporary

535 KM 1931/12-13, 424-427.

536 KM 1932/14-15, 565-573.

537 MP 1937/9, 378-391, 1937/10, 535-543.

538 'W obronie nowej muzyki' [In defense of new music] (Muzyka 1934/5, 200-203).

539 KM 1932/14-15, 489-503. 
music in social life, except that he believed that naive appeals to draw inspiration from folk music were just 'turning a blind eye to the problem and only scratching its surface. ${ }^{540}$ Palester mostly polemicised in his article with Kondracki, starting from the extension of the scope of the term 'modernism,' through the author of 'Modernism and modernists' coming solely, as we remember, to a trend, the essential feature of which is polytonality. This, moreover, according to Palester, should be extended with an understanding in a strictly harmonic sense, even if only 'colouristic', referring to the 'spots' of the sound of the entire orchestra. $\mathrm{He}$ also deemed Kondracki's omission of Schönberg in the circle of modernists a mistake, though he had after all 'drawn only the very last of the great consequences from the exceptional development of functional harmony, ... he was the first to directly ... begin looking for new means of expression, ... the term atonality was applied for the first time to his music. ${ }^{541}$ To sum up, regardless of the private evaluation of the work of the creator of the Viennese school, 'the presentation of the state and achievements of German music [in Kondracki's article] looked almost comical' because of the omission of this name. ${ }^{542}$

Another subject taken up by Palester referred to making music reach those social classes which were consumed by 'harmful and aimless work' and could not afford 'the luxury of aesthetic interests. ${ }^{\text {.543 }}$ These reflections were not concerned solely with the aesthetics of music but also contributed to the slowly growing movement which advocated discussion on music sociology.

Another Polish pianist and composer, Czesław Józef Marek, who lived and worked in Switzerland from 1916, focused only on reflections on his own works. ${ }^{54}$ As he stated himself, part of his compositions grew 'on Polish soil' (in terms of rhythm and melody - for example, Suita [Suite] and Symfonia [Symphony]), but they do not contain any 'presupposed ideology ${ }^{545}$ apart from that. The composer admitted that questions about his output had always embarrassed him, but it did not stop him from summing up the previous years by saying that in the first half of the 1920s he had not yielded to the ideologies of that time, on the contrary, he had anticipated neoclassicism, a trend which became visible in European music only a few years later. Marek's statement

540 Ibid., 503.

541 As above, p. 493.

542 As above, p. 494

543 As above, p. 500.

544 Czesław Marek, 'Idea, życie i moje "credo"' [Idea, life and my 'credo'] (KM 1930/8, 355-358).

545 As above, p. 358. 
ended with 'Postscriptum' added by the editorial team, which profiled the musician and his achievements. His music was performed in Prague, Zürich, Frankfurt, Leipzig, Rome and Budapest, but apparently, he was not well-known in Poland, even though his compositions were sometimes played, for example, by orchestras directed by Grzegorz Fitelberg. This opinion may be somewhat surprising, as it constitutes a rarity on the pages of Kwartalnik. We remember questionnaires held among composers of various generations and nations that were printed on the pages of the Muzyka monthly (e.g., in the aforementioned special issue no. 7-9/1928 entitled Romantyzm w muzyce [Romanticism in music], where questions were asked about the interpretation of this concept by musicians and the presence of elements of the Romantic current in their works), but even there opinions were not so extensive and did not focus only on the respondent's own work. The fact that the composer's analysis of his own works is present in Kwartalnik in a form diverging from the convention of a scholarly periodical is explained by Chybiński's already quoted words from his letter of 14 March 1931 (see above footnote 534).

Among the authors of the younger generation, in whom Chybiński saw scholarly potential and who had the makings of valuable colleagues, there was Julian Pulikowski, who joined the 'second' Kwartalnik in the final period. I have already written about the controversy he caused, especially in Warsaw. I think that as years went by, the professor had a chance to see for himself what a difficult and neurotic personality this educated and ambitious 'immigrant' had. $\mathrm{He}$ came from Vienna, where he had studied, and Hamburg, where he obtained his doctoral degree. He was introduced to the SMDM thanks to the backing of Stanisław Michalski. In the beginning, due to his matter-of-fact attitude, which gave away a certain 'German drill' that had shaped his personality, he won over the members of the editorial office in Warsaw. ${ }^{546}$ Similarly, Chybiński - who was delighted with Pulikowski's achievements from the very beginning - wrote about the crowning of his education in Vienna as follows: 'Pulikowski obtained his doctor's degree in Vienna under Lach and Haas. Lach rated his work as "one of the best in the last few, and perhaps a few dozen, years." I consider Pulikowski a great star in our future musicology. ${ }^{347}$ Besides, Pulikowski had already made contact with Kwartalnik and its editor-in-chief outside Poland - he submitted his first review in 1929 (from Karl Nef's publication Die neun Sinfonien Beethovens).

546 Zalewski 1977, 138.

547 Chybiński to Bronarski from Lviv 21 XII 1931, AACh-BUAM, Bronarski’s archive, p. 72. 
He waited a few years to submit his own text - his monographic article on six Silesian songs from 1810 was published only in the last but one issue of the magazine (no. 17/18, 1933), although he made arrangements concerning the elaboration of the topic of 'folk song and musicology ${ }^{348}$ shortly after his first review.

Józef Koffler had every reason to join the group of regular contributing authors of Kwartalnik Muzyczny. Koffler was an experienced columnist, the author of numerous papers published in music periodicals which he run (he was the editor of Muzyk Wojskowy, Okriestra and a monthly entitled Echo), a composer and a theoretician, and on top of that, he came from Lviv and maintained professional contacts with the professor (as an editor and an activist of the local branch of TMW). Despite all that, Chybiński asked him to contribute a paper just once, when an issue devoted to pedagogy and psychology was being prepared. The main title of his article could suggest an academic or even school lecture on diatonic modulation, but what he actually did was present his own teaching method. He proposed to solve modulations using Riemann's system, which was not commonly known at that time. In reality, his paper showed how to use this simplified method in practice. ${ }^{549}$

Similarly surprising can be the minor presence of Łucjan Kamieński - the head of Poznań musicology and Chybiński's long-time friend and follower in environmental discussions and disputes - on the pages of Kwartalnik; and the research problem ultimately undertaken by him is slightly astonishing, too. What Kamieński - an avid ethnomusicologist and the creator of the first Polish phonographic collections - submitted for publication, was not the result of current works of his department, but a text that was categorised in the 'pedagogy, musical reproduction' section by Maria Kielanowska-Bronowicz in the bibliography of Kwartalnik being prepared by her, but its context would be more adequate to the borderland of musicology, medicine and psychophysiology. ${ }^{550}$ The author regarded the increase in the level of psychophysiological research

548 Pulikowski to Chybiński from Vienna 12 XII 1929, AACh-BJ, box 3, P-28/7.

549 'Modulacja diatoniczna. Nowa droga nauczania' [Diatonic modulation. A new path of learning] (KM 1931/10-11, 275-286).

550 'Z najnowszych badań nad fizjologią gry fortepianowej' [From the most recent research into the physiology of piano playing] (KM 1929/5, 62-66). Kamieński also had ideas for other publications for Chybiński, but he did not complete them. He wrote, for example, to Lviv: 'So that you may not have to be constantly angry with my illiteracy, I will tell you that I am writing something on hymnology. It will even be an entire collection of such "somethings", see Kamieński to Chybiński from Poznań 1 III 1930, AACh-BJ, box 6, K-3/62. 
on musical practice as one of the priority tasks that musicology should undertake in order to bring about the 'scientific reinforcement of musical pedagogy. ${ }^{551}$ In his view, if this were not the case, musicology would still mean very little in music practice, whereas musicological (historical) knowledge would be nothing more than an unnecessary episode for potential music students. He referred to researchers dealing with performance practice, most importantly Kurt Johnen (a historian who represented the school of Kretzschmar and Wolf and the Stumpf school of psychology, as well as a student of physiology and physics), who in his paper Neue Wege Zur Energetik Des Klavierspiels used his comprehensive education to present a new approach towards 'energetic playing,' which Kamieński regarded as exemplary. The Poznan musicologist's text is actually a review of the above-mentioned paper by Johnen, yet the importance of problems which he took up and their critical presentation most probably induced the editorial team (just like in several other cases) to label it an article (even though they used Brevier type, typical for the section of materials and reports). In the next years, despite his earlier assurances that he had some texts ready, Kamieński failed as an author and did not publish in Kwartalnik. ${ }^{552}$

A separate group was formed by authors who collaborated with the magazine only sporadically, such as the singer and pedagogue Bronisław Romaniszyn Adolf Chybiński's long-time close friend and a distinguished activist of Tatra associations, ${ }^{553}$ the pianist and folklore researcher Helena Windakiewicz, Janusz Miketta (a ministerial clerk in the 1930s and Chybiński's future dedicated and humble companion), the acoustician Gabriel Tołwiński, Father Władysław Skierkowski - an excellent researcher and promoter of Kurpie culture, or the musical publicist Karol Stromenger.

The latter's article on Bach's Brandenburg Concertos ${ }^{554}$ appeared on the pages of Kwartalnik at the explicit request of Tadeusz Ochlewski, although it immediately met with the professor's critical evaluation, about which we can read in Teodor Zalewski's memoirs: 'When an article on Karol Stromenger was published in issue no. 5 due to pressure from Ochlewski ... for a long time Chybiński could not get over the fact that he allowed publication of a "non-musicological"

551 Ibid., 62.

552 His second pre-war text for Chybiński appeared in the first volume of PRM.

553 It was in his apartment in Cracow that Chybiński's private archive brought from Lviv survived.

554 Karol Stromenger, 'O koncertach brandenburskich J.S. Bacha' [About J.S. Bach's Brandenburg concertos] (KM 1929/5, 14-18). 
statement. ${ }^{355}$ Ochlewski recognised his mistake soon as well, writing to Lviv on 'the fact of disgracing myself with a dilettante article void of content on $\mathrm{Mr}$ Stromenger's Brandenburg concertos by Bach. ${ }^{556}$ Moreover, as we learn from the correspondence with Kazimierz Sikorski, Stromenger himself wanted to withdraw his text at the last moment, feeling that 'the article is not suitable for the direction assumed by Kwartalnik Muzyczny. ${ }^{357}$ In fact, although the reader could expect an analytical monograph of the title concerti grossi of the Leipzig cantor, from the columns of the academic musicological journal he receives only an assessment of the dedication accompanying the cycle, written 'from the standpoint of the history of customs, ${ }^{558}$ preceded by elements of a casual and vague description.

The above-mentioned acoustician invited to publish in Kwartalnik was Gabriel Tołwiński, who represented the Warsaw centre. He was a professor of music acoustics and worked at the conservatoire in Warsaw. In the future, in the middle of the 1930s, he would join the teaching staff of the fourth musicological department in Poland, which was being born at that time. Tołwiński was a physicist and an astronomer by education; he was also fascinated by the history of photography. According to information provided by Magdalena Dziadek, before 1906 he gave lectures at the Imperial University of Warsaw. When the astronomical observatory that he had run was closed, he began teaching physics and promoting the knowledge of exact sciences. ${ }^{559}$ His texts exploring the ins and outs of mathematics and physics were addressed both to a broad group of recipients and to narrow niche groups, such as readers of music magazines. In Mateusz Gliński’s Muzyka, he published an extensive article on variously interpreted relationships between mathematics and music, ${ }^{560}$ in which he also referred to the 'theory of acousticity' of theatrical and concert halls, stressing that the 'main goal to be pursued in the construction of these halls is to ensure that sounds are heard well from every place. ${ }^{561}$ It seems that this field of research, that is the acoustics of concert halls, was of particular interest to Tołwiński and the first out of two

555 Zalewski 1977, 111.

556 Ochlewski to Chybiński from Warsaw 21 XI 1930, AACh-BJ, box 1, O-1/46.

557 Sikorski to Chybiński from Warsaw 13 IV 1929, AACh-BJ, box 4, S-10/25.

558 Karol Stromenger, op. cit., 17.

559 Dziadek 2011, 348.

560 'Muzyka a matematyka' [Music and mathematics] (Muzyka 1931/2, 69-73).

561 Ibid., 73. 
articles which he submitted to Kwartalnik was devoted to this subject as well. ${ }^{562}$ In the second one, entitled 'O gamie idealnej' [On the ideal scale], ${ }^{563}$ he laid out a scale with 53 notes and preceded his argument with a historical overview of the development of musical scales. He started from the simplest ones, made up of two or three sounds and characteristic of songs composed by primitive peoples, then moved on to the Old Greek system, five-note scales, the Pythagorean seven note-scale, the phenomenon of musical temperament, the twelve-note scale, and ended with detailed mathematical calculations describing 'the ideal scale,' which was interesting from a theoretical point of view but had no practical applications. Articles written by Tołwiński were the only examples of reflections which bordered on exact sciences that came out in Kwartalnik Muzyczny. They were aimed at a very small group of readers, ready to get through mathematical formulas and calculations which appeared in the text. For the editorial team, accepting articles of this kind could represent an additional risk of being criticised for limiting the 'target group' of readers, which was quite small anyway. However, articles signed by an experienced physicist and a long-term university lecturer doubtlessly increased the scientific value of the journal.

Bronisław Romaniszyn was first and foremost a singer and pedagogue; he studied music in Vienna and Paris and law and philosophy at the Jagiellonian University in Cracow. He finished his solo career in the middle of the 1910s; over the years following World War I, he fulfilled various political and social missions and subsequently returned to singing already as a pedagogue. As Anna Woźniakowska writes, 'Romaniszyn is a pioneer of the theory of vocal studies in Poland and the author of many works in this field.564 Adolf Chybiński commissioned two of these works for Kwartalnik Muzyczny. The starting point for the first publication - an extensive study 'Światła i cienie we współczesnej sztuce i pedagogice wokalnej' [Lights and shadows in contemporary vocal art and pedagogy $]^{565}$ - was the opinion expressed by Janusz Miketta a few years earlier that 'there is probably none of the so-called vocational education departments that would suffer from such an abundance of various misunderstandings, as the

562 'Najnowsze badania nad akustyką sal teatralnych i koncertowych' [The most recent research on the acoustics of theatre and concert halls"] (KM 1928/1, 72-77).

563 KM 1930/9, 40-49.

564 Woźniakowska 2004/1. Already after the war, he wrote, among others, the work $Z$ zagadnień sztuki i pedagogiki wokalnej [Selected issues of vocal art and pedagogy] (Cracow 1957).

565 KM 1931/10-11, 215-261. 
music educational system. ${ }^{566}$ Romaniszyn narrowed this theory to the education of singers, and he pursued his discourse, bringing up several topics, in order to confirm the opinion 'about the difficulty of the profession of a singing teacher. ${ }^{567}$ On the one hand, he referred to the specific character of this profession as compared to other music specialisations. It required singers to be sensitive not only to sounds but also to words. Despite the fact that he was accused of keeping away from the history of singing, he did take up a few 'historical' themes (bel canto and Mozart's operas), showing them as the foundation of the educational process. He supported all his theses with the most important 'classic' source literature on this topic: papers by Franziska Martienssen, an outstanding pedagogue, Hermann Killer, an expert on the performance of Mozart's operas, and Przemysław Odrowąż-Pieniążek, the first Polish laryngologist. Romaniszyn concluded his reflections with remarks on the organisation of singing lessons and the help provided by 'government representatives.'

In the second text, which was in fact a transcript of the speech which Romaniszyn had given at the Convention of Music and Singing Teachers of the Silesia Province in Katowice in 1933 (at that time, he had been a lecturer in the conservatoire in Katowice), ${ }^{568}$ the author focused entirely on strictly pedagogical issues and teaching methods. He wanted to show a conscious, correct and methodical way of teaching the youngest generation, in order to ensure that its representatives become conscious music performers and connoisseurs. Romaniszyn posed a few questions which could have started a discussion among music teachers, yet it did not happen in Kwartalnik, which was not a journal devoted to education. It most probably contributed to the fact that it was not popular in the singing community (let us recall that singing associations, both nationwide and local, had their own magazines, which satisfied the need for professional literature).

Helena Windakiewicz had no formal musicological education, yet she replaced it with thorough studies on music (in Lviv, Cracow and Paris), and linguistic and literary studies at the Jagiellonian University. Such preparation allowed her to take care of the issues of rhythmics, versification, and tonality of Polish folk songs, among others. She started publishing works in this area even before 1900 .

566 Janusz Miketta, 'O szkolnictwie muzycznym, jego celach i wartości' [About music education, its goals and values'] (Muzyka 1928/2, 59-62).

567 Bronisław Romaniszyn, op. cit., p. 216.

568 'Głos dziecka i jego kształcenie' [The Childs voice and its education] (KM 1933,19-20, 157-172). 
Furthermore, Piotr Dahlig recalls that 'she was the first musicologist to tackle the problem of the relationship between music folklore and compositional works of I.J. Paderewski and F. Chopin. ${ }^{569}$ She was one of only ten authors who created the first anniversary book for Adolf Chybiński. She submitted an article entitled ' $\mathrm{Ze}$ studiów nad formą muzyczną pieśni ludowych. Okres kolisty’ [From studies on the musical form of folk songs. The circular period]. ${ }^{570}$ Windakiewicz was not often featured on the lists of authors whose texts came out in music magazines popular in the interwar period, such as Przeglad Muzyczny, Muzyka or Muzyka Polska. She worked in Cracow, so she preferred to publish the results of her research in Rozprawy Akademii Umiejętności or ethnographic magazines and series published in that city. We can guess that her papers came out in Chybiński's journal thanks to the initiative of his friends and pupils who wanted to honour the professor. This opened up the path for her to publish in journals which he ran: the penultimate issue of Kwartalnik included her theoretical reflections on the pentatonic scale, ${ }^{571}$ whereas her historical essay on three satirical songs from sixteenth-century sources (the tablature from the City Library of Gdańsk and the tablature of Joannis de Lublin) came out in PRM. ${ }^{572}$

Father Władysław Skierkowski was another person who dealt with music folklore, in the same form that had been taken up a few decades earlier and then followed for years by Oskar Kolberg, the father of Polish ethnographic research. Skierkowski's magnum opus was the collection of songs from the Kurpie region of Puszcza Zielona, where he worked as a priest. He had been writing down and gathering the songs for twenty-six years. Selected songs from his collection inspired derivative works by Karol Szymanowski, Michał Kondracki and other composers. He also gained the recognition of musicologists interested in folklore. This was evidenced, for example, by the fact that Adolf Chybiński invited him to contribute to Kwartalnik. Skierkowski prepared a short yet exhaustive essay on the music of the Kurpie region, ${ }^{573}$ which made readers familiar with the culture of the peoples who lived in that area, their typical instruments, dances and performing practice. This highly personal text confirms the passion with

569 Dahlig 2012/3, 204-205.

570 Księga pamiątkowa 1930, 115-123.

571 'Pentatonika w muzyce polskiej ludowej' [The pentatonic scale in Polish folk music] (KM 1933/17-18, 1-26, final part in PRM 1936/2, 162).

572 'Z dziejów satyry ludowej' [From the history of folk satire] (PRM 1936/2, 153-158).

573 'Muzykalność ludu kurpiowskiego' [The musicality of Kurpie folk”] (KM 1933/17-18, 44-47) and 'O niektórych tańcach kurpiowskich' [About some Kurpie dances] (PRM 1936/2, 159-161). 
which Father Skierkowski had been penetrating the land of Łomża for over twenty years, and, on the other hand, it gives an image of the researcher as a man aware of everyday life, conscious of the risks brought to people by 'bostons, shimmy and various foxtrots performed in a way that a person with a refined taste cannot look at these kinds of "stunts". 574

Janusz Miketta, later dedicated to Chopin, performed clerical functions at the turn of the 1930s. Before that, he gained teaching experience in the music education system (he was the headmaster of music schools in Lublin and Warsaw, and in 1924 he became a professor at F. Chopin University of Music in Warsaw). He also published papers in the music press (e.g. in Muzyka). His texts were devoted to pedagogy and education. It was similar in the case of his cooperation with Kwartalnik Muzyczny. He prepared statistical reports with data related to all music schools which operated in Poland at that time (as well as music programmes in other artistic schools, e.g. film or drama schools). These reports included information such as the year of establishment of a given school, the number of teachers, the number of male and female students, their religious denomination, and further issues. ${ }^{575}$ It should be highlighted that this report had no scientific value, though it was an interesting pendant for other materials in a thematic volume on 'pedagogy' in its various aspects (and that was what the 10/11 issue of the Kwartalnik was).

Complementing the information on the names found in the pages of Kwartalnik Muzyczny also requires writing about authors from outside the strictly musicological community. Such people include Stanisław MałachowskiŁempicki, a graduate of the Law School in St. Petersburg, judge of the District Court in Warsaw during the interwar period, who worked as a lawyer later in his life. ${ }^{576} \mathrm{He}$ was a prominent researcher in the history of Polish Freemasonry and began his writing accomplishments on this subject with publications about both the presence of this movement in the musical community and music's role in the Masonic ritual. ${ }^{577}$ Chybiński probably knew Małachowski-Łempicki, or at least had heard about him. One should note that the author's debutant text

574 Ibid., 47.

575 'Ze statystyki szkolnictwa muzycznego' [From statistics about music education] (KM 1931/10-11, 156-169).

576 Information based on Hass [without date].

577 See amongst others: 'Wolnomularstwo polskie a muzyka. Materiały' [Polish Freemasonry and music. Materials] (WM 1925/7, 186-192); 'Wolnomularstwo polskie a muzyka' [Polish Freemasonry and music] (WM 1926/11, 37-39, 1926/12, 49-51). 
in the pages of Wiadomości Muzyczne (the already mentioned materials on Freemasonry from 1925) was adjacent to the papers by the professor himself ${ }^{578}$ and by Feliks Starczewski. ${ }^{579}$

Małachowski prepared two texts for the Kwartalnik: 'a handful of unknown details' regarding Henryk Macrott's reports on musicians active in Warsaw in the first decades of the nineteenth century ${ }^{580}$ (Maria Szymanowska, Stanisław Serwaczyński, Józef Bielawski) and - earlier - a substantial contribution to the subject of the Freemasonry episode in the life of Józef Elsner ${ }^{581}$ which briefly presented Elsner's quick path to promotion in Masonic structures in the Warsaw-based period of his life. Along with the publications from Wiadomości Muzyczne, the texts in the Kwartalnik based on the Masonic archives infiltrated by Małachowski (and hard to reach for others) are still one of the few sources of knowledge about this movement in Poland's musical community.

In a sense, Małachowski-Łempicki's text was also connected to the material published in the same volume of the Kwartalnik by the theatre historian and theatre critic Wiktor Brumer: 'Pierwsze przedstawienie Niemej z Portici Aubera w Warszawie' [The first performance of The mute girl of Portici by Auber in Warsaw $]^{582}$ on the difficult preparations for the premiere of this revolutionary opera in the period preceding the outbreak of the November Uprising and its triumphant shows during the months of insurgent successes - both authors were showcasing little-known facts from the life of the musical community in the Congress Warsaw.

Stanisław Furmanik, a literature theoretician and a literary critic from Warsaw, a Russian literature translator and the author of introductions to editions of Polish poetry also came from outside the music circle. As a linguist, he dealt

578 'Przyczynki do historii krakowskiej kultury muzycznej w XVII i XVIII wieku' [Contributions to the history of Cracow musical culture of the XVII and XVIII centuries] (WM 1925/7, 179-186).

579 'W sprawie repertuaru orkiestr wojskowych' [In the matter of repertoire of military bands] (WM 1925/7, 193-194).

580 'Szpieg Henryk Makrott-syn o muzykach' [Spy Henryk Makrott-son about music] (KM 1931/12-13, 434-435). Let us recall that at the same time he was preparing to publish an edition of these documents: Raporty szpiega Makrotta o wolnomularstwie polskim 1819-1822 [Reports of spy Makrott about Freemasonry in Poland], Warsaw [1931].

581 'Józef Elsner jako wolnomularz (na podstawie nieznanych materiałów archiwalnych)' [Józef Elsner as a freemason (Based on unknown archival materials)] (KM 1929/5, $67-71)$.

582 KM 1931/12-13, 435-444. 
with metre and versification. ${ }^{583}$ His papers came out in pre-war music press only a few times. He published, for example, in Muzyka Polska:584 he wrote two times for Kwartalnik, including his presence in the group of several authors of the first issue. His article 'O kulturę muzyczną w Polsce' [On music culture in Poland] ${ }^{585}$ was a polemic evaluated as 'excellent' in Warsaw. ${ }^{586}$ The author posed the question of why the level of musicality in the nation was so low and made an attempt to find the reasons behind this situation (did it lie in only occasional flashes of genius, manifested by the legacy of Chopin, Moniuszko and Karłowicz? In 'the horrifying nudity' of Polish 'theoretical production, that is textbooks written by local authors? In the fact that the society did not develop a need to participate in concert life? Or maybe in the lack of a music 'industry', which he understood as a small number of orchestras which were active in the previous decades?). Furmanik did not blame artists for this situation; he only said that 'l'art... c'est l'art - et puis... voilà tout.' He claimed that the audience mainly influences the level of culture (including musical), and the "lack of a cultural listener is the key reason for the low level of musical culture in Poland, ... acquisition of such a [cultural] listener and his subsequent multiplication becomes the chief task of actions in this regard,' and the fruits of these activities can bring only 'an intensification of a fair and creative aesthetic thought.' ${ }^{587}$

The second text written by Furmanik was leaning towards aesthetics. This time, he was looking for an answer to the fundamental question of what music is and what its subject is. ${ }^{588}$ The author based his extensive reflections on theses taken from the works of Aleksei Losev, a Russian philosopher and musicologist (Music as a Subject of Logic, Moscow 1927) and Bogdan Suchodolski, a philosopher and a historian of culture (Przebudowa podstaw nauk humanistycznych [The remodelling of the foundations of humanities], Warsaw 1928). The author asks, for example, why music, which 'has no specified qualities', still 'brings tears

583 After the war, he published a book entitled Podstawy wersyfikacji polskiej: (nauka o wierszu polskim) [The basics of Polish versification: (A study of Polish poems)] (Warsaw 1947). He also wrote the introduction to Forma dźwiękowa prozy polskiej $i$ wiersza polskiego [The sound form of Polish prose and poetry] by Kazimierz Wóycicki (Warsaw 1960).

584 'Muzyka w filmie' [Music in film] (MP 1936/5, 328-336).

585 Op. cit.

586 See Sikorski to Chybiński from Warsaw 18 IX 1928, AACh-BJ, box 4, S-10/7.

587 Stanisław Furmanik, 'O kulturę muzyczną....' op. cit., 81.

588 'Próba wyznaczenia przedmiotu muzyki' [An attempt to determine the subject of music] (KM 1929/3, 272-283). 
to our eyes without any apparent reason, triggers courage and valour, awakens longing and love'? ${ }^{589}$ What might be the answer to the question is élan vital - the creative force that helps 'substantiate a formless object of a given piece of music ... into a subjective complex of psychophysical qualities, if we want it to exist for us as something complete and "understandable," instead of a loose collection of aural sensations. ${ }^{590}$ Furmanik's dissertation, of course, did not provide comprehensive answers to the questions posed, but at the time it was one of the few attempts to delve into a discussion in the field of musical aesthetics.

The author who clearly dominated Kwartalnik, both when it comes to the number of publications and their scientific level, was Ludwik Bronarski. He was one of those people who inaugurated the interwar history of the journal. Bronarski, who was ten years younger than Adolf Chybiński, started musicological studies and comprehensive music studies in Vienna (one of his teachers was Guido Adler). He then moved to Fribourg to take lessons from Peter Wagner. He was granted a doctoral degree for his dissertation on the song of St. Hildegard of Bingen. Afterwards, he rarely went back to medieval music and completely focused his research work on issues related to Chopin. It is difficult to know how the professor got to know about the young musicologist's activities and achievements. Chybiński's memoirs break off during the first years of his stay in Lviv, whereas the first letters they exchanged come from the second half of the 1920s. Nevertheless, even as early as that, Chybiński, and all the more Bronarski treated each other with great esteem and respect, which had its roots in the fact they shared the same intellectual plane.

It was not immediately certain that the cooperation would end up fruitful. Unfortunately, the requests to provide the editorial team, submitted during preliminary editorial works and repeated on several occasions, on behalf of Kwartalnik with either a chapter or paragraph of the forthcoming Chopin monograph ('Or maybe a special article in the field of harmonic problems in the works of Chopin?'), ${ }^{591}$ were turned down by the musicologist from Fribourg. ${ }^{592}$ Pressurised by further invitations, he submitted a text to the first volume. It talked about publishing posthumous works, using the example of Chopin's Waltz in A-flat major, ${ }^{593}$ which had been composed in the 1830 s but was not published by

589 Ibid., 276.

590 Ibid., 277.

591 Chybiński to Bronarski from Lviv 7 II 1929, AACh-BUAM, Bronarski’s archive, p. 12.

592 At that time, he was already planning a monograph on Chopin's harmony 'of greater scale,' see Bronarski to Chybiński from Geneva 26 IX 1928, AACh-BJ, box 6, B-26/4.

593 Ludwik Bronarski: 'W sprawie wydania pośmiertnych dzieł Fryderyka Chopina' [On the matter of publishing Chopin's posthumous works] (KM 1928/1, 55-59). 
Fontana until a few years after Chopin's death. From this moment on, his studies and reports were present in almost all pre-war volumes of Kwartalnik. However, his name did not appear in volume 14/15 and 17/18, but in volume 12/13, half of which was devoted to Chopin, he published four texts: 'Korespondencja w sprawie pośmiertnego wydania pieśni Chopina' [Correspondence on posthumous publication of Chopin's songs], 'Akord "chopinowski"' ['The Chopin' chord], “Anonimowe ronda" Chopina' [Chopin's 'Anonymous Rondos'”], and a report entitled 'Nowe Chopiniana' [New works on Chopin]. ${ }^{594}$ In total, he submitted eleven articles and an abundance of reviews to the pre-war Kwartalnik (in addition to the four dissertations in the post-war editions). Being aware of the high level of Bronarski's research, the editor-in-chief did not put any barriers or limitations as to the content and form of the expected texts: 'I cordially ask for your work on Schumann's evaluations of Chopin, and at the same time let me assure you that the size of your work cannot, and will not, be hampered in any way.... I am of the opinion that all Chopin works, provided that they bring positive results and contribute to the expansion of Chopinology, should be favoured with special respect. ${ }^{3} 95$

The cooperation between Bronarski, Chybiński and the editorial team of Kwartalnik is one of the professor's best-documented relationships because letters from and to Bronarski was preserved in Chybiński's archive. As already mentioned, when organisational work on the new project started, Chybiński had already been in touch with Bronarski. Even though they had contact only through letters, they exchanged them regularly, and their relationship was very warm and full of respect. As far as is known, even though the author of Harmonika Chopina [Chopin's harmonic] occasionally visited Poland, he never met the professor.

594 Respectively pp. 362-369, 369-380, 393-401, 401-405. In addition, articles and materials were also published: 'Stosunek Schumanna do twórczości Chopina' [Schumann's attitude to Chopin's works] (KM 1929/3, 260-271, 1929/4, 396-412); 'O kilku reminiscencjach u Chopina' ['A Few Chopin Reminiscences'] (KM 1929/5, 25-32); 'Listy Chopina w Genewie' [Chopin's letters in Geneva'] (KM 1930/6-7, 184187); 'Chopin w Leksykonie Gathy'ego' [Chopin in Gathy's lexicon] (KM 1930/6-7, 239-240); 'Pierwszy akord Sonaty b-moll Chopina' [The first chord of Chopin's B minor sonata] (KM 1930/8, 313-320); 'Kilka uwag o basso ostinato w ogóle, a u Chopina w szczególności' [A few remarks concerning bass continuo in general and in Chopin in particular] (KM 1932/16, 705-715). Bronarski's last 'pre-war' text for Chybiński's editorial - a report on publications about Chopin - appeared PRM (more below).

595 Chybiński to Bronarski from Lviv 28 II 1929, AACh-BUAM, Bronarski’s archive, p. 13. 
Nevertheless, his personality, revealed in the very first sentences of his letters, had charmed the professor for many years to come. It was Bronarski who became one of the professor's confidants. Sometimes, Chybiński simply 'reported' to him all events related to his university, scientific, musicological, editorial and private life. Bronarski, who was extremely discreet and more reserved when it came to expressing his emotions and views, esteemed the professor and showed recognition for his activities, so he kept the correspondence going. Years later, their letters make it possible to correct certain known facts and reconstruct many unknown ones, as well as private reflections of the father of Lviv musicology.

Bronarski presented as an author at the highest European level, and his works (articles and book) aroused appreciation of the music and musicological milieu in the country. Zofia Chechlińska also notes that 'Bronarski represented a type of musicologist which is rather rare nowadays, as he combined in-depth theoretical knowledge with music practice. ${ }^{396}$ The recognition of this versatility was expressed in inviting him, alongside Paderewski and Turczyński, to join the select group of authors who were working on an edition of Chopin's works. Chopin's Harmonic, which was published in 1935, received very favourable reviews, including the one written by Józef Chomiński for the second volume of PRM, which stood out from others due to its professionalism. Chybiński also wrote about Szymanowski's reaction to his other publications devoted to Chopin: 'He mentioned the papers [by Bronarski] with real pleasure. Actually, I was surprised that musicology could be so interesting to a musician. He went into raptures over the Chopin-Rossini problem, even though you'd rather expect something else from him., 597

Bronarski submitted diverse papers to Kwartalnik Muzyczny. Some of them were monographs, such as a long paper on the evolution of Robert Schumann's attitude towards the output of Frederic Chopin, based on critical reviews which the German composer and publicist had published in Allgemeine Musikalische Zeitung, Viennese Musikalische Anzeiger and most importantly Neue Zeitschrift für Musik. ${ }^{598}$ Schumann's reviews were widely known, but in the past they had never been the subject of musicological research. Bronarski also submitted an analytical article devoted solely to the melodic phrase which was one of the most characteristic features of Chopin's music. Bronarski wrote that in this melodic

596 Chechlińska 1977, 8.

597 Chybiński to Bronarski from Lviv 21 VII 1930, AACh-BUAM, Bronarski’s archive., p. 43.

598 'Stosunek Schumanna...,' op. cit. 
phase, 'the fifth jump of the dominant seventh chord still touches the nearest upper tone before it moves on the octave of the tonic chord. ${ }^{599} \mathrm{He}$ also submitted his reflections on two 'lapidary and symbolic' chords opening the finale of Sonata in B-flat minor. ${ }^{600}$ These well-thought-out and extensive papers were supplemented with introductory articles, inspired by collections which the musicologist gradually discovered (as was in the case of the antiquarian collection of the Fatio family from Geneva) or by historical lexicons which he read, in this case, Musikalisches Conversations-Lexicon... from 1835, edited by August Gathy. Chopin's biographical entry in this book was much longer than the entries devoted to his contemporaries (such as Schumann or Liszt). On top of that, there were cross-references to Chopin in the entries on mazurkas and piano études. Bronarski was also a regular Chopin reviewer, and Chybiński assigned one of his 'reports' a place among articles. This text referred to two publications which at that time were keenly commented on by representatives of the musicological community. One was an edition of the newly discovered Mazurka in A-flat major (from the collection of Adam Mickiewicz Museum in Paris). It was prepared to be published by pianist Maria Mirska. The second publication was a book by Leopold Binental which commemorated the 120th anniversary of the composer's birth. ${ }^{601}$

Monographs and articles written by Bronarski were proof of the highest level of scientific expertise and the great erudition of which this researcher could boast. The editor-in-chief emphasised this fact multiple times. He not only treated Bronarski as a 'regular contributor', but was also ready to trust the renowned author completely in all matters related to Chopin or even give Bronarski a 'monopoly' on Chopin in Kwartalnik. ${ }^{602}$ As he put it himself, he often treated him as 'Retter in der Not', who would undoubtedly support the editorial team, also by fulfilling 'orders' when there were no texts to be published.

Apart from Bronarski the 'Helvetus', materials for the second edition of Kwartalnik were sent from abroad by a few other authors. I have already

599 'Akord "chopinowski”“, op. cit., 369.

600 'Pierwszy akord..., op. cit.

601 'Nowe chopiniana, op. cit. Bronarski he was very interested in the new discovery, he heard this Mazurka performed by Mirska herself, a concert pianist, on a French radio programme, see Bronarski to Chybiński from Geneva 11 III 1930, AACh-BJ, box 6, B-26/29. On the contrary, Chybiński, who was skeptical about these sensational messages, Chybiński to Bronarski from Lviv 15 III 1930, AACh-BUAM, Bronarski’s archive, p. 34.

602 Chybiński to Bronarski from Lviv 7 II 1929, AACh-BUAM, Bronarski's archive, p. 12. 
mentioned Paul Brunold, who was one of them. Chybiński asked the editorial team from Warsaw for an opinion on cooperating with European musicologists. Bronisław Rutkowski answered: 'Some time ago you asked whether it was possible to make foreign scientific forces cooperate with Kwartalnik. In our view, it is possible, but not in the historical section, which is exemplarily represented by Polish forces. ${ }^{603}$ Perhaps this question was related to the issue planned due to the Pan-Slavic Singing Congress which took place in Poznań in May 1929. It was then that Chybiński was planning to initiate cooperation with Josef Hutter, a Czech publicist and musicologist (who would write about 'Czech musicology and the worship of early music in Czechoslovakia'), Dragan Plamenac, a Croatian musicologist and composer, and Kosta P. Manojlović, a Serbian composer and ethnomusicologist (who would write about 'musicology and the worship of early music in Croatia and Serbia'). ${ }^{64}$ However, this plan did not come to fruition. The only author who responded to the invitation to publish a paper in Kwartalnik was Benedict Szabolsci, a Hungarian ethnomusicologist, who made the Polish music community familiar with over a hundred years of musicological (or rather musicographic) research in Hungary. ${ }^{605}$ A few years later, Joseph Wihtol from Latvia, the director of the Riga Conservatoire, ${ }^{606}$ prepared a paper on Latvian folk songs. ${ }^{607}$

The first issues of Kwartalnik Muzyczny were dominated by historical subjects, such as Old Polish music, sometimes supplemented by materials on Chopin and occasionally by articles on systematic musicology. Close cooperation with Ludwik Bronarski and using his achievements in research on the life and, most importantly, the art of Frederic Chopin allowed Chybiński to develop his idée fixe related to the constant presence of Chopin in his journal. He was not trying to hide this fact since, for example, he wrote: 'Kwartalnik will be constantly concerned with the output of Chopin so as to give an impetus for the development of our Chopinology. ${ }^{308}$ At the same time, he counted on Bronisława

603 Rutkowski to Chybiński from Warsaw 11 I 1930, AACh-BJ, box 4, R-19/12.

604 Chybiński to Bronarski from Lviv 21 III 1929, AACh-BUAM, Bronarski’s archive, p. 14.

605 Benedict Szabolcsi, 'Główne kierunki badań muzycznych na Węgrzech' [Main directions of music research in Hungary] (KM 1930/9, 68-73).

606 Properly Jāzeps Vìtols, Latvian composer, organiser of the national opera stage, longtime professor and rector of the Latvian Conservatoire.

607 'O pieśni ludowej na Łotwie słów kilka' [A few words about Latvian folk songs] (KM 1933/17-18, 65-69).

608 Chybiński to Bronarski from Lviv 20 IV 1929, AACh-BUAM, Bronarski’s archive, p. 15. 
Wójcik-Keuprulian, whom he had himself promoted much earlier and who had already had experience in studying Chopin, and on Ludwik Bronarski, who at that time was given carte blanche as to the contents and form of his texts.

This desire manifested by Chybiński was a continuation of the tradition of Chopin worship which was present in Polish culture. Throughout decades, reverence and adoration for the composer were expressed in numerous nineteenthcentury magazines, as well as in critical and journalistic works published by the leading figures of Polish music literature. This situation continued until Chopin's death in 1849. This date coincided with the flowering of the literary career of a group of Warsaw publicists, who later became involved in Ruch Muzyczny. First in Biblioteka Warszawska and a year later as a brochure, Józef Sikorski published a text entitled Wspomnienie Szopena [A remembrance of Chopin], whose style was rather exalted but appropriate at that time, shortly after the composer's death. Despite its 'Romantic rhetoric' ${ }^{\prime} 009$ - the term coined by Elżbieta Szczepańska-Lange - Sikorski’s text in its analytical part is a worthy predecessor of Karasowski's and Hoesick's works. Only a few years later Gazeta Warszawska published a Chopinological essay by Józef Kenig, who remarked that too little time had passed since the composer's death 'to show us his importance in general art'; 610 in the early 1960s, Biblioteka Warszawska published a sketch 'Młodość Chopina' [Chopin's youth] by Maurycy Karasowski. ${ }^{611}$

Chybiński, who devoted only short introductory articles to Chopin and his art, believed that it was his duty to maintain this tradition in the journal which he ran. However, his efforts from the interwar period resulted in filling just a part of one of the issues. Both the readers and the editor-in-chief of Kwartalnik had to wait until 1949 for the fulfilment of Chybiński's plans. It was the anniversary of the composer's death and the musicological community, which was still recovering from the war, supported by some authors from abroad (such as the unfailing Ludwik Bronarski), prepared a commemorative volume devoted to Chopin (in fact, two special issues were published on this occasion and entitled $Z$ życia i twórczości Fryderyka Chopina [On the life and art of Frederic Chopin] - the double issue 26/27 and issue 28). Nevertheless, he only managed to persuade two authors to cooperate on this topic. These were Bronarski (whose

609 Szczepańska-Lange 1997.

610 Józef Kenig, 'Z powodu wydania pośmiertnych dzieł Chopina' [On the occasion of the publication of Chopin's posthumous works] (Gazeta Warszawska 1856/121).

611 The second part of the work was published there in 1869, and the enlarged monograph Friedrich Chopin, sein Leben, seine Werke und Briefe was issued by Karasowski in Dresden in 1877. 
writings about Chopin I have already presented) and Feliks Starczewski, who (as always) could only submit short introductory articles based on excerpts from the nineteenth-century press, this time reviews of Chopin's works from Paris newspapers (see above). The editorial team did not even manage to fill the report section with thematic reviews (even though there were almost thirty papers in this section). The paper on 'new publications devoted to Chopin,' which was submitted by Bronarski, was also qualified as an article by the editorial team, due to the scientific discussion started by the author.

The first ideas as to specific topics had already emerged earlier. From numerous private opinions expressed by Chybiński in his letters, we can infer that a large part of the editorial plans referred to monographic projects. Even in the editorial from the inaugural issue, we can read that despite the fact that 'we are enthusiasts of early music, we do not detach it from the present, we do not contrast it with foreign art, ${ }^{612}$ but already two years later, summarising their achievements and presenting plans for the next year, the editorial team wrote: 'in volume II of the annual, just like in volume III, we are going to expand the sections which so far couldn't be properly developed in Kwartalnik Muzyczny: ... theoretical ..., ethnographic ... and pedagogical sections [, whereas] the number of contributing authors will rise significantly and will exceed forty names.' This fragment was followed by the names of authors from all Polish musicological centres and many cities in other countries. ${ }^{613}$ Privately, Chybiński admitted: 'I would like to "modernise" the second yearly a little bit, that is direct it mostly towards more recent music, thereby putting earlier music in the second place. This does not mean that it will be "neglected," which would be unthinkable when I am a co-editor. Unfortunately, my past experience tells me that it will come with some difficulties. I received a few papers on "more recent" music. Apart from our Chopinologists, nobody else deserved to be taken into account.' ${ }^{614} \mathrm{He}$ was aware of the fact that he could not (or rather should not) limit himself: first of all, to the themes which fell within his own research interests (that is early music, Chopin and folklore) and secondly, to the group of authors made up of his pupils:

I'm putting in every effort for the level to be even higher so that we can at least get closer to the maximum height that we can talk about in these conditions, which are still pitiful. ... Difficulties consist mainly in the fact that 'Lviv' simply has to deliver most papers,

612 [Editorial] (KM 1928/1, II).

613 'Od Redakcji' [Editorial] (KM 1930/9, I).

614 Chybiński to Bronarski from Lviv 20 IV 1929, AACh-BUAM, Bronarski’s archive, k. 15. 
whereas I would like to see the whole of Poland represented in Kwartalnik. ... I would like to modernise Kwartalnik with regard to themes, which I will surely carry out this year, once again thanks to doctoral dissertations written by Lvivians (Miss Łobaczewska's work on Debussy's harmony before Pelléas and Dr Lissa's work on Scriabin's harmony, then Miss Łobaczewska's one about Szymanowski's piano compositions and Miss Lissa's work on the polytonality and atonality in light of the latest research).... It's not possible for Lvivians to jostle even more in 'their' Kwartalnik. ${ }^{615}$

Over time, plans became more specific: 'Most probably, volume IX will be solely about folklore. Volume X or XI, or the double volume X/XI, will be devoted exclusively to the output of $\mathrm{K}$. Szymanowski; it is already almost entirely organised. It will be a manifestation on behalf of an artist who has suffered more "in the country" than we could assume... I want to devote one issue entirely to younger composers, whereas still another one will be devoted to music culture in Poland, etc. ${ }^{616} \mathrm{~A}$ month and a half later, the professor wrote more specifically: 'I want to come forward with an "impressive" issue and I am designing a special issue devoted to the output of Karol Szymanowski, which will be created by $\mathrm{x}$ Polish forces, possibly coming solely from Lviv, just to spite Warsaw ... . It will be a double issue, and it will not come out soon, maybe in 1932.617 In November of that year, he also thought about an edition which he 'wanted to fill with works referring exclusively to Chopin's work.' ${ }^{\prime 618}$

Despite numerous ideas for thematic issues, Chybiński managed to finish only two of them, or rather two and a half: 10/11, which was referred to as pedagogical and 17/18, which was referred to as ethnographic, as well as the abovementioned issue $12 / 13$, half of which was devoted to Chopin.

The issue which was planned the most uniformly and whose execution was the most consistent was the one devoted to teaching, music pedagogy and psychology. It turned out that among musicologists and musicians, there was a group of authors who actively worked towards the development of teaching methodology, which included both practice and theory of music education, as well as the methodology of research on the problems of educating society,

615 Chybiński to Bronarski from Lviv 3 XI 1929, AACh-BUAM, Bronarski’s archive, p. 23.

616 Chybiński to Bronarski from Lviv 18 IV 1930, AACh-BUAM, Bronarski's archive, p. 37. In fact, the double edition 10/11 was devoted entirely to issues in the field of pedagogy, psychology, teaching, and education; the ethnographic edition was not published until 1933 (no. 17/18). A monographic edition devoted to Szymanowski was not created at all.

617 Chybiński to Bronarski from Lviv 3 VI 1930, AACh-BUAM, Bronarski’s archive, p. 39.

618 Chybiński to Bronarski from Lviv 7 XI 1930, AACh-BUAM, Bronarski’s archive, p. 49. 
starting from common schools and ending with specialist music studies. Luckily for readers, at that time (around 1930), Karol Szymanowski became the rector of the Warsaw Conservatoire. His speech at the inauguration of the academic year was used by several editorial teams, including Kwartalnik Muzyczny. The erudite speech given by Szymanowski, supplemented with statistics on the music education system prepared by Janusz Miketta, served as an introduction to papers devoted to current problems in music education. Henryk Opieński expressed his opinion on the need for changes in the teaching of music theory in light of newly emerging trends in music. Seweryn Barbag referred to a similar problem, but he focused on the teaching of music theory. Zofia Lissa wrote about the necessity of developing research on child psychology which would make it possible to direct human education from an early age in order to reach a high level of aesthetic life (she postulated to gradually limit elements of play, which need to be used at the beginning of the educational process to enable the development of the child). Seweryn Barbag authored another text which appeared in the issue and presented a new project of organising higher music education system, emphasising that it was necessary to treat each student individually in order to discover and fully use his or her talents, regardless of the specialisation which he or she chose. Bronisław Romaniszyn had similar reflections, which he applied to his primary field, which was singing.

Two texts were slightly different from the rest of this issue. One of them had a strictly practical value (Józef Koffler, using his own teaching experiences, proposed a specific method of teaching diatonic modulations), whereas the second one was written by Feliks Starczewski, who introduced the topic of German music schooling at the beginning of the nineteenth century, and was the only strictly historical paper in this issue. This rich project involved many papers and was supplemented by the report section, which spanned over fifty pages. This informed readers about over three hundred publications, which had various ties to the topics taken up in the volume. It needs to be emphasised that the authors of the reports were solely Lvivians and 'Chybiński's people', most importantly Zofia Lissa and Seweryn Barbag, but also Julian Pulikowski and Jerzy Freiheiter, as well as the authors of single reviews, that is Ludwik Bronarski, Bronisława Wójcik-Keuprulian and Maria Szczepańska. There were also two reports written by Chybiński. The only 'outsider' was Father Henryk Nowacki, a proponent of the revival of Gregorian chant, an editor of magazines devoted to church music, the director of the Warsaw Archcathedral choir and an author of religious compositions. After the Second World War, he founded the Church Music School in Niegów in Mazovia. For Kwartalnik, he prepared a review of a book devoted to church singing. 
Not everyone had a high opinion of materials which focused on the new currents in musicological research. Opieński, as a representative of classicallyoriented methodology, wrote:

For a few weeks, I've been studying the "psychological" issue of Kwartalnik, but I must admit that I can only swallow such things in very small doses. Besides, regardless of all the arguments of the Schönberg school, I believe that using the adjective atonal in music is devoid of any sense, for composition X may be neither major nor minor, yet it must be tonal, just like butter can't be abuttery or glassy, it can only be buttery; hypertrophy in the differentiation of functions has reached the stratosphere, in which the natural sense of tonality was lost, and yet everything that makes a sound has its origin in some tonic key and belongs to some tonic key. ${ }^{619}$

It is hard to say whether others shared this opinion. From today's perspective, the project itself should be seen as quite cohesive and its implementation as a fair presentation of the then-current problems which were vital for the whole music community.

The realisation of the idea behind the second thematic volume, the ethnographic one, differed from Chybiński's plans. Today, we can see that as always, this volume was also filled with papers written by trusted contributing authors of Kwartalnik (Szczepańska, Opieński, Chybiński, Wójcik-Keuprulian, and also Helena Windakiewicz, Pulikowski, Skierkowski). Nevertheless, in the beginning, contributions were supposed to be international: 'Finns and Swedes are going to write about a dance called "polská" and the Romanians about the dances of Romanian highlanders, which are so similar to our highlanders' dances. I would really like to have something "Lithuanian," but boćwinki620 are a hard nut to crack. Even the Latvian promised to submit an article (Wichtols, the director of the Riga Conservatoire). In the reports, there will even be something about Estonian runic melodies. There will also be reports on publications issued in Tokyo, etc., etc. ${ }^{\prime} 21$ However, attempts to create a homogenous volume failed. Since most of the expected materials which were supposed to bring up strictly ethnomusicological themes were lacking, the professor decided to use some historical and theoretical texts. And so before Helena Windakiewicz went on to present her extensive reflections on the pentatonic scale in Polish folk music, she provided a theoretical introduction which concerned the presence of the diatonic

619 Opieński to Chybiński from Morges 16 VII 1932, AACh-BJ, box 6, O-2/ 127.

620 A pejorative term for impoverished Lithuanian gentry and, in a broader meaning, Lithuanians in general.

621 Chybiński to Bronarski from Lviv 25 XI 1930, AACh-BUAM, Bronarski's archive, p. 52. In the end, as mentioned, only a brief report by Joseph Wihtol was published. 
scale and the anhemitonic pentatonic scale in the music of different cultures (from the historical point of view), at the same time referring to essays written by European theoreticians and historians (Hugo Riemann, August Wilhelm Ambros, François-Auguste Gevaert, Théodore Reinach, Hugo Leichtentritt). The aim of the theoretical background was to prepare readers for the next part of the article, in which, using examples from the collections of Father Skierkowski and Kolberg, the author shortly analysed to what extent and in what way the pentatonic scale survived in Polish folk music.

Following the article by Windakiewicz, three contributions to seventeenth-, eighteenth- and nineteenth-century sources indicating traces of folk art should rather more be considered as belonging to publications presenting 'old-Polish' music than musical folklore. In her paper entitled 'Z folkloru muzycznego w XVII wieku' [From the music folklore in the seventeenth century], ${ }^{622}$ Maria Szczepańska brought forward two lute tablatures which were not well known at that time. One tablature was written by Dusiacki (and described a few years earlier by Helmuth Osthoff), whereas the second one was the so-called Gdańsk tablature, which Szczepańska was dealing with herself (she was, for example, preparing transcriptions of compositions included in it), stopping by those compositions whose titles suggested that they could have originated from folk music. Julian Pulikowski prepared a short historical announcement ${ }^{623}$ about a collection entitled Schlesische Lieder which dated back to 1810 and included a few Polish songs. He had found it in the archive of Gesellschaft der Musikfreunde in Vienna. He also provided incipits of these songs, and as a commentary, he quoted the words of Christian Friedrich Daniel Schubart, who remarked on the majestic and graceful songs of the Polish nation which were imitated by the whole Europe. This 'historical' part ended with the above-mentioned 'Przyczynek do dziejów poloneza w XVIII wieku' [Contribution to the history of the polonaise in the eighteenth century] by Henryk Opieński.

The second part of the ethnographic volume was made up of publications which referred strictly to folklore research conducted by their authors. These publications included an article written by Chybiński himself. He addressed the issue of indigenousness and originality of the music played by highlanders from Podhale, as well as the borderland nature of Podhale and its cultural and ethnic consequences for the whole region. ${ }^{624}$ Initial theoretical considerations served as

622 KM 1933/17-18, 27-34.

623 'Sześć pieśni śląskich z roku 1810’ [Six Silesian songs from 1810] (KM 1933/17-18, 32-35).

624 'O źródłach i rozpowszechnieniu dwudziestu melodii ludowych..., op. cit. 
an introduction to the second part, in which the author, who mentioned ten-odd popular highlanders' songs, debunked the myth that they were of local and native origin and made a reference to the musical tradition of Slovaks, Lemkos, Vlachs, Hutsuls and Hungarians. As he argued in the summary of his article, he wanted to 'show the far reach of melodies from Podhale, which spread to ethnically diverse regions,' such as Romania and Yugoslavia. At the same time, he admitted that his aim was not to 'demonstrate some kind of musical unproductivity of Skalne Podhale ... and yet it was necessary ... to show that just like all other melodies from ethnic borderlands, melodies from Skalne Podhale also bear the characteristics of an exchange of assets of spiritual culture between a few nations which are direct or indirect neighbours.' ${ }^{.25}$

The remaining articles written by Father Skierkowski, Joseph Wihtol and Bronisława Wójcik-Keuprulian (about Turkish music ${ }^{626}$ ), which have been mentioned previously, were supplemented with reports on the most recent publications: an edition of folk melodies from Podhale (byStanisław Mierczyński), Masuria (by Hedwig Borowski), Lemkivshchyna (by Filaret Kołessa), Romanian carols (by Sabin Vasile Drăgoi), as well as the editions of "folk" songs composed at that time by Szymanowski and Maklakiewicz.

Neither Chybiński's strong interest in ethnographic research nor the subtitle of Kwartalnik, which emphasised that it was a journal devoted to 'the theory, history and ethnography of music,' made this research field grow on authors who cooperated with the journal. The monographic issue contained eight out of ten papers devoted to music folklore, which had been published under the pre-war edition of the journal (the remaining two papers were publications written by Michał Kondracki).

The theme of at least two monographic issues dominated the contents of other issues as well. When it comes to materials related to pedagogical matters and performance practice, along with texts on aesthetics, philosophy, sociology and psychology of music, twenty-five such papers were sent, which is quite surprising as compared to nineteen papers on 'Old Polish' topics, ten on more contemporary Polish music and twenty devoted to Chopin (supported mainly by the significant contribution made by Bronarski). Given the editor-in-chief's undisguised aversion towards research on foreign music (he was a fan of Grieg, and yet he believed that young musicologists should direct all their scientific impetus towards reflections on domestic creative output), texts devoted to general music

625 Ibid., 64-65.

626 'Muzyka Bliższego Wschodu II' [The music of the Nearer East II], op. cit. 
could rarely be found in Kwartalnik (in total, there was a little over ten articles and contributions). Systematic musicology was represented by just a few titles. In fact, theoretical reflections were taken up solely by Zofia Lissa and Stefania Łobaczewska. The main acoustician at that time was Gabriel Tołwiński, who a few years later (in PRM) was joined by Marek Kwiek, a young graduate of the Department of Musicology in Poznań. Therefore, it is clear that the polarisation of interests manifested by musicologists who published in Kwartalnik contributed to the emergence of a group of authors who represented social sciences (within the framework of music research) and methodologies which ten-odd years later dominated research on the history of music. Another group involved with Kwartalnik were historians, both Chopinologists and those who studied Early Music.

As already mentioned, the column with reports and reviews related to current music and musicological literature was surprisingly full. Reviewed titles were obtained in a variety of ways. It is known that Chybiński himself obtained many of the most important and the latest publications (he bought, exchanged and collected free copies, also from abroad). Musicologists who cooperated with Kwartalnik and were staying abroad (mainly in Switzerland and France) were also asked to submit their reviews. In the beginning, 'due to the squeeze which began to make itself felt', the editorial team planned to publish only short, one-page reports. The column was expanded over time, whereas the professor's appetite for reporting the latest musicological publications was constantly growing. $\mathrm{He}$ tried to follow the rule of supplementing monographic issues with reviews referring to the same topics: 'Romanticism! ... If you happened to have some new publications concerning this epoch and Romantic or Neoromantic composers, please do not hesitate and do what you will. ... You could, for example, review Bory's book about Liszt and his "scandalous" escape to Switzerland, etc..' 627

He did not write much himself, mostly papers on German and French publications, but also English and Italian ones. He was ready to learn Spanish and Scandinavian languages ${ }^{628}$ 'for the cause.' He also kept motivating his pupils and associates to work on their papers. At one point, he was thinking about expanding the report section, and on that account wanted to formalise

627 Chybiński to Bronarski from Lviv 14 III 1931, AACh-BUAM, Bronarski's archive, p. 60. In the letter this is about Robert Bory's work Une retraite romantique en Suisse: Liszt et la Comtesse d'Agoult (Paris 1930).

628 For more information on Chybiński's contacts with Norwegian composers, maintained also with the help of diplomatic posts, see Łopatowska-Romsvik 2016. 
his cooperation with Ludwik Bronarski. He offered Bronarski to 'write regular papers on Polish piano music, that is new Polish piano compositions ... regular papers on the history of piano music ... regular papers on works related to the history of piano music ... papers on works concerning the Romantic Period.' Furthermore, the list of publications which he was ready to send to Switzerland straight away was quite impressive. ${ }^{629}$ Apart from Bronarski, the journal had a few other 'reviewers on duty', that is Stefania Łobaczewska, Zofia Lissa, Jerzy Freiheiter and other Lvivians. The number of announced books and editions of sheet music was impressive, especially when we realise that obtaining these items must have been much more difficult than it is now, not only due to the fact that today's communication has been greatly facilitated, but mostly because the financial situation of musicology departments, which are niche scholastic centres (as compared to the faculties of law or medicine, which have traditionally been the most popular ones), were pitiful at that time. Therefore, we should appreciate the efforts of the editorial team of Kwartalnik and its editor-in-chief all the more. Thanks to them, each issue provided information about ten-odd new titles (and sometimes even more than that).

Distinct and clear statistics related to the 'second' Kwartalnik are included in a short summary, which can be found in the introduction to the bibliography of the periodical written by Maria Kielanowska-Bronowicz: 'In total, there were published ... 14 volumes, including 6 double volumes, with 1868 printed pages overall. Individual volumes had 101-160 pages on average, except for volume 10/11, which had 228 pages. Kwartalnik measured $28 \times 19.5 \mathrm{~cm}$, and its cover design was quite luxurious for its time: the paper was durable, the print exact, the semi-rigid cover colourful and modelled after a stylised drawing by Edward Manteuffel.' ${ }^{630}$ However, the aesthetic values of the journal did not increase its popularity. Its price ( 5 zlotys for a single issue) and the academic level of published papers, which were usually refined, only made matters worse. Another thing which did not help was the reluctance of the editorial team to open up to

629 Amongst others: Richard Gress, Die Entwicklung der Klaviervariation von Andrea Gabrieli bis zu Johann Sebastian Bach, [no city] 1929; Cornelia Auerbach, Deutsche Klavichordkunst des 18. Jahrhunderts, Kassel 1930; Oskar Deffner, Über die Entwicklung der Fantasie für Tasteninstrumente bis J.P. Sweelinck, Kiel 1928; Hans Bosch, Entwicklung des romantischen in Schuberts Liedern, Leipzig 1930; Julien Tiersot, La chanson populaire et les écrivains romantiques, Paris 1931 - these are just some of the books proposed to Bronarski, see Chybiński to Bronarski from Lviv 12 III 1931, AACh-BUAM, Bronarski's archive, p. 59.

630 Kielanowska-Bronowicz/Michałowski 1963, 13. 
'external' authors, especially those who were related to or sympathised with the centre in Cracow: 'Chybiński attached much importance to ensuring that all articles which came out in Kwartalnik were serious, scientific and unlike journalistic texts. ${ }^{6} 11$ During the years when the professor was working as an editor (that is, in fact, throughout all his life, starting from 1928), he often complained about inconveniences related to this activity, which, in his own words, diminished his health capital. ${ }^{632}$ On the one hand, he was irritated by critical opinions which accused him of restricting the group of authors to those from the Lviv centre. On the other hand, despite his declarations that he was going to widen the group of authors publishing in Kwartalnik to include representatives of different musicological centres, Chybiński felt the most confident when he published works written by Lvivians and some of his 'favourites' from outside this circle. When it comes to musicological 'professionalism,' he was a very demanding editor. $\mathrm{He}$ expected papers whose scientific style did not deviate from the model which he himself preferred. The highest professional level of the journal was his overriding goal, and he believed that the only possibility of carrying out his plan was using Lviv forces. Unfortunately, he usually could not count on cooperation with other centres and complained that 'Poznan' did not send him anything 'because it doesn't have anything,' whereas Cracow 'is turning towards belles-lettres.'633

Chybiński's own interests influenced the final shape of Kwartalnik Muzyczny. However, the professor was also burdened by the realisation of what mission a scientific journal should undertake: to disseminate knowledge on the highest academic level, regardless of the opinions voiced by groups which were ill-disposed towards musicology as an academic discipline. Almost from the point when the editorial team got down to work, the management board of the SMDM could not agree on the shape of the periodical. After over a year of work, Kazimierz Sikorski, the head of the editorial office of Kwartalnik in Warsaw and Chybiński's loyal associate, wrote as follows: 'They [the management board of the SMDM] scolded me for the "musicological" orientation of Kwartalnik. What do they want? Does Kwartalnik necessarily need to be similar to Muzyka or Ekspres Poranny (a Warsaw rag); perhaps we should introduce some topical illustrations. I sat tight and defended the current scope and direction of Kwartalnik. I think

631 Zalewski 1977, 111.

632 See Chybiński to Bronarski from Lviv 17 IX 1929, AACh-BUAM, Bronarski’s archive, p. 19.

633 Chybiński to Bronarski from Lviv 27 VI 1930, AACh-BUAM, Bronarski’s archive, p. 41. 
that at least one journal needs to be scientific and serious (i.e. musicological). We are trying to introduce more recent problems as far as possible, but the main thing is to [illegible] the history of Polish music. Each volume of Kwartalnik is one chapter of this history. But they don't get it. ... It's because what we are doing now will resonate some 20 years or more!'634

Nevertheless, despite the fact that his relations with both Chybiński and members of the Society were deteriorating, Mateusz Gliński, one of the most opinion-forming figures in the community, expressed his opinion in favour of the academic direction which the editorial team had set for Kwartalnik. In the previously quoted article which appeared in 'Musical Impressions' column, he referred to musicology as a branch of science and evaluated the legitimacy of a scientific journal:

If we take into account the fact that despite extreme publishing difficulties and the tiny number of people whose academic work is related to musicology, we still have a musicological journal, such a journal is exactly the place where the specialised work of our musicologists should be unloaded.... Our friend is painfully in the wrong if he believes that this journal should make compromises, seek contacts with professionals who are not musicologists, or aim at popularising knowledge. Today, Poland has about ten music magazines, which encompass all the fields of practical knowledge, without any exceptions.... In this case, the most important thing is a precise, careful division of competences. Slight, almost poor interest in music research will increase in wider music circles if this kind of knowledge ceases to be forced upon them in a crude form, unrelated to anything else and unsynthesised, which not only leaves readers indifferent, but also irritates them. ${ }^{635}$

For the professor, the possibility of adopting and keeping this form of the periodical, which would have been close to his vision of scientific literature, was a sine qua non condition in his cooperation with the publisher, SMDM. The disputes he had to lead to enforce the rules imposed by him earlier finally led to the decision that the members of the management board and the editorial team (or rather the editor-in-chief) should go their separate ways (and it needs to be noted that this was a mutual decision, fully appreciated by both parties). I have already referred to this situation in chapter I-2, where I briefly outlined the history of the SMDM. As the result of discrepancies between the expectations of the Management Board in Warsaw and the professor's aspirations, in 1933 it was decided that the competences of the editorial office would be divided. A quarterly (which soon became a bimonthly and finally a monthly) under the new name Muzyka Polska,

634 Sikorski to Chybiński from Warsaw 3 I 1930, AACh-BJ, box 4, S-10/35.

635 Gliński 1930, 684. 
which was headed by Bronisław Rutkowski, was supposed to broadly comment on current musical life and provide musicological materials, but its form was to be much lighter than in the past, for example, through publishing shorter papers. From then on, Chybiński's cooperation with the editorial team of this journal was rather symbolic. The professor fulfilled his aspirations by running the newly established (also under the auspices of the SMDM), strictly scholarly annal that he had been dreaming about for years. However, due to numerous adversities or perhaps mostly the professor's lack of organisational skills, which had already thwarted many of his earlier initiatives and would also have an impact on some later ones, only two volumes of PRM appeared before the war. 


\section{Muzyka Polska (1934-39) - Polski Rocznik Muzykologiczny $(1935,1936)$}

Conceived as a quarterly devoted to the issues of musical life in Poland, Muzyka Polska began to appear at the beginning of 1934. In the autumn of 1933, the question of the future of Kwartalnik Muzyczny was settled, and Bronisław Rutkowski and Kazimierz Sikorski wanted to inform Chybiński personally and exhaustively about the results of one of the meetings of the SMDM Board, holding a 'conference' with him in Lviv. The meeting, which took place on November 18, 1933, lasted six hours, and the conclusions from its course were briefly summarised in a letter to Ludwik Bronarski: 'The quarterly whose life has been hanging by a thread in the last few weeks will continue to appear, but in an "updated" form [Muzyka Polska], edited by Sikorski surrounded by the "editorial committee" (along with my humble self). On the other hand, the "luxus" will disappear, i.e. the scientific, strictly musicological part, which since 1934 has been transferred to the POLSKI ROCZNIK MUZYKOLOGICZNY [PRM] remaining under the editorship of the undersigned. ${ }^{636}$

Chybiński counted on the fact that 'this new Kwartalnik is not too different from the previous one' ${ }^{637}$ and should merit the support of regular, proven authors. In reality, however, the nature of the periodicals from the very beginning was cut off from its predecessor, because the published materials mainly concerned Polish music, chiefly Polish contemporary musicians and Polish musical life, the current concert movement, and were complemented by reviews and evaluation of new musical works. Texts concerning music theory, ethnography, aesthetics and psychology, historical materials and commentaries on musicological literature were published in the new journal only occasionally, even though the editors asserted that they would not 'be confined to matters related solely to our art and music culture. The musical life of the West and the East will be of equal interest [to them] and informing the readers about it will be regarded as their duty. ${ }^{338}$ Emphasis was also placed on news related to musical life.

636 Chybiński do Bronarski from Lviv 20 XI 1933, AACh-BUAM, Bronarski’s archive, p. 95.

637 Chybiński do Bronarski from Lviv 20 XI 1933, AACh-BUAM, Bronarski’s archive, k. 95.

638 'Od Redakcji' [Editorial] (MP 1934/1, 2). 
We should not lose sight of the fact that from the very beginning it was practising musicians who made up the core of the group of authors directly or indirectly linked with Kwartalnik Muzyczny. These musicians were also involved in publishing activities. In the first years they had been interested in early music which they had been performing, but at that particular moment they focused mostly on establishing professional relations with contemporary composers. They believed that the most important materials which could be published were related to the current life of the music community. In any case, the editors explained the reasons for the decision to change the profile of the periodical in their first editorial:

As before, we believe that there should be a scholarly music journal in Poland which could serve as a footing for the research work of our theoreticians and musicologists. Polish musical life poses many serious questions and notions which need to be publicly disclosed and discussed. These notions are not directly related neither to history nor music theory, and they often give rise to passionate disputes. That is why they cannot be addressed in a scholarly journal, even though they are of major importance to our musical life. However, since we did not want to disregard these vital matters, we decided to move all historical and theoretical texts to a new journal entitled Polski Rocznik Muzykologiczny, whereas Kwartalnik Muzyczny will be transformed into a journal devoted to current issues related to Polish musical life. We also decided to give it a new name - Muzyka Polska./The name chosen by us illustrates the objectives of the new journal and what it will be concerned with./ Contemporary history of Polish music clearly indicates that it has entered a period of intensive growth and despite unfavourable conditions it is paving its own path, slowly gaining artistic individuality. We are aware of this important fact and want to express it in our journal. ${ }^{639}$

Already in the summary of the first year of activity, the editors were pleased to note that 'contrary to the pessimists' warnings, the journal called up a resounding response among musicians and music lovers' and that 'one of the basic ... intentions was realised: the magazine gathered around musicians of the Polish younger generations, drew them into a concerted effort and active cooperation to solve numerous ... problems of musical life. ${ }^{340}$

It soon turned out that to achieve one of the primary objectives set out by publishers, that is keeping up to date with music news, the journal had to appear more often. This is why a change was announced in the last issue from 1935: long,

639 Ibid., 1-2.

640 'Od Redakcji' [Editorial] (MP 1934/4, 257-258). 
quarterly intervals would be reduced, and the journal would be turned into a bimonthly and finally into a monthly. Throughout the analysed year 1936, there was only a brief mention of the transformation of Muzyka Polska from a quarterly to a biweekly and then into a weekly (which 'became possible thanks to hard work of the editorial team and contributors as well as the keen interest of readers') that was included in TWMP Management Report in the year 19361 in point II 'Journals'; it was also announced that TWMP would publish a new magazine, that is Gazetka Muzyczna, aimed mostly at school age youths.

In the middle of the next year, the function of the Editorial Committee of Muzyka Polska (consisting of Chybiński, Sikorski, Zalewski) was taken over by the Board of TWMP, which meant changing the people involved and moving the burden of responsibility for the content of the monthly to journalists and practising musicians - Zalewski, Ochlewski, Rutkowski, moving the decision about the profile of the magazine slightly away from theoreticians and musicologists Sikorski and Chybiński, who was in fact marginalised from the beginning. Due to work overload at TWMP, Rutkowski quickly replaced Zalewski (who 'organised the journal with great buoyancy ${ }^{341}$ ) and took over the position of chief editor of Muzyka Polska. Rutkowski was still supported by Kazimierz Sikorski and from the following year, also by Julian Pulikowski. When Rutkowski assumed the new position, he immediately asked the professor for editing support. Chybiński's opinion was still being taken into account at the beginning of 1936 when it had already been decided that the publication frequency of the journal needed to be changed.

In the next years, Julian Pulikowski, Konstanty Régamey (who became the chief editor in 1937) and Michał Kondracki joined the closely-knit editorial team of Muzyka Polska. The secretary's office was run by Jadwiga Pietruszyńska (later Sobieska). After her, this function was taken over by Stefan Kisielewski, followed by Feliks Kęcki, author of, among others biographical sketch about Mieczysław Karlowicz (Warsaw 1934), incidentally a few years earlier, very positively, though succinctly assessed by Chybiński. ${ }^{642}$

Among regular collaborators, the editorial office of the quarterly (or with the time of the bimonthly and monthly) listed: Ludwik Bronarski, Adolf Chybiński, Zbigniew Drzewiecki, Zbigniew Dymmek, Jerzy Freiheiter, Feliks Kęcki, Michał Kondracki, Faustyn Kulczycki, Feliks Łabuński, Jan Maklakiewicz, Zygmunt Mycielski, Tadeusz Ochlewski, Henryk Opieński, Roman Palester, Julian

641 Rutkowski to Chybiński from Warsaw 20 II 1934, AACh-BJ, box 4, R-19/38.

642 See review MP 1934/2, 156-157. 
Pulikowski, Bronisław Rutkowski, Kazimierz Sikorski, Tadeusz Szeligowski, Stefan Śledziński, Stanisław Węsławski, Stanisław Wiechowicz, Teodor Zalewski. The majority of the people from this group belonged to the Warsaw music community; from the Silesian Music Conservatoire in Katowice there was Kulczycki and Dymmek, permanently living in Cracow, Węsławski was a highly regarded animator of musical life in Vilnius, Bronarski lived in Switzerland, as did Opieński, who settled in Morges in 1926; Chybiński only rarely came from Lviv to Warsaw.

Muzyka Polska was supposed to publish shorter scholarly texts concerned with contemporary music, whereas historical themes would be reduced to 'synthetic and popular' papers. Wanda Bogdany analysed the contents of Muzyka Polska and identified thirteen thematic groups which then served as the basis to systematise the reference list of the periodical. She stresses the fact that the essence of the journal was shaped by articles on contemporary Polish music and the Polish music community (such as biographies of composers and performers, as well as reviews of both current cultural events and music publications). ${ }^{643}$ She also notes that texts related to general music history and those concerned with the past or with 'other fields (aesthetics, psychology, music theory, folklore, music critique) were also published, but they were not the ones that breathed life into the journal. ${ }^{3}{ }^{44}$

The new journal published by TWMP had its tested authors. The Lviv group of musicologists strongly supported its editorial team. Chybiński dealt with his own particular themes - the person and works of Mieczysław Karłowicz (in the aforementioned article that opens the first edition of the new quarterly and in the reflections around the theme of inspiration in the composer's output ${ }^{645}$ ) and Karol Szymanowski (apart from the one-off texts commemorating the artist after his death (see below), it is also worth recalling the sketch published a year earlier, showing the beginnings of the Harnasie creator's fascination with highlander folklore, which - as we know - was mainly inspired and witnessed by Chybiński. ${ }^{646}$ The professor was also the author of several 'jubilee' articles: about Grzegorz Gerwazy Gorczycki (in the two hundredth anniversary of his death), ${ }^{647}$

643 Bogdany 1967, 11.

644 Ibid.

645 'Do kwestii “wpływologii” muzycznej (na przykładzie twórczości Karłowicza)’ [To the question of musical 'influencology' (on the example of Karłowicz's Work] (MP 1934/4, 281-288).

646 'Do genezy Harnasiów Karola Szymanowskiego' [To the genesis of Karol Szymanowski’s Harnasie] (MP 1936/3, 196-199).

647 MP 1934/3, 196-200. 
about Haendel and Bach (in the two hundredth and fiftieth anniversary of their birth), ${ }^{648}$ Giovanni Battista Pergolesi (in the two hundredth anniversary of his death) ${ }^{649}$ and Franz Liszt (in the fiftieth anniversary of his death). ${ }^{650} \mathrm{He}$ also wrote many reviews.

Zofia Lissa published only two texts in Muzyka Polska, and they were both published in the first year's issue of the journal. In the first article, she was pondering on the misery of Polish music critique and reminded the readers what roles (informative and educational) it should fulfil. Lissa was also trying to pinpoint the reason behind the fact that Polish critics lacked essential qualifications and were not credible. ${ }^{651}$ The second article was the result of her interest in music pedagogy which she had a chance to explore in the Institute of Psychology in Lviv, where she started examining the musicality of children and youth in $1934 .{ }^{652}$ One could imagine that the new journal would be an appropriate medium for Lissa to popularise her research results, especially as Lwowskie Wiadomości Muzyczne $i$ Literackie (LWML) which was so dear to her, stopped coming out at that time. However, this was not the case. Rather than send her texts to the editorial office at SMDM, she decided to publish in social journals: Przeglad Społeczny, Przeglad Socjologiczny, Wiedza i Życie.

Her Lviv friend, Stefania Lobaczewska, sharing her interests in the field of music psychology, published a comprehensive (as per norms of the then monthly) article on this subject ' $Z$ psychologii słuchacza muzyki współczesnej'653 [On the psychology of the listener of contemporary music] in Muzyka Polska. In it, she analysed how radically the imaginations and habits of the 'conservative listener' brought up on the music of Mozart and Beethoven, had to change in relation to impressionist music, and how they must continue to evolve in the face of the latest trends in European creativity. After a few years, she again referred to current culture, this time raising the question of the role of criticism in contemporary music creation. ${ }^{654}$

648 MP 1935/1, 1-6.

649 MP 1936/2, 116-118.

650 MP 1936/2, 119-120.

651 Zofia Lissa, 'Dylematy krytyki muzycznej w Polsce' [Dilemmas of music criticism in Poland] (MP 1934/2, 132-137).

652 Zofia Lissa, 'Badanie muzykalności a wychowanie muzyczne'[Measuring musicality and music education] (MP 1934/3, 216-221).

653 MP 1938/7-8, 317-327.

654 MP 1939/4, 191-203. 
Papers written by Father Hieronim Feicht were published in Muzyka Polska only twice: in the issue commemorating Szymanowski (Feicht was one of the authors reminiscing about the composer), and when he presented the profile of Adolf Chybiński, his mentor. ${ }^{65}$ The extended sketch laid out the professor's academic career in great detail. In order to complement the paper, the professor was interviewed by Jan Józef Dunicz. ${ }^{656}$ Dunicz himself wrote a few reviews for the Warsaw journal, starting from 1936. Most importantly, he submitted an article on the national element in Polish carols, the incorporation of Polish motifs into specific elements of the Bethlehem story and the transformation of a lyrical and religious song into an epic tale. ${ }^{657}$

Józef Chomiński, a friend of Dunicz, published one of his works on Stravinsky ${ }^{658}$ in Muzyka Polska as early as in 1936. It needs to be noted that at that time he was working intensively on Szymanowski. The result was a series of extensive analytical articles for PRM, which will be discussed in the next pages of this chapter. A year later ${ }^{659}$ he presented his view on the distinctness of Szymanowski's works as compared with composers who were his contemporaries and yet were so distant from the Polish musician in terms of style. He mentioned Stravinski and Schönberg, the representatives of the European avant-garde. In a sketch filled with scholastic argumentation, he argued how Szymanowski passed through a much more difficult a way to achieve his own style, not having a home base for a modernist formation of, as Chomiński writes, a 'musical worldview.' These two articles complete the theoretical deliberations on the question of the Atma artist's melodics in the light of tonal transformations, which can be reduced to Szymanowski treating harmony in three different phases: 'functionality, absolute sound qualities and new energy dependencies. ${ }^{\prime 60}$ Chomiński devoted several more articles to theoretical issues, including considerations about form ${ }^{661}$ and instrumentation. ${ }^{662}$

655 MP 1937/1,. 5-10.

656 'Wydawnictwo Dawnej Muzyki Polskiej' [Publisher of early Polish music] (MP 1937/1, 10-12).

657 MP 1937/12, 552-556.

658 'Fortepianowa twórczość Karola Szymanowskiego' [Karol Szymanowski’s piano works] (MP 1936/5, 313-329).

659 MP 1937/5, 224-232.

660 MP 1938/7-8, 327-332, cit. p. 327.

661 'Problem formy w okresie wielkich przemian (głównie formy sonatowej w ostatnim pięćdziesięcioleciu)' [The problem of form in the period of great changes (Mainly sonata form during the last fifty years)] (MP 1938/12, 535-543).

662 'Kilka uwag o instrumentacji' [A few remarks about instrumentation] (MP 1939/4, 203-208). 
Jerzy Freiheiter, another graduate of the Lviv centre, was interested in the radio, which was a very important medium of the time. Let us recall that the role of the radio was also brought up by Zofia Lissa. Freiheiter submitted two texts to Muzyka Polska related to this issue: the former was about radio opera regarded as a new field of composing activity, ${ }^{663}$ whereas the latter talked about sociological aspects related to the radio and the role of this medium, which served its listeners as the primary source of access to art in general, including music art. ${ }^{664}$ Freiheiter was also the author of numerous reviews. Most importantly, he served as a permanent correspondent in Lviv, at least until the editorial team established a very promising relationship with Jan Józef Dunicz and decided to hand this task over to him. ${ }^{665}$

Among other authors of the magazine, it is worth distinguishing several names, most frequently linked formally with the editors in a personal manner. Excluding the first years of his writing practice, when he was dealing with music criticism in the bi-weekly Echo Tygodnia, it was indeed in Muzyka Polska that Stefan Kisielewski published his first musical texts addressing contemporary music issues, even entering into considerations in the field of sociology; ${ }^{.66}$ he also wrote a few reviews of new pieces by contemporary composers and entered into discussion with Konstanty Régamey in a review of his study Treść i forma $w$ muzyce [Content and form in music] ${ }^{667}$ Frequent guests in the pages of Muzyka Polska were writers well known for years from other musical magazines, such as Henryk Opieński, Stanisław Wiechowicz and Feliks Starczewski. Traditionally, they wrote short historical works, biographic sketches (often commemorative and written at the request of the editorial office) or comments on vital current issues related to music culture. New names also appeared: Tadeusz Szeligowski, ${ }^{668}$

663 MP 1935/1, 29-32.

664 'O drogę do nowego słuchacza' [About the path to the new listener] (MP 1935/4, 286-289).

665 Rutkowski consulted Chybiński regarding this change, see Rutkowski to Chybiński from Warsaw 12 VI 1936, AACh-BJ, box 4, R-19/51.

666 'O "wartościach społecznych" w muzyce' [About 'community values' in music] (MP 1936/3, 199-204).

667 MP 1936/1, 54-56.

668 He participated in the publication of Szymanowski's edition 'pro memoriam.' Inspired by Chybiński's postulate to stop tying Karłowicz's work with 'Tatra legends,' he also published considerations on the search for sources of this work in the Vilnius region, see 'Karłowicz, wilnianin redivivus' (MP 1935/2, 127-129). He also commented on current musical life. 
a multi-talented critic and publicist, a pianist and composer, and Michał Kondracki, a pianist and a folklore collector valued by Chybiński. Surprisingly, Zdzisław Jachimecki did not join this group of authors until 1939 when he submitted an article related to the emergence of the libretto for King Roger by Szymanowski. ${ }^{669}$

Since 1937, that is from the beginning of the term of office of the editor-inchief of Muzyka Polska, a clear quantitative domination has been noted - and it could also be said that to a certain extent qualitative - in the works of Konstanty Régamey, the author, first and foremost, of articles about key issues of Polish and European contemporary music. He commented upon the achievements and place of Polish creativity in the past twenty years, amongst others in the article 'Muzyka polska na tle współczesnych prądów' [Polish music against a background of contemporary trends] ${ }^{670}$ he presented the characters of his peers in occasional articles, ${ }^{671}$ shared relaxed comments with readers about the hottest new trends in European creativity in those years, ${ }^{672}$ and frequently wrote reviews and criticism.

The editorial team of Muzyka Polska risked publishing two articles on the condition of music culture and its organisation in two neighbouring countries ruled by authoritarian regimes: Marian Neuteich ${ }^{673}$ wrote about the communist Soviet Union, whereas Otto Graf ${ }^{674}$ wrote about the Third Reich ruled by the Nazi Party. Each of these texts, especially Neuteich's article, could be successfully transferred to a later epoch, namely to the reality of fascist and socrealistic dictatorships, in which ideology was more important than art itself, and perfect organisation made it possible to fully control the artistic and academic community. The editorial team, being aware of the controversial nature of the rhetoric (independently adopted by both authors) and content of the articles, declared that these articles did not embody its views and that they are only

669 MP 1939/3, 111-123.

670 MP 1937/7-8, 341-352.

671 About Bolesław Woytowicz on the occasion of granting him a state prize (MP 1937/3, 116-119), about Antoni Szałowski in a conversation with him (MP 1938/2, 57-60).

672 'Czy atonalizm jest naprawdę atonalny' [Is atonalism really atonal?] (MP 1936/1, 32-39).

673 Marian Neuteich, 'Muzyka w ZSRR' [Music in the USSR] (MP 1934/4, 294-300).

674 Otto Graf, 'Organizacja życia muzycznego w Niemczech' [Organisation of musical life in Germany] (MP 1935/2, 113-126). 
informative and open to debate ${ }^{675}$ Words such as 'the dialectical and materialistic analysis' which clearly set the path of Soviet musicology, as well as references to Reichsmusikkammer, an office which became 'one of the bodies of collective national culture which raises the German society' must have been equally frightening. Even though Reichsmusikkammer was not supposed to create a new music culture, it did 'set its new ideological direction. ${ }^{367}$ In order to familiarise readers with issues discussed in his article, Graf pointed to the words of Joseph Goebbels, the Minister of Propaganda, and Richard Strauss, the president of Reichsmusikkammer. Regardless, both publications must have been a surprising experience for readers, even though they did not trigger any discussion.

The editors of Muzyka Polska did not give titles to monographic editions, but in some of them focused on a predetermined circle of issues. The first issue already had a clear centre of gravity, marking the twenty-fifth anniversary of the death of Mieczysław Karłowicz. This circumstance allowed the editorial office to inaugurate the new magazine - speaking colloquially - 'from high C', that is with an extensive and wide-ranging dissertation by Adolf Chybiński, bringing both the composer's character and his work closer to readers in a colourful way ('Mieczysław Karłowicz,' pp. 3-21). ${ }^{677}$ An interesting and valuable supplement to this monographic text was Henryk Opieński's edition of several letters from the composer held in his private archive (' $Z$ korespondencji Mieczysława Karłowicza' [From the correspondence of Mieczysław Karłowicz], pp. 22-28) and Karłowicz's letters to Felicjan Szopski prepared for publication by the editors (pp. 29-30). The body of these materials was closed by memoirs penned by musician Apolinary Szeluto (pp. 31-32).

The 7/8 edition from 1937 was also designed as a monograph, in which texts of both theoreticians and young composers on current trends in music were included. It was then that Józef Chomiński published one of his first analyses of contemporary functional harmony ('Ewolucja harmoniki współczesnej' [The evolution of contemporary functional harmony], pp. 327-340). It was a theme which would set the main path of his research after the war. This theoretical introduction to new composing solutions was then developed by representatives of the modern current in Polish music, who often wrote articles or even devoted

675 Ibid., 113.

676 Ibid., 114.

677 It should be noted that in the future the editors avoided such extensive articles, as they wanted to reach out to the broadest possible group of readers interested in generally understood musical culture. 
their whole lives to writing, critique and journalism. These were Konstanty Régamey, the only representative of the older generation who belonged to this group ('Muzyka polska na tle współczesnych prądów' [Polish music as compared to contemporary currents], pp. 341-352), Stefan Kisielewski ('Oblicza duchowe muzyki współczesnej' [Spiritual facets of contemporary music], pp. 357-365), Andrzej Panufnik ('Abstrakcje w muzyce współczesnej' [Abstraction in contemporary music], pp. 365-369), Zygmunt Mycielski ('Chodzi o muzykę’ [It's all about music], pp. 369-371) and Jerzy Waldorff ('Problemy słuchacza muzyki współczesnej' [The problems of a contemporary music listener], pp. 352-357) ${ }^{678}$ On the one hand, their texts constituted an analysis as well as an evaluation of the sources of the newest art, and on the other hand, they were a polemic on the place that this art occupied in journalism, in the cultural policy of the country, and in the concert life of that time. It is not the scholarly and musicological basis for these reflections that is important, but rather the sensitive attempt to reach listeners and present to them the authors' arguments related to the following issues: why do we create like that, and should we fear contemporaneity (in art), even though we know that when twenty years pass, contemporary art (and who knows today whether it is good or bad) will no longer be contemporary? Nevertheless, texts published in Muzyka Polska were not scholarly papers since they were not aimed (solely) at the academic community, but at the broadly defined music community.

Earlier still, when it comes to the thematic selection of publications, an edition devoted to the organisation of musical life and the condition of musical culture was prepared (Muzyka Polska 1935 no. 2), for which materials were contributed by, amongst others, Zbigniew Drzewiecki ('Frontem do muzyki' [Facing the music], pp. 99-103, an article which constituted a collection of reflections concerning the fall of musical culture in Poland and neglect in this area) and Teodor Zalewski ('Problem organizacji zawodu muzycznego' [The problem of organisation in the music profession], pp. 104-112).

The issue of Muzyka Polska which came out in April 1937 was unplanned and created ad hoc due to the death of Karol Szymanowski. The issue was created jointly by all the authors who could make a significant contribution to the knowledge of the life and oeuvre of Szymanowski, either due to their friendship with the composer or their professional fascination with his work, starting from

678 The pendant to these materials was an article of another young composer, Michał Kondracki 'O kierunkach współczesnej muzyki polskiej' [On the directions of contemporary Polish music], included in the previous number (MP 1937/6, 267-273) 
Adolf Chybiński, who presented the musician in a very personal way ('Karol Szymanowski (1883-1937), pp. 147-150), through Konstanty Régamey, who wrote an aesthetic sketch on the musical writings of the composer and the aesthetic qualities which guided him ('Ideologia artystyczna Szymanowskiego' [Artistic ideology of Szymanowski], pp. 160-169) and young composers, such as Witold Lutosławski ('Tchnienie wielkości' [A breath of greatness], pp. 169-170), Kazimierz Wiłkomirski ('Jeszcze o dziele Karola Szymanowskiego' [A few more words on the works of Karol Szymanowski], pp. 180-181), Michał Kondracki ('O kult dzieła Szymanowskiego' [On the cult of the works of Szymanowski], pp. 183-184), ending with numerous memoirs and a list of the composer's works. The next issue included a reprint of the speech which Józef Ujejski, a deputy minister, made at the funeral (pp. 150-155), which was supplemented by the eulogy mentioned above written by Father Hieronim Feicht after ceremonies which had taken place at the end of April 1937 in Cracow Skalka. ${ }^{679}$ The eulogy came out in the next issue.

Muzyka Polska deserved very positive appraisal among the milieu. Ludwik Bronarski shared his impressions from reading: 'The magazine was edited with youthful verve and was even "catchy," with very topical themes. ${ }^{380}$ Henryk Opieński wrote: 'I am in a hurry to express my true delight from looking at Muzyka Polska - the volume itself, simple and pleasing on the outside, is in good taste, and the tone is serious, but not overloaded with science, and it is suitable for the wider reading layers. I ask myself whether this fashionable and necessary campaign against "statism" in music, against the involvement of the state in matters related to music (= political protectionism), which is brought up by some articles in Muzyka Polska, won't stand in opposition to the "kingpins" of our journal? Won't journals fall victim to "repressions" because of this approach?'681 A very favourable review of the journal appeared in Ateneum. It was signed by 'k.b.' After a few paragraphs criticising Muzyka, which was already burning out, the journal published by TWMP was presented as a publication which boldly engaged in discussions on difficult issues that were of importance to the music community and, contrary to the monthly published by Gliński, 'apart from articles on practical issues, [published] also theoretical considerations and ambitious works, whereas it was almost impossible to encounter such texts in Muzyka. ${ }^{622}$ The reviewer was impressed with the extensive informative section,

679 MP 1937/5, 219-224.

680 Bronarski to Chybiński from Geneva 8 VI 1934, AACh-BJ, box 6, B-26/97.

681 Opieński to Chybiński from Morges 5 III 1934, AACh-BJ, box 6, O-2/138.

682 k.b., 'Muzyka i Muzyka Polska' (Ateneum 1938/3, 524-526). 
the highlights of musical life and systematic correspondence with the main cities in Poland and abroad, as well as the "balance between practical and theoretical matters.' In such a formula Muzyka Polska was genuinely - as k.b. wrote - a magazine 'about music for musicians.' The only complaint made by the editorial team is that the selection among the not so numerous group of meritorically wellprepared authors of the periodical and the exclusion from cooperation of some outstanding 'pens' writing about music was not clear.

Anyway, Muzyka published by Mateusz Gliński, which once entered the cultural market with a go-ahead attitude, was losing momentum year by year, whereas Muzyka Polska began to appear more often, thanks to which it became a topical journal in which a group of young Polish composers were interested, and which they trusted. The journal was consequently developing and appeared regularly up to and including the summer of 1939. It is also worth remembering that (from the point of view of post-war history of Polish music journals) Ruch Muzyczny, which was launched in autumn 1945, was influenced by Muzyka Polska and its interest in current affairs. A few years later, Muzyka was also trying to continue this tradition. It was a monthly following the doctrine of socialist realism which was published in years $1950-56$ by PIS. However, when it comes to the scholarly quarterly under the same title, also published by PIS from the second quarter of 1956, the only thing it had in common with Muzyka Polska was the same graphic element on the cover: the font used on the title page.

The second title which was supposed to be published by TWMP was PRM, whose nature was academic by definition. It was the result of a compromise reached with Adolf Chybiński, the chief editor of Kwartalnik Muzyczny (a journal which was being closed down), as well as with the most devoted and the best-educated readers of Kwartalnik. Now we need to go back to 1921 to examine how the idea to establish an annal for Polish musicologists evolved. It was then that Łucjan Kamieński first thought that he would like to take over editing a journal, preferably an annal, aimed at the musicological community. He was full of youthful enthusiasm and got involved in several projects at once, for example, drawing up an inventory of music relics and editing the 'monuments' of Polish music as well as the history of European music which was being written by a group of authors and comprised of a few volumes. He wanted to base an annal for Polish musicologists on the existing monthly Muzyka i Spiew. However, not everything went as planned, and the journal kept coming out in its original, unchanged form until 1935. Even in later years, Kamieński did not manage to bring any of his subsequent 'press' projects into effect.

The idea for the yearbook was still waiting on favourable circumstances to see its actual realisation. At some point, it became apparent that a scholarly journal 
with a relatively high frequency of publication probably has no place in the realities of a still small environment and these changes were inevitable. Let us see how it came to them. ${ }^{683}$

Already in January 1930, a board meeting was held at the headquarters of SMDM in Warsaw. It was devoted to different perspectives on the form which Kwartalnik Muzyczny, which was published by SMDM, should take. For Chybiński, it was a periodical aimed at a particular community which contained strictly scholarly papers, most importantly those written by certified musicologists. However, publishers from Warsaw were instead thinking about publications aimed at educated musicians and enlightened laymen which would contain music news. Nevertheless, everybody agreed that they should keep the status quo and decided 'not to change. ${ }^{364}$ But in late autumn 1933, Adolf Chybiński received a letter from Warsaw signed by Bronisław Rutkowski, the president of SMDM. He asked Chybiński to come up with a date on which he and Kazimierz Sikorski, his fellow worker, could visit the professor in Lviv. The reason behind this visit was related to the future of Kwartalnik Muzyczny. The university journal run by the professor was modelled after the most important European musicological periodicals, but when it came to its popularity and readership, it did not meet the expectations of Warsaw publishers. For this reason they proposed to create a quarterly journal with much lighter content whose aim would be to popularise music. Chybiński was supposed to become one of the members of the Editorial Board. Starting from 1934, the scholarly, strictly musicological part was supposed to be moved to a new journal, that is PRM. The professor referred to this part as 'luxury.' At first sight, the whole situation seemed to be quite comfortable, but Chybiński quickly began having second thoughts:

It is only now, when I'm processing the situation with the journals, that I'm beginning to admire the Warsaw cunning. Kwartalnik will be updated, the scientific part will be removed and exiled to Rocznik. Indeed, I was given a sovereign state and a castle on a rock, surrounded by chasms and a deep lake. I can't see anyone and nobody can see me... The residence of a master who has no impact on anything around him... Luxury... And when it comes to the updated Kwartalnik, I'll have no say, no influence over any opinions! ... Luxury and comfort surrounded by a wall and a moat with a draw bridge. ... In fact, nothing will change, we will just feel better 'in each other's company' and won't feel uncomfortable about any potential 'miscomprehensions.' ${ }^{655}$

683 More about this subject see also Sieradz 2011.

684 See Chybiński to Bronarski from Lviv 10 II 1930, AACh-BUAM, Bronarski’s archive, p. 31.

685 Chybiński to Bronarski from Lviv 20 XI 1933, AACh-BUAM, Bronarski’s archive, p. 95 
By the end of the year, Chybiński was unsure about the new journal's future. No agreement was signed, no budget was set. Finally, the first volume of Rocznik was granted 3000 zlotys by FNP: 'The Management Board of SMDM decided to give 250 zlotys to the Professor to reimburse him for the costs related to editing Rocznik, whereas the rest of the sum (2750 zlotys) was entrusted to the Professor who will spend it on printing and potential author's fees. ${ }^{686}$

The announcement of the new magazine was published in the first issue of Muzyka Polska in 1934. Using the hospitality of the friendly pages, the editorial staff of the Yearbook, apart from presenting the expected profile of the publication, asked potential authors with an appeal that sounded like an incentive to give up the feud among musicologists in the name of the good of the discipline. It was claimed that the journal 'will include not only research on earlier and newer music but also on contemporary Polish music and will be open to research on pure music theory and all its subfields. ... we will only publish papers of significant scholarly value, which bring positive scholarly results and further knowledge ..., research materials and critical papers. ${ }^{687}$

Even though it was uncertain whether the journal would be financed, shortly after the publication of volume I of Rocznik dated 1935, the editorial team continued their work and volume II appeared in due time (in 1936). The chief editor, even though he repeated the statement which had already been made in previous years, i.e. that Rocznik should have nationwide range, still preferred articles written by tested authors. The inner circle of trusted contributors of the former Kwartalnik Muzyczny warmly welcomed a journal which was even more ambitious: 'Dear Professor, if you still wish to have my papers published in Rocznik, I am very flattered, and I will try to fulfil your wishes as best I can and as far as I can. So far, I am sending a review of Chopin in Dresden; I guess it can be published with the papers I sent earlier. I will just look through the reporting article on the Oxford edition of Chopin's works, which has long been ready, and then I will send it to you, ${ }^{\prime} 68$ to which Chybiński replied as enthusiastically as always: 'Eine allgemeine Regel, zurückgeführt auf jeden besonderen Fall: everything that you will be kind enough to send for Polski Rocznik Muzykologiczny will be printed. The same applies to Ganche, who will be as precious and valuable to me as all the works and papers that I have received from you so far. ${ }^{689}$

686 Rutkowski to Chybiński from Warsaw 4 IV 1935, AACh-BJ, box 4, R-19/43.

687 MP 1934/1, [81].

688 Bronarski to Chybiński from Geneva 15 XII 1933, AACh-BJ, box 6, B-26/87.

689 Chybiński to Bronarski from Lviv 12 VI 1934, AACh-BUAM, Bronarski's archive, p. 114. Ludwik Bronarski's report 'Z najnowszej literatury chopinowskiej' [From the 
To the second volume, like the first, Bronarski did not prepare any article, but - as before - he addressed current Chopin literature. This time he reported on Édouard Ganche's Souffrances de Frédéric Chopin. Essai de médecine et de psychologie (Paris 1935) and Chopin. His Life by William Murdoch (London 1934) and the essay „Hexameron," Bellini i Chopin by Maria Szczepańska (Lviv 1935). We also know that he edited concise materials for the third volume about two unknown pieces by Chopin from the collections of the Library of the Paris Conservatoire - Nocturne c-minor (WN 62) and Largo E flat-major (WN 61), and about Chopin's mazurka dedicated to Emil Gaillard. ${ }^{690}$

Upon hearing about the new Lviv publication, Henryk Opieński, the creator of the first Kwartalnik (which was the voice of WTM in years 1911-14) wrote from Morges, where he settled after leaving Poznań: 'Rocznik - we finally have some sort of a musicological collection! Finally! But with what a great effort and personal sacrifice on your part! ... You know that this Rocznik of yours will make me feel like getting down to some work.' ${ }^{3}$ And indeed, he did not fail as an author. For the first volume, he prepared a paper on unknown letters from Elsner to Breitkopf and Härtel, ${ }^{692}$ at the same time announcing a paper on parts of an unknown organ tablature from the end of seventeenth or the beginning of eighteenth century ${ }^{693}$ and an edition of a few letters from Karłowicz from his private archive. ${ }^{694}$ These were some of the last publications of this

latest Chopin literature] opened the column 'Referaty krytyczne' [Critical Reports] and included discussions on five publications: Hans Volkmann's Chopin in Dresden (Berlin 1933), Frederic Chopin: Lettres edited by Henryk Opieński (Paris 1933), Leopold Binental's Chopin (Paris 1934), The Oxford Original Edition of Frédéric Chopin (London 1932) and Édouard Ganche's Voyages avec Frédéric Chopin (Paris 1934).

690 Both materials were used in the post-war version of KM, see Chapter III-4.

691 Opieński to Chybiński from Morges 25 IV 1935, AACh-BJ, box 6, O-2/146.

692 'Józef Elsner w świetle nieznanych listów' [Józef Elsner in the light of unknown letters] (PRM 1935/1, 76-90).

693 'Kilka kart nieznanej tabulatury' [A few pages of unknown tablature] (PRM 1936/2, 116-121). Chybiński also planned a second 'tablature' material in the same volume his own text on Warsaw's organ tablature, supplementing the description of the relic with a history of Polish organ culture in the seventeenth century, see Adolf Chybiński, 'Warszawska tabulatura organowa z XVII wieku' [Warsaw organ tablature of the XVII century] (PRM 1936/2, 100-115).

694 'Z korespondencji Mieczysława Karłowicza' [From Mieczysław Karłowicz’s correspondence] (PRM 1936/2, 147-152). 
musicologist, who resided in Switzerland and died there in 1942. He left no other materials which could be published by Chybiński.

Józef Chomiński, a young graduate of Lviv musicology, presented his texts in both volumes of Rocznik. The first volume opened with an extensive analysis of organum quadruplum in Sedereunt by Pérotin (pp. 1-27), which was a continuation of his earlier research interest in medieval music; for the second volume, he prepared his first study on the works of Karol Szymanowski ${ }^{695}$ and a report on Stilwende der Musik by Ernst Pepping. He informed the editorial team about it in September 1935 and promised to submit the texts within a month. ${ }^{696}$ Soon he also submitted a rather short, but extremely probing review of Harmonika Chopina [Chopin's harmonica] by Ludwik Bronarski which had just been published by TWMP.

Maria Szczepańska, who was probably Chybiński's most trusted assistant, published the results of her studies in Kwartalnik many a time. She also submitted subsequent papers to Rocznik: 'O dwunastogłosowym Magnificat Mikołaja Zieleńskiego z r. 1611. Do historii stylu weneckiego w Polsce' [On the 12-part Magnificat by Mikołaj Zieleński (1611). Contribution to the history of the Venetian style in Poland] $(1935 / 1,28-54)$ and the aforementioned paper, 'as thick as a book,' 'O utworach Mikołaja Radomskiego (z Radomia) (wiek XV)' [On the compositions of Mikołaj Radomski (Mikołaj of Radom) (15th century)] (1936/2, 87-94). Concerning the quantity of material about Mikołaj Radomski, and due to its special value, then the editor still wrote: 'I will enter the path of editorial inflation, i.e. "further consequences." And so I will halve a work which is very good, but as thick as a book, by Dr Szczepańska about Mikołaj Radomski (XV century). It would be a pity for her, but if it were not for the Rocznik, she would not be able to show herself so quickly, and it is necessary to hurry, let the people know once who this master really was, about whom Ludwig wrote with such admiration in his letter to me. ${ }^{397}$

695 In his research plans he intended to make further studies on the creative work of Karol Szymanowski: analysis of the violin sonata and quartets which he 'conceived' from the end of summer 1937, see amongst others Chomiński to Chybiński from Werchrata from 2VIII, 17 VIII, 2 IX 1937, 2 XI 1938, 5 I 1939, AACh-BJ, box 5, C-10/ 51, 52, 54, $76,80$.

696 Chomiński to Chybiński from Werchrata 13 IX 1935, at AACh-BJ, box no. 5, sign. C-10/7.

697 Chybiński to Bronarski from Lviv 21 XII 1935 r., at AACh-BUAM, Bronarski’s archive, k. 145. 
The authors centred around Kwartalnik Muzyczny (Chomiński, Szczepańska, Opieński, Kamieński ${ }^{698}$ ) were for the first time joined by Alicja Simon, who had already been an experienced author ${ }^{699}$ and Jan Józef Dunicz, the favourite pupil of Chybiński. ${ }^{700}$ At the time, Dunicz was also working on his doctoral dissertation Adam Jarzębski i jego „Canzoni e concerti” (1627) [Adam Jarzębski and his 'Canzoni e concerti' (1627)], which he defended in 1937 and which Chybiński used the following year to inaugurate a new series Lwowskie Rozprawy Muzykologiczne. Even though he was preoccupied with this text, he managed to submit two texts for publication in volume II: ' $Z$ badań nad muzyką polską XVIII wieku: Jacek Szczurowski (ur. 1718)' [Studies in Polish music of the eighteenth century: Jacek Szczurowski (born on 1718) $]^{701}$ and a short notice 'Do biografii Mikołaja Zieleńskiego' [On the biography of Mikołaj Zieleński] ${ }^{702}$ which was a commentary and a sort of complement to the article written by Maria Szczepańska for volume I of Rocznik. The editor-in-chief in this volume did not publish any of his own text, but for the needs of volume II he prepared the aforementioned treatise on the Warsaw organ tablature (see above footnote 693) and an edition of two letters from Sebastian Sierakowski to Karol Kurpiński and two letters from Kazimierz Kratzer to Józef Sikorski. ${ }^{703}$

The list of the most trusted authors was topped up with a few more names Father Hieronim Feicht, one of the best graduates of Lviv musicology, Helena Windakiewiczowa, the author of works on music ethnography, Father Władysław Skierkowski, who was devoted to the Kurpie Region, Łucjan Kamieński, ${ }^{704}$ the leader of musicology in Poznań, Marek Kwiek, an acoustician, as well as Julian Pulikowski, Aleksander Patkowski and Kazimierz Tyszkowski who were supposed to publish in volume III.

698 Kamieński also had the material for the second volume of Rocznik, this time about the group of 'sitting' songs. However, he had to accept the refusal to publish due to volume size restrictions.

699 ‘Życie muzyczne w świetle “Pamiętników” Józefa hr. Krasińskiego’ [Musical life in the light of the ‘Memoirs' of count Józef Krasiński] (PRM 1935/1, 91-106).

700 'Z badań nad muzyka polską XVIII wieku. 1. Kasper Pyrszyński (1718-1758)’ [From research into Polish music of the XVIII century. 1. Kasper Pyrszyński (1718-1758)'] (PRM 1935/1, 55-75).

701 PRM 1936/2, 122-139.

702 PRM 1936/2, 95-97.

703 PRM 1936/2, 140-142, 142-146.

704 'Monografia pieśni zmówinowej z Kaszub południowych' [Monograph about prenuptial agreement songs from southern Kaszuby] (PRM 1935/1, 107-131). 
The reception of the first volume of PRM was no different from what had been expected. Musicologists from Cracow did not want to comment. Kamieński from Poznan, grateful for the careful preparation of his article, wrote enthusiastically: 'Rocznik looks great.... In terms of sheet music, it represents steady progress compared to Kwartalnik.... It is a pity, of course, that unfortunate material reasons have restricted the whole to a relatively modest size, but it is quite an accomplishment that we have, at last, a purely scholarly publication, and from a to $\mathrm{z}$.... There is perhaps too much Pulikowski in the reviews.... Perhaps in the next yearbook he won't need to observe such radical reserves as from a certain A.Ch.?'705

In general, Warsaw responded favourably: 'I allow myself to add my personal opinion: the overall impression is great! Absolutely on the same level as Revue de musicologie, Acta musicologica and Zeitschrift für Musikwissenschaft. Strictly scholarly, serious, no pretence, no clichés ${ }^{306}$ - wrote Pulikowski. However, he then moved on to substantive criticism of almost all the papers published in Rocznik. The only texts he praised without any objections were 'great' reviews written by Bronarski. For Chybiński, this critical review was all the more heartwrenching because he had been waiting for it for a few months ${ }^{707}$ and expected

705 Kamieński to Chybiński 5 V 1935 r., at AACh-BJ, box no. 6, sign. K-3/81.

706 Pulikowski to Chybiński from Warsaw 22 IV 1935, at AACh-BJ, box no. 3, sign. $\mathrm{P}-28 / 93$. It is worth adding here that a few months earlier Pulikowski, under his monogram T.K., published in Muzyka Polska (1934/4, 329-331) a review of 'the new musicological journal' published in Cracow under the editorship of Zdzisław Jachimecki. He wrote: 'The publication [of Rozprawy i Notatki Muzykologiczne] is a very reassuring event. Even though the publisher did not establish fixed dates on which the journal would appear systematically, we still hope that Rozprawy $i$ Notatki will appear often and that it will successfully carry out its task, which can be summed up thus [as was pointed out in the editorial]: "to serve the growing needs of society with regards to a field of science which is quite young in our country, and to fill in huge gaps apparent in all branches of scarce musicological literature." ... The contents of the first issue is really varied ... [articles by B. Wójcik-Keuprulian, W. Poźniak, S. Śledziński, J. Reiss]. The choice of themes deserves praise.' It is true that in his review of this volume Pulikowski criticised almost all the articles, but his arguments were strictly scientific, substantive and devoid of bias. He voiced his opinions as part of a scholarly discussion. Two authors, Wójcik-Keuprulian and Poźniak responded (see Bronisława Wójcik-Keuprulian and Włodzimierz Poźniak: [response to T.K.'s review of Rozprawy i Notatki Muzykologiczne vol. I (Muzyka Polska 1935/5, 70-74), and also Odpowiedź autora sprawozdania [Reply by the report's author] (Muzyka Polska 1935/5, 74-76), which I mentioned in chapter II-3.

707 In June 1935 he wrote to Bronarski and expressed his disappointment: 'I've just received the newest issue of Muzyka Polska. I'm stunned! Not a single word, no 
(quite reasonably) only words of praise for the journal. The consequence of the unfortunate paper was putting a halt to texts which had already been submitted to Muzyka Polska by unknown authors working for PRM.

At the end of 1936, there was a harbinger of the first serious problems with the annal; as Warsaw reported, 'FKN has problems with loans and in MWRiOP the sums for music are rubbish. ${ }^{308}$ This is contradicted by the professor's account of his visit in Warsaw which he described in his letter to Bronarski just over a month later: 'The biggest ... advantage of the Warsaw outing is that Rocznik will grow in size. I must admit that I got down to this task mit List und Gewalt and requested as "much" as 5 thousand zlotys for Rocznik and I got what I wanted, that is 4 thousand, which will allow me to increase the number of pages to 250 . And when it comes to the next year, they promised me more cash for Rocznik to keep elbowing its way through. ${ }^{709}$

Anyway, it can be assumed that the threat of financial instability (but definitely not just that) could have had an influence on the delayed publication of the next, third volume of the journal. In autumn 1936, when the second volume was almost finished, Chybiński was already working on the next volume which he had planned to publish at the end of the year. However, during this time he was preoccupied more than ever with pedagogy and his own works. He was preparing the next volumes of the WDMP series, the first volume of Monumenta Polyphoniae Medii Aevi in Polonia and a monograph on Mieczysław Karłowicz, which, according to Chybiński himself ${ }^{710}$ was taking a lot of his time due to source and documentary material which was piling up at an alarming rate. (The book - Mieczysław Karłowicz (1876-1909) - progressed slowly and finally saw the light of day in 1939 when it was published by TWMP.)

Following the correspondence with potential authors for the third volume of PRM - Chomiński or Bronarski - it can be noticed that in the second half of 1937, and even in the spring of 1938, the editor of the yearbook was still at the stage of collecting the materials and planning the edition: Chomiński sent a study of structural questions in Szymanowski's sonatas to Lviv in the summer of

mention of Polski Rocznik Muzykologiczny! What is that supposed to mean? What's the reason?', Chybiński do Bronarski from Lviv 27 VI 1935, AACh-BUAM, Bronarski’s archive, p. 134.

708 Rutkowski to Chybiński from Warsaw 15 XI 1936, AACh-BJ, box 4, R-19/54.

709 Chybiński to Bronarski from Lviv 29 I 1937, AACh-BUAM, Bronarski's archive, p. 156.

710 See for example, letters to Bronarski from Lviv 29 III, 3 V, 1 VI 1937, AACh-BUAM, Bronarski's archive, p. 158, 159, 160. 
$1937,{ }^{711}$ and the fate of Aleksander Sadkowski's article was in the balance many months later. In 1937 the professor's sight got worse, which significantly limited his ability to work. The postponement of the printing date was also influenced by the message he received from Switzerland, about Bronarski's discovery in the Library of the Paris Conservatoire of two unknown works by Chopin - Largo E flat major and Nocturne c-minor. A lively discussion took place between Lviv, Fribourg and Warsaw on this subject. ${ }^{712}$ Chybiński, moved by the announcement of submitting an edition of this material together with a commentary, to the PRM, wrote: 'For, no matter what, I wanted the volume of the yearbook being printed to include yours work on the fortunate discovery of two Chopin works, I therefore stopped - of course - the printing of the volume to await the treasure from your friend. I notified TWMP about this pause in printing, giving reasons so as to not to suspect me of laziness or sluggishness. ${ }^{713}$

At the same time, TWMP approached the Chopinologist and offered to publish the edited works as separate music sheets. However, it was not so simple because the administration of the Paris Library only gave its consent for publishing these findings in a scholarly journal. Because of that, Chybiński offered Bronarski to publish the article and facsimile of the manuscripts as an article in Rocznik, while their analysis could be published as a supplement to the journal. It would contain the information that it is an integral part of the journal, but in this form it could also function on its own. Unfortunately, TWMP held a different view. In response to the offer to publish Chopin's works as a supplement to Rocznik, Teodor Zalewski sent a letter to Lviv in January 1938: 'I think that we will publish these works for practical use in the customary form, i.e. similarly to other piano compositions. In my opinion, it is not advisable to sell copies of Rocznik with these works, which are academically analysed, because it will diminish the effect that they could otherwise have. This is why, in my opinion, our popular edition and the publication of the works in Rocznik must

711 Chomiński to Chybiński from Werchrata from 24 VI and 12 VII 1937, AACh-BJ, box 5, C-10/47 and C-10/48. This study was definitively published in KM 1948/21-22, 170-207.

712 See Chybiński do Bronarski from Lviv 13 and 27 XI 1937 and also 7 I 1938 (AACh-BUAM, Bronarski's archive, p. 163, 164, 166), and Bronarski to Chybiński from Fribourg 11 XI, 20 XI, 5 XII, 27 XII 1937, 17 I, 5 II 1938 (AACh-BJ, box 6, B-26/156-161).

713 Chybiński to Bronarski from Lviv 13 XI 1937, AACh-BUAM, Bronarski’s archive, p. 163. 
be regarded as distinct. Therefore, the concept of an "insert" proposed by the Professor is out of the question. ${ }^{714}$

Chybiński, although partly guided by purely pragmatic considerations, first and foremost wanted a set of materials related to the discovered Largo and Nocturne to appear under the banner of the scholarly magazine. Financed by Warsaw, he could not, however, disagree with Zalewski's suggestion, although this solution caused further misunderstandings between him and the Warsaw community. ${ }^{715}$ For some consolation in the middle of May 1938, Bronarski sent him, perhaps useful, as the author believed, 'in view of the delay in the publication of the yearbook', a text about Chopin's mazurka dedicated to E. Gaillard. ${ }^{716}$ A number of older reviews by other authors, kept from the previous edition, were also to be included in this volume due to the need for savings caused by high costs of clichés for Chomiński’s article about Szymanowski’s Słopiewnie.

In early spring 1939, the professor was asked whether the next issue would be published by July. In May the preoccupied or maybe even irritated members of the Management Board of SMDM wrote an authoritative letter: 'We assume that once again some serious obstacles are preventing Rocznik from being published. We are concerned with this fact and admit that it is quite problematic for us. FKN requires that we present a financial statement accounting for the subsidy granted to Rocznik. The deadline expired a long time ago.... Dear Professor, please intervene at the printing house so that we can get complete receipts as soon as possible. ${ }^{717}$ Before all this, the number of copies of Rocznik had been discussed as well. When we take into account the needs of the small community of musicologists, this number was clearly unreasonable (the print run was reduced from 500 to 300 pieces, ${ }^{718}$ and even 150 was considered, 'because ... we have no hope for greater demand ${ }^{719}$ ).

At the same time, Julian Pulikowski was trying to take advantage of the fact that the publication of PRM was delayed by two years. Pretending that he was concerned about the journal and the professor's health, he proposed to expand the editorial teams of both Rocznik and WDMP. In the beginning, he only put up Feicht, but in subsequent letters he also mentioned himself. His idea was

714 Zalewski to Chybiński from Warsaw 11 I 1938, AACh-BJ, box 5, T-10/42.

715 Both compositions prepared for publication by Ludwik Bronarski were printed by TWMP in 1938.

716 See Bronarski to Chybiński from Fribourg 16 V 1938, AACh-BJ, box 6, B-26/165.

717 Rutkowski to Chybiński from Warsaw 16 V 1939, AACh-BJ, box 4, R-19/65.

718 Rutkowski to Chybiński from Warsaw 5 V 1939, AACh-BJ, box 4, R-19/63.

719 Ochlewski to Chybiński from Warsaw 18 X 1938, AACh-BJ, box 1, O-1/90. 
supposed to be put into practice with the help of PTM, which was reactivated thanks to Łucjan Kamieński. In January 1939 in Poznan and in June in Cracow PTM was going to organise more meetings of delegates from all musicological centres - Poznań, Cracow, Lviv and Warsaw (where musicology, as we can remember, had existed for a few years as part of the Conservatoire, with occasional lectures at the university). However, this idea was just an incident which was not of significant importance to the fate of Rocznik and did not affect the work of its editorial team. Even though Warsaw kept insisting and flooding the authors with questions, they did not manage to publish another issue before September 1939.

The pre-war stage of the history of the magazine and the events of the first weeks of the war can be closed with the dramatic words that Chybiński wrote in his short notes to Ludwik Bronarski at the turn of 1941 and 1942: 'The Bolshevik gang destroyed the third volume of the Rocznik Muzykologiczny in the printing house, there were some proofreading sheets, but little. In general, this band destroyed a lot: they confiscated my whole private library together with music. Up to now, I have no hope of recovery'.720 'The third volume of the Yearbook, almost finished, was destroyed by the Bolshevik gang at the printers along with the stereotypes, but the entire proof was retained. ${ }^{721}$

The idea of publishing the PRM was undertaken at the beginning of the 1950s, when Józef Chomiński edited, as part of his work in PIS, volume I-II of Studia Muzykologiczne (1953). The PRM returned in 2004, published under the auspices of the Musicologists' Section of the ZKP and the forces of the Editorial Committee, which included Ludwik Bielawski, J. Katarzyna Dadak-Kozicka, Agnieszka Leszczyńska, Ewa Obniska and Barbara Przybyszewska-Jarmińska. The third volume was dedicated 'To the creators of Polish musicology' Chybiński and Jachimecki - and filled with entirely different content, constituting a testimony of contemporary Polish musicological research.

720 Chybiński to Bronarski from Lviv 19 XII 1941, AACh-BUAM, Bronarski's archive, p. 175.

721 Chybiński to Bronarski from Lviv 24 II 1942, AACh-BUAM, Bronarski’s archive, p. 176. 
III. Difficult years - Kwartalnik Muzyczny in the years 1948-1950 



\section{New context of the functioning of the academic milieu and their publications - 'bourgeoisie musicology'}

Despite immense destruction across the country, the post-war chaos did not last long. Day by day, Poland was trying to restore the order abandoned in 1939, also when it came to scientific and cultural life. However, the new political system quickly got down to extending the biological debilitation of the nation by degrading the most opinion-forming and culture-forming social group, namely prewar intelligentsia. Despite all that, humanistic, technical and artistic universities in the main Polish cities shortly began to resume their activity. Similarly, various associations and institutions were either established or resumed their previous activity. This is shown, for example, by the actions undertaken by Mieczysław Drobner, a composer, pedagogue, musicologist and pupil of Zdzisław Jachimecki. In autumn 1944 in Lublin, which was already free at that time, Drobner and some other musicians established the Polish Composers' Union (ZKP). Soon, the prewar Association of Polish Composers (SKP) was reactivated under the direction of Adam Wieniawski. ${ }^{1}$ The Ministry of Culture and Arts operating within the structures of the new government, in which the aforementioned Mieczysław Drobner was appointed as the head of the Department of Music (February 1945), quite quickly took over control over the entire artistic community, including the music environment. By the end of summer 1945, there were already plans for launching the First National Congress of Composers, during which the new Association was founded and its statute was passed, and immediately after the meeting, the Festival of Polish Contemporary Music was held. Stefan Kisielewski wrote the following about this in Ruch Muzyczny, the newly founded journal reporting on current musical life: 'The Festival of Polish Contemporary Music in Cracow was an event that none of the other European nations could be able to organise following such a terrible occupation.'

1 Wieniawski also became vice-president of the reactivated WTM (the president at that time was the actor Henryk Ładosz).

2 Stefan Kisielewski, 'Pierwsze Boże Narodzenie' [First Christmas] (RM 1945/6, 3). To supplement this information, it should be added that PTMW was reactivated in April 1946 (Zbigniew Drzewiecki - president, Barbara Podoska-Palester - secretary, and members: Stefania Łobaczewska, Maria Dziewulska, Stanisław Wiechowicz, Zygmunt Mycielski, Artur Malawski, Edmund Rudnicki). In the following years, Tadeusz 
Events which took place in the last period of the Second World War resulted in the forced migration of Poles. These events included the total destruction of Warsaw during and after the Warsaw Uprising, considerable losses in Poznan as the front line moved west in January and February 1945, losses in Wroclaw, which in the last weeks of the war became a stronghold doomed to almost total annihilation, destruction of many other cities, and the establishment of new borders at the Yalta Conference. It shortly turned out that the geography of Polish science shifted as well and this affected a large group of representatives of the musicologist community. Before the war, there were four academic centres in which musicology developed: Jan Kazimierz University in Lviv, the Jagiellonian University in Cracow, the University in Poznań, and Warsaw. When it comes to the latter city, it attracted a large group of active musicologists, and in the years 1938-39 there were first attempts to introduce regular musicology courses at the University of Warsaw. After the war, the academic centre in Lviv was irretrievably lost. Instead, Poland gained the foundation of a new scientific centre, the University in Wroclaw, which had a long tradition as a German scientific institution.

Among the pre-war departments, the least damage when it comes to both finances and personnel was suffered by the department in Cracow, whereas Warsaw was still awaiting its years of glory, while in Poznan the collections of the phonographic archive were irretrievably lost. However, the most significant losses affected Lviv, which - besides the plundering suffered during the German and Soviet occupations - found itself within the boundaries of the Soviet Union after the end of the war. Part of the city's Polish community decided to resettle the areas remaining within the new borders of the country, often in areas known as the Recovered Territories; the issue of goods left was dramatic - both private and public collections of art, property of universities and cultural institutions, offices; sometimes it was possible to evacuate these resources before closing of the borders ${ }^{3}$ or recover them as a result of international agreements, but in a small quantity. ${ }^{4}$

Ochlewski, Kazimierz Sikorski and Hieronim Feicht were also elected to the Board of PTMW, while Roman Palester was supporting the IMS ranks.

3 This, fortunately, happened to the archive of Adolf Chybiński, who left the city a few months before the end of the war and deposited part of the collection at the home of his friend, Bronislaw Romaniszyn, in Cracow.

4 For example, the collections of the Ossolineum, which after the war were moved from Lviv to Wroclaw, but only in part. For example, the whole collection of journals remained in Lviv. 
The first years of working in new conditions were conducive to summarising the history of the discipline in Poland and to establishing a starting point for a 'new opening' in musicology. Around the same time, a few publications which presented the situation of the musicological community came out. On one occasion PAU commissioned Zdzisław Jachimecki to work on Muzykologia i piśmiennictwo muzyczne w Polsce ${ }^{5}$ [Musicology and musical writing in Poland], another time the concise information was printed in the pages of Ruch Muzyczny, 'Uwagi o muzykologii' [Comments about musicology], in which Włodzimierz Poźniak indicated the most important tasks that musicologists should address as a response, on the one hand, to war losses, on the other - to earlier neglect, for example, in the area of establishing a single unified musical/musicological terminology, the absence of which made precise analysis of musical works significantly more difficult. ${ }^{6}$ Another demand put forward by Poźniak was the necessity of compiling a dictionary of Polish musicians ${ }^{7}$ and devising a classification of musicology. The foundation for it was supposed to be a monograph written by Seweryn Barbag $^{8}$ before the war.

5 In the series Historia Nauki Polskiej w Monografiach [History of Polish science in monographs], vol. 23, Cracow 1948.

6 See Poźniak 1948. The whole community felt the need to develop such a dictionary. Adolf Chybiński and his students were the quickest to react to this situation (Chomiński, Feicht, Łobaczewska), who, inviting Janusz Miketta, Tadeusz Szeligowski and Bolesław Woytowicz to join their group, set up a Terminological Committee. The first meeting of this committee took place on 2-4 IV 1948 at the headquarters of the Poznań Institute of Musicology. Information on this subject was provided, among others by RM 1948/7, 23.

7 Poźniak was referring to a name card catalogue compiled in Cracow before the war, 'during the work on Biographical Dictionary of the Polish Academy of Learning.' Due to the lack of communication between the main musicological centres, he could not have known that these materials (even though at that time they only covered data up to the history of Old Polish music) had already been compiled by Adolf Chybiński and were being prepared for print as a supplement to the third edition of Kwartalnik Muzyczny. It needs to be added that before the war, Tadeusz Ochlewski also gathered data on nineteenth- and twentieth-century musicians, concurrently with the dictionary which was being compiled by Chybiński. Unfortunately, Ochlewski's work 'was destroyed in 1944,' as we can learn from a short note which announced an edition of Słownik muzyków dawnej Polski [Dictionary of early Polish musicians], see KM 1948/21-22, 300.

8 Barbag 1928. 
Zofia Lissa, briefly outlining the situation of musicology from a distance of only a few years, ${ }^{9}$ recalled the names of musicologists and theorists that were missing in the new post-war reality, including Father Wacław Gieburowski (d. 1943). Seweryn Barbag (died in autumn 1944 due to tuberculosis in a tuberculosis sanatorium in Świder near Warsaw), Józef Koffler (Maciej Gołąb ${ }^{10}$ described the confusing history of Koffler's family and his not fully-explained wartime fate), Jerzy Freiheiter, Jan Józef Dunicz, Emilia Elsner, Irena Hüssowa, Erazm Łańcucki, Helena Dorabialska - for the most part members of the Lviv musicological community. ${ }^{11}$ It was hard to make up for such losses. One should also add names omitted by Lissa at that time - Henryk Opieński who died in 1942 in Morges, Julian Pulikowski, who died in 1944 in Warsaw, and Łucjan Kamieński who survived the war but was accused of collaborating with the occupiers and sentenced to prison. After leaving prison, he was removed entirely from all academic research.

As an additional difficulty in developing post-war Polish musicology Lissa indicated divergent methodological attitudes that polarised the community: historically and factually marked research by seniors of Polish musicology - Adolf Chybiński, Zdzisław Jachimecki and Józef Reiss as well as several of their followers - Hieronim Feicht, Maria Szczepańska, Włodzimierz Poźniak, Jan Prosnak or Marian Sobieski and Jadwiga Sobieska, against whom she opposed the philosophical and sociological approach - also arising from theoretical and historical research - taken by a group of pre-war graduates of the Lviv-based department (Stefania Łobaczewska, Józef Chomiński, Zofia Lissa) and representatives of the youngest generation, commencing its operations following 1945, including Witold Rudziński and Stefan Jarociński, amongst others. ${ }^{12}$ According

9 Lissa 1957.

10 Gołąb 2007.

11 The dramatically prolonged period of uncertainty about the fate of the war victims is confirmed by a short note, which can be found in RM: 'Dr Jan Dunicz, ... musicologist, former U.J.K. Assistant, deported in July 1944 from Warsaw to camp in GrossRosen, remaining in Linz until May 1945. His sister - Helena Dunicz - asks to send any information about his whereabouts at the address of Ruch Muzyczny," see RM 1946/7, 28. After the war, Helena Dunicz worked in PWM, including the executive editorial office of KM. See also Niwińska [née Dunicz] 2005.

12 Lissa 1957. Here there are unjust words about, amongst other issues, the 'dim methodological awareness of the older generation' (op. cit., p. 267); this charge should, of course, include the failure of the elders to apply the assumptions of historical materialism and Marxist historiosophy in force in these years in learning. 
to Lissa, such a split caused the weakening of the whole discipline, which in turn, over time worked against the unification of the programme of musicological studies. ${ }^{13}$ The lack of personnel was also an argument that for only a few years the activity of academic-didactic centres should be limited to two locations Warsaw and Cracow.

In May 1945, ethnomusicologist Marian Sobieski and acoustician Marek Kwiek, two pre-war employees of the former Musicology Department at the University of Poznań, resumed classes in this institution. Łucjan Kamieński, who was the founder of the department and its head before 1939, was not involved in these actions. Suspected of collaboration with Germans, he was put under arrest and remained on the margin of academic life even after his exoneration. However, it was obligatory for a university department to be headed by a faculty member with a postdoctoral degree, so in spring 1945, the Humanistic Faculty Board asked Adolf Chybiński to take up this position. Since he could not hope for a return to Lviv, he accepted the offer from Poznan, and at the beginning of the new academic year, he gladly began organising the Department.

(Let us remember that by the end of 1939 musicology in Lviv ceased to function in the form in which it had been operating since 1912. At that time the Department - its staff, students, and the entire property - was incorporated into the structures of the Lviv National Conservatoire named after Mykola Lysenko. In 1940, Zofia Lissa was appointed dean of the faculty of music theory, but we know that she still regarded herself as a pupil of Chybiński and participated in seminars organised by him, during which she heralded the results of her research, a matter she gave information about after the war during her efforts to obtain habilitation.)

The financial (and material) situation of musicology in Poznań was very difficult. The pre-war property was almost completely destroyed, and this fact had to set future research plans: 'after the withdrawal of the invaders the Department is highly impoverished, plundered. After handling such a Department as I had in Lviv, now I am merely a pauper. There, I could undertake works in every respect. Here - in truth, not even one' - wrote the professor. ${ }^{14}$ The majority of materials from the phonographic archive were irretrievably damaged, and only remnants of the former library collection survived. However, after the war, there were many actions aimed at retrieving library collections and acquiring new titles.

13 Ibid.

14 Chybiński to Bronarski from Poznań 5 IX 1946, AACh-BUAM, Bronarski's archive, p. 196. 
They quickly yielded results. Thanks to the generosity of Zofia Lissa, gifts from the Ministry of Culture and Art were also added to the collection. Lissa was a ministerial official and could decide, at least to a certain degree, how the gains stored in ministerial warehouses were distributed. Four years after Chybiński had become the head of the Department, he wrote: 'In 1945, there was a handful of music materials and 80 books... This week, we'll exceed 1000 books and about 2500 documents on music. It's not much! But it's still a lot for such a short time. ${ }^{15}$ In terms of artefacts of Old Polish music, the situation was saved by the professor's private collections - an abundance of compositions from as far as the eighteenth century gathered before the war by Chybiński himself and his students, which often constituted the material basis of master theses and editing of the renewed WDMP.

Knowing the enormity of work associated with running the Department, the professor from the early days sought support from his younger colleagues classes were still conducted by Marian Sobieski and Marek Kwiek, except that Kwiek had quite quickly (in 1946) received his habilitation in the field of acoustics and science on musical instruments, which indicated his future scientific path. ${ }^{16}$ On account of devoting himself to the technical aspects of acoustic research, he had temporarily withdrawn from his interest in musicology. Already in the initial period, in addition to senior colleagues, Kornel Michałowski - a young student - volunteered to help with the library collections. Edmund Duliński and Zygmunt M. Szweykowski - the professor's pupil - soon appeared in the role of assistants. However, the most important figure in the professor's group was Maria Szczepańska - his most faithful assistant who remained in Lviv even in the first months after the liberation. Nonetheless, she was soon relocated to Poznań as a result of the newly-established border arrangement. Szczepańska, despite her many notable academic achievements and publications, and her persistent teaching activities, did not advance within the academic structures. Although she served as the pillar of the department after Chybiński's death, her career did not flourish, also in connection with the marginalisation plans already launched at that time in Warsaw and (eventually) the closure of the Poznan-based academic centre.

One of the most important tasks which Chybiński undertook in Poznań was to confer more postdoctoral degrees in order to make it possible to open new

15 Chybiński to Bronarski from Poznań 14 XI 1949, AACh-BUAM, Bronarski's archive, p. 208.

16 Harajda 1997. 
departments of musicology or to strengthen the existing ones. In the second year of his work as the head of the department in the Humanistic Faculty, he conferred the first postdoctoral degree on one of his pupils from Lviv. In total, four of his Lviv pupils obtained such degrees. Father Hieronim Feicht, who in March 1946 settled in a parish in Oporów near Wroclaw, also taught classes at the newly formed Department of Musicology in the Humanistic Faculty at the University in Wroclaw (see below) and started forming a music academy in this city. The necessity of obtaining authorisations regarding the conduct of didactic and academic activities prompted him to quickly apply for the opening of the postdoctoral habilitation procedure based on the dissertation Ronda Fryderyka Chopina [Frederic Chopin's Rondos], and the successful completion of the procedures related to obtaining the degree took place in the first days of July $1946^{17}$. Still, during autumn of the same year, Zofia Lissa's habilitation application was submitted from Moscow to the address at the University of Poznań. Her case was to be referred in the first place by the rector of the University of Poznań, the professor of psychology Stefan Błachowski, who was also from Lviv and was 'a musically-gifted man who knows the issues psychology of music. ${ }^{18}$ In the beginning, Chybiński thought it impossible to confer a degree in musicology on Lissa due to insufficient documentation of her historical research. ${ }^{19}$ However, things turned out differently. All in all, it was beneficial to the discipline in the hard years when the musicological community was being rebuilt, and a new musicological centre was being formed at the University of Warsaw.

For another 'Lviv' habilitation it was necessary to wait some more months until Stefania Łobaczewska completed her monograph on the life and works of K. Szymanowski. According to the original plans, after obtaining her qualification, Łobaczewska was to take a position in Łódź. However, at the Faculty of Humanities of the local university, classes on the history of music were already led by Alicja Simon. Furthermore, Łobaczewska did not find Łódź interesting and, anyhow, from 1944, the researcher had taken up permanent residence in Cracow, where after the war she participated in the organisation of PWSM, and where she gave lectures from 1946 almost to her death. She was strongly associated with the city and wanted to connect with the local musicology community,

17 The dissertation was published two years later in three parts in the pages of KM (1948/21-22, 11-34, 1948/23, 23-62, 1948/24, 7-54).

18 Chybiński to Chomiński from Poznań 24 XI 1946, at APCh.

19 'There's no way she could get a postdoctoral degree in musicology because she didn't write a single paper on the history of music, only works on psychology and theory. Anyway, this matter will be settled by the committee", ibid. 
knowing full well that the department would remain in the hands of its creator, Zdzisław Jachimecki. Despite the circumstances, after obtaining her qualification in the first days of June 1949 in Poznan and after conducting appropriate procedures related to the transfer of her tenure, and with the support from Eugenia Krassowska who had been serving as Deputy Minister at the Ministry of Education, Science and Higher Education for years, in 1951 she was employed at the Department of History and Theory of Music of the Jagiellonian University. Following the death of Zdzisław Jachimecki in 1953, she was appointed as the head of the unit.

The last habilitation, that of Józef Michał Chomiński, took place at a moment when it was not entirely clear whether the habilitation procedure must be preceded by the publication of the dissertation or not. Taking advantage of this gap in the regulations, Chomiński chose his pre-war, but still unpublished, dissertation written in 1937, Zagadnienia konstrukcyjne w sonatach fortepianowych Karola Szymanowskiego [Structural issues in Karol Szymanowski's piano sonatas], ${ }^{20}$ despite the fact that at some point Chybiński had proposed submitting the work on Chopin's preludes that was being prepared at that time..$^{21}$ The term of habilitation was set for 1 July 1949, and although after the event the candidate had many doubts about the quality of his lecture, the professor was able to note the success of the Lviv school with satisfaction.

In the context of these four habilitations, the professor's observation seems interesting. He wrote to Ludwik Bronarski: 'Have you noticed that all of my existing habilitation candidates work in areas from which I have not published a single work?! Strange, isn't it? But it seems to be the result of my "Lviv" teaching assumptions [that] my students work, as far as possible, in various departments

20 Planned for the third volume of PRM 'Zagadnienia konstrukcyjne w sonatach fortepianowych Karola Szymanowskiego,' which was published finally in two parts in KM (1948/21-22, 170-207, 1948/23, 102-157), formed one of the elements of the broadly conceived Studia nad twórczością Karola Szymanowskiego [Studies on Karol Szymanowski's work], of which the first part - 'Problem tonalny w Stopiewniach' [The tonal problem in Stopiewnie] - appeared exactly in PRM (1936/2, 53-86), and the last 'Chóralne pieśni kurpiowskie' [Kurpie choral songs] - closed the cycle (KM 1948/24, 55-83). The Studia were published in full after years by the Cracow based PWM (1969).

21 The essay 'Problem formy w preludiach Chopina' [The problem of form in Chopin's preludes] was published in the 'Chopin' editions of KM: 1949/26-27, 183-288, 1949/28, 240-395. 
and directions missing in our musicological inventory. However, new and newest music prevails. Ha, oh well!'22

Conferring postdoctoral degrees on his pupils was a priority to Chybiński, but it was not his primary occupation. The most important task was to educate a new generation of musicologists who would fill war losses and make up for the years in which no new diplomas were obtained. At the end of the 1940s and the beginning of the 1950s, about 100 candidates took up musicological studies. Prior to Chybiński's death, thirty-eight students were awarded master's degrees. ${ }^{23}$ The second generation of the professors' alumni were such prominent musicologists as Zygmunt M. Szweykowski, Tadeusz Strumiłło, Mirosław Perz, Anna Czekanowska, Jan Stęszewski, Ludwik Bielawski, the earlier mentioned Kornel Michałowski, Danuta Idaszak, Father Tadeusz Miazga and many others some of whom were forced to migrate to Warsaw to complete their studies after closing the Poznań department.

Just as before the war in Lviv, Chybiński’s lecture topics covered a very broad range - from the music of the Ars Antiqua period, through the history of instrumental and vocal music of the Renaissance and Baroque, symphonic music of the Classicism period and the period following Beethoven, romantic solo songs. Chybiński was particularly close to Polish themes within three periods: Early Polish music, Chopinology and Karłowicziana, but he did not even try to get closer to the new research methodology desired by the state authorities. As it soon turned out, this led to the weakening of the Poznan Department's position and exploitation of its potential, both material and human, to build a new musicology in Warsaw. The centrally planned syllabus, in which the professor got confused, did not help at all. The introduced obligation to prepare a detailed plan of lectures contradicted the principle of independence of the university and its academic staff, and researchers educated before the war found this principle difficult to accept.

Intensive didactic and research work (just in October 1950, the professor had to 'review' ten more master's theses ${ }^{24}$ ) did not protect the musicology department

22 Chybiński to Bronarski from Poznań 4 VI 1949, AACh-BUAM, Bronarski’s archive, p. 202. The topics of theses in Poznań were different and corresponded completely with Chybiński's research passions: 'from the former Polish music and ethnography. Just one topic on foreign music (“Grieg's Sonata in E minor”), see Chybiński to Bronarski from Poznań 12 XI 1949, AACh-BUAM, Bronarski’s archive, p. 208; works on Chopin also featured in the next year.

23 Michałowski 1999, 54.

24 Chybiński/Chomiński 2016, 293-294. 
against constant controversies about its place in the university's structure. The attitude of some representatives of university authorities was adverse towards musicology. At the same time, Zofia Lissa made the first attempts to concentrate musicological 'forces and measures' in the new department which was being developed at the University of Warsaw. It soon led to scientific migration, this time in the direction of the Polish capital. Thanks to her connections with communist authorities, when Lissa came back to Warsaw, she was initially appointed associate director of the Department of Music at the Ministry of Culture and Art. This position enabled her to think about engaging in her own research activity and organising music and musicological life in Poland. She became one of the most important figures in post-war music and musicological life. As Sławomir Wieczorek put it in his dissertation, she was also the boss of this community. ${ }^{25}$ Lissa encouraged attempts to create an atmosphere of friendly cooperation, to devise uniform plans, and to come up with collective and coordinated actions. It was her answer to 'the fragmentation of research, typical for the pre-war period (which was conditioned by the isolationism of individual musicologists and the hostility expressed by other communities). ${ }^{26}$ The priority for her was to build a new musicological centre at the University of Warsaw, for which she quickly obtained bureaucratic consent (and above all she managed to get the promise of maintaining musicology as a field within university structures), which did not, however, indicate, immediate realisation of this project. Despite certain manoeuvres (which were also undertaken by Chybiński who followed in the footsteps of old contacts from Lviv), Lissa did not receive the promised facility, the allocation of which she expected throughout 1948. Transfer of her habilitation from the UP was also problematic because at some point some even dared to question submitting a dissertation at the Greater Poland-based university.

A quarter of a century later, in the anniversary book on Warsaw musicology, Lissa wrote about the beginnings of her lonely efforts to create a new unit at the Warsaw University as well as her struggle with MKiS, which wanted to mimic the system adopted by the 'fraternal Soviet state' and form historical and theoretical

25 The author made a distinction between mentors ('the leaders of the ideological front', giving as an example Bolesław Bierut and Jakub Berman), bosses ('the key figures of postulating criticism,' in literature, these were, for example, Adam Ważyk and Jerzy Putrament) and executors ('authors of daily reviews providing literary criticism services'). He added that it was, in fact, a four-tier hierarchy, since the lowest position was occupied by the statements made by the creators themselves, that is the ones who were bossed around, see Wieczorek 2014, 28 and Sławiński 1990.

26 Lissa 1957, 276-277. 
divisions within conservatoires (then already higher music schools) and 'support conservatoire professors with the few musicologists who have already gained a certain academic renown. ${ }^{27}$ This aspiration contributed to the fairly common (also known from history) misunderstanding of musicology as an academic field of study amongst a large part of the academic university staff.

To meet her goal, Lissa had to strengthen (or rather build) the academic community in Warsaw at the expense of other centres of learning and, most importantly, move away from the pre-war model of university departments headed by one professor acting as the master: 'The fight for musicology in Warsaw was also the fight for a new essence and direction of Polish musicology. These tasks could not be fulfilled in single-person musicological centres.... The Warsaw centre aimed to attract several experts who could work together to implement a curriculum with a wide array of specialisations. ${ }^{28}$ Her own ambitions, as well as war losses and the deaths of further musicologists after the war, had a bearing on the fact that in the end, musicology was concentrated in two main centres.

She mentioned that she had undertaken didactic activity (without her own place to run classes, but with twelve students) on 1 October 1948. Classes were held in the lecture hall of the University of Warsaw. However, it is worth mentioning that on the basis of surviving correspondence, we can say that the meeting with Minister Krassowska, to whom Lissa presented the proposed activities of the future Department of Musicology at the University of Warsaw, actually took place in the first days of 1949. She was planning to open a historical, theoretical and 'folk' division:

The first unit, due to the need of our methodological, Marxist approach - would be led by me for the time being, although I feel that you Sir should be the one giving lectures on medieval music. In general, it seems to me that theory and history would intermix between the two of us. For example, I would teach psychology and aesthetics of music. Theory of history - you. We could also bring Fr. Feicht, Krassowska feels like it - but he would have to give up lectures focused on religious forms. I have a feeling that he would consent to this. The folklore unit is the most difficult. Krassowska does not want to move the Sobieskis from Poznan to Warsaw due to the co-operation of the Archive and its devices with the departments of dialectology and linguistics. And so - has Witold Kandulski already become such a refined folklorist to be able to cover lectures and classes on ethnology? I doubt it. ${ }^{29}$ Since the plan for the development of the department

27 Lissa 1978, 9.

28 Lissa 1978, 9-10.

29 Witold Kandulski, a young musicologist from Poznań, did not join the ranks of teachers in Warsaw, while a year later the Poznań School of Music, in which he served as the first director, was opened thanks to his efforts. 
of musicology in Warsaw is long-term, we could develop this unit only after a year or two. ${ }^{30}$

Stanisław Golachowski's name was also included in the letter. He contributed greatly to the preservation of Karol Szymanowski's legacy. At that moment in time he was professor at the PWSM in Łódź and from the previous year had been a member of the PAU and was able to take the acoustics classes. ${ }^{31}$

Chomiński enthusiastically responded to the invitation to participate in the construction of a new research and teaching facility. Let us quote here a larger part of an extensive letter which he sent to Lissa, immediately accepting the ideological interpretation of the new syllabus as obligatory:

I prepared a detailed study programme which basically overlaps with your project.... Since this plan will be read out at the meeting of the Humanistic Faculty Council, I was trying to formulate it in such a way that it does not frighten old 'Mohicans' and at the same time contains everything that is needed. What I mean is that the new methodological (Marxist) approach is there, yet I did not expressly call it that. That is why the first division, the theoretical and methodological one, will have such a great importance. I also included in it the methodology of historical research and aesthetics, because from our point of view all these elements will be interrelated and will complement each other. I left the methods of gathering and sorting musical ethnographic materials in the third, ethnology division. It is because these methods are purely technical and different than the methodology of research on music theory and the history of music. Moreover, music theory cannot keep following the old path, but should rather be based on dialectical thinking. These are the most difficult matters. This is why it is very important for me to hold a conference with experts on Marxist dialectics in the near future (most importantly with Prof. A. Shaff $\left.{ }^{32}\right)$... You will surely be surprised by the fact that the theory of harmony, counterpoint and forms were separated from general music theory. Well, on the one hand, I would like the subject called 'general music theory' to be the foundation of a thorough discussion and examination of matters related to the modern way of thinking, and on the other hand to cover issues which will not be explained in detail for now, e.g. the theory of rhythmical realisation, melodics and instrumentation. The history division looks formalistic only at first sight. I did not specify individual

30 Lissa to Chomiński from Warsaw 4 I 1949, APCh.

31 Stanisław Golachowski fell ill towards the end of his life - he died at the beginning of January 1951. The actual lecturer in the field of acoustics, from the academic year 1951/52, was Marek Kwiek, who, as mentioned earlier, for a certain amount of time, still at UP, gave up musicology in favour of physics.

32 Adam Schaff (1913-2006), a Polish philosopher. He initially represented the views of Marxist philosophy and specialised in epistemology. Later, he became an advocate of Eurocommunism, whereas in his twilight years he moved closer to contemporary anti-globalists. 
branches of the history of music culture because it depends on the needs and will of the lecturer. Anyway, it should be about the presentation of a cultural, sociological and economic ground, which should be as broad as possible. The same applies to the history of musical forms and instruments (the sociological and economic factor!).... The third division is self-explanatory. In the fourth division, an important and a new issue will be the correlation between acoustics and music theory.... And one more thing, ..., namely the issue of classical counterpoint. To date, the importance of this subject used to be greatly exaggerated. ${ }^{33}$

The conclusion of this long reasoning seems interesting: Namely, Chomiński considered it necessary to open a new journal that would 'forge [this] modern methodological approach,' a journal that would legitimise the work of the new centre - 'Warszawski Rocznik Muzykologiczny' [Warsaw musicological annual] with a subtitle 'Rozprawy Warszawskiego Instytutu Muzykologicznego' [Reports of Warsaw institute of musicology]. This idea evolved in connection with new tasks, which Chomiński soon undertook outside of UW: work in the newly created PIS resulted in the opening of a new title - Studia Muzykologiczne (see chapter III-2).

Warsaw musicology was allocated a flat in the tenement house at Hoża street 74 in August 1949. Soon, Chomiński ${ }^{34}$ started his teaching there; earlier, he had also been proposed lectures on the subject of music reviews for the Journalism Studies course at the Academy of Political Science ${ }^{35}$. The formalities related to the transfer of his tenure from Poznan were completed in the spring of 1951; Krystyna Wilkowska, Chomiński's wife, also undertook classes with students alongside her husband; Father Feicht moved to Warsaw, soon afterwards also Marian Sobieski, and the first graduates of Warsaw also worked with the next years - Michał Bristiger and (in time) Andrzej Chodkowski, Anna Czekanowska, Józef Patkowski, Elżbieta Dziębowska. In the academic year 1952/53, the Department moved to a new address to the university building at Krakowskie Przedmieście, and in the new political reality, in 1957 musicology received rooms in the Warsaw Palace of Culture and Science.

Before moving to Warsaw, in the spring of 1946, Father Hieronim Feicht arrived in Wroclaw, assuming the duties of a parish priest in Oporów near Wroclaw. He quickly gained a position of renown amongst the main figures of the local music environment: he was one of the founders (together with Kazimierz Wiłkomirski,

33 Chomiński to Lissa from Szklarska Poręba 7 I 1949, APCh.

34 This information, like much in this work regarding details of the life history of Józef Chomiński, can be found in: Gołąb 1995/2 and Gołąb 2008 (passim).

35 Chomiński to Academic Board of Study from Warsaw 30 III 1949, APCh. 
Ryszard Bakst, Ryszard Bukowski and Zbigniew Liebhart, also a lvivian) of the Lower Silesian Music Society. ${ }^{36} \mathrm{He}$ also contributed to the opening of the PWSM, and became the first rector.

It should be noted that the pioneer of musicology in the Wroclaw-based Alma Mater was another student of Adolf Chybiński, namely Zbigniew Liebhart, who along with a group of repatriates, associated before the war with the Lviv University, began the construction of a new Polish academic centre, which in the autumn of 1945 became the University of Wroclaw. He personally decluttered the rooms, where in November 1945 he began giving classes for the first students. His great merit was the preservation of a large part of the pre-war library sources belonging to the Institut für Kirchen und Schulmusik. Due to lack of habilitation, he could not apply for running the institution; however, he was entrusted with the position of assistant professor.

The newly created course in Wroclaw had a solid foundation in the form of two units before the war at Universität Breslau - the earlier mentioned Institut für Kirchen und Schulmusik and Musikwissenschaftliches Seminar. ${ }^{37}$ Almost immediately after the war ended, pianist Stefania Allinówna made the first attempts to create conditions which would be sufficient to conduct musicology classes. She acted on behalf of the Ministry of Education. However, in August 'Liebhart submitted a request for considering his candidacy for the position of an employee of the future department of musicology in the Humanistic Faculty for the attention of Prof. Stanisław Kulczyński, Rector of the University. ${ }^{38}$ In the first days of October, he became the first and at that time the only employee of the newly established Department. At the end of November, he started didactic activity by opening a seminar on music palaeography, which most probably resulted from his personal interest in the music of the earliest times. Let us recall that in Lviv (in 1932), Liebhart earned his doctorate on the basis of his dissertation Rozwó $j$ progresji $w$ muzyce wczesnego średniowiecza [The development of progression in music of the Early Middle Ages]. ${ }^{39}$

The atmosphere at the university in Wroclaw was favourable to musicology, which gave hope for expanding the academic staff and establishing a new musicology department in the future. The only problem was the requirement for a

36 Feicht 2008, 79 (footnote 50).

37 See Ugrewicz 1996, Ugrewicz 1998, Ugrewicz 2005, Drożdżewska 2011, Drożdżewska 2012. For a comparison of pre-war musicology in Wroclaw and Lviv see Gołąb 2012.

38 Ugrewicz 1998, 73.

39 In Lviv, he did not devote himself to an academic career, but conducted pedagogical, conducting and journalistic activities. 
department to be headed by a faculty member with a postdoctoral degree, which Liebhart did not have. Zdzisław Jachimecki did not intend to leave Cracow, whereas Chybiński was already employed at the University of Poznań. However, they both put forward their own candidates. Jachimecki named Józef Reiss, a pre-war associate professor (docent). His rival, named by Chybiński, was Father Feicht. The procedure of granting a postdoctoral degree to Feicht had already been underway at the University of Poznan and was finalised (as stated above) in the first days of July 1946. Reiss's youthful age worked against him. However, already in summer 1945 Feicht was ready to seek a position in Wroclaw. ${ }^{40}$ Even though according to procedures the nomination should have taken some more time, in early spring 1946 he became a deputy professor pursuant to the decision of the Rector of the University of Wroclaw.

In Wroclaw, classes were devoted mostly to historical matters (the history of music, palaeography, counterpoint). Aesthetic reflections and problems related to music sociology were disregarded. At the same time, apart from lectures and classes, intensive organisational work was still ongoing. The collection of books, musical instruments and phonographic resources gathered by employees of the Department and volunteers grew surprisingly quickly. There was also some equipment needed for recording and playing music. According to Ugrewicz, these resources 'significantly surpassed the collections of departments from Cracow and Poznan. ${ }^{41}$ Still, despite fulfilment of the formal conditions and strenuous efforts by the Council of the Humanities Faculty, there was no professorial nomination for Feicht, which would have given the opportunity to create an independent department. On the contrary, even though he did get a position at university, he was employed only as an assistant professor at the Department of Art History, which was superior to the Institute of Musicology. The future of the Institute at the University of Wroclaw remained uncertain in the following academic years. Despite all that, recruitment continued until the academic year 1949/50. In the meantime, the academic staff was extended. Józef Majchrzak, who was still studying musicology at that time, was employed as an unofficial assistant lecturer. In the future, he became a folklore researcher, meritorious for Lower Silesia.

The Wroclaw centre, despite the efforts of Feicht, Liebhart and a small group of listeners, was unable to develop without the central support of Warsaw. In autumn of 1947 Zofia Lissa wrote: 'We managed to resolve the case of Father

40 Ugrewicz 2005, 76.

41 Ibid., 79. 
Feicht favourably, which means that the department of musicology at the University of Wroclaw was saved. The case will be presented to the Ministry of Education Council in the second half of September, and there is a $90 \%$ chance that it will be settled in our favour, ${ }^{32}$ she herself had plans to organise musicology at the University of Warsaw at the time, even at the expense of others indeed of Wroclaw and (remaining in the sphere of the desires of Alicja Simon) of Łódź, and in the future - as it turned out - also in Poznań. The fate of the Institute in the west was sealed at the beginning of the 1950s. Its liquidation started in spring 1951. The legacy of the Institute was claimed by the University Library (which took the manuscripts and old prints), the State Higher Music School in Wroclaw (the book collection and instruments) and the Association of Linguistic Departments (the recording and playing equipment). However, these attempts were blocked by the Ministry of Science and Higher Education. Phonographic equipment and a large part of the library collection were transferred to the Institute of Musicology at the University of Warsaw, which had already been operating for three years and was headed by Zofia Lissa. Lissa convinced Father Feicht to go to Warsaw. In 1956, he officially opened the Institute of Musicology at the Catholic University of Lublin. According to an agreement between the Episcopate and the government (concluded in 1950), this university preserved at least some of its autonomy and could follow its own curriculum.

In effect, the Wroclaw Department of Musicology was closed at the end of the academic year 1951/52, which was a consequence of the policy of centralising academic work, and according to which research was concentrated only and exclusively in selected centres. In the case of musicology, among the five planned after the war - Warsaw, Cracow, Poznań, Wroclaw and Łódź - only the first three remained, and with time it turned out that the position of the third, Poznan, was significantly weakened.

During the few short years of its post-war activity, the Institute of Musicology in Wrocław actively contributed to rebuilding musical culture in Lower Silesia. However, its contribution to the creation of a Polish nationwide musicological community and its academic output were much smaller. Works written by Zbigniew Liebhart resembled journalistic writing and a critique of contemporary music life rather than academic papers. In the bibliographies of musical writing, the author has only one position - a review of the monograph by Paul Egert,

42 Lissa to Chybiński from Warsaw 14 IX 1947, AACh-BUAM, fol. K-Ł, p. 149. 
Chopin, published in Kwartalnik Muzyczny. ${ }^{43}$ Feicht wrote significantly more, although in large part for the needs of regional magazines, such as for example, Zeszyty Wrocławskie. ${ }^{44} \mathrm{He}$ was sporadically an author for Ruch Muzyczny, at the beginning, at least till 1948, the only forum for the milieu. ${ }^{45}$ As far as his academic achievements are concerned, in the first (double) edition of the newly created Kwartalnik Muzyczny the first of the three parts of his habilitation thesis ('Ronda Fryderyka Chopina' [Frederic Chopin's rondos]) was printed. ${ }^{46}$

Three new musicological centres were built on ruins, both literally and metaphorically. The only institute whose structure did not change after the war and which was still headed by the same person was the one at the Jagiellonian University. Both Zdzisław Jachimecki and Józef Reiss survived the war in Cracow. However, the professor (who had left for Lviv in the first weeks of the war together with his wife, but came back in the first days of November due to meetings scheduled at the Jagiellonian University) spent a few weeks as a German captive and was then kept for some time in Sachsenhausen-Oranienburg concentration camp near Berlin. ${ }^{47} \mathrm{He}$ survived the rest of the war by giving music lessons. After the war, musicology in Cracow functioned at the university as the Seminar (and later as the Department) of Music History and Theory, which officially started its activity in the academic year 1947/48. It soon turned out that even though the city did not suffer wartime damage, the only thing left from the pre-war property

43 KM 1948/23, 182-184. He also planned a thesis on Chopin's music realism ('Chopin's music $=$ realistic reflection of the socio-cultural characteristics of the epoch'), Liebhart to Chomiński from Wroclaw 5 V 1949, APCh.

44 The quarterly Zeszyty Wroctawskie appeared in the years 1947-52, initially as an organ of the local Circle of Polish Language and Literature Enthusiasts, later Wydawnictwo im. Ossolińskich. Feicht included, amongst others, in the pages of the magazine the articles 'Dolny Śląsk w pieśni śląskiego ludu' [Lower Silesia in songs of the Silesian folk] (1948/1-2, 99-106) and 'Chopin we Wrocławiu' [Chopin in Wroclaw] (1949/1-2, 13-24).

45 See for example, 'Wpływ Chopina na muzykę niemiecką i skandynawską' [Chopin’s influence on German and Scandinavian music] (RM 1949/11-12, 30-33).

46 In the same year, Feicht gave the editorial office two more reviews and was the author of a talk during the Congress of the Musicologists Section in November 1948 on the need to restore the programme of early music concerts, published later along with other speeches of the congregation in KM 1949/25 (pp. 232-236). In the following years he cooperated with periodicals published by PIS, later IS PAN - the monthly Muzyka, the annual Studia Muzykologiczne, the periodical Materialy do Studiów i Dyskusji z Zakresu Teorii i Historii Sztuki, and finally - the quarterly Muzyka.

47 Jachimecki 2005. 
of this institution was the book collection stored in the Jagiellonian Library. The good news was that it was possible to find a new teaching location. Musicologists of the younger generation soon supported the two principal lecturers: 'In 1947 the habilitation studies of Dr Włodzimierz Poźniak took place, and in the following year the Department received a second full-time assistant, namely Dr Aleksander Frączkiewicz, whereas Dr Józef Reiss was appointed as full-time assistant professor. In 1949, the latter obtained the title of professor and retired two years later. In 1951, Stefania Łobaczewska, habilitated in 1949 in Poznań, received veniam legendi at the Jagiellonian University. In 1950 came a new assistant, Stanisław Haraschin, MA.... In 1953 Stanisław Lachowicz, MA, was hired as an assistant along with the promising Tadeusz Strumiłło, MA, who died tragically in the Tatra Mountains, Zygmunt Szweykowski, MA and for of two years Bogusław Schäffer, MA, received a contract to run classes. ${ }^{3}$

Post-war Cracow musicologists signed up as the creators of several important monographs and syntheses. Reiss published a popular history of Polish music Najpiękniejsza ze wszystkich jest muzyka polska [The most beautiful of all is Polish music] (Cracow 1946), Jachimecki, amongst others, a study Muzyka polska w rozwoju historycznym [Polish music in historical development] (Cracow 1948 and 1951) and a monograph Chopin. Rys życia i twórczości [Chopin. An overview of his life and work] (Warsaw 1949), Łobaczewska - the basis for her habilitation, the monograph Karol Szymanowski: życie i twórczość, 1882-1937 [Karol Szymanowski: Life and work, 1882-1937] (Cracow 1950) and Zarys historii form muzycznych [An overview of the history of musical forms] (Cracow 1953). Tadeusz Strumiłło was very promising, who at the age of twenty-five had already published Szkice z polskiego życia muzycznego w XIX w. [Sketches from Polish musical life in the nineteenth century] (Cracow 1954) and the monograph Źródła i poczatki romantyzmu w muzyce polskiej [Sources and beginnings of Romanticism in Polish music] (Cracow 1956). Just like before the war, Cracow musicologists had more difficult access to the columns of the academic press - the only author of the reactivated, post-war Kwartalnik Muzyczny was Włodzimierz Poźniak, whose article about Moniuszko's unrealised operatic projects was already accepted for the first, double issue of the magazine (pp. 234-251). On the other hand, all of them wrote for the Warsaw Muzyka, which from 1950 took over the role of Kwartalnik, although its profile was far from the standards of academic journalism.

48 Poźniak 1967, 451. Students also took part in the organisation of the Seminar - Maria Biliżanka and Wiktor Spodenkiewicz. 
As soon as military operations stopped, Polish universities did everything in their power to resume their activities and restore the old order. However, it soon turned out that the new government was going to introduce a new order, which would not spare the structure of academic institutions, universities and scientific societies. All schools of higher education were supposed to be managed by the state, which meant losing their autonomy. The official process of imposing these norms started as early as in 1946. In the next few years, all actions undertaken by state officials delegated to manage science and higher education focused on preparing the First Congress of Polish Science, which took place at the end of June and at the beginning of July 1951. In just a few years (1945-51), authorities issued multiple decrees which organised this sphere of life in the country, e.g. the decree on censorship, libraries and the protection of library collections signed in 1946, or the decree on the organisation of science and higher education adopted at the end of October 1947, which ensured state protection of research. According to Degen and Hübner, 'In the field of humanities, institutional conditions, in particular those related to science policy, have ... a special meaning because they are directly related to the idea of freedom of science and the rule of autonomy of scientific institutions,' '[humanist scholars] did not have ... huge expectations related to institutionalised science: it was not hope that prevailed, but rather the fear of institutionalisation or other tools of science policy, as well as the policy itself. ${ }^{39}$

The development of free humanistic thought was limited by restrictions leading gradually, amongst others, to liquidation of the traditional structures of the humanities departments at the resurging universities and suspend the activities of scientific societies - PAU and the Warsaw TN - which was to be replaced by the centrally conceived PAN. However, before this happened, immediately after the war, the pre-war scientific societies resumed their work in major cities, or new groups undertook initiatives. It could no longer function in its earlier TN form, dating back to the beginning of the century, founded by Oswald Balcer in Lviv (initially under the name Society for Supporting Polish Science), of which Adolf Chybiński was also a member before the war. Scientists who had emigrated from Lviv constituted a substantial part of the academic teaching staff at the new Polish university in Wroclaw and chose this academic centre to revive their organisation. The first attempts to formalise their meetings started as early as in autumn 1945. After a few months, in June 1946, there was an official opening session. Out of twenty-two founding members, seventeen came from

49 Degen/Hübner 2006/1, 39, 41. 
Lviv. The first president was Stanisław Kulczyński, botanist, rector of the UJK in the thirties, also a political activist (an active member of SD); the board additionally included: law professor Kamil Stefko, economist Wincenty Styś and the outstanding mathematician Hugo Steinhaus. ${ }^{50}$

The Warsaw TN, which had been established before the war by graduates of the Szkoła Główna, members of the Kasa im. Józefa Mianowskiego and the capital's circle of PAU, after the war, faced considerable losses, both personal and material, resulting from the dramatic fate of Warsaw itself (amongst other matters the home of the TN was destroyed - Staszic Palace - which, although rebuilt in 1950, was passed on to the Society, but soon, along with all other assets, it became part of the estate of the newly established PAN). In the post-war period, in the field of musical publications, the Warsaw TN agreed two titles Korespondencja Fryderyka Chopina [Correspondence of Frederic Chopin] (1947) and Bibliografia F.F. Chopina [Bibliography of F.F. Chopin] (1949) (both positions prepared by Bronisław E. Sydow).

The oldest science forum active after the Second World War operated in Poznan. The history of the Poznan Society for the Advancement of Arts and Sciences (Poznańskie Towarzystwo Przyjaciół Nauk) dates back to the middle of the nineteenth century. It resumed its activity in the middle of May 1945. The first president of the Society was Zygmunt Wojciechowski, a historian of state and law. Chybinski had high hopes for the Society and believed that its establishment would benefit the whole academic community. This is where, at the Committee of History of Art, he intended to try and create the Musicological Section, and also here he thought to resume work on the continuation of the pre-war Rocznik Muzykologiczny. ${ }^{51}$

The pre-war history of PAU and musicologists' associations with the Academy before 1939 were briefly described in chapter II-2. Here, it should be remembered that Chybiński, Jachimecki and Józef Reiss, as well as Stefan Śledziński and Zofia Lissa, were invited to present the results of their research during the meetings of the congregation and in the publishing houses of the society before 1939. After the war, in the first months of the reactivated Academy's activity, Jachimecki gave papers at the Commission's academic meetings ('80 utworów lirycznych skomponowanych do słów pieśni Mignon' [80 lyrical works composed to the words of Mignon], 'Czy znasz ten kraj?' [Do You know this country?]) as did

50 Information concerning the Wroclaw TN see for example, http://pauza.krakow. pl/325_2016.pdf, accessed 17 VII 2019.

51 Chybiński/Chomiński 2016, 161. 
Reiss ('O materiałach do polskiej kultury muzycznej' [About materials for Polish musical culture], and a year later a paper 'Plutarcha z Cheronei dialog o muzyce' [Plutarch of Chaeronea's dialogue about music]). Both heads of the musicological departments were appointed in 1929 and 1930 as correspondent members, and just after the war, Chybiński became an active member, ${ }^{52}$ and at the twilight of its existence, in 1951 - an honorary member..$^{53}$

In 1947, the Musicological Committee came into being. It was one of the very few new committees and the only one at Faculty I. Unfortunately, grudges between Chybiński and Jachimecki once again led to organisational problems. The polarisation between the two cradles of Polish musicology (the Lviv and Cracow schools), which had been going on for many years, reached not only the ears of Professor Tadeusz Lehr-Spławiński, secretary of the Faculty of Philology, but also the ears of Kazimierz Nitsch. At that time Nitsch was the President of PAU, as well as a linguist, an expert in Slavic studies, a historian of the Polish language and a dialectologist. In theory, when the PAU authorities were planning to open a musicology section, they did not have to take easily foreseeable misunderstandings into account. However, Nitsch, who knew that the situation was volatile, asked the professors to put forward candidates for new members of PAU. Chybiński gave the names of Chomiński, Łobaczewska, Lissa, Szczepańska, Sobieski and Sobieska; Jachimecki - Włodzimierz Poźniak, Władysław Hordyński (musicologist and librarian, who at that time was the head of the music department in BJ), and the pianist and composer, lecturer at the Cracow Conservatoire, Adam Rieger and 'a few other unknown names (mostly his master's students, who had not presented anything). ${ }^{54}$ No candidate emerged from among the group, but further negotiations finally allowed the inclusion of Stanisław Golachowski into the correspondent-member group

52 See the report from PAU for the year 1945/46 in: Rocznik Polskiej Akademii Umiejętności $1945 / 1946$, IV. The professor was a member of one of the so-called shared committees the Ethnographic Commission, together, amongst others, with Zdzisław Jachimecki, Jan St. Bystroń, Adam Chętniki, Jan Czekanowski, Cezaria Jędrzejewiczowa, Stefan Szuman, Helena Windakiewiczowa and Juliusz Zborowski, and a member of the Commission for the History of Education and Schools in Poland.

53 See Rocznik Polskiej Akademii Umiejętności 1946/1047, IV. Jachimecki was a member of the Art History Committee and the Committee of Western European Philology of the Philology Faculty, the Sociological Commission of the Historical-Philosophical Faculty, and the Joint Ethnographic Commission.

54 Chybiński/Chomiński 2016, 95. 
in 1948 and (despite some formal problems related to his permanent residence in Switzerland) of Ludwik Bronarski, while in the middle of the year 1948 Józef Chomiński informed the professor: 'Yesterday, I received a decree appointing me an associate of the Musicology Committee of the PAU. Due to this honour, I would like to give my sincere thanks to you and assure you that I will continue my work on expanding the Polish cultural output as far as my abilities and strengths allow me to do this. I can only hope that the results of my work will be better than up to date; I feel truly embarrassed that I have not achieved anything so far. ${ }^{55}$

As for the structure of the 'authorities' in the Section, Chybiński accepted the likely choice of Jachimecki as the chairman of the Section, but he was surprised by the name of Roman Ingarden 'promoted' by Cracow to the position of deputy. ${ }^{56}$ He hesitated and did not know how he should react to this situation, especially as the group from Lviv did not manage to attend the first voting session because invitations had been sent too late (which according to Chybiński, was an intentional act). This situation only reinforced the conflict between the two centres which had been going on for many years. In the end, Chybiński did not become discouraged by the turbulent passage of the works underway at the Committee. He had already conferred habilitation on four of his students from Lviv, who were now ready to head any department of musicology and was able to plan further: 'After the holidays, I intend for us to take over the PAU Musicological Commission, ${ }^{57}$ and he also wanted to talk to about a similar Commission with

55 Ibid., 80. Finally, the Musicological Commission at the Faculty of Philology, which was established in February 1948, consisted of: Ludwik Bronarski, Adolf Chybiński, Józef Michał Chomiński, Zygmunt Estreicher, Aleksander Frączkiewicz, Stanisław Golachowski, Władysław Hordyński, Roman Ingarden, Zdzisław Jachimecki, Adam Kleczkowski, Zygmunt Latoszewski, Zofia Lissa, Stefania Łobaczewska, Tadeusz Mańkowski, Adam Mitscha, Wojsław Mollé, Alina Nowak-Romanowicz, Włodzimierz Poźniak, Konstanty Régamey, Józef Reiss, Adam Rieger, Alicja Simon, Jadwiga Sobieska, Marian Sobieski, Maria Szczepańska, Stefan Szuman, Stefan ŚledzińskiLidzki, Władysław Tatarkiewicz, Helena Windakiewiczowa (information on this subject was noted for example, in 'Kronika' in RM 1949/16, 44).

56 Roman Ingarden, as a philosopher dealing with issues of aesthetics, was, of course, also close to musicologists; the fruit of his reflections on aesthetics in the context of music was the dissertation Utwór muzyczny i sprawa jego tożsamości [The work of music and the problem of its identity]. In the structures of PAU he was a member of many Commissions: Western European Philology, Polish Literature, Art History, Polish Philosophy, Sociology, and the Committee of Kwartalnik Filozoficzny.

57 Chybiński/Chomiński 2016, 161. 
the general secretary of the Warsaw TN, Julian Krzyżanowski. However, when in 1950 a project of establishing a disposition towards the then officials of the PAN was created, the fate of both PAU and the Warsaw TN, with all their assets, intellectual property and personal status was decided.

The militant attitude of the group of musicologists from Lviv must have resulted in events that only deepened the Lviv-Cracow conflict which had existed for years. 'The clique,' as the professors' supporters were willing to say about themselves,$^{58}$ prepared a letter of protest about the treatment of the nonCracow group, which they planned to send to Tadeusz Lehr-Spławiński, who was also a lecturer of the Lviv Alma Mater before the war. Chomiński, Lissa and Łobaczewska were ready to sign them, and they also counted on Father Feicht. Chybiński, who wanted to protect his co-workers from Poznań against being ostracised by a part of the community, was most probably trying to talk Maria Szczepańska and Marian Sobieski out of participating in the protest. Today, we know that these operations could have been effective only for a very short period, because all this happened at a time when all local scientific communities were losing their basis of existence in favour of the central Academy of Sciences, and PAU, intended by the then authorities as a kind of unique 'trust of brains' or 'parliament of Polish science' as described by Julian Dybiec after Jan Mydlarski and the trade union of science workers, ${ }^{59}$ for several consecutive years struggled with financial and organisational difficulties resulting from the authorities' reaction to the lack of acceptance of the Cracow institution for the science policy of the times.

The short-lived activity of the PAU brought only one title in musicology. In 1948, PAU published the paper mentioned above by Zdzisław Jachimecki, Muzykologia i piśmiennictwo muzyczne w Polsce [Musicology and music literature in Poland], which appeared as part of the series Historia Nauki Polskiej w Monografiach (The history of Polish science in Monographs). It was also planned to use other existing societies for publishing purposes. In fact, it was the societies themselves that were trying to bring such plans to fruition, whereas musicologists were considering various options. For instance, when the decision on reviving

58 Corresponding with Chomiński about the collective declaration, Łobaczewska wrote: "That it will look like a "clique" - I am not afraid of this at all. I willingly belong to such "cliques", see Łobaczewska to Chomiński from Cracow 6 I 1950, APCh.

59 Dybiec 1993, 19. The author here cites the voice of anthropologist Jan Mydlarski, professor at the Marie Curie-Skłodowska University, who published in the journal Życie Nauki (1946/7-8, 42-47, the article 'W sprawie organizacji nauki polskiej' [In the matter of organising Polish science]). 
Kwartalnik had already been made, Chybiński wrote to Warsaw: 'It seems to me that historical papers will have to come out mostly in publications issued by the PAU or other scientific societies. (The society from Poznan is at my disposal, and the PAU more or less). My paper on Jacek Różycki (who died ca. 1700) will be published by the WTM at the request of this society. I told Mrs Lissa about this. So, please do not remove the work about Różycki from the programme of Kwartalnik Muzyczny. ${ }^{\prime}{ }^{6}$ However, the political conditions and central offices watching over the entire scientific life quickly verified these plans.

Already in the first months of the new order under the wings of the MKiS, which in the beginning of May 1945 was Władysław Kowalski, changed at the beginning of 1947 by Stefan Dybowski, various commissions and bodies were established, which had to decide the image of creative and artistic environments in a planned and controlled manner. When it comes to the music community, musicologists were frequently invited to join such groups. Adolf Chybiński was very often asked to chair committees, whereas Zdzisław Jachimecki was rarely appointed to such positions. For instance, Chybiński was the chairman of the Programme Committee at the Ministry of Culture and Art. Its main aim was 'on the one hand to deepen and expand the boundaries of general music education of music specialists of all kinds and on the other hand to adjust this educational system to contemporary music practice and the findings of contemporary science, ${ }^{61}$ At the same time, thanks to Tadeusz Ochlewski's determination, the revival of the music publishing house - continuing the tradition of TWMP, though transferred from Warsaw to Cracow and under the state banner - on 5 November 1949, called up a thirty-nine person (though in time reduced to twenty-three ${ }^{62}$ ) State Music Publishing Committee as an organ for advice and opinion forming for the Ministry, also chaired by Chybiński. In addition to the professor, for history and theory of music, the Council of the Committee

60 Chybiński/Chomiński 2016, 40. Let us add that this publication was not released. Chybiński was interested in Różycki from almost the beginning of his academic career. In 1911 he submitted a transcript of a text to print, which he had already had the opportunity to deliver at the meeting of the Faculty of Philology of AU 'Jacek Różycki, nadworny kapelmistrz i kompozytor Jana III' [Jacek Różycki, court kapellmeister and composer to Jan III Sobieski] (PM 1911/4, 3-4, 1911/5, 3-5), and, also in the pages of PM a dozen years later, the sketch, 'Jacek (Hyacinthus) Różycki' (PM 1926/4, 1-4, $1926 / 5,1-7)$.

61 RM 1945/6, 23.

62 See Ochlewski to Chybiński from Cracow 10 III 1948, at AACh-BUAM, folder O-P, k. 47. 
included Mieczysław Drobner, Hieronim Feicht, Stanisław Golachowski, Stefania Łobaczewska, Janusz Miketta, Roman Palester, Piotr Rytel, Kazimierz Sikorski and Bolesław Woytowicz. During the first session of the Council, a publishing plan was established, according to which among publications in the field of theory and pedagogy there would be a textbook on harmony prepared by Kazimierz Sikorski and guidebooks concerning methods of teaching music history (by Łobaczewska and Feicht) and teaching harmony (Sikorski and Chomiński), and from the field of Polish music history - a monograph about Karol Szymanowski by Stefania Łobaczewska and the correspondence of the creator of Harnasie to Stefan Spiess and Jarosław Iwaszkiewicz would be prepared for publication by Stanisław Golachowski. Concerning music magazines, 'The Council decided to maintain Ruch Muzyczny in its current form, resume issuing Kwartalnik Muzyczny and try to renew Rocznik Muzykologiczny under the editorship of Prof. A. Chybiński.'63

In a short time, PWM monopolised the entire market for music and professional publications, which was the result of the policy of nationalising all private property, in this case, small publishing houses and printers.

In the beginning, the work of editorial teams which prepared academic journals was not controlled by the state. In these new organisational conditions, the desire to go back to the old paths and restore pre-war structures and press titles induced authors to revisit projects which had been abandoned a few years earlier. In any case, this was the situation immediately after Poland regained freedom. In all probability, members of creative associations and editorial teams could only think of financial difficulties but clearly did not imagine that there would be any other obstacles to renewing their cultural and academic activity, which had been suspended during the war. Gradually, the work on some prewar music journals was renewed. The first of these journals was most probably Spiewak, which was published in Silesia. It is worth remembering that in the interwar period it was the longest-appearing music magazine, which, especially under the editorial term of Stefan Marian Stoiński, had ambitions to be not only the organ of the Union of Silesian Singing Circles in Katowice, following the choral community, ${ }^{64}$ but also to open their pages to academic papers. Let us recall that for this purpose a special supplement of Myśl Muzyczna was created, although it is true that this idea was realised very one-sidedly and

63 RM 1946/2, 15.

64 In the 1930s it even gained a nationwide range, which was announced by the subtitle as the organ of the United Polish Singing and Music Unions in Warsaw 
quite briefly (in the years 1928-29) - and almost exclusively authors of these publications were: permanently invited to collaboration were Adolf Chybiński and Stoiński himself while Maria Szczepańska ${ }^{65}$ incidentally published on the pages of Spiewak. The monthly itself was published almost until the outbreak of the war; shortly after its end, in February 1946 the first, special issue of the new edition was published, edited by Józef Ligęza and Jan Fojcik, who earlier, in 1922-25, had already been its editor-in-chief. ${ }^{66}$ Soon, the short history of Spiewak (January 1947-September 1948) was to see another change of editor with the position being taken by Józef M. Michałowski. ${ }^{67}$ Among the authors, several names of employees and close associates of the editorial office dominated - Józef Ligęza, Jerzy Pogonowski, Józef Swatoń, Feliks Starczewski; also occasionally appearing in the pages of the post-war period Spiewak (maybe because of pre-war sentiments) were Adolf Chybiński and (more frequently) Józef Reiss, who popularised the closer and further history of Polish music and musical culture in accessibly written articles. ${ }^{68}$

More or less around the same time, several industry titles were inaugurated, which, moreover, rarely had ambitions to support themselves with musicological forces. The Poznań Życie Muzyczne was created in 1946 as the organ of the Wielkopolska Singing Union, the Union of Professional Musicians, the Composers' Union and Union of Church Choirs, and renamed a year later as Życie Śpiewacze (editors Stanisław Kwaśnik, Mieczysław Barwicki), and then, along with the organisational changes covering the whole singing movement in Poland and the centralisation of the environment in 1948, appearing as the organ of the Supreme Council of the Union of Polish Singing Ensembles. Just like in the case of Śpiewak, the principal authors of Życie Śpiewacze were people active in the singing community, such as Stanisław Kwaśnik (the editor), Józef Swatoń, and many others, who have now been forgotten. The contents of the periodical

65 For more about the Silesian Śpiewak see chapter I-3.

66 Stefan M. Stoiński, long-time editor-in-chief of the magazine, died in 1945.

67 See Dziadek 2004/2.

68 See for example, the history of the tradition of choral singing from the founding of the rorantists' chapel to the present day of Józef Reiss (the many-parted text 'Jak rozwijała się u nas kultura chóru' [How the cult of the choir is developing for us] published in Spiewak 1947 in numbers 2-6), Adolf Chybiński” reminiscences about Karol Szymanowski in the tenth anniversary of his death (Śpiewak 1947/3, 2-5), and Reiss's interesting sketch introducing the first reports about Mozart's operas noted in the eighteenth and nineteenth century Polish press ('Mozart w świetle pierwszej krytyki polskiej' [Mozart in the light of the first Polish critics], Spiewak 1948/6, 5-7). 
were dominated by news concerning the choir movement and reports on music events, which was additionally emphasised in an editorial published in issue 7/8 of 1947 (the first issue that came out under the changed title). In the abovementioned article, the editorial team wrote: 'we will be interested solely in the life of our choirs, and we will be devoted mostly to matters related to the choir movement in Poland and abroad. ${ }^{69}$

In 1947, in the Ludowy Instytut Muzyczny [People's Music Institute, further LIM] launched in Łódź, a monthly called Poradnik Muzyczny, devoted to issues of dissemination of musical culture was founded, which with the passage of time was transferred under the auspices of the Union of Polish Singing Unions. The magazine was run by Stanisław Golachowski, who resided in Łódź, and from 1950 by Józef Lasocki, who co-operated with Franciszek Wesołowski. Poradnik, similarly to several other titles, was short-lived: its last three issues came out in 1952. However, it needs to be noted that in 1949, due to administrative changes resulting from the establishment of the Państwowy Instytut Sztuki [State Institute of Art, further PIS] (which absorbed all the functioning social and cultural institutions and associations, including LIM from Łódź), the editorial team became subordinate to the Supervisory Board of the Union of Polish Singing Associations. However, the form of the magazine did not change. It was still aimed at amateur musicians and cultural organisers, whereas its goal was to increase knowledge about music among the general public. Permanent editorial staff and collaborators announced illustrative articles in the fields of: scholarship concerning music (Witold Rudziński), musical instruments (Mieczysław Drobner), musical forms (Henryk Swolkień), instrumentation and issues related to orchestras (Stefan Śledziński), folk music (Jadwiga and Marian Sobieski), organology (Marek Kwiek). Experienced pre-war journalists also wrote - Emma Altberg, Karol Stromenger, Bronisław Rutkowski. Among the other authors, the names known for academic achievements only appeared sporadically, but here they were invited to promote music. First and foremost this was Józef Reiss, who prepared a whole series of 'silhouettes' of Polish composers for the editors of Poradnik, including Ignacy Jan Paderewski, Władysław Żeleński, Juliusz Zarębski, Henryk Wieniawski (amongst the foreign composers - Modest Mussorgsky); Włodzimierz Poźniak, starting from 1948 lasting almost to the end of 1950 revealed the secrets of harmony in 'episodes'; Zofia Lissa wrote about the promotion of music in the $\mathrm{USSR}^{70}$ and about the arrangements of motifs from

69 'Od Redakcji’ [Editorial], Życie Śpiewacze 1947/7-8, 1.

70 Poradnik Muzyczny 1947/8-9, 1-4, 1947/10, 1-4. 
Polish folk songs by Soviet composers in the war years; ${ }^{71}$ Stefania Łobaczewska was the author of a short biographical sketch about Jan Sebastian Bach, ${ }^{72}$ Adolf Chybiński finally signed off under a cursory sketch $O$ Wacławie $z$ Szamotut [About Wacław of Szamotuły]. ${ }^{73}$

At the turn of the 1940s and 1950s there were publications of an incidental nature of the type Kalendarz Muzyczny (one volume for the year 1948/49, published in Cracow; between the years 1950 and 1958 with the title Notatnik Muzyczny), ${ }^{74}$ and - similarly - the incidental Kalendarz Roku Chopinowskiego projected by Krystyna Kobylańska, and the Poznań monthly Echo Teatralne $i$ Muzyczne which appeared only from October 1948 to the spring of 1949. It is also worth mentioning Radio i Świat, a weekly published by the MKiS and the Polish Radio, whose editor was Jan Prosnak. Shortly before the war, he attended lectures given by Pulikowski at the University of Warsaw, and after the war, he was a student of Hieronim Feicht in Wroclaw. This weekly published texts written by Łobaczewska, Lissa, Rudziński, Rutkowski, Sobieski and others, including Chybiński.

Other titles, previously important for the musical and musicological milieu Hosanna, Muzyka Kościelna, Muzyka Polska, Orkiestra, Śpiew w Szkole - were not recreated after 1945.

There is a marked difference between the number of active musicologists who wanted to publish articles in the few post-war periodicals and the group of authors who had co-operated with similar journals appearing in the interwar period. A pre-war journal which used to be the equivalent of the abovementioned periodicals was Przeglad Muzyczny, published in Poznan by the Union of Polish Singing Associations. It attracted all Polish musicologists of the time, who were keen to co-operate with it. When it comes to the magazines which were shortly described here, one clearly stands out. It is Ruch Muzyczny; a journal started in autumn 1945 by Stefan Kisielewski, which was a continuation of the pre-war Muzyka Polska. Thanks to its editor's unbridled journalistic

71 'Polska pieśń ludowa w Moskwie w latach wojny' [Polish folk song in Moscow in the war years], Poradnik Muzyczny 1948/10, 3-5.

72 Poradnik Muzyczny 1950/1-2, 2-5.

73 Poradnik Muzyczny 1947/10, 4-7.

74 The content exactly corresponded to the title - a small-format annual calendar was completed, among others about 'the most important dates from the life and work of Frederic Chopin' (prepared by Janusz Miketta), 'Alphabetical list of the works of Frederic Chopin,' PWM catalogue, current addresses of active musicians and musicologists, data about music education, information about the Chopin Year. 
personality, Ruch soon became the forum for rebellious journalists. Mainly due to Kisielewski's writing, the magazine boldly commented on the intensifying influence of the state over contemporary musical output and academic life, which degraded art. It was also the forum for ideological discussions, where the enthusiasts and opponents of formalism in music quarrelled with each other.

Kisielewski had already had experience in journalistic writing and music criticism. Apart from thorough musical education in theory, composition and piano playing, he also studied for a few semesters at the Faculty of Polish Studies and Philosophy at the University of Warsaw. At the beginning of the 1930s, he worked as a reviewer for a few Warsaw magazines, including the bi-weekly Echo Tygodnia. In 1936, he became a reviewer and a member of the editorial team at Muzyka Polska, and until 1938, he was also the secretary of the editorial office. After the war Kisielewski wet to Cracow (already in March 1945) in connection with the possibility of taking on work in the local PWSM (harmony, counterpoint, instrumentation), and as a side task took on the role as permanent proofreader in the editorial team of the weekly Przekrój; in the summer, at the invitation of Jerzy Turowicz, he began working as a columnist for Tygodnik Powszechny, and having to hand his former boss from TWMP, Tadeusz Ochlewski, who had been in Cracow for some time, and who was also in charge of PWM, he immediately decided to organise the editorial of a new magazine, as an organ of the Union of Professional Musicians of the Republic. In a short time, he also invited a group of prominent writers, critics, essayists and columnists to cooperate, for the most part already known from Warsaw. The beginnings were not easy, and Ochlewski wrote to Adolf Chybiński about this when the inaugural edition was still hot off the press. From his words, it can be concluded that contrary to the common opinion, binding decisions on the form of Ruch Muzyczny were taken by the director of the publishing company, even though Kisielewski's strong personality definitely had a profound impact on the biweekly: 'The first issue triggered the power of personal dissatisfaction and the Musicians' Union is afraid to continue to endorse this magazine. I propose creating an Editorial Committee comprising people such as Wiechowicz, Drzewiecki, Hoffman, Łobaczewska, Rieger, Palester, editorial secretary - Kisielewski. What is your view on the matter? Answer Miketta about all this and ask him what he thinks. ${ }^{75}$

The proposed Committee was not mentioned again, and the above-mentioned people were involved in Ruch mainly as authors. Nevertheless, reshuffling in the editorial team of the magazine was very dynamic. The first 'full-time' member of

75 Ochlewski to Chybiński from Cracow 9 X 1945, AACh-BUAM, fol. O-P, p. 9. 
the editorial team (starting in autumn 1946) was - apart from Stefan Kisielewski Zygmunt Mycielski, shortly to be joined by Jerzy Broszkiewicz and the next 'emigrant' from Warsaw, Bronisław Rutkowski, and then Roman Haubenstock. Kisielewski himself left the editorial group in April 1947, and from number 4/1948 - also Mycielski; in the middle of that year - and only then - Stefania Łobaczewska joined the three-person group (as the only musicologist among the editors), while, at the beginning of 1949, Rutkowski was dismissed from his function and this state of affairs probably lasted until May; in the middle of 1949 Łobaczewska resigned - from that moment until the closure of the editorial office, the editorial footer was signed as "The Committee. ${ }^{76}$ It is not commonly known that when Bronisław Rutkowski stepped down, Włodzimierz Sokorski offered Zofia Lissa to become a co-editor. However, Lissa was 'terribly disinclined,' even though it seems that she had some plans related to the form of the magazine because she mentioned that it was necessary to introduce a new section with 'an analysis of some work in each issue. ${ }^{77}$ Chomiński was also invited to participate in the editorial board. However, he was busy with other projects (and involved in running Kwartalnik) and thus refused.

The magazine, following the example of its forbearer, the nineteenth-century Ruch Muzyczny under the editorial run by Józef Sikorski, was supposed to stand out with its impartiality and open columns for various opinions. However, Michał Bristiger, the author of a monographic article about the four years of operation of the 'Cracow-based' Ruch, draws attention to the 'public understanding of journalistic activities' common for the two editorials. ${ }^{78}$ It was supposed to be run under the patronage of the works of two mega-figures - Poles and Europeans Chopin and Szymanowski. ${ }^{79}$

When Kisielewski opened the bi-weekly, he wanted to deal with the past and with the war. He mentioned recent losses in the music community but also published a report on the First Convention of Polish Composers which took place at the end of August and at the beginning of September, as well as on the Festival of Contemporary Polish Music, which accompanied the Convention. In this way, he set the direction for the magazine in which Polish music, mostly contemporary music, was supposed to be assessed by professional music critics who

76 It seems that this was a fairly common practice at the time, because a similarly mysterious 'Committee' was leading Muzyka, a magazine of PIS, during the first years, more below.

77 See Lissa to Chomiński from Warsaw 8 II 1949, APCh.

78 Bristiger 1979, 68.

79 RM 1945/1, 2-3. 
were up to this task. The guarantee of this could have been the experience in the field of journalism and music criticism of the leader and people joining the editorial office - Bronisław Rutkowski, Zygmunt Mycielski, Roman Haubenstock. However, the group was accused of focusing mainly on Cracow musical life and maintaining a perceptible, local character, which could be explained by the concentration of a large part of the musical environment in Cracow, resulting from the lowest wartime losses in the city compared to other the pre-war Polish cultural centres. To remedy that impression and to recognise what blows were aimed at the musical environment in the entire country throughout the war, the editors addressed readers with request for cooperation in the very first issues: 'We ask you fervently to send any reports, references, articles, and information about Polish musical life under occupation - to collect these materials, documenting the history of our art in the past six years - this comprises one of the goals of our magazine. ${ }^{80}$

Despite the invitation, the editors based their work mainly on materials provided by regular collaborators. Maria Michałowska included in this group apart from the already mentioned people - Stefan Jarociński, Jerzy Broszkiewicz, Konstaty Régamey, and Józef Swaton and a few other authors, ${ }^{81}$ which I would supplement with Janusz Miketta, consequently seeking to include not only 'musical' officials, but also active musicologists in the group. ${ }^{82}$ Among the rapporteurs of the current musical life were Zbigniew Turski, Henryk Swolkień, Waldemar Voisé, Florian Dąbrowski and many other correspondents from the whole country. For us, a significant contribution to the shape of Ruch Muzyczny was made by authors-musicologists, who effectively extended the formula of the journal, is important, going beyond the scope of criticism and music journalism with many articles. It needs to be emphasised that during the post-war rebirth, musicology was publicly discussed in Ruch, not in Kwartalnik. The editors of the monthly posed several questions, for example, related to the relation between musicology and early and contemporary music, or to the differences between

80 RM 1945/2, 21.

81 Michałowska 1981.

82 Janusz Miketta (1890-1954) was not a qualified musicologist; he studied music in Warsaw and Leipzig. In the inter-war period, he held clerical functions and also worked at the F. Chopin Higher School of Music in Warsaw. After the war, he joined the Cracow PWSM. He was the author of the first volume of the series conceived by Adolf Chybiński together with Tadeusz Ochlewski, Analizy i objaśnienia dzieł wszystkich Fryderyka Chopina (Mazurki) [Analysis and explanation of the complete works of Frederic Chopin (Mazurkas), (Cracow 1949). 
musicology and music criticism, which they addressed both to musicologists and musicians. The discussion probably did not develop according to the editors' intentions, but 'remarks on musicology' were published by Konstanty Régamey, Stefania Łobaczewska and Włodzimierz Poźniak.

Without a doubt, a significant part of Régamey's statements fitted to the prewar confrontation with musicology in the Lviv 'rite.' This composer and linguist understood musicology in a very broad sense, 'simply as the science of music, and thus a broadly conceived discipline concerning all aspects of music that can be studied with academic methods' ${ }^{3}$ he did not accept the limitations to the matter of musicological research to 'music philology' - only to the study of the history of music and music analysis with the exception of the latest works: 'Some would like to limit musicology ... to the study of old music, the development of its "formal grammar" and musical ethnography. ${ }^{34}$ Similarly, he did not agree to exclude matters related to the aesthetics of music from the scope of academic inquiry: 'If musicology were to rely solely on determining the original text or dating it, aesthetics would obviously be unnecessary. However, if we want to analyse not only the technique but also the output of a given author, it is indispensable to understand this author's views on aesthetics.... And the history of aesthetic views with utmost care for academic objectivity requires a certain fundamental standpoint, a certain perspective which becomes a scientific worldview in itself. ${ }^{85} \mathrm{He}$ also stated that a musicologist, who should be thoroughly familiar with the issues of harmony, counterpoint, instrumentation or musical forms, also in their historical development, cannot simultaneously ignore the existence of acoustic, physiological or psychological research.

In comparison to Régamey's exhaustive statement, the 'remarks on musicology' noted by Stefania Łobaczewska seem to be quite schematic. In accordance with the rhetoric of socialist realism, whose popularity kept growing, a large part of this short text is taken up by the information on current tasks of musicology which are related to 'contemporary practice.' As she wrote, this sphere 'has not yet officially become a separate section, especially here. We can

83 Régamey 1948, 2.

84 Ibid., 3. If we interpret Régamey's words as a reproach of the main achievements of the Lviv school, we must, of course, simplify the scope of interest of the founder of this school. It is commonly known that Chybiński promoted the output of young Polish composers (or rather composers affiliated with Young Poland, whose creations at that time already belonged to a distant epoch) and that in the inter-war period he played an important role in popularising the music of Karol Szymanowski.

85 Ibid. 
only see some indications here and there which tell us that this new aspect of musicology will be coming shortly. What I mean is ... the interaction of intuitive, artistic and academic elements in contemporary music culture. ${ }^{86}$ Remembering Łobaczewska's main research interests and passions - sociology and aesthetics it can be observed that she considered research in the field of Polish music history and ethnography to be the most urgent tasks in the field of the scientific work of musicologists: 'In fact, the history of Polish music, studying its artefacts, historical publications and academic monographs, as well as publishing early music for practical purposes, etc., requires a huge contribution from our historians. So far, only certain periods have been studied in detail. The rest is the music of the future. ${ }^{87}$

Stefania Łobaczewska was the most frequent 'academic' cooperating with the Cracow editorial office, publishing texts which were both purely analytical, ${ }^{88}$ as well as profile pieces, ${ }^{89}$ and also reviews of current publications; ${ }^{90}$ she was echoed by Józef Chomiński, author of several significant titles in the pages of the Cracow magazine..$^{91}$ The celebrations of the Chopin Year, which was a significant event, were not really emphasised. It is true that a medallion with the composer's profile (which was an over-stylised version of the Chopin Year logo designed by

86 Łobaczewska 1948/3.

87 Ibid.

88 See for example, 'O Słopiewniach Karola Szymanowskiego' [About Karol Szymanowski's Słopiewnie], (RM 1948/4, 2-7).

89 Reprint of the paper given at the II Congress of Composers and Critics in Prague (May 1948) 'O tradycji w muzyce' [About tradition in music] (RM 1948/13-14, 2-7).

90 Special place is given here for an enthusiastic review on the subject published by Zofia Lissa in KM in the article 'Aspekt socjologiczny w polskiej muzyce współczesnej' [The sociological aspect in contemporary Polish music] (KM 1948/21-22, 104-143), a text through which Lissa took her place as one of the ideologues of contemporary musicology (see RM 1948/22, 10-11), or the text of the paper 'O społecznych funkcjach muzyki artystycznej i popularnej' [Concerning the social function of art and popular music] presented by the same author at the II International Congress of Composers and Music Critics (KM 1948/23, 211-222, see also Łobaczewska's report from the Congress in Prague RM 1948/22, 19-26, particularly p. 26).

91 Starting from a strictly academic, theoretical lecture on problems of contemporary harmony (RM 1948/9, 2-5, 1948/10, 2-5) after the controversial, ideologising statement on the subject of 'Zagadnienia formalizmu i tendencje ideologiczne w polskiej muzyce współczesnej na tle rozwoju muzyki światowej' [Issues of formalism and ideological tendencies in Polish contemporary music against the background of the development of world music] (RM 1948/20, 2-6). 
Konstanty Sopoćko) was added to the layout of the editorial page in all issues that came out in 1949, but the number of articles on Chopin was not increased in comparison with the previous year. Adolf Chybinski did not join the group of authors who took up themes related to 'the life and art' of the great Frederic Chopin. At that time, Chybiński was working on projects related to Kwartalnik. It also needs to be emphasised that Chybiński was virtually absent among the authors engaged in Ruch. Despite strong personal connections with the editorial circle of the bi-weekly and despite the warm invitation of the directorpublisher of the magazine, Tadeusz Ochlewski, already starting his work, ${ }^{92}$ the professor signed under a mere six pieces and each time they were occasional, perhaps with the exception of a comprehensive 'report' on the wartime fate of Polish musical artefacts, with which together with other authors he opened the magazine's activity. ${ }^{93} \mathrm{He}$ also voiced his opinion on the importance which should be attached to collections of songs and songbooks for children and youth. According to him, it would help rebuild the country which was damaged not only physically but was also in a state of cultural collapse. He had special motivation to speak up on this matter because at that time he planned and prepared to publish his own songbook - a selection of Polish folk melodies Od Tatr do Bałtyku [From the Tatras to the Baltic].${ }^{94} \mathrm{He}$ remembered two figures particularly close to him: Karol Szymanowski in connection with the tenth anniversary of his death ${ }^{95}$ and one of his favourite students, Jan Józef Dunicz. ${ }^{96} \mathrm{He}$ also sent for publication the text of the speech he gave during the academy accompanying the commemoration of the three hundred and seventy-fifth anniversary of the death of Szamotulczyk. ${ }^{97}$

92 Ochlewski to Chybiński from Cracow 13 X 1945, AACh-BUAM, fol. O-P, p 11.

93 RM 1945/1, 9-11.

94 The songbook did not appear until a few years after his death (Cracow 1958). It was ultimately published based on materials prepared by Tadeusz Strumiłło, one of the professor's pupils.

95 RM 1947/5, 2-4. Pendant to this sketch was the contribution 'O nieznanym notatniku muzycznym Szymanowskiego' [About an unknown musical notebook belonging to Szymanowski] (RM 1947,5, 9-13), which at the same time was a supplement to the sketch published before the war Karol Szymanowski a Podhale [Karol Szymanowski and the Podhale] (Cracow 1938).

96 RM 1948/8, 10.

97 RM 1947/19-20, 9-10. Chybiński mentioned contacts with the city authorities and their plans to commemorate this occasion several times, including in correspondence to Józef Chomiński, see Chybiński/Chomiński 2016, 25-26. 
After a year of functioning of Ruch Muzyczny, in connection with taking over the co-editor's chair, a few explanations about this change were directed to 'Do Czytelników' [To readers] by Zygmunt Mycielski. ${ }^{98}$ It was the first time when the plan to revive Kwartalnik Muzyczny was finally voiced. The editor claimed that the form of the monthly would be expanded so that until Kwartalnik was revived, it could fulfil some of its functions. However, he also admitted that it would be hard to find enough space for strictly academic, extensive articles and essays. First and foremost, Ruch was supposed to be a 'living' magazine. Maria Michałowska summed up the words of Mycielski who talked about the main aim of Ruch: 'to represent and promote properly understood culture, which consists of keeping a sense of proportion and good taste, whereas one of the main ambitions should be to discover artists who create real art, which is not affected and which is devoid of sentimentality. ${ }^{99}$ In order to realise these intentions, the editors soon had to take up the 'verbal' struggle against the ever-stronger expansion of the new ideology encroaching into cultural life, which especially from the spring of 1948, when the Congress of Composers and Critics took place in Prague, when art was allocated new tasks which were ruthlessly enforced by regime officials. Nonconformist texts, which appeared in the pages of Ruch - whether polemics by Stefan Kisielewski in connection to Józef Chomiński's article about formalism in music, ${ }^{100}$ or certain editorial articles, which called up criticism of Soviet activists in the pages of the Soviet monthly Sovetskaâ Muzyka $a^{101}$ - were perceived as evidence of the editorial's overt pro-modernist activity, contrary to the only correct ideology. Critical opinions were clearly political and directed from centres much more geographically distant from Cracow than could be assumed, including from the Polish embassy in Moscow, which in turn undoubtedly took such orders from the employees of the relevant Soviet offices. ${ }^{102}$ Controversial articles on contemporary music culture were characteristic of post-war Ruch Muzyczny and soon led to dismissing the members of the editorial team and finally to closing the magazine down in 1949. The ministry wanted its function to be taken over by Muzyka, a new monthly established as part of the newly opened State Institute of Art in Warsaw.

98 RM 1946/19, 2-6.

99 Michałowska 1981, XV.

100 Chomiński 1948.

101 Lew Kułakowski's review was also published (in Polish translation) in RM (1949/11$12,42-45)$, let's add that after the changes, which took place in the editorial office more or less in the middle of that year. See also Michałowska 1981, XVII-XXII.

102 See Chybiński/Chomiński 2016, 132. 



\section{Ideologisation of learning about music - conferences, conventions, congresses - Marxist musicology - Państwowy Instytut Sztuki - gradual radicalisation in academia}

The communist regime which was in power at the end of the 1940s and the beginning of the 1950s expected the work of all citizens to bear fruit for the benefit of the new ideological order, regardless of the occupation of a given person. The authorities of that time also demanded loyal admiration for the doctrine, which quickly became 'New Faith,' as Władysław Malinowski called it years later, in the first decade of the 21th century, in his widely discussed speech delivered at one of the conferences organised by De Musica Association. ${ }^{103}$ The activity of the whole nation was submitted to central planning managed by various committees, boards and advisory bodies. At the Ministry of Culture and Art, there was the Programme Committee which set the direction not only for the special and individual education of artists (the music education system) but also for the commonly understood music culture (musical institutions). The State Music Publishing Board was established at PWM, whereas in July 1946, the Polish Science Revival Committee was set up at the Central Planning Office. This organisational unit dealt, for example, with awarding research grants. ${ }^{104}$ All kinds of conventions, meetings and conferences became extremely common. Their aim was either to set the direction of progress in the country which was being rebuilt or to encourage people to adopt declarations of loyalty to the new government.

When it comes to music output in the times of socialist realism, the characteristics which were essential and determined its correctness were related to the role and place of music works, not their form and sonic substance. We should

103 Malinowski 2006. Katarzyna Dadak-Kozicka did not agree with Malinowski’s opinion that socialist realism had a quasi-religious character. She claimed that it is difficult to talk about creators being spiritually infatuated with the new ideology because assurances as to the great role of art and the important position of artists in the new society were followed by strictly enforcing the performance of their duties, see DadakKozicka 2011, especially p. 184.

104 Józef Chomiński used such a stipendium when he was preparing his habilitation thesis, see Chybiński/Chomiński 2016, 97. 
agree with Michał Bristiger, the musicologist who expressed his opinion during a discussion in De Musica periodical. ${ }^{105} \mathrm{He}$ claimed that composers had not created a new sound system which would make the works of socialist realism stand out from those created earlier and that the affiliation of such works with the new, ideologically weighted music was determined by lyrics or the programme of compositions, which go beyond the work itself. Some features which had a bearing on whether a work of art was deemed correct were listed by Władysław Malinowski and included the reflection of reality and the ideological nature of the creative output. When it came to the music itself, authorities had for many years criticised not only the fossilised sound system present in the output of 'bourgeois' composers but also the experiments and pursuits of the European avant-garde. It quickly began to be generally believed that the kind of music which was convenient for the regime and which fulfilled various tasks of propaganda was the legacy and tradition of Romanticism, spiced up by 'folklore' or 'nationalism.' In literature, it was the literary output of Mickiewicz and Słowacki, whereas in music this concerned the works of Chopin and Moniuszko. The task of popularising culture and science, which was supposed to become one of the characteristics of the new society, was entrusted to the intelligentsia that had been decimated during the war (however, on condition that this social group accepted the transformations which were going on under the supervision of the new occupier). At the same time, it was assumed that it was necessary to educate the next generation of the intelligentsia, which would live up to the expectations of the new authorities. Maybe it goes without saying that musicology (and most probably every other academic discipline as well) had representatives who had distanced themselves from traditional methodologies back before the war and undermined the value of scientific achievements up to date. Therefore, Zofia Lissa was no exception.

A few publications by Ewa Rzanna-Szczepaniak ${ }^{106}$ presented a wide range of reflections on the formation of socialist humanities and the activity of the most important cultural and scientific institutions involved with music life in the first years after the war. What is important in her works is that in order to comprehensively present the situation of the music and musicological community in the first decade after the war, she did not limit herself solely to analysing the minutes from the conventions of the Związek Kompozytorów Polskich [the

105 The discussion took place in the Warsaw offices of the editorial group De Musica 22 XI 2001, see 'Socrealizm' [Social realism], 2006.

106 See Rzanna-Szczepaniak 2009, Rzanna-Szczepaniak 2012, Rzanna-Szczepaniak 2013. 
Polish Composers' Union, further ZKP] and official speeches, even though they are frequently cited in studies on the history of music in the difficult Stalinist period. Such popular texts include, for example, the keynote address of Bolesław Bierut, delivered at the opening of the radio station in Wroclaw in November $1947,{ }^{107}$ as well as texts written by Włodzimierz Sokorski, deputy minister of culture and art, who was keenly interested in music culture ${ }^{108}$ and almost always present at the conventions of the ZKP, including the conference for composers and musicologists that took place in September 1949 in Łagów Lubuski which was crucial for assessing and setting the direction of music creativity. RzannaSzczepaniak started from a concise presentation of the assumptions of Marx's historical materialism and Lenin's continuation of these ideas. She consulted documents which prove what tasks the most important representatives of the party apparatus of that time had assigned to the community of intellectuals, creators and scientists. She included the speeches of Jakub Berman and Władysław Gomółka, minutes of the meetings of the PZPR [the Polish United Workers' Party] and certificates from Russian archives. ${ }^{109}$ Finally, these official opinions were supplemented by journalistic texts of that time, which supported the government and were written as if on its request.

When we look at the titles of the most important social and literary or social and cultural periodicals of that time, it is worth noting that musicologists, musicians and music critics took part in the discussions that were published in them. Regular columnists in periodicals such as Odrodzenie ${ }^{110}$,

107 Ewa Rzanna-Szczepaniak also notes that a few months later, in summer 1948 during the meeting of the Central Committee of PPR, Bierut unequivocally 'negatively evaluated the aesthetic values recognised to date, artistic practice, ways of disseminating art.... He also criticised the passive attitude towards burdens and remnants of the former "bourgeois-aristocratic" culture,' which became an interpretation both for artistic and academic communities involved in the study of past creativity, see RzannaSzczepaniak 2009, 37.

108 We may recall here that Włodzimierz Sokorski’s brother, Jerzy (1916-2005), was educated as a pianist and composer. He was briefly associated with the then newly founded PIS.

109 However, it should be remembered that, as Dadak-Kozicka rightfully concluded, 'the doctrine of Marx (which was original and coherent) was used selectively and instrumentally by the ideologists of the new power, who just wanted to justify their misuse of authority in the process of gaining and consolidating their power,' see Dadak-Kozicka $2011,186$.

110 A socio-literary weekly run from 1944 by a Lviv journalist and publisher, Karol Kuryluk, and from 1948 by the founder of the magazine, Jerzy Borejsza. The editors, initially taking a centre position, with time came to support socialist realism in culture. 
Nowiny Literackie ${ }^{111}$, Nowe Drogi ${ }^{112}$, Kuźnica ${ }^{113}$, Nowa Kultura ${ }^{114}$ and Myśl

In Odrodzenie publishing authors included, amongst others, Zofia Lissa (for example, 'O polską pieśń masową'[About Polish mass songs], 1947/29, 3), Stefania Łobaczewska (for example, 'O organizację kultury muzycznej' [About organisation of musical culture], 1945/28, 2), Witold Rudziński (report from the meeting of the composers in Łagów Lubuski, 1949/35, 2), and Zygmunt Mycielski (see for example, 'Prostota czy prostactwo. O Kwartalniku Muzycznym' [Simple or primitive. About Kwartalnik Muzyczny], 1948/30, 7).

111 An independent literary weekly which was published for a little over eighteen months in Warsaw in the years 1947-48, edited, for example, by the writer and poet Jarosław Iwaszkiewicz. Among publications written by contributors with various ideological orientations, such as literary men, researchers and officials serving the political system of that time, in Nowiny Literackie we can find texts by Stefania Łobaczewska ('Muzyka sztuka realistyczna czy abstrakcyjna' [Music - realist or abstract art], 1947/13, 4), Stefan Kisielewski ('Elementy schyłkowe w sztuce współczesnej' [Decadent elements in contemporary art], 1947/20, 2) and Zygmunt Mycielski (for example, a report on the situation in PWM, 1947/32, 1).

112 This monthly, which survived several political transformations in post-war Poland, was published in the years 1947-48. Its founder and the first editor-in-chief was Franciszek Fiedler, a historian. As a body of the political party which had been in the lead for years, the periodical presented ideological materials which conformed with the official party line. In this periodical, Zofia Lissa published a few texts which followed 'the only right' message, see for example, 'Ideologiczne oblicze polskiej twórczości muzycznej' [The ideological face of Polish music output'] (Nowe Drogi 1948/7, 109-117).

113 Perhaps the most 'engaged' social and literary periodical (at first a monthly, then a weekly) in the first period after the war. It was run by Stefan Żółkiewski, a literary historian, and then by Paweł Hoffman, a publicist. It was aimed at left-leaning intelligentsia and attracted writers and intellectuals who were faithful to socialist ideas and contested a traditional (conservative) approach towards humanities. Literary men centred around its editorial team relied on Marxist ideology and became involved in promoting socialist realism. Zofia Lissa is also counted among the contributing authors of Kuźnica (for example, 'O społecznych funkcjach muzyki artystycznej i popularnej' [On the social functions of artistic and popular music], 1948/30, 9), as well as Stefan Jarociński ('Na drogach współczesnej nauki polskiej' [On the routes of contemporary Polish science], 1948/34-35, 25-26).

114 A social and literary weekly which was created in 1950, when the editorial offices of the above mentioned Odrodzenie and Kuźnica were merged. As early as in the first year, Lissa published her text on mass songs in this periodical ('Krok naprzód' [A step forward], 1950/26, 4-5) and a year later she submitted an article entitled 'O wybór właściwych tradycji' [About the right choice of traditions] $(1951 / 46,3)$. In a column entitled 'Dziesiąta woda po Kisielu' [Tenth water after Kisiel] $(1950 / 18,7)$, 
Współczesna ${ }^{115}$ were Zofia Lissa, Stefania Łobaczewska, Witold Rudziński, Zygmunt Mycielski and Stefan Jarociński. Polemics against the official stance of the government were published in Catholic social and cultural monthlies Znak and Tygodnik Powszechny, whose frequent contributor was Stefan Kisielewski. Tygodnik often published texts written by Witold Rudziński ${ }^{116}$ or even Zdzisław Jachimecki, ${ }^{117}$ whose name rarely appeared in the press after the war.

The foundations for organising cultural and scientific life in the new order were provided by committees formed at State National Council, a new governmental body. In this case, it was the Committee of Culture, Science and Education, which started working in October 1944. Among the new structures which emerged in the following months, there was the Department of Music established at the Ministry of Culture and Art. The Department was initially headed by Mieczysław Drobner, whose deputy was Stanisław Golachowski. After some time, as the result of personnel changes, Witold Rudziński was appointed director, whereas Zofia Lissa became associate director. Further changes at the Ministry did lead to the closure of 'thematic' departments, but some more developed central artistic and cultural organisations and institutions, including PWM, survived and remained part of the Ministry. From the point of view of current needs of the musicology of that time, one division of the Department was of particular importance, namely the Department for Supporting Creativity. It had at its disposal music collections, libraries and museums (which were gradually brought under state control). It also had contact with ZKP, which musicologists later joined as a separate Section. It soon turned out that the aim of this sort of state patronage was not to support, but rather to centrally manage and control all subordinate institutions (such as publishing houses and societies) by granting financial subsidies depending on whether the activities of a given

Witold Rudziński referred to a statement made by Stefan Kisielewski, who talked about starting a philosophical and aesthetic discussion on new music and new compositional output in the context of the ongoing fight with formalism in art.

115 Myśl Współczesna was initially run by Józef Chałasiński, a sociologist, and from 1948 by Adam Schaff, a philosopher. Even though it did not publish texts written by representatives of the musicological community, other papers which appeared in it are important to the history of humanities of that time. An example of such texts is an article written by Juliusz Starzyński, the newly appointed director of the PIS, entitled 'Zadania polskiej sztuki i nauki o sztuce' [The tasks of Polish art and study of art] $(1950 / 10,12)$.

116 'Na froncie muzycznym' [On the musical front], Tygodnik Powszechny 1946/47, 6.

117 'O muzyce narodowej' [About national music], Tygodnik Powszechny 1947/3, 7. 
institution were in line with current ideology, rather than whether it answered actual substantial needs.

At the same time, the academic field witnessed a gradual dominance shift at universities and in scientific societies. It was a move from humanities towards social sciences, which throughout the years led to reversing the ratio of the share which humanistic faculties and sections had in the newly-established scientific units, as compared to those which had existed up to that time. In the first period of functioning of the new state, pre-war structures were spontaneously revived, and nobody even suspected how quickly this process would be stopped. The first signals which indicated that priorities had changed, that the whole potential of Polish science would be directed mainly to build economic power and that Polish humanities would be almost completely disregarded appeared, for example, in official speeches of the leading apparatchiks. ${ }^{118}$ Therefore, due to the fact that at PAU two out of four sections were humanistic, whereas at the Warsaw TN two out of five sections were humanistic, it was decided that the PAN, established in 1951, would have only one (out of four) section with a similar profile, namely the social sciences section (and there was no humanistic section). ${ }^{119}$

Following the example from other domains of social life, a visible indication of the gradual centralisation of groups of creators and scientists were all sorts of conventions for artistic circles. They had been organised ever since the first months after the war. In the beginning, they were spontaneous, like for example, the first meeting of the members of the reactivated IFCh, which took place in May 1945, the meeting of the WTM in September of the same year, and most importantly the National Convention of Composers, which was held in Cracow from 29 August to 2 September 1945. However, as time went by, conventions

118 At the open meeting of PAU (the Polish Academy of Learning) in June 1946, in his speech which opened the session, Bolesław Bierut said that 'The role of Polish science ... should be bigger than it has ever been. The Academy of Learning may be transformed into one of the most important links of progressive scientific thought, regulating our manufacturing industry, setting a healthy direction for the development of our national economy ...: devising a plan of extending our waterways, ... creating a synthetic fuel industry, a rubber industry and many others which are indispensable to us.... Another urgent problem is the expansion of our coal production,' see Bierut 1945/46. Even though he did not mention basic academic research in his speech, at that time, it was not assumed that the PAU would be dissolved or that science would be centralised. Moreover, the official commemoration of the 75th anniversary of the PAU and the 130th anniversary of the establishment of the Cracow TN were supposed to be organised under the patronage of President Bierut.

119 Degen/Hübner 2006/2, 16. 
were organised under pressure from state authorities and became saturated with the prevailing ideology. A series of 'ministerial' meetings for writers, visual artists, actors, and architects, whose aim was to adopt the bases of the new aesthetics in art and the new methodology in art research, were organised over several months in 1949. Włodzimierz Sokorski, deputy minister at the Ministry of Culture and Art, was present at these meetings and reminded their participants about the basic requirements of socialist realism which applied to everybody, including creators and academics, for example, theoreticians dealing with art science. When it comes to musicologists, their interpretation of the new reality was supposed to follow, or perhaps actually followed, the words of the leading mentor of cultural life which he had uttered at the opening of the third convention of the ZKP on 20 November 1947. His speech determined the principles which were supposed to guide not only the creative process but also research on creative output: 'the so-called formalism in music should be understood as a creative method which has become infertile nowadays and which regards content solely as a function of the form. This approach stands in opposition to socialist realism, which sees the form and creative crafts as a structural expression of its content, mood, and artistic passion. Therefore, it is based on the unity of content and form, which make for a uniform creative act, conditioned by the epoch itself and by present musical means.'120

After these words, there were a few more specific suggestions. During his speech, Sokorski pointed out contemporary composers, both experienced ones and those from the youngest generation, who had taken the right path so as not to sound 'deadly in a working-class hall'121: these were Panufnik, Lutosławski, and Woytowicz, who perhaps had not yet discovered the musical language of the new epoch, but were at least going in this direction. ${ }^{122}$ However, this was not about resolving the dilemma of whether it was 'easy or difficult music' that was more correct. After such phrases as the necessity of 'overcoming the imitative music of declining capitalism, which has already had the characteristics of formalistic

120 Sokorski 1949, 174.

121 Ibid., 178.

122 Opinions held by the party apparatus were not stable. Just two years later, at a conference in Łagów Lubuski, Sokorski himself criticised the same composers (apart from Lutosławski and Panufnik, he also disapproved of Turski and Baird) for the formalism of their creative output. At least a part of the musical and musicological community went to Łagów because they wanted to discuss the influence of the doctrine on contemporary art. However, these plans were verified by the course of the conference, which was dominated by the decision-makers who were present there. 
degeneration,' ${ }^{123}$ it became difficult for researchers who studied Polish contemporary music to evaluate Karol Szymanowski and his legacy. Starting with the convention in Łagów Lubuski in 1949, the legacy of the composer of Harnasie had been criticised and classified by state authorities as a manifestation of formalism and cosmopolitism. A few months earlier, this assessment had not yet been critical because the inspiration with folk music was still remembered, along with Szymanowski's exemplary conduct as a pedagogue and his understanding for the need to widely promote music culture. ${ }^{124}$ On the one hand 'the past period of breaking the sacred rules of classical tonality and harmony seemed useful from the point of view of the development of musical creativity', as exemplified by the works of Szymanowski, while on the other hand, unfortunately the trend in which he had been creating 'did not thrive ... during a historical revolution, but on the contrary, it ran along the downhill slope of economic, political, moral, and aesthetic systems,' ${ }^{\prime 25}$ which of course gave proof to the downfall of both the direction in music as well as its representatives.

The authorities did not give straightforward guidelines to researchers interested in Szymanowski and his artistic output. On account of this fact, it was necessary to demonstrate a certain kind of scientific cunning. It should be remembered that even before 1939, the legacy of this artist, who was the most important composer of the interwar period, was the subject of inquiries and analyses of a large group of musicologists, theoreticians and music critics. Adolf Chybiński also contributed to the widespread fascination with Szymanowski's

123 Sokorski 1949, 172.

124 Take for instance Szymanowski's text entitled 'Wychowawcza rola kultury muzycznej w społeczeństwie' [The educational role of music culture in society] (KM 1931/10-11, 129-156). In this paper, there were statements consistent with the future ideology of socialist realism, for example, 'in today's social life, music is a huge, constantly active force; it is something absolutely necessary to a much greater extent than visual arts and literature because it is like a wave which spreads over all social classes, but at the same time it does not require such a high level of individual intellectual culture' (p. 135). Szymanowski was also convinced that 'an artist's individual creation becomes really high-flying when it hits the only certain springboard that exists, namely social artistic culture' (p. 131). Other statements made by Szymanowski were less suitable for potential use by communist officials. He, for example, admitted that there was an inextricable link between the most important facts in the history of music and the biggest revolution in the world, that is Christianity' (p. 147).

125 Sokorski 1949, 174. 
music, as he devoted a series of articles to the composer. ${ }^{126}$ Zdzisław Jachimecki did the same. ${ }^{127}$ Among the graduates from the Lviv department, Józef Chomiński was the one who conducted in-depth studies devoted to Szymanowski's songs. $\mathrm{He}$ announced the results of his research work in papers published in or prepared to be published in PRM. ${ }^{128}$ An impressive archive with music and literary manuscripts left by Szymanowski was gathered and stored during the war by Stanisław Golachowski, a musicology graduate from Cracow. Finally, Stefania Łobaczewska summed up many years of her research on Szymanowski with a monograph. ${ }^{129}$ Right before its publication, it got the author in real trouble when it turned out that some geographical data in the text had not been corrected and were out-dated due to geopolitical changes that had been introduced after the Yalta Conference.

However, it was first and foremost Frederic Chopin who was anointed as the composer who complied with the model image of an artist accepted by the authorities of the socialist realism regime. It was believed that Chopin was a genius not only on account of excellence of form and composing techniques, which are characteristic of his works but also because he 'had sensed the future and greatness of Polish music, related to the folk foundation of his own nation. He had sensed the revelatory value of his songs and folk melodies, which grew out of the daily toil of anonymous creators and their age-old work, which had been going on for centuries. ${ }^{130}$ The opportunity to celebrate the living memory of the composer appeared very soon. It was the 100th anniversary of his death, and the whole community of Polish musicologists was involved in commemorating

126 See for example, 'Mazurki fortepianowe Karola Szymanowskiego' [Karol Szymanowski's piano Mazurkas] (Muzyka 1925,1, 12-15, 1925/2, 61-64); 'Do genezy Harnasiów' [To the genesis of Harnasie] (MP 1936/3, 184-196).

127 See for example, 'Karola Szymanowskiego kompozycje fortepianowe' [Karol Szymanowski’s Piano compositions] (Młoda Muzyka 1909/22, 6-8); 'Karol Szymanowski' (Śpiewak 1926/10, 1-3, 1926/11, 1-3, 1926/12, 5-8, 1927/1, 2-6).

128 Let us remember this is about 'Studia nad twórczością K. Szymanowskiego' [Studies on K. Szymanowski's creative work]: part I: 'Problem tonalny w Słopiewniach' [The problem of tonality in Słopiewnie] (PRM 1936/2, 53-86), part II: 'Zagadnienia konstrukcyjne w sonatach fortepianowych' [Structural issues in the piano sonatas] (KM 1948/21-22, 170-207, 1948/23, 102-157), part III: 'Chóralne pieśni kurpiowskie' [Kurpie choral songs] (KM 1948/24, 55-83).

129 Stefania Łobaczewska, Karol Szymanowski: życie i twórczość (1882-1937) [Karol Szymanowski: Life and art (1882-1937)] (Cracow 1950).

130 Malinowski 2006, 137. 
it, for example, by accepting the invitation to send papers and reviews devoted to Chopin to the editorial office of Kwartalnik Muzyczny.

Just like before the war, musicologists wanted to be united in a collective body to intensify the voice of the community, which was needed all the more at the time when goods were distributed, and positions were filled based on top-down decisions by state authorities. Discussions in small groups had begun many months before the next, this time the third, Convention of Composers. Chybiński, Łobaczewska and Lissa also discussed amongst themselves. For Lissa, it was important that 'the union of Polish musicologists will be capable of starting group work. ... when it comes to its form, we'll have to think about it.'131

The representatives of science, in this case musicologists and music theorists, were supposed to support composers. The community which had been forming in Poland ever since the turn of the twentieth century had never been put under such ideological pressure (of which its representatives were not fully aware in the beginning) as in post-war reality. It is assumed that the first two years of freedom did not foreshadow future rigour. Everything changed at the opening of the radio station in Wroclaw in November 1947, when Bolesław Bierut gave a keynote speech on plans concerning cultural policy (which included music culture). Ewa Rzanna-Szczepaniak quotes Władysław Włodarczyk, who talked about the acceptance of the enforced state care (or in fact control) exercised over the activity of artistic and research communities ${ }^{132}$ and universal access to values which used to be reserved for the elites. His point of view fits in with the tone of opinions voiced even some time later by certain musicologists, not only those who unequivocally stood for the new order, such as Zofia Lissa. In this context, we can, for example, take into consideration the words of Zdzisław Jachimecki, who talked about the mass quality of science in his speech at the first convention of the Division of Musicologists, 'I have always put forward the idea that even the musicology which is strictly academically understood cannot be aimed at just a handful of people, but rather at a crowd of many thousands, at people who crave for culture. ... Polish musicology should ... not serve narrow esoteric circles, ... it cannot escape the world and hide in stifling nooks and crannies of infertile speculations, which often turns into a certain kind of cultural parasitism.' ${ }^{\text {'133 }}$ Paradoxically, this rhetoric fit in perfectly with the policy which consisted of

131 Lissa to Chybiński from Warsaw 14 IX 1947, AACh-BUAM, fol. K-Ł, p. 148.

132 Rzanna-Szczepaniak 2012, 11. Rzanna-Szczepaniak refers to the work by Wojciech Włodarczyk Socrealizm. Sztuka polska w latach 1950-1980 [Social-realism. Polish art in the years 1950-1980] (Paris 1986).

133 Jachimecki 1949/2, 201. 
popularising all areas of social life, including culture and science. Joseph Stalin, the principal author of this doctrine, repeatedly talked about the necessity of class struggle, which was obviously aimed at enforcing the foundations of socialist realism and the duty to use dialectical materialism as the fundamental doctrine in humanistic and social sciences.

Repressions deepened year by year, especially those directed against intellectuals, creators and artists. The rule of total planning and centralisation led to the elimination of all manifestations of individualism and activity in small communities, which could potentially get out of state control. At the same time, criticising this state of affairs was entirely out of the question. (Ruch Muzyczny was, for example, a victim of this offensive).

The history of the beginnings of the ZKP, as well as subsequent years of its activity, was presented in detail in reports and memoirs included in a commemorative book published for the 50th anniversary of the Union, ${ }^{134}$ and also in publications by Ewa Rzanna-Szczepaniak and J. Katarzyna Dadak-Kozicka. ${ }^{135}$ Let us just remember that the first board was made up of: Piotr Perkowski (president), Roman Palester (I vice-president), Stanisław Wiechowicz (II vicepresident), Witold Lutosławski (secretary, treasurer) and members - Jan Ekier, Tadeusz Kassern, Bolesław Woytowicz - and alternate members - Tadeusz Szeligowski, Kazimierz Wiłkomirski. As Warsaw was in ruins, which brought problems with finding enough rooms, it was proposed that the Union could have its seat in Cracow. However, tradition prevailed, and it was decided that the Union needs to operate in the capital city. Former pre-war members were automatically entered into the list. New members were accepted on the basis of a declaration that had been printed, for example, in the first issue of Ruch Muzyczny. Eventually, it was the Qualification Committee that decided to accept new members. The Committee evaluated the actual artistic output of candidates, whereas statements saturated with the new ideology, talking about 'the mission of reviving Polish culture' or 'the issue of music for the masses' were written down in the charter. However, their function was mainly propagandist, and they served as a smokescreen which was supposed to prevent state authorities from meddling with internal affairs of the musicological community.

It was as early as in the summer months of 1947 that the group of 'Lvivians' and people associated with the Department of Music at the Ministry of Culture and Art started thinking about establishing a Section of Musicologists, which

13450 lat ZKP [50 years of ZKP], particularly Chodkowski 1995.

135 Rzanna-Szczepaniak 2012; Dadak-Kozicka 2011. 
would be an individual body but would at the same time function under the umbrella of the ZKP. Without a doubt, Zofia Lissa wanted to take this opportunity to fulfil her own ambitions. At the same time (also due to the connections between the highest-ranking officials of the regime of that time $\left.{ }^{136}\right)$, she was becoming the leader of the music and musicological community. Having the necessary contacts, she made the first attempts to organise musicology in Warsaw. When she initiated the activity of musicologists within such a significant group as the union of creators, she strengthened her own position in the community. The intention of ministerial decision-makers was for musicologists to have an impact on the shape of contemporary music by evaluating it. On the one hand, this evaluation was supposed to be backed by academic knowledge, and on the other by the only correct worldview, held by the leading representatives of this branch of science.

In August 1947, Stefania Łobaczewska, in consultation with Lissa and Chybiński, was working on correcting the Charter of the ZKP, which would make it possible to establish the Musicologists' Section. Musicologists participated in the Third Convention, which took place in autumn. They wanted to take the steps which would make it possible to establish the Section (and before that, to adopt necessary amendments in the charter of the Union). However, they were not welcomed as a group of guests. It was also the first time that Lissa spoke at the Convention. She persuaded the musicologists who were reluctant to changes that the project she was pushing was valid (it cannot be ruled out that for the gathered creators, the main argument in favour of the project was the more significant financial support from the ministry that they expected Lissa to gain). ${ }^{137}$ A year later, several months before the scheduled meeting, the themes of the scheduled papers were approved. They were to be prepared for the first conference of the Section; at that time, it was also decided to accept non-musicologists as members. 'The Musicology Section wishes to invite for cooperation excellent composers and tutors, who write textbooks or are often interested in theoretical matters. These are the foreseen persons: ... Prof. [Kazimierz] Sikorski,

136 In the documents left by Zofia Lissa, which are stored at the Archive of Polish Composers at Warsaw University Library, we can find for example, her letters to Jakub Berman (who was one of the most important figures in the structures of the socialist realism regime in Poland). It also seems that she had regular 'working' contact with Włodzimierz Sokorski, who was Deputy Minister (and then became the Minister) at the Ministry of Culture and Art.

137 Details showing the next steps preceding the acceptance of musicologists as members of the ZKP, see Dadak-Kozicka 2011, particularly pp. 202-206. 
[Konstanty] Régamey, [Tadeusz] Szeligowski, [Bolesław] Woytowicz, [Witold] Rudziński; therefore, the Section will adhere to a completely different principle for selecting its members compared to the PAU Section. In the ZKP Section, it is not the scientific title that decides, but rather the skills and artistic achievements. ${ }^{3} 138$ Apart from the musicians who had been honourably counted among men of science, the following were also invited to the meeting of the Section: Adolf Chybiński, Stefania Łobaczewska, Zdzisław Jachimecki, Włodzimierz Poźniak, Józef Reiss, Alicja Simon, Hieronim Feicht, Józef Chomiński, Stanisław Golachowski, Jadwiga Sobieska, Marian Sobieski, Maria Szczepańska and Zofia Lissa. The list of potential full members that was presented to the Management Board of the ZKP did not include Reiss (by mistake?), but someone added the names of Helena Windakiewicz and two researchers residing permanently outside Poland, that is Ludwik Bronarski and Zygmunt Estreicher. The next six persons, that is Stefan Śledziński, Aleksander Frączkiewicz, Leon Witkowski, Adam Rieger, Władysław Hordyński and Mieczysław Drobner, were put forward as associate members, and four others as candidates (Stefan Jarociński, who did not make his debut in the local musicologist community until he came back from Paris, Alina Nowak-Romanowicz, a young graduate from Cracow musicology who worked in Katowice, Jan Prosnak, the editor of the weekly Radio $i$ Świat and Zbigniew Liebhart, an academic who worked at the department of musicology in Wroclaw). ${ }^{139}$

The first convention of the Division of Musicologists took place on 18-19 November 1948 and preceded the Fourth Convention of the ZKP (held on 20-21 November). An extensive report from the November Convention and the text of all significant speeches were soon published in Kwartalnik Muzyczny, ${ }_{1}^{140}$ whereas selected texts also came out in Ruch Muzyczny. Ruch Muzyczny, which was a monthly and could therefore keep the readers updated on events from music and musicological life, published the text of three speeches delivered at the convention. These were the ideological opening speech by Włodzimierz Sokorski, ${ }^{141}$ the speech by Zygmunt Mycielski ${ }^{142}$ and the lecture given by Zdzisław Jachimecki. ${ }^{143}$ The monthly also published an extensive report on

138 Chybiński/Chomiński 2016, 97.

139 For a copy of the documents see Dadak-Kozicka 2011, 206, 207.

140 KM 1949/25, 166 ff.

141 Sokorski 1949.

142 Mycielski 1949/2.

143 Jachimecki 1949/1. 
the proceedings of the convention, written by Stefania Łobaczewska. ${ }^{144}$ In her opinion, the most significant advantage of the meeting was that it united two communities that were professionally involved with music, namely artists and researchers, which was possible thanks to the establishment of the Division of Musicologists (with its own Management Board and Qualification Committee) at the ZKP. When it comes to the introductory speech by Sokorski, she believed that the most important thing was how he regarded the mission of contemporary musicology: 'to meet new creative problems and new research methods. ... to stand in line with composers in order to support them in gaining new artistic forms and to mediate the process of making these forms available to the recipient, especially the new recipient,' as well as to diagnose 'what the crisis in contemporary music really consists of and provide a scientific explanation for it, which will make it easier to overcome this crisis. ${ }^{345}$

When it comes to musicologists, it was emphasised that contrary to the convention which had taken place ten years earlier in Poznan (during Polish Music Days organised in this city), this time the meeting was joined by the representatives of all communities and centres, regardless of previous animosities. This breakthrough was presented as a result of planned actions taken by the Ministry of Culture and Art. Indeed, Zdzisław Jachimecki also joined the Praesidium of the Convention, which was dominated by the representatives of the pre-war Lviv school (Chybiński as the chairman, accompanied by Feicht and Łobaczewska). Apart from speeches given by the aforementioned praesidium members, ${ }^{146}$ the sessions were filled with speeches by Alicja Simon, ${ }^{147}$ Marian Sobieski, ${ }^{148}$ Józef Chomiński, ${ }^{149}$ Zofia Lissa, ${ }^{150}$ Witold Rudziński. ${ }^{151}$

According to the reporter, the discussion indicated a high academic level, marked by concern for the welfare of ... scholarship and its comprehensive development in line with the needs of the moment and hence emerging tasks. ${ }^{152}$

144 Łobaczewska 1948/1.

145 Ibid., 6.

146 Chybiński 1949; Feicht 1949; Łobaczewska 1949/1; Jachimecki 1949/2.

147 Alicja Simon, [co-report with A. Chybiński about Polish musical artefacts] (KM 1949/25, 190-192).

148 Sobieski 1949.

149 Józef Chomiński, [co-report with Zdzisław Jachimecki] (KM 1949/25, 207-212).

150 Lissa 1949/2.

151 Witold Rudziński, [co-report to paper by Stefania Łobaczewska] (KM 1949/25, 230-231).

152 KM 1949/25, 168. 
Speeches were at times saturated with all-pervasive socialist realism rhetoric and focused on reminding the listeners about the most important issues which had been present in the activities of musicologists ever since its first representatives started the discipline. For example, one of the most important resolutions adopted by the Convention was the decision to establish a committee which would deal with coordinating the registration of the artefacts of Polish music. It was supposed to be composed of: Adolf Chybiński, Alicja Simon, Włodzimierz Poźniak, Władysław Hordyński (and in this context, a reference could be made to the actions initiated back in the nineteenth century by Father Józef Surzyński or the research activity of Chybiński himself) and, analogically, the second one, established to register and collect Polish folk music, with a recommendation to form the Central Phonographic Archive at the prospective Institute of Art (which would refer to the Poznań collection gathered by Łucjan Kamieński with a group of musicology students and staff, as well as to the Central Phonographic Archive which had been run before the war at the National Library by Julian Pulikowski). The pre-war tradition of reviving early music was continued and included adding this kind of repertoire to concert programmes, starting to promote it as early as in primary schools, and extending the curricula of institutions of higher education so that they included early music classes. All these actions were reminiscent of the operating plans adopted by such organisations as the SMDM or ORMuz.

When it comes to musicology at the university level, the two most important topics brought up during the session was the problem of organising musicology studies (this topic was taken up in a paper delivered by Zdzisław Jachimecki, which provoked a broader discussion and even inspired a supplementary paper co-presented with Józef Chomiński), as well as the organisational and ideological foundation of musicological research, discussed in the keynote address by Zofia Lissa.

In his speech, Jachimecki started from summing up the pre-war structure, which had been based on the foundations laid by Adler, and the organisation of musicological studies in Poland, pointing out some imperfections and inconveniences of that system (for example the lack of specialist Polish literature). Recalling the authority of the British musicologist Edward Dent, a representative of such a significant centre as Cambridge University, he wondered 'what type of musicologist should nowadays leave the premises of university institutes and go into the field of cultural life ${ }^{\prime 153}$ : the type that, being a specialist himself, does

153 Jachimecki 1949/2, 199. 
not forget about the layman-readers. 'A modern musicologist must maintain, in his works for the public, a clearly defined direction, from which he cannot deviate in favour of the ostensible and extremely dubious academicism' (and here he pointed to model examples in the activity of foreign musicologists, such as the Czech author Zdeněk Nejedlý or the group of authors who wrote History of Russian Music, published in 1940). ${ }^{154}$ Unfortunately, just like before the war, he kept presenting those researchers dealing with the history and theory of music who believed that 'Musicologists too often make their methods appear scientific by mechanically putting together the most ordinary combinations of chords, the most commonly used rhythmic formulas, steps, leaps in melody, etc. ${ }^{355}$ When it comes to the course of studies, he proposed to end them with exams, such as: 1) erudite criticism of music works (here the theory and history of harmony and counterpoint, theory and history of musical forms, musical palaeography, systematics of musicology), 2) a combination of acoustics, organology, the study of instruments and a 'vocal instrumentation technique,' which sounds rather enigmatic, 3) a combination of music ethnology with psychology and aesthetics with elements of sociology, 4) the history of general music with particular focus on Polish music. He also assumed that university education would have two stages, leading to a master's or doctoral degree (the latter supported by the state thanks to a scholarship system).

Presenting these as well as other plans for the new organisation of musicology, he was open towards discussion, which was immediately taken up by his co-reporter, Józef Chomiński. Chomiński agreed with the preceding speaker about the principled question that was retaining the studies of music within the structures of humanist universities instead of transferring it to artistic institutions; as well as to the exaggeration 'regarding the speculative treatment of technical and formal matters, which are based on the optical image of a musical work, and often fail to match with the real action of the measures applied'; ${ }^{156}$ he also supported the need to increase the number of teaching staff, but concerning other issues he held a quite different approach. He stressed that 'the main task of musicology is ... to produce researchers, future researchers' and further that 'scientific research, always requiring great professional preparation, cannot be simplified without prejudice to its level and results. ${ }^{157}$ As for the establishment

154 Ibid., 200.

155 Ibid., 205.

156 Józef Chomiński, [co-report. . .], as above, 208.

157 Ibid. 
of the curriculum and examination plan, he proposed appointment of a special commission. Moreover, he considered it necessary to create a theoretical and methodological department and 'modernise research methods' in view of the reigning 'modern' outlook with 'the use of achievements of the dialectical materialist methodology.' 158

In general, reviewers managed to evade 'the only right' rhetoric by sticking to a factual description of the current situation, various activities taken by the community and the current and anticipated achievements of musicology. An ideological style, which was expected by party officials, was followed to a lesser degree by Stefania Łobaczewska and Józef Chomiński and sometimes by Jachimecki (which is visible in some excerpts quoted here) and to a greater degree by Zofia Lissa, who had experience in writing official speeches. Her text was divided into two parts - the first was devoted to the organisation of musicology, the second part was about implementation of a new methodology of scholarship (and thinking) based on Marxist assumptions. Overall, the speaker's words included many valuable remarks. Lissa was certainly characterised by outstanding intellect and even though we could assume that she adopted the Marxist ideology and followed it with deep belief in its rightness, she was still aware of the true values of academic science in the spirit of Adler (and yet extended to observe music phenomena from the point of view of social development) and it made her fight for maintaining the ties between musicology and academic centres, rather than try to tie it in with higher music schools (in accordance with the Soviet fashion). For Lissa, the basis for successful research were collective actions, cooperation between all academic centres and planning joint projects 'for the long run.'159 The aim of the new union of musicologists and the first Convention, which had already been underway, was to specify these tasks and provide guidelines which could be used to organise future cooperation.

By combining in his speech the 'musicological' and 'composer' part of the 1948 Meeting, the chairman Zygmunt Mycielski regarded the merger of these two communities - artistic and academic - as the most important event. However, he saw the greatest benefits in cooperation between these two groups differently than Sokorski. Not in centralisation, which would aim at 'working out issues of contemporary art' and coordinating in accordance with the scientificallydeveloped guidelines of artistic activity, ${ }^{160}$ but rather traditionally - as focus on

158 Ibid., 209.

159 Lissa $1949 / 2-267$.

160 Sokorski 1949, 178. 
discovering new materials, 'that might become [for composers] an inexhaustible source of creative ideas. [Though] in the compositional technique of the former masters, in anthologies, and ethnographic sources, we can find the thing that any honest artist is looking for, either consciously or unconsciously: the precision of one's own style, own language, awareness of what Polish music actually is. ${ }^{361}$

Musicologists were obliged to use historical materialism, which had officially become the methodology of the new era, in order to prepare research foundations that would support composers in creating works conforming to the assumptions of real socialism. Such interventions were opposed by (the majority of) composers, treating the fact of extending the Union to the Musicologists' Section as an attempt to break the unity of the environment. A united stance adopted by members of the ZKP was directed against superior authorities (the Ministry of Culture and Art) and visible for example, in the universal standpoint on the election of union authorities (which for example, resulted in a gentlemanly agreement that a representative of composers should always chair the union). However, I do not think (as Dadak-Kozicka suggests) that the crux of the struggle between the Management Board and the government lay in existential and financial matters. ${ }^{162}$ They were rather used as a safe subject for the most important discussions held at the convention, thereby distracting the officials' attention from the problem of contemporary artistic output and its assessment.

The next Conventions of the Musicologists' Section were organised at the same time as the gatherings of the whole ZKP. One of its guests was usually deputy minister Włodzimierz Sokorski and sometimes also minister Stefan Dybowski. This shows how important it was for the ministry to follow the life of the broadly defined music community. This was, for example, the case at the opening of the fifth Convention, which took place after a longer break, in June 1950. However, this break did not result from some kind of sluggishness demonstrated by the Management Board of the ZKP. During the break, one of the most important events of that time was held, that is the conference of composers and music critics in Łagów Lubuski, which took place on 5-8 August 1949. These two meetings were both culmination points for introducing and enforcing the assumptions of dialectical materialism, as well as for the discussion on realism and formalism in music, both in terms of composing practice and music research. Indeed it was in Łagów that 'the final formation and announcement of the party's position on the

161 Zygmunt Mycielski, 'Kompozytor polski w obliczu nowych zadań' [Polish composer in the face of new tasks] (KM 1949/25, 178-183, see p. 178).

162 Dadak-Kozicka 2011, 190. 
issue of musical creation ${ }^{163}$ took place. As the conference's rapporteur asserted on the pages of Ruch Muzyczny, the first task that Sokorski set for creators upon opening the debate was 'to attempt to establish the terms and definitions concerning the overall issues of today's music, and afterwards - to attempt to apply these definitions in practice ${ }^{164}$ (the second was to undertake preparations for the organisation of the Festival of Polish Contemporary Music). The stormy sessions, which led to a split caused by a different understanding of formalism by 'official factors' (Sokorski) and musicologists (Lissa, Chomiński), were described several times in the last few years, for example, by the authors who have already been mentioned here. An in-depth analysis of these events, including the behaviour and direct reactions of those who had participated in these discussions, as well as efforts and attempts to take a safe position 'on the ideological battlefront' will surely become the subject of many more monographs. Subsequent generations of researchers are more distanced and more open to judge the attitude and decisions made at that time. On the other hand, there is a real danger that since the authors who take up such subjects did not experience living at the turn of the 1950s, their judgement will unnecessarily become too harsh or that they will fail to take into consideration the human factor, which has many a time proved to be extremely susceptible to the operations of omnipresent regimes.

In any case, the fifth ZKP meeting, held several months following the Łagów conference, was marked with a plethora of criticism and self-criticism from musicologists. Upon opening the session alongside Zygmunt Mycielski, Lissa addressed her speech - concerning the lack of ideological preparation for the creation of a new style that would be consistent with the assumptions of the new socialist realism ideology - to the composers; as for critics, however, she accused them of a kind of over-zealous use of unnecessary expressions in their evaluations of musical creations, leading to the exclusion of part of the repertoire from the general circulation. Józef Chomiński in turn, apart from comments directed to composers concerning the lower possibility of impacting the audience through instrumental music in comparison with vocal music, also 'criticised... the previous works of musicologists, who could neither strictly nor professionally determine the conditions to be met by realistic symphonic music. ${ }^{365}$ Discussions

163 Rzanna-Szczepaniak 2012, 49.

164 'Konferencja kompozytorów' [Composers' conference] 1949, full minutes of the meeting on pp. 12-31.

165 'Sprawozdanie $\mathrm{z}$ obrad V Walnego Zgromadzenia' [Report on the fifth general meeting]. 
which accompanied these and some other speeches (such as the keynote address by Sokorski) were some of the most heated ones in the history of meetings organised by the ZKP. It is also generally believed that some of the composers and musicologists used the dominant ideology to settle accounts or secure their own position.

A year later, in December 1951, at the sixth Convention of the ZKP, the first symptoms of softening the stance on twentieth-century output ${ }^{166}$ appeared. Even though Sokorski still referred to Jakub Berman's speech on artistic output and the role of socialist art (Sokorski referred here to musical creativity) and kept emphasising the role of critique and self-critique in the pursuit of one's goals (which included artistic goals), the next speakers talked about unnecessary omissions in certain aspects of artistic output (for example, in the case of small forms for extended vocal-instrumental compositions), whereas Zofia Lissa appreciated the fact that contemporary composers were using technical measures developed in the previous epoch (whilst rejecting decadent content). The sixth Convention was also the right place for summing up the Festival of Polish Music, which lasted from April to December of that year.

Newspeak, filling both official and spontaneous speeches in the period of socialist realism, often gained applause, as one can see upon reviewing protocols from conventions and meetings, and in the case of the musical community the ZKP and Musicologists' Section, or interdisciplinary bodies, as in the case of activities of PIS: 'involvement of many creators of art and culture in political activities, as well as adherence to the assumptions of the socialist realism methodology, resulted from a deliberate ideological choice arising from a naive faith in the validity of the assumptions and principles of cultural policy pursued following 1948. ${ }^{167} \mathrm{I}$ believe that such attitudes sometimes expressed the fear of unsure professional future or repression, and sometimes resulted from conformism, hidden under the pretence of acting 'for a good cause.' Yet it needs to be emphasised that such attitudes were not typical of the first community meetings. We need to remember that in the beginning, what prevailed was widespread enthusiasm and an authentic desire to build and rebuild.

For Katarzyna Dadak-Kozicka, documents from General Conventions of the ZKP (texts of speeches, minutes, etc.) served as the foundation to delineate the 'dramatic outline' of the battle for music waged against the government of

166 'Sprawozdanie z obrad VI Walnego Zgromadzenia' [Report on the sixth general meeting].

167 Rzanna-Szczepaniak 2012, 22-23. 
that time by the community of artists. This author's works are valuable especially because she not only draws attention to the fact that discussions held at the conventions included an analysis and assessment of music language (and she assesses these discussions), but she also analyses (and evaluates) the language which artists used to make comments about music. ${ }^{168}$ The politically correct rhetoric, full of calls to composers to fight for a better tomorrow, undertake creative work on behalf of the nation and fulfil socialist duties, was growing year by year. On a side note, it can be added that Polish readers had already had an opportunity to encounter the rhetoric of the new order in music press back before the war. Let us recall an article written by Marian Neuteich, a composer, a cellist and a conductor, 'Muzyka w ZSRR' [Music in the USSR]. ${ }^{169}$ This included phrasings such as: 'the Middle Ages, with its feudal system based on an extreme oppression of the masses ... created ... scholastic music forms almost unavailable to the public due to their complicated structure' (p. 294), 'While the works of Bach were created during the stabilisation of absolutism, Beethoven ... became a preacher of the democratic ideals of the victorious middle class' (p. 295), 'the new system of the USSR is built by the masses, thus Soviet artistic creativity sets a goal: to cooperate actively in social reconstruction, reflect the psychology of the collective effort of the masses, and address their "artistic needs."... Hence the slogan "socialist realism," that would become the basis of the musical style in the USSR' (p. 297).

It is hard to say how seriously this text was taken by its contemporaries. It seems that it provoked either laughter or terror, but it did not spark a wider discussion on socialist realism, which was not generally known at that time. Perhaps it was difficult to imagine such an understanding of history and art in real life. However, we know that the direction which Neuteich had set in his article was not totally unfamiliar to a particular group of young critics and musicologists, including the leading enthusiasts of this trend, that is Lissa and Łobaczewska. As early as in the 1930s, the latter of these researchers talked about the two 'aesthetics' which, in her opinion, were the only ones adopted at that time. On the one hand, there was artistic output 'with remarkably individualist assumptions' and on the other popular art. She suggested that each of these attitudes was poor and emphasised that none fulfilled actual social expectations. ${ }^{170}$

168 Dadak-Kozicka 2011, 189.

169 MP 1934/4, 294-300.

170 Łobaczewska 1934. 
For as long as Zofia Lissa was an official of the regime, the Lviv fraction of the musicologist community could feel relatively safe. It was Lissa whom her friends from the University of Lviv approached to plan any potential personnel reshuffling, which she could effect on the ministry level. And vice versa, Lissa was the main provider of reports on music life for the system, ordered by the government. After returning in 1947 to Warsaw from Moscow, where she had fulfilled the function of cultural attaché, in addition to making efforts related to an academic career - opening and finalising procedures related to habilitation in the shortest possible time - she assumed the office of deputy director in the department of music of MKiS. Thanks to her contacts among the officials of the regime, she was one of the few people who could often travel abroad. She kept in touch not only with academic centres in the Eastern Bloc (in Moscow, Prague and Berlin) but also with scientific circles in Western Europe (she visited France and Switzerland). In 1952, she was a member of an official cultural delegation sent to Beijing. However, even such a strong attachment to the political structures of that time did not fully protect her against the attacks of people ill-disposed towards her, be it the group of composers who opposed the enforced direction of 'the only right' artistic path, or some critics and publicists who openly opted for creative freedom of all musicians. The group of organisers of cultural and scientific life was also growing, and they were willing to take over the most lucrative positions in the structures of operating institutions. In addition, the system of dependence, control and repression in all aspects of society was growing more and more every year.

A sharpening of activities towards culture and science took place in the years 1950 and 1951. Then, within a few months, there were at least three important events that set a course of action for both artists and academics across all areas of art. In February 1950, a resolution on the organisation of the First Congress of Polish Science was adopted. In the end, it took place from 29 June to 2 July 1951. In September 1950, there was a meeting of art historians which was part of ongoing preparations to this event. At this meeting, the tasks of Polish art and study of art were outlined by Juliusz Starzyński, who had just become the leader of the newly established State Institute of Art in Warsaw. He was clearly in favour of adopting dialectical and historical materialism as the only right research method to be used in the study of history and art. ${ }^{171}$ What was supposed

171 Starzyński went even further and turned against the prevailing model of practising science, which promoted elitism and avoided massification. He said: 'Both individual scientists and research centres need to definitively break away from any inclination to elitist isolation and the slogan of "science for science's sake," which in the light of 
to serve musicologists as an introduction to the Congress were articles written by the leading representatives of the community which concerned the condition of this discipline and its tasks in the near future. These articles were prepared at the request of Muzyka, a monthly which had been operating since 1950 as a body subordinate to the PIS. As a result, in the September issue, only Stefania Łobaczewska's ${ }^{172}$ text was published, in which (as it was written) she made the 'first assessment' of the state of musicology.

The author indicated three topics within her statement: 1) the need to 'shift research on history and aesthetics onto the path of Marxist methodology and thus... overthrow of the old, erroneous scientific methods ..., 2) to establish a new relation towards musical traditions, 3 ) develop new ideological assumptions for contemporary practice.' ${ }^{173}$ She took the first of them for granted well in advance. She devoted the next part of the dissertation to the incorrect assumptions in the former understanding of musical tradition: without regard to its class character on the one hand, and the strive to purify music from the hypertrophy of the literary, philosophical or mystical factor, which was imposed by the ideological superstructure, applicable to German art from the second half of the nineteenth century' (which resulted in focus on form, technique and intellect). ${ }^{174}$ To change this, new analytical works were needed, which would take into account not only the study on the form but also content that each and every piece of music carries (ought to carry). Łobaczewska emphasised that changes in the methodology cannot result from measures imposed top-down but must be developed together with the necessary (and appropriate) change in ideology amongst academics. In this respect - the correct, 'modern' assessment of older as well as newer works would be supported by music criticism. Meanwhile, it did not meet contemporary expectations: 'It mainly sees music that is either "good" or "bad" in terms of craftsmanship and form, not asking for the emotional and social qualities.... If a contemporary Polish critic often sins against the basic postulates of the present... [,] then the main barrier here is the inability to overcome these emotional burdens, leading to false valuations. ${ }^{375}$ Once again the need to organise research in

its formalist consequences seems to be just as dangerous as "art for art's sake," the slogan which had been preached by aestheticism and which we are currently trying to overcome, see Starzyński 1950.

172 Łobaczewska 1950/2.

173 Ibid., 6.

174 Ibid., 8.

175 Ibid., 10. Łobaczewska herself, as a musicologist educated based on German models, did not completely cut off the traditional criteria for evaluating musical 
historical fields around group projects was indicated, which is enforced by the 'multilateralism of scientific horizons ... opened by the Marxist methodology' According to Łobaczewska, '[a] single author ought to be replaced by a team specialised in various historical periods, particularly national environments.'176

In the next part of the report, the author provided a comprehensive statement on the cooperation between musicologists and composers, based on underlining the moments in history from which contemporary composers should draw, namely romanticism. But not fully, because 'a romantic put himself and his feelings in the first place,' whereas a contemporary composer must 'blend in with the surrounding new life, with the world of people who make up this new life.177 A contemporary composer, just like a romantic one (with the necessary provision that a representative of the early Romantic period) must move the listeners with his music, but in the modern sense, taking into account the needs of a musically uneducated listener. Hence the need to simplify the work, which should not be confused with primitivising it. In conclusion, Łobaczewska expressed the belief that thanks to the new methodology musicology would 'lose ... its current position of a field of purely theoretical, exact science, insulated from the practice of life, and obtain the significance of scientific discipline, closely associated with life.' ${ }^{178}$

Other leading musicologists were preparing to participate in another meeting with the same intent, that is to 'determine the key assumptions of Marxist music aesthetics in its aspect which could become a guideline for our music life, that is both research and practice.179 In the middle of December (11-16) 1950 in Cracow, the First Polish Nationwide Conference on Art Research took place (known as the Wawel Conference due to its location). At its opening, Juliusz Starzyński reminded participants of the assumptions which he had already presented at the conference of art historians in September. Discussions were then held in thematic sections. It seems that participation in the conference was certainly obligatory in the case of people to whom named invitations were issued, and in practice it boiled down to all musicologists who were active at

works: 'Personally, I am, of course, far from the idea to consider the issues of form, compliance with the rules of sound material, etc. as factors irrelevant to the value of the musical work. It undoubtedly always has its importance, but only as directly related to the content of the work, as dependent on the content' (ibid.).

176 Ibid., 12.

177 Ibid., 16.

178 Ibid., 17.

179 Łobaczewska 1950/1, 10. 
the time. Already at the preparation stage, specific programme papers were requested, as in the case of Józef Chomiński, who was entrusted with the topic 'Rola tradycji w muzyce współczesnej' [The role of tradition on contemporary music]. ${ }^{180}$ Adolf Chybiński, who reluctantly accepted the invitation, also had to talk about tradition.

When the discussions ended, Łobaczewska immediately published a report on the meeting of the Music Section in the monthly Muzyka. ${ }^{181}$ According to her discussions were to be planned around the issue of Leninist theory of reflection in music ${ }^{182}$ presented by Zofia Lissa and the problem of perception of tradition in the context of Polish contemporary music. It was about defining the characteristics of the Polish national style that had not been captured even in the works of Frederic Chopin (excluding the obvious 'folk' elements). The study should aim at abstracting, as it were, these ingredients in the works of composers of different eras, which could be regarded as 'progressive,' 'tendencies representing an ideological and social avant-garde of their epoch' (Drobner), ${ }^{183}$ and one should apply a 'class aspect in historical research' (Lissa). ${ }^{184}$ The debaters could not agree on the evaluation of works from the first decades of the twentieth century. Łobaczewska noted that Chomiński criticised her highly unilaterally, while 'as well as the reverse tendency there was also a second direction, a more progressive current .... It constituted a minority; nonetheless, one should not forget about it if only because of the requirements of historical truth. ${ }^{185}$

Lissa's paper and the postulates in it about the indissolubility of content and form in musical works were discussed in a wide group - Józef Chomiński, Mieczysław Drobner, Jan Ekier, Stefania Łobaczewska, Janusz Miketta, Witold Rudziński, Jerzy Sokorski, Stefan Szuman, Janusz Urbański, Bolesław Woytowicz took the floor on this subject, and Lissa's final position reporting the debate was expressed by the statement that 'the process of reflecting reality in music is not

180 See Juliusz Starzyński (Przewodniczący Podsekcji Badań Sztuki [Leader of the undersection for art research]) to Chomiński from Warsaw 26 VII 1950, APCh.

181 Łobaczewska 1950/1.

182 Again, I refer here to work of Wieczorek 2014 in which the author conducted a thorough analysis of the presence of the Leninist theory of reflection and other ideologies that in the 1950s was the basis for the socialist realist discourse on contemporary music as well as the aesthetics, theory and history of music.

183 Łobaczewska 1950/1, 11.

184 Ibid. Here, Lissa gave an example of nineteenth-century Polish patriotic songs, which, according to her, were examples of revolutionary songs, amongst others.

185 Ibid., 11-12. 
straightforward as in either literary works or paintings, but it is rather indirect. Music primarily reflects reality through its emotional content, the feelings of a man posed in a certain historical and class surrounding. ${ }^{\prime 86}$ After these ideological talks, statements focused more on pragmatic issues - Marian Sobieski discussed the tasks faced by folklore researchers, Stefania Łobaczewska - issues of documentation, organisation of research and publishing postulates.

The arrangements made in Cracow concerned various activities taken by artistic circles, including the musical and musicological community. From then on, research and publishing work was planned in accordance with guidelines adopted at the Wawel Conference. As was written in conference reports, 'appreciating the value of achievements from the history of Polish music, mainly in the field of factual materials collected, it was decided to put the main emphasis on the extraction of a national and progressive trend of Polish music and examine hitherto neglected areas, such as the Polish dissident music in the sixteenth century, etc.' ${ }^{\prime 87}$ It might have seemed that such declarations opened the way to many subsequent publications. However, it turned out, that the activity in this field, even in the case of such a safe and non-semantic art as music, could also be full of reefs and shoals. Ideologisation imposed on the sole musical publishing house, namely PWM, reached a level of absurdity even to the extent that works by Chopin which were highly propagated by the system were affected. In connection with the edition of Dzieła Wszystkie Fryderyka Chopina [Complete works of Frederic Chopin] edited by Paderewski, Bronarski and Turczyński (work which was started before the war), Tadeusz Ochlewski once wrote to Chybiński: 'I have an order to remove the name of Paderewski from the cover page and cut off the "From the Publishers" page in Chopin. Do you have any way to explain to Grosicki that this is a wrong decision?'188 Chybiński himself experienced serious problems and financial losses connected with the publication. In his monograph about Karłowicz, when writing about the family estate in Wiszniew, the professor described it as being situated near Lake Narocz, which he said was the largest lake in Poland, not taking into account the change of the borders. In addition, 'the whole book, "your" point of view, gentry, involuntary delight about

186 Ibid., 14.

187 See Materiały do Studiów i Dyskusji z Zakresu Teorii i Historii Sztuki, Krytyki Artystycznej oraz Metodologii Badań nad Sztuka [Materials for studies and discussion in the field of art theory and history, art critique and methodology of art research], 1950 [Special edition in connection with the works of the First National Scientific Conference on art research], 329.

188 Ochlewski to Chybiński from Cracow 14 II 1949, AACh-BUAM, fol. O-P, p. 68. 
the past' threatened serious consequences both for the author and the management of the publishing house, hence Ochlewski's decision (consulted with Zofia Lissa ${ }^{189}$ ) on the withdrawal of the printed publication from circulation (including author's copies) in order to replace pages from the volumes with new pages, with politically correct text. ${ }^{190}$ More serious consequences (including removal from the party, which at that time strongly condemned the 'victim') affected Stefania Lobaczewska in 1950 in connection with the author's assessment of history and content not entirely corresponding to the assumptions of the Marxist methodology ${ }^{191}$ in Tablice, ${ }^{192}$ and still earlier in connection with the publication of her monograph about Szymanowski.

Strong mottos given during the Congress of Polish Science also entailed determined actions in terms of both the current methodology and organisation of science. Much focus was placed on the centralisation of research and the preference for teamwork - organisation of large projects of a lexicographical, handbook, monographic and source character, launching works on different kinds of directories, dictionaries, publication series, which would bring together larger research teams that would be, at the same time, also easier to control. Individual achievements were to be of a lesser value, and Soviet science became the role model for Poland. During this time, on the agenda were statements saying for instance that the organisational model ... was organically shaped between 1950 and 1951 based on changes and practices of our lives. Getting acquainted with the experiences and patterns of similar institutions in the Soviet Union was of utmost help. ${ }^{193}$ Finally, the meeting and findings of the Congress resulted directly in the establishment of PAN, a central institution, the launch of which

189 See Ochlewski to Lissa from Cracow 14 II 1949, extant AZL-BUW.

190 Ochlewski to Chybiński from Cracow 14 II 1949, AACh-BUAM, fol. O-P, p. 68.

191 'Eobaczewska was punished beyond all reason: she was removed from the party as an "enemy of the working class," removed from the State Higher Music School, removed from any actions whatsoever. "Tablice” [Tables] were confiscated. "Zarys historii form muzycznych" [Outline of the history of musical forms] won't help at all, because it contains flawed expressions as well. Lissa is also strongly accused, but so far, she has not been degraded nor removed from her post. ... When it comes to Łobaczewska's friends from Cracow, a delegation went to Warsaw to defend her because the die has not been cast yet,' see Ochlewski to Chybiński from Cracow10 VIII 1950, AAChBUAM, fol. O-P, p. 121.

192 Stefania Łobaczewska, Tablice do historii muzyki: objaśnienia [Tables for the history of music: Explanations], (Cracow 1949).

193 'Sprawozdania z działalności Instytutu [PIS] za 1951 r." [Reports of the institute's activities [PIS] for 1951], archives of Instytut Sztuki PAN, box D-0312 (A 33), 320. 
was associated with the liquidation of the existing major scientific societies PAU and Warsaw's TN and diminishing of the importance or significant reduction of autonomy of others, such as PTPN.

In view of the 'gentle revolution' making progress in science and aimed at deconstructing the existing foundations of the Polish academic establishment, pompous disputes within the environment of local musicologists (including the cultivation of the long-standing Lviv-Cracow controversy) were in fact merely peripheral, based on personal disputes, and did not significantly alter the fate of the discipline, which was determined by completely different bodies. On 7 February 1948, a meeting was held during which it was decided to establish PIS as one of the 'centres of "new science" located outside the structure of the university' ${ }^{\prime 194}$ and the de facto facility given the task of controlling all aspects of research within the disciplines associated with the history of art, understood in an interdisciplinary manner.

Joanna Sosnowska recalls the arguments provided by Aleksander Jackowski, the deputy director of the newly appointed Institute, aimed at justifying the creation of the facility: 'In 1950, the hierarchy of tasks was obvious, at first - participation in shaping contemporary culture - and then documentation and research on ancient art.... The Institute was established primarily because it was needed in the then system as an institution that would pave the way for Marxist ideology, acting as a battering ram of the new cultural policy.' ${ }^{195}$ Whereas Zofia Lissa, when she was stating the reasons why research on art was centralised, wrote that it was necessary to 'overcome the former isolationism of researchers, the cronyism of individual groups and their antagonisms... and find methods of group work.... Scientific planning made it possible to incorporate musicological disciplines into a wider scope of comprehensive research.... The fact that a group of musicologists participated in the work of the Committee of Art History and Theory at Department I of the Polish Academy of Sciences in 1951 and that the Music Section was established in 1950 at the State Institute of Art ... was a sign of the attempts to devise a uniform research plan.196

Organisational tasks which were entrusted to a delegate of the Ministry of Culture and Art, Juliusz Starzyński, who was an art historian, led to the adoption of Regulation of the Council of Ministers of the Republic of Poland of

194 Degen/Hübner 2006/2, 13.

195 Starzyński 1950/2, 152.

196 Lissa 1957, 266-267. 
30 November 1949 concerning the establishment of the State Institute of Art. ${ }^{197}$ A conference 'concerning tasks facing the Music Section at the Institute and to discuss editorial and music issues ${ }^{198}$ was planned to take place on 8 December. Starzyński, previously the director of the international cooperation office at MKiS, was appointed as the Director of the Institute as of 1 January 1950. Aleksander Jackowski, an ethnographer and art historian, was appointed as Deputy Director. The Institute was established through the merger of the National Institute for Research on Folk Art and Theatre Institute, and afterwards the liquidated LIM. As one of the flagship institutions of this kind in the new system, involved in the area of science of arts, MKiS had specific tasks which can be found even in the report on the institute's activities 1949-50: 'In case of its scientific-research and organisational activities, the Institute adheres to the assumptions and methodology of dialectical and historical materialism. In evaluating the developments and achievements of art, the Institute relies on the criteria of socialist realism.... The Institute has set itself a goal of breaking the existing system of individualistic thinking in a substantial portion of our scientists, educators and art critics.'199

Like the other newly-appointed academic institutions, PIS was to take care over all forms of research activities - in this case, the science of art. Six sections (including the Music Section) were launched, which 'as science and research collectives in the field of their specialisation together constitute co-ordination centres that gather a plethora of teams appointed for taking up collective works. ${ }^{200}$ As part of the Music Section, several departments were created: e.g. of methodological and historical issues, contemporary music, promotion of music, and the editorial and documentation department. At the beginning of 1950, a comprehensive and ambitious plan for the functioning of the cell was established. It envisaged conducting and coordinating research, documentation, and editorial works not only by the editorial staff of the Institute but - in the context of total centralisation - also by other university centres.

197 Most information about the first period of activity of the PIS can be found in archive documents stored in the archive of the Institute of Art of the Polish Academy of Sciences in Warsaw and the materials of the Department of Musicology of the said Institute.

198 Starzyński to Chomiński from Warsaw 30 XI 1949, APCh.

199 Sprawozdanie $z$ działalności Instytutu 1949-1950 [Reports of the institute's activities 1949-50], extant in archives of IS PAN, box D-0312 (A 32), 3-4.

200 Ibid., 4. 
Unit I, dealing with theoretical and programme works, cooperated with the Subcommittee for Theoretical and Programme Affairs of the Scientific Committee of Academic Music Education - in the hands of this particular department was the formation of the editorial committee for the planned encyclopaedia of music, and there were also proposals for providing institutional support and subsidising the works on Historia muzyki powszechnej [General music history] by Z. Lissa and J. Chomiński, and Chomiński's Historia form muzycznych [History of musical forms]. There were also plans to translate the work of Boris Asafyev entitled Muzykalnaâ forma kak process. Unit II was responsible for historical studies, both in terms of Polish and mainstream music. Here, in addition to the works on monographs of Polish composers (as well as the history of Polish music), there were plans, amongst others, for subsidising the issue of the second edition of volume I of Zdzisław Jachimecki's Muzyka polska $w$ rozwoju historycznym od czasów najdawniejszych do doby obecnej [Polish music in historical development from the earliest days to the present day] ${ }^{201}$ preparing the Moniuszko Almanac ${ }^{202}$ and leading the works of the Frederic Chopin Institute. Unit III was to deal with works on the encyclopaedia of music. All these ranges were coordinated by Stefan Jarociński, a young musicologist, also educated in law, philosophy and sociology at universities in Warsaw and Paris, employed at PIS as of 1 January 1950. Unit IV - involved in the dissemination of music (both preparing lectures for the State Agency for Artistic Events 'Artos' and analysing the demand for musical culture amongst rural and urban communities) - was to be run by Józef Lasocki, employed at the Łódź provincial department of culture and art who, at the same time, served as the head of LIM since 1945 (recall - part of LIM's activities was to be taken over by PIS). Lasocki was employed in Warsaw only for the first three months of 1950. Unit V - Study of contemporary music - on the one hand was to formulate the principles of Marxist aesthetics and on the other - to organise closed programmes on contemporary music, and explore issues of film music as well as (in cooperation with the Section of Folk Art Research at PIS) the function of folk music in the works of contemporary composers. The head of the department was to be Jerzy Sokorski, Włodzimierz Sokorski's brother, one of the main eulogists of socialist realism in terms of culture, art and science. However,

201 Jachimecki's dissertation was issued in the following year, similarly to its first part (published in 1948) by the Cracow-based publishers Księgarnia Stefana Kamińskiego.

202 Almanach Moniuszkowski 1872-1952 [Moniuszko almanac 1872-1952] (the chronicle of life developed by Witold Rudziński, other sections by Jan Prosnak) was ultimately released in 1952 by Czytelnik. 
in 1949 Jerzy Sokorski received a UNESCO music scholarship and soon left to study composition with Nadia Boulanger, among others.

The Documentation Unit (VI) was supposed to deal with the accumulation of both sound artefacts (record collection) as well as the preparation of catalogues containing both Polish and foreign musical publications (an archive of articles and reviews). From our point of view, the most important part of this plan was the project for the development of Unit VII - Editorial, conceived as a decision-making centre for the entire country: it was supposed to assemble 'reviewer teams, the tasks of which would be giving opinions on publishing any music book publications of both the Institute and PWM as well as other publishing companies and, furthermore, provide appropriate comments in order to reformulate the work reviewed by the author or the publishing house. ${ }^{203}$ Stanisław Borowy was responsible for the works of the Unit. As we can read from the abundance of correspondence between persons involved in publishing matters and contacts with PWM (Lissa, Chybiński, Chomiński, Ochlewski), and the activities (and often simply lack of any action) undertaken by Borowy (and deputy director Jackowski) often caused all kinds of perturbations in the development of musicological publications: pursuant to those decisions, all materials were placed on his desk (in practice - for an indefinite period), which often resulted in considerable delays in transferring them to Cracow. The slowdown of procedures that had previously relied on acceptance of incoming materials for print only through the appointed, substantial and competent PWM Programme Council, had a significant impact on the course of works of Kwartalnik Muzyczny and marginalised the position of its editorial team.

However, not only scientific tasks were assigned to the Music Section: in the framework of the methodological and historical works, apart from 'cooperating with the departments of musicology at universities in order to collect and summarise scientific achievements and inspire works related to the scientific needs of the Section,' the goal was to 'train musicians, musicology research workers, pupils [sic] of musical schools, etc. in the field of Marxist aesthetics.' At the same time, the department of contemporary music, whose aim was, amongst other things, to organise discussions on the premieres of works by contemporary composers, and upon presenting the results of these discussions to 'employees and scientific teams

203 Appendix to the Plan pracy Działu naukowo-historycznego Sekcji Muzyki Państwowego Instytutu Sztuki na miesiac luty $1950 r$. [Work plan for the unit for science-history of the music section of the PIS for the month of February 1950], in the archive of the Department for Musicology, unsigned 
working on issues of musical aesthetics.' They also undertook to maintain 'international contacts with the Society of Progressive Music and other music centres involved in the progressive contemporary ideas in the USSR and other countries. ${ }^{204}$ It was recommended to organise a competition for a monograph written using the assumptions of historical materialism, with an indication of the figures of Polish musicians - Moniuszko, Elsner, Żeleński, Różycki, beginning work on an anthology of musical criticism 'to include issues of the struggle for realism in aesthetics and music criticism of the nineteenth and twentieth centuries. ${ }^{205}$

The above-mentioned members of the Music Section were employed as academic staff, which usually had little to do with their actual scientific competencies (except for Stefan Jarociński, who received a degree, as has already been said, from both a Polish university and a foreign university). The actual scientific base of the Section was made up of its external associates (some, like Chomiński, soon to be employed in PIS): Zofia Lissa ('methodological issues, managing the teams preparing the Moniuszko Encyclopaedia and Monograph, scientific consultations and opinions on publications'), Józef Chomiński ('methodological and historical issues, managing the general music history team, scientific consultations and opinions on publications'), Roman Haubenstock ('current affairs of the Section and the journal in Cracow, opinions and reviews'). Moreover, the 'secretary-general' of the new body established by the State Institute of Art, that is the monthly Muzyka, was Jerzy Broszkiewicz, a literary man and a musician, who used to work in Cracow in the editorial team of Ruch Muzyczny. ${ }^{206}$

This initial structure soon changed, as in 1951 the Section was divided into two Departments: Theory and History of Music (with its seat in Warsaw) and Folk Music and Dance (in Poznań). It was then that 'Given the scarcity of human resources in the field of musicology, one of the main tasks of the Section [at this stage] was to coordinate cooperation with other institutions and centres, in particular with the Departments of Musicology at the Universities of Warsaw, Poznań and Cracow. ${ }^{207}$

204 Sprawozdanie z działalności Instytutu 1949-1950 [Reports of the Institute’s Activities 1949-1950], op. cit., 22.

205 Ibid., 26.

206 Just like Bronisław Rutkowski, who was assigned to study the methods of popularising music on behalf of the State Institute of Art, see schedule to Plan pracy Działu naukowo-historycznego Sekcji Muzyki (op. cit.).

207 'Sprawozdanie z działalności Państwowego Instytutu Sztuki za rok 1951' [Reports of the State Institute of Art's activities for the year 1951], Materiały do Studiów i Dyskusji 
There were specific expectations regarding magazines: 'Publishing during the year 1950 - 9 numbers of Muzyka (there was one Bach edition in this and one festival ${ }^{208}$ ) ... [and] 4 numbers of Kwartalnik Muzyczny - in this one number dedicated to the Congress of Science.209 The strength of the impact of these expectations on the environment may be conveyed by Józef Chomiński’s words sent to Tadeusz Ochlewski: 'PISz ... insists that a Marxist-themed booklet of Kwartalnik ought to appear for the Science Congress. This booklet is necessary, for its release will affect not only the fate of Kwartalnik but also the fate of any musicological journal and musicologists in Poland. That is why this booklet will be released in the third quarter of the year so that it appears in November at the very latest.'.210

Evaluation of the first years of PIS activities cannot be unambiguous - the facility was established and operated at the expense of at least several research centres in terms of 'human resources', thus disorganising (as any central behemoth) the previous work organisation in the field of science of the arts. Even before the official launch of the facility, plans for its scope (for example, replacing the scientific Kwartalnik Muzyczny with a kind of a monthly 'collage' that would combine theoretical material with current and popular news) had been prepared and - as Zofia Lissa indicated - 'dictators of newly-found Institute of Art sat down to work. ${ }^{211}$ However, under the auspices of the Institute, many projects which had been started earlier could finally come into fruition (thanks to the support of the party apparatus), which soon led to tangible effects - in terms of the work of the team of musicologists, this gave, for example, five volumes of Studia Muzykologiczny, the volumes Historia muzyki powszechnej [General music history], Słownik muzyków polskich [Dictionary of Polish musicians], the edition Muzyki polskiego Odrodzenia [The music of Polish Renaissance] and the beginnings of work on the series Monumenta Musicae in Polonia.

At the end of this rather cursory sketch on the ideologisation of the musical/ musicological life in the difficult period of the Stalinism era, in which the 'new opening' of Polish musicology took place along with the generational shift within of the faculty's personnel. It can be stated that despite the odium of the

z Zakresu Teorii i Historii Sztuki, Krytyki Artystycznej oraz Metodologii Badań nad Sztuka 1951/1, 328.

208 In connection with the Festival of Polish Music which was ongoing from mid-April to mid-December 1951, see also Wieczorek 2014, 64.

209 Sprawozdanie z działalności Instytutu 1949-1950 (op. cit.), 28.

210 Chomiński to Ochlewski from Wesoła 15 V 1950, APCh.

211 Lissa to Chybiński from Warsaw 11 XI 1949, AACh-BUAM, fol. K- $€$, p. 177. 
'ever-present phantom' over all spheres of life, a large part of society - including artists and scientists - in these complicated years of communist terror took up an effort to continue works leading not only to the enrichment of the 'body' of the country, but also its 'spirit.' Attitudes of people towards that system still evoke conflicting opinions and still constitute a very sensitive subject, and so it would be difficult to decide, for example, where to place the boundary between honesty and conformism (caused either by a pragmatic assessment of the situation or rather fear?). Could we consider whether the words Adolf Chybiński addressed to Zofia Lissa as truly spontaneous: 'congratulations on the Łagów successes .... I have been expecting it already from the announcement of your well-prepared discussion material. ... I look forward with great anticipation to the announcement of the Łagów report in Ruch Muzyczny,' ${ }^{212}$ or another time: 'I don't know how to thank you for the unmatched care over this case [Phonographic Archive in Poznań] as I would like to. But at the same time I have to once again assert that cases, be it either scientific or any other, rarely fare well without the personal interest from the "ministerial factors." You became a "Providential lady" (with a capital "P") for the Archive, and not only"213 - and we find many examples of such rhetoric from the professor's pen in his correspondence with students.

212 Chybiński to Lissa from Zakopane 21 VIII 1949, AZL-BUW.

213 Chybiński to Lissa from Zakopane 8 VIII 1947, AZL-BUW. 


\section{An attempt to continue the formula of the magazine - Adolf Chybiński and his collaborators (Zofia Lissa, Tadeusz Ochlewski, Józef M. Chomiński - scope of cooperation and organisation of editorial work) - new organisation of publishing work (PWM, PIS)}

The war found members of the musicological community in various places, and the fates of the principal dramatis personae of this milieu turned out differently. The founders of SMDM survived in Warsaw - Ochlewski, Zalewski, Rutkowski, Sikorski. Teodor Zalewski gained a position as a legal advisor in the Polskie Elektrownie cooperative (which gave him an Ausweis, necessary for a relatively safe life in the city); the others attempted to work in their profession, such as Sikorski for example, who was director of the Staatliche Musikschule (performing the function of the previously closed Warsaw Konserwatorium). Scattered in all directions after the fall of the Warsaw Uprising, they migrated after the war. Let us recall that Ochlewski and Rutkowski moved to Cracow. After some time, Ochlewski brought to Cracow everything that was left of the assets of TWMP after the Uprising. Sikorski settled in Łódź, whereas Zalewski came back to Warsaw. Łucjan Kamieński, who was born in Poznań, married a German singer. At the beginning of the war, he was imprisoned by Germans and then released thanks to his wife's intervention. Due to this episode, as well as his alleged cooperation with Germans and the signing of the Volksliste, he was persecuted after the war. Mateusz Gliński left for Rome at the beginning of the war. He stayed there until 1956 and organised, for example the international IFCh. Henryk Opieński, who settled permanently in Switzerland in 1926, died in Morges at the beginning of 1942. Ludwik Bronarski, who also resided permanently in Switzerland, survived the war within the safe borders of that country. ${ }^{214}$ Michał Kondracki, one of the promising young authors of Kwartalnik

214 During the war, Chybiński continued to exchange letters with Bronarski, but for obvious reasons, less frequently than before. For some time, the musicologist from Fribourg acted as a contact man between Lviv and Józef, Chybiński’s son who first stayed in Le Bourg-d'Oisans near Grenoble and then in Toulouse. 
Muzyczny, was travelling around the Mediterranean when the war broke out. He travelled to South America and after a few years moved to the United States. He never came back to Europe. Seweryn Barbag, who was born in Lviv, lectured in the city conservatoire throughout the Soviet occupation. He had tuberculosis and in 1942 left Lviv and stayed in the sanatorium in Swider near Warsaw, where he died in autumn 1944. Zdzisław Jachimecki survived the whole war in Cracow, except for the tragic months which he spent in Sachsenhausen concentration camp.

When it comes to younger musicologists from Lviv, only Maria Szczepańska stayed in the city until $1946 .{ }^{215}$ Zofia Lissa, who, together with the Soviet army, left to the depths of the Soviet Union before the advent of German occupation and returned to Warsaw in 1947. Stefania Lobaczewska spent the war years in the estate of Zarzecze in Podkarpacie then she settled in Cracow. Jan Józef Dunicz suffered a dramatic fate; he was arrested for underground activity in 1943 in Warsaw and deported to a concentration camp - he died in the Dora camp in April 1945. ${ }^{216}$ Józef Chomiński spent the war years in Warsaw and Międzyborów near Warsaw; he was also deported twice to distant areas of the country for forced labour. However, he did not give up his studies - he continued his activities around the work of Szymanowski, prepared a dissertation on the analysis of musical forms and harmonic analysis. ${ }^{217}$

For the greater part of the military occupation of Poland, Adolf Chybiński lived in Lviv. In the last period of the war, he left for Zakopane and then, from March to September 1945, he lived in Cracow. He deposited his private archive (which included, for example, materials for some issues of WDMP and some proofread texts submitted to Polski Rocznik Muzykologiczny, whose volume III had been typeset in 1939) in Cracow, at the house of Zbigniew Romaniszyn, his friend, a singer, actor and teacher. After the war, he left Cracow and settled permanently in Poznań. Until June 1941, he worked in the Mykola Lysenko National Conservatoire in Lviv. When the Germans seized Lviv, as a former professor at the Conservatoire, he was entitled to an allowance (Unterstützung). Combined

215 During the Soviet occupation, Adam Sołtys was employed in the Lviv Lysenko Conservatoire and continued working as a conductor. After Lviv was seized by the Nazis, he began teaching at the Economic School, see Sołtys 2008, 150-157.

216 See Chybiński 1948; Niwińska 2005/2, 121-125.

217 During this time he wrote the two-volume Wstęp do analizy [muzycznej] [Introduction to [musical] analysis], which, like other smaller works, was burned during the Uprising. Many details about Chomiński’s life and academic achievements in Gołąb 2008, part. I 'Biografia' [Biography], 21-97. 
with his wife's remuneration for the portraits and miniatures which she painted, it was enough to make ends meet. At first, he hoped that his private library collection, which had been seized by the Russians, would be returned (he even filed the required official forms). He also hoped that a Polish music school would be opened (in Lviv, there was naïve talk that there would be a Polish and Ukrainian university) and that he could lecture there. Finally, he was employed as a translator at a social insurance company.

During the war, Chybiński kept up correspondence with many people with whom he had worked or whom he had taught before the war. Some of them were the authors of papers submitted to Chybiński. These were, among others, Bronarski, Dunicz, Chomiński, Janusz Miketta and Myrosław Antonowycz. ${ }^{218}$ It also seems that he grew strongly attached to Tadeusz Ochlewski. In 1943 Ochlewski offered to lend the professor a hand if it was necessary to evacuate his private library from Lviv and move it to Warsaw (fortunately, this did not happen). They made use of the prewar projects of TWMP, which had been frozen, and made plans for the following years: they were thinking about a potential edition of Szymanowski's correspondence, a monograph on Szymanowski and an analysis of Chopin's works, hoping that the first three volumes could appear before the centenary of the composer's death. Chybiński was asked to take care of the editorial side of the series. At the same time, he was working on his earlier projects. He wrote about it to Switzerland: 'I've finished volume II of "Karłowicz" (it's thicker by half - and better - than volume I). A large part of volume III (works) is ready. The Dictionary of Polish musicians (to 1800) is also ready, and it has 2500 entries. I'm reworking a large tome entitled "Muzyka Podhala" [The Music of Podhale], as well as several smaller but not shorter works. ${ }^{219}$

In 1943 he began preparing analyses of Chopin's Nocturnes, Scherzi and Impromptus. Soon, he offered Bronarski to analyse the Sonatas, Ballads, Etudes, Preludes and/or Fantasies ('something like Leichtentritt's analysis, but more extensive, deeper, better, more precise, paying attention to scientific views and taking a stance on these views. Mainly an analysis of the form, of course, but rather to serve as the basis to discuss other factors and their synergy ${ }^{220}$ ).

218 See 'Listi Adolfa Hybinskogo'.

219 Chybiński to Bronarski from Lviv 24 II 1942, AACh-BUAM, Bronarski’s archive, p. 176.

220 Chybiński to Bronarski from Lviv 6 XII 1943, AACh-BUAM. The invitation to work on the analysis of Chopin's works was also accepted by Jan Józef Dunicz (Chamber music) 
The 'underground,' war projects of TWMP also included a return to editing magazines. Bronisław Rutkowski added to one of the letters from Ochlewski to Lviv: 'We are constantly working, believing that this work may be useful in the future. We have many projects; all of them seem to be important and real. Among others - we are also thinking of MP. We're already starting to collect materials. We are also counting on you, Mr Professor. ${ }^{221}$ At other times, Ochlewski himself asked: 'How are matters getting on with the third volume of PRM? When will the proof be ready? Will the new content of the number be supplemented, increased? Can the material be prepared for printing in order to start it immediately after the war? [.. . In a nutshell, I am asking you for information necessary to orient SMDM in this matter,'222 to which the professor suggested that the run should be printed 'simply and cheaply', i.e. prepare zinc plates to print photographs of rescued materials.

None of these ideas was implemented as planned. Shortly after the war, Muzyka Polska was replaced by Ruch Muzyczny, which was initiated by Polish Musicians' Trade Union, whereas Rocznik was transformed (for a mere three years) into Kwartalnik. The first signals of the revival of the journal could be heard in December 1946, when State Music Publishing Council prepared plans for PWM. Nevertheless, many months before that, Chybiński had written to Switzerland: 'We are going to publish Kwartalnik Muzyczny this year and revive Polski Rocznik Muzykologiczny. ... My earnest request is that you submit articles on any reader-friendly topic (perhaps something about musical life in Switzerland, taking into account the participation of Poles in this life).223

Chybiński assumed that he would be able to realise Rocznik 'with content identical to that which was placed in the third volume destroyed in $1939.224 \mathrm{He}$ obtained permission to use pre-war texts from Bronarski, and in the same matter he contacted Józef Chomiński. Chomiński, although he wanted to make a few amendments to the article he had written only a few years earlier, found this was, however, not possible due to his stay of almost one year in the sanatorium in

and Józef Chomiński (Preludes). It even seemed that this cooperation could 'transcend divisions' when Zdzisław Jachimecki agreed to analyse Polonaises and Songs.

221 Ochlewski to Chybiński from Warsaw 22 I 1942, AACh-BJ, box 1, O-1/98.

222 Ochlewski to Chybiński from Warsaw 1 XI 1943, AACh-BJ, box 1, O-1/116.

223 Chybiński to Bronarski from Cracow 22 I 1946, AACh-BUAM, Bronarski’s archive, p. 195.

224 Chybiński to Bronarski from Cracow 22 I 1946, AACh-BUAM, Bronarski’s archive, p. 195. 
Leysin, Switzerland. He finally agreed to publish the pre-war version, at the same time asking for annotation under the text 'Lviv 1937.'

Unfortunately, attempts to resurrect the journal turned out to be futile. Chybiński could not bring himself to accept this decision because he had always believed that a journal published annually best reflected the scientific aspirations of the musicological community. We need to bear in mind that from the beginning of his academic career, Chybiński had been thinking about publishing a journal modelled after German 'Jahrbuch', which would be a kind of chronicle of current achievements of the academic musicological community, as well as a seedbed for serious academic discussion within this community. Other youthful representatives of Polish musicology were of the same opinion. For example, Henryk Opieński wrote in one of his letters to Lviv: 'When it comes to cooperation, I'd be glad to submit a short paper to an annual journal.225

Meanwhile, in autumn 1947, the post-war fate of Kwartalnik Muzyczny was resolved. The final decision concerning the resumption of the magazine based on the formula developed before the war was taken two years after Chybiński took the Chair of Musicology at the UP. It took place in Warsaw, at the meeting of the Editorial Committee, which happened on October 22, 1947, in the Department of Music of the MKiS, in which Zofia Lissa, a graduate of Lviv musicology, was then director. Already over a month earlier, Lissa had reported to the professor: 'we have money to resurrect Kwartalnik Muzyczny. I talked about financial issues with Ochlewski. ... We can provide a potential editorial committee and a regular secretary. I propose Dr Chomiński for secretary. He's just come back from Switzerland.'226

It was agreed that the magazine would be published by PWM, which was already fully functioning, and the organisation of the publishing calendar was taken over by director Ochlewski in November of that year, designating February 1948 as the deadline for submitting the set of materials for printing. All articles were to be given in the form of typescript, 'and musical examples clearly, though not calligraphically. ${ }^{227}$

After the war, ten issues of Kwartalnik Muzyczny were published in seven volumes. The first and the last volume $(21 / 22,29 / 30)$ and the special Chopin edition (26/27) had double numbering. When Maria Kielanowska-Bronowicz was preparing a list of sources for all editions of Kwartalnik (including two volumes

225 Opieński to Chybiński from Łódź 11 II 1920, AACh-BJ, box 6, O-2/67.

226 Lissa to Chomiński from Warsaw 14 IX 1947, AACh-BUAM, fol. K-Ł, p. 149.

227 Ochlewski to Chomiński from Cracow 24 XI 1947, APCh. 
of PRM), she concluded that in the years 1948-50 the total number of pages was 1956 (which was more than in the interwar period, when twenty issues had been published). Apart from numerous reports, there were fifty-six articles, texts and introductions, which was about half of the analogous publications from the late 1920 s and early 1930s. One of the reasons behind this disproportion was the fact that even though Chybiński often claimed that authors would move away from writing long texts and splitting articles to publish them in several issues, this is precisely what was happening throughout the whole history of Kwartalnik. ${ }^{228}$

Similarly to the pre-war period, each issue had a table of contents in both Polish and French. At some point, around the time when the issues devoted to Chopin came out, Chybiński suggested that abstracts could be translated into French as well, but this idea never came to fruition. ${ }^{229}$

The journal was not illustrated, unless there were articles in which illustrations played a vital role or served as the starting point in the discussion. Some examples are an article on manuscripts of two works by Chopin from the library of Paris Conservatoire, ${ }^{230}$ an article on the history of the portrait of Chopin and George Sand painted by Eugène Delacroix, ${ }^{231}$ and a text about autographs on Chopin's letters ${ }^{232}$ (in this case, we know that the cost of photocopies of the said autographs was PLN 1000, whereas the price of one copy of Kwartalnik was PLN 250). Generally, Maria Szczepańska ${ }^{233}$ was the calligrapher for the musical examples. Already at the stage of sending materials for production, the number of overprints (in practice, only selected articles) was also established,

228 An extreme case was a paper submitted by Józef Chomiński, namely 'Problem formy w preludiach Chopina' [The question of form in Chopin's preludes], which was 262 pages long.

229 The first abstracts (initially added only sporadically, over time more regularly) appeared at the beginning of the 1960s in a quarterly entitled Muzyka. They were put together at the end of the part which contained articles and other materials. To continue the tradition of 'the second' Kwartalnik, in which tables of contents were provided in French, this time abstracts were also translated into French. Over time, translations into German and English were added as well.

230 Ludwik Bronarski, 'Dwa nieznane utwory Chopina' [Two unknown works by Chopin] (KM 1948/21-22, 60-74).

231 Bronisław Edward Sydow, 'Chopin i Delacroix. (Historia jednego portretu)' [Chopin and Delacroix. (The history of one portrait)] (KM 1949/26-27, 15-26).

232 Ignace Blochman, 'Dwa autografy listów Chopina w Belgii' [Two autographs on Chopin's letters in Belgium] (KM 1949/26-27, 38-47).

233 Chybiński mentioned this in a letter to Zofia Lissa (from Poznań 30 XII 1948, AZL-BUW). 
the number of which usually boiled down to fifty pieces - completely sufficient for the popularisation of texts in a still small environment. A dissertation ${ }^{234}$ by Zofia Lissa on the sociological aspect in Polish contemporary music was subjected to exceptional treatment - at the author's request and due to the timing of the problem: the article, printed twice with differing pagination was also published separately from Kwartalnik, in a print run of 1000 copies, from which 900 copies were to be directed for sale. ${ }^{235}$ (It was planned that in the case of articles divided between several editions, the bound work was to be in the form of a supplement only after the appearance of all anticipated parts.)

What we also need to remember is that throughout its short history, post-war Kwartalnik was published along with excerpts from Słownik muzyków dawnej Polski [A Dictionary of Early Polish musicians], a work written by Chybiński before the war on the basis of materials which he had gathered throughout the years. Fragments of the dictionary were regularly added to subsequent volumes of the journal. This idea was brought up by the author himself. He had a feeling that it was the quickest and safest way to publish his lexicon. At first, he tried to check whether it was possible at all and consulted Zofia Lissa about his idea (which was 'modelled after older musicological journals ${ }^{236}$ ). On the one hand, he had no hopes of publishing the dictionary in a different form, but on the other, he saw it as an opportunity to help Kwartalnik in case there were not enough texts to publish. The length of one 'attachment' was supposed to be one sheet, so that it would only slightly increase the length of the journal, which was expected to be about 9-10 sheets. It was found that in terms of typography, the publication would have a layout characteristic of this type of study, two-column, although Chybiński, paying attention to the cost of typesetting and printing, suggested breaking the text in the continuous single column; titles of entries (names of musicians) were to be printed in plain print with spaces, not in bold (block

234 KM 1948/21-22, 104-144 and Cracow 1948.

235 On this occasion, it is worth noting that on the basis of the Chopin editions (perhaps also others - this information was not always specified), we can say that the print run of KM was set to 1500 copies. Published from 1950 by PIS the monthly Muzyka was printed in around 2700-2800 copies. In the sixties, the circulation of the quarterly Muzyka magazine issued by the PAN Institute of Art oscillated between 1150 and 1950 copies, after which it was raised to 2,500 , and even 3,135 copies of a single issue in the mid-eighties. These numbers are surprising and have nothing to do with the real demand of the environment. In the final years, the print run of Muzyka was set to the level of 350-400 copies.

236 Chybiński to Lissa from Poznań 7 I 1948, AZL-BUW. 
capitals were finally agreed), with the font "borrowed" in terms of cut from the pages of Ruch Muzyczny (heading 'Correspondence') ${ }^{237}$. The possibility of combining the subsequent parts of the dictionary was assumed thanks to the cover printed at the end of the publication process. Other articles, as already mentioned, were additionally printed in fifty copies ${ }^{238}$.

As we get back to the chronology of events related to the publication of the old/new journal, let us recall that there were three official letters in Chybiński's archive which Lissa had sent to the professor between 23 and 31 October. In the first one, she informed him that 'Department of Music at Ministry of Culture and Art (MKiS) has begun preliminary work on the revival of Kwartalnik Muzyczny. She added that 'The ministry invites you to cooperate and asks for a written notification on the types of strictly musicological papers which the editorial office may demand from you. ${ }^{239}$ The contents were vague; perhaps the note was sent to all active musicologists of the time. However, a few days later, Chybiński received an official invitation from Department of Music at MKiS, in which he was asked to 'accept the position of Chief Editor of Kwartalnik Muzyczny.240 On 14 September, Lissa privately informed Chybiński that some decisions favourable to the musicological community were made: 'You'll certainly be happy when you hear that we have money to resurrect Kwartalnik Muzyczny. ... will you agree to look after Kwartalnik redivivus? ${ }^{241}$ She also insisted that personnel decisions and plans related to the contents of the first volumes be made as quickly as possible, so that a concrete plan, which only needed approval, could be presented on the incoming meeting of ZKP and the congress of musicologists.

On the matter of personnel, it was decided that 'Apart from Citizen [Chybiński] the editorial committee will consist of: Prof. Dr Zdzisław Jachimecki, Father Dr Hieronim Feicht, Dr Zofia Lissa, Dr Stefania Łobaczewska, Rector Kazimierz Sikorski, Dr Józef M. Chomiński, ed. Zygmunt Mycielski and Master Marian Sobieski, ${ }^{242}$ but it quickly tuned out, however, that the de facto grey eminence

237 This, and other details in the correspondence between Chybiński/Chomiński 2016, 52-54.

238 Chybiński wrote about this in a letter to Ochlewski from Warsaw 10 III 1948, APCh.

239 Lissa [MKiS] to Chybiński from Warsaw 23 October 1947, AACh-BUAM, fol. 3 'Materials concerning the cooperation of Adolf Chybiński with publishing houses, scientific institutions, state administration offices,' p. 43.

240 Lissa [MKiS] to Chybiński from Warsaw 27 X 1947, AACh-BUAM, ibid., p. 44.

241 Lissa to Chybiński from Warsaw 14 IX 1947, AACh-BUAM, fol. K- $€$, p. 149.

242 Lissa [MKiS] to Chybiński from Warsaw 31 X 1947, at AACh-BUAM, fol. 3 'Materials concerning the cooperation of Adolf Chybiński with publishing houses, academic institutions, state administration offices,' p. 45. 
of Kwartalnik was Lissa herself, who - at times - acted officially on behalf of the editor-in-chief. ${ }^{243}$ Correspondence stored at the University Library of Warsaw (BUW) and in the private archive of the Chomiński family tells us that she was the person whom Józef Chomiński consulted about every 'sensitive' matter related to Kwartalnik and its chief editor. Above all, however, in the first weeks following the decision to revive the journal, it was Lissa who took steps to appoint the editorial committee and carry out work necessary to prepare the first volume. She also quickly hired a new secretary. Moreover, even though it might seem that most materials had to be accepted by the nominal chief editor, he was not necessarily the one to have the final say on the contents of volumes. For example, it turned out that 'The contents of volume 1 have already been determined by Mr Chomiński,' as Lissa wrote. ${ }^{244}$

Lissa began thinking about appointing Józef Chomiński as secretary of the editorial office quite early on. She wrote about it in the above-mentioned letter from September: 'I propose Dr Chomiński for secretary. He came back to Poland from Switzerland. ... I have already talked to him (tentatively, since I'm waiting for your proposal) about it and this job would really suit him.2. ${ }^{245}$ At that time she also asked the professor about possible editorial portfolio resources, combining further editorial procedures with the official calendar of the milieu: 'The Professor reminded me in his time that he has manuscripts of various musicological works that could fill two Rocznik Muzykologiczny. Do not you think, Mr Professor, that at least some of them could be printed in Kwartalnik? b) which of your works would you like to print there, Mr Professor? ... These are all matters that we should resolve before the composers' meeting so that we just pass the final resolution there.246

Adolf Chybiński, even though he believed that the pre-war PRM would be resurrected, finally welcomed the decision of the ministry. He responded to Lissa's invitation by sending her a letter from Zakopane, where he used to spend a few weeks each holiday: 'So Kwartalnik Muzyczny will come back to life! One more achievement to your credit! It will be the "third" Kwartalnik Muzyczny. As things stand, I accept every proposal formulated in your letter. I accept the editorship, Chomiński, the editorial committee. ${ }^{347}$ In order for the committee not

243 See for example, Lissa to the Presidium of the Council of Ministers from Warsaw 4 XII 1948 (at APCh), where Lissa had initialled 'on behalf of the editor in chief' next to the signature of Józef Chomiński ('secretary').

244 Lissa to Chybiński from Warsaw 10 I 1948, AACh-BUAM, fol. K-€, p. 153.

245 Lissa to Chybiński from Warsaw 14 IX 1947, AACh-BUAM, fol. K-Ł, p. 149.

246 Ibid.

247 Chybiński to Lissa from Zakopane 22 IX 1947, AZL-BUW. 
to be appointed pro forma et honore but rather in accordance with substantive criteria, the professor came up with an idea how to distribute editorial duties among members, depending on their qualifications: Lissa (psychology and theory), Łobaczewska (aesthetics), Father Feicht (history and theory), Bronarski (history), the professor himself (ethnography), perhaps two practising musicians (theoreticians, composers), Sikorski (to make a reference to the tradition of 'the second' Kwartalnik) and Witold Rudziński, whom the professor valued for his 'academic education.' It cannot be ruled out that Chybiński was also taking into account the ministerial function held by Rudziński (at that time he was the Director of the Department of Music at MKiS).

The future showed that from the group proposed by the Ministry and also those suggested by the professor, only Chybiński, Lissa and Chomiński associated themselves with the daily work of Kwartalnik. ${ }^{248}$ The first weeks of joint work on the planning and collection of materials were filled with doubts about the success of the project: 'or that Rocznik, more extensive than before, would not be more appropriate. For it seems to me that our musicological production will not keep up with the quarterly pace. How much can people work, or seriously work?! May it be that later from necessity that actual news does not outweigh theory, history and musical ethnology. ${ }^{249}$ Chybiński wanted the post-war edition to be a continuation of the series from 1928-33, assigning the new issue the next number in turn, hence 21 (in the end, the double edition appeared as the first 21/22). Warsaw and Cracow were given as the place of publication, although the editorial work was divided between three centres. The professor, who was the chief editor, lived in Poznań, so the address of the Institute of Musicology in Poznań, namely Wały Wazów 26, appeared in the masthead next to the address of the secretary's office of the journal, which was located in Warsaw at Rakowiecka Street 4 (the seat of Department of Music of MKiS, the place in which Zofia Lissa worked and from which Józef Chomiński collected materials for his articles) and the Cracow address of the administration (the executive editorial office) of Kwartalnik, which was located in the offices of PWM at Basztowa 23 Street. ${ }^{250}$ The director of the publishing company was Tadeusz Ochlewski, a

248 'in the matters of KM we will need to talk at greater length with all three of us, for there are pressing and important matters in abundance,' see Chybiński/Chomiński 2016, 73.

249 Chybiński/Chomiński 2016, 47.

250 In the beginning, the editorial office of Kwartalnik was located in the Library of Warsaw Philharmonic at Nowogrodzka 49 Street (in the building which houses the ROMA Musical Theatre), but this address never made it to the masthead. Over time, 
long-term co-worker of Adolf Chybiński. They had been cooperating since the establishment of SMDM (and his relationship with the professor became even closer during the war, as has already been mentioned). The secretary of the executive editorial office in Cracow was Helena Dunicz, ${ }^{251}$ a violinist, the sister of Jan Józef Dunicz, one of Chybiński's favourite pupils, who died tragically in the last weeks of the war.

The office occupied by the periodical's administration was located in Cracow, which was partially due to the necessity to coordinate its production. In a sense, it brought together Kwartalnik and Ruch Muzyczny, another monthly published by PWM, especially when it came to logistics. The same publishing company ${ }^{252}$ was not the only thing that the two journals had in common. The relationships between their authors and editors were close as well. Let us remember that the creator of Ruch was Stefan Kisielewski, who gained professional experience in the editorial office of Muzyka Polska, where he worked as a secretary before the war. Another member of the editorial team of Ruch was Bronisław Rutkowski, thanks to whom Adolf Chybiński had become involved with Kwartalnik years before. Moreover, in different periods, the editorial committee also included Stefania Łobaczewska and Zygmunt Mycielski (before 1939 he was a member of the editorial team of the aforementioned 'sister' journal, Muzyka Polska). They were both appointed, at least in the beginning, as members of the Kwartalnik team. A strong reference to the pre-war edition of the journal was its unchanged cover (with an illustration by Edward Manteuffel). However, PWM proposed to add a dust jacket to the special Chopin edition. Its design was completely different

due to purely pragmatic reasons (in order to enable authors and other members of the editorial team to contact him quickly), Chomiński updated the address depending on where he happened to be staying at a given moment: Centralny Instytut Kultury (Central Institute of Culture) in Szklarska Poręba, Kościelna 9 Street (where he resided for a few months at the turn of 1949), Department of Creation at MKiS (but this time at Krakowskie Przedmieście 17 in Warsaw), in Wesoła near Warsaw at 15 Grudnia 11/1 Street (which was Chomiński's home address). The last double volume which came out in 1950 was published by PIS, whose office was located at Długa 28 Street in Warsaw, which is now the address of the Institute of Art of the Polish Academy of Sciences.

251 Over time, Lidia Kisielewska also started signing letters from the 'administration' of Kwartalnik.

252 Moreover, the publishing company offered potential readers a joint subscription of both journals on favourable terms (four volumes of Kwartalnik a year cost PLN 1200, whereas with Ruch the price was PLN 1900). 
from the traditional image of the journal: "Due to "commercial" reasons, this idea is good and even necessary. ${ }^{253}$

Tadeusz Ochlewski coordinated both the organisational and production work related to Kwartalnik as a whole. As the director of PWM, he felt responsible for all publications of the publishing house and treated Kwartalnik Muzyczny as one of the 'flagship' products; hence he spontaneously joined in the editorial work of the magazine. Although he had no de facto formal basis for this, he moderated - albeit reluctantly - work between Warsaw and Poznań. Comparing the mentioned correspondence with other source corpora (Chybiński's letters to Bronarski from the Poznań collection, Zofia Lissa's correspondence with Chybiński from the archives in the Gabinet Zbiorów Muzycznych BUW [BUW Music Department], Chomiński's archive kept there, and above all the private Chomiński archive), it is possible to see how the situation inside the editorial office was essentially untamed and full of insinuations and how the procedures related to the editorial work were ambiguous.

From the very beginning of cooperation between the three centres which were involved in the making of Kwartalnik, there was significant tension resulting from time pressure. Chybiński, as the intermediary between the secretary's office and the publisher, could not keep up with sending proofread texts and promised materials, whereas PWM wanted to submit the first volume for print as soon as possible. It was supposed to contain both pre-war materials and a few quite original, new texts. These texts had to come a long way and they usually landed on the desks of Lissa, Chybiński and Chomiński before they finally arrived in Cracow. Due to the large volume of texts which the professor wanted to submit for 'number one' and in order to 'speed up printing,' Ochlewski suggested to move some texts (e.g. 'Niezrealizowane projekty operowe Moniuszki' [Moniuszko's unrealised opera projects] by Włodzimierz Poźniak and 'Teoria dwutonowych melodii' [The theory of two-tone melodies] by Zygmunt Estreicher) to the next issue. ${ }^{254}$ At the beginning of May 1948 the situation seemed serious: not only that the printing of the new issue was drawn out, PWM had still not received any materials for the next issue. At this point, the censor helpfully stepped in and did not allow the publication to exceed the volume reported earlier (two hundred pages), and this fixed the determination of the volume by the double numbering $21 / 22.255$

253 Chybiński to Lissa from Zakopane 29 VIII 1949, AZL-BUW.

254 See Ochlewski to Chybiński from Cracow 23 IV 1948, AACh-BUAM, fol. O-P, p. 48.

255 See Ochlewski to Chybiński from Cracow 13 V 1948, AACh-BUAM,fol. O-P, p. 50. 
When finally, at the end of June 1948, the first post-war issue of Kwartalnik was published, Chomiński wrote to the professor using moderately enthusiastic words: 'Kwartalnik Muzyczny was finally published. ... its content, I think, is satisfactory - and quite good. I hope it will remain so in the future.256 The editorin-chief was less distanced: 'It seems to me,' he wrote, 'that we can congratulate ourselves on the double issue I/II, and his further words were as if taken from one of his letters written years ago: "Lviv" still places much pressure in terms of quantity and weight of the works, yet I would like that it was not only Lviv."257

Opening the new edition of Kwartalnik Muzyczny, for Adolf Chybiński, it was not enough that he reached for pre-war editorial reserves and, to a large extent, used materials prepared for the third volume of PMR, he again reminded everyone and summarised the history of the magazine in the editorial of the first/twenty-first number - the content of those twenty editions which consisted of 'nearly 110 works and around 300 critical papers by 40 Polish and foreign authors, ${ }^{258}$ and briefly recalled two directions, in which Kwartalnik evolved after closing its activities in 1933: informational in the character of the formula of Muzyka Polska and the scholarly, hermetic Rocznik. He did not refer directly to the tragic circumstances in which the printed copies of volume III of Rocznik were destroyed (but we know what had happened from his letters to Ludwik Bronarski), ${ }^{259}$ he only mentioned that almost all proofread materials which had been submitted to this volume survived by a stroke of luck. He added that since the condition and number of these texts could be determined, he had arguments which he could present in the discussion on the revival of the journal which he would lead with the representatives of Department of Music at MKiS. Chybiński stressed the fact that the direct link to the earlier periodical would be emphasised thanks to the decision made by the Department. It was supposed to be achieved

256 Chomiński to Chybiński from Warsaw 30 VI 1948, at. APCh.

257 Chybiński to Lissa from Poznań 28 VI 1948, AZL-BUW. Almost twenty years earlier, Chybiński wrote to Ludwik Bronarski, words that have already been quoted in this work: " "Lviv" must simply deliver the largest number of works and I would like to see the whole of Poland in Kwartalnik, see Chybiński to Bronarski from Lviv 3 XI 1929, AACh-BUAM, Bronarski's archive, p. 23.

258 Adolf Chybiński, 'Od Redakcji' [Editorial] (KM 1948/21-22, 7).

259 Even during the war, Chybiński sent short letters with the latest news to Switzerland. For instance, in December 1941 he wrote: 'The Soviet band destroyed volume III of Rocznik Muzyczny in the printing house. There are some proofread sheets left, but not many', see Chybiński to Bronarski from Lviv 14 December 1941, AACh-BUAM, Bronarski's archive, p. 175). 
by appointing him as the chief editor, continuing the numbering, and keeping the same graphic design. The reference to the tradition of the earlier Kwartalnik was also supposed to be to maintain its scholarly character, additionally, however, taking into account current artistic issues (whatever that was supposed to mean) and giving the sociology of music a special place among the considerations. ${ }^{260}$ This, however, seems not to have resulted from the actual preferences of the editor-in-chief, but was only a necessary declaration in the then political realities. ${ }^{261}$

The section 'From the Editors' from the first post-war issue of Kwartalnik was the only editorial that Chybiński selected in those years. 'The editors' signed only under the text 'Ankieta' [Questionnaire], which was addressed to contemporary creators and related to their compositional techniques. And although soon, at the turn of the year 1949 and 1950, the professor led stormy correspondence about the future of the magazine, both with Józef Chomiński, and also with Tadeusz Ochlewski, he was not tempted - as had happened in the year 1933 to make any comment to readers about the suspension of the title. He was too embittered by the situation and felt that he would close the editorial chapter of his professional life forever.

Kwartalnik was typeset in the Cracow printers - PKZG and Graphic Works "Styl." In general, this cooperation was seen as positive, even though there were some technical problems, such as an inadequate number of Brevier fonts, which had a bearing on the layout of individual parts of Kwartalnik and the assignment of texts to these parts. On the other hand, the patience of the printing house was overstretched by the editorial office's sluggishness and authors who were late in sending materials and corrections, sometimes resulting in additional costs and

260 Adolf Chybiński, 'Od Redakcji' (KM 1948/21-22, 9).

261 In the three-year, post-war history of KM only a few texts from the field of sociology of music were issued, mostly unoriginal, written for the need of the editorial staff, but the papers acquired for the publication (Zofia Lissa, Hans Eisler) had been given at the Second International Congress of Composers and Music Critics, which took place in Prague on 20-29 May 1948.

Lissa also understood her first sociological publication in the new Kwartalnik Muzyczny as a 'need of the time.' She summarised the extensive study entitled 'Sociological Aspect in Polish Contemporary Music' with the words: 'These practical, hotly grasped, sociological aspects of our historical day.... Their inclusion in the academic research journal ... I deemed purposeful. They are an expression of the fact that modern music studies cannot, and should not, do without the sociological aspect, imposed on us by today's day' (see Lissa 1948, 143). 
uncomfortable tensions on the Cracow-Warsaw line and warnings addressed to content editors.

On a day-to-day basis, Kwartalnik was subject to the sovereignty of the Press Control Office, the officials of which passed decisions about the allocation of paper or gave permission (or not) to increase the volume in advance (200 pages). ${ }^{262}$ However, the budget of Kwartalnik Muzyczny was the responsibility of MKiS and was granted as 'an allowance' from the Department of Music (and since mid-1948 - the Department of Artistic Creativity); later on, the money was directed to PWM, which dealt with the distribution of fees and other financial issues. The annual subsidy that Kwartalnik received from the Ministry amounted to about three million zloties. In the case of the special 'Chopin' issues, the staff applied for subsidy to the Executive Committee of the Chopin Year, ${ }^{263}$ which was not, however, granted, while the Director of the Executive Committee Office, Edmund Rudnicki (pre-war Music Director at Polish Radio) suggested to apply for a bank loan for this purpose. ${ }^{264}$ The fees were set at 1,500 PLN per one printed page in the size of the so-called 'small eight' (paper size 17x24 cm); on special occasions, such as the preparation of Chopin issues, the editor-in-chief received additional remuneration.

Written to the Ministry, or directly to the Presidium of the Council of Ministers, efforts to procure material resources were imbued with the rhetoric typical of those times, which Zofia Lissa used freely. At the end of the first year of the new edition of the magazine, being able to support the first editions, a request for continued subsidy was made, arguing:

Kwartalnik is the only scholarly journal in Poland devoted to the issues of music. It not only fulfils an important outward propaganda mission, but at the same time it spreads progressive ideological slogans, based on assumptions of Marxist ideas. In view of the outdated research methods based on the prevailing Polish musicology, the editorial staff of Kwartalnik wants to extend its activities in terms of research methodology in order to contribute to the change in attitude amongst senior musicologists and indicate an appropriate development path for music studies for younger scholarly workers. Our

262 The problem with the volume emerged in the first year of the new edition of the magazine when the articles (ten and a half sheets) and other materials printed in small print along with the insert with fragments of Chybiński’s Słownik muzyków [Musicians dictionary] took a total of seventeen sheets.

263 See Chomiński to Rudnicki from Warsaw 11 V 1949, APCh.

264 Rudnicki to Chomiński from Warsaw 25 V 1949, APCh. 
editorial staff, attaching itself to the general ideological mainstream, is convinced that it performs important and useful work. ${ }^{265}$

An edition with 180 pages was planned for the inauguration. The programme of the 'revived' Kwartalnik Muzyczny assumed that - apart from the reference to the magazine's tradition of the pre-war period, at least in the scope of the presented divisions of music writing - it would seek to expand the scope already outlined: 'there ... will be special focus on the current issues of artistic and scholarly musical knowledge ${ }^{266}$ - all in the name of good Polish musical culture.

Soon it turned out that due to several reasons - besides approaching deadlines and the excess of texts in the editorial files and desire for their immediate publication, which led to the expansion of the volume to three hundred pages - the editors had to decide to double the numbering of the first issue of the new edition. ${ }^{267}$ In total, the issue comprised twelve essays and six extensive reports. And, as it turned out, this did not exhaust the editorial resources, contrary to Chybiński's fear that the community would not keep up with delivering new, original material for publication. ${ }^{268}$

Despite a full portfolio, the first shipment to the publishing house in Cracow was delayed and included material that was incomplete. Furthermore, the final arrangement of content was modified during production. Practice showed that this almost always happened, which was very uncomfortable for the production stage (more on the contents of the first and subsequent Kwartalnik issues below) and resulted in a series of tensions between Poznan and Cracow. Even the editorial introduction, although works on the issue started early enough, was revised and supplemented by Chybiński in January 1948.

265 The editors of Kwartalnik Muzyczny to the Presidium of the Council of Ministers from Warsaw 4 XII [1948], APCh.

266 Adolf Chybiński, 'Od Redakcji' (KM 1948/21-22, 9).

267 During winter of the same year, the editorial team was counting on the Ministry's approval on increasing the size of the quarterly. Chomiński wrote to Cracow: 'The Ministry of Culture and Arts wishes the first post-war issue to be bigger than the previous one. Therefore, it will cover the costs of exceeding the volume, see Chomiński to PWM from Warsaw 28 II [1948], APCh. In May it turned out, however, that ultimately the Press Control Office did not allow them to exceed the expected volume of 200 pages. Therefore Dir. Ochlewski decided that a double issue would be printed. In the following months, the situation was saved by the allocation of paper from MKiS, dependent, however, on the authorisation from Central Press, Publication and Performance Control Office on the volume increase.

268 See Chybiński/Chomiński 2016, 47-50. 
At the request of Lissa and Chybiński, printed copies of the first post-war Kwartalnik were sent to a number of official addresses: to the President of the Republic, Vice Minister for Education Eugenia Krasowska, Włodzimierz Michajłow, acting Director of the Department of Science and Higher Education of the Ministry of Education, and to the most important representatives of the academic milieu, including Dean of the Faculty of Humanities of UW Prof. Dr Bogdan Nawroczyński, Prof. Dr Kazimierz Nitsch, President of PAU, Prof. Dr Adam Skałkowski, Dean of the Faculty of Humanities of UP, Prof. Dr Stefan Błachowski, Rector of UP, and also to Zdzisław Jachimecki for a gracious insight ... with a polite request to express his valuable opinion about it [about the first edition] ${ }^{269}$ (we must remember that Jachimecki was formally among the members of the editorial office of the magazine, although like a few other people he did not take an active part in the editorial works). However, when the first issue came out, the journal was not really evaluated by the general public, either due to a low level of activity of the musicological community or to a relatively small press market. It is difficult to find reviews of the new journal and opinions in archived letters are scarce as well. Traditionally, Bronarski did not forget to send his congratulations, ${ }^{270}$ whereas when it comes to other opinions, Chybiński wrote: 'Kwartalnik is generally regarded as impressive, I received a few messages about it. I share these congratulations with you and with Zofia [Lissa]. May we continue to hold such standards. ${ }^{271}$

It seems that all materials, at least those from the first period of works of the editorial staff, passed through the hands and desk of Zofia Lissa, who either accepted them or reviewed them as the person best oriented in the expectations of the state officials - both the Ministry and censorship. At the time, she was one of those persons who were a true bedrock for the professor in the difficult years of the communist regime. Perhaps Lissa, thinking of her scientific career and about developing a new musicological centre in Warsaw, threw the career of some of her colleagues and the functioning of some centres on the scales (one can find little on this matter in the surviving correspondence between members of the then society - and this was one of the main sources of knowledge about facts and events for me), but many of her actions (as leading to the revival of the scholarly journal, or - especially - efforts to maintain musicology at universities) supported post-war Polish musicology. Let us remember that she was not always

269 Chomiński to Jachimecki from Warsaw 30 VI 1948, APCh.

270 Bronarski to Chybiński from Fribourg 6 IX 1948, AACh-BUAM, fol. A-C, p. 130.

271 Chybiński to Chomiński from Zakopane 8 VII 1948, APCh. 
protected by the system and yet she could share the privileges resulting from being one of its links with others. After the war, as a mature and independent scholar, in her creative prime and with a strong position within the office and institutional structures, she could ignore her former teacher and even hamper his activities (and she had the instruments to do so) - she had to, after all, know and remember his unfriendly attitude towards the directions and methodologies to which she devoted herself in musicological research from the very beginning of her academic path. In the years occupied with re-building the entire discipline, strained due to wartime damages, along with other pupils of Chybiński she formed the second generation of Polish musicology, which soon began to replace the departing seniors and gave the shape to the university studies of music for the decades to come. Throughout the final periods of the professor's life, just like other students, she confirmed his belief of his indisputable authority and the leading role within the community, and she exercised absolute necessity to consult with him on all - both important and less important - issues as well as both professional and - often - private matters. This was also the case when it comes to the works of the editorial staff of Kwartalnik - nominally remaining a mere 'foot soldier', one of the members of the journal's Editorial Board, she in fact served as the 'power behind the throne' and played a crucial role in the daily work of the editors, as well as in key and behind-the-scenes activities in the most important moments, such as efforts to obtain funding, acquiring 'politically correct' texts, negotiating with departmental 'factors' on the terms and conditions for the editorial's existence.

Chomiński's and Chybiński's roles in the daily works of Kwartalnik were obvious and clear. They shared among themselves the content and linguistic editing of incoming materials, sometimes only asking someone from the members of the editorial board for additional opinions. In the beginning, their publications were, traditionally, of a twofold character: scholarly articles and reports (or, as it was called back then, papers) - from books and current events, both scholarly and propaganda. Already, however in the first year - in editions 23, 24 - and in 25 from the following year, the practice was established of adding presentations by Polish and foreign musicologists, which had taken place during national and international meetings and conventions of musicalmusicological environments, to the contents of the edition; a matter dictated by pure opportunism. In addition, a bibliography of Polish and European music literature was systematically presented, supplementing current information on missing years, starting from 1939. In February 1948, so during the work on the first post-war edition, Chybiński wrote that he had the thought of 'the necessity of creating a separate section "Materials to the history of music in Poland" 
(sporadic and petite!) in Kwartalnik Muzyczny. This can always be useful. Even trifles are sometimes useful after some time....272 This, however, was not a new idea. Already in the first number of Kwartalnik, in the year 1928, a section was chosen 'Materiały historyczne' [Historical materials], in which the editor-inchief himself published a series of extracts from Józef Sikorski's notebooks on the Polish musical baroque, and Feliks Starczewski brought closer a publication from the pages of Pamiętnik Muzyczny Warszawski from 1836 in which there had been talk of 'the first beginnings of methods of musicalisation.'273

Despite the efforts to adjust to the expectations of the department in terms of both form and content, the fate of Kwartalnik was still uncertain. The system's main decision-makers questioned the legitimacy of the existence of a scholarly journal in a pre-war formula ('A few days ago minister Sokorski asked a question whether Kwartalnik Muzyczny is indeed necessary. But he was persuaded that it in fact is. For now, we have peace of mind' - wrote Chomiński ${ }^{274}$ ). The professor had only one answer to this: 'for the next year I expect the renewal of... Rocznik Muzykologiczny because we need to have our own organ, even despite the possible collapse of Kwartalnik Muzyczny.275 A special issue, dedicated to Chopin, named for the Chopin Year and prepared in connection with the celebration of the centenary of the composer's death, was supposed to be a lifeline for the editorial staff. But the success of those works, namely the issue $26 / 27$, which was doubled due to the abundance of collected materials, and another - 28 - in which other texts were included, did not help. Working in an atmosphere of constant threat of closure of the magazine increasingly frustrated the professor, who wrote: 'I have some data that before obtaining grants for Kwartalnik Muzyczny in 1950 we will be requested to develop an ideological article, such as the one from the upcoming Ruch! Thus, we will include it in edition I 1950. Who will write it? For a second I had a thought of resigning from serving as the editor-in-chief. ${ }^{276}$

In the early autumn of 1949 , it was already known that from January of the following year the title would go under the care of the newly appointed PIS, ${ }^{277}$

272 Chybiński/Chomiński 2016, 68.

273 KM 1928/1, 82-86.

274 Chybiński/Chomiński 2016, 159.

275 Chybiński/Chomiński 2016, 161.

276 Chybiński/Chomiński 2016, 174-175.

277 Although PIS was officially appointed on 30 XI 1949, Chomiński reported on the plans of the future authorities of the Institute concerning Kwartalnik already in September of that year, see Chybiński/Chomiński 2016, 203-205. 
while the predictions regarding the status of the current editorial office were unclear. Chomiński proposed 'either write when they invite and earn, and do not get involved in editing, or do not write, but this must be a "strike" by the whole group, so that nobody would violate it. Only Krzysia [Wilkowska-Chomińska] is afraid that then, for sabotage, they can shove everyone away from everything they have a great desire for. ${ }^{278}$ At that time, amongst members of the editorial staff in Warsaw there was an idea to resurrect the annals: 'Ms Zofia Lissa will in those days address the Ministry of Education with the aim of resuming Polski Rocznik Muzykologiczny or even creating Kwartalnik Muzykologiczny. The editorial staff would, of course, remain the same as in the current Kwartalnik. Thus, we would change only the company, ${ }^{279}$ preparing for a more scholarly journal. ${ }^{280}$ Chybiński was positively inclined towards the idea of reactivating the yearbook, though he definitely refused taking over the 'editorship.'

Meanwhile, however, the new PIS authorities were planning to take over the editorial portfolio in order to verify and assess ${ }^{281}$ it. Chybiński wanted to protect all the texts that he regarded valuable (completion of studies on the works of Mikołaj Radomski by Maria Szczepańska and Chopinological articles by Krystyna Wilkowska-Chomińska, Józef Chomiński and Jan Prosnak - with some reservations - František Zagiba) from an uncertain fate by attaching them to editions prepared at that time - the second Chopin edition and another one, scheduled for 1950. The few remaining works (for example, Jurij Kremlew on Soviet musical aesthetic issues), he was determined to give 'to the new Kwartalnik.'

Soon, there were also rumours about the plans of the future Vice-Director of PIS, ethnographer and art historian Aleksander Jackowski regarding the publication of the musicological yearbook. At that moment, however, they did not have a firm basis, because it soon turned out that, despite the necessity of directing all 'quarterly' texts to Cracow via PIS ${ }^{282}$ which caused great difficulties for the

278 Chybiński/Chomiński 2016, 217-219.

279 At this juncture we should remember that Kwartalnik Muzyczny was a title belonging to MKiS.

280 Chybiński/Chomiński 2016, 217-219.

281 Chybiński/Chomiński 2016, 222-223.

282 Chomiński informed the professor about the principles established with the director of the Institute: 'I had a conference with Mr Jackowski with the matter of Kwartalnik at the top of the agenda and planned publications of the Art Institute. And so, without his acceptance, we are not allowed to print any work in Kwartalnik; therefore, all materials will first go to the Art Institute, and then to PWM. However, I reserved the right to jointly discuss work from a professional standpoint, for which Mr Jackowski agreed,' see Chomiński/Chybiński 2016, 243-244. 
fluency of the editorial work, but there were still certain perspectives for the magazine in the formula it had had to date. For example, after the conference of music composers and critics in Łagów Lubuski, MKiS awaited the publication of the 'Łagów' edition, but this was abandoned in late autumn. However, the year 1950 gave another, after Chopin, anniversary opportunity, but this time, with the thinness of the Polish musicological milieu, it was much more difficult to implement: the Ministry of Culture and Art and its minister, Włodzimierz Sokorski, awaited a special 'Bach' publication on the bicentenary of the death of Leipzig cantor. Furthermore, it was agreed with the management of PIS to make a double issue - the second and third in a year. Chybiński's comment on this situation was clear: 'I was dumbfounded, and I fainted etc.'283 'Maybe Bronarski would give an article "Bach and Chopin" - that would be something.... "Bach and Poland" maybe? Why not? One can write works such as "Bach and the elephant," "Bach and the sardine," "Poland and the Egyptian pyramids" etc. Anything can be done. Who knows, maybe I will take to the topic "Bach's Polonaise." But please do not hold on to my words. ${ }^{284}$

A few weeks later, the official agents also resigned from the 'Bach' issue because there was a new order - in connection with the upcoming Science Congress it was expected from the editorial staff to issue a 'methodological' edition ('from a Marxist point of view'). ${ }^{285}$ This project was even more risky than the Bach theme. Chybiński admitted that he did not know anyone who could honestly and wisely write about Marxism in music, and in the middle of the year Chomiński openly resigned from further efforts to organise this edition. The actual lack of willingness of PIS to cooperate with the editorial team was confirmed by other experience in this field, when the print-ready materials for the second Chopin sheet were made to wait 'for stamping' by director Jackowski for over a month. The Institute also planned to replace the man serving as the editor of Kwartalnik - it wanted to appoint Stefan Jarociński, one of the new employees of PIS engaged in running the Music Section.

In addition, it seemed that PWM was no longer interested in Kwartalnik, due to constant publishing problems and increasing delays in printing. Although the preliminaries for the 1950 edition were finally approved in July, and in August

283 Chybiński to Ochlewski from Poznań 17 I 1950, AACh-BUAM, Ochlewski’s archive, p. 73.

284 Chybiński/Chomiński 2016, 246-247.

285 Chybiński/Chomiński 2016, 262-263. 
Chomiński began to organise materials for the next edition $(31 / 32){ }^{286}$ it was an unfavourable atmosphere for academia in general (and the threat to musicology through being transferred to PWSM structures in particular), prolonged proofreading of outstanding editions and personal tensions between the centres led to the final decision to close the title and new plans in PIS at the end of 1950: 'Kwartalnik ended its life properly with the second volume of the Chopin edition. Indeed, there will be another double edition for the current year, but there are, among others, works that fundamentally deviate from the level it has been to date. Instead of Kwartalnik, PIS intends to publish some discussion material. Mrs Zofia Lissa has informed me that they want to draw me into these discussions. ${ }^{287}$

The tight circle of people connected with Kwartalnik - Chybiński, Chomiński, Ochlewski - wanted to lead the annal to the end of 1950, that is, the issue of the last, double edition, which did not succeed.

Meanwhile, in Warsaw, there were ongoing works on the announced yearbook which was to be an organ of PIS. This had already sparked controversy between the editor-in-chief and editorial assistant, the details of which will be described in chapter V. It should be emphasised, however, that this was the first misunderstanding between the master and his disciple. Throughout the years, starting from the Lviv period, up to that moment, relations between them were exceptional, which can be found in the surviving correspondence. The first preserved letters from Werchrata, where Chomiński and his family spent a large part of the time following his graduation, come from the year 1933. Nonetheless, it is probable that the new graduate of the Lviv department of musicology had been writing to the professor much earlier. At that time, he sought advice on matters both of academic and private nature - it can be seen that the tutor was a great authority for the aspiring musicologist. From the very first letter to the last

286 Łobaczewska was to write a work about the romantic scherzo, Chybiński for some time now had planned to present the systematics of musicology, Stanisław Golachowski prepared material about Szymanowski's relationship to folk music, Szczepańska’s research about Mikołaj z Radomia was still incomplete, Chybiński’s was working on John Stuart Mill's views on the music penned by the historian and philosopher, and also the student of Poznańs musicology, Waldemar Voisé, under pressure from Warsaw, Olga Łada's text was to be published, both editors considered publishing Chomińskis dissertation in Kwartalnik, and the professor also saw the possibility of offering some of his students' dissertations for publication, but only in the future.

287 Chybiński/Chomiński 2016, 295. 
surviving one from 1951, each began with the words 'Most Reverend Professor', 'Honourable..., 'Venerable and dear..., 'Dear...' - the student never passed the barrier, which - as he thought ${ }^{288}$ - should 'protect' him against the temptation to become over-familiar with the professor.

After the outbreak of war, Chybiński remained in touch with Chomiński until the spring of 1940 - the last letter from period comes from 25 March. It was sent from Przemyśl and stored in Chybiński’s archives in BJ. Upon reconstructing Chybiński's wartime fate based on two biographies written by himself, Maciej Goląb mentions the particularly dramatic first months of the occupation, filled with forced labour and the loss of his wife who was deported to the Ravensbrück camp. ${ }^{289} \mathrm{He}$ survived the following years in Warsaw, where he married for a second time, and where he re-established contact with Jan Józef Dunicz, Tadeusz Ochlewski and perhaps other members of the former SMDM. Indeed, during the first weeks of post-war freedom, he sent the professor up-to-date news from Międzyborów, where he lived after the war.

Already during Chomiński's studies at UJK, Chybiński regarded him as a 'wildly talented man' and one of his best students, although he regretted that he was not a Pole but 'Rusyn. ${ }^{.290}$ Chomiński, at the time, was already extremely devoted to his promoter and mentor. Despite the fact that he was an outstanding graduate, he could not count on employment at the Institute after obtaining a master's degree in 1931 or a doctorate just five years later (on account of the small allocation of posts for musicology). Shortly before the war, he managed to get a permanent place of work in the National Library thanks to the support and protection of the professor in the group gathered around SMDM.

288 He wrote about it in one of his letters, perhaps in response to an invitation from the professor to break the rigid conventions: 'In the first place I want to assure you, Sir Professor, that all titles which I have used so far were not just an ordinary convention, but the sheer need of the heart and an expression of deep reverence and respect which I have for you as a person and an authority. I am very moved by your decision, Sir Professor, but please believe me that I personally could not dare to call you a colleague, being aware that currently neither my knowledge nor my academic achievements, which, to tell the truth, are more than negligible, may not constitute grounds for any comparisons. In any case, I promise to work steadfastly and best to my modest abilities so that the kindness and sympathy, which you have for me, Sir Professor, can still find their justification,' see Chomiński to Chybińsk from Werchrata 11 VIII 1936, AACh-BJ, box 5, C-10/12.

289 Gołąb 2008, 36 ff.

290 Chybiński to Bronarski from Lviv 3 X 1932, AACh-BUAM, Bronarski’s archive, p. 81. 
After the war, in autumn of 1945, Chybiński proposed to Chomiński to take over as assistant-volunteer at the reactivated Poznan musicology, to which Chomiński probably would have agreed if not for family responsibilities and the need to address normal, everyday needs. The professor, thanks to his prominent position within the artists' and scholars' community in Poznań, could recommend his pupil also to the team of educators at the Poznan conservatoire. $\mathrm{He}$ also helped establish contact regarding possible employment, this time with the authorities of Poznań Academy of Music. ${ }^{291}$ In response to this, in October 1945, Józef Chomiński volunteered to work as a professor of theory at the Faculty of Education of this artistic university, despite the distance from Warsaw, in the vicinity of which he had lived at that time. Unfortunately, it soon became apparent that his health reasons prevented him from fulfilling his responsibilities. ${ }^{292}$ Perhaps, at that time he was not exactly interested in working in artistic education, seeing his future within the musicologist environment, rather than music.

In the first months after the war, Chominski was also nominated by the professor as a member of the 'theoretical section,' which dealt with, among others, developing a curriculum of theoretical subjects in music education and providing a set of textbooks for this purpose under the aegis of MKiS in cooperation with PWM. ${ }^{293}$ At that time a harmony handbook project was developed with an aim to serve as 'continuation' of Sikorski's handbook and "dereference" the new gains from the enormous material following 1910,294 and a music forms handbook, wherein the content was to be distributed for development between Hieronim Feicht (rondo and forms of Church music), Stefania Łobaczewska (variations, sonata and the theoretical part of the book) and Józef Chomiński (solo song, cantata, opera, drama, evolutionary figurative forms). ${ }^{295}$ Unfortunately, in this case, he could not fulfil all of these commitments adequately due to the above-mentioned health problems. He had been informing the professor about this on an ongoing basis upon discussing the progress of papers submitted to the section meetings and other works ordered. ${ }^{296}$

291 Chybiński/Chomiński 2016, 1.

292 We know that Chomiński, who was commuting from Warsaw, was not able to cope with those obligations due to worsening health problems (developing tuberculosis).

293 Janusz Miketta presented the goals and tasks of this and other ministerial committees in a short report on music education in Poland in the pages of the first post-war edition of KM (1948/21-22, 269-275).

294 Chybiński/Chomiński 2016, 4-5.

295 Chybiński/Chomiński 2016, 9-10.

296 One of the results of cooperation with the said section was a book entitled Metodyka nauczania form muzycznych $w$ średnich szkołach muzycznych [Method for teaching 
The whole time he worked on several open projects. Nearly one year's stay at the Swiss sanatorium in Leysin allowed him to continue his work on Metodyka nauczania form muzycznych $w$ średnich szkołach muzycznych [Methodology of teaching musical forms in secondary music schools] ${ }^{297}$, the idea was to prepare the first volume of Harmonia ('Podstawy harmoniki funkcyjnej' [The basics of functional harmony]), Zarys harmonii nowoczesnej [Overview of contemporary harmony], Zarys ogólnej teorii muzyki jako wstępu do teorii harmonii i kontrapunktu oraz do teorii formy muzycznej [Overview of general music theory as an introduction to theory of harmony and counterpoint and theory of musical form], participation in Witold Rudziński's project for an Historyczny atlas muzyczny (wiek XII-XV) [Historical atlas of music (XII-XV centuries)], Teoria potencjatu harmonicznego [Theory of the potential of harmony], he started work on analysing Chopin's Preludes ${ }^{298}$ and wrote systematically to Chybiński ${ }^{299}$ about all of these projects.

The proposal to take over as Editorial Assistant, which Lissa had for Chomiński in connection with reactivation of Kwartalnik Muzyczny delighted Chybiński for it allowed him to enter the history of Polish music periodical press not only as an author but also as an editor. Chomiński totally engaged himself in his new tasks even though - as mentioned before - he initially had doubts whether he would be able to fulfil the tasks entrusted to him sufficiently. Practice has shown that he coped extremely well with work organisation and proved to be worthy of his scholarly renown. Over time, it turned out that due to adverse rulings of PIS authorities regarding the fate of Kwartalnik, the Warsaw part of the editorial staff (mainly Chomiński, but without Lissa who was busy developing musicology in

musical form in music secondary schools] (Cracow 1946). As for the objectives which the Theoretical Commission set for itself, Chomiński had substantial doubts (evident to any musicologist) in line with the age-old debate whether the theoretical-musical expertise should be the domain of universities and conservatoires: 'during the forum there came out this difficult matter of theory as a main subject in [music] university, which was presented not as a problem but as a principle. This approach resulted in almost insurmountable difficulties: for how can you reconcile the objective of a professional art school with the subject of a theory that should be understood literally, not in the sense of normative science, namely musical expertise?', see Chybiński/Chomiński 2016, 8-9.

297 Cracow 1946.

298 Analizy i objaśnienia dzieł wszystkich Fryderyka Chopina, vol. 9 Preludia [Analysis and explanation of Frederic Chopin’s complete works, vol. 9 Preludes] ed. Józef Chomiński, Cracow 1950.

299 See for example, Chybiński/Chomiński 2016, 13-15, 22-23. 
Warsaw at the time) undertook a project related to the plans of PIS - the launch of a scientific journal (alongside the popular monthly), published irregularly.

Chybiński did not accept either the proposed title of the new magazine/series (he deemed both Muzykologia Polska and Studia Muzykologiczne pretentious and imprecise) or the fact that it would be an organ of the Warsaw Institute. He felt that decisions made beyond him and pushing him to the margins of editorial activities were highly unfavourable for him (which can be deduced from his correspondence with both his former pupil and a few trusted people - Ochlewski, Bronarski, Miketta). This situation sealed his plans to conclude the long-term period of editorial work, signalled by the Lviv professor already in the past. 


\section{Authors and subjects as well as concepts, problems and work methods - continuation of the pre-war work - around the current issues of musical socialist realism - thematic projects}

In the editorial which inaugurated the post-war edition of Kwartalnik Muzyczny, AdolfChybiński briefly described the history of the journal, which started in 1928. He reminded the readers of evolutionary changes which took place after 1933, when two new titles, namely Muzyka Polska and Polski Rocznik Muzykologiczny, emerged. He regarded the establishment of a journal which would continue the mission of Muzyka Polska as an 'urgent need.' This mission focused on making readers familiar with notions related to broadly defined music culture, which included both current events in the music and musicological community and the promotion of knowledge about music. At the same time, he emphasised the importance of the fact for propagating musical culture and learning about music, that Ruch Muzyczny was brought into being as an 'organ of the Polish musical world' and 'gave and continues to give its pages to publish works, which in fact go beyond its proper scope, and works which are sometimes very extensive, not mentioning their academic nature. ${ }^{300}$ Finally, he determined programme assumptions which the new/old editorial team was supposed to follow: 'all sections of music literature will be represented in the new Kwartalnik, just like they used to be represented in the old one. From the very beginning, the Editorial Board will also strive to expand their scope .... It will not stand in the way of adopting a favourable attitude towards all the factors of the new music thought, regardless of its origin, given that it has productive value for our music needs. That's why, depending on current needs, we will also take up issues related to music sociology. It seems self-explanatory to me that the good of Polish music culture will be of utmost importance in our editorial programme. ${ }^{301}$

The programme so formulated by Chybiński resulted from previous arrangements that were made in the editorial team during preparations for the

300 Adolf Chybiński, 'Od Redakcji' [Editorial] (KM 1948/21-22, 7).

301 Ibid., 9-10. 
first post-war edition of Kwartalnik. At the beginning of December 1947, Józef Chomiński had a 'conference' with Zofia Lissa; he related the meeting thusly:

Ms Lissa has presented a general overview of her plan to me, stressing the topicality of contents. Because of that, I was told to make contact with Slavic music centres (in the USSR, Czechoslovakia, Yugoslavia, and Bulgaria) to ensure cooperation with foreign musicologists and musicians, only Slavs for the time being. ... Each issue should contain a paper on Polish music written by some Slavic musicologist or musician (someone from abroad) or a paper written by a Pole about Slavic music (the section can be chosen freely) or finally a paper written on Slavic music (but not Polish music) by a Slav from abroad. ... I was also told to ensure that no issue is dominated by historical papers, especially those about distant epochs.'302

Chybiński, who agreed with Lissa's programme in terms of the general direction' of the new magazine as a very ambitious publication had doubts as to whether there would be any space in the magazine for historical articles which had traditionally taken up the majority of space in the pre-war Kwartalnik. He had an alternative idea about which he wrote: 'It seems to me that historical papers will have to come out mostly in publications issued by the PAU or other scientific societies. (The society from Poznan is at my disposal, and the PAU more or less). My paper on Jacek Różycki (who died ca. 1700) will be published by the WTM at the request of this society. ${ }^{303}$ Fortunately, there was no such separation and, as it soon turned out, the editorial office, based mainly on the work of the authors hailing from schools built on assumptions of Adler-type musicology, was able to successfully defend itself for a time against the 'novelties' and publications based on the dialectical materialism applicable in historical and social sciences at that time.

Finally, the first edition was to include the pre-war texts by Ludwik Bronarski ${ }^{304}$ and the study by Józef Chomiński, ${ }^{305}$ for which Chybiński gained the agreement of the authors, as well as the dissertation by Father Hieronim Feicht. ${ }^{306}$ In addition,

302 Chybiński/Chomiński 2016, 37-38.

303 Chybiński/Chomiński 2016, 40.

304 Chybiński used two contributions from Bronarski from before 1939: 'Dwa nieznane utwory Chopina’ [Two unknown works by Chopin] (KM 1948/21-22, 60-66) and 'Mazurek Chopina poświęcony E. Gaillard' [Chopin's Mazurkas dedicated to E. Gaillard] (KM 1948/21-22, 67-74).

305 'Studia nad twórczością K. Szymanowskiego'[Studies on K. Szymanowskis creative work] part II: 'Zagadnienia konstrukcyjne w sonatach fortepianowych' [Structural issues in the piano sonatas] (KM 1948/21-22, 170-207, 1948/23, 102-157).

306 'Ronda Fryderyka Chopina' [Frederic Chopin's Rondos] (KM 1948/21-22, 35-59, 1948/23, 23-62, 1948/24, 7-54). 
he also turned to other trusted pupils and colleagues for new works: this time to Stefania Łobaczewska, ${ }^{307}$ Bronisław Romaniszyn ${ }^{308}$ and Janusz Miketta; ${ }^{309}$ Zofia Lissa ${ }^{310}$ also joined the group of authors; however, Marian Sobieski did not send the expected article about mazurkas. What we know is that the professor had one more paper, which he referred to as posthumous. It was most probably 'Zagadnienia i zadania historii muzyki' (Issues and tasks of the history of music) written by the late Julian Pulikowski, a musicologist whose behaviour towards the occupier during the war was regarded very critically. There were also many controversial opinions on Pulikowski which were echoed in Poland at that time. Under these circumstances, Chybiński decided not to use the text which he had kept for many years. Instead, he decided to open his journal to new authors. The above-mentioned group of authors who cooperated with post-war Kwartalnik was joined by Konstanty Régamey ${ }^{311}$ and permanently resident in Switzerland, Zygmunt Estreicher ${ }^{312}$ (who on several occasions proved helpful in collecting materials for the bibliography of European musical literature included in the post-war editions), and also the promising (also in the eyes of the Lviv professor) students of Cracow musicology, Włodzimierz Poźniak ${ }^{313}$ and - as authors of the report - Stanisław Golachowski, Krystyna Wilkowska and Stefan Szuman. Chybiński, as editor-in-chief, considered it appropriate to start the new edition of the journal not only with an editorial prepared by himself but also with his own article. ${ }^{314}$ However, did not gain the editorial's acceptance of the article on the music to Goethe's poem Mignon ('Kennst du das Land', and the translation of Mickiewicz's Do $H^{* * *}$ ) sent by Zdzisław Jachimecki.

307 'O zadaniach i metodzie monografii muzycznej' [About the tasks and methods of musical monographs] (KM 1948/21-22, 144-169).

308 'Technika wokalna wobec środków muzyki mechanicznej' ['Vocal Technique in Relation to Mechanical Musical Means'] (KM 1948/21-22, 252-268).

309 Report on the subject of 'Szkolnictwo muzyczne w Polsce (1945-1948)' [Musical education in Poland (1945-1948)'] (KM 1948/21-22, 269-275).

310 'Aspekt socjologiczny w polskiej muzyce współczesnej' [The sociological aspect in contemporary Polish music] (KM 1948/21-22, 104-143).

311 'Próba analizy ewolucji w sztuce' [An attempt at analysis of evolution in art] (KM 1948/21-22, 75-103).

312 'Teoria dwutonowych melodii' [Theory of two-tone melodies] (KM 1948/21-22, 208-233).

313 'Niezrealizowane projekty operowe Moniuszki' [Moniuszko's unrealised opera projects] (KM 1948/21-22, 234-256).

314 'Wacław z Szamotuł (XVI w.)' [Wacław of Szamotuły (XVI century)] (KM 1948/21-22, 11-34, and the continuation: 1948/23, 7-22, 1948/24, 100-131). 
Just like all his earlier works, Chybiński's paper on Wacław of Szamotuły was based on the classic German methodology of historical research on music. The author started from an overview of musical life in sixteenth-century Cracow, as well as the presence and activity of other musicians who belonged to the royal band. The life and art of Wacław were presented from the perspective of his relationship with this band. Then Chybiński moved on to briefly present the works of the composer, starting from the first known music publication from Cracow, Lamentationes..., which was published by the printing house of Łazarz Andrysowicz in 1553. Then he discussed further achievements of the brilliant musician from Cracow. Upon preparing a detailed sketch of the character and work of Szamotulczyk, Chybiński referred to the earlier works about him and the music of his circle, including the only monograph published in 1935 by Henryk Przybylski, a tireless researcher of the history of Szamotuly. In the course of writing the article (in the section 'Sprostowania i uzupełnienia' [Rectification and additions] to his article), the author could refer to information given to him at the time by Przybylski. This concerned correction of Wacław's dates of birth and death: the presumed birth year of 1529 given earlier by Przybylski was changed to four years later, and as for the moment of death, Chybiński agreed to the turn of the year 1567-1568. He regarded these new arrangements as revelations which he forecasted in his letter to Chomiński. ${ }^{315} \mathrm{~A}$ complete novelty in the arrangements made by Przybylski, who was not a music historian and most probably was not sensitive to the issue of compositional output, was the fact that the professor supplemented the list of compositions with the motet entitled Nunc scio vere.

Materials collected for Wacław's monograph and the jubilee occasion of the 400th anniversary of birth of the poet and musician allowed Chybiński to write a few more contributions of a popularising character, while the quarterly text can be treated as the last original thesis of such calibre to come from under his pen: published in 1949 by PWM, the extensive monograph Mieczysław Karłowicz (1876-1909). Kronika życia artysty i taternika [Mieczysław Karłowicz (1876-1909). Chronicle of the life of the artist and mountaineer] had a long history, the hardships of collecting the documentation and the writing itself were repeatedly reported by the professor in letters to friends back in the 1930s, but he had no time to prepare it for publication before the war. He did not manage to finish the second part of his work, devoted to the composer's legacy, before the

315 Chybiński/Chomiński 2016, 84-86. This information is no longer current. For the dates of Wacław of Szamotuły's life generally accepted are circa 1524-circa 1560. 
end of his life. At the beginning of 1951, when the fate of Kwartalnik had already been sealed, Chybiński prepared one more text, 'Murky', but it was just a small introductory article which was finally published in the monthly Muzyka. ${ }^{316}$

However, for the first edition of the studies the professor did not make use of materials he had from his earlier reserves; he extended the deadline for the typed copy of Maria Szczepańska’s dissertation about Mikołaj z Radomia by several months in order to give her time to put the final touches to the text and arguments. This work had a long history: due to its large size it was not accepted by Chybiński at the moment of inception, at the time when the professor was head of the second Kwartalnik, and then had to wait a few years to be printed. The situation changed with the opening of $\mathrm{PRM}^{317}$ when the first part of the monograph - 'Introduction' - was prepared for release. The next part was planned for the third volume of the annual, ${ }^{318}$ the circulation of which, as it is known, was not printed because of the dramatic events of the first days of the war. After the break caused by the war, Szczepańska apparently needed some more time to prepare her paper, and in late spring 1948 she was still busy 'finishing Mikołaj. ${ }^{319}$ Finally, 'Studia o utworach Mikołaja Radomskiego (Wiek XV)' [Studies on the works of Mikołaj Radomski (15th century)] was published in parts - at the end of 1948 together with the edition closing the history of Kwartalnik, ${ }^{320}$ and was characterised, like all the earlier publications by this author, by the extraordinary academic detail, diligence and logic of the discussion presented learned in the Lviv musicological school. Apart from Chybiński’s studies on Wacław of Szamotuly, these were the only examples of publications in the field of early Polish music in the pages of the post-war edition of the magazine. ${ }^{321}$

This time, Old Polish materials were completely dominated by publications on different topics. Three contributions devoted to Chopin which came out in the first issue of the new edition confirmed Chybiński's belief, which he had

\section{$3161951 / 8,26-27$.}

317 For this subject see for example, Sieradz 2011, Sieradz 2012/2.

318 Chybiński to Bronarski from Lviv 22 I 1938, AACh-BUAM, Bronarski’s archive, p. 167.

319 Chybiński/Chomiński 2016, 76-77.

320 KM 1949/25 7-54, 1950/29-30, 64-83. The first part, in addition to chapter I, II and III, also contained an introduction, almost exactly reprinted from the pre-war publication. The second part contained the fourth and last chapter.

321 As mentioned in chapter III-2 and III-3, the editorial office were advised to take care that 'there was no excess of historical works - especially from distant ages', Chybiński/ Chomiński 2016, 37-38. 
voiced many years before, that Kwartalnik should first and foremost promote the cult of Chopin. The Chopin Year was drawing near. Private talks on celebrating it had already been held during the war, yet the Professor did not want to delay the publication of papers on Chopin which he had at his disposal. He believed that they were the most valuable materials, especially because two of these texts were signed by Bronarski, an outstanding Chopinologist who had supported the editorial team for many years by submitting his articles for publication, whereas the third text presented the result of research conducted by Father Hieronim Feicht, mostly in the 1940s. Although, as he said in a statement on a Polish Radio programme, he dedicated (only) two dissertations to Chopin, ${ }^{322}$ and indeed it is one of them, published in three subsequent editions of Kwartalnik 'Ronda Fryderyka Chopina' [Frederic Chopin's rondos], ${ }^{323}$ which two years earlier had been the foundation for his habilitation thesis. ${ }^{324}$ First and foremost, however, his speciality was 'early pre-Chopin Polish music.' ${ }^{325}$ He proved this many times in the following years of his academic work, dealing almost exclusively with the music of the Polish musical Middle Ages, Renaissance and Baroque. However, for Kwartalnik he had already prepared two reviews - of Włodzimierz Poźniak’s ${ }^{326}$ Pasja chorałowa w Polsce [Chorale passions in Poland] and Études sur Chopin by Ludwik Bronarski. ${ }^{327}$ In addition, he was also the author of one the papers published in Kwartalnik which had been presented at the first Congress of Polish Musicologists, which took place in Warsaw on 18 and 19 November $1948 .{ }^{328}$

Themes related to Chopin were the essence of Ludwik Bronarski's research. Before the war, the author from Fribourg gave Chybiński over ten articles and introductory articles, as well as numerous reviews of literature on Chopin. As has already been said, during the war, two of these texts were stored in the

322 Quotation after: Kałamarz 2012, 13, see footnote 1.

323 KM 1948/21-22, 35-59, 1948/23, 23-62, 1948/24, 7-54.

324 The second of these dissertations was published more than a decade later 'Dwa cykle wariacyjne na temat “Der Schweizerbuba” F. Chopina i J.F. Marcksa' [Two variation cycles on the subject 'Der Schweizerbub' by F. Chopin and J.F. Marcks] (in: F.F. Chopin, edited by Zofia Lissa, Warsaw 1960, 56-78). Feicht was also the author of several articles popularising the figure and work of Chopin, including in the pages of Zwierciadło (a supplement to Wroclaw's Słowo Polskie) and RM.

325 Kałamarz 2012, 15.

326 KM 1948/21-22, 282-285.

327 KM 1948/23, 177-182.

328 Hieronim Feicht, 'Wznowienie koncertów poświęconych muzyce dawnej' [Resumption of concerts dedicated to Early music] (KM 1949/25, 232-236). 
Professor's home archive. When reading them, ${ }^{329}$ particularly the first one about Chopin's two unknown works, we can clearly see that after years the editors did not interfere to the slightest extent in the corrected versions of texts that have survived from the pre-war third volume of PRM. The first sentence from this text is as follows: 'The Library of the Conservatoire ... in Paris has a collection of Chopin's manuscripts which include two compositions that were unknown until today and which are published here for the first time. ${ }^{330}$ In the meantime, the Nocturne c-minor and Largo E flat-major were published by TWMP in 1938. As can be seen, neither the editorial team nor the author considered it appropriate to correct this misleading information and add an explanatory footnote to the title. Irrespective of that fact, Bronarski remained the one who discovered these small compositions by Chopin. The announcement in Kwartalnik includes their detailed description. The second article voiced an opinion in the discussion about another 'trifle' left by Chopin, the Mazurka in a minor, which used to be called 'posthumous' and which was numbered Op. 42A. In his short introductory article, Bronarski endeavoured to reconstruct the chronology of its composition and edition, elevate this work and find the right place for it in the whole musical output of the master.

Bronarski who, due to his artistic, professional and scientific duties, was unable to provide the editorial office with as many materials as in previous years, was absolutely taken by the professor's words: 'I am utterly grateful for the honourable invitation [to] participate as an "articulist" in the Chopin booklet of Kwartalnik. I dare not refuse, especially to you, Sir Professor; but I do not dare to make any promises. If I am able, I will send a contribution with the greatest pleasure. ${ }^{331}$ For the requirements of the jubilee number, he assigned two articles - appropriate for the title of the edition: one 'from life' and one 'from creative work.' 332 The first one was quite literally related to the 100th anniversary of the composer's death. The aim was to solve issues related not so much to the worldly life, but rather circumstances related to procedures undertaken after Chopin's death, including the legends and myths related to opening the composer's body

329 See above footnote 304.

330 Ludwik Bronarski, 'Dwa nieznane..., op. cit., 60.

331 Bronarski to Chybiński from Fribourg 6 IX 1948, AACh-BUAM, fol. A-C, p. 129.

332 'Z ostatnich dni ziemskiej pielgrzymki Chopina' [From the last days of Chopin's earthly pilgrimage] (KM 1949/26-27, 7-14), and 'Sekstola w muzyce Chopina' [Sextuplets in Chopin's Music] (KM 1949/26-27, 95-101). Both Chopin volumes of Kwartalnik had the subtitle ' $Z$ życia i twórczości Fryderyka Chopina' [From the life and creativity of Frederic Chopin]. 
and sprinkling Polish soil over his grave. The second text, with the title resembling Bronisław Wójcik-Keuprulian's contribution O trioli w mazurkach Chopina [On triplets in Chopin's Mazurkas] published in the first memorial book for Chybiński, ${ }^{33}$ was not intended to be a continuation of the topic undertaken by the her, but an original consideration of potential ways of interpretation of this figure by the composer supported by various examples.

Moreover, after Chybiński’s death, Ludwik Bronarski kept in touch with Polish musicologists and sent results of his Chopinological research, for example, to the editors of Rocznik Chopinowski founded by the TiFC, several times. ${ }^{334}$

The fruit of many years of work, which had started in the first half of the 1940s, was the essay on the history of contemporary music prepared by Konstanty Régamey. The author wanted to publish its first part, entitled 'Próba analizy ewolucji w sztuce' (An attempt to analyze the evolution in art), in Kwartalnik. Régamey, who was a composer and a music publicist, but also (mostly after the war) an Indologist and a linguist, wrote most of his Polish language articles, polemics, introductory articles and critical reviews before the war. ${ }^{335}$ First and foremost he published in the pages of Muzyka Polska (of which, we should remember he was editor-in-chief in the years 1937-39), but also in the magazine focused around the philosophical thought of Józef Hoene-Wroński and the Polish messianism periodical Zet, whose collaborators included amongst others Karol Irzykowski, Bolesław Miciński, Stanisław Ignacy Witkiewicz, and with the ideologically aligned with ONR artistic-literary weekly Prosto $z$ mostu. Apart from critical reviews of current music events, he also wrote aesthetic and theoretical texts, as well as articles on the notions of content and form in music.

After the war, Chomiński stayed in a sanatorium in Switzerland. He contacted Régamey (whom he had met at a meeting of a Warsaw group centred around the TWMP, who regularly provided him with the books he needed and even visited

333 Ksiega pamiatkowa ku czci Profesora Dr. Adolfa Chybińskiego ofiarowana przez uczniów i przyjaciót [Memorial book dedicated to Professor Adolf Chybiński, PhD, offered by students and friends], Cracow 1930, 107-114.

334 Ludwik Bronarski, 'Chopin, Cherubini et le contrepoint' (Annales Chopin 1958/2, 238-242); also 'Les éleves de Chopin' (Annales Chopin 1961-64/6, 7-12).

335 Konstanty Régamey (1907-82) was a pianist and composer, as well as a music critic. He studied classical and Hindu philology as well as Oriental studies and linguistics (in Warsaw and Paris), as well as composition (with Kazimierz Sikorski). During the war (after surviving the Warsaw Uprising and a short stay in the Stutthof camp) as a Swiss citizen he got to Switzerland, where from the end of 1944 he lectured in oriental and Slavic philology at the universities of Fribourg and Lausanne. 
him in Leysin. The invitation to join the group of authors of new Kwartalnik was a natural consequence of these contacts.

Taking the statement that the 'history of art is not the same as aesthetics, ${ }^{336}$ as a starting point for his considerations, Régamey favoured the opinion that it is impossible to abandon 'aestheticisation' completely in reflections on art (particularly modern art), because this will allow us 'to adopt a better position that opens broader perspectives than conventionalism and allow us to explain more facts. ${ }^{337}$ Unfortunately, there is a risk that if we look at 'unattainable exemplars' from earlier epochs, we will always assess contemporary art critically as moving away from the ideal, even though the ideal was understood differently in different epochs.

Important paragraphs of the thesis concerned Régamey's topic of 'creative potentiality' which provokes the artist to start a new work upon completion of the previous creative process. The most important observations relate to the problem of creative freedom and social role of creativity: 'Artistic creation is not constrained by either external conditions ... or utilitarian purposes. ${ }^{338}$ Closing his reasoning and writing about the controversy between the two concepts (speaking on the one hand about the development of the autonomy of art, and on the other about the treatment of the history of art in close connection with the culture and the 'world view' of the era), he asserts:

When the artist cannot find a means of expression which could become the material for both personal and collective experiences, he either gives up all social impact and confines himself within 'art for art's sake,' reducing his art to a private experiment, or tries to appeal to the general public by intentionally lowering his sights and gives up trying to reach deeper personal motivations. It is then that his art turns into propaganda, agitation and didactics or becomes a mere tool for entertainment, such as popular literature, the so-called light music, etc. In all these cases, art loses its grandeur, it ceases to be creation. ${ }^{339}$

Régamey's reflections on the evolution of form and formal measures that had been started earlier but were published only in 1948 failed to spark a discussion on a strictly academic level. The same goes for the second text sent by him 'Źródła i tło kryzysu sztuki współczesnej' [The source and background to the crisis in contemporary art], ${ }^{340}$ in which he tried to prove that, even though it is

336 Konstanty Régamey, 'Próba analizy..., op. cit., 75.

337 Ibid., 76.

338 Ibid., 78.

339 Ibid., 102.

340 KM 1948/23, 75-103. 
necessary to adopt a distance towards the critical evaluation of everything that was avant-garde, innovative and different from works embedded in the style concerned, this does not refer to contemporary music. When it comes to the assessment of relations between art (including music) and social policy, he did not take as decisive a stance as soon became obligatory in academia and which was represented, for example, by Zofia Lissa. Nevertheless, he partially agreed with it. He emphasised that 'the extent of the impact that art had on society in various historical epochs was very varied. We know of periods in which whole societies lived and breathed art, even innovative art; all we need to do is point to the frequently quoted example of Greek theatre .... We also know of epochs in which art used to belong only to some social classes .... It was the demands of the French Revolution, which wanted to make all classes equal, and universalist demands of the Romanticism which changed this situation, also in the field of music.. $^{341}$

Régamey seeks reasons for the 'dissonance between art and society' mainly in the shock caused to the modern listener (even those who feel the 'living need for art') by contemporary works that 'irrespective of their level and artist's talent generates ... an almost panicked need to oppose this art.' The lack of organisation of measures used by contemporary artists and the 'internal conflict' of their art result in their isolation from society. In the end, it was stipulated that the image of crisis which he had presented should not be understood as criticism of everything that was happening at that time. The aim was rather to acknowledge that 'uncritical admiration of blasé snobs for everything that's new and unconventional, as well as the suggestions of those who oppose such art and just as uncritically reject everything bearing at least some hallmarks of innovation ..., and finally the so-called objectivism of reliable critics and theoreticians, who "learnedly" put all manifestations of modern art on the same level ..., all that blurs the simple yet natural fact that in the present epoch, apart from the crowd of artistic bluffers there is also an active group of truly creative individuals, which is smaller and yet quite numerous. ${ }^{342}$

Lissa’s article 'Czy muzyka jest sztuką asemantyczną?' [Is music an asemantic artform?], ${ }^{343}$ along with which other opinions concerning modern musicology were to be published, was submitted to the issue no. 25 in 1949, but it was 
ultimately accompanied only by Stefania Łobaczewska's work. ${ }^{344}$ The author of the question asked here prepared reflections discussing the sociological aspect in modern Polish music for the editors. As she confessed in a letter to the professor, she wanted 'through showing examples of historical relationships of musical style with an economic and social base, to draw some conclusions for the creativity of our era. ${ }^{345}$ As a pioneer of this type of research, she had, however, many concerns: 'even though the sociological method is almost terra intacta et incognita in our field, I am taking the first steps in it without any support. Soviet musicological literature generally does not take up such issues, and the ways of executing this method in their history textbooks often seem quite primitive to me.... When it comes to Western European literature, I only know of two books of this type. ${ }^{346}$

In spite of her fears, she undertook the task of making an objective evaluation of the state of music culture at the time of the 'breakthrough and rapid changes,' commencing from the analysis of phenomena, through 'arguments of a normative type' and ending with 'arguments of a postulative type. ${ }^{347}$ She justified the need for adopting a sociological approach towards the study of music by pointing to the fact that this approach was hardly present in historical research conducted up to that time. Explanations related to the methodological foundation of such research were an introduction to the next part of the article, in which she reflected on specific historical periods. Then she explained the sources and figures of 'the crisis in which contemporary music has been for years.' According to the author, the currently existing new group of listeners with new needs and 'desire for cultural advancement' present to artists a new kind of 'demand arising from political, economic and social change. ${ }^{348}$ Sławomir Wieczorek pointed out that in her article published in Kwartalnik, Lissa for the first time 'demanded [from composers] much more than just writing mass songs. Most importantly, ... she no longer addressed them in the same way. It was not an appeal; she did not point out current social needs, but rather made demands, justifying them by new social conditions. She acted as an authority who possesses and transmits the knowledge of the right direction for the development of contemporary musical creativity. This was the moment when a hierarchical system started

344 'Problem wartościowania i wartości w muzyce' [The problem of evaluation and value in music] (KM 1949/25, 55-119).

345 Lissa to Chybiński from Warsaw 10 I 1948, AACh-BUAM, fol. K-L, p. 153.

346 Lissa to Chybiński from Warsaw 29 VI 1948, AACh-BUAM, fol. K-L, p. 160.

347 Zofia Lissa, 'Aspekt socjologiczny..., op. cit., 104.

348 Ibid., 133. 
to function'; ${ }^{349}$ the researcher also backs up his observations with an example of the expression of exemplary importance for the author: 'New life does not require artistic withdrawal from the Polish composer, but it claims - which is in line with composers' needs - their inclusion in the progressive social trend of our culture. ${ }^{350}$

The narration illustrated by the above-mentioned statements accompanied Lissa and the main current of her research for a few years. Lissa had taken up the issue of semanticism/asemanticism of music back in the 1930s when she started preparing a speech on this topic at the request of the Polish Philosophical Association. A decade later, she used the thoughts she had formulated earlier and only tried to 'update them, especially in view of those questions of musical creativity that are currently emerging. ${ }^{351}$ Lissa's second article appeared in the pages of the 'third' Kwartalnik and opened with words of the crisis in European music in the interwar period. First and foremost, the author considered that 'previous reflections concerning both the study of musical styles and the psychology of musical creativity did not give credit to the influence which the composer's general worldview had on that composer's creative process and its direction, ${ }^{352}$ and this opinion concerned not just historical-musical issues in the terms defined by Adler or Riemann, but also research about music history against a background of general spiritual cultural development (Ambros, Schering), or Kurth's psychological theory, and finally Hanslick's theory 'identifying content of a musical work with its form. ${ }^{353}$

Lissa's conclusion, assuming that 'there is, therefore, no pure programme music and no pure absolute music.... Hence, it is difficult to talk about music as a clearly asemantic field of art' was not controversial, in fact, yet in the author's assumption arguments which constitute 'a psychological test of the established theory of "content in music", 354 would spark a debate on the problem of meaning carried by both music aestheticians and psychologists. When the editorial team decided to reprint Lissa's article which had been published in Myśl Wspótczesna, it meant that they agreed with this opinion to some extent. In an extensive footnote added by the editorial team we can read that 'in relation to the ongoing discussion on ideological topics, the problem of content in music has reappeared ...

349 Wieczorek 2014, 42.

350 Zofia Lissa, 'Aspekt socjologiczny...' op. cit., 142.

351 Zofia Lissa, 'Czy muzyka jest sztuką..., op. cit., 125.

352 Ibid., 123.

353 Ibid.,122-123.

354 Ibid. 
the paper written by Associate Professor Dr Z. Lissa is a new attempt at showing this issue from the point of view of the most recent findings of psychology and musicology. ... due to the limited length of the paper, the author could not analyse in detail all the themes which she brought up; nevertheless, the fact that she took up this topic should encourage other researchers to keep working in this field. ${ }^{355}$ On the pages of Kwartalnik, however, this invitation did not meet with a response, even though (as mentioned earlier) (a)semanticity was one of the main topics of scholarly discourse expected by 'mentors' and 'setters' in those times.

Stefania Łobaczewska also submitted her earlier methodological reflections for the first post-war issue of Kwartalnik to the editors; the treatise 'O zadaniach i metodzie monografii muzycznej' [On the tasks and method of a musical monograph ${ }^{356}$ served as an introduction to the recently completed monograph on Szymanowski. In the reality where academic discourse based on dialectal materialism was gaining more and more popularity, it became easy to criticise both 'traditional' methodology, which the author had used in her long-term studies on Szymanowski, and the narration of the book, which stemmed from the fact that Łobaczewska's musicological education was based on the German tradition. Nevertheless, her opinion emphasising that strictly musical elements of the musical work are the most important ('as the starting point for reflections on the image of the artistic era ... we always assume musical form understood in the broadest sense, i.e. as the weave and interaction of all elements of music rhythm, melody, timbre, dynamics, texture, formal pattern - and in its function in relation to the sound material ${ }^{357}$ ) was softened by the researcher underlining the importance of both social and psychological conditions for the creation and functioning of a musical work.

Like Lissa, Łobaczewska only sent one original text to the editor-in-chief 'Problem wartościowania i wartości w muzyce' [The problem of evaluating and values in music]. ${ }^{358}$ In this extensive dissertation, she assumed that '[a]ssessment is a judgement which can normally take two forms in any aesthetic experience, namely the subconscious and the conscious form. In its subconscious form, a judgement accompanies something ... which in the initial stage of this process makes the listener give in to the aesthetic object more and more intensely, more

355 Ibid., 120.

356 See above footnote 307.

357 Stefania Łobaczewska, 'O zadaniach i metodzie...,' op. cit., 144.

358 KM 1949/25, 55-119. 
and more eagerly. When it comes to the conscious form, this judgement appears in the next stages of the aesthetic experience. ${ }^{359}$ According to the author, a sense of beauty can be determined both by a sound knowledge of the style of the work under evaluation and by the general opinion on the work, which 'supported' the evaluator's judgement in a certain way. The ordered arrangement and course of the structure of 'frictionless' works (as Łobaczewska put it several times ${ }^{360}$ ), on which the output of the classical period is based, produces the feeling of listening pleasure in audiences, even those less educated ones. When it comes to contemporary music, habits stemming from listening to compositions based on the minor and major structures make it impossible to evaluate it positively. What could be helpful here are such means of expression as intensified dynamics, the lack of sentimentalism ..., radical harmonic sounds ..., violent instrumentation effects, their lively rhythmical realisation, which strengthens the feeling of vitality. ${ }^{361}$ Finally, the value of a musical work is based on the adequacy of stylistic criteria different for the realisation of a particular musical genre, which results in works that 'for various external purposes, are, even if just on account of size, incomparable to each other. ${ }^{362}$

In the future, Łobaczewska did not continue her reflections on the problem of value in music. Even though the aesthetics of music must have always been present among her main research interests, the papers she wrote on this topic were significantly less numerous than in the pre-war period. The only text within this scope - although a significant one - in which she made settlements with the past epoch was 'Próba zbadania realizmu socjalistycznego w muzyce na podstawie polskiej twórczości 10-lecia' [An attempt to explore socialist realism in music on the basis of the Polish output of 10 years]. ${ }^{363}$

The last text created before the war that fit into the 'new opening' of Kwartalnik was Józef Chomiński's study on Karol Szymanowski's output. ${ }^{364}$ Chomiński started working on Szymanowski's piano music in the first half of the 1930s, preparing, among others, an article on that subject for the Muzyka Polska monthly, and studies for PRM (the essay 'Problem tonalny w Stopiewniach' [The problem of tonality in Słopiewnie], see more about this in chapter II-5). It was also at that time, in the summer of 1937, that he delivered another part of his reflections

359 Stefania Łobaczewska, 'Problem wartościowania..., op. cit., 55.

360 Ibid., 62, 63.

361 Ibid., 77.

362 Ibid., 119.

363 Studia Muzykologiczne 1956/5, 7-195.

364 See above footnote 305 . 
on the works of the author of Hagith for publication in the third volume of the periodical that was never printed before the outbreak of the war - I have already referred to the history of publication of this volume a few times. ${ }^{365}$

The studies on Szymanowski, which were printed in Kwartalnik, in particular, their second part related to structural issues in piano sonatas, was the foundation for Chomiński's habilitation. At the same time, he was working on a monograph about Chopin's preludes and wrote about it to Chybiński multiple times. However, as he wanted to bring the habilitation procedure to an end as soon as possible, he focused on his studies devoted to Szymanowski and gave himself one more year to finish the monograph about the preludes. Thanks to his correspondence with the professor, we know quite a lot about the creative process and methodological dilemmas which accompanied Chomiński when he was writing his dissertation. In his letters from 1946 and 1947, we can read, among other issues, about the beginnings of the analyses. ${ }^{366}$ A detailed analysis of the subject area described there would take too much space here - disproportionately much in relation to presentations of other publications in Kwartalnik. I will only quote a fragment that is an explicit declaration of the starting point determined by the author of article 'Problem formy w Preludiach Chopina' [Problems of form in Chopin's preludes] for his works:

I treat form as the resultant of interaction between all elements, thanks to which no detail can be omitted. One other thing is that depending on a given case, I take into account the elements which shape the form - [illegible] tectonic and the auxiliary ones. In this way, it is possible to graphically present the richness of various formal approaches in Chopin's Preludes. The analysis aims to show the uniformity of Op. 28. Even preliminary studies on this topic yielded surprising results. The problem of the analytical method will be the analysis of value. Even though we all know what the value of Chopin's works is, science demands objective evidence, which can be checked not only psychologically, but also in other ways. In this case, the technical side of the work will be an auxiliary measure in the analytical method. The technical discipline will be studied once again, this time with a view to the conscious and subconscious (innate creative predispositions) creative processes. The relation between the technique and emotional factors will be presented in the right perspective by demonstrating the significance of Chopin in his epoch and for the future. All that will, of course, be based on the same resources that Chopin used in his Preludes, yet in many cases, it will also be necessary to take into account other works of Chopin and other composers. ${ }^{367}$

365 See also chapter III-3 and Sieradz 2011, Sieradz 2012/2.

366 See for example, Chybiński/Chomiński 2016, 23-24, 32-33, 33-34.

367 Chybiński/Chomiński 2016, 33-34. 
Apart from the basic chapters (in agreement with the methodology assumed at the beginning of the work) into which the author divided the monograph (formcreating actions 1) melody, 2) harmony, 3) agogics and dynamics, 4) piano texture, 5) integration of formal development 6) its cyclical nature), in the summary he referred to the genesis of the Chopin preludes, starting from indicating sources in the tablatures of Adam Ileborgh, through Corelli, Bach, Beethoven, Hummel and others. ${ }^{368}$ Both due to the size (260 pages of both parts combined) and the entire spectrum of issues covered by Chomiński's considerations, this study was an unprecedented example in the pages of Kwartalnik Muzyczny.

It seems that the only problem which the author had to face (and I do not have in mind any creative issues, because science was his passion and the only trouble here could be the multitude of new concepts and how to handle them) was how to reconcile the chosen topic (which had been taken up back in the days of academic freedom) with the interpretation imposed on academia by the new regime. At the time when state authorities imposed the ideological fight against formalism in art, Chomiński was dealing with the problem of form in a musical composition and had to look for arguments which would defend his research. This is what he wrote in the 'Introduction': 'It could seem that a work devoted to the issue of form has become outdated these days .... Fortunately, this outdated understanding of form is a thing of the past. Today, form is not only the resultant of interaction between all the elements of a musical work but at the same time becomes the evidence of its expression, its emotional content. ... a modern analysis of a musical work cannot do without considering its technique and form simply because both technique and form are the carriers of the emotional content of a given work. ${ }^{369}$

Chomiński, who focused primarily on his own projects, also prepared a number of reviews for the editors, including the one closing the last issue of Kwartalnik, no. 29/30, in which the author returned to his earliest research passions - medieval music; incidentally, he became one of the participants in the long-year dispute that was pursued by Adolf Chybiński and Maria Szczepańska on one side and by Zdzisław Jachimecki on the other side ${ }^{370}$ about Mikołaj of Radom and his compositions.

368 Chomiński's study 'Problem formy w preludiach Chopina' was published in KM 1949/26-27, 183-288 (part I), 1949/28, 240-395 (part II).

369 Ibid., part I p. 183.

370 See KM 1950/29-30, 118-124. The review of 'Zagadnienia beztekstowej kompozycji Mikołaja z Radomia z rękopisu nr 52 Biblioteki Krasińskich w Warszawie’ [The issue of Mikołaj of Radom's textless composition from the manuscript no. 52 of the Krasiński Library in Warsaw] by Zdzisław Jachimecki (Sprawozdania z czynności i posiedzeń 
Returning to the contents of the first post-war issue of Kwartalnik, we must recall Adolf Chybiński’s friend, Bronisław Romaniszyn. Romaniszyn published many articles, including (alongside those referring to his beloved mountains) texts about vocal training and music pedagogy; before the war, he wrote for such periodicals as Ślaskie Wiadomości Muzyczne, ${ }^{371}$ Muzyka Polska $a^{372}$ or the Śpiew $w$ szkole $e^{373}$ monthly. Already at that time (see Chapter II-4) he accepted (twice) invitations to co-operate from his Lviv friend; the same happened after the war. This time, in response to an urgent request for 'some work' received from Poznań at the end of 1947, he prepared 'Technika wokalna wobec środków muzyki mechanicznej' [Vocal technique in relation to mechanical musical means] in only one month. He presented his arguments in favour of using any inventions in vocal pedagogy which could help teach vocalists, both in recording and reproduction. At the same time, he was aware of the fact that 'not every voice which sounds good in a concert or opera hall will retain its beautiful sound when it is converted by a microphone or recorded on tape, ${ }^{374}$ but it is the ability to adjust the vocal technique to a different space than the one the vocalist is used to that forces him or her to master new skills related to voice emission, breathing, diction, etc.

At the beginning of his second co-operation with Kwartalnik, another pre-war author, Janusz Miketta, presented a report on the condition of music education in Poland in the first three years of existence of the new state. Thus, he referred to his publication from the 1930s. It was attached to the 'pedagogical' issue (1931/10-11) and informed readers about statistic results concerning the educational section of that time. This time, he moved away from dry facts presented in numbers and tables and focused on a descriptive analysis of the phenomena he observed in the school system and on presenting the current state, as well as legislation which was in force at that time.

Soon, the author became known not only as an experienced departmental bureaucrat but also as a researcher of the works of Frederic Chopin, a matter which

PAU 1949/7, 380-386) was actually the opinion that the author formulated and wanted to deliver during one of the heated sessions of the Musicological Commission of the Polish Academy of Sciences (PAU); however, he was prevented from doing so.

371 See, for example, a memory about Jan Reszke in 1939 summer issues of the monthly.

372 'O roli i znaczeniu dykcji w nauczaniu śpiewu' [On the role and importance of diction in singing instructions], MP 1935/8, 55-279.

373 'Głos dziecka i jego kształcenie' [The child’s voice and its education] (Śpiew w szkole 1933-34/4, 70-71).

374 Bronisław Romaniszyn, op. cit., 259. 
had its roots in his works for years. Chybiński had known Miketta for a long time. As early as in 1920, he got a letter in which Miketta introduced himself as the president of the Music Society in Lublin (he had already held this position for a year) and a teacher in the music school in this city. It turns out that at that time, he had already been interested in the works of Chopin and was also trying to instil this interest in his students. He wrote: 'at the beginning of the school year, I would like to start a historical and aesthetic seminar in the school. First and foremost, I would like to write an aesthetic and historical paper on Chopin. ${ }^{375}$ In the 1920s, when he participated, for example, in works of the committee for the reform of the education system on behalf of the MWRiOP, he adhered to the SMDM, but had a critical attitude to the contemporary plans of establishing an institution promoting the cult of Chopin. Already in the spring of 1928, he hoped that 'something will finally happen which is neither a Music Society nor "in the name of Fr. Chopin."'376

In the 1930s Miketta had already developed material on mazurkas. Unfortunately, the prepared monograph was destroyed, ${ }^{377}$ but the author's many years of experience in studying Chopin's work proved fruitful after the war. Firstly, he was one of only two musicologists whose volume in the series Analizy

375 Miketta to Chybiński from Lublin 2 III 1920, AACh-BJ, box 6, M-19/1.

376 Miketta to Chybiński from Warsaw 9 IV 1928, AACh-BJ, box 6, M-19/10.

377 'Everything on this matter that I gathered, collected and compiled in my own way ... was lost in 1940! Just taken away... and lost, and no intervention helped. But ... I started anew from scratch..., Miketta to Chybiński from Żaby 10 IX 1943, AACh-BJ, box 6, M-19/41.

On this occasion, it is worth quoting a further passage of this letter, which, together with another letter complements a number of details about Chopin-themed publishing plans which were set during the war by Chybiński and the members of TWMP (on this subject, among others, also in chap. III-3): 'In 1949, on the Chopin anniversary it would be good to ornament this great music anniversary with a full set of Polish studies on Chopin. This is how I understand it, and please tell whether it is correct. Such a full set of studies ought to provide us with 1) an ultimate, definitive critical edition of the entire Chopin volume, 2) monographs of all phases of his artistic work, 3) a book in a yet unrecorded type: "Chopin - artwork!" (not life! I think this abundant, multilingual garland from Hoesick to ... Binental would be enough!?). I find two positions for this book that I might assess as such. I think that after Dr WójcikównaKeuprulian we can still work on melodies; I can hardly imagine how could we complete Bronarski. But it seems to me that in view of these basic works, rhythm remains almost untouched, and with it the form, as well as agogics and dynamics (maybe together, maybe separately). I find an abundance of intact, almost or a little (a la Leichtentritt) rhythm problems! ... I was told that you Sir Professor are working on 
i objaśnienia dzieł wszystkich Fryderyka Chopina [Analysis and explanation of Frederic Chopin's complete works] was published. ${ }^{378}$ Secondly, he was amongst the authors invited by the editors of Kwartalnik for the jubilee booklets in 1949 . On this occasion, he prepared a two-part monographic dissertation entitled ' $\mathrm{Ze}$ studiów nad melodyką Fryderyka Chopina (szkice chopinologiczne)' [From studies on Frederic Chopin's melodics (Chopinological sketches)], ${ }^{379}$ which he dedicated to Chybiński 'with expressions of the highest respect.' The starting point for the author's arguments were two basic Chopinological positions by Polish authors, which appeared in the interwar period - Harmonika Chopina [Chopin's harmony] by Ludwik Bronarski and Melodyka Chopina [Chopin's melodics] by Bronisława Wójcik-Keuprulian (supplemented with her article 'O typowych postaciach melodii Chopina' [About typical melodic forms in Chopin] printed in the pages of LWMiL in 1926). As compared with standards applied to papers published in the periodical, the article written by Miketta is quite extensive and contains numerous sheet music examples. Still, the author concludes that 'the length and nature of this study do not allow me to exhaust the material nor to form definitive conclusions about its role, ${ }^{380}$ and earlier, in reference to the 'Chopin motif,' which he undertook to abstract from all the master's works, he stipulated that the theses he proposed were purely hypothetical and not 'generalising.' Miketta's second Chopin material - 'O nieautentyczności Mazurka Fis-dur uchodzącego za utwór Fryderyka Chopina' [About the inauthenticity of the Mazurka in F sharp Major assumed to be a work of Frederic Chopin] ${ }^{381}$ - fit in the type of publications which made it possible to correct knowledge about the composer's resource heritage, sometimes increasing it, and sometimes (as in this case) decreasing it.

These were not all the texts that Miketta prepared for Kwartalnik. He also announced further developments in the form of sketches on inversion embellishments' and 'Chopin accompaniment, ${ }^{382}$ yet he did not have time to

Scherzos, Impromptus and Nocturnes? May we live to see the monograph's template!! How much easier it will be for others to work! ..., see ibid.

378 Vol. I. Mazurki (Cracow 1949). Preludia, prepared by Józef M. Chomiński, was published in print a year later. Miketta did not complete the works on the analysis of polonaises, planned as vol. II of the series.

379 KM 1949/26-27, 289-359.

380 Ibid., 359.

381 KM 1949/28, 149-166.

382 See Miketta to Chybiński from Cracow 7 VII 1949, fol. M-N, p. 143. 
prepare them before the closure of the editorial's activity. However, for the second 'Chopin' volume, he submitted a comprehensive analytical review from the third and fourth volumes of the edition Chopin's Dzieła Wszystkie [Chopin's complete works] (Ballady and Impromptus). ${ }^{383}$ When it comes to the value of Miketta's writing, Zofia Chechlińska, who shortly reviewed the methodology adopted by the researcher, described it as characteristic of the studies on Chopin conducted in the inter-war period: the author only described 'numerous details concerning harmonics, melodics, and the formal pattern of individual compositions, but did not form general conclusions.' ${ }^{384}$ It seems that Miketta, who completed music studies, simply did not have sufficient musicological preparation to formulate binding scholarly opinions, although he tried to ensure that his searches for the 'Chopin motif' would be as important as the emergence of the 'Chopin chord' by Ludwik Bronarski.

The last two authors who appeared in the table of contents of the first post-war issue of Kwartalnik came from Cracow and belonged to the second generation of Polish musicologists. For the musicological community, it could serve as a clear sign of the fact that the editorial team was going to move beyond its pre-war group of authors from Lviv.

Zygmunt Estreicher, who was Jachimecki's student in the years 1937-39, may have received a recommendation from Ludwik Bronarski, whom he had met and even consulted about his works during his permanent stay in Switzerland, at the time of getting in touch with the editors of Kwartalnik. He also kept in touch with Józef Chomiński during his stay in the sanatorium in Leysin. ${ }^{385} \mathrm{He}$ could have been close to Chybiński's heart also due to the fact that he specialised in ethnomusicology, even though the main subject of his research (the music of Inuits) could make the honourable senior of Polish musicology a little uncomfortable since he had traditionally focused on Polish musical folklore. ${ }^{386}$ However, because Estreicher was also very willing to co-operate in providing a bibliography of foreign musicological literature starting in 1939, the editors decided to

383 KM 1949/28, 396-406.

384 Chechlińska 2000/2.

385 Thanks to Estreicher, Chomiński could then use the Library of the Department of Musicology at the University of Fribourg, see Chybiński/Chomiński 2016, 20-22.

386 Estreicher was a top-class specialist in this field. Already from 1948, he became the head of the department of musical ethnography at the Musée d'Ethnographie in Neuchâtel, and was also the author of many professional publications, including the entry Eskimo-Musik in MGG. 
add the article 'Teoria dwutonowych melodii' [Theory of two-tone melodies] 387 to the issue no. 21/22. The article written by Estreicher, even though it was devoted to a theme that was distant for Polish (ethno)musicologists (mainly in geographical terms), deserves attention for two reasons. First of all, it seems to be exemplary when it comes to the construction of the study. The researcher started with describing the Inuit music style and then presented the theory of two-tone melodies, which in his view were not as primitive as it might seem, especially when we take into account the uncomplicated structure of the scale used to compose them. His erudite reasoning was backed by extensive European literature. Secondly, 'Teoria dwutonowych melodii' was the only paper on ethnomusicology which came out in the post-war edition of Kwartalnik. Other attempts to make authors who studied music folklore (especially Sobieski and his wife, as well as the youth from their circle) interested in publishing in the journal came to nought, even though the editorial office worked on it for three years.

The second representative of the Cracow school was Włodzimierz Późniak. The musicologist was one of Zdzisław Jachimecki's first students - he studied at the Seminar of History and Theory of Music at the Jagiellonian University in the years 1927-30, after which he went to Wroclaw and Berlin to supplement his musicological knowledge (e.g., in classes ran by Franz Arnold Schmitz, Arnold Schering and Ernst Pepping). He became an assistant lecturer at the Cracow Seminar of Musicology as early as 1930; he took this position again after the war, in 1946, and a year later he earned a habilitation degree in Cracow on the basis of his monograph on the choral Passion. ${ }^{388}$ At the same time, he also got in touch with Adolf Chybiński, to whom he sent a copy of his dissertation on the Passion 'with a polite request to graciously accept it.". tached an off-print of his work 'about our national anthem,' which, as he wrote, he had received shortly before the war and, therefore, could not send earlier. ${ }^{390}$ Respectful contacts, the fact that Poźniak was interested in Early Polish music (which was close to Chybiński's heart) and the professionalism of materials which

387 See above footnote 312.

388 Pasja chorałowa w Polsce [The Choral Passion in Poland]. "Nasza Przeszłość” III (1947) pp. 37-91.

389 Poźniak to Chybiński from Cracow 14 IX 1947, AACh-BUAM, fol. O-P, p. 232.

390 Ibid. Włodzimierz Poźniak published at least two texts about Dąbrowski’s Mazurka: on the pages of Kalendarz Ilustrowany Kuriera Codziennego in 1938 and in the Spiewak monthly a year later. In this way, he took part in a broader discussion about the authorship of the hymn that continued in the interwar period, with opinions expressed, among others, by Łucjan Kamieński and Stanisław Zetowski. 
he sent to the professor must have endeared him to Chybiński, who decided that he would print the article on Stanisław Moniuszko's unrealised opera projects, which Poźniak had sent him, in the very first issue of Kwartalnik.

Completed at the end of 1947, the text was a result of research conducted by Późniak after the war and referred to this part of the collections of the WTM that luckily survived the conflagration of war. The author presented the information about Moniuszko's planned operas (Budnik, Wanda, Aleksota) that he had found by himself - and the previously unknown sources, as he rightly noticed 'were used to reach some interesting conclusions, shedding light on the composer's social and literary views as well as the technique of his work in the area of creating dramatic pieces. ${ }^{391}$

In 1947, Poźniak said that he was ready to send another text, this time devoted to Polish oratorios, cantatas and ballads from the nineteenth-century, but for unknown reasons, this paper was never published in Kwartalnik.

Apart from that, a few more previously absent authors co-operated with the editors of the post-war Kwartalnik (mainly in connection with Chopin-related projects). Such was, for example, the case of another Cracow author, Władysław Hordyński - a musicologist who graduated from studies under Jachimecki’s guidance shortly before the war, but also an experienced employee (or as Chybiński put it, 'a bureaucrat') ${ }^{392}$ of BJ. Already before the war, thanks to a query performed in his home library, he had an occasion to announce information about Chopin souvenirs kept by it that had never been included anywhere else: he presented Chopin's four letters and two tickets to Zofia Rosengardt. ${ }^{393}$ After the war, he returned to further queries, which resulted in finding further letters - this time they survived among souvenirs of Adolf Cichowski kept in the collection of the National Museum. ${ }^{394}$ This publication put the author among explorersdiscoverers of Chopin's new memorabilia who announced their findings via Kwartalnik Muzyczny, which incidentally improved the position of the magazine: Ludwik Bronarski (the aforementioned information about two unknown works - Largo in E flat-major and Nocturne c-minor), Bronisław Sydow (the history of the portrait of Chopin and Sand) and the presentation of a juvenile letter of

391 Włodzimierz Poźniak, 'Niezrealizowane projekty operowe. ..,' op. cit., 251.

392 Chybiński to Bronarski from Zakopane 9 VIII 1949, AACh-BUAM, Bronarski's archive, p. 204.

393 Władysław Hordyński, 'Nieznane listy Chopina' [Chopin’s unknown letters] (Kalendarz IKC 1937, 217).

394 Władysław Hordyński, 'Nieznane listy Chopina do Adolfa Cichowskiego' [Chopin’s unknown letters to Adolf Cichowski] (KM 1949/26-27, 27-37). 
the composer's father Mikołaj which had not been known before and was shown at the Chopin exhibition in Paris), ${ }^{395}$ Ignace Blochman (a contributory text on souvenirs of Chopin in the Mariemont Royal Museum - see also below) ${ }^{396}$ and František Zagiba (a message - along with photocopies - about the autograph of Variation op. 2 from the collection of the Vienna Staatsbibliothek, see below). ${ }^{397}$

A catalogue of Chopin souvenirs kept in Cracow libraries, museums and archives that was prepared by Hordyński served as a sort of pendant to information about Chopin's previously unknown memorabilia in the National Museum in Warsaw (manuscripts, prints, iconographic souvenirs of various kinds). ${ }^{398}$ At the time when the very first plans were made to study the material legacy left by Chopin, it was still important to sort out the assets of institutions from Cracow and to draft not a catalogue, but rather a list of their belongings. It would create the foundation for undertaking further work in all similar institutions in the country (which was of particular importance on account of wartime losses which had been hard to assess at that time).

At the turn of 1947 and 1948, the editorial office remained in contact with Jan Prosnak, who before the war took courses with Julian Pulikowski at the University of Warsaw. After the war, Prosnak continued his studies in Wroclaw under Fr. Feicht, and also studied composition under Kazimierz Sikorski. All these connections undoubtedly helped the young musicologist find himself amongst the trusted authors of Kwartalnik, while his close contacts with Lviv musicologists are confirmed by the numerous letters found in Chybiński's archive in Poznań and the correspondence with the periodical's secretary's office kept in Chomiński's private archive. Prosnak's research interests focused mainly on the history of music culture of the eighteenth and nineteenth century, whereas 'the foundation of [his] research work ... were source queries in libraries in Poland and abroad, ${ }^{399}$ which must have been appreciated by the Professor, who loved archive queries.

395 Bronisław Edward Sydow, 'Chopin i Delacroix. (Historia jednego portretu)' [Chopin and Delacroix. (The history of one portrait)] (KM 1949/26-27, 15-26); also 'Nieznany list Mikołaja Chopina' [Unknown letter by Mikołaj Chopin] (KM 1949/28, 131-141).

396 Ignace Blochman, 'Dwa autografy listów Chopina w Belgii' [Two autograph letters by Chopin in Belgium] (KM 1949/26-27, 38-47).

397 František Zagiba, 'Nieznana wariacja Fryderyka Chopina na temat Mozarta' [Unknown variations by Frederic Chopin on a theme by Mozart] (KM 1949/26-27, 127-130).

398 Władysław Hordyński, 'Pamiątki po Chopinie w zbiorach krakowskich' [Chopin souvenirs in the Cracow collections] (KM 1949/26-27, 378-393).

399 Chmara-Żaczkiewicz 2004. 
At the end of 1947, Prosnak closed his work on material about the history of music education. ${ }^{400}$ The article ' $\mathrm{Z}$ dziejów szkolnictwa muzycznego $\mathrm{w}$ Polsce' [From the history of musical education in Poland] appeared in two parts: 1. 'Nauczanie muzyki w okresie Komisji i Izby Edukacyjnej' [The teaching of music during the period of the commission and chamber of education' and 2. 'Prywatne nauczanie muzyki oraz prywatne szkolnictwo muzyczne $\mathrm{w}$ latach $1773-1830$ ' [The private teaching of music and private music education in the years 1773-1830 ${ }^{401}$ and was a precursor to the book Dzieje szkolnictwa muzycznego w Polsce [History of musical education in Poland]. ${ }^{402}$

At the beginning of 1948, Prosnak offered the editors a 'short thing about a few carol melodies from the XVII century'; ${ }^{403}$ a few months later, he repeated his proposal, which apparently did not meet with interest and remained unanswered. ${ }^{404}$ The editorial office accepted for publication a contribution on Karol Kurpiński's ${ }^{405}$ activities as a theorist, in which the author presented the creator's three handbooks by the writer of Zamek na Czorsztynie [Czorsztyn Castle] (Wykład systematyczny zasad muzyki na klawikord [Systematic learning of the principles of music on the clavichord], Zasady harmonii tonów z dołaczeniem jenerałbasu praktycznego [Principles of harmony of pitches with a practical guide to general bass] and Zasady harmonii wykładane $w$ sposobie lekcji dla lubowników muzyki [Principles of harmony explained in the form of a lesson for music enthusiasts]), giving more attention to the third. What is important from a cognitive point of view is not so much the presentation of the 'treaties', but rather Prosnak's evaluation of them (including references to the corresponding items available in Kurpiński's times) and appreciation of the importance of his attempts in the field of music theory, even if they only had local coverage.

He learned about the organisation of the Chopin edition directly from the editors of Kwartalnik, with whom (both Chybiński and Chomiński) he remained in frequent contact by mail. His comprehensive treatise on the musical culture of

400 Prosnak to Chomiński from Brwinów 18 XII 1947, at APCh.

401 KM 1948/23, 158-168 (part I), 1948/24, 84-99 (part II).

402 See ibid., part I, footnote on page 158. This project found its completion years later when Prosnak published the book Polihymnia uczaca. Wychowanie muzyczne w Polsce od średniowiecza do dni dzisiejszych [Polihymnia learning. Musical education in Poland from the Middle Ages to the present day] (Cracow 1964).

403 Prosnak to Chomiński from Brwinów 3 I 1948, APCh.

404 Prosnak to Chomiński from Brwinów 20 IX 1948, APCh.

405 KM 1949/25, 138-155. 
Warsaw from 1810 to 1830 was directed to the second 'Chopin' booklet. ${ }^{406}$ This article, which talked about the music community in Warsaw in Chopin's lifetime, similarly to the other two articles published in Kwartalnik (about education and Kurpiński as a theoretician), belonged to Jan Prosnak's main line of interest. $\mathrm{He}$ focused on the history of Polish music culture from the 1770s. He paid particular attention to the area of Warsaw, focusing mainly on source queries supported by an in-depth study of nineteenth-century literature devoted to these issues. ${ }^{407}$

Prosnak himself was an editor of Radio i Świat - a weekly issued by the Polish Radio. Thanks to his efforts, the magazine published articles by experienced publicists and musicians, such as Piotr Rytel, Karol Stromenger or Stefan Jarociński, and the editors tried to establish co-operation with Adolf Chybiński ${ }^{408}$ or Józef Chomiński. ${ }^{409}$

Another author with whom talks were undertaken during the initial period of editorial works was Alicja Simon - a Kwartalnik veteran. She had debuted already in the first issue of the periodical: she published an article 'Stosunek Sperontesa Singende Muse an der Pleisse... do muzyki ludowej polskiej' [The relationship of Sperontes' Singende Muse an der Pleisse... to Polish folk music] edited by Henryk Opieński. ${ }^{410}$ She belonged to the same generation as the founding fathers of the musicological departments. She was widely educated, both when it came to music (she studied piano, violin and the theory of music at the conservatoire in Warsaw) and humanities (she had musicology classes with Hermann Kretzschmar and Johannes Wolf; in Berlin, she also attended lectures on philosophy, psychology and the history of art). Reading her biogram in basic lexicons, ${ }^{411}$ we can consider her to have lived a globetrotter's life. She was professionally

406 Jan Prosnak, 'Środowisko warszawskie w życiu i twórczości Fryderyka Chopina' [The Warsaw milieu in the life and work of Frederic Chopin] (KM 1949/28, 7-126).

407 The author rarely stretched beyond the history of music, this time in connection with the person of Adolf Chybiński, preparing a jubilee article for the book, ' $\mathrm{Z}$ zagadnień polskiego folkloru muzycznego' [From the issues of Polish musical folklore] (in: Ksiega pamiatkowa 1950, 320-338).

408 For example, a special issue of the weekly was planned in connection with the Festival of Folk Music organised by the PR; on that occasion, authors such as Stefania Łobaczewska, Stanisław Mierczyński, Bronisław Rutkowski and Marian Sobieski were invited to co-operate. Chybiński was asked to submit a 'short article ... for the cycle "Musicologists and composers about folk music", see Prosnak to Chybiński from Warsaw 29 IV 1949, AACh-BUAM, fol. O-P, p. 246.

409 Prosnak to Chomiński from Brwinów 8 II 1949, APCh.

410 KM 1911/1, 48-54. For this subject see also chapter I-1.

411 Andrzejewski 1997; Morawska 2007/2. 
connected with Zurich, Berlin, Geneva and Washington, where she worked as Head of the Music Department of the Library of Congress; having returned to Warsaw, she was Head of the Music Department of the State Collection of Art. She was one of the initiators of establishing an association bearing Karol Szymanowski's name, which was set up during the composer's lifetime.

Upon settling in Łódź after the war, it seemed that Alicja Simon had a good chance to develop one of the musicological centres at the local university: for a few years she was the head of the Musicological Department run at the Faculty of Humanities; after its liquidation, up to 1957, the researcher gave classes on the history and theory of music amongst the changing structures of Łódź University.

Already in the first decade of the twentieth century, Alicja Simon co-operated with Roman Chojnacki (Młoda Muzyka and Przeglad Muzyczny) and Kwartalnik Muzyczny by Henryk Opieński, and in the 1920s she co-operated with Mateusz Gliński $(M u z y k a)$. As we remember, she prepared a contributory text 'Życie muzyczne w świetle Pamiętnika Józefa hr. Krasińskiego' [Musical life in the light of A Memoir by Józef Count Krasiński] for Chybiński at that time. ${ }^{412}$ Primarily, however, she had a rich output ${ }^{413}$ abroad. After the war, Chybiński felt obliged to invite the Nestor of Polish musicology to co-operate with the new version of Kwartalnik. ${ }^{414}$ As a consequence of this invitation to the 'Chopin' issue, the author prepared 'Przyczynek genetyczny do Grande Valse Brillante op. $34 \mathrm{nr} 1$ Fryderyka Chopina' [A genetic contribution to Grande Valse Brillante Op. 34 no. 1 by Frederic Chopin] ${ }^{415}$ (earlier, from her texts from the Convention of Polish Musicologists, a reprint her co-paper on 'Rejestracja i zabezpieczenie zabytków muzyki polskiej' [The registration and protection of monuments of Polish music $\left.{ }^{416}\right)$. With this article, she returned to pre-war research on Chopin's Tempo di Valse As-dur, a facsimile of which she received from the Thun family from Jílové in Czechoslovakia (in Chopin's times, they ruled the castle in Děćín). The author lost both her work and copies during the Warsaw Uprising - fortunately, not irretrievably. ${ }^{417}$ The materials discovered after the war served Simon both to prepare the manuscript anew from the Thun family archive and compare it with the Paris edition of Chopin's Grande Valse Brillante op. 34 no. 1. The

412 PRM 1935/1, 91-106.

413 See Morawska 2007/2.

414 See, for example, Chybiński/Chomiński, 2016, 47-50.

415 KM 1949/26-27, 48-94.

416 KM 1949/25, 190-192.

417 She also mentioned the same issue, see Alicja Simon, 'Przyczynek genetyczny..., op. cit., 51 . 
author completed her material with a transcription of the Děćn version and the copy of the Paris version printed in extenso, and she also added images of places and figures associated with the birth of the 'first inspiration' for later compositions - the Děčín castle and two portraits of Thun-Hohenstein sisters. Compilation of a detailed list of differences found between the Děčín version and the release from 1838 took Simon more than twenty pages which testifies to the researcher's extraordinary meticulousness and, at the same time, constitutes the only example of a source and critical edition found on the pages of Kwartalnik Muzyczny.

Bronisław Edward Sydow's activity in musicological circles, particularly the Chopinological one, began around 1945, when he became a member of the Management Board of the restored IFCh. He was an economist by education, but his fascination with Chopin's work and life allowed him to publish his first texts on that subject already in the second decade of the twentieth century, when he stayed in Chile. ${ }^{418} \mathrm{He}$ won recognition thanks to the efforts that he made during the war in order to obtain and secure Chopin's letters and other historical materials that eventually helped him prepare, among others, Bibliografia F.F. Chopina [F.F. Chopin's bibliography] (Warsaw 1949), Almanach Chopinowski [Chopin almanac] (along with Karol Stromenger. Warsaw 1949), and two volumes of Korespondencja F. Chopina [F. Chopin's correspondence] (Warsaw 1955).

Sydow, who would be connected with Chybiński not only due to co-operation with Kwartalnik, ${ }^{419}$ willingly took part in the editors' Chopin-related projects. He intended to write 'about Delacroix as Chopin's painter. ... a bibliographic contribution concerning Chopin's portrait that ... was cut apart and experienced different fates. ${ }^{320}$ He was also the author of the unsigned bibliography of Chopinological and Chopinographic literature for the period 1939-49, which was attached to the first 'Chopin' issue. ${ }^{421}$

418 See Idzikowski 1963.

419 'Due to the will of certain factors', they were supposed to prepare the second issue of the three-volume biography by Ferdynand Hoesick Chopin. Życie i twórczość [Chopin. Life and works] (Warsaw 1910-11). Finally, Hoesick's monograph was published only in the 1960s (vol. I Cracow 1962, vol. II Cracow 1965, vol. III Cracow 1966) with comments and footnotes by Franciszek German and Jadwiga Ilnicka.

420 Chybiński/Chomiński 2016, 130-131. Sydow’s article ‘Chopin i Delacroix. (Historia jednego portretu)' [Chopin and Delacroix. (The history of one portrait)] (KM 1949/26-27, 15-26).

421 KM 1949/26-27, 394-401. 
There was also another author hailing from outside the musicologist community. Doctor-psychologist Stefan Szuman was an already known authority. He had been associated with the Jagiellonian University since the 1920s, and in 1946-48 he served as the first rector of the Higher School of Pedagogy in Cracow. From the beginning of his scientific career, he was particularly involved in child psychology, developmental psychology and research on developing artistic talents and education through art. Chybiński considered it an honour to work with Szuman, thus probably the idea to invite him in connection with the subject of Chopin. Although the author did not prepare the text in time, the article 'Wyobrażenia taneczne sugerowane przez Walce Chopina' [Dance ideas suggested by Chopin's waltzes] was interesting because of the different view of a work that is a dance that - when played - should not only be listened to but it also, as the author puts it: 'actuates the listener in a kinetic manner.' It was included afterwards in the second 'Chopin' volume. ${ }^{422}$ Szuman, who was not a musicologist, discussed his conclusions both with already classic European literature (Leichtentritt, Bourguès, Denéréaz, Niecks et al.) and the latest Polish publications (Lissa, Łobaczewska, Ingarden). Besides, as he mentioned, he had consulted Łobaczewska about his article to the musicological extent and was preparing a book Jak stuchać muzyki [How to listen to music] together with Lissa at that time, so the circle of musicologists was not unfamiliar to him. As a practising doctor and psychologist, he provided the only example of a publication on the borderland of music and psychology in the postwar edition of the magazine ${ }^{423}$ that brought a completely different perspective on the issue of the composer's heritage.

Another author who joined the pages of Kwartalnik in its third edition was Krystyna Wilkowska (after marriage Wilkowska-Chomińska). She published two monographic articles on Chopin: 'Impromptus Chopina' [Chopin's Impromptus] and 'Środki wyrazu emocjonalnego w Balladach Chopina' [Means of emotional expression in Chopin's Ballads]. ${ }^{424}$ They both represent a methodology and narrative very similar to those that characterise Chomiński's academic papers. Wilkowska, who received musical education (piano at the conservatoire in Bydgoszcz and Poznań) and also studied (although interrupted by war) humanities at the University of Poznań (Polish philology and musicology),

422 KM 1950/29-30, 26-63, cit. p. 30.

423 Here I would like to recall that in the 'pedagogical' issue of the interwar KM Zofia Lissa published, amongst others, an article 'Z psychologii muzycznej dziecka' [From the child's musical psychology] (1931/10-11, 173-207), which was based, among others, on her own research.

424 Respectively 1949/26-27, 102-182, 1949/28, 167-239. 
had the foundation to prepare such insightful analyses of Chopin's Ballad and Impromptus. She was aided in her works with consultations and cooperation with Józef Chomiński, which she had not forgotten and placed her thanks in the introduction to the first of her articles.

Among the authors, there was also a small group of foreign musicologists, whom Chybiński did not approach with enthusiasm whatsoever. Perhaps this is why foreign texts were published only in connection with the publications of the jubilee Chopin year. Never-the-less, Franz (František) Zagiba, a Slovak musicologist educated and connected with Vienna, soon the initiator of the founding of the Austrian Chopin-Gesellschaft and the author of a monograph Chopin und Wien (Vienna 1951), followed the advice of Zdzisław Jachimecki and approached Józef Chomiński with a proposal to develop an article on the rediscovered by himself, previously unknown, variation on the theme Là ci darem la mano. ${ }^{425}$ The editors also commissioned the French version of the text from the author, proposing its publication in two versions, but this never materialised. ${ }^{426}$ Lajos Hernádi was a renowned Hungarian pianist; unfortunately, I did not manage to find out how he got in touch with the editors of Kwartalnik. His article on Chopin's piano style 'in a historical light ${ }^{\text {'427 }}$ brings interesting arguments that confirm the uniqueness and individualism of the composer's piano style and its impact on similar compositions by other nineteenth-century and twentiethcentury artists. Finally, the pianist Ignace Blochman, though with Polish roots, bound his professional artistic life with foreign countries from his youth. $\mathrm{He}$ arrived from Warsaw to Brussels to study piano playing in the 1920s and already became highly popular there before the war. As has been mentioned, he sent information to Kwartalnik ${ }^{428}$ about Chopin's previously unknown autographs from Belgian collections; in the course of time, he received a proposal to write an article about Chopin's piano playing technique. ${ }^{429}$

\section{See above footnote 397.}

426 The idea of 'internationalisation' of KM in the Chopin Year failed. The magazine was provided only with a table of contents in Polish (at the beginning of the issue) and in French (at the end of the issue). Foreign-language summaries were not published, although Chomiński initially considered abstracts with a volume of around ten typed pages.

427 KM 1949/26-27, 360-377.

428 See above footnote 396.

429 Chomiński to Blochman from Warsaw 14 III 1949, APCh. 
Among those less desired, there were names associated with the overwhelming trend in art scholarship - socialist realism - which was imposed or enforced by factors from above.

In the last months of their work, the editors received, through Zofia Lissa, an opinion article on the aesthetics of music, which presents the tasks that Soviet music aesthetics undertakes in order to determine 'dialectic-materialistic' fundamentals of the essence of music. Julij Kremlew's text 'Zagadnienia radzieckiej estetyki muzycznej' [The issues of Soviet music aesthetics] ${ }^{430}$ was intended to express opposition to the 'persistent orientation of the formalistic trend' of Soviet music, which 'put idealism in place of materialism and metaphysics in place of dialectics', which pushed aesthetic reflections towards decadence. Because of new aesthetics based on the theory of reflection, music would no longer be perceived as an isolated and incomprehensible field, but it would be 'one of the fields of human artistic activity. ${ }^{431}$ Kremlew stresses that the theory of reflection is different from the 'naive materialistic' theories of imitation that have already emerged in aesthetics and lose 'the subject in the object.' A work of art cannot be reduced to a simple imitation of reality, whereas a work of art derives its whole content from the real world. All elements making up a work of art draw upon reality, but the work itself 'is a product of human consciousness, instead of a passive, mirror copy of the external world.'432

Kremlew's article belonged to a group of texts from the content bibliography of Kwartalnik which formed part of a trend of socialist realism literature. We cannot forget that in the 'Reports' column appearing from the very first issue of the magazine, the editors found a separate section outlining the current 'significant' events from musicological and musical life of both the Polish and international communities. Edition number 3 from 1948 refers to the AllUnion Congress of Soviet Composers in Moscow (April 1948) and the Second International Congress of Composers and Music Critics in Prague (May 1948) (33 $^{43}$ as well as the most important theses spoken by Boris Asafyev (in Moscow) and Antonín Sychra, and Zofia Lissa (in Prague).

430 KM 1950/29-30, 7-25.

431 Ibid., 24-25.

432 Ibid., 11.

433 As it was written, 'one could also mention the Twenty-Second International Festival of Contemporary Music in Amsterdam [June 1948] - but not in order to assign this festival any importance.' Although the level of works performed there did not 'raise objections of either technical or ... artistic nature,' but during the festival 'no lessons from the growing historical changes were taken,' see KM 1948/23, 194. 
Lissa, well educated in music theory and musicology, made efforts to explain why it is not always worth excluding other representatives of the musical tradition, not so fitting to the rhetoric of socialist realism. Her Prague speech was intended, among others, to assume that the 'selection [of music productions] carried out using the non-homogeneous criteria, as it takes place in environments with an elitist attitude' may be imperfect, and 'may lead ... to exclusion of not only creations of a significantly decayed character but also those that are just difficult to apprehend,' therefore 'the burning issue becomes ... this specific kind of music that can meet the educational functions for the new music consumer without lowering its flight. ${ }^{3} 34$

The analysis of these two texts, and even a third one, published in the Kuźnica weekly (which, moreover, was a reprint from Kwartalnik), as well as the context in which they were located in the framework of the socialist realist discourse was provided by Sławomir Wieczorek in one of the subsections of his dissertation entitled 'można dziś wymagać od naszych kompozytorów' [today one can demand from our composers], ${ }^{435}$ in which he noted that they differed only slightly, mainly in terms of differently distributed accents. ${ }^{436}$ 'Lissa's texts established a new situation of communication, building a specific hierarchy of expressions. It was the first time when a leader's statement was heard, who, when putting forth the guidelines formulated by the mentor, submitted a request put forward in relation to the creators of music. ... Lissa expanded the whole argumentation with a historiosophical aspect, noting the historical correctness, to which creators are subject. ${ }^{3} 37$ This historiosophical aspect could not, however, suffice to give Lissa's highly-involved arguments the academic nature which should characterise publications found on the pages of a scientific periodical. The researcher directed her appeals to the composers, and to theorists and critics, she assigned as little (or perhaps so much) as the obligation to ensure that creators do not deviate from the correct creative path. The place of musicology was verbally indicated in the summary of the three mentioned speeches printed from the 'Appeal' adopted at the end of the meeting of the convention in Prague, which referred to the need to 'exchange experiences and thoughts between progressive composers and musicologists from all over the world [so that their] selfless and

434 Zofia Lissa, 'O społecznych funkcjach muzyki artystycznej i popularnej' [On the social functions of artistic and popular music], KM 1948/3, 211-222, quotation pp. 217-218.

435 Wieczorek 2014, 42-46.

436 Ibid., footnote 149.

437 Ibid., 43-44. 
one-purpose work defeats the lingering contemporary crisis and provides music with its important and noble role within society.438

Excerpts from Prague speeches were continued in the subsequent issue of Kwartalnik Muzyczny (no. 24), which contained Alan Bush's text 'Struktura i wyraz muzyki współczesnej' [Structure and expression of contemporary music], and Hans Eisler's 'Podłoże społeczne muzyki współczesnej' [Social foundations of contemporary music]. ${ }^{439}$ Just like the previous texts, both discussed the social context of the existence of music, from which - as might be presumed - directives can be derived for contemporary artists.

In the course of completion of materials for Kwartalnik, the editors held talks with some other authors - among others, with Mieczysław Drobner (about the publication of fragments of his master's thesis written before the war under Jachimecki's direction in Cracow, and some other topic was being considered for the Chopin issue ${ }^{440}$ ), with Zbigniew Drzewiecki about a work 'in the field of pianism, e.g., the problems of pianism in Chopin's music, ${ }^{341}$ with Marian Sobieski, ${ }^{442}$ with Roman Palester 'about folk themes in music,' ${ }^{343}$ with Józef Swaton about the article 'New forms of organisation of music education in Poland - plans and programmes, ${ }^{344}$ with Jerzy Pogonowski about a work 'from the borderland of music and literature, ${ }^{445}$ with Andrzej Ryszkiewicz about the organisation of music libraries and the most recent methods of cataloguing music and musicological works, ${ }^{446}$ or with Helena Windakiewicz about her work 'Stosunek

438 'Odezwa uchwalona jednogłośnie na II Międzynarodowym Zjeździe Kompozytorów i Krytyków Muzycznych w Pradze' [An appeal passed unanimously at the second international congress of composers and music critics in Prague] (KM 1948/23, 223-224).

439 Corresponding pages $180-187$ and 187-194.

440 Drobner to Chomiński from Łódź 9 I 1949, APCh; Chomiński to Drobner from Szklarska Poręba 15 I 1949, APCh.

441 Chomiński to Drzewiecki from Warsaw 14 III 1949, APCh.

442 The only text published by Marian Sobieski in KM is a printed version of his speech on the organisation of the Folklore Collection Campaign (delivered during the Convention of Musicologists in November 1948, KM 1949/25, 192-197).

443 Chomiński to Palester from Warsaw 29 VIII 1948, APCh.

444 Chomiński to Swatoń from Szklarska Poręba 27 XII 1948, APCh.

445 Chomiński to Pogonowski from Wesoła 21 X 1949, APCh. Jerzy Pogonowski wrote such books as Liryzm i Słowiańszczyzna [Lyricism and slavdom] (1924) and Bój o Lwów [The Battle of Lviv] (1921).

446 Chomiński to the Editors of RM from Wesoła 12 X 1949, APCh. Andrzej Ryszkiewicz, an art historian and subsequently the long-serving deputy director and director of the State Institute of Art and the Institute of Art of the Polish Academy of Sciences, was in charge of libraries of the Ministry of Culture and Art and PIS in the years 1945-51. 
systemów tonalnych greckich do polskiej muzyki ludowej i artystycznej' [The relationship of Greek tonal systems to Polish folk and artistic music], ${ }^{447}$ with Feliks Wrobel an article on the subject of 'Barwa i dźwięk' [Sound and colour] ${ }^{448}$ and nearly unspecified representatives of the Musicological Section of the Soviet Composers' Union. ${ }^{449}$ The short life of post-war Kwartalnik made it impossible to realise these plans.

In addition to substantive and ideological publications, the pages of Kwartalnik contained various kinds of materials filling news sections, such as questionnaires, reports or bibliographies; the latter were particularly important after years of being cut off from international information on the market of musical and musicological publications. In one case, it was 'Bibliografia radzieckiej literatury teoretyczno-muzycznej za okres 1935-1948' [Bibliography of Soviet Tteoretical-music literature for the period 1935-1948] $]^{450}$ completed by Zofia Lissa (who had made use of her 'Eastern' contacts), Zygmunt Estreicher from Switzerland delivered three times: 'Bibliografia za rok 1939-1941' [Bibliography for the year 1939-1940], 'Bibliografia za rok 1942-1943' [Bibliography for the year 1942-1943] and 'Bibliografia za rok 1944-1945' [Bibliography for the year 1944-1945] (all three covering world literature) ${ }^{451}$, and by Bronisław Edward Sydow, 'Bibliografia literatury chopinologicznej i chopinograficznej za okres 1939-1949' [Bibliography of Chopinological and Chopinographic literature for the period 1939-1949], ${ }^{452}$ and also in the last edition, Krystyna Wilkowska and Andrzej Ryszkiewicz's 'Bibliografia polskiego piśmiennictwa muzycznego za okres 1945-1949' [Bibliography of Polish music literature for the period 19451949]. ${ }^{453}$ Reviews and reports from the latest publications played an even more important role. Usually, following the practice that had proved effective for years, the editors acquired charge-free copies from the publishing houses that they co-operated with or via their private contacts; however, in view of the uncertain future of the magazine, even the home publisher - PWM - was willing to ${ }^{454}$ only

447 Chybiński to Lissa from Zakopane 12 VIII 1948, at AZL-BUW.

448 Ibid.

449 Chomiński to Khrennikov from Warsaw 22 VI 1948, APCh.

450 KM 1949/25, 156-161.

451 KM respectively: 1948/21-22, 276-279, 1948/23, 169-176, 1948/24, 132-139.

452 KM 1949/26-27, 394-401.

453 KM 1950/29-30, 84-113.

454 Also in accordance with the top-level guidelines of the Supreme Audit Office from Łódź, see Ochlewski to Chomiński from Cracow 19 IV 1950, APCh. 
submit those items that had a real chance of being reviewed. In addition, Director Ochlewski made attempts to submit works of Polish composers being currently published for review (starting from Moniuszko and finishing with Maklakiewicz or Sikorski), but Kwartalnik, being a strictly scientific and musicological rather than critical and journalistic magazine, never reviewed publications of this kind.

The second volume (no. 23) of Kwartalnik contained a questionnaire for composers prepared by the editors; many active artists received personal invitations to join this survey (amongst others to Kazimierz Sikorski, Tadeusz Szeligowski, Witold Lutosławski, Stefan Kisielewski, Zygmunt Mycielski, Roman Palester, Piotr Rytel, Tadeusz Szeligowski, Bolesław Woytowicz, Antoni Szałowski, Michał Spisak, Andrzej Panufnik...). However, the survey met with limited response, mainly from the artists who co-operated with Kwartalnik and the narrow editorial circle also in other fields: Bolesław Woytowicz, Konstanty Régamey ${ }^{455}$ and Zygmunt Mycielski. ${ }^{456}$

Normal operation of the editorial and ad hoc ideas, such as the survey as mentioned above, from which it was (wrongly) expected to witness wide participation from composers and, therefore, a steady inflow of texts, were not able to guarantee the full scope of materials for publication. Themed booklets are a natural solution in such a situation, but success is guaranteed only if the project draws in a sufficiently large group of interested authors. The authorities' use of the figure and works of Chopin for propagandist academic projects resulted in the creation of something of the character of a patriotic mission and expectations of the results seemed to be challenging to meet. The Chopin booklet, planned not only by the editorial staff but also at the level of ministries, 'should, according to "higher directives," consist of 500 pages. I have a feeling that this is too much' - Chybiński wrote. ${ }^{457}$ The act of collecting materials with such a narrow circle of musicologists and experts in Chopin's works seemed to be a difficult challenge. Already in the summer of 1948, the professor had considered obtaining materials, although with some reservations. ${ }^{458}$ An official invitation

455 Their answers in KM 1948/24, 141-165.

456 KM 1949/25, 162-164.

457 Chybiński to Bronarski from Zakopane 2 IV 1949, AACh-BUAM, Bronarski’s archive, p. 200.

458 '[E]ven today we should start our efforts [to get materials - MS]. From whom? Not only from Polish musicologists, but - apart from them - only from Slavic ones, and none other! For example, not from French musicologists by any means - for obvious reasons,' Chybiński to Lissa from Zakopane 11 VII 1948, AZL-BUW (underlining original). 
letter addressed to people dealing with Chopin issues on a regular basis or at least in the past - Bronarski, Feicht, Łobaczewska, Miketta, Jachimecki, Liebhart, Simon, Reiss, Szczepańska, Frączkiewicz and Poźniak - was sent from the editors in the first days of January 1949. When an issue with an enlarged volume was announced, authors were asked to submit works not longer than 40 typed pages and reports on most recent Chopinological literature by 30 April.

The first project of the issue was not fulfilled. The editorial file contained forthcoming dissertations: by Chomiński ('about preludes'), by Krystyna Wilkowska ('about impromptus by Schubert vs. Chopin'), by Janusz Miketta ('about Chopin's motif'), by Alicja Simon ('about 2 versions of some work by Chopin, maybe a waltz - for the time being, the matter is being kept secret') and two articles by Bronarski. However, the following planned texts were not submitted: by Lissa ('about development in Chopin's sonatas'), ${ }^{459}$ by Prosnak ('about musical relations in the Warsaw Conservatoire in Chopin's times along with excursions towards Hummel and Kalkbrenner'), ${ }^{460}$ 'something by Lobaczewska. ${ }^{361}$ The 'essay about Chopin's "motif”" by Chybiński (the professor prepared a short sketch on reminiscences in Chopin's works for the second Chopin volume of Kwartalnik) ${ }^{462}$ and other texts in the possession of the editors, such as a pre-war work by Zofia Lissa 'Chopin w świetle badań antropologicznych' [Chopin in the light of anthropological research $]^{463}$ or 'a short article by prof. Jan Bartók about publication of

459 The editors rather expected her to submit a work on Chopin's personality; this text would open the Chopin issue, mainly because 'Kwartalnik has to stress and document a new methodological approach,' see Chomiński to Lissa from Szklarska Poręba 14 II 1949, APCh.

460 Modified in respect of its thematic scope, Prosnak's article 'Środowisko warszawskie w życiu Fryderyka Chopina' [The Warsaw milieu in the life and work of Frederic Chopin] was published in the second 'Chopin' issue of Kwartalnik.

461 Chybiński to Bronarski from Poznań 25 IV 1949, AACh-BUAM, Bronarski’s archive, p. 201.

462 Adolf Chybiński, 'Do kwestii reminiscencji w dziełach Chopina' [On the subject of reminiscence in Chopin's works] (KM 1949/28, 142-148). The article 'O pewnym “motywie" w dziełach F. Chopina' [About a certain 'motif' in Frederic Chopin's works], submitted to the editorial file of Kwartalnik at that time, was used by Józef Chomiński in the first volume of Studia Muzykologiczne (published already after the professor's death in 1953).

463 'My pre-war article, once submitted to the Chopin magazine and not printed, has survived, but I doubt if this topic, which sounded militant in 1939, still makes any sense today. This article ... proved that, in spite of all Dinaric (anthropological) characteristics, Chopin's music and its style resulted from the Slavic environment. I carried out detailed anthropological surveys with one of the assistants of Professor [Jan] 
Chopin's Waltzes by Bela Bartók, ${ }^{364}$ and unspecified material from Aleksander Frączkiewicz were not published, either.

Alas, it was impossible to print the monograph volume by the end of the Chopin Competition, held from 15 September to 15 October in Warsaw. Contrary to the fear that had been expressed on numerous occasions during the editorial work, the content of edition number 26-27 was, however - in scientific terms - extremely satisfactory and the materials on Chopin still flowed in quantities that allowed the editors to prepare the second part of the special issue $Z$ życia i twórczości Fryderyka Chopina [From the life and creative work of Frederic Chopin]. The editor-in-chief also planned to release an anniversary issue in 1950, although it was eventually published as a closing edition in $1949 .{ }^{465}$ According to an earlier plan, issue no. 28 had been supposed to gather vaguely specified speeches from the composers' conference in Łagów, ${ }^{466}$ but in the situation when the PIS had already decided to close down Kwartalnik, it became necessary to publish all Chopin's memorabilia as quickly as possible.

Also in 1949, in connection with the approaching Bach Year and the resulting expectations of the Ministry, the editors made very reluctant attempts to compile an issue devoted to the Leipzig cantor. Chybiński approached this idea very sceptically at once, and so did Lissa, but there were also authors ready to contribute something to the Bach issue. Łobaczewska 'would definitely like to give something about the problem of form in Wohltemperiertes Klavier, ${ }^{367}$ in connection with the same Chomiński planned 'to make a pendant for this problem and write something about fugues, ${ }^{346}$ Jan Prosnak 'would be happy to work up a less-known issue related to Bach.' ${ }^{369}$ In addition, the content of the edition was to

Czekanowski .....' Before the war, Lissa had dealt with the 'anthropological' context in research on Chopin: in the Lviv daily Chwila, she published an article 'Jakiej "rasy" był Fryderyk Chopin?' (What was Frederic Chopin’s race?) (issue of 26 II 1938, p. 10).

464 Chybiński/Chomiński 2016, 169-170.

465 The consequence of the unexpected abundance of Chopin materials, which eventually filled up two large volumes of the magazine, was the plan to launch a new periodical, Rocznik Chopinowski [Chopin Yearbook], more in 'Conclusion.'

466 Tadeusz Ochlewski referred to the 'Łagów issue' in one of his letters from Brwinów to Chybiński (AACh-BUAM, fol. O-P, p. 88), but he added a few days later that 'the Ministry of Culture and Art does not want the Łagów issue of Kwartalnik any more' (Ochlewski to Chybiński from Cracow 28 XI 1949, AACh-BUAM, File O-P, p. 89).

467 Łobaczewska to Chomiński from Cracow 29 I 1950, APCh.

468 Chomiński do Łobaczewskiej from Wesoła 11 II 1950, APCh.

469 Prosnak to Chomiński from Brwinów 4 II 1950, APCh. 
be complemented with papers presented in Leipzig during the Bach conference by the deputy head of the PIS, Aleksander Jackowski. ${ }^{470}$

In turn, at the beginning of 1950, the plans laid out by the Music Section of PIS, the then-publisher of Kwartalnik Muzyczny, included 'selection of works that should be realised ... taking into account the need to link their topics with the issues faced by the Section in connection with the Science Congress (issue of a special number of Kwartalnik Muzyczny).471 This project of a methodological issue 'due to the Science Congress' was valid for a few successive months, ${ }^{472}$ but the planning of a 'Marxist' ${ }^{\text {'773 }}$ issue began already in the middle of the year. Łobaczewska responded to plans for such a monograph with full enthusiasm and readiness; ${ }^{474}$ there were also plans to include 'congress'" papers (or maybe those presented at the Conference on Research on Art) in the content. Much earlier, in 1948, there was an idea of dedicating number 25 to the issues of content in music and the then heated 'formalism,' which 'had to create a sound basis for the ongoing ... discussion. ${ }^{375}$ The editors invited, among others, Zygmunt Estreicher, Konstanty Régamey, Stefan Szuman, Roman Ingarden and Stefania Łobaczewska to participate in this issue. Consequently, the only texts concerning this problem were Zofia Lissa's dissertation 'Czy muzyka jest sztuką asemantyczną?’ [Is music an asemantic artform?] and Stefania Łobaczewska’s

470 Chomiński wrote about these texts: 'These are papers by a certain Hugow and Mayer. I read both of them, and my hair instantly stood up on end. I understand that you can stretch some facts, speculate etc., but if someone claims that there was no one in Germany before Bach, that it was a desert, that neither Buxtehude, Pachelbel, nor others were born and are legends, it starts to get a little uncomfortable,'see Chybiński/ Chomiński 2016, 289-290.

471 'Sprawozdanie z działalności Instytutu 1949-1950' [Reports of the Institute's activities 1949-1950], extant in Archive IS PAN, fol. D-0312 (A 32), 25.

472 Wilkowska to Ochlewski from Wesoła 22 IV 1950, APCh.

473 Ochlewski from Chomiński from Cracow 5 VI 1950, APCh. The idea of a Marxist edition was interesting for the editorial staff only for pragmatic and financial reasons: Chomiński expected to strengthen the editorial finance from PIS's budget.

474 Łobaczewska to Chomiński from Cracow 6 VI 1950, in APCh: 'With regard to the latter issue - i.e. the work for the Marxist volume of "Kwartalnik": I will probably write a kind of widely-treated programme article ("Musical Aesthetics in the Light of the Marxist Method" or something like that), I suppose it will be done there on the spot and, at the same time, it would be beneficial to realise the changes in the points of view, selection of problems, etc.'

475 Chomiński to Estreicher from Milanówek 2 XI 1948, APCh. 
essay on the aesthetics of music 'Problem wartościowania i wartości w muzyce' [The problem of evaluation and value in music]. ${ }^{476}$

An overview of publications in the post-war edition of Kwartalnik Muzyczny allows us to divide them into two groups: 'traditional' and 'modern' texts. Despite top-level guidelines and expectations of government officials, most texts were still dissertations based on German-type musicology being cultivated by a majority of then-active researchers - analyses of compositions using proven theoretical systems, historical materials based on source materials, or contributions presenting the results of queries. Interdisciplinary and at least partly musicological matters were brought up only occasionally. The articles belonging to this group were always original material that was published for the first time on the pages of Kwartalnik. ${ }^{477}$ On the other hand, some materials were either created due to the influence from the prevailing ideology or served as recordings of the current events from the area of science and politics, addressed to the editorial staff with a top-down instruction to have them published. Examples of socialist realist literature, few in Kwartalnik, also fit into their climate. Zofia Lissa primarily prepared these, but not Józef Chomiński (nor articles by Krystyna Wilkowska), whom Stefania Łobaczewska, with all due respect and recognition for the academic advantages of his analyses, however, accused of being burdened with the former formalist method. Although the analytical method adopted in the three dissertations constitutes, according to Łobaczewska, a 'very serious effort to go beyond the limitations of traditional formalist methods [but] its only innovative feature is the assumption that the form of a piece of music results from cooperation between all the musical elements.' Still, however 'the aspect of form remains dominant, the aspect of content - secondary.'478

When reading the review of Chopin-related issues of Kwartalnik Muzyczny quoted above, which was written in 1951/52 - that is, at the moment of the strongest ideological pressure on various spheres of national life, including the spheres of culture and science - we feel the stigma of the 'discourse of social realism' marking Łobaczewska's evaluation. The pressure that the 'setters' and 'mentors' exerted on researchers weakened over time. For the first post-war decade, many scientists stuck to research in the traditional sense of the word, and the rhetoric

476 See above footnote 344 .

477 Removing the 'Preface' that had already been published in PRM (available to a very limited extent in the 1940s) before the war from Maria Szczepańska's dissertation on Mikołaj Radomski would make it difficult to pursue a logical line of reasoning consistently and clearly, hence the decision to repeat this part of the monograph.

478 Stefania Łobaczewska, [review] (SM 1953/1, 387-393). 
of social realism was present only in publications by some musicologists. We can perceive the extent to which Marxist theories determined the direction of historical research in post-war science, including musicology, and how the leading researchers strayed in their own thoughts not just in official speeches. Their actual commitment to the ideas they proclaimed is reflected even in their private correspondence - for example, Zofia Lissa's very interesting reflections on her Chopin-related plans for Kwartalnik, which were also quoted by Maciej Gołąb:

it has been 'my heart's' desire to write 'On Chopin's era' for a long time now. It has been written (and I have done this as well) that violins were playing underneath the windows at the time when Chopin was born. And who knows that at the time when Chopin was born the first strikes in the world were sparked in England, machines were demolished as a means of the proletariat's first response against capitalist exploitation. Who knows what took place in Germany and France when Chopin was playing in the salons of the Rothschild family? It is extremely tempting to put these distant phenomena next to each other and try to detect a thread that led from one to the other... I want to write this article for Kwartalnik, absolutely. ${ }^{479}$

The academic character of the magazine run by Adolf Chybiński, devoid of accessible content and current news that would encourage broad masses, influenced the fact that it was ultimately considered too elitist, niche and unnecessary in the reborn, socialist state, while the aspirations of the editorial staff were deemed uncomfortable for the publisher. Given this situation, the management of PIS, to which Kwartalnik had already been subject at that time, decided to suspend further financing and shut down the title. In a short time, it turned out that in a rerun of the situation from the 1930s, the existing academic journal turned into two new magazines - the popular monthly Muzyka, packed with ideological concepts and (later on) Studia Muzykologiczne, which continued the traditions of the strictly academic Polish musicological literature.

479 Lissa to Chomiński from Warsaw 8 II 1949, APCh, see also Gołąb 2008, 46. 

Conclusion 



\section{Premises of the publishing crisis - change of generation - new publishing initiatives in the field of musicological periodicals: Muzyka, Studia Muzykologiczne, Rocznik Chopinowski}

The political reality of the 1940s throughout the country which comprised, amongst others, of the fight against the erstwhile Sanation era and promotion of the widespread centralisation and also contributed to a generational change - including in the academic centres. Important positions in scientific and artistic institutions, as well as editorial offices, were passed to representatives of the subsequent generation; as for the Polish musicological community, this applied primarily to the students of Adolf Chybiński. Concentrating all the major activities from the areas of both research and education as well as publishing in the capital city and subordinating the functioning of academic and cultural units to central decisions taken arbitrarily by MKiS, MN, and PIS, was at odds with the principle of self-determination of academic and creative communities, on which all the existing generation of intellectuals and artists had grown up. Combining weaker departments into larger units focused around selected universities resulted in a kind of brain drain and inevitable migration of both teaching staff and students from the liquidated institutions (in case of musicology, first from Wroclaw, afterwards also from Poznań), or the takeover (sometimes under the guise of borrowing for reverses) of library and archival resources as well as equipment, as it was the case with resources of Wroclaw musicology, given 'as deposit' to Warsaw, among others.

This situation also concerned taking over the position of editor-in-chief of what was then the only professional musicological journal - Kwartalnik Muzyczny. The first signal of the upcoming changes was the transfer of the title to the PIS and consequently entrusting the function as a leading magazine to the Institute's representative. In the autumn of 1949, Chybiński wrote to Ludwik Bronarski that 'from the New Year there will be an editorial change. The editor is to be Mr [Stefan] Jarociński, because Kwartalnik is being placed under the budget of the newly created Institute of Art. So let the professional musicologists rest!'

1 Chybiński to Bronarski from [Zakopane] 1 XI 1949, AACh-BUAM, Bronarski's archive, p. 207. In other letters, the name of the director of the Department of Music at MKiS, Witold Rudziński was also mentioned. 
On the one hand, he expressed the hope that Rocznik Muzykologiczny would be revived, but on the other, even though there were explicit signs 'from above' that the decision to close down Kwartalnik had already been made, in the last days of December 1949 he still saw many possibilities for further development of his journal. However, personal changes were only postponed a little bit and came about with the crisis related to the lack of new material which could be published. In the middle of 1950, after publishing two significantly delayed yet bulky issues devoted to Chopin, there was very little 'raw material' - as Chybiński called it - which could fill the planned volumes. In 1950, the editorial office managed to prepare one more issue, 29-30, but even though it was double, its contents and volume were very humble. However, Chybiński still hoped that he would at least be able to conclude that year's issues. Nonetheless, this did not happen, and the history of Kwartalnik Muzyczny ended at that moment, and the last double issue, released under the banner of PIS, was signed anonymously by the 'Editorial Committee.' It is known that until the closing of issue 29/30 nothing changed personally and the old editorial staff finalised the work, but the materials had to be censored, however, by the Institute management: 'both editions [number 28 and 29-30], although prepared, cannot be put to print due to checking the material at the Institute of Art. They've been there for three weeks.'2

In connection with top-down, significant reshuffling in the small group of Polish musicologists and the opening of new career perspectives to the young professionals, relations within the editorial department - between Chybiński and Chomiński - deteriorated during 1951. Chomiński, as well as several other pupils of the Lviv department, decided to adopt an attitude in relation to the system, which facilitated fruitful work in the field of musicology, certainly not against, but alongside the imposed ideological expectations of the state apparatus. In those years, a different choice could have led to complete exclusion from the profession, and Chomiński was already an experienced researcher, considering further academic and didactic plans, the author of accomplished publications, whose first and main admirer was Chybiński himself. It was not surprising then that when in 1950 he received a proposal for a position in PIS (which was also connected with taking over the management in the new musicological journal and the new series of musical editions, ${ }^{3}$ and thus the simultaneous takeover of

2 Chomiński to Łobaczewska from Wesoła 11 II 1950, APCh.

3 The first volume of Studia Muzykologiczne appeared in the year 1953, and the first volume established by Chomiński in 1951 of the source-critical series Monumenta Musicae in Polonia (Tabulatura Jana $z$ Lublina in a facsimile publication prepared 
Chybiński's activity from the orbit of the two main areas of his interest), and later also at the newly created Institute of Musicology at UW - he did not hesitate.

Decisions made by Chomiński brought about a cooling of the long-term fond relationship between the master and his pupil, which is evidenced by his correspondence with the professor. Chybiński, who kept making publishing plans which he expressed in his letters to those whom he trusted, wrote to Chomiński with irritation:

I obviously can't write an opinion on any report or paper because I'm overloaded with work anyway. ... I really don't care anymore (with all the work that I have to do) whether we call something an analysis or a monograph. A monograph cannot be an analysis, and an analysis cannot be a monograph. How come these two terms are being confused!!! Therefore, I am going to resign from the position of editor of 'Analizy'. ... I cannot submit any paper to Kwartalnik just because of the lack of time. I'm too busy with my own work. ${ }^{4}$

A little earlier he evaluated the series brought into being by PIS, Monumenta Musicae in Polonia:

Thank you for the clarification on the 'monuments.' Now I am even more convinced of the correctness of my views, and I wish to loyally swear that I will fight against opposing views. I am still of the opinion that the publication of a 'series' of 'monuments', in view of such a small inventory of our old music, will make us a laughing stock. ... are we supposed to publish works that have already been issued in WDMP? Why? For what purpose? How will the science benefit from the fact that we will once again issue Pękiel's, Mielczewski's, Zieleński’s, Gorczycki's, Szarzyński’s works, whom Italians and other Western nations have in abundance and certainly do not intend to print everything that remained after them?! ${ }^{5}$

All of his closest collaborators wanted to resolve the conflict, which was felt in an unfortunate manner by others; all the more so because in 1950 the professor had his 75th birthday, which his students and friends wanted to mark with special celebrations and a jubilee book. The misunderstanding dragged on; in autumn 1951 Tadeusz Ochlewski wrote: 'Warsaw have asked me to appease your anger towards Chomiński, because no one has the strength to fight and everyone is overloaded with work, and it is difficult to eliminate Chomiński, especially in the current situation in PIS.6

by Krystyna Wilkowska-Chomińska in cooperation with Katarzyna Swaryczewska (Morawska), with a thematic catalogue and alphabetical index) was published in 1964.

4 Chybiński/Chomiński 2016, 320-321.

5 Chybiński/Chomiński 2016, 315-316.

6 Ochlewski to Chybiński from Cracow 27 IX 1951, AACh-BUAM, fol. O-P, p. 142. 
At the same time, Zofia Lissa continued to act in favour of the development of Warsaw musicology and its community therein. According to many - this was at the expense of other centres, although the appraisals of her decisions are today not clearly negative:

It is said that she eliminated the Wroclaw department of musicology of Fr. prof. Hieronim Feicht. Well, this was required by the then centralisation. The whole nation was building the capital at that time. Hence, music libraries were imported to Warsaw, and not only from Wroclaw. Zofia Lissa, however, did not forget about the Father Professor and took him into the Warsaw Institute of Musicology that she had established. ${ }^{7}$

As for the relationship between Lissa and Chybiński, all the post-war letters preserved in the Poznan and Warsaw archives exude the respect and concern that the former student showed her 'dear and beloved Mr Professor.' She consulted all important decisions influencing the current fate of musicology with him; she also confided to him about her most serious problems and trusted him with various secrets of the milieu. Even if these were merely acts of courtesy, they would undoubtedly allow Chybiński to understand the value of his opinions for subsequent generations.

A succession of unfavourable events in his professional life, the feeling that his academic career was in decline, as well as health problems made Chybiński feel very weak from the beginning of 1952. Even as late as in spring, he and his doctors still attributed this 'physical exhaustion' to being overworked. This condition and the growing uncertainty about the future of musicology in Poznan gradually discouraged him from taking any action. In April of that year he wrote with sadness to Ludwik Bronarski: 'probably musicology will prove to be unnecessary for Poznań (according to opinions beyond Poznań), which somehow fits strangely with my - so to say - feeling of pedagogical satiety or fatigue.8 And further: 'I would like to move from Poznan to Cracow (my home town) or near Cracow or to some lovely town in the highlands, and who knows, maybe

7 Bilica 2008, 33. Lissa herself explained her decision to Chybiński: 'I know that the Professor probably is displeased with me - about Fr. Feicht. I suppose that the Professor wanted to have him. In this case, two moments decided the matter: the fact that Warsaw musicology does not have any pure-blood historian and a historian of Polish music in particular. And so Fr. Feicht here has two roles; in addition, the fact that Warsaw is the capital and that the Minister of Education first and foremost cares about the correct positioning of the capital's musicology, see Lissa to Chybiński from Warsaw 10 V 1951, AACh-BUAM, fol. K-L, p. 213.

8 Chybiński to Bronarski from Poznań 28 IV 1952, AACh-BUAM, Bronarski’s archive, p. 216. 
to Zakopane, although, it may already be too high. I do not know when this will happen. I would like it as soon as possible. ${ }^{9} \mathrm{He}$ did not undertake any new obligations, such as writing just ten entries for the Polish Musicians Dictionary planned and proposed to him by the PIS. ${ }^{10}$

In September 1952, Adolf Chybiński found himself in hospital where he underwent surgery. He did not return to health but did continue to make plans for the future. In the last of his extant letters that remained in the cavernous archives from the professor's correspondence, he wrote to Tadeusz Ochlewski: 'I will get out of hospital in 5-6 weeks. I suffer from hunger for work. And this really pleases me!!'11 He passed away on 31 October.

It is true that in the last years of his life, the professor was widely respected as one of the honourable seniors of Polish musicology and was invited to chair the most important community organisations, but due to his age, he found himself in more and more situations in which his pupils subtly and slowly relegated him to the margins of academia to pursue their own professional plans. However, it needs to be emphasised that until the very end (despite some misunderstandings) and clearly due to the respect they had for their teacher, they tried to pretend that all their actions were still centred around the professor. Scattered all over Poland, they took every opportunity to meet the professor: and it was Father Feicht, who while on a short vacation in Olcza in Podhale in September 1947 visited Chybiński, who always stayed in Zakopane in the summer, and it was Zofia Lissa who took the professor in her Warsaw apartment at ul. Madalińskiego; ${ }^{12}$ the feeling of attachment, which most of them probably held for their mentor, can be expressed by the words that Stefania Łobaczewska wrote in 1950: "I was thinking about how nice it is to belong to the "Lviv School" of prof. Chybiński, and adore our Professor just as we all do! I felt it more strongly now than ever, ${ }^{\prime 3}$ and which we can supplement with another quote from Lissa's letter: 'Stefa [Łobaczewska] and Chomiński are standing over me and telling me to pour into this letter as much cordiality and warm words as possible. I am doing this on behalf of all three..14

9 Ibid.

10 Ibid.

11 Chybiński to Ochlewski from Poznań 8 IX 1952, AACh-BUAM, Ochlewski's archive, p. 114.

12 Chybiński to Lissa from Poznań 14 IV 1948, AZL-BUW.

13 Łobaczewska to Chybiński from Cracow 20 XII 1950, AACh-BUAM, fol. K-Ł, p. 310.

14 Lissa to Chybiński from Warsaw 1 XII 1950, AACh-BUAM, fol. K-Ł, p. 204. 
A token of the pupils' commitment (despite many a misunderstanding between the professor and some of his students back in the Lviv years) and respect for the professor was the second memorial book prepared by his closest musicologist friends, prepared as an anniversary gift for his seventieth birthday. ${ }^{15}$ The texts included were signed by - apart from Maria Szczepańska ('Nieznana tabulatura lutniowa krakowska $\mathrm{z}$ drugiej połowy XVI stulecia' [Unknown lute tablature from Cracow from the second half of the sixteenth century], pp. 198217), Zofia Lissa ('Uwagi o metodzie marksistowskiej w muzykologii' [Remarks on the Marxist method in musicology], pp. 50-119), Stefania Łobaczewska (' $Z$ zagadnień metodycznych historii muzyki' [From methodological issues of music history], pp. 120-145), Józef Chomiński (' $Z$ zagadnień analizy formalnej' [From issues of formal analysis], pp. 146-197) and Father Hieronim Feicht (Marcin Mielczewski - Missa super O gloriosa Domina, pp. 218-232), also Ludwik Bronarski ('Kilka słów o obiegniku w utworach Chopina' [A few words about the turn in Chopin's works], pp. 233-241), Janusz Miketta ('Fuga a-moll Fryderyka Chopina' [Frederic Chopin's fugue in A Minor], pp. 242-257), Helena Windakiewiczowa ('Tematy obce w muzyce Chopina' [Foreign themes in Chopin’s music], pp. 258-262), Stanisław Golachowski ('Niedokończony Koncert fortepianowy Karola Szymanowskiego' [Karol Szymanowski's unfinished piano concerto], pp. 263-274), Marian and Jadwiga Sobieski ('Wielkopolskie wiwaty' [Greater Poland fanfares], pp. 275-319), Jan Prosnak ('Z zagadnień polskiego folkloru muzycznego' [From issues of Polish musical folklore], pp. 320-338), Maria Turczynowiczowa ('Schematy Wielkiego Księstwa Poznańskiego' [Schemata of the Grand Duchy of Poznań], pp. 339-346), Alicja Simon ('Na drodze historycznego rozwoju gęśli słowiańskich' [On the path of historical development of Slavic gusle], pp. 347-353), Zdzisław Szulc ('Lutnicy polscy od XVI wieku do czasów najnowszych oraz ich karteczki rozpoznawcze' [Polish luthiers from the Sixteenth century to the latest times and their distinguishing signs], pp. 354-379); Tadeusz Ochlewski concluded the book with a summary of the history of Chybiński's editorial work (pp. 380-389), and the whole was complemented by a bibliography of Chybiński's works prepared by the then student, but also volunteer, in the Poznań department, Kornel Michałowski (pp. 26-43). The volume was presented to Chybiński during the National Scientific Conference for Arts Research, whose proceedings were held as mentioned above (see chapter III-2) in December 1950 in Cracow. During the same event, the professor was awarded the Order of the Banner of Work, First Class.

15 Księga pamiątkowa 1950. 
After Chybiński's death, did all of his close associates and students prove their loyalty towards him? It seems that some of the Lviv-based pupils were guided by pragmatic reasons when planning their professional future (for example, in connection with the announced launch of the new print of syntheses or the enhanced editorial projects, just as the new source-critical series Monumenta Musicae in Polonia). Józef Chomiński, in a letter written to Zdzisław Jachimecki in the summer of 1953, informed the Cracow professor of his approval concerning the composition of the editorial committee (while the head of musicology in Poznań had unsuccessfully asked about personal issues in Monumenta); ${ }^{16}$ he also gave reasons for the many years of delay in launching cooperation with Cracow and the proceedings in this matter in spite of himself, just in order to 'not upset prof. Chybiński. ${ }^{17}$ In any case, for the beginning of the next year, 1954, he proposed a contract to Jachimecki to prepare Zieleński's Offertories and Communiones for publication, but this came to nothing - the Cracow Nestor passed away on October 231953.

A year after Adolf Chybiński's death, at a meeting of the Programme Board of PWM, Józef Chomiński submitted a motion to prepare a reprint of selected papers and materials from the master's oeuvre. Soon, a draft of this publication was prepared by Tadeusz Strumiłło with the help of Maria Szczepańska. Strumiłło was one of the first pupils that the professor taught in Poznan after the war. $\mathrm{He}$ belonged to the next generation of musicologists and was one of the youngest assistants in the Poznan department. The draft was sent both to Cracow and to Chomiński. ${ }^{18}$ It is possible that Strumiłło based his work on the professor's own version of the idea. We find this fragment in Tadeusz Ochlewski's correspondence: 'As for the publication of my works printed earlier in publications: keep calm! They require so many modifications and additions that there is no way to print even just the first volume of the three (volume I would have around 350 printed pages). So, alas, the way things are, we need to leave it until 1951/52.19 Nowadays, we do not know the content of 'series' discussed with the director of PWM. We do know that Chybiński did not manage to send the materials and the project proposed by the students was realised only in part. A few years later (in

16 See Chybiński/Chomiński 2016, 324-325.

17 See Chomiński to Jachimecki from Sobieszewo 23 VII 1953, AJCh-BUW.

18 See Strumiłło to Chomiński from Poznań 6 XI 1953, AJCh-BUW (letter with a request for any remarks).

19 Chybiński to Ochlewski from Poznań 15 IV 1950, AACh-BUAM, Ochlewski’s archive, p. 81. 
1956), Strumiłło perished in the Tatra Mountains, while his colleague, Ludwik Bielawski, prepared the selected ethnomusicological works for print. ${ }^{20}$

It shortly turned out that at least for the next two years, command over people's hearts and minds in Polish musicology would be passed on to four principal representatives of the second generation. In 1954, the Department of Musicology at UP (and at the University of Wroclaw, where the Seminar ceased to exist by the end of the 1940s) was suspended, so there were two academic centres left: Zofia Lissa kept successfully developing the Unit (then the Department and finally, from 1958, the Institute) at the University of Warsaw, whereas Stefania Łobaczewska took over the Department at the Jagiellonian University from the late Zdzisław Jachimecki. In 1956, Father Hieronim Feicht created another Department at the Catholic University of Lublin. Józef Chomiński had supported Lissa in her didactic work from the very beginning, whereas when it came to his editing and publishing activity, he was involved mostly with PIS (in 1959, it was called Institute of Art of Polish Academy of Sciences, or IS PAN). In all fields he showed incredible energy that allowed him to carry out research work (which, amongst others, was crowned with the creation of the foundations of a new theory - sonology), as well as managing the work of several editorial offices the aforementioned source-critical series Monumenta Musicae in Polonia, Studia Muzykologiczne, the quarterly Muzyka, Rocznik Chopinowski. Indeed, around Chomiński and Lissa and their friends, a new milieu formed, which in the following decades contributed to the building of Polish musicology.

Changes and reshuffling resulting from the central decisions, which were taking place at the turn of the 1940s and 1950s, had slowly but systematically affected the transfer of the main functions and positions to the second generation of Polish musicologists. Previously, Chybiński hoped to use this situation and returned once again to the idea of resurrecting the annual, with the assumption to make it a strictly scientific journal, perhaps a little niche and beyond the circle of interests and ideological pressure from the officers in Warsaw. As mentioned, Chybiński considered the resumption of PRM already in the first months after the war, in early 1946, before the ministerial decision of 1947 on the reactivation of Kwartalnik Muzyczny as a community magazine. At that time he reached out to Chomiński on the possible revision of his pre-war materials for the third

20 Adolf Chybiński, O polskiej muzyce ludowej. Wybór prac etnograficznych [About Polish folk music. A selection of ethnographic works], prepared for publication by Ludwik Bielawski (from the writings of Adolf Chybiński II) (Cracow 1961). 
volume, and he obtained Bronarski's permission to use the earlier texts, although he did not even fully remember which ones. Alas, these efforts, let us repeat, proved futile, and the selected archival materials were used upon planning and editing the reborn Kwartalnik Muzyczny.

Chybiński accepted decisions to which there was no alternative, but in reality, he had always believed that a quarterly more than an annual best corresponded to the scientific aspirations of the musicological community. It seems that from the early years of his academic career, he had been thinking about creating a journal modelled after the German 'Jahrbücher,' which would be a chronicle of current achievements of the musicological academic community, as well as an impetus for serious scientific discussion within that community. In 1947, he accepted the offer to act as the editor of Kwartalnik, even though he had been dissuaded from it, but he still harboured hopes to revive the annual. After just three years, the authorities decided that Kwartalnik would be suspended once again. It seemed that this was finally the time for the professor's idea of publishing an annual to be brought to life and Chybiński shared his new hopes with trusted friends:

In place of Kwartalnik, the function of the organ of Polish musicology will be served (as 'predicted' by me already a long time ago) by Polski Rocznik Muzykologiczny in a volume at least twice as large compared to the pre-war Rocznik ... . Who will edit Rocznik is not yet certain, but apparently it will be the current editor of Kwartalnik, who wishes to finally have peace of mind to complete several of his works, which are quite voluminous and, due to the editor's seventy years of age, is not a minor concern. ... But perhaps we will be able to pass this work to the youths. ${ }^{21}$

The professor expected the crisis to reach the current editors not only because of the plans of the ministry but above all 'due to lack of materials. ${ }^{22}$ There was also fear that "our "friends" will take over the title. ${ }^{23}$ It soon turned out that in place of Kwartalnik, which was closed in 1950 and the last numbers of which appeared under the banner of PIS, the 'friends' - namely the Directorate of the Institute appointed a body which departed significantly from the academic profile - the Muzyka monthly (with time a bi-monthly), which served as a forum for socialist realist thought in Polish musicology. As Chomiński predicted - 'They will be ... focused on ideological articles, concerning ... more recent materials. ${ }^{24}$

21 Chybiński to Bronarski from Poznań 14 XI 1949, AACh-BUAM, Bronarski’s archive, p. 208.

22 Chybiński/Chomiński 2016, 220-222.

23 Ibid.

24 Chybiński/Chomiński 2016, 239-241. 
It turned out that the aim of establishing a music journal at PIS, which was supposed to support the study of art, was not to spread the word of science, but instead to provide an ideological background for science: 'a new synthesis of Ruch Muzyczny and Kwartalnik was born!!! ... They want to publish a fat monthly with popular articles, theoretical papers, current news and field updates... Cicer cum Gaule - as Tuwim wrote in Problemy. ${ }^{25}$ This was also confirmed by the editorial, the populist-sounding introduction in the first issue: 'Muzyka is to be a magazine not only for strictly musical circles, but also for all those for whom the issues of music are not alien, indifferent, or who are interested in the organisation of musical life, or education, or creativity, or creative work. ${ }^{26}$ The fight against formalism taken in those years and encouragement aimed at composers to combine their music with the life and work of the broadest masses was to be supported by the experience of 'the Soviets, the people's democratic states and progressive elements of the West. ${ }^{27}$

(It is worth noting here, that today's $M u z y k a^{28}$ is not a continuation of the pre-war monthly created by Mateusz Gliński, nor the socialist realist magazine opened by PIS - only the title is the same; published since 1956 by the same institute, the quarterly journal is in fact the heir to Kwartalnik Muzyczny. ${ }^{29}$ However,

25 Lissa to Chybiński from Warsaw 11 XI 1949, AACh-BUAM, fol. K-Ł, p. 177.

Properly: 'Cicer cum caule czyli groch z kapustą: panopticum i archiwum kultury' [Cicer cum caule or peas with cabbage: panopticum and culture archive]. In the years 1949-53 Polish poet Julian Tuwim wrote a column with this title in the monthly Problemy about literary curiosities collected in the period after 1945 . The cycle was then published as a book in three parts by the publishing house Czytelnik $(1958,1959,1963)$.

26 [Od Redakcji] [Editorial], (Muzyka 1950/1,3-4, quote p. 3).

27 Ibid.

28 This is about the academic quarterly dedicated to the history and theory of music (and in accordance with the subtitle in the first period, until 1964 - also academic and artistic criticism), published by PIS (today IS PAN) from the second quarter of 1956, then edited by Józef Chomiński. The change in the position of editor-in-chief of the periodical took place only in 1972 - this function was taken by Elżbieta Dziębowska, formerly acting as the secretary of the editorial office (together with Andrzej Chodkowski, both were present in the editorial team from issue no. 3 in 1956) and deputy editor-in-chief. More than sixty years of history of the quarterly Muzyka forms a separate, very extensive chapter in the history of Polish academic music journalism and is material for a separate monograph.

29 On the other hand, the outer design is connected indirectly with the pre-war quarterly/ bimonthly/monthly Muzyka Polska, from which it borrowed the typeface on the title page and rough cover layout. 
there are indeed clear parallels between the goals that Muzyka had before the war and later when it assumed a 'social realist' form. Both journals were aimed not only at professionals, but also readers with no musical education. Moreover, materials published in them were shorter and had a much lighter tone than those published in their academic counterparts. They reflected current problems of the musicological community and commented on current events, thus serving as a concert chronicle and an almanack. However, the monthly published by Gliński was not under political pressure, whereas the one published by PIS was the ideological mouthpiece of the communist regime.)

The first issue of post-war Muzyka was issued, as intended by the management of the Institute, in the spring of 1950, which also coincided with the closure of the editorial board of Ruch Muzyczny at the end of 1949. The editors dedicated the editorial to the new, 'non-mannered' listener. They declared that it ought to be a journal 'for all those to whom the matters of music are neither foreign nor indifferent.' The magazine, which would participate in building a new socialist culture 'based on scientific principles of Marxism-Leninism and the designs of the victorious socialist state, our ally, the great Soviet Union.' It was supposed to not be limited to the function of information, but rather aim at influencing composers who, upon abandoning the previously prevailing artistic formalism, would adopt the interpretation of social realism for their works as the direction that will bring music to the masses. It was planned to deal not only with 'pure' music (whatever that meant) but also with new issues in the music press - popular music, dance, opera - as well as post reviews of Polish and foreign journals. Finally, the words of the memorandum formulated by the group of Soviet delegates during the memorable Prague congress of composers and critics in 1948 were recalled: 'Progressive musicians around the world cannot look calmly at the sinister deformation of contemporary musical art. We all feel an understandable anxiety about the fate of contemporary music. Therefore, progressive musicians of all countries more frequently raise their voices in defence of realism, addressed against the destructive and disastrous influence of formalism.' This 'confession of faith', as defined by the editors themselves (unsigned under the editorial), branded the new Muzyka with the prevailing ideology and left no illusions as to what materials were expected from potential authors.

Muzyka focused on popularising a few main themes which dominated the contents of six annuals: issues related to the opera, cantata and songs (with an emphasis on mass songs), issues related to folk music and folklore in general, and the task of maintaining the cult of artists who were convenient for the regime. It was communist mentors and influential members of the musicological community who chose such artists. They included Chopin, Moniuszko and (after a 
certain point in time) also Szymanowski. When it comes to foreign composers, it was mostly Bach and Beethoven, the so-called 'revolutionists.' Mass songs were considered to be one of the most natural methods of making the general public familiar with music, whereas the fact that modern composers did not incorporate enough mass songs in their work was regarded as one of the most serious problems. This theme turned out to be the most important for the editorial staff, and it was to this subject that Zofia Lissa dedicated her extensive article that opened the first edition. ${ }^{30}$ This issue was returned to many times, through preparing, amongst others, a block of several texts about mass songs that filled most of the 'non-informative' part of one of the monthly's numbers. ${ }^{31}$

Issues featuring meeting and conference materials were prepared regularly. The first occasion arose early in the summer of 1950 . The combined booklet $3 / 4$ included speeches delivered during the recently completed fifth ZKP Congress. One and a half years later, Muzyka lent its columns for papers and reports on the next, sixth Congress. On the eve of the Polish Music Festival, which opened in April 1951, an article prepared by Tadeusz Marek, the editor of Muzyka, was published in late autumn 1950 on this occasion, under the title 'Growth of the music of work, friendship and peace. ${ }^{32}$ Short statements about music 'in the fight for peace' were also requested for this edition from leading apparatchiks from neighbouring countries - Miroslav Barvik, Georg Knepler, Olga Pozdniewa, and to the number $9 / 10$ from 1954, talks on the conference devoted to the problems of entertainment and dance music. One of only two texts in Muzyka signed by Chybiński at that time was his presentation during the First National Scientific Conference on Research on the Arts. ${ }^{33}$

The editorial team also sought 'anniversaries' which gave it a chance to pay tribute to artists whose creative achievements were praised for fighting with formalism. However, it may be surprising that the revolutionary feature of the legacy

30 Zofia Lissa, 'Raz jeszcze o polską pieśń masową' [One more time about Polish mass songs] (Muzyka 1950/1, 5-17).

31 The above-mentioned issue No. 7/8 from 1954 included, amongst others, materials by Witold Rudziński ('Pieśń masowa na punkcie zwrotnym' [Mass songs at the turning point], pp. 34-38), Elżbieta Dziębowska ('Pieśń masowa w twórczości W. Lutosławskiego' [Mass songs in the creative work of W. Lutosławski], pp. 38-44), Alina Kawczyńska ('O popularności pieśni masowych Alfreda Gradsteina’ [Concerning the popularity of mass songs by Alfred Gradstein], pp. 44-48).

32 Muzyka 1950/7-8, 9-14.

33 Adolf Chybiński, 'Zagadnienia tradycji narodowych muzyki polskiej' [Issues of national traditions of Polish music] (Muzyka 1951/1, 3-7). 
of Ludwig van Beethoven, which had been noticed even before the war, did not lead to publishing commemorative materials in post-war Muzyka (the 180th anniversary of the composer's birthday was not celebrated with a single paper), while authors readily and frequently wrote about Bach. Part of the 1950 number 6 edition was dedicated to him (speeches and reports from the main celebrations organised on the bicentenary of the death of the Leipzig cantor authored by Jerzy Jasieński, Zofia Lissa, Dmitri Shostakovich, Georgi Chubow, supplemented with a sketch by Jarosław Iwaszkiewicz ${ }^{34}$ which introduced monographic articles sent for the occasion by Bronisław Rutkowski and Jan Ekier) ${ }^{35}$ and only a few months later, a block of materials being the aftermath of the Bach inter-school competition in Poznań: apart from reflections and remarks, there were also monographic studies (though extremely sketchy and popular) by Bronisław Rutkowski, Emma Altberg, and Bronisław Romaniszyn.

In the fifth anniversary year of the death of Béla Bartók (and also the occasion of the upcoming seventieth anniversary of his birth) the editors prepared several characterisations of his work, written by another distinguished Hungarian, Zoltán Kodály, ${ }^{36}$ and a translation of the composer's reflection 'O muzyce ludowej' [About folk music]. ${ }^{37}$

Folklore was frequently present in the pages of Muzyka and in a variety of ways - in the context of its connections with art music (for example, through the plot of the 'folk' operas as they were described by Leon Schiller), ${ }^{38}$ in an analytical view (for example, the series of articles by Włodzimierz Kotoński 'Uwagi o muzyce ludowej Podhala' [Remarks on the folk music of Podhale]) ${ }^{39}$ and in current reports (such as for example, Kotoński's impressions 'Po konkursie kapel góralskich w Zakopanem' [Following the highlander band competition in Zakopane $]{ }^{40}$ supported, however, by an academic commentary referring to the works of Mierczyński and Chybiński). The progress of the collection of folklore initiated by employees of the PIS was also monitored. ${ }^{41}$

34 'Związki J.S. Bacha z Polską' [J.S.Bach’s links to Poland] (Muzyka 1950/6, 53-56).

35 'Jan Sebastian Bach' and 'W dwóchsetną rocznicę śmierci Jana Sebastiana Bacha' [On the two-hundredth anniversary of Jan Sebastian Bach's death] (Muzyka 1950/2, 11-17, 18-27).

36 'Bartok jako folklorysta' [Bartok as a folklorist] (Muzyka 1950/9, 57-60).

37 Muzyka 1950/9, 60.

38 'O treść oper ludowych' [About the content of folk opera] (Muzyka 1951/9, 13-18).

39 Muzyka 1953/5-6, 3-25, 1953/7-8, 43-58, 1953/11-12, 25-45, 1954/1-2, 14-27

40 Muzyka 1952/7-8, 84-90.

41 'Śladami Akcji Zbierania Folkloru' [Tracing the action of collecting folklore] (Muzyka 1950/5, 45); Jadwiga Sobieska, 'Folklor muzyczny w Rzeszowskiem i Lubelskiem (Z 
Due to the relaxation of the atmosphere of the fight with formalism and the pervasive reign of methodology developed for education and culture by historical materialism, starting from editions from 1954, and even in issues from the second half of the year 1953, the number of materials and contributions deriving from previously applicable ideological schemes based on the Marxist philosophy of history gradually increased. In issue 5/6 of the monthly Muzyka from 1954, we find a report from a conference on the development of a new profile of the magazine, which took place in mid-March in PIS. ${ }^{42}$ Apart from representatives of the institute (director Juliusz Starzyński and his deputy Aleksander Jackowski, as well as Józef Chomiński, director of the Music Section) 'distinguished musicians' also took part in it, but there were other guests as well. Among the debaters mentioned above, there were Jarosław Iwaszkiewicz, Wojciech Dzieduszycki, Stefan Śledziński, Jan Prosnak, Zygmunt Latoszewski, Józef Powroźniak, Kazimierz Serocki, Michał Bristiger, and Kazimierz Wiłkomirski. The reporter stressed the absence of a representative of ZKP. Among different options which surfaced during the debate, it seems that the idea presented by Kazimierz Serocki was the best one. He believed that Muzyka 'should be transformed into a professional quarterly and apart from that, we should publish a popular science music biweekly like Nowa Kultura and a popular weekly magazine for amateurs, something like Przyjaciótka.43

The magazine's profile did not change immediately. 'Propaganda' still dominated, as evidenced by, for example, a block of articles about mass songs published in the following edition, and in the next a series of texts about entertainment and dance music (including a report from a creative meeting devoted to this subject).$^{44}$ However, historical articles gradually began to dominate, often centred around current anniversaries (though without giving any features of monographic editions): dedicated to Michail Glinka (in the 150th anniversary of his birth, Muzyka 1954, No. 11/12), Chopin (in preparation for the Fifth Piano Competition, especially Muzyka 1955, No. 1/2 and 3/4), Adam Mickiewicz (due to the 100th anniversary of the poet's death Muzyka 1955, No. 10/09 and 11/12). At the beginning of 1955, the external appearance of the monthly changed: the

akcji zbierania folkloru muzycznego w Polsce)' [Musical folklore in Rzeszowskie and Lubelskie regions (From the action of collecting musical folklore in Poland)] (Muzyka 1951/5, 29-46).

42 'Narada w sprawie Muzyki' [Consultation concerning Muzyka] (Muzyka 1954/5-6, 105-106).

43 Ibid., 106.

44 Muzyka 1954/9-10, 49-55. 
cover which had been used for five years with staves and an 'emblem' with the number of booklet at the foreground, signed by outstanding graphic artist Henryk Tomaszewski, was replaced by a modern title font occupying almost the entire surface of the cover, as 'composed' by the artist Tadeusz Błażejowski. ${ }^{45}$ At the same time, the 'layout' of Muzyka was also established, which, despite major changes in the nature and content of the journal, was adopted in 1956 by the editors of the quarterly and was still valid until recently.

Progressive changes, which were getting deeper with time, concerned the form of the periodical, the nature of articles, as well as target readers. As a result, the socialist realist page in the history of Muzyka was finally turned. The last issue appeared in the first quarter of 1956. Without warning, in spring of that year, PIS published a quarterly under the same title but with entirely different content. It was devoted to the history and theory of music and (at least according to initial declarations) scientific criticism and art criticism. The previous 'Committee' was dissolved with Józef M. Chomiński as the only member who remained in the new editorial team; he assumed the position of chief editor. Chomiński was joined (in the editorial committee) by Lvivians - Lissa, Łobaczewska, Father Feicht, Maciej Zalewski (a music theorist), and Stefan Jarociński, who became the secretary of the editorial office. The journal referred directly to the traditions of all editions of 'Kwartalnik' and set the standards for Polish musicological literature which are still applicable to this day.

It is worth mentioning that the editorial committee of the monthly (which, according to Lissa's words, was to have been 'huge, a dozen or so, with one musicologist - as bait') ${ }^{46}$ was not disclosed until the spring edition (number 3/4) of 1954. It then turned out that the editor-in-chief of Muzyka was Witold Rudziński, his deputy Tadeusz Marek, and they were supported by a group consisting of Józef Chomiński (chair), Maria Andrzejewska, Aleksander Jackowski, Jerzy Jasieński and Zygmunt Mycielski (who, along with Chomiński, apparently initially completely refused to participate in the editorial work; ${ }^{47}$ from the middle of 1954 he was replaced by the young composer, Włodzimierz Kotoński, who at the same time aligned himself academically with PIS, as he researched recordings of polish folk material stored in the phonographic archive of the Institute, which

45 The format of the magazine changed earlier: the initial format A4 $(21 \times 30 \mathrm{~cm})$ was reduced after two years to $\mathrm{B} 5(17,5 \times 24 \mathrm{~cm})$.

46 Lissa to Chybiński from Warsaw 11 XI 1949, AACh-BUAM, fol. K-€, p. 177.

47 See Ochlewski to Chybiński from Cracow 16 XII 1949, AACh-BUAM, fol. O-P, p. 90. 
resulted in the publication of the monograph Góralski i zbójnicki [Highlander and bandit] (Cracow 1956). ${ }^{48}$

The assignment of functions within the 'committee' would definitely be subject to rotation. The correspondence from Warsaw musicologists to Poznań and letters from others to Chybiński, and the CV written down by Aleksander Jackowski show that he had initially (1950-51) led the editorial office. From other sources, we know that Tadeusz Żakiej (who used the pseudonym Tadeusz Marek and appeared in PIS magazines under this name) 'took over' Muzyka in May $1951 .^{49}$ Regardless of who was in charge, Adolf Chybiński did not reply to their hot requests for new texts. His name appeared twice in the magazine and only in 1951: the previously mentioned speech at the Wawel conference opened that year, and the only original contribution is a message about a mysterious term 'Murky.'50 The professor was still determined to send a portfolio to the editor, Jackowski, consisting of 'feuilleton (5 pages typewritten with margins and spaces)' 'Do kwestii reminiscencji w dziełach Fr. Chopina' [To the question of reminiscence in the works of Fr. Chopin $],^{51}$ but the intermediary in the transmission of the typescript, Chomiński, predicted that he had no chance of a quick publication and stopped the material for printing in the second edition of the Chopin Kwartalnik. ${ }^{22}$

48 In behind-the-scenes conversations about nominations for the editorial office of Muzyka the names Stefan Jarociński and Jerzy Broszkiewicz were also mentioned, see Ochlewski to Chybiński from Cracow 10 I 1950, AACh-BUAM, fol. O-P, p. 94. Let us recall that before the war, Stefan Jarociński studied law at the University of Warsaw. After the war, when the POW camp in Murnau was liberated, Jarociński ended up in Paris, where he took up philosophical and sociological studies. He had started acquiring musicological knowledge at the end of the 1930s in Warsaw, where he attended lectures given by Julian Pulikowski. He continued his education in Paris, where he went to lectures given by Paul-Marie Masson. Jerzy Broszkiewicz, a writer and publicist who also had the experience of studying musicology in Lviv and (for a brief period of time) in Cracow, was the editor of RM and most probably accepted the invitation to the Editorial Committee of Muzyka as well. However, I could not get to sources which would provide more details and unequivocally verify this piece of information.

49 See Marek to Chybiński from Warsaw 8 V 1951, AACh-BUAM, fol. M-N, p. 16.

50 Adolf Chybiński, 'Murky' (Muzyka 1951/8, 26-27).

51 Chybiński/Chomiński 2016 233-235. He wrote further: 'I saw that it pleased him, me too, because I will have a moment of calm with possible nagging me for writing to the monthly'

52 KM 1949/28, 142-148. 
Furthermore, the names of other doyens occasionally appeared as well. Zdzisław Jachimecki was amongst the authors of the booklet dedicated to Karol Szymanowski. He elaborated on the composer's unknown stage composition - Loteria na mężów, czyli Narzeczony nr 69 albo Główna wygrana [Lottery for a husband: Fiancé No. 69 or the main prize]..$^{53}$ Józef Reiss published his contributions concerning the music culture of the nineteenth century ${ }^{54}$ three times, but only beginning with the fourth year of the appearance of Muzyka. Hieronim Feicht was co-author (together with Chomiński and Lissa) of a review of the latest synthesis on Polish musical culture, a book by Igor Bełza. ${ }^{55}$ The authors of the monthly were also the founding members of the pre-war period SMDM - Bronisław Rutkowski, amongst others, twice prepared Bach materials, ${ }^{56}$ Tadeusz Ochlewski and Emma Altberg permanently cooperated, preparing current information about new releases for the editorial office. From the pre-war circles, there was also Chybiński’s friend, the singer and pedagogue Bronisław Romaniszyn already known for his publications about vocal matters, ${ }^{57}$ and the music journalist Karol Stromenger, who this time presented George Bernard Shaw's achievements in the field of music criticism. ${ }^{58}$ Another experienced and known Warsaw author, Piotr Rytel, prepared two occasional texts: he introduced the composer Reinhold Glier (in the seventy-fifth anniversary of his birth) and reminiscences about Józef Turczyński; ${ }^{59}$ Janusz Miketta, who before 1939 was a ministerial bureaucrat, but who already during the war deepened his musicological knowledge, published a 'chopinological' ${ }^{60}$ contribution.

53 'Operetka Karola Szymanowskiego' [Karol Szymanowski’s operetta] (Muzyka 1952/34, 27-39).

54 Including the monographic article on the theme of Polish dance music of the nineteenth century (Muzyka 1953/9-10, 26-44).

55 'Radziecka książka o dziejach polskiej kultury muzycznej' [Soviet book about the history of Polish musical culture] (Muzyka 1954/11-12, 33-39).

56 'Jan Sebastian Bach' (Muzyka 1950/2, 11-17). Let us remember that Bronisław Rutkowski was a propagator of Bach's work both as a journalist and musician - organist and pedagogue. More than a dozen years after the events described, in 1964, he died in Leipzig, where he was a member of the jury of the International Bach competition.

57 Here also, similarly to KM, focused on vocal issues (Muzyka 1950/9, 47-49, 1955/5-6, 47-57).

58 Muzyka 1951/1, 42-44.

59 Muzyka 1950/1, 41, 1954/5-6, 74-76.

60 The sketch 'Chopin o Mickiewiczu' [Chopin on Mickiewicz] (Muzyka 1953/9-10, 44-51). 
The new journal published by PIS was definitely dominated by representatives of the second generation, including Zofia Lissa. Even though in the beginning she did not support the form of the journal proposed by PIS, she quickly started using it to publish the results of her comprehensive scientific activity. She published texts of conference presentations, reports on current events, ${ }^{61}$ discussions of works by contemporary artists ${ }^{62}$ and normal 'productions,' such as the already mentioned monographic sketch on the subject of mass song, but also historical contributions, for example, about the Warsaw episode in the life of Michail Glinka. ${ }^{63}$ Together with Józef Chomiński, she prepared what was for the norms of Muzyka an extensive historical article 'Muzyka polskiego Odrodzenia' [Music of the Polish Renaissance] ${ }^{64}$ (which was the fruit of their joint monograph published by PWM under the same title), and earlier reflections on folklore in the work of contemporary Polish composers. ${ }^{65}$ Chomiński himself focused on contemporary $\operatorname{art}^{66}$ on the one hand, and on contemporary ideology on the other ${ }^{67} \mathrm{He}$ was also the chosen one among Adolf Chybiński's students who after the death of the professor wrote a memoir about him. ${ }^{68}$

Tadeusz Marek, the editor of Muzyka, was able to match Lissa in terms of the number of published materials. In his case, however, most comprised ongoing relations from the musical life and publishing movements; he undertook historical themes rather occasionally. ${ }^{69}$

61 Amongst others 'Próba podsumowania Festiwalu [Muzyki Polskiej] i wyników Zjazdu [ZKP]' [An attempt to summarise the festival [of Polish music] and results of the conference [ZKP]] (Muzyka 1952/1-2, 21-33).

62 For example, 'Koncert na orkiestrę Witolda Lutosławskiego' [Witold Lutosławski's Concerto for Orchestra] (Muzyka 1955/3-4, 25-52).

63 'Michał Glinka w Warszawie' [Michail Glinka in Warsaw] (Muzyka 1954,11-12, 15-26).

64 Muzyka 1953/11-12, 5-25.

65 Muzyka 1951/5-6, 3-24.

66 For example, 'Koncert na orkiestrę smyczkową Grażyny Bacewicz' [Grażyna Bacewicz's concerto for string orchestra] (Muzyka 1955/5-6, 20-29).

67 Such as in the case of the article 'inspired' by Lenin's theory of reflection, 'O możliwościach poznawczych w muzyce' [About cognitive possibilities in music] (Muzyka 1951/3-4, 5-7).

68 Muzyka 1953/3-4, 15-22.

69 For example, 'Książęcy kapelmistrz' [Princely Kapellmeister] (Muzyka 1954/11-12, 44-51). As he himself wrote, this was supposed to be a fragment from a monograph by Joseph Haydn prepared for print. This monograph, however, did not appear. 
These are, of course, not all the authors of Muzyka. The list should be supplemented with the names of editorial staff members - Zygmunt Mycielskie Aleksander Jackowski, Witold Rudziński and regular co-operators with the editors Maria Andrzejewska, Igor Bełza, Mirosław Dąbrowski, Mieczysław Drobner, Jerzy Jasieński, Jan Prosnak, Stefan Śledziński, amongst others; Witold Lutosławski also wrote a few analytical articles for Muzyka. Perhaps due to the Zofia Lissa's intercession, the monthly also provided debuts for representatives of the youngest generation of Polish musicologists at that time. For the first time texts appeared by Alina Nowak-Romanowicz, Tadeusz Strumiłło, Zygmunt Szweykowski, Elżbieta Dziębowska, Krystyna Kobylańska and not just in information columns. ${ }^{70}$

Only some of the cited names had the opportunity to also appear in another periodical, whose form was significantly different, and which was aimed at educated musicologists and music theorists. It was supposed to be a continuation of the literary tradition built by Chybiński. Almost simultaneously with the launch of Muzyka, independently of the professor's earlier plans - an idea to publish a strictly scientific journal called Studia Muzykologiczne surfaced there. It was supposed to be headed by Józef Chomiński, who cooperated with PIS. Apart from Chomiński, the editorial team was made up of former students of the Department of Musicology in Lviv: Zofia Lissa, Stefania Łobaczewska, Father Hieronim Feicht. Despite the age of seventy years and fatigue, Chybiński still expected that the generational change would not happen and he would once again serve as the head of the editorial team. When it became known that it would be otherwise, he could not conceal his grief: 'Alas, Kwartalnik Muzyczny came to an end. Instead of Kwartalnik, PIS will issue Studia Muzykologiczne. It will be a periodical. I will not be a part of Studia for it will be a publication of the Institute. It will be edited by Dr Chomiński, an employee of the Institute.71

70 See for example, Alina Nowak-Romanowicz, 'Przynależność J.K. Elsnera do kultury polskiej' [J.K. Elsners belonging to Polish culture] (Muzyka 1954/1-2, 31-38), Tadeusz Strumiłło, 'Jan Kiszwalter (1787-1843)' (Muzyka 1952/7-8, 36-41), Zygmunt Szweykowski, 'Zapomniana polska śpiewaczka Teodozja Friderici-Jakowicka' [Forgotten Polish singer Teodozja Friderici-Jakowicka] (Muzyka 1952/7-8, 41-45), Elżbieta Dziębowska, 'Pieśń masowa w twórczości W. Lutosławskiego' [Mass songs in the creative work of W. Lutosławski], (Muzyka 1954/7-8, 38-44), Krystyna Kobylańska, 'Henrietta Sontag' (Muzyka 1951/7, 23-27).

71 Chybiński to Bronarski from Poznań 11 IX 1951, AACh-BUAM, Bronarski’s archive, p. 214. 
Already during the preliminary preparation for opening the title, a sharp dispute was triggered between Chybiński and Chomiński over the title of the magazine, which was one of the examples of frictions accompanying the generational shift in Polish musicology, difficult to accept for the senior. Initially, the title Myzykologia Polska was proposed in Warsaw, on which Chybiński commented: 'I do not like this ostentatious title at all. Why not call the annual Rocznik Muzykologii Polskiej, if you do not want to title it after the pre-war Polski Rocznik Muzykologiczny. ${ }^{72} \mathrm{He}$ also wrote to Director Ochlewski: 'The successor to Kwartalnik is supposed to be Muzykologia Polska.... He [Chomiński] wrote me, that they don't want to be cramped by the name "annual," because they intend to publish two or even three volumes per year .... I replied that it is possible to publish two thicker volumes as a so-called semi-annual: "Halbbaende" rather "Halbjahrbaende." He wrote back to me that it was still being settled." ${ }^{73}$

The title of the new journal led to a serious misunderstanding between Chybiński and Chomiński, which continued for many weeks. The professor expressed his opinion in a balanced, yet unambiguous way: 'I won't write a lot, just a few words about the planned publishing of Muzykologia polska. I've thought a lot about this title, which strikes me to some extent with its ostentatiousness. This title sounds like a title of a chapter in some paper on musicology in general. In my opinion, we could make a reference to the pre-war annual and publish it as volume III of Polski Rocznik Muzykologiczny. And if we want to avoid. . "tradition," give it the title of Rocznik Muzykologii Polskiej. ${ }^{74}$ Chomiński wavered for several months, fearing that the word 'annual' would determine and limit in practice the real needs with regards to the frequency of publishing. It was finally decided that the new periodical (published by PIS) would have the title Studia Muzykologiczne. While it was intended to be a semi-annual (in 1953, two extensive volumes were published), in the course of the next three years, it became a de facto yearbook.

Adolf Chybiński, who remained in Poznań and had lived for years in the hope of reactivating Rocznik, did not participate in the editorial works, although he had some tips and suggestions for the new editors: 'I would ... believe that you should cease printing kilometre-long works in the musicological journal.

72 Chybiński to Bronarski from Poznań 28 II 1951, AACh-BUAM, Bronarski’s archive, p. 213.

73 Chybiński to Ochlewski from Poznań 21 III 1951, AACh-BUAM, Ochlewski’s archive, p. 101.

74 Chybiński/Chomiński 2016, 304-305. 
Everywhere, annuals, semi-annuals and monthly journals contain shorter works; some are very short. And this makes sense. Do not shun "contributions." In years, they make up for greater things. Longer works should be published as books and pamphlets; shorter ones should be assigned to Rocznik. ${ }^{35}$ This was not quite in line with the plans of the young editors. As to the scale of the publication, it should be stated that the Studia were dominated by extensive dissertations, although the possibility of printing was allowed to 'works limited only to discussing some details, ${ }^{76}$ however, subject to their originality and use of the presented material for future syntheses.

Even though Studia Muzykologiczne were published by the Music Section of PIS, the inaugural editorial announced cooperation with all three Departments of Musicology at the universities in Warsaw, Cracow and Poznań. However, only about a dozen authors' names appeared on the pages of the periodical. Among those, there were Lvivians, that is Chybiński (only in the first volume), Lissa, Łobaczewska, and Chomiński, as well as other authors who had already had their debuts (e.g. in Kwartalnik Muzyczny), such as Krystyna Wilkowska, Jan Prosnak and Janusz Miketta. However, some new names also began to appear which formed the next generation of Polish musicologists: Tadeusz Strumiłło, Alina Nowak-Romanowicz, Józef Kański, Stefan Jarociński, Andrzej Koszewski, Henryk Anders and others.

As to the frequency of the publication of following volumes of Studia, reality verified the original plans. Although Chomiński intended to issue a new title on a semi-annual or quarterly cycle, from the third number, the journal was de facto an annual. Initially, the new title fully expressed the ideological assumptions that were in effect in academia at the time - acceptance of dialectical materialism for historical research, the most prominent example of which was Zofia Lissa's opening dissertation, 'Niektóre zagadnienia estetyki muzycznej w świetle artykułów Józefa Stalina o marksizmie w językoznawstwie' [Some issues of musical aesthetics in the light of Joseph Stalin's articles on Marxism in linguistics $]^{77}$ and the words from the first page of this publication: 'Today, we consider historical and dialectical materialism to be the only scientific direction of thought leading to a true knowledge of reality. ${ }^{78}$ Adoption of such priorities also determined the layout of content: the volume did not open - as is usually

75 Ibid.

76 'Od Redakcji' [Editorial] (SM 1953/1, 9).

77 SM 1953/1, 11-154, also printed in 1954 by PWM as an individual publication.

78 Ibid., 11. 
the case of musicological journals - with historical works but with essays on the 'theory of methodology-aesthetics.' They were followed by chapter '2) the history of music with contemporary music' and - later on - '3) ethnomusicology, 4) historical materials, 5) reports and discussions. ${ }^{39}$ The position taken by the editors - applying in music scholarship a method based 'on the experience of Soviet science ${ }^{80}$ - did not disturb them in taking as the most important goal to 'direct the main attention to the history of Polish musical culture.81 It was assumed that the interest in popular music should be reconsidered: 'in this area, the most important issue will be papers studying musical relations between Poland and Russia, as well as our artistic relations with nations which form the Soviet Union and people's democracies. ${ }^{32}$ Critical studies on contemporary works were aimed at helping composers with 'rapid ideological maturation' (in accordance with guidelines from the national meetings of musicians, musicologists and music critics held at the time), while in case of ethnomusicological works it was expected to go beyond the circles of the 'bourgeois culturalhistorical school' and not be restricted to research on rural folklore. Finally, in the reporting section, besides discussions on Polish works, it was recommended to deal with Soviet works as well, because as it was written 'we believe that the experience of Soviet studies will help Polish musicology completely master the modern scientific method and ensure its comprehensive development in the service of the society. ${ }^{83}$

Authors and members of the editorial team did not have problems with formulating scientific arguments which were very much in line with the expected socialist phrasing and rhetoric. Moreover, Stefania Łobaczewska started working on reformulating nineteenth-century foundations for the analysis of musical works to adapt them to the assumptions of Marxist aesthetics. She presented her reflections on the example of two previous volumes of Analizy i Objaśnienia Dziet Wszystkich Fryderyka Chopina [Analysis and explanation of the complete works of Frederic Chopin] (that is Mazurki [Mazurka] written by Janusz Miketta and Preludia [Preludes] prepared by Józef Chomiński). ${ }^{84}$ Chomiński himself also remained in the circle of musical analysis; he examined the issue

79 'Od Redakcji' [Editorial] (SM 1953/1, 7).

80 Ibid.

81 Ibid., 8.

82 Ibid.

83 Ibid., 10.

84 Stefania Łobaczewska, 'Z zagadnień analizy muzykologicznej' [From the issues of musicological analysis] (SM 1953/1, 155-188). 
of musical elements as the subject of analytical considerations..$^{85}$ In both texts, their authors came to a similar conclusion that the value of a musical work is determined by the balance of its content and form, and the aspect 'content-form' is 'a necessary condition as a starting point for the analysis. ${ }^{36}$ Publishing her 'Studia nad klasowym obliczem tańców polskich w epoce renesansu' [Studies on the class aspect of Polish dances in the Renaissance], ${ }^{87}$ Krystyna Wilkowska went further: she declared the transition from a postulative only approach to changes in analytical principles to their realisation in practice. The adoption of such an 'action' approach by the author may be confirmed, for example, by her criticism of the not entirely consistent, in her opinion, division of dances from the tablature of Joannis de Lublin, which was conducted by Chybiński in a fundamental paper on this monument, published in 1911-13 on the pages of the 'first' Kwartalnik Muzyczny. ${ }^{88}$ Although Wilkowska acknowledges that the professor 'even attempted to divide the dances from two points of view: national and class', but 'when it comes to interpreting the class aspect of the dances by Joannis de Lublin, then Chybiński only distinguishes two categories of dances, namely peasant and courtly. This is, of course, an incomplete division. In the face of rapidly developing cities, it is difficult to suppose that an urban culture would not be created at that time. 89

It is hard to say whether the professor would have crossed swords with Wilkowska or instead agreed with her. When the first volume of Studia Muzykologiczne came out, the master had already been dead for a few months. We know from numerous letters that he did not agree with many decisions made in his twilight years. He was also irritated by the behaviour of some of his colleagues and pupils. Until the very end, he represented 'the old school' and could not adapt the new methodology to his own research work. When it comes to papers written at that time, he just kept clumsily 'squeezing' some phrases or sentences into them which could protect him against the criticism of ill-disposed state functionaries (like for example, the sentence closing the article which was posthumously published in the first volume of Studia: ${ }^{90}$ 'I did not have enough works of Slavonic composers in writing this work, to make the most use of them.

85 SM 1953/1, 189-213.

86 Stefania Łobaczewska, 'Z zagadnień. .., op. cit., 188.

87 SM 1953/1, 214-248.

88 See chapter I-1, footnote 102.

89 Krystyna Wilkowska, 'Studia nad klasowym obliczem. .., op. cit., 217.

90 Adolf Chybiński, 'O pewnym "motywie” w dziełach F. Chopina' [About a certain motif in the works of F. Chopin] (SM 1953/1, 249-266). 
This particularly applies to the very rich piano music of Russian and Czech masters'). ${ }^{91}$

Jan Prosnak also protected himself with the socialist realist narrative; his restricted his work on Chopin's flute variations, (E-major on the theme of Non più mesta from Act II of the opera La Cenerentola by Gioachino Rossini) to classical description and analysis, ${ }^{92}$ as did Marian Sobieski, who (against the editorial board's recommendations) who exclusively undertook 'rural' folklore and presented the tonal qualities of Polish folk music, without taking into consideration possible social conditions of this work. ${ }^{93}$ This group of 'a-ideological' works from the first volume of Studia was filled by material prepared by Stefan Jarociński, who was starting his career path in PIS, entitled 'Z korespondencji Romana Statkowskiego' [From the correspondence of Roman Statkowski], based on the letters preserved in the archives of Wilski family (cousins of the composer). ${ }^{94}$

The volume concluded with a report on publications which tied up some loose ends. First of all, due to the aspirations of the editorial team, these were to a large extent (or rather the majority) Russian books (including the translation of a monograph by Vyacheslav Paskhalov, Chopin a polska muzyka ludowa [Chopin and Polish folk music]). It was at the same time one of a few works on Chopin. Apart from this, two commemorative issues of Kwartalnik Muzyczny devoted to Chopin were also discussed, as well as reflections of Karol Szymanowski entitled 'O Chopinie' [On Chopin], which were prepared by Stanisław Golachowski. Another paper by Szymanowski was also introduced; it was worthy of attention because it contained 'a giant load of progressive thought. ${ }^{95}$ There was also a huge monograph devoted to the composer (Karol Szymanowski. Życie i twórczość. [Karol Szymanowski. Life and work], Cracow 1950), written by Stefania Łobaczewska. The circle of reviewers was quite closed. Commentaries were

91 Ibid., 266. I do not rule out that these kinds of notes were not authored by the professor himself, but were issued by the editorial staff.

92 Jan Prosnak, 'Wariacje fletowe Chopina' [Chopin's flute variations'] (SM 1953/1, 267-307).

93 Marian Sobieski, 'Oblicze tonalne polskiej muzyki ludowej' [The tonal aspect of Polish folk music] (SM 1953/1, 308-332).

94 SM 1953/1, 333-349.

95 Stefania Łobaczewska, 'Karol Szymanowski: Wychowawcza rola kultury muzycznej [Karol Szymanowski: Educational role of music culture] with a preface by Zbigniew Drzewiecki. PWM. Cracow 1949' (SM 1953/1, 382). 
written by Lissa, Łobaczewska and Wilkowska, as well as Kornel Michałowski and Józef Patkowski, young assistants from Poznań and Warsaw.

Volume II of the Studia had a similar, primarily 'Polish' content, with considerations (after Lissa's 'aestheticising' dissertation 'O specyfice muzyki' [The special nature of music] $)^{96}$ about the creative work and lives of Chopin, Szymanowski and Moniuszko. Articles by Łobaczewska, Chomiński, Prosnak and another young Poznań musicologist, Andrzej Koszewski, and material by Witold Rudziński (supplemented with a translation of a paper by the German musicologist and music sociologist at the musicological conference in Berlin, Ernst H. Meyer, on the theme of 'Beethoven i muzyka ludowa' [Beethoven and folk music]), ${ }^{97}$ made up the entire publication, deprived this time of the reports. Already in this book one can recognise refraining from the ideological programme, unequivocally designated in the editorial, which the office wanted to impose. ${ }^{98}$ As Elżbieta Dziębowska wrote, 'the normatively recognised aesthetic and methodological issues lost their central position, ... historical themes began to prevail with a clear preference of the nineteenth and twentieth centuries. ... volume 5 [the last, completed in 1954, released in 1956 - ed. MS] is dominated by analyses

96 SM 1953/2, 7-132.

97 SM 1953/2, 153-166.

98 Although it should be noted that the subtitle of Chomiński's article on Chopin's sonatas - 'Sonata jako element nadbudowy ideologicznej' [Sonata as part of ideological superstructure] - and his first sentence ('Examination of the ideological side of an artistic work is conditioned by the possibility of penetrating its content,' op. cit., p. 167) still placed the author at the forefront of representatives of the current humanities methodology. The socialist realistic 'class' optics adopted by him indeed sparked criticism on the pages of Muzyka. In issue 1954/7-8 (pp. 83-87) an extensive review was published by a theatre and literary critic, one of the employees of the then PIS Theatre Section, Tadeusz Sivert. Although the author was not a musicologist, he was able to report substantively on the content of volume II of MS, providing the broadest discussion on Lissa's study 'O specyfice muzyki, stressing the author's valuable and innovative contribution and her analysis of the problems of music to studies on music and its social role. He devoted much less space to Chomiński's monographic article and, at the same time, despite paying attention to the author's insightful explanations, first of all pointed to the simplification in the form of 'conclusions on the class of Chopin's sonatas in view of the fact that such complex material is an expression of the artist's emotional relationship towards various elements of music.' Next, upon citing Chomiński, he refuted the value of conclusions that can be drawn by looking amongst Chopin's works for merely 'peasant' and 'bourgeois' elements and 'class aspects. 
of works from contemporary composers. ${ }^{99}$ Looking through all the volumes of Studia one can say that the number and value of the Chopin-based papers significantly contribute to the cult of Chopin. ${ }^{100}$

The topic of creating a magazine entirely dedicated to the works and figure of Chopin had been appearing in discussions amongst musicologists - primarily from the circle of Adolf Chybiński - for many years, much before the jubilees of 1949 and 1950. In connection with the upcoming anniversaries, the creation of a new research unit - the Institute for Chopin Research - had been considered at the very highest level. ${ }^{101}$ In these difficult years of rebuilding the country, all works related to Chopin were given the green light because it was seen as an opportunity for propaganda. Let us recall that the Frederic Chopin Institute, which was established in 1934, did not operate during the war. It renewed its activity in the first months of freedom and resumed work on the edition of Dzieła Wszystkie Fryderyka Chopina [The Complete Works of Frederic Chopin], edited by Ignacy Jan Paderewski, Ludwik Bronarski and Józef Turczyński (eventually, the volumes appeared in print in the years 1949-61). After 1950, the Institute functioned as the Frederic Chopin Society. It attracted a growing number of researchers who studied the composer's legacy, as well as activists who wanted to keep his memory alive.

The announcement of Chopin Year was supported by the Resolution of the Council of Ministers and the creation of a relevant Executive Committee. In its composition, besides the appointed departmental and union officials, there were also musicologists Adolf Chybiński, Zdzisław Jachimecki, Hieronim Feicht and Zofia Lissa, along with musicians Stanisław Kazuro, Zbigniew Drzewiecki and Stanisław Szpinalski, and Juliusz Starzyński - acting as director of the international cooperation office at MKiS, and the future director of the newly opened PIS. The Jubilee Committee had to fulfil several tasks, including to prepare 'a) a

\section{Dziębowska 2000, 187.}

100 In total, nine articles were published in SM on Chopin along with twelve reviews of books devoted to the work and the figure of the composer.

101 See Chybiński to Lissa from Zakopane 12 VIII 1948, AZL-BUW: 'Institute for Research on Chopin... 100 years of health for President [Bierut] for such a wish! As soon as possible! For it also has political significance (not only in relation to France). I think the matter will be ripe for realisation next year'. The professor also informed Bronarski about the matter: 'by the will of the President of the Republic of Poland, the Institute of Research on Chopin's life and work will be created next year (I don't yet know the name of the institute), see Chybiński to Bronarski from Zakopane 24 VIII 1948, AACh-BUAM, Bronarski's archive, p. 198. 
collective issue of the works of Frederic Chopin under the editorship of Ignacy Paderewski, b) issue of monographs and research works related to the life and work of Frederic Chopin ${ }^{102}$ : they considered, among others, translation of the Chopin monograph by Bernard Scharlitt (Leipzig 1919), resume of Chopin by Ferdinand Hoesick (after necessary amendments), and the issue of collective work analysing the individual elements of the composer's work. ${ }^{103}$

Chybiński kept cherishing his idée fixe, which was related to promoting expert knowledge about the life and work of Frederic Chopin. He started thinking about establishing an annals devoted to the composer just a few months after he assumed the position of chief editor of the new-old Kwartalnik. In response to the news about official initiatives, he shared his idea with Chomiński and some time later also with Lissa. He planned to 'create either something like "Chopin Annual" or ... something like "Studies in the Life and Work of Frederic Chopin." It would be a non-periodical publication in hardcover or paperback.'104

to celebrate the Chopin anniversary in 1949 one could think of initiating a special series of publications devoted to the life and works of Chopin. Bach-Studien and HandelJahrbuch, as well as Beethoven-Jahrbuch, can be issued abroad - why shouldn't we create something similar on Chopin?! Eventually, this could be called Rocznik Chopinowski what do you think? This would also have a good side, we could place smaller works there along with special articles and mini-articles, a 'chronicle' of matters relating to Chopin worldwide etc. ... The editor need not be a musicologist, but in any case someone close to Chopin's affairs. IFC may be involved in this work, but with the most far-reaching reservations. For example, why not appoint [Bronisław] Sydow as editor? Without a doubt, he is the most serious amongst the IFC members. A man of good, and even the best intentions, and a bibliographer of Chopin. He could be given a small committee (e.g. two people), and thus we could be calm about everything. ... And if IFC would not follow our line, then we can manage without the IFC as well. ${ }^{105}$

A year later, he had another candidate for the position of chief editor - Janusz Miketta. He wrote about this to Ludwik Bronarski:

we are thinking about bringing Rocznik Chopinowski to life in order to relieve the quarterly in 1950. We will discuss it in detail with associate professor Lissa and doctor Chomiński .... For the time being, I don't want Rocznik to have more than 15-20 printed sheets .... I would like Janusz Miketta to become chief editor of Rocznik. ... In

102 The full text of the Resolution of 20 III 1948 was included, among others, in RM 1948/8, 24.

103 Chybiński/Chomiński 2016, 70-71.

104 Chybiński/Chomiński 2016, 71-73.

105 Chybiński to Lissa from Zakopane 11 VII 1948, AZL-BUW. 
relation to Rocznik I dare ... ask whether you would like to honour volume I of Rocznik with your presence in it. A more extensive paper would be welcomed.'106

Lissa agreed with the idea of preparing a publication on Chopin, except that she saw it as a volume of analytical studies related to the jubilee. For this purpose, the professor was ready to give up most of the Chopinological materials dedicated to Kwartalnik, although he already expressed the opinion that there is too little time for organising such a volume. As an alternative, Chomiński presented his next project - a series of several volumes, 'similar to Bücken - on the widest possible scale' which would be entitled Chopinologia Polska [Polish Chopinology]:

Volume I would cover the history of our Chopinography and Chopinology along with criticism of previous work. Volume II: Chopin and his epoch (Zofia Lissa wants to work on this topic, and of course besides a sociological approach she would have to take into account the pan-cultural, and especially the historical-musical background). Volume III: Rhythmics. Volume IV: Melodics. Volume V: Harmonics. Volume VI: Form. Volume VII: Piano texture... etc. What is your, Sir Professor, view on this plan? Besides, upon my stay in Poznań, we could discuss this plan in detail. As it turns out, X. Feicht and Ms Zofia Lissa will be there as well.'107

The professor this time also distanced himself from the idea of a collective study, indicating the superiority of the destiny of Rocznik Chopinowski, 'after the model of such projects dedicated to Bach, Haendel, Beethoven, Wagner. This would be a place for specialised research, and only after some time becoming a kind of "Corpus Chopinianum." I will show you when we talk that it is much too early for this, even though the very idea is excellent.' ${ }^{108}$ Eventually, Chomiński agreed with the professor regarding the periodic nature of the publication, but they still could not reach an agreement on the optimal volume. The professor, who was experienced and could realistically assess the capabilities of the musicological community, imagined volumes comprising of about one hundred and fifty pages rather than four hundred or five hundred. ${ }^{109}$

Further efforts did not follow the professor's thoughts. The news he gave Bronarczyk two months later was not optimistic. He informed that Rocznik Chopinowski would not be published ('The reasons for this are not financial, but

106 Chybiński to Bronarski from Poznań 26 VI 1949, AACh-BUAM, Bronarski’s archive, p. 203.

107 Chybiński/Chomiński 2016, 173-174.

108 Chybiński/Chomiński 2016, 1775-176.

109 Chybiński/Chomiński 2016, 177-178, 178-179. 
of a completely different nature, about which it is not worth writing'), ${ }^{110}$ and at the beginning of November he closed the subject with the remark: 'Rocznik Chopinowski, planned by myself, is unfortunately not happening.'111

The idea of launching a magazine entirely dedicated to the works of Chopin was not abandoned, and soon it was undertaken by Chomiński, who took over as editor-in-chief. This time the appointed editorial committee included Zofia Lissa and Stefania Łobaczewska, along with musicians - pianists connected with the TiFC - Zbigniew Drzewiecki, Jan Ekier, Jan Hoffman and Stanisław Szpinalski (only in the initial period - he died in mid-1957) - and a theorist who had been associated with the publishing community for years, and was Chybiński's trusted associate - Kazimierz Sikorski, and the young musicologist Józef Kański. Krystyna Wilkowska-Chomińska was appointed as secretary. The first volume of Rocznik was released in 1956. The materials were published in several sections: 'Life and work,' 'Performance style,' 'Heritage and the cult of Chopin,' 'Bibliographic materials,' 'Reports.' Among the first authors were both members of the editorial committee - Łobaczewska ${ }^{112}$ Lissa ${ }^{113}$ Chomiński, ${ }^{114}$ Drzewiecki, ${ }^{115}$ Kański ${ }^{116}$ - as well as invited musicologists - Franciszek German, ${ }^{117}$ Krystyna Kobylańska ${ }^{118}$ and the Russian historian, Igor Bełza. ${ }^{119}$

110 Chybiński to Bronarski from Zakopane 9 VIII 1949, AACh-BUAM, Bronarski’s archive, p. 204.

111 Chybiński to Bronarski from Zakopane 1 XI 1949, AACh-BUAM, Bronarski’s archive, p. 205.

112 'Wkład Chopina do romantyzmu europejskiego' [Chopin's contribution to European Romanticism] (RCh 1956/1, 9-95).

113 'Problem polskiego stylu narodowego w twórczości Chopina' [The problem of the Polish style in Chopin's works] (RCh 1956/1, 96-170).

114 'Mistrzostwo kompozytorskie Chopina' [Chopins compositional mastery] (RCh 1956/1, 171-226).

115 'Próba charakterystyki polskiego stylu wykonawczego dzieł Fryderyka Chopina' [An attempt at characterisation of a Polish performance style of Frederic Chopin's works] (RCh 1956/1, 254-262).

116 'Raport Polskie prace o Chopinie (1945-1955)' [Report of Polish works about Chopin] (RCh 1956/1, 330-349).

117 'Chopin i Mickiewicz' [Chopin and Mickiewicz] (RCh 1956/1, 227-253).

118 'Chopin w Polsce Ludowej' [Chopin in the Polish People's Republic] (RCh 1956/1, 282-303), and 'Zbiory muzealne Towarzystwa im. F. Chopina w Warszawie' [Museum Collections of the F. Chopin society in Warsaw] (RCh 1956/1, 304-323).

119 'Tradycje uprawiania muzyki Chopina w Rosji i ZSRR' [The tradition of performing Chopin in Russia and the USSR] (RCh 1956/1, 263-281) and the report 'Książki radzieckie o Chopinie' [Soviet books about Chopin] (RCh 1956/1, 324-329). 
Subsequent issues did not appear regularly, but the editorial team did try to make up for delays. After a two-year break, the second and third volume were published almost simultaneously, whereas, in the following years, two or three annuals were merged into one volume. Starting from number two, the journal entered the international arena thanks to abstracts translated into French. Therefore, the plans that Chybiński and then Chomiński had been making for many years finally came to fruition. This time, the editorial office took things a step further and published materials in original language versions. The annual started coming out under the title Annales Chopin. In-depth research and a separate monograph would be needed to study international contracts related to this fact, the history of the journal, which started coming out in English in 1985, as well as the history of post-war Frederic Chopin Society, which currently operates as the Institute of Frederic Chopin, and the Frederic Chopin Museum. 


\section{Afterword}

The Polish music periodical press will soon celebrate its bicentenary, and its history can be divided into two almost equal periods. Nearly one hundred years of the first period of development of this field of activity amongst Polish musicographers and enthusiasts of music historiography gave many examples of efforts to popularise knowledge about music to the extent allowed by their practical education in this direction, general erudition and passion with which critics/ columnists/reviewers/popularisers practised the profession. Editorial works and the achievements of those who became pillars of this story - Kurpiński, count Cichocki, Kenig, Karasowski, Sikorski, Kleczyński, Rajchman, Chojnacki and others - their own literature on the one hand and efforts to obtain collaborators and co-authors (musicians, writers, historians, or simply music aficionados) for the magazines on the other, made it possible to shape a community of readers interested not only in chronicles of current musical events, but also in acquiring and expanding knowledge of the history of this art. The turn of the nineteenth and twentieth centuries was a period in which pieces of 'professional' literature were featured in social and cultural journals, sometimes daily newspapers - after all, for decades all the major individuals from the area of domestic musicology had been engaged in both popularisation and musical criticism. Nonetheless, it was not journalism, but scientific contributions that gave testimony of their academic knowledge and the basis for including within the group of 'experts', and the opening of the first departments of musicology at several European universities in the last decade of the nineteenth century led to a slow but systematic crystallisation of the community's elite prepared to read strictly academic treatises, but they required specialised periodicals.

Initiation of the first edition of a music magazine with academic aspirations Kwartalnik Muzyczny - coincided almost exactly with the opening of two Polish musicological departments. Was this by accident? Yes, and no. The magazine was not led by Adolf Chybiński, the head of the Lviv department, nor by Zdzisław Jachimecki, the head of the Cracow department. Both the idea and its realisation belonged to Henryk Opieński, musicologist, composer and conductor, who did not take care of completing the formalities related to the confirmation of his doctorate (he was therefore not a qualified musicologist) and most of his professional activity was associated in the future with artistic activity, but he was as strong as both 'founding fathers,' devoted to academia, and deeply convinced of 
the need to create columns worthy of the scientific work of the first generation of Polish music historians.

Could Opieński have successfully carried out his project if it had not been for his cooperation with Chybiński, as well as the professor's dedication and incredible ability to describe the history of music in the short papers which were supposed to fill the pages of the new periodical? I believe that the above history of all three editions of Kwartalnik Muzyczny and the cursory review of other titles, that is various national, local and community periodicals, constitute a basis for claiming that for half a century, the professor was the key figure in this regard. Chybiński was an active author and editor, as well as the catalyst for many initiatives. While reading his correspondence, one gets the impression that the relations with editorial teams became a sort of his idèe fixe. This theme was constantly present in letters to both his loved ones and co-workers. Moreover, various aspects of editorial activity turned out to be his passion, and he was clearly in his element.

Meetings with Kwartalnik in the academic life of the professor were quite short episodes, always rich in strong emotions. When at the end of the first decade of the twentieth century he received a proposal to cooperate with the new periodical, for four years the then WTM organ became the main forum for the exchange of musicological thought at the academic level in the Polish language; this state, however, was interrupted by the outbreak of the Great War. The reason for the relatively short life of Kwartalnik in the interwar period was the fact that the planned formula of the magazine, built in the shape of German periodicals, well-known to the professor from his first years of study, was too ambitious for the small musicologist community. Finally, in the period of socialist realism, the extinguishing of the editorial after three years of operation was a result of pressure placed on the scientific community from the 'official agents.' We cannot forget that Kwartalnik was not the only title run by Chybiński: we should also add the following years of editorial work, this time in issuing Polski Rocznik Muzykologiczny which already gives a total of nearly twenty years of activity in the field, on which he obtained a monopoly - the few attempts made by other contemporary musicologists and journalists never comprised substantial competition for magazines run by the Lviv professor.

Using the best European models, Chybiński, first as an author, then the editor, set out the academic direction and imposed the strictly academic shape of Kwartalnik Muzyczny, commenting on current events. Although he was mostly surrounded by Lvivians and only a handful of trusted authors outside the circle of his department, he became a key figure for the whole environment. Therefore, it is unquestionable that he became the father of not only Polish musicology, 
but also Polish musicological literature, whose further development took place on the basis of transferring the editorial baton by successive heads of editorial teams to his academic heirs: after Chybiński, running new periodicals were the annual Studia Muzykologiczne from1953, Rocznik Chopinowski (Annales Chopin) from 1956 and the same time the academic quarterly Muzyka - taken by Józef Michał Chomiński; years later Muzyka was taken over by his students, Elżbieta Dziębowska and (for a short time) Katarzyna Morawska, and in time a representative of the next generation of students, the creator of sonology, Maciej Gołąb. The next head of the quarterly, Elżbieta Witkowska-Zaremba, began her academic path under the tutelage of another student of Chybiński, Zofia Lissa. Currently, the editor-in-chief of Muzyka is Paweł Gancarczyk, who was preparing his $\mathrm{PhD}$ thesis years ago under Elżbieta Witkowska-Zaremba.

Throughout the existence of Kwartalnik, its editorial team received both sincere acclaim and harsh criticism. Paradoxically, it always happened for the same reason: the very high standard of the publication. It either allowed the niche musicologist community to lead a refined academic discourse (which was praised) or made it impossible to popularise musical knowledge among a wide group of music enthusiasts (which was criticised, while 'paper' science practised by the group close to Chybiński was ridiculed at the same time). However, at the end of his life, the editor himself could take pride in the fact that he never agreed to change the nature and image of his journal, which was on a par with the most important periodical publications in Europe, and many a time its level was even higher. ${ }^{120}$

The second paradox lies in the fact that, although the title itself can almost be identified with the figure of Chybiński, formally the professor was always separated from the editorial office by kilometres (or was the distance necessary for him to work?). Chybiński will always remain the founder of the Lviv musicological centre, and even in post-war Poznań, he maintained the academic atmosphere he had developed years earlier. Kwartalnik itself was in no form a 'Lviv' magazine. This was always (in terms of organisation of publishing works) a Warsaw-based title, in the third, post-war instalment - formally speaking also a Cracow-based one, through the secretariat run by PWM and the budget determined there. The status of the magazine, firstly a body of WTM, then SMDM, based in Warsaw, with an address of the editorial office, secretariat and

120 He immodestly wrote: 'Now I had a look through Revue belge de Musicologie, and the devil take me, for they can't in any way compare to our Kwartalnik,' Chybiński/ Chomińsk 2016, 274. 
printing-office in the capital, probably does not give grounds to journalists and historians to consider it a Lviv magazine, though - due to the editor-in-chief and the group of authors frequently featured on its pages - musicologists with Galician roots - we do associate it mainly with this particular centre. However, this does not change the fact that the writing provided on the pages of Kwartalnik Muzyczny set the standards for successive generations of representatives of all Polish musicological centres up to the present day, and the journal itself has a worthy successor in the form of the quarterly Muzyka published by the PAN Instytut Sztuki. 


\section{Abbreviations}

AACh-BJ Adolf Chybiński’s Archive, Department of Music Collections, Jagiellonian Library

AACh-BUAM Adolf Chybiński's Archive, Special Collections Department, University Library in Poznań

AJCh-BUW the legacy of Józef Michał Chomiński, Archives of Polish Composers of the 20th Century, University Library in Warsaw

AZL-BUW Zofia Lissa's Archive, Archives of Polish Composers of the 20th Century, University Library in Warsaw

AU Academy of Learning

BJ Jagiellonian Library

$\mathrm{BN}$ National Library

BPCM

BUAM

Bibliography of the Polish Music Periodicals

BUW

University Library in Poznań

CAF

University Library in Warsaw

EM PWM

Central Phonographic Archive

EMT

Music Encyclopaedia of the Polish Music Publishing House

EMTA

Echo Muzyczne i Teatralne [Musical and Theater Echo]

Echo Muzyczne, Teatralne i Artystyczne [Musical, Theater and

Artistic Echo]

FKN National Culture Fund

GM Gazeta Muzyczna [Musical Paper]

GMT

GP

Gazeta Muzyczna i Teatralna [Musical and Theater Paper]

Gazeta Polska [Polish Daily]

GTM

Galician Music Society

IFCh

IKC

Frederic Chopin Institute

IMS

ISCM

Ilustrowany Kurier Codzienny [Illustrated Daily Courier]

International Musicological Society

International Society for Contemporary Music

IS PAN

Institute of Art of the Polish Academy of Sciences

KC PZPR Central Committee of the Polish United Workers' Party

$\mathrm{KM}$

KW

Kwartalnik Muzyczny [Musical Quarterly]

LIM

Kurier Warszawski [Warsaw Courier]

People's Institute of Music

LWML Lwowskie Wiadomości Muzyczne i Literackie [Lviv Music and Literary News] 
MKiS

$\mathrm{MN}$

MP

MTMN

MTMW

MW

MWRiOP

NGD

NIFC

NIK

ORMuz

PAN

PAU

PIS

PM

PMT

PPR

PPS

PR

PRM

PSB

PTM

PTMW

PTPN

PWM

PWSM

PZPR

RAF

$\mathrm{RCh}$

RM

Rocznik PAU

SD

SKP

SM

SMDM
Ministry of Culture and Arts

Ministry of Science

Muzyka Polska [Polish Music]

International Society for Modern Music

International Society for Contemporary Music

Muzyk Wojskowy [Military Musician]

Ministry of Religious Denominations and Public

Enlightenment

New Grove Dictionary

Frederic Chopin National Institute

Supreme Chamber of Control

Music Movement Organization

Polish Academy of Sciences

Polish Academy of Learning

National Institute of Art

Przegląd Muzyczny [Musical Review]

Przeglad Muzyczny i Teatralny [Musical and Theatre Review]

Polish Workers' Party

Polish Socialist Party

Polish Radio

Polski Rocznik Muzykologiczny [Polish Musicological

Yearbook]

Polski Słownik Biograficzny [Polish Biographical Dictionary]

Polish Musicological Society

Polish Society for Contemporary Music

Poznań Society for the Advancement of Arts and Sciences

Polish Music Publishing House

State College of Music

Polish United Workers' Party

Regional Phonographic Archive

Rocznik Chopinowski [The Chopin Yearbook]

Ruch Muzyczny [Musical Movement]

Rocznik Polskiej Akademii Umiejętności [Yearbook of the

Polish Academy of Learning]

Democratic Party

Association of Polish Composers

Studia Muzykologiczne [Musicological Studies]

Association of Lovers of Early Music 
Sprawozdania AU Sprawozdania Akademii Umiejętności [Academy of Learning Reports]

TiFC Frederic Chopin Society

TMD Tygodnik Muzyczny i Dramatyczny [Music and Dramatic Weekly]

TN

TPN

Scientific Society

Society of Friends of Sciences

TWMP

Polish Music Publishing Society

WRiOP

UJ

UJK

[Ministry of the] Religious Denominations and Public Enlightenment

UJP

Jagiellonian University in Cracow

Jan Kazimierz University in Lviv

UKSW

UP

Józef Piłsudski University in Warsaw

Cardinal Stefan Wyszyński University

Poznań University

UW

UWr

Warsaw University

Wroclaw University

WDMP

Polish Early Music Publishing House

WM

Wiadomości Muzyczne [Musical News]

WTM

Warsaw Music Society

ZKP

Polish Composers' Union 



\section{Bibliography}

\section{Secondary Literature}

50 lat ZKP

Adamowicz 1979

Andrzejewski 1997

Bartkowski 2009

Berwaldt 1980

Bielawski 1997

Bielawski 2004

Bilica 2008

Bogdany 1955

Bogdany 1967

Bogdany 1976

Bogdany/Michałowski

Boziewicz 1919

Bristiger 1968
50 lat Związku Kompozytorów Polskich, Warszawa 1995.

Adamowicz Tadeusz 'Materiały do Studiów i Dyskusji z zakresu teorii i historii sztuki, krytyki artystycznej oraz metodologii badań nad sztuką, in Rafał Marszałek (ed.), Polskie powojenne czasopiśmiennictwo artystyczne (Wrocław-Warszawa-Kraków-Gdańsk 1979), 7-15.

Andrzejewski Jerzy, Simon Alicja, in PSB 37/4, vol. 155 (Warszawa-Kraków 1997), 518-520.

Bartkowski Bolesław, 'Julian Pulikowski (1908-1944),' De Musica 7/8 (2009), 151-158.

Berwaldt Jacek, 'Kazimierz Sikorski', Magazyn Kulturalny 10/1 (1980), 44-45.

Bielawski Ludwik, 'Kamieński Łucjan, in EM PWM, vol. 5 (Kraków 1997), 18.

Bielawski Ludwik, 'Adolf Chybiński, twórca polskiej etnografii muzyczne, PRM 3 (2004), 213-218.

Bilica Krzysztof, 'W świetle pism, RM 52/22 (2008), 30-34.

Bogdany Wanda (ed.), Gazeta Muzyczna i Teatralna 1865-1866, Przeglad Muzyczny 1877 (= BPCM 4) (Kraków 1955).

Bogdany Wanda (ed.), Muzyka Polska 1934-39 (= BPCM 12) (Kraków 1967).

Bogdany Wanda (ed.), Muzyka 1950-1956 (= BPCM 15) (Kraków 1976).

Bogdany Wanda, Michałowski Kornel (eds.), Ruch Muzyczny 1857-1862 (= BPCM 3) (Kraków 1957).

Boziewicz Władysław, Polski kodeks honorowy (Kraków 1919).

Bristiger Michał, 'Muzykologia i piśmiennictwo muzyczne w latach 1957-1963, in: Elżbieta Dziębowska (ed.), Polska wspótczesna kultura muzyczna 1944-1964 (Kraków 1968), 137-155. 
Bristiger 1979

Bristiger 2014

Chechlińska 1977

Chechlińska 2000/1

Chechlińska 2000/2

Chechlińska/

Guzy-Pasiakowa/

Sieradz 2001

Chłopecki 2007

Chmara

Żaczkiewicz 2004

Chodkowski 1984

Chodkowski 1995

Chomiński 1953

Chomiński 1967

Chomiński/Lissa 1957

Chybiński 1948
Bristiger Michał, 'Ruch Muzyczny - 1945-1949, in Rafał Marszałek (ed.), Polskie powojenne czasopiśmiennictwo artystyczne (Wrocław-WarszawaKraków-Gdańsk 1979), 67-79.

Bristiger Michał, 'Pamięć o Sewerynie Barbagu (1891-1944)', http://www.demusica.pl/cmsimple/ images/file/dm13_mbristiger1.pdf, access 13.04.2014. Chechlińska Zofia, 'Ludwik Bronarski (1890-1975),' Rocznik Chopinowski 10 (1977), 7-9.

Chechlińska Zofia, 'Józef Michał Chomiński (24 VIII 1906-20 II 1994), in Edward Krasiński et al. (ed.), Instytut Sztuki Polskiej Akademii Nauk 1949-1999 (Warszawa 2000), 266-269.

Chechlińska Zofia, 'Miketta Janusz,' in EM PWM, vol. 6 (Kraków 2000), 260.

Chechlińska Zofia, Guzy-Pasiakowa Jolanta, Sieradz Halina, 'Kultura muzyczna Królestwa Polskiego (18151875),' in Anna M. Drexler (ed.), Kultura miejska w Królestwie Polskim 1815-1875 (Warszawa 2001), 283-306.

Chłopecki Andrzej, 'Karol Szymanowski i Międzynarodowe Towarzystwo Muzyki Współczesnej 1923-1939,' RM 51/26 (2007), 8-13.

Chmara-Żaczkiewicz Barbara, 'Prosnak Jan', in EM PWM, vol. 8 (Kraków 2004), 216-217.

Chodkowski Andrzej, 'Dunicz Jan Józef,' in EM PWM, vol. 2 (Kraków 1984), 478-479.

Chodkowski Andrzej, 'Na początku był Kraków' in 50 lat Związku Kompozytorów Polskich (Warszawa 1995), 39-47.

Chomiński Józef, 'Adolf Chybiński,' Muzyka [monthly] 4/3-4 (1953), 15-21.

Chomiński Józef, 'Hieronim Feicht (1894-1967), Muzyka 12/1 (1967), 3-5.

Chomiński Józef Michał, Lissa Zofia (eds.), Kultura muzyczna Polski Ludowej 1944-1955 (Kraków 1957).

Chybiński Adolf, 'Jan Józef Dunicz (1910-1945), RM 4/8 (1948), 10-11. 
Chylińska 1975

Chylińska 2002

Czekanowska 2003

Czekanowska 2004

Czekanowska 2005

Dadak-Kozicka 2011

Dahlig 1993

Dahlig 2004

Dahlig 2011

Dahlig 2012/1

Dahlig 2012/2

Dahlig 2012/3

Dąbrowski 1996

Degen/Hübner 2006/1
Chylińska Teresa, 'Tadeusz Ochlewski (22 IV 1894-26 II 1975),' Muzyka 20/2 (1975), 3-4.

Chylińska Teresa, 'Ochlewski Tadeusz', in EM PWM, vol. 7 (Kraków 2002), 134-136.

Czekanowska Anna, 'Adolf Chybiński jako pedagog i historyk', Musica Humana [Lviv] 1 (2003), 47-57.

Czekanowska Anna, 'O profesorze Adolfie Chybińskim i narodzinach polskiej muzykologii,' PRM 3 (2004), 198-200.

Czekanowska Anna, 'Adolf Chybiński i jego polscy uczniowie na uniwersytetach we Lwowie i w Poznaniu, in Maciej Gołąb (ed.), Muzykologia we Wrocławiu. Ludzie - historia - perspektywy (Wrocław 2005), 119-129.

Dadak-Kozicka J. Katarzyna, 'Początek powojennej batalii o muzykę w świetle dokumentów z Walnych Zjazdów Związku Kompozytorów Polskich,' PRM 9 (2011), 183-215.

Dahlig Piotr, 'Julian Pulikowski i Akcja Zbierania Folkloru muzycznego w latach 1935-1939,' Muzyka 38/ 3-4 (1993), 119-156.

Dahlig Piotr, 'Pulikowski Julian', in EM PWM, vol. 8 (Kraków 2004), 242.

Dahlig Piotr, 'Julian Pulikowski (1908-1944): the Polish Leader in Comparative Musicology and Enthusiast of Folk Song Research', Musicology Today 9 (2011), 65-73.

Dahlig Piotr, 'Bronisława Wójcik-Keuprulian (18901938) - the First Union of Musicology and Chopin Research,' Musicology Today 9 (2012), 74-80.

Dahlig Piotr, 'Windakiewiczowa Helena', in EM PWM, vol. 12 (Kraków 2012), 204-205.

Dahlig Piotr, 'Wójcik-Keuprulian Bronisława,' in EM PWM, vol. 12 (Kraków 2012), 268-269.

Dąbrowski Florian, 'Henryk Opieński. Materiały biograficzne i bibliograficzne,' in Z dziejów kultury muzycznej Poznania (Poznań 1996).

Degen Dorota, Hübner Piotr, 'Instytucje naukowe, towarzystwa, biblioteki, wydawnictwa i 
Degen/Hübner 2006/2

Długońska 1991-92

Dmitrowicz/Sowa 2006-07

Draus 2007

Drobner 1951

Drobner 1958

Drobner 1980

Drożdżewska 2011

Drożdżewska 2012

Dunicz-Niwińska 2013

Duszyk/

Dziębowska 1993

Dybiec 1993

Dziadek 2002/1

Dziadek 2002/2 czasopiśmiennictwo naukowe, in Urszula Jakubowska, Jerzy Myśliński (eds.), Humanistyka polska w latach 1945-1990 (Warszawa 2006), 39-63.

Degen Dorota, Hübner Piotr, 'Polityka naukowa władz Polski Ludowej w zakresie humanistyki (19451990)', in Urszula Jakubowska, Jerzy Myśliński (eds.), Humanistyka polska w latach 1945-1990 (Warszawa 2006), 11-38.

Długońska Barbara, 'Rytel Piotr,' in PSB, vol. 33 (Wrocław-Warszawa-Kraków 1991-92), 576-579.

Dmitrowicz Piotr, Sowa Andrzej, 'Stromenger Karol,' in PSB, vol. 44 (Warszawa, Kraków 2006-07), 360-363.

Draus Jan, Uniwersytet Jana Kazimierza we Lwowie 1918-1946. Portret kresowej uczelni (Kraków 2007).

Drobner Mieczysław, 'Prof. Stanisław Golachowski', Muzyka [monthly] 2/2 (1951), 49-50.

Drobner Mieczysław, 'Życie muzyczne w Polsce Ludowej 1944-1946,' Muzyka 3/1-2 (1958), 112-121.

Drobner Mieczysław, 'Muzykologia krakowska' in Mieczysław Drobner, Tadeusz Przybylski et al. (eds.), Kraków muzyczny 1918-1939 (Kraków 1980), 162-174.

Drożdżewska Agnieszka, 'Otto Kinkeldey i narodziny wrocławskiej muzykologii,' Muzyka 56/3 (2011), 5-26.

Drożdżewska Agnieszka, Życie muzyczne na Uniwersytecie Wrocławskim w XIX i I połowie XX wieku. Edukacja muzyczna - działalność naukowa ruch koncertowy (Wrocław 2012).

Dunicz-Niwińska Helena, Drogi mojego życia. WspomnieniaskrzypaczkizBirkenau (Oświęcim 2013). Duszyk Krystyna, Dziębowska Elżbieta, 'Jachimecki Zdzisław', in EM PWM, vol. 5 (Kraków 1993), 384-388. Dybiec Julian, Polska Akademia Umiejętności 18721952 (Kraków 1993).

Dziadek Magdalena, Polska krytyka muzyczna w latach 1890-1914. Czasopisma i autorzy (Cieszyn 2002).

Dziadek Magdalena, Polska krytyka muzyczna w latach 1890-1914. Koncepcje i zagadnienia (Katowice 2002). 
Dziadek 2004/1

Dziadek 2004/2

Dziadek 2004/3

Dziadek 2005

Dziadek 2011

Dziadek 2016

Dziębowska 1968/1

Dziębowska 1968/2

Dziębowska 1979

Dziębowska 1980

Dziębowska 1984

Dziębowska 1987/1

Dziębowska 1987/2
Dziadek Magdalena, 'Adolfa Chybińskiego i Zdzisława Jachimeckiego droga do muzykologii uniwersyteckiej', PRM 3 (2004), 178-182.

Dziadek Magdalena, 'Miejsce Śpiewaka Ślaskiego w polskim czasopiśmiennictwie muzycznym,' Śpiewak Śląski 43/2-3 (2004), 28-32.

Dziadek Magdalena, 'Twórczość krytyczno-muzyczna Stefanii Łobaczewskiej,' Muzyka 49/4 (2004), 87-110.

Dziadek Magdalena, 'Młoda Polska muzyczna we Lwowie,' Musica Galiciana 9 (2005), 92-102.

Dziadek Magdalena, Od Szkoły Dramatycznej do Uniwersytetu. Dzieje wyższej uczelni muzycznej w Warszawie 1810-2010, vol. 1 (Warszawa2011).

Dziadek Magdalena, 'Wydział Muzykologiczny Państwowego Konserwatorium Muzycznego w Warszawie w latach 1934-1938, in Dagmara Łopatowska-Romsvik, Aleksandra Patalas (eds.), Sto lat muzykologii polskiej. Historia - teraźniejszość perspektywy (Kraków 2016), 104-112.

Dziębowska Elżbieta (ed.), Polska wspótczesna kultura muzyczna 1944-1964 (Kraków 1968).

Dziębowska Elżbieta, 'Związki, towarzystwa, stowarzyszenia, in Elżbieta Dziębowska (ed.), Polska wspótczesna kultura muzyczna 1944-1964 (Kraków 1968).

Dziębowska Elżbieta, 'Profesor Zofii Lissy prace i zasługi', in Elżbieta Dziębowska, Zofia Helman et al. (eds.), Studia musicologica aesthetica, theoretica, historica (Kraków 1979), 7-10.

Dziębowska Elżbieta, 'Zofia Lissa (1908-1980), Muzyka 25/4 (1980), 9-13.

Dziębowska Elżbieta, 'Chomiński Józef Michał', in EM PWM, vol. 2 (Kraków 1984), 106-108.

Dziębowska Elżbieta, 'Badania naukowe uzykologii krakowskiej,' in Elżbieta Dziębowska (ed.), Muzykologia krakowska 1911-1986 (Kraków 1987), 7-21.

Dziębowska Elżbieta (ed.), Muzykologia krakowska 1911-1986 (Kraków 1987). 
Dziębowska 1997/1

Dziębowska 1997/2

Dziębowska 2000

Dziębowska/

Helman 1979
Dziębowska Elżbieta, 'Lissa Zofia,' in EM PWM, vol. 5 (Kraków 1997), 368-370.

Dziębowska Elżbieta, 'Łobaczewska Stefania', in EM PWM, vol. 5 (Kraków 1997), 466-469.

Dziębowska Elżbieta, 'Studia Muzykologiczne, in Edward Krasiński et al. (eds.), Instytut Sztuki Polskiej Akademii Nauk 1949-1999 (Warszawa 2000), 186-187.

Dziębowska Elżbieta, Helman Zofia et al. (eds.), Studia musicologica aesthetica, theoretica, historica (Kraków 1979).

Faryna-Paszkiewicz 2000 Faryna-Paszkiewicz Hanna, 'Materiały do Studiów i Dyskusji - Sztuka i Krytyka, in Edward Krasiński et al. (eds.), Instytut Sztuki Polskiej Akademii Nauk 1949-1999 (Warszawa 2000), 176-178.

Fik 1991

Fojcik 1985/1986

Frączkiewicz 1967

Fuks 1975

Gajkowska 1991

Gąsiorowska 2011

Gładysz 1981

Golachowska 1952

Gołąb 1995/1

Gołąb 1995/2

Gołąb 1995/3
Fik Marta, Kultura polska po Jałcie, vol. 1-2 (Warszawa 1991).

Fojcik Jan, 'Monografia Śpiewaka miesięcznika literacko-muzycznego (1920-1948)', Śpiewak Ślaski 24-25/1-2 (1985/1986), 5-41.

Frączkiewicz Aleksander, 'Włodzimierz Poźniak (1904-1967), Muzyka 12/1 (1967), 6-7.

Fuks Marian, 'Mayzel Maurycy', in PSB, vol. 20/2 (Wrocław-Warszawa-Kraków-Gdańsk 284-285.

Gajkowska Cecylia, 'Rosenzweig Józef,' in PSB, vol. 32 (Kraków 1991), 78-79.

Gąsiorowska Małgorzata, Kisielewski (Kraków 2011).

Gładysz Antoni, Oświata - kultura - nauka w latach 1947-1959 (Warszawa-Kraków 1981).

Golachowska Stanisława, 'Archiwum Karola Szymanowskiego, Muzyka [monthly] 1952/3-4, 50-62.

Gołąb Maciej, Józef Koffler (Kraków 1995).

Gołąb Maciej, 'Józef Michał Chomiński (1906-1994), Rocznik Chopinowski 21 (1995), 9-16.

Gołąb Maciej, 'Ludwik Bronarski (1890-1975),' Rocznik Chopinowski 21 (1995), 265-275. 
Gołąb 1997

Gołąb 2000

Gołąb 2005

Gołąb 2007

Gołąb 2008

Gołąb 2012

Gołos 1981

Harajda 1974

Harajda 1997

Harajda 1999

Hass/Wykaz

Helman 2002

Helman 2007
Gołąb Maciej, 'Koffler Józef', in EM PWM, vol. 5 (Kraków 1997), 129-133.

Gołąb Maciej, 'Muzyka,' in Edward Krasiński et al. (eds.), Instytut Sztuki Polskiej Akademii Nauk 19491999 (Warszawa 2000), 178-181.

Gołąb Maciej (ed.), Muzykologia we Wrocławiu. Ludzie - historia - perspektywy (Wrocław 2005).

Gołąb Maciej, 'Garść informacji o Józefie Kofflerze i jego rodzinie z ksiąg metrykalnych gminy żydowskiej w Stryju,' Muzyka 52/2 (2007), 61-73.

Gołąb Maciej, Józef Michał Chomiński. Biografia i rekonstrukcja metodologii (Wrocław 2008).

Gołąb Maciej, 'Początki muzykologii na uniwersytetach we Wrocławiu (1910) i we Lwowie (1912),' Muzyka 57/4 (2012), 3-15.

Gołos Jerzy, 'Jeszcze o Henryku Opieńskim, RM 25/10 (1981), 16.

Harajda Helena, 'Akustyka w poznańskim ośrodku muzykologicznym, in 50-lecie powołania Katedry Muzykologii przy Uniwersytecie im. Adama Mickiewicza w Poznaniu (Poznań 1974), 98-102.

Harajda Helena, 'Kwiek Marek', in EM PWM, vol. 5 (Kraków 1997), 255.

HarajdaHelena, 'Akustykanastudiach muzykologicznych w Poznaniu', in Maciej Jabłoński, Danuta Jasińska, Jan Stęszewski (eds.), Muzykologia na Uniwersytecie im. Adama Mickiewicza w Poznaniu w latach 1974-1999. Tradycje, działalność i dokumentacja (Poznań 1999), 101-108.

Hass Ludwik, 'Stanisława Małachowskiego-Łempickiego dorobek naukowy', http://www.wbc.poznan.pl/ Content/96430/Hass\%20uzupe\%C5 \%82nia\%20 Ma\%C5 \%82achowskiego.pdf, access 16.03.2014.

Helman Zofia, 'Dwie koncepcje historiografii muzycznej w pierwszej połowie XX wieku,' Muzyka 47/3-4 (2002), 115-127.

Helman Zofia, 'Szymanowski Karol', in EM PWM, vol. 10 (Kraków 2007), 275-298. 
Hrab 2005

Hrab 2007

Hrab 2009

Hrab 2010

Idaszak 1975

Idaszak 1987

Idzikowski 1963

Jabłoński/Jasińska/

Stęszewski

Jakubowska/

Myśliński 2006

Jarociński 1952

Jarociński 1955

Jarociński 1957

Jarociński 1959
Hrab Uljana, 'Adolf Chybiński i Lwowska Szkoła Muzykologiczna', in Maciej Gołąb (ed.), Muzykologia we Wrocławiu. Ludzie - historia - perspektywy (Wrocław 2005), 101-111.

Hrab Uljana, 'L’vivśka muzikologična škola Adol'fa Hibinśkogo âk cilicnij naukovo-doslidnij naprâm u pol'śkomu ta ukraïnśkomu muzikoznastvi,' Musica Galiciana 10 (2007), 29-35.

Hrab Uljana, Muzikologiâ âk universitetśka disciplina. L’vivśka muzikologična škola Adolfa Hibinśkogo (19121941) (L’viv 2009).

Hrab Uljana, 'Ukraińscy uczniowie Adolfa Chybińskiego we Lwowie,' Musica Galiciana 12 (2010), 129-140.

Idaszak Danuta, 'Bibliografia', in Zofia Lissa et al. (eds.), Opera musicologica Hieronymi Feicht, vol. 1 Studia nad muzyka polskiego średniowiecza (Kraków 1975), 22-39.

Idaszak Danuta, 'Feicht Hieronim,' in EM PWM, vol. 3 (Kraków 1987), 83-85.

Idzikowski Mieczysław, 'Bronisław Edward Sydow (1886-1952)', RM 7/7 (1963), 12-14.

Maciej Jabłoński, Danuta Jasińska, Jan Stęszewski (eds.), Muzykologia na Uniwersytecie im. Adama Mickiewicza w Poznaniu w latach 1974-1999. Tradycje, działalność i dokumentacja (Poznań 1999).

Urszula Jakubowska, Jerzy Myśliński (eds.), Humanistyka polska w latach 1945-1990 (Warszawa 2006).

Jarociński Stefan, 'Adolf Chybiński,' Przegląd Kulturalny 1/11 (1952), 3.

Jarociński Stefan (ed.), Antologia polskiej krytyki muzycznej XIX i XX wieku (Kraków 1955).

Jarociński Stefan, 'Związki muzyczne', in Józef M. Chomiński, Zofia Lissa (eds.), Kultura muzyczna Polski Ludowej 1944-1955 (Kraków 1957), 53-57.

Jarociński Stefan, 'Polskie czasopiśmiennictwo muzyczne w XIX I XX w. (do 1939 r.),' Muzyka 4/1 (1959), 23-42. 
Jarociński 1968

Jarociński 1979

Jarociński 1984

Jarowiecki 2003

Jarowiecki/Góra 1994

Jarzębska 2004

Jasieński 2006

Jasinowski 2005

Jasińska 1979

Jędrzejczak 1981/1

Jędrzejczak 1981/2

Kaczyński 1963

Kafel 1966

Kałamarz 2012
Jarociński Stefan, 'Muzykologia i piśmiennictwo muzyczne w latach 1945-1956,' in Elżbieta Dziębowska (ed.), Polska współczesna kultura muzyczna 19441964 (Kraków 1968), 120-136.

Jarociński Stefan, 'Muzyka 1950-1955. Czasopiśmiennictwo artystyczne Polski Ludowej; in Rafał Marszałek (ed.), Polskie powojenne czasopiśmiennictwo artystyczne (Wrocław-WarszawaKraków-Gdańsk 1979), 80-86.

Jarociński Stefan, 'Muzykologia a krytyka', in Irena Poniatowska et al. (eds.), Dzieło muzyczne. Historia teoria - interpretacja (Kraków 1984), 147-152.

Jerzy Jarowiecki (ed.), Kraków - Lwów: książki, czasopisma, biblioteki XIX i XX wieku, vol. 6/1-2 (Kraków 2003).

Jarowiecki Jerzy, Góra Barbara, Prasa lwowska w dwudziestoleciu międzywojennym. Próba bibliografii (Kraków 1994).

Jarzębska Alicja, 'Profesor Zdzisław Jachimecki założyciel krakowskiej muzykologii,' PRM 3 (2004), 187-189.

Jasieński Jerzy, 'Pamiątka sprzed siedemdziesięciu lat,' RM 50/4 (2006), 32-33.

Jasinowski Jurij, 'Adolf Chybiński i jego ukraińscy uczniowie na Uniwersytecie Jana Kazimierza we Lwowie, in Maciej Gołąb (ed.), Muzykologia we Wrocławiu. Ludzie - historia - perspektywy (Wrocław 2005), 113-118.

Jasińska Danuta, 'Borrel Eugène Marie Valentin', in EM PWM, vol. 1 (Kraków 1979), 372.

Jędrzejczak Wojciech, 'Henryk Opieński 1870-1942, part I', RM 25/7 (1981), 4-6.

Jędrzejczak Wojciech, 'Henryk Opieński 1870-1942, part II,' RM 25/8 (1981), 14-16.

Kaczyński Tadeusz, 'Młoda do ostatnich dni,' RM 7/5 (1963), 6-7.

Kafel Mieczysław, Prasoznawstwo. Wstęp do problematyki (Warszawa 1966).

Kałamarz Wojciech (ed.), Szkice do portretu Hieronima Feichta (Kraków 2012). 
Kaniewska 1977

Kaniewska Irena, ‘Skoczek Józef Stanisław' in PSB, vol. 38/1 (Warszawa-Kraków 1997), 206-207.

Kielanowska-Bronowicz/ Kielanowska-Bronowicz Maria, Michałowski Kornel Michałowski 1963 eds.), Kwartalnik Muzyczny 1911-1914, 1928-1933, 1948-1950. Polski Rocznik Muzykologiczny 1935-1936 (= BPCM 8) (Kraków 1963).

Kisielewski 1964

Kosińska 2009

Kosmanowa 2000

Kowalczyk/

Jaraczewska-Mockałło

Krysmalska 1957

Lissa 1957

Lissa 1963

Lissa 1967

Lissa 1974

Lissa 1978

Lissa 1990

Madaj 1996
Kisielewski Stefan, 'O Bronisławie Rutkowskim,' RM 1964 8/14, 4-5.

Kosińska Małgorzata, 'Konstanty Regamey', https:// culture.pl/pl/tworca/konstanty-constantin-regamey, access 25.06.2019, https://www.polmic.pl/index. php? option $=$ com_mwosoby\&id $=667$ \&litera $=20 \& v i e$ $\mathrm{w}=$ czlowiek\&Itemid=5\&lang=pl, access 25.06.2019.

Barbara Kosmanowa (ed.), Prasa dawna i współczesna, part 1 (Poznań 2000).

Kowalczyk Henryka, Jaraczewska-Mockałło Krystyna, Kazimierz Sikorski. Życie i twórczość. W 100-lecie urodzin Profesora (Warszawa 1995).

Krysmalska Kornelia (introduction), in Ruch Muzyczny 1857-1862, Wanda Bogdany, Kornel Michałowski (eds.) (= BPCM 3) (Kraków 1957).

Lissa Zofia, 'Historia i teoria muzyki', in Józef M. Chomiński, Zofia Lissa (eds.), Kultura muzyczna Polski Ludowej 1944-1955 (Kraków 1957), 265-278.

Lissa Zofia, 'Wspomnienie o Stefanii Łobaczewskiej,' RM 7/5 (1963), 3-5.

Lissa Zofia, 'Znaczenie Hieronima Feichta w polskiej muzykologii,' RM 11/11 (1967), 3-5.

Lissa Zofia, 'Instytut Muzykologii Uniwersytetu Warszawskiego w latach 1948-1974,' Rocznik Uniwersytetu Warszawskiego 14 (1974), 91-104.

Lissa Zofia, 'Instytut Muzykologii Uniwersytetu Warszawskiego w latach 1948-1974,' in Adam Neuer (ed.), Z zagadnień muzykologii współczesnej (Warszawa 1978).

Lissa Zofia, 'Gużewski Adam' in PSB, vol. 32 (Wrocław-Kraków-Warszawa 1990), 198.

Madaj Katarzyna, 'Józef Koffler o muzyce współczesnej,' Muzyka 41/2 (1996), 159-165. 
Malinowski 2006

Marek 1950

Markuszewski 2005

Marszałek 1979

Mazepa 1995

Mazepa 2005

Mazepa/Mazepa 2003

Mądry 2009

Mękarski 1970

Michalewicz 2005

Michałowska 1961

Michałowska 1981
Malinowski Władysław, 'Socrealizm? Cóż to właściwie było? (Przyczynek do historii sacrum w sztuce), De Musica 1-3 (2006), 138-168.

Marek Tadeusz, 'Prof. Dr Adolf Chybiński. (Z okazji 50-lecia pracy naukowej)', Muzyka [monthly] 1/9 (1950), 71-72.

Markuszewski Paweł, 'Działalność Stefanii Łobaczewskiej we Lwowie,' Musica Galiciana 9 (2005), 154-159.

Marszałek Rafał (ed.), Polskie powojenne czasopiśmiennictwo artystyczne (Wrocław-WarszawaKraków-Gdańsk 1979).

Mazepa Leszek, 'Szkolnictwo muzyczne we Lwowie (XV-XX w.), in: Henryk W. Żaliński, Kazimierz Karolczak (eds.), Lwów: miasto - społeczeństwo kultura, vol. 1 Studia z dziejów Lwowa (Kraków 1995), 19-26.

Mazepa Leszek, 'Poprzednicy Akademii Muzycznej we Lwowie,' Musica Galiciana 9 (2005), 9-31.

Mazepa Leszek, Mazepa Teresa, Šlâh do Muzičnoï Akademiï u L'vovi: u dvoh tomach, vol. 1 Vid dobi mis'kih muzikantiv do Konservatorii / Droga do Akademii Muzycznej we Lwowie, part 1 Od doby muzyków miejskich do Konserwatorium (XV w.-1939) (Lwów/Lviv 2003).

Mądry Alina, 'Surzyński Mieczysław', in PSB, vol. 44/1 (Warszawa-Kraków 2009), 47-48.

Mękarski Stefan, 'Z dziejów Uniwersytetu Jana Kazimierza w okresie niepodległości 1919-1939, in Mieczysław Sas-Skowroński (ed.), Kongres wspótczesnej nauki i kultury polskiej na obczyźnie (Londyn 1970), 177-185.

Michalewicz Jerzy (ed.), Relacje pracowników Uniwersytetu Jagiellońskiego o ich losach osobistych $i$ dziejach uczelni $w$ czasie drugiej wojny światowej (Kraków 2005).

Michałowska Maria (ed.), Nowości Muzyczne: 19031914; Lutnista: 1905-1907 (= BPCM 6) (Kraków 1961). Michałowska Maria (ed.), Ruch Muzyczny 1945-1949, 1957-1959 (= BPCM 14/1-2) (Kraków 1981). 
Michałowski 1950

Michałowski 1955

Michałowski 1956

Michałowski 1959

Michałowski 1967

Michałowski 1979

Michałowski 1981

Michałowski 1999

Michniewicz 1983

Morawska 1976

Morawska 2007/1

Morawska2007/2
Michałowski Kornel, 'Bibliografia prac prof. Adolfa Chybińskiego,' in Ksiega pamiątkowa ku czci Prof. Adolfa Chybińskiego w 70-lecie urodzin. Rozprawy i artykuły z zakresu muzykologii (Kraków 1950), 26-43. Michałowski Kornel, Bibliografia polskiego piśmiennictwa muzycznego (Kraków 1955).

Michałowski Kornel (ed.), Gazeta Teatralna 18431844 (= BPCM 2) (Kraków 1956).

Michałowski Kornel, 'Bibliografia prac naukowych i publicystycznych Adolfa Chybińskiego', in Adolf Chybiński, Wczasach Straussa i Tetmajera. Wspomnienia, Anna and Zygmunt Szweykowscy (eds.) (Kraków 1959), 210-257.

Michałowski Kornel (ed.), Muzyka 1924-38 part. 1-2 (= BPCM 9/1-2) (Kraków 1967).

Michałowski Kornel, 'Polskie Towarzystwo Muzykologiczne w latach 1928-1931', Muzyka 24/3 (1979), 21-33.

Michałowski Kornel, 'Adolf Chybiński a Młoda Polska w muzyce,' in Młoda Polska a modernizm (Kraków 1981), 101-111.

Michałowski Kornel, ' $Z$ historii muzykologii poznańskiej, in Maciej Jabłoński, Danuta Jasińska, Jan Stęszewski (eds.), Muzykologia na Uniwersytecie im. Adama Mickiewicza w Poznaniu w latach 19741999. Tradycje, działalność i dokumentacja (Poznań 1999), 49-56.

Michniewicz Grażyna, 'Geneza i działalność Instytutu Fryderyka Chopina 1934-1939,' Rocznik Chopinowski 15 (1983), 117-141.

Morawska Katarzyna, 'Badania nad muzyką dawną w Polsce w XIX wieku, in Zofia Chechlińska (ed.), Szkice o kulturze muzycznej XX w., vol. 3 (Warszawa 1976), 7-127.

Morawska Katarzyna, 'Simon Alicja,' in EM PWM, vol. 9 (Kraków 2007), 273.

Morawska Katarzyna, 'Szczepańska Maria,' in EM PWM, vol. 9 (Kraków 2007), 234. 
Mrowiec 2004

Mrygoń 1979

Mrygoń 1982

Mrygoń 1984

Mrygoń 1989

Mrygoń 1997

Mrygoń 2007

Muszkalska 1999

Muszkalska 2005

Muszkalska 2011/1

Muszkalska 2011/2

Muszkalska 2012

Myśliński 1969
Mrowiec Karol, 'Wspomnienie o profesorze Zdzisławie Jachimeckim,' PRM 3 (2004), 196-197.

Mrygoń Adam, 'Bibliografia prac prof. dr Zofii Lissy,' in Elżbieta Dziębowska, Zofia Helman et al. (eds.), Studia musicologica aesthetica, theoretica, historica (Kraków 1979), 11-45.

Mrygoń Adam, Stanisław Wiechowicz, vol. 1 Działalność (Kraków 1982).

Mrygoń Adam, 'Bibliografia prac profesora Józef Chomińskiego,' in Irena Poniatowska et al. (eds.), Dzieło muzyczne. Historia - teoria - interpretacja (Kraków 1984), 19-28.

Mrygoń Adam, Stanisław Wiechowicz, vol. 2 Twórczość (Kraków 1989).

Mrygoń Adam, 'Kondracki Michał', in EM PWM, vol. 5 (Kraków 1997), 158.

Mrygoń Adam, 'Sikorski Kazimierz', in EM PWM, vol. 9 (Kraków 2007), 262-263.

Muszkalska Bożena, 'Poznańskie środowisko etnomuzykologiczne - tradycje i teraźniejszość, in Maciej Jabłoński, Danuta Jasińska, Jan Stęszewski (eds.), Muzykologia na Uniwersytecie im. Adama Mickiewicza w Poznaniu w latach 1974-1999. Tradycje, działalność i dokumentacja (Poznań 1999), 89-100.

Muszkalska Bożena, 'Postać Marii Szczepańskiej w świetle materiałów archiwalnych, in Maciej Gołąb (ed.), Muzykologia we Wrocławiu. Ludzie - historia perspektywy (Wrocław 2005), 131-139.

Muszkalska Bożena, 'The Figure of Maria Szczepańska (1902-1962) in the Light of Archive Materials', Musicology Today 9 (2011), 81-93.

Muszkalska Bożena, 'Łucjan Kamieński (1885-1964) as an Ethnomusicologist and Man in his Works and Letters', Musicology Today 9 (2011), 94-131.

Muszkalska Bożena, 'Bronisława Wójcik-Keuprulian niepokorna uczennica Profesora, Muzyka 57/4 (2012), 47-70.

Myśliński Jerzy, 'Czasopiśmiennictwo naukowe w Galicji w dobie autonomicznej. Uwagi wstępne, 
Natkowska 1999

Neuer 1978

Neuer 2000

Nidecka 2005

Niwińska 2005

Nowik 1995

Ochlewski 1950

Ochlewski 1970

Ochwat 2007

Osiński 2008

Ossowscy 1935

Ostrowska 1975

Paczkowski 1980

Peret-Ziemlańska 1985
Rocznik Historii Czasopiśmiennictwa Polskiego 4 (1969), 477-500.

Natkowska Monika, Numerus clausus, 'getto ławkowe,' numerus nullus, 'paragraf aryjski.' Antysemityzm na Uniwersytecie Warszawskim 1931-1939 (Warszawa 1999).

Neuer Adam (ed.), $Z$ zagadnień muzykologii współczesnej (Warszawa 1978).

Neuer Adam, 'Marek Tadeusz', in EM PWM, vol. 6 (Kraków 2000), 83.

Nidecka Ewa, 'Polskie czasopiśmiennictwo muzyczne Lwowa pierwszej połowy dwudziestego wieku,' Musica Galiciana 9 (2005), 210-221.

Niwińska Helena, 'Jan Józef Dunicz (1910-1945),' Muzyka 50/2 (2005), 121-125.

Nowik Wojciech, 'Bronisława Wójcik-Keuprulian (1890-1938) - w cieniu zapomnienia, Rocznik Chopinowski 21 (1995), 259-262.

Ochlewski Tadeusz, 'Z dziejów pracy wydawniczej prof. A. Chybińskiego', in Ksiegga pamiątkowa ku czci Prof. Adolfa Chybińskiego w 70-lecie urodzin. Rozprawy i artykuly z zakresu muzykologii (Kraków 1950), 380-389.

Ochlewski Tadeusz, 'Muzyka w Warszawie podczas okupacji', RM 14/11 (1970), 16-17.

Ochwat Elżbieta, Zakład Muzykologii na Uniwersytecie Jana Kazimierza we Lwowie w latach 1912-1939, PhD diss. UKSW (Warszawa 2007).

Osiński Zbigniew, Janusz Jędrzejewicz - piłsudczyk i reformator edukacji (1885-1951) (Lublin 2008).

Ossowscy Maria and Stanisław, 'Nauka o nauce, Nauka Polska 20 (1935), 1-12.

Ostrowska Teresa, 'Czasopisma o nauce,' Przegląd Humanistyczny 19/9 (1975), 61-73 (part 1), 19/10 (1975), 57-68 (part 2).

Paczkowski Andrzej, Prasa polska w latach 1918-1939 (= Historia Prasy Polskiej 3) (Warszawa 1980).

Peret-Ziemlańska Zofia, 'Aes perenne. Wywiad z prof. Dr h.c. Kazimierzem Sikorskim,' Poradnik Muzyczny 39/9 (1985), 3-5. 
Peret-Ziemlańska 1999 Peret-Ziemlańska Zofia, 'Kazimierz Sikorski (1895-1986)', in W hołdzie zmarlym absolwentom $i$ pedagogom Akademii Muzycznej im. Fryderyka Chopina w Warszawie (Warszawa 1999), 46-51.

Perkowska 1979

Perkowska Małgorzata, 'Opieński Henryk', in PSB, vol. 24 (Warszawa 1979).

Perz 1964

Perz Mirosław, 'Hieronim Feicht,' in Zofia Lissa (ed.), Studia Hieronymo Feicht septuagenario dedicata (Kraków 1964), 7-13.

Perz 1967

Perz Mirosław, 'Hieronim Feicht w oczach uczniów, RM 11/11 (1967), 7.

Pfeiffer 1962-64

Pfeiffer Halina, 'Idzikowski Władysław, in PSB, vol. 10 (Wrocław-Warszawa-Kraków 1962-64), 140-142.

Piekarski 2010/1

Piekarski Michał, 'Działalność polskich i ukraińskich wychowanków lwowskiej szkoły muzykologicznej (do 1939 roku), Rozprawy z Dziejów Oświaty 47 (2010), 73-108.

Piekarski 2010/2

Piekarski Michał, 'Fryderyk Chopin (18101849) i jego lwowscy kontynuatorzy. Cz. XV lwowscy muzykolodzy o Chopinie,' http://www. dziennikpolski24.pl/artykul/2844430,fryderykchopin-18101849-i-jego-lwowscy-kontynuatorzy,id,t. html, access 16.06.2019.

Piekarski 2010/3

Piekarski Michał, Polskie i ukrainskie środowisko Zakładu Muzykologii Uniwersytetu Jana Kazimierza we Lwowie, master thesis UW (Warsaw 2010).

Piekarski 2012

Piekarski Michał, 'Prof. Adolf Chybiński (18801952) - Founder of Polish Musicology. For the Centenary of the Faculty of Musicology at Lvov University (1912-2012), Musicology Today 9 (2012), 38-64.

Piekarski 2014

Piekarski Michał, 'Uniwersytet a muzyka. Droga do powołania we Lwowie Zakładu Muzykologii, Rozprawy z Dziejów Oświaty 51 (2014), 99-124.

Piekarski 2017

Piekarski Michał, Przerwany kontrapunkt. Adolf Chybiński i początki polskiej muzykologii we Lwowie 1912-1944 (Warszawa 2017).

Pigła 1991

Pigła Włodzimierz, Centralny katalog polskich czasopism muzycznych $i$ wydawnictw ciagtych o tematyce muzycznej. Zbiory polskie (Warszawa 1991). 
Piskurewicz 1989

Piskurewicz 1998

Poniatowska 1974

Poniatowska 1984/1

Poniatowska 1984/2

Poniatowska 1993/1

Poniatowska 1993/2

Poniatowska 1995

Porębowiczowa 1964

Pośpiech 2009

Poźniak 1965

Poźniak 1967
Piskurewicz Jan, 'Refleksja naukoznawcza w środowisku uczonych II Rzeczpospolitej', Zagadnienia Naukoznawstwa 25/3-4 (1989), 601-613.

Piskurewicz Jan, Primo inter pares. Polska Akademia Umiejętności w latach II Rzeczypospolitej (Kraków 1998).

Poniatowska Irena, Kronika ważniejszych wydarzeń muzycznych $w$ Polsce 1945-72 (Kraków 1974).

Poniatowska Irena, 'Profesor Józef Michał Chomiński - uczony i dydaktyk', in Irena Poniatowska et al. (eds.), Dzieło muzyczne. Historia - teoria interpretacja (Kraków 1984), 11-17.

Poniatowska Irena et al. (eds.), Dzieło muzyczne. Historia - teoria - interpretacja (Kraków 1984).

Poniatowska Irena, 'Ferdynand Hoesick (18671941) - muzykograf $\mathrm{z}$ przełomu stuleci', in Irena Poniatowska, Historia i interpretacja muzyki. Z badań nad muzyka od XVII do XIX wieku (Kraków 1993), 165-186.

Poniatowska Irena, 'Historyzm w myśli i muzyce XIX i XX wieku,' in Irena Poniatowska, Historia $i$ interpretacja muzyki. Z badań nad muzyka od XVII do XIX wieku (Kraków 1993), 9-26.

Poniatowska Irena, 'Historyzm i tradycja w badaniach nad muzyką (Na jubileusz kongresów MAEO)', Barok 2/3 (1995), 117-125.

Porębowiczowa Anna (ed.), Młoda Muzyka 19081909, Przeglad Muzyczny 1910-1914, 1918-1919 (= BPCM 7) (Kraków 1964)

Pośpiech Remigiusz, 'Liturgia Sacra w kontekście tradycji kościelnych periodyków muzycznych oraz soborowej odnowy muzyki liturgicznej; Ateneum Kapłańskie 153/1-2 (2009), 56-72.

Poźniak Włodzimierz (ed.), Echo Muzyczne 18771882; Echo Muzyczne Teatralne i Artystyczne 18831907, part 1 (= BPCM 5/1) (Kraków 1965).

Poźniak Włodzimierz, 'Studium muzykologii w Uniwersytecie Jagiellońskim,' in Zeszyty Naukowe Uniwersytetu Jagiellońskiego 139, Prace Historyczne 16. 
Poźniak 1972

Studia z dziejów Wydziału Filozoficzno-Historycznego Uniwersytetu Jagiellońskiego (Kraków 1967), 447-453.

Poźniak Włodzimierz (ed.), Echo Muzyczne 1877-
1882; Echo Muzyczne Teatralne i Artystyczne 1883-
1907, part 2 (= BPCM 5/2) (Kraków 1972).

'Profesor Adolf Chybiński' 'Profesor Adolf Chybiński', in Księga pamiatkowa ku czci Prof. Adolfa Chybińskiego w 70-lecie urodzin. Rozprawy $i$ artykuły z zakresu muzykologii (Kraków 1950), 9-25.

Prokopowicz $1961 \quad$ Prokopowicz Maria (ed.), Gazetka Muzyczna 19361939, Muzyka Współczesna 1936-1939, Chopin 1937 (= BPCM 13) (Kraków 1961).

Prosnak 1964

Prosnak Jan, 'Komisja Programowa Szkolnictwa Muzycznego,' Muzyka 9/3-4 (1964), 111-122.

Przybylski 1975 Przybylski Tadeusz, 'Maszyński Piotr', in PSB, vol. 21/1 (Wrocław-Warszawa-Kraków-Gdańsk 1975), 166-167.

Przybylski 1980 Przybylski Tadeusz, Karol Kurpiński (Warszawa 1980).

Przybylski 1987 Przybylski Tadeusz, 'Rozwój studiów muzykologicznych w Uniwersytecie Jagiellońskim, in Elżbieta Dziębowska (ed.), Muzykologia krakowska 1911-1986 (Kraków 1987), 23-39.

Przybylski 2004

Przybylski Tadeusz, 'Początki studiów muzykologicznych w Krakowie,' PRM 3 (2004), 190-195.

Przybyszewska- Przybyszewska-Jarmińska Barbara, 'Syntetyczne Jarmińska 2016 opracowania historii muzyki polskiej publikowane $\mathrm{w}$ pierwszej połowie XX wieku,' in Dagmara ŁopatowskaRomsvik, Aleksandra Patalas (eds.), Sto lat muzykologii polskiej. Historia - teraźniejszość - perspektywy (Kraków 2016), 133-150.

Przybyszewska-Jarmińska/ Przybyszewska-Jarmińska Barbara, WitkowskaWitkowska-Zaremba 2000 Zaremba Elżbieta, 'Zakład Historii i Teorii Muzyki', in Edward Krasiński et al. (eds.), Instytut Sztuki Polskiej Akademii Nauk 1949-1999 (Warszawa 2000), 115-122.

Rostworowski $1974 \quad$ Emanuel Rostworowski et al. (eds.), Polska Akademia Umiejętności 1872-1952. Nauki humanistyczne i społeczne (Wrocław-Warszawa-Kraków-Gdańsk 1974). 
Rudnicka-Kruszewska 1974 Rudnicka-Kruszewska Hanna, 'Maria Szczepańska,' in 50-lecie powołania Katedry Muzykologii przy Uniwersytecie im. A. Mickiewicza w Poznaniu (Poznań 1974), 123-134.

Rudziński 1952 Rudziński Witold, 'Zofia Lissa. Laureat nagrody Związku Kompozytorów Polskich', Muzyka [monthly] 3/1-2 (1952), 57-59.

Rzanna-Szczepaniak 2009 Rzanna-Szczepaniak Ewa, Polityka kulturalna a rozwój kultury muzycznej w Polsce w latach 1944-1956 (Poznań 2009).

Rzanna-Szczepaniak 2012 Rzanna-Szczepaniak Ewa, Działalność Związku Kompozytorów Polskich na tle sytuacji w kraju (19451956) (Opole 2012).

Rzanna-Szczepaniak 2013 Rzanna-Szczepaniak Ewa, Stalinizm a powojenna kultura muzyczna w Polsce (Opole 2013).

Semkowicz 1938

Semkowicz Władysław, ‘Życie naukowe współczesnego Krakowa,' Nauka Polska 23 (1938), 25-108.

Sieradz 2011

Sieradz Małgorzata, "Natus est ROCZNIK MUZYKOLOGICZNY!" Polski Rocznik Muzykologiczny" w korespondencji od i do Adolfa Chybińskiego,' PRM 9 (2011), 21-42.

Sieradz 2012/1

Sieradz Małgorzata, 'Adolf Chybiński i "Klub fachowej prasy muzycznej”, Muzyka 57/3 (2012), 67-78.

Sieradz 2012/2

Sieradz Małgorzata, 'Lwowscy uczniowie Adolfa Chybińskiego jako autorzy czasopism muzycznych (do roku 1939),' Muzyka 57/4 (2012), 71-96.

Sieradz 2016

Sieradz Małgorzata, 'Adolfa Chybińskiego spotkania z Kwartalnikiem Muzycznym. Trzy odsłony tematu, in Dagmara Łopatowska-Romsvik, Aleksandra Patalas (eds.), Sto lat muzykologii polskiej. Historia teraźniejszość - perspektywy (Kraków 2016), 179-191.

Sieradz 2017/1

Sieradz Małgorzata, Archivum Helveto-Polonicum spuścizna Henryka Opieńskiego i inne muzykologiczne zbiory w zasobach fryburskiej Fundacji, in Beata Bolesławska-Lewandowska, Jolanta Guzy-Pasiak (eds.), Twórcy - źródła - archiwa (= Muzyka Polska za Granicą 1), Warszawa 2017, 259-280.

Sieradz 2017/2

Sieradz Małgorzata, 'Henryk Opieński (1870-1942) w znanej i nieznanej korespondencji Stanisława Wyspiańskiego, Józefa Mehoffera i Stanisława 
Sikorski 1963

Skowron 2002

Sobieski 1954

Socrealizm 2006

Sołtys 2008

Sosnowska 2011

Spóz 1973

Spóz 1980

Stachowska 1974

Staszkiewicz 2012

Stempniewicz 1966

Stęszewski 1967

Strumiłło 1955
Estreichera. Wątki nie tylko muzyczne, Muzyka 62/4 (2017), 3-52.

Sikorski Czesław, 'Doc. Dr Maria Szczepańska. Wspomnienie pośmiertne,' RM 7/20 (1963), 7.

Skowron Zbigniew, 'Historyzm jako podstawa badawcza w historiografii muzycznej XX wieku, Muzyka 47/3-4 (2002), 145-155.

Sobieski Marian, 'Profesor dr Adolf Eustachy Chybiński', Lud 41 (1954), 27-32.

'Socrealizm? Dyskusja redakcyjna', De Musica 1-3 (2006), 169-184.

Sołtys Maria Ewa, Tylko we Lwowie. Dzieje życia $i$ działalności Mieczysława i Adama Sołtysów (Wrocław 2008).

Sosnowska Joanna, 'Juliusz Starzyński (1906-1974),' Rocznik Historii Sztuki 36 (2011), 146-159.

Spóz Andrzej, 'Tradycje moniuszkowskie w Warszawskim Towarzystwie Muzycznym w latach 1871-1914,' in Zofia Chechlińska (ed.), Szkice o kulturze muzycznej XIX w., vol. 2 (Warszawa 1973), 233-289.

Spóz Andrzej, 'Warszawskie Towarzystwo Muzyczne,' in idem, Kultura muzyczna Warszawy drugiej połowy XIX wieku (Warszawa 1980), 42-54.

Stachowska Irena, 'Muzykologia,' in Emanuel Rostworowski et al. (eds.), Polska Akademia Umiejętności 1872-1952. Nauki humanistyczne i społeczne. Materialy sesji jubileuszowej Kraków 3-4 V 1973 (WrocławWarszawa-Kraków-Gdańsk 1974), 249-254.

Staszkiewicz Dorota, 'Zalewski Teodor', in EM PWM, vol. 12 (Kraków 2012), 320.

Stempniewicz Mirosława (ed.), Przeglad Muzyczny 1925-1931, Życie Muzyczne i Teatralne 1934-1935 (= BPCM 11) (Kraków 1966).

Stęszewski Jan, 'Marian Sobieski (1908-1967),' Muzyka 12/ 4 (1967), 3-5.

Strumiłło Dobrochna, Tygodnik Muzyczny 18201821, Pamiętnik Muzyczny Warszawski 1835-1836 (= BPCM 1) (Kraków 1955). 
Strumiłło 1957

Swaryczewska 1964

Szaniawski 1980

Szczawińska 1972
Strumiłło Tadeusz, 'Wydawnictwa muzyczne', in Józef M. Chomiński, Zofia Lissa (eds.), Kultura muzyczna Polski Ludowej 1944-1955 (Kraków 1957), 91-103.

Swaryczewska Katarzyna, 'Badania Zakładu Historii i Teorii Muzyki Instytutu Sztuki PAN', Muzyka 9/3-4 (1964), 59-67.

Szaniawski Klemens, 'Autorytet w nauce', in Paweł Rybicki, Janusz Goćkowski (eds.), Autorytet w nauce (Wrocław 1980), 19-25.

Szczawińska Elżbieta (ed.), 'Muzyka w polskich czasopismach literackich i artystycznych 19011918,' (= Bibliografia Muzyczna Polskich Czasopism Niemuzycznych 4) (Kraków 1972).

Szczepańska-Lange 1997 Szczepańska-Lange Elżbieta, 'Józef Sikorski (18131896). Szkic biograficzny', Muzyka 42/1 (1997), 31-69.

Szczepańska-Lange 2010 Szczepańska-Lange Elżbieta, 'Kult Chopina w Warszawie pod zaborem rosyjskim,' Muzyka 55/3 (2010), 63-93.

Szczepański 1980

Szczepański Jan, 'Autorytet w nauce,' in Paweł Rybicki, Janusz Goćkowski (eds.), Autorytet w nauce (Wrocław 1980), 13-18.

Szweykowski 1980

Szweykowski 1984

Ślęczka

Śródka 1999

Szweykowski Zygmunt M., 'Chomiński, Józef Michał', in NGD, vol. 5 (London 1980).

Szweykowski Zygmunt M., 'Chybiński Adolf', in EM PWM, vol. 2 (Kraków 1984), 197-199.

Ślęczka Adrian, 'Działalność popularyzatorska Józefa Reissa, www.muzykologia.uj.edu.pl/kwartalnik/ numery/nr5/slaczka,pdf, access 25.11.2009.

Śródka Andrzej, 'Historycy nauki w tomach XXXVII i XXXVIII Polskiego Słownika Biograficznego,' Kwartalnik Historii Nauki $i$ Techniki 44/3-4 (1999), 43-52.

Świderska 1961

Świderska Józefa, Lwowskie Wiadomości Muzyczne i Literackie 1925-1934, Szopen 1932, Echo 1936-1937 (= BPCM 10) (Kraków 1961).

Tarnawska-

Kaczorowska 1987

Tatarska 1986
Tarnawska-Kaczorowska Krystyna (ed.), Melos, logos, etos (Warszawa 1987).

Tatarska Janina, 'Łucjan Kamieński 1885-1965, RM 30/1 (1986), 24-25. 
Tatarska 1999

TiFC

Tołoszniak 2008

Tomaszewski 2004

Tomicki 1988

Troski i spory 1983

Tyszkiewicz 1997

Ugrewicz 1996

Ugrewicz 1998

Ugrewicz 2005

Waldorff 1964

Wieczorek 2014
Tatarska Janina, ‘Łucjan Kamieński - twórca polskiej etnomuzykologii', in Maciej Jabłoński, Danuta Jasińska, Jan Stęszewski (eds.), Muzykologia na Uniwersytecie im. Adama Mickiewicza w Poznaniu w latach 19741999. Tradycje, działalność i dokumentacja (Poznań 1999), 61-79.

TiFC historia, strona http://tifc.chopin.pl/historia. php, access 25.11.1017.

Tołoszniak Natalia, 'Życie muzyczne Lwowa w latach 20. i 30. XX wieku w publicystyczno-krytycznej analizie Borysa Kudryka,' Musica Galiciana 11 (2008), 183-196.

Tomaszewski Mieczysław, 'O profesorze Zdzisławie Jachimeckim,' PRM 3 (2004), 183-186.

Tomicki Jan (ed.), Polska odrodzona: 1918-1939: państwo, społeczeństwo, kultura (Warszawa 1988).

Troski i spory muzykologii polskiej. 1905-1926 (ed. Krystyna Winowicz) (Kraków 1983).

Tyszkiewicz Monika Henryk Opieński - pisarz i krytyk muzyczny, master thesis UAM (Poznań 1997).

Ugrewicz Adam, 'Zarys powojennej działalności naukowo-dydaktycznej Zakładu Muzykologii Uniwersytetu Wrocławskiego,' Zeszyty Naukowe Akademia Muzyczna im. Karola Lipińskiego we Wrocławiu 69 (= Tradycje Śląskiej Kultury Muzycznej 8) (Wrocław 1996), 231-241.

Ugrewicz Adam, Działalność naukowo-dydaktyczna Zakładu Muzykologii Uniwersytetu Wrocławskiego w latach 1945-1952. PhD. diss. UWr (Wrocław 1998).

Ugrewicz Adam, 'Hieronim Feicht i działalność Zakładu Muzykologii Uniwersytetu Wrocławskiego w latach 1945-1952', in Maciej Gołąb (ed.), Muzykologia we Wrocławiu. Ludzie - historia - perspektywy (Wrocław 2005), 71-90.

Waldorff Jerzy, 'Bronisław Rutkowski', Świat 14/24 (1964).

Wieczorek Sławomir, Na froncie muzyki. Socrealistyczny dyskurs o muzyce w Polsce w latach 1948-1955 (Wrocław 2014). 
Wierszyłowski 1964

Więckowska 1947

Więckowska 1966

Wilk 2000/1

Wilk 2000/2

Wilk 2000/3

Wilk 2000/4

Wilkowska-

Chomińska 1967

Winowicz 1974

Winowicz 1978

Winowicz 1979

Winowicz 1982

Winowicz 1989
Wierszyłowski Jan, 'Muzyka. Kwartalnik poświęcony historii i teorii muzyki oraz krytyce naukowej i artystycznej. Organ Państwowego Instytutu Sztuki Polskiej Akademii Nauk,' Muzyka 9/3-4 (1964), 151-163.

Więckowska Helena, Piśmiennictwo naukowe Polski powojennej (Warszawa 1947).

Więckowska Helena, 'Zarys czasopiśmiennictwa naukowego w Polsce, Studia i Materiały z Dziejów Nauki Polskiej Seria E (1966), 87-110.

Wilk Piotr, 'Józef Władysław Reiss', in Jan Dybiec (ed.), Złota ksiega Wydziału Historycznego (Kraków 2000), 235-238.

Wilk Piotr, 'Stefania Łobaczewska,' in Jan Dybiec (ed.), Złota księga Wydziału Historycznego (Kraków 2000), 299-302.

Wilk Piotr, 'Włodzimierz Poźniak', in Jan Dybiec (ed.), Złota ksiega Wydziału Historycznego (Kraków 2000), 461-463.

Wilk Piotr, 'Zdzisław Jachimecki,' in Jan Dybiec (ed.), Złota księga Wydziału Historycznego (Kraków 2000), 247-250.

Wilkowska-Chomińska Krystyna, 'Hieronim Feicht człowiek i uczony,' RM 11/11 (1967), 5-6.

Winowicz Krystyna, 'Profesor Adolf Chybiński w listach swoich uczniów i przyjaciół', Zeszyt Naukowy [PTM] (1974), 113-122.

Winowicz Krystyna, 'Adolf Chybiński. W 25. rocznicę śmierci', RM 22/6 (1978), 2-4, 17.

Winowicz Krystyna, 'Listy do Adolfa Chybińskiego jako źródło wiadomości o rozwoju polskiej kultury muzycznej w pierwszej połowie XX wieku,' Muzyka 24/3 (1979), 95-99.

Winowicz Krystyna, 'Adolf Chybiński. Z materiałów epistolarnych', Res Facta 9 (1982), 317-324.

Winowicz Krystyna, 'Poznańskie środowisko muzykologiczne w latach 1919-1939 w świetle listów do Adolfa Chybińskiego', Kronika Miasta Poznania 57/2 (1989), 32. 
Winowicz 1999

Winowicz 2004

Winowicz Krystyna, 'Adolf Eustachy Chybiński', in Maciej Jabłoński, Danuta Jasińska, Jan Stęszewski (eds.), Muzykologia na Uniwersytecie im. Adama Mickiewicza w Poznaniu w latach 1974-1999. Tradycje, działalność i dokumentacja (Poznań 1999), 81-88.

Winowicz Krystyna, 'Profesor Adolf Eustachy Chybiński,' PRM 3 (2004), 201-212.

Witkowska-Zaremba 2002 Witkowska-Zaremba Elżbieta, 'Historia wobec teorii. Na marginesie historii teorii muzyki', Muzyka 47/3-4 (2002), 105-114.

Witkowska-Zaremba 2006 Witkowska-Zaremba Elżbieta, 'Muzykologia w latach 1945-1990', in Urszula Jakubowska, Jerzy Myśliński (eds.), Humanistyka polska w latach 1945-1990 (Warszawa 2006), 262-281.

Witkowski 1965

Witkowski Leon, 'Kamieński Łucjan,' in PSB, vol. 11/4 (Kraków 1965), 540-541.

Woźna 1976

Woźna Małgorzata, 'Jan Kleczyński - pisarz, pedagog, kompozytor,' in Zofia Chechlińska (ed.), Szkice o kulturze muzycznej XIX wieku, vol. 3 (Warszawa 1976), 130-323.

Woźna-Stankiewicz 2012 Woźna-Stankiewicz Małgorzata, 'For Many or for the Chosen Few? Zdzisław Jachimecki's Project for Musicological Studies at the Jagiellonian University Before 1939,' Musicology Today 9 (2012), 7-37.

Woźniakowska 2004/1 Woźniakowska Anna, 'Romaniszyn Bronisław', in EM PWM, vol. 8 (Kraków 2004), 444-445.

Woźniakowska 2004/2 Woźniakowska Anna, 'Rutkowski Bronisław' in EM PWM, vol. 8 (Kraków 2004), 528.

Wrocławskie

Wrona 1997

Wrocławskie Towarzystwo Naukowe. Historia, http:// www.wtn.wroc.pl/historia/, access 08.06.2019.

Wrona Grażyna, 'Polskie czasopisma naukowe w latach 1918-1939. Stan badań, postulaty badawcze, zarys problematyki, in Józef Szacki, Krzysztof Woźniakowski (eds.), Literatura, prasa, biblioteka: Studia i szkice ofiarowane Profesorowi Jerzemu Jarowieckiemu w 65-lecie urodzin i 40-lecie pracy naukowej (Kraków 1997), 139-147.

Wrona 2003

Wrona Grażyna, 'Materiały źródłowe do dziejów polskich czasopism naukowych w latach 1918-1939 w archiwach i bibliotekach lwowskich,' in Jerzy 
Jarowiecki (ed.), Kraków - Lwów: książki, czasopisma, biblioteki XIX i XX wieku, vol. 6, part 2 (Kraków 2003), 176-181.

Wrona 2005

'Współcześni-

Chybiński’ 1910

'Współcześni-

Chybiński’ 1949

'Współcześni-

Chomiński’ 1949

'Współcześni-Feicht' 1949 'W

‘Współcześni-Lissa’ 1949

Wypych-Gawrońska 2006 5/9 (1949).

Wrona Grażyna, Polskie czasopisma naukowe w latach 1918-1939 (Kraków 2005).

'Współcześni muzycy polscy (Dr Chybiński), Przegląd Muzyczny 1/19 (1910), 8-10.

'Współcześni muzykolodzy polscy. Adolf Eustachy Chybiński,' RM 5/1 (1949).

'Współcześni muzykolodzy polscy. Józef Michał Chomiński', RM 5/7-8 (1949).

'Współcześni muzykolodzy polscy. X. Hieronim Feicht,' RM 5/5-6 (1949).

'Współcześni muzykolodzy polscy. Zofia Lissa', RM

Wypych-Gawrońska Anna, 'Stoiński Stefan Marian, in PSB, vol. 44 (Warszawa 2006), 5-7.

Zalewska-Wróbel Anna (1897-1985),' http://www.palestra.pl/index. php?go=artykul\&id=2626, access 25.11.2015.

Zduniak 2005

Zduniak Maria, 'Muzyka i historia muzyki na Uniwersytecie Wrocławskim w XIX i I połowie XX wieku,' in Maciej Gołąb (ed.), Muzykologia we Wrocławiu. Ludzie - Historia - Perspektywy (Wrocław 2005), 11-44.

Zdzisław Jachimecki 2011 Zdzisław Jachimecki (1882-1953) twórca muzykologii $w$ Uniwersytecie Jagiellońskim [catalogue of exposition in Jagellonian Library] (Kraków 2011).

Zetowski 1938 Zetowski Stanisław, 'Śp. Dr Bronisława WójcikKeuprulian,' Muzyka Polska 5/6 (1938), 253-258.

Zieliński 1981

Żaliński/Karolczak

Żarnowski 1964-65

Żłobicka
Zieliński Zygmunt, Bibliografia katolickich czasopism religijnych w Polsce 1918-1944 (Lublin 1981).

Żaliński Henryk W., Karolczak Kazimierz (eds.), Lwów: miasto - społeczeństwo - kultura, vol. 1 Studia z dziejów Lwowa (Kraków 1995).

Żarnowski Janusz, 'Jaroszewicz Władysław', in PSB, vol. 11 (Wrocław-Warszawa-Kraków 1964-65), 13.

Żłobicka Barbara, 'Loth August Karol', in PSB, vol. 17 (Wrocław-Warszawa-Kraków-Gdańsk 1972), 564-566. 


\section{Primary Literature}

Barbag 1928

Barbag 1935

Bierut 1945/46

Binental 1926

Chojnacki 1910

Chomiński 1948

Chybiński 1913

Chybiński 1928

Chybiński 1930

Chybiński 1934/1

Chybiński 1934/2

Chybiński 1935

Chybiński 1938

Chybiński 1949

Chybiński 1959/1

Chybiński 1959/2
Barbag Seweryn, Systematyka muzykologii. Lwów 1928.

Barbag Seweryn, 'Przykre sprawy muzykologii polskiej', Muzyka 1935/1/2, 18-19.

Bierut Bolesław, 'Przemówienie,' Rocznik PAU 1945/46, 50-51.

Binental Leopold, 'Z dziejów prasy muzycznej w Polsce,' Muzyka 1926/4, 143-149, 1926/5, 240.

Chojnacki Roman, 'Chybiński Adolf', PM 1910/19, 8-10.

Chomiński Józef Michał, 'Zagadnienia formalizmu $\mathrm{i}$ tendencje ideologiczne $\mathrm{w}$ polskiej muzyce współczesnej na tle rozwoju muzyki światowej, RM 1948/20, 2-6.

Chybiński Adolf, 'Uniwersytet a muzyka,' PM 1913/2, 1-5.

Chybiński Adolf, 'Muzykologia wśród nauk uniwersyteckich', Myśl Muzyczna 1928/2, 9-12.

Chybiński Adolf, 'O zadaniach historycznej muzykologii w Polsce,' Muzyka 1930/10, 587-595.

Chybiński Adolf, 'Do kwestii wpływologii muzycznej', MP 1934/4, 281-288.

Chybiński Adolf, 'W obronie muzykologii polskiej', Muzyka 1934/6-7, 270-271.

Chybiński Adolf, 'Dyskusja i polemika, MP 1935/1, 69-70.

Chybiński Adolf, 'Przedmowa,' in Jan Józef Dunicz, Adam Jarzębski i jego „Canzoni e Concerti” (1627) (= Lwowskie Rozprawy Muzykologiczne 1) (Lwów 1938)

Chybiński Adolf, 'Rejestracja i zabezpieczenie zabytków muzyki polskiej,' Kwartalnik Muzyczny 1949/25, 183-190.

Chybiński Adolf, $W$ czasach Straussa $i$ Tetmajera. Wspomnienia, Anna and Zygmunt Szweykowscy (eds.), Kraków 1959.

Chybiński Adolf, 'Wspominając Opieńskiego i „Spółkę młodych kompozytorów" - z czasów monachijskich,' RM 1959/8, 8-11. 
Chybiński/

Chomiński 2016

Deklaracja 1945

Dunicz 1937

Feicht 1937

Feicht 1949

Feicht 2008

Gliński 1929

Gliński 1930

Gliński 1931

Gliński 1934

Idzikowski 1934

Jachimecki 1923

Jachimecki 1931

Jachimecki 1934

Jachimecki 1935/1

Jachimecki 1935/2
Sieradz Małgorzata (ed., introduction and comments), Adolf Chybiński - Józef Michat Chomiński. Korespondencja 1945-1952 (Warszawa 2016).

'Deklaracja Zjazdu Kompozytorów Polskich w Krakowie (29 VIII-2 IX [1945 r.]), RM 1945/1, 11-12.

Dunicz Jan Józef, 'Wydawnictwo Dawnej Muzyki Polskiej. (Wywiad z prof. Dr Adolfem Chybińskim), MP 1937/1, 10-12.

Feicht Hieronim, 'Adolf Chybiński', MP 1937/1, 5-10.

Feicht Hieronim, 'Wznowienie koncertów poświęconych muzyce dawnej', KM 1949/25, 232-236.

Feicht Hieronim, Wspomnienia, Wojciech Kałamarz (ed.) (Kraków 2008).

Gliński Mateusz, 'Konsolidacja prasy muzycznej,' Muzyka 1929/2, 105-106.

Gliński Mateusz, [without title], Muzyka 1930/11-12, 683-684.

Gliński Mateusz, 'Impresje muzyczne', Muzyka 1931/1, 29-30.

Gliński Mateusz, “"Zmierzch nauki” w dziedzinie muzycznej', Muzyka 1934/5, 217-218.

Idzikowski Mieczysław, 'Jak powstała i jak się zrealizowała inicjatywa Instytutu Fryderyka Chopina,' Muzyka 1934/6-7, 264.

Jachimecki Zdzisław, 'Muzykologia w Polsce,' Polska Wspótczesna 1923/3-4, 125-131.

Jachimecki Zdzisław, 'Polska muzykologia i polscy muzykologowie,' Muzyka 1931/1, 24-27.

Jachimecki Zdzisław, 'Losy muzykologii na terenie stolicy', Muzyka 1934/3, 113-114.

Jachimecki Zdzisław, Jeszcze trochę o "Wpływologji muzycznej" w oświetleniu prof. dr Adolfa Chybińskiego, o "Symfonji średniowiecznej" Mikołaja $z$ Radomia $i$ Polskiem Radjo, o różnicy między nauka i "nauka" prof. Chybińskiego i kilka smutnych refleksji w zwiazku $z$ temi sprawami (Kraków 1935).

Jachimecki Zdzisław, Pod jakim katem patrzy profesor dr. Adolf Chybiński na kwestię wplywologii muzycznej (Kraków 1935). 
Jachimecki 1939

Jachimecki 1946

Jachimecki 1947

Jachimecki 1948

Jachimecki 1949/1

Jachimecki 1949/2

Jachimecki 1951

Jachimecki 2005

Jarociński 1948

Kamieński 1934

Kisielewski 1945

Kisielewski 1948

Kisielewski 1952

Kleczyński 1892
Jachimecki Zdzisław, 'Henryk Opieński', Biuletyn Stowarzyszeń Młodych Muzyków 1939/3.

JachimeckiZdzisław, 'Henryk Opieński. Wspomnienia pośmiertne,' RM 1946/19.

Jachimecki Zdzisław, 'Znaczenie muzyki i muzykologii w społeczeństwie,' RM 1947/21, 2-6, 1947/22, 2-5.

Jachimecki Zdzisław, Muzykologia i piśmiennictwo muzyczne w Polsce (= Historia Nauki Polskiej w Monografiach 23) (Kraków 1948).

JachimeckiZdzisław, 'Problemorganizacjimuzykologii (Odczyt wygłoszony na Zjeździe Kompozytorów i Muzykologów Polskich), RM 1949/1, 6-10, 1949/2, 2-4.

Jachimecki Zdzisław, 'Problem organizacji studiów muzykologicznych,' KM 1949/25, 197-207.

Jachimecki Zdzisław, 'W sprawie zagadnień kadr naukowych i organizacji studiów muzykologicznych w Polsce,' Muzyka [monthly] 1951/10, 49-50.

Jachimecki Zdzisław, 'Autobiografia wojenna (19391945), in Jerzy Michalewicz, Relacje pracowników Uniwersytetu Jagiellońskiego o ich losach osobistych $i$ dziejach uczelni $w$ czasie drugiej wojny światowej (Kraków 2005), 761-762.

Jarociński Stefan, 'Na drogach współczesnej nauki polskiej', Kuźnica 1948/34-35, 25-26.

Kamieński Łucjan, 'Budujemy naukę o pieśni ludowej, Muzyka 1934/5, 203-206.

Kisielewski Stefan, 'Pierwsze Boże Narodzenie,' RM 1945/6, 3.

Kisielewski Stefan, 'Czy w muzyce istnieje formalizm, RM 1948/22, 2-6.

Kisielewski Stefan, 'O Polskim Wydawnictwie Muzycznym,' Tygodnik Powszechny 1952/46, 9.

Kleczyński Jan, 'Maurycy Karasowski', EMTA 1892/448, 207-208.

'Klika czy nie klika?' 1937 'Klika czy nie klika? W odpowiedzi na “w odpowiedzi”, Muzyka 1937/3, 85.

'Konferencja kompozytorów’ 1949
'Konferencja kompozytorów w Lagowie Lubuskim,' RM 1949/14, 12-31. 
‘Konsolidacja’ 1929

'Konsolidacja prasy muzycznej', Muzyka 1929/2, 105-106.

Księga pamiątkowa 1950 Księga pamiątkowa ku czci Prof. Adolfa Chybińskiego w 70-lecie urodzin. Rozprawy i artykuty $z$ zakresu muzykologii (Kraków 1950).

Księga pamiątkowa 1930 Ksiega pamiątkowa ku czci Profesora dr. Adolfa Chybińskiego ofiarowana przez uczniów i przyjaciót (Kraków 1930).

Leszczyński 1910 Leszczyński Jarosław, 'Z polskiej literatury historyczno-muzycznej,' PM 1910/20, 21-23.

Lissa 1934

Lissa Zofia, Dylematy krytyki muzycznej w Polsce, MP 1934/2, 132-137.

Lissa 1948

Lissa Zofia, 'Aspekt socjologiczny w polskiej muzyce współczesnej', KM 1948/21-22, 104-143.

Lissa 1949/1

Lissa Zofia, 'Czy muzyka jest sztuką asemantyczną?, KM 1949/25, 120-137.

Lissa 1949/2

Lissa Zofia, 'Organizacja twórczości muzykologicznej', KM 1949/25, 212-221.

Lissa 1950

Lissa Zofia, 'Uwagi o metodzie marksistowskiej w muzykologii,' in Ksiega pamiątkowa 1950, 50-119.

Lissa 1951

Lissa Zofia, 'Zagadnienie kadr naukowych i organizacji studiów muzykologicznych w Polsce, Muzyka [monthly] 1951/8, 11-14.

Lissa 1954

Lissa Zofia, 'Z perspektywy dziesięciolecia (referat wygłoszony na Walnym Zjeździe ZKP), Muzyka [monthly] 1954/7-8, 3-26.

List ze Lwowa 1913

'Listi Adolfa

Hybiňskogo’ 2003

'List ze Lwowa (Kilka uwag o stosunkach muzycznych),' PM 1913/18, 11-14.

'Listi Adolfa Hybiňskogo do Myroslava Antonovyča,' Jurij Jasinowśkij (ed.) Musica Humana 1 (2003), 67-110.

Łobaczewska 1927

Łobaczewska Stefania, 'Muzykologia polska', in Mateusz Gliński (ed.), Muzyka polska. Monografia zbiorcza (Warszawa 1927), 143-151.

Łobaczewska $1930 \quad$ Łobaczewska Stefania, 'Seweryn Barbag: Systematyka muzykologii', LWML 1930/7-8, 5.

Łobaczewska 1931 Łobaczewska Stefania, 'Seweryn Barbag: Systematyka muzykologii', Muzyka 1931/2, 102. 
Łobaczewska 1933

Łobaczewska 1934

Łobaczewska 1947

Łobaczewska 1948/1

Łobaczewska 1948/2

Łobaczewska 1948/3

Łobaczewska 1949/1

Łobaczewska 1949/2

Łobaczewska 1950/1

Lobaczewska 1950/2

'Memoriał Pierwszego

Zjazdu’ 1949

'Memoriał w sprawie' 1946

Mycielski 1948

Mycielski 1949/1

Mycielski 1949/2

Mydlarski 1946

'Na froncie' 1932
Łobaczewska Stefania, 'Żywe czy umarłe piękno, Słowo Polskie 1933/105, 6.

Łobaczewska Stefania, 'Czy muzyka dzisiejsza ma funkcję społeczną?,' MP 1934/2, 184-190.

Łobaczewska Stefania, 'Ze zjazdu kompozytorów i krytyków muzycznych w Pradze,' RM 1947/13-14, 13-16.

Łobaczewska Stefania, 'I Zjazd Muzykologów Polskich,' RM 1948/12, 6-8.

Łobaczewska Stefania, 'II Zjazd Kompozytorów i Krytyków Muzycznych w Pradze,' RM 1948/22, 19-26. Łobaczewska Stefania, 'Uwagi o muzykologii', RM 1948/2, 7.

Łobaczewska Stefania, 'Muzykologia a krytyka muzyczna,' KM 1949/25, 221-230.

Łobaczewska Stefania, 'Problem wartościowania i wartości w muzyce,' KM 1949/25, 55-119.

Łobaczewska Stefania, 'Po Pierwszej Ogólnopolskiej Konferencji Naukowej w Sprawie Badań nad Sztuką, Muzyka 1950/9, 10-16.

Łobaczewska Stefania, 'Przed Kongresem Nauki Polskiej. Kilka uwag o współczesnej muzykologii polskiej,' Muzyka 1950/6, 6-17.

'Memoriał Pierwszego Zjazdu Muzykologów Polskich obradującego w Warszawie w dniach 18 i 19 listopada 1948 r.', KM 1949/25, 237-238.

'Memoriał w sprawie potrzeb muzyki polskiej,' RM 1946/11-12, 2-6.

Mycielski Zygmunt, 'Prostota czy prostactwo? O Kwartalniku Muzycznym,' Odrodzenie 1948/30, 7.

Mycielski Zygmunt, 'O zadaniach Związku Kompozytorów Polskich,' RM 1949/14, 6-10.

Mycielski Zygmunt, 'Przemówienie na Walnym Zjeździe Kompozytorów Polskich, RM 1949/1, 2-6.

Mydlarski Jan, 'W sprawie organizacji nauki polskiej', Życie Nauki 1946/7-8, 42-47.

'Na froncie muzykologicznym bez zmian', Muzyka 1932/3-4, 111. 
Ochlewski 1946

Ochlewski 1951

Poźniak 1948

‘Prace komisji' 1945

Pulikowski 1934

Régamey 1948

Reiss 1913

Rudziński 1949

Sokorski 1949

Sokorski 1952

Sprawozdanie

Komitetu WTM

Sprawozdanie $z$ działalności

'Sprawozdanie z obrad V Walnego

Zgromadzenia' 1950

'Sprawozdanie z obrad VI Walnego

Zgromadzenia' 1951

Starczewski 1937
Ochlewski Tadeusz, 'Rok pracy Polskiego Wydawnictwa Muzycznego (sprawozdanie), RM 1946/11-12, 19-24.

Ochlewski Tadeusz, 'Polskie Wydawnictwo Muzyczne. Zagadnienia - plany - realizacja,' Muzyka 1951/1, 104-105.

Poźniak Włodzimierz, 'Uwagi o muzykologii,' RM 1948/7, 10-11.

'Prace komisji programowych przy Ministerstwie Kultury i Sztuki,' RM 1945/6, 22-23.

Pulikowski Julian, 'Muzykologia - l'art pour l'art?', MP 1934/3, 201-209.

Régamey Konstanty, 'Uwagi o muzykologii', RM 1948/1, 2.

Reiss Józef, 'Polska historiografia muzyczna,' PM 1913/1, 7-9.

Rudziński Witold [report from the composers' congress in Łagów Lubuski], Odrodzenie 1949/35, 2.

Sokorski Włodzimierz, 'Formalizm i realizm w muzyce (Przemówienie wygłoszone na Walnym Zjeździe Kompozytorów Polskich w dniu 20 listopada 1947 r.),' KM 1949/25, 172-178 (also RM 1948/23-24, 2-5).

Sokorski Włodzimierz, 'Od Łagowa do Festiwalu Muzyki Polskiej', Muzyka 1952/1-2, 3-11.

Sprawozdanie Komitetu Warszawskiego Towarzystwa Muzycznego za rok 1906 [do 1915] (Warszawa 190716) (WTM archive).

Sprawozdanie $z$ działalności Instytutu 1949-1950 (IS PAN archive).

'Sprawozdanie z obrad V Walnego Zgromadzenia Związku Kompozytorów Polskich, które odbyło się w Warszawie w dniach 16-19 czerwca 1950 roku, Muzyka 1950/5, 46-59.

'Sprawozdanie z obrad VI Walnego Zgromadzenia Związku Kompozytorów Polskich 11-13 grudnia 1951', RM 1952/1-2, 45-56.

Starczewski Feliks, 'Warszawskie Towarzystwo Muzyczne', Muzyka 1937/1, 62-65. 
Statut PTMW 1927

Statut PTM

Statut Stowarzyszenia

Pisarzy 1929

Stromenger 1930/1

Stromenger 1930/2

Szopski 1931

Szymanowski I-IV
Statut Polskiego Towarzystwa Muzyki Współczesnej (Warszawa 1927).

Statut Polskiego Towarzystwa Muzykologicznego (in AACh-BUAM).

Stowarzyszenie Pisarzy i Krytyków Muzycznych (Warszawa 1929).

Stromenger Karol, 'Fundusz Kultury Narodowej a Muzyka,' GP, 1 Nov. 1930, 5.

Stromenger Karol, 'Mumifikacja muzyki,' Wiadomości Literackie 1930/51-52, 8.

Szopski Felicjan, 'Henryk Opieński. Na marginesie obchodu jubileuszowego,' Muzyka 1931/1, 19.

Teresa Chylińska (ed.), Karol Szymanowski. Korespondencja. Petna edycja zachowanych listów od $i$ do kompozytora, vol. 1 (1903-1919) (Kraków 1982), vol. 2 (1920-1926) (Kraków 1984), vol. 3 (1927-1931) (Kraków 1997), vol. 4 (1932-1937) (Kraków 2002).

Wójcik-Keuprulian 1931 Wójcik-Keuprulian Bronisława, 'Barbag Seweryn ...: Systematyka muzykologii - Lwów 1928,' KM 1931/1011, 323-326.

Wójcik-Keuprulian 1934 Wójcik-Keuprulian Bronisława, 'Stanowisko muzykologii w systemie nauk', Rozprawy i Notatki Muzykologiczne 1 (1934), 1-14.

Wójcik-Keuprulian 2018 Sieradz Małgorzata (ed., introduction and comments), Bronisława Wójcik-Keuprulian korespondencja do Szwajcarii. Listy do Henryka Opieńskiego (1925-37) i Ludwika Bronarskiego (192938) (Warszawa 2018).

Wójcikówna 1918

Wójcikówna Bronisława, 'Muzyka jako przedmiot studiów uniwersyteckich,' GM 1918/3, 21-22.

X.Y. 1913

X.Y., 'Listy ze Lwowa. Kilka uwag o stosunkach muzycznych,' PM 1913/18, 11-14.

'Z działalności 'Z działalności Polskiego Wydawnictwa Muzycznego. PWM' 1950

Zalewski 1937
Plan wydawniczy PWM na rok bieżący,' Muzyka [monthly] 1950/1, 65-66.

Zalewski Teodor, 'W odpowiedzi', MP 1937/3, 97-99. 
Zalewski 1977

Załącznik do

Planu pracy 1950

Znaniecki 1925

'V Zjazd ZKP' 1950
Zalewski Teodor, Pót wieku wśród muzyków 1920 1970. Przyczynki do dziejów polskiej kultury muzycznej (Kraków 1977).

Załącznik do Planu pracy Działu naukowohistorycznego Sekcji Muzyki Państwowego Instytutu Sztuki na miesiac luty 1950 r. (in IS PAN archive)

Znaniecki Florian, 'Przedmiot i zadania nauki o wiedzy', Nauka Polska 5 (1925), 1-78.

'V Zjazd Związku Kompozytorów Polskich', Muzyka 1950/3-4, 14-37.

\section{Archival collections}

Adolf Chybiński’s Archive, Department of Music Collections, Jagiellonian Library (AACh-BJ)

Adolf Chybiński’s Archive, Special Collections Department, University Library in Poznań (AACh-BUAM)

Private Chomińskis' Archive (APCh)

Józef Michał Chomiński’s Archive, Archives of Polish Composers of the 20th Century, University Library in Warsaw (AJCh-BUW)

Zofia Lissa's Archive, Archives of Polish Composers of the 20th Century, University Library in Warsaw (AZL-BUW)

Ludwik Bronarski's Archive in AACh-BUAM (AACh-BUAM, archiwum Bronarskiego)

Tadeusz Ochlewski's Archive in AACh-BUAM (AACh-BUAM, archiwum Ochlewskiego)

Archive of Institute of Arts of Polish Academy of Science 


\section{Index}

A

Adler Guido 33, 34, 66, 114, 119, 146, 172, 179, 190, 204, 211, 241, 249, 264, 274, 290, 308, 399, 401, 446,456

Adorno Theodor W. 154

Allinówna Stefania 362

Altberg (Altberżanka) Emma 84, 156, 375, 499, 503

Ambros August Wilhelm 241, 318, 456

Anders Henryk 507

Andrysowicz Łazarz 448

Andrzejewska Maria 501, 505

Annunzio Gabriel d' 119

Antonowycz Myrosław 169, 203, 421

Arteaga Stefano 255

Aristotle 21

Asafyev Borys 414, 474

Askenazy Szymon 166

Auber Daniel 306

Augustine, Saint 213

B

Bacewicz Grażyna 504

Bach Johann Sebastian 24, 28, 29, $59,128,129,154,185,186,203$, 208, 212, 253, 258, 300, 301, 321, $329,376,405,417,439,460,480$, 481, 498, 499, 503, 513, 514

Bagarówna Wilhelmina 208, 271

Bahle Julius 279

Baird Tadeusz 391

Bakfark Bálint (Valentinus Greff Bakfark) 36, 114, 140, 144, 281, 284

Bakst Ryszard 362
Balzer Oswald 166

Banach Stefan 166

Barbag Seweryn 66, 70, 72, 109, 113, 116, 171, 172-175, 177, 178, $210,226,233,239,248,251,253$, 254, 259, 262 -266, 289-291, 316, $351,352,420$

Barblan-Opieńska Lydia 136

Barcewicz Stanisław 109, 118, 230

Bartók Bela 295, 480, 499

Bartók Jan 479

Barvik Miroslav 498

Barwicki Mieczysław 374

Barwinśki Wasyl 108, 204, 210

Baudouin de Courtenay Ehrenkreutz Jędrzejewiczowa Cezaria 147, 233, 369

Baudouin de Courtenay Jan 118

Beck Józef 78

Beethoven Ludwig van $68,119,173$, $176,183,185,199,200,212,253$, 284, 299, 329, 357, 405, 460, 498, 499, 511, 513, 514

Bellini Vincenzo 200, 212, 339

Bełza Igor 503, 505, 515

Bereza Stefan 54

Berg Alban 202

Berlioz Hector 20, 33

Berman Jakub 358, 387, 396, 404

Bielawski Józef 306

Bielawski Ludwik 346, 357, 494

Bilińska-Riegerowa (Biliżanka)

Maria 208, 366

Binchois Gilles 208

Binental (Binenthal) Leopold 50, $78,79,81,83,84,119,153,260$, $311,339,462$

Bloch Ernest 295 
Blochman Ignace $10,424,467,473$ Błachowski Stefan 355, 435

Błażejowski Tadeusz 501

Bogdany Wanda 22, 243, 328

Bohn Emil 252

Bołoz-Antoniewicz Jan 166, 178

Borejsza Jerzy 387

Borimius (Borzymski) Johannes 28

Borowski Hedwig 319

Borowy Stanisław 415

Borrel Eugène Marie Valentin 269

Bory Robert 320

Boulanger Nadia 94, 96, 294, 415

Bourguès Lucien 472

Boy-Żeleński Tadeusz 118

Boziewicz Władysław 54

Brahms Johannes 29, 173, 203

Branberger Jan 117

Bristiger Michał 172, 173, 361, 378, 386, 500

Brodziński Kazimierz 15, 16

Bronarski Ludwik 10, 11, 66, 67, 71-73, 75, 80-84, 93, 97-99, 116, 155-157, 160-163, 168, 169, 189, 191, 192, 196, 199, 202, 204, 206, 208, 209, 217, 221, 269-273, 279, 289, 293-295, 289, 308-322, 325, $327,328,335,337-340,342-346$, 353-357, 370, 397, 410, 419, 421, $422,424,428,430,431,435,439$, 441, 444, 446, 449-452, 462-464, $466,478,479,487,490,492,495$, 505, 506, 512-515

Broszkiewicz Jerzy 378, 379, 416, 502

Brożek-Broscius Jan 143, 219

Bruchnalski Wilhelm 178, 179

Bruckner Anton 29, 176

Brumer Wiktor 107, 306

Brunold Paul 84, 85, 156, 160, 272, 291, 312

Brzeziński Franciszek 207
Brzostowski Wieńczysław 292

Brzowski Józef 214

Bücken Ernst 180, 241, 514

Bukowiński Władysław 139

Bukowski Ryszard 362

Bush Alan 476

Busiakiewicz Bolesław 118

Busoni Feruccio 115, 154

Buxtehude Dietrich 481

Bystroń Jan Stanisław 369

C

Capellen Georg 280

Cecilia, Saint 170

Chałasiński Józef 389

Chausson Ernest 207

Chechlińska Zofia 19, 247, 310, 464

Cherfils Christian 108

Chętnik Adam 369

Chmielikowska Maria 70

Chodkowski Andrzej 361, 395, 496

Chojnacki Roman 15, 25-27, 31, $32,34,103,138,143,248,251$, 470, 517

Chomicz Paulina 108

Chomiński Józef Michał 10, 11, 77, 84, 116, 169, 193, 204-207, $234,271,276,277,282,310,330$, $333,340,341,343-346,351$, $352,355-357,360,361,365$, $368-373,378,381-383,385,393$, 397-401, 403, 409, 413-417, 419, 420-424, 426-443, 446, 448, 452, 458-460, 463, 464, 467-473, 476, 477, 479-483, 488,489, 491-496, 500-508, 511, 513-516, 519

Chopin Fryderyk 17, 24, 28, 30, 34-36, 41, 48-50, 61, 71, 77-84, $88,93,97,108,109,112-115$, $117-119,127,135,142,156,157$, $170,172,173,176,188-191$, 193, 195, 198, 200, 202, 206, 208, 
212-214, 244, 254, 258, 266, 270, 272, 275, 276, 284, 286, 287, 289, 291, 292, 294, 295, 304, 305, $307-315,319,338-340,344,345$, $355-357,365,366,368,376,378$, 379, 381, 382, 386, 393, 394, 409, 410, 414, 421, 423-425, 429, 433, 437-440, 443, 446, 449-452, 459, 460, 462-464, 466-473, 476-480, 482, 483, 488, 492, 494, 497, 500, 502, 503, 508-516, 519

Chopin Mikołaj 467

Chrzanowski Witold 172, 275

Chubow Georgij 499

Chwistek Leon 166

Chybiński Adolf 9-11, 21, 26-31, $33,34,36-46,49-68,70-77$, 80-84, 86, 88, 91-95, 97-101, $103,104,106,107,112-116,118$, 120, 123-134-142, 144-147, 151-157, 159-166, 168-172, 175, 177-188, 190-212, 214,, 215, $217,218,220-224,226-237,239$, 243, 245-252, 255-260, 262-264, 269-284, 286, 288, 289, 291-295, 298-302, 304, 305, 307-333, 335-346, 350-358, 362, 363, $364,367-374,376,377,379,380$, $382,383,385,392,394,396-399$, 409-411, 415-452, 455, 459-473, 477-481, 483, 487-496, 498, 499, 501-507, 509, 512, 513-519

Chylińska Teresa 292, 293

Cichocki Józef 17, 18, 142, 245, 254, 262, 287, 517

Cichowski Adolf 466

Ciconia Johannes 277

Coeuroy André 116

Cohn Arthur Wolfgang 264

Corelli Arcangelo 460

Czartoryski family 245

Czartoryski Adam 242
Czekanowska Anna 357, 361

Czekanowski Jan 166, 369, 480

Czerniawski Tadeusz 51

Czerwiński Adam 176

Czerwiński R. 177

Czyżykowska Bożena 223, 226, 227

D

Dadak-Kozicka J. Katarzyna 346, 385, 387, 395-397, 402, 404

Dahlhaus Carl 246

Dahlig Piotr 188, 231-233, 304

Damse Józef 211, 214, 230

Dankowski Wojciech (Adalbertus) 285

Dauriac Lionel 287

Dawidowicz Eugeniusz 53, 174

Dąbrowski Florian 379

Dąbrowski Jan Henryk 224, 225, 465

Dąbrowski Mirosław 505

Dąbrowski Stanisław 16

Debussy Achille-Claude 27, 28, 30, 174, 182, 207, 271, 279, 315

Deffner Oskar 321

Degen Dorota 367, 390, 412

Delacroix Eugène 424, 467, 471

Delacroix Henri 279

Denéréaz Alexandre 472

Dent Edward 399

Deroux Jean 280

Dłużniewski Jan 236

Dobrzycki Henryk 35

Dobrzyński Ignacy Feliks 214

Domaniewski Zbigniew 54

Donizetti Gaetano 212

Dorabialska Helena 71, 72, 211, 230, 234-237, 352

Doroszewski Witold 233

Drăgoi Sabin Vasil 319

Draus Jan 166, 167

Drexler-Pasławska Zofia 66 
Drobner Mieczysław 10, 211, 215 , 282, 349, 373, 375, 389, 397, 409, 476, 505

Drozdowski Jan 179

Drożdżewska Agnieszka 252, 262

Drzewiecki Zbigniew 51, 63, 64, $66,327,334,349,377,476,510$, 512,515

Dukas Paul 96, 115, 199, 294

Duliński Edmund 354

Dunicz Jan Józef 76, 77, 116, 169, 185, 206, 207, 247, 271, 276, 330, $331,341,352,382,420,421$, 429,441

Dunicz-Niwińska Helena 352, 420

Duparc Henri 207

Dvořák Antonín 117

Dybiec Julian 371

Dybowski Stefan 372, 402

Dymmek Zbigniew 327, 328

Dziadek Magdalena 27, 106, 181, 182, 190, 234-236, 247, 301,374

Dzieduszycki Wojciech 500

Dziewulska Maria 349

Dziewulski Zdzisław 88

Dziębowska Elżbieta 195, 210, 361, 496, 498, 505, 511, 512, 519

E

Eblisiewicz Ryszard 177

Egert Paul 364

Eisler Hans 107, 432, 476

Eitner Robert 273

Ekier Jan 395, 409, 499, 515

Elgar Edward 115

Elsner Emilia 352

Elsner Józef 15, 16, 19, 22, 23, 214, $220,246,285,286,306,339,352$, 416,505

Erpf Hermann 280

Estreicher Stanisław 36
Estreicher Zygmunt 10, 370, 397, 430, 447, 464, 465, 477, 481

Euclid of Alexandria 220

F

Fabry Władysław 50, 51, 53, 54, 119, 175

Fabrycy Jan of Żywiec 140, 281

Falla Manuel de 115, 295

Feicht Hieronim 10, 71, 72, 91, 94, $95,104,112,116,134,138,141$, $145,153,156,163,172,185,187$, 191, 195-198, 200, 207, 209, 220, 221, 238, 270, 271, 273-275, 277, $330,335,341,345,350-352,355$, $359,361-365,371,373,376,397$, $398,426,428,442,446,450,467$, 479, 490-492, 494, 501, 503, 505, 512,514

Ferek Roman 257

Ferkówna Stanisława 257

Festenburg Stefania see Łobaczewska Stefania

Fétis François-Joseph 20, 241

Fibich Zdeněk 117

Fiedler Franciszek 388

Findeisen Nikolai 33

Fischer Johann (Jan) 41, 184, 186,188

Fischer Wilhelm 232

Fitelberg Grzegorz 25, 29, 44, 62, $63,109,118,182,281,298$

Fleischer Oskar 140, 238, 286

Fojcik Jan 104, 374

Fontana Julian 309

Forkel Johann Nikolaus 19, 241

Franck César 173, 207, 289

Frankowski Eugeniusz 233

Frączkiewicz Aleksander 211, 366, 370, 397, 479, 480

Freiheiter Jerzy (Izydor) 109, 116, 175, 195, 201, 202, 206, 207, 
210, 271, 277, 278, 316, 321, 327, 331,352

Freyer August 35

Friderici-Jakowicka Teodozja 505

Friedländer Max 238, 287

Friemann Witold 127, 209

Furmanik Stanisław 53, 156, 272, 306-308

G

Gabrieli Andrea 321

Gaffurius Franchinus 180

Gaillard Emil 339, 345, 446

Gajkowska Cecylia 43

Ganche Édouard 80, 114, 119, 338, 339

Gaszyński Jerzy 54, 55

Gathy August 309, 311

Gebethner Gustaw Adolf 116, 263

Geiringer Karl 154

Georgiades Thrasybulos 180

German Franciszek 471, 515

Gevaert François-Auguste 318

Gieburowski Wacław 33, 70, 72, $77,145,153,172,221-223$, 227,352

Glareanus Henricus 285

Glier Reinhold 503

Glinka Michail 500, 504

Gliński Mateusz 10, 32, 49-58, 60-66, 74, 75, 85, 89, 90, 97, 99, $103,109,110,112-116,118-130$, $139,145,151,153,159,162,173$, $178,188,192,194,213,215,220$, 230, 235, 238, 239, 259-262, 267, $293,301,323,335,336,419,470$, 496, 497

Głodziński Tadeusz 208, 271

Głowacki Jan 50

Gniesin sisters 85

Goebbels Joseph 333

Goethe Johann Wolfgang 447
Golachowski Stanisław 10, 83, 211, $282,283,360,369,370,373,375$, $389,393,397,440,447,492,510$

Gołąb Maciej 174, 175, 183, 247, 252, $352,361,362,420,441,483,519$

Gołębiowski Władysław 53, 104

Gombert Nicolas 180

Gombosi Otto 114

Gomidas (also Komidas Vardapet) 276

Gomółka Mikołaj 18, 31, 47, 132, $179,212,213,217,272$

Gomółka Władysław 387

Gorczycki Grzegorz Gerwazy 94, 95, 104, 107, 197, 245, 274, 275 , 328, 489

Grabner Hermann 280

Grabowski Ambroży 241

Gradstein Alfred 498

Graf Otto 332, 333

Grafczyńska Melania 70, 72, 116, 200, 215

Granados Enrique 295

Gress Richard 321

Grieg Edvard 24, 29, 109, 185, 186, 196, 202, 203, 205, 207, 226, 277 , 319,357

Groblicz Marcin 38

Gromski Piotr 177

Grosicki Jerzy 410

Grosman Ludwik 24

Grzegorzewska-Lachowska Janina 66

Gużewski Adolf 42, 43

Guido of Arezzo 114, 180

$\mathbf{H}$

Haas Robert 298

Haendel (Händel) Georg

Friedrich 29, 185, 186, 197, 203, 212, 329, 513, 514

Haller Romuald 25 
Halpern Feliks R. 118

Handschin Jacques Samuel 264

Hanslick Eduard 170, 456

Harajda Helena 228, 354

Haraschin Stanisław 366

Härtel Gottfried Christoph 285, 339

Hasse Johann Adolf 224

Haubenstock Roman 378, 379, 416

Hausegger Friedrich 31

Hausman Wiktor 109

Haydn Joseph 23, 504

Hegel Georg Wilhelm Friedrich 19

Heinitz Wilhelm 232

Heising Roman 136

Helfert Vladimir 117

Helman Zofia 241, 292

Herman Juliusz 39

Herzenstein, see Gliński Mateusz

Hildegard of Bingen Saint 308

Hindemith Paul 67, 112, 296

Hirschfeld Robert 170

Hoene-Wroński Józef 107, 108, 116, 143, 452

Hoesick Ferdynand 79, 118, 244, $262,275,313,462,471,513$

Hoffman Jan 377, 515

Hoffman Paweł 388

Hofmannstahl Hugo von 119

Honegger Arthur 67

Hordyński Władysław 369, 370,

397, 399, 466, 467

Hornbostel Erich von 114

Hornung Anna 207

Horzyca Wilam 292

Hrab Uljana 166, 178, 180-184, 186, 202, 203, 253

Hübner Piotr 367, 390, 412

Hugo-Bader Kazimierz 82

Hulewicz Witold 119

Hummel Johann Nepomuk 460, 479

Humperdinck Engelbert 286

Huneker James 135, 275
Hüssowa Irena 352

Hutter Josef 239, 312

I

Idaszak Danuta 198, 357

Idzikowski Mieczysław 78, 79, 83,471

Ileborgh Adam 460

Indy Vincent d' 115, 284, 286

Ingarden Roman 10, 193, 370, 472, 481

Irydion, Amfiloch's son 288

Irzykowski Karol 452

Iwaszkiewicz Jarosław 79, 115, 119, $373,388,499,500$

J

Jachimecki Zdzisław 9, 10, 18, 26, $27,30-34,36,40,41,45-47,49$, $58,60,61,68,70,72-75,81,82$, $101,103,112-114,116,118,119$, $125,126,128,132,138,142,153$, $162,165,175,176,179,180,182$, 201, 211, 212, 214, 215, 217-221, $230,231,234,239,243,247,250$, 251, 252, 254-260, 262, 269, 270, 273-275, 282, 332, 342, 346, 349, $351,352,356,363,365,366$, 368-372, 389, 393, 394, 397-399, $401,414,420,422,426,435,447$, 460, 464-466, 473, 476, 479, 493, 494, 503, 512, 517

Jackowski Aleksander 412, 413, 415, 438, 439, 481, 500, 501, 502, 505 Jahnke Zdzisław 94 Jan of Lublin 28, 38, 40, 42, 46, 509 Jaraczewska-Mockałło Krystyna 93 Jarociński Stefan 17, 18, 20, 123, $352,379,388,389,397,414,416$, 439, 469, 487, 501, 502, 507, 510 Jaroszewicz Władysław Romuald 79 
Jaroszewiczowa Zofia 79

Jarzębski Adam 30, 94, 95, 206, 207, 341

Jasieński Jerzy 499, 501, 505

Jasinowski Jurij 203

Jasińska Danuta 222

Jastrzębowski Wojciech 96

Jaworski Michał 101

Jeske August 22

Jędrzejczak Wojciech 36

Jędrzejewicz Janusz 78, 167, 230,

233, 237

Jędrzejewicz Wacław 230

Jirák Karel Boleslav 117

Joachim Joseph 88

Johnen Kurt 300

Josquin des Prés 169

Jurzykowski Alfred 94

K

Kaden-Bandrowski Juliusz 54, 79

Kalisz Władysław 211

Kalkbrenner Friedrich 479

Kamieński Łucjan 33, 49, 51, 56-58, $62,63,67-75,103,115,119,135$, $136,152-154,162,180,200$, 221-224, 226-229, 231, 233, 234, $239,255,262,264,269,299,300$, $336,341,342,346,352,353,399$, 419, 465

Kamieński Maciej 77

Kamiński Stefan 336, 414

Kandulski Witold 226, 359

Kania Emanuel 24, 35

Kański Józef 507, 515

Karasowski Maurycy 18, 20, 22, 23, 242, 244, 254, 313, 517

Karczewski Wacław 54, 55

Karłowicz Jan 35

Karłowicz Mieczysław 29, 30, 35, $36,38,41-44,118,124,126,128$,
130, 208, 215, 259, 281, 286, 307, $327,328,331,333,339,343,357$, $410,421,448$

Kasparek Helena 207

Kasparek Sabina 88, 185

Kassern Tadeusz 228, 395

Kaszczewski Sebastian Antoni 132

Kawczyńska Alina 498

Kazuro Stanisław 95, 103, 512

Kątski Apolinary 20

Kenig Józef 18, 313, 517

Keuprulian Bronisława see WójcikKeuprulian Bronisława

Kęcki Feliks 327

Kętrzyński Stanisław 40, 42

Khrennikov Tikhon 477

Kielanowska-Bronowicz Maria 44, 299, 321, 423

Kiepura Jan 122

Kiesewetter 19

Kieycher Bartłomiej 41

Kijeńska-Dobkiewiczowa Helena 93

Killer Hermann 303

Kinkeldey Otto 221, 252

Kisielewska Lidia 429

Kisielewski Stefan 10, 101, 292, 327, $331,334,349,376-378,383,388$, $389,429,478$

Kiszwalter Jan 505

Kleczkowski Adam 370

Kleczyński Jan 23, 24, 34, 35, 245, 517

Klemetti Heikki 269

Knepler Georg 498

Kobylańska Krystyna 376, 505, 515

Kochański Wacław 88

Kodály Zoltán 499

Koffler Józef 66, 71, 72, 95, 109, 116, 171, 174-178, 193, 202, 210, 230, $278,279,294,299,316,352$ 
Kolberg Oskar 20, 21, 226, 258, 304, 318

Kolischer Anna 208

Kołessa Filaret 319

Kołodij Jarosława 207

Kondracki Michał 65, 85, 174, 176, 294-297, 304, 319, 327, 332, 334, 335,419

Konopnicka Maria 24

Koszewski Andrzej 507, 51

Koszewski M. 70

Kotoński Włodzimierz 499, 501

Kowalczyk Henryka 93

Kowalski Władysław 372

Kozaruk Jakiw 203, 208

Kozłowska Zofia 66

Kozłowski Józef 283

Koźmian Stanisław 46

Krasiński Józef 143, 341, 470

Krasiński Zygmunt 288, 289

Krassowska-Jodłowska

Eugenia 356, 359

Kratzer Kazimierz 341

Kremlew Julij 438, 474

Křenek Ernst 112, 115, 175

Kretzschmar Hermann 33, 171, 221,

251, 264, 300, 469

Kromalicki 154

Kroyer Theodor 33, 179, 180

Kruziński Wincenty 23

Kryński Adam 118

Krzyżanowski Ignacy 35

Krzyżanowski Julian 371

Kudryk Borys 203, 208, 210

Kulczycki Faustyn 176, 327, 328

Kulczyński Stanisław 362, 368

Kułakowski Lew 383

Kurdybacha Łukasz 289

Kurpiński Karol 15-18, 22, 214, $215,285,288,341,468,469,517$

Kurth Ernst 206, 279, 280, 456

Kuryluk Karol 387
Kwaśnik Stanisław 136, 138, 374

Kwiek Marek 223, 224, 227, 228, $283,320,341,353,354,360,375$

L

Lach Robert 232, 298

Lachowicz Stanisław 366

Laks Szymon 85

Lanckorońska Karolina 166

Landowska Wanda 84, 87, 154

La Rue Pierre de 180

Laskiewicz Alfred 223

Lasocki Józef 375, 414

Lasso Orlando di 141, 180

Latoszewski Zygmunt 53, 76, 77, 227, 370, 500

Le Brun Tomasz 22

Lehr-Spławiński Tadeusz 369, 371

Leichtentritt Hugo 114, 140, 160, $274,275,284,318,421,462,472$

Lenartowicz Teofil 24

Lenormand René 280

Leopolita Marcin 132, 197, 212, 274, 277

Leszczyńska Agnieszka 346

Liban Jerzy 143, 219

Liebeskind Marceli 215

Liebhart (Liebhardt) Zbigniew 208, 362-365, 397, 479

Ligęza Józef 374

Lilius Franciszek 142

Lipiński Karol 214

Liske Franciszek Ksawery 166

Lissa Zofia 11, 43, 47, 66, 67, 81, $82,105,106,109,116,169,171$, $177,178,181,191-197,206-210$, $219,246,255,271,274,278-280$, 291, 315, 316, 320, 321, 329, 331, 352-355, 358-361, 363, 364, 368-372, 375, 376, 378, 381, 386, $388,389,394,396-399,401$, 403-406, 409, 411, 412, 414-420, 
$423-428,430-433,435,438,440$, 443, 446, 447, 450, 454-457, 472, 474, 475, 477-483, 490-492, 494, 496, 498, 499, 501, 503-505, 507, 511-515, 519

Liszt Franciszek 20, 24, 28, 30, 33 , $185,205,253,259,284,311,320$, 329

Loewenbach (Löwenbach) Jan 117

Loewenbach (Löwenbach) Josef 117

Loth August Karol 88

Lucian of Samosata 220

Ludkewycz Stanisław 204, 210

Lutosławski Witold 335, 391, 395 , 478, 498, 504, 505

Łabuński Feliks 96, 327

Łada Kazimierz 22, 244, 287

Łada Olga 440

Ładosz Henryk 349

Łańcucki Erazm 191, 207, 352

Ławrowski Jan 203

Łazarski Zygmunt 155, 163

Łobaczewska (Gerard de Festenburg)

Stefania $10,26,29,33,42,63,66$, 67, 70, 72, 75, 82, 105-109, 112, $116,119,124,127,129,134,171$, $174,177,178,189-195,206,207$, 209, 210, 230, 246, 255, 262, 263, 265, 271, 278-280, 291, 315, 320, $321,329,349,351,352,355,366$, 369-371, 373, 376-378, 380, 381, $388,389,393,394,396-398,401$, 405, 407-411, 420, 426, 428, 429, $440,442,447,455,457,458,469$, 472, 479-482, 488, 491, 492, 494, 501, 505, 507-511, 515

Łubkowski Mieczysław 79

\section{M}

Mackrott (Macrott, Makrott)

Henryk 306

Madaj Katarzyna 174, 175
Mahler Gustav 28, 30, 175

Majchrzak Józef 363

Majewski Tadeusz 66

Maklakiewicz Jan Adam 85, 95, 107, $176,234,269,319,327,478$

Malawski Artur 349

Malinowski Władysław 385, 386, 393

Maliszewski Witold 79, 82, 88, 231

Małachowski-Łempicki Stanisław 305, 306

Manojlović Kosta P. 293, 312

Manteuffel Edward 321, 429

Marcks J.F. 450

Marczewski Lucjan 35

Marek Czesław 294, 297, 298

Marek Tadeusz 498, 501, 502, 504

Martienssen Franziska 303

Marx Adolph Bernhard 19

Marx Karl 387

Marynowycz Jarosław 203

Masson Paul-Marie 502

Maszyński Piotr 41, 43, 118

Matusiak Szymon 138

Maxylewicz Wincenty 281

Mayzel Maurycy 79

Melcer Henryk 25, 29, 63, 86, 88, 95, 290

Mendelssohn-Bartholdy Felix 29, 33, 174

Mersmann Hans 175, 279, 280

Meyer Ernst H. 511

Mianowski Józef 17, 39, 69, 89, 368

Miazga Tadeusz 357

Michajłow Włodzimierz 435

Michalski Stanisław 59, 89, 96, 298

Michałowska Maria 379, 383

Michałowski Aleksander 118, 119

Michałowski Józef M. 374

Michałowski Kornel 44, 69, 72, 73, $111,113,122,123,138,139,141$, 
$145,222,224,243,270,292,321$, $354,357,492,511$

Michniewicz Grażyna 78

Miciński Bolesław 452

Mickiewicz Adam 81, 386, 447, 500, 515

Mielczewski Marcin 91, 92, 94, 140, 156, 218, 272, 281, 489, 492

Mierczyński Stanisław 319, 469, 499

Migot Georges 96

Miketta Janusz 51, 84, 88, 94, 96, $174,233,290,300,302,303,305$, $316,351,373,376,377,379,409$, 421, 442, 444, 447, 461-464, 479, 492, 503, 507, 508, 513

Mikołaj of Kraków (N.C., Nicolaus Cracoviensis) 28

Mikołaj of Radom (Radomski) 40, 141, 163, 198-200, 273, 340, 438, $449,460,482$

Mikuli Karol 170

Milhaud Darius 280

Mill John Stuart 440

Minasowicz Józef Dionizy/

Dyonizy 16

Mirska Maria 311

Mitscha Adam 104, 370

Młynarski Emil 44, 63, 78, 79, 82, $118,122,174$

Mochnacki Maurycy 17, 19

Mollé Wojsław 370

Moniuszko Aleksandra 28, 103, 281

Moniuszko Stanisław 20, 28, 30, 35, $37,50,77,78,95,103,116,125$, $142,143,198,213,275,281,284$, $307,366,386,414,416,430,447$, $466,478,497,511$

Morawska Katarzyna 198, 240-245, 469, 470, 489, 519

Morawski Eugeniusz 79, 122, 231

Morawski Kazimierz 216

Moszyński Kazimierz 233
Mottl Feliks 41

Mozart Franz Xaver Wolfgang 170

Mozart Wolfgang Amadeus 23, 170, 211, 303, 329, 374, 467

Mrygoń Adam 229, 294, 295

Muchanow Sergiusz 35

Münchheimer Adam 35

Münzer Leopold 66

Murdoch William 339

Mussorgsky Modest 375

Muszkalska Bożena 186, 199, 222, 223, 276

Mycielski Zygmunt 10, 327, 334, $349,378,379,383,388,389,397$, 401-403, 426, 429, 478, 501, 505

Mydlarski Jan 371

$\mathbf{N}$

N.C. see Mikołaj of Kraków

Nawroczyński Bogdan 435

Nef Karl 299

Nejedlý Zdeněk $68,69,117$, 204, 400

Neuhauser Franciszek 104

Neumark Ignacy 32

Neuteich Marian 332, 405

Niecks Frederick (Friedrich) 78, 284, 472

Niemcewicz Julian Ursyn 16

Niementowska Anna 171

Nietzsche Friedrich 213

Niewiadomski Stanisław 56, 57, 60, $78,79,81,82,103,116,118,119$, $175,176,214,253$

Nikisch Artur 110

Nitsch Kazimierz 233, 369, 435

Noskowski Zygmunt 23, 24, 43, 286

Nowacki Henryk 145, 316

Nowak-Romanowicz Alina 211, 220, 370, 397, 505, 507

Nowowiejski Feliks 95, 115

Nyzankivskij Nestor 203 
O

Obniska Ewa 346

Obrochta Bartłomiej (Bartuś) 133

Ochlewski Tadeusz 11, 59, 60, 84-89, 91, 93, 95-98, 100, 155, $163,210,300,301,327,345,350$, $351,372,377,379,382,410,411$, $415,417,419,421-423,426,428$, 430, 432, 434, 439-441, 444, 477, 478, 480, 481, 489, 491-493, 501-503, 506

Odrowąż-Pieniążek

Przemysław 303

Ogiński Michał Kleofas 214, 220, 224

Olcha Jan see Rutkowski Bronisław

Opieński Henryk 9, 15, 17, 25-27, $29,31,33-40,42-45,49,63,68$, $71,72,79,81,83,93,95,103$, $104,116,118,119,125,130-139$, 142-144, 151-153, 156, 161, 175, $176,180,188,189,200,208,221$, $229,255,262,272,275,283-286$, 294, 316-318, 327, 328, 331, 333, $335,339,341,352,419,423,469$, $470,517,518$

Orel Alfred 232

Orłowski W. 33

Orzech Wojciech 145

Orzeszkowa Eliza 24

Ossowska Maria 239

Ossowski Stanisław 239

Osthoff Helmuth 318

Ostrowska Ewa 197

$\mathbf{P}$

Pachelbel Johann 481

Paderewski Ignacy Jan 24, 29, 42, $81,83,116,118,119,213,284$, 294, 304, 310, 375, 410, 512, 513

Padlewski Roman 223
Palester Roman 10, 96, 294, 296, 297, 327, 350, 373, 377, 395, 476, 478

Palestrina Giovanni Pierluigi da 24, 104, 116, 135, 197

Pałubicki Konrad 223, 226

Panieńska Teresa 41

Pankiewicz Eugeniusz 41, 95, 214

Panufnik Andrzej 334, 391, 478

Patkowski Aleksander 341

Patkowski Józef 361, 511

Paulus Paulirinus of Prague (Pavel Žídek) 219

Paygert-Świeżawska Helena 190

Pepping Ernst 205, 340, 465

Pereświet-Sołtan Stanisław 118

Pereyra Marie-Louise 160

Pergolesi Giovanni Battista 329

Perkowski Piotr 85, 95, 101, 395

Perotinus Magnus (Pérotin) 205, 277, 340

Perz Mirosław 357

Pękiel Bartłomiej 94, 95, 112, 134, 163, 196, 197, 207, 245, 273, 274, 489

Pietruszyńska-Sobieska Jadwiga 223, 226-228, 327, 352, 369, 370, 375, 397, 492, 499

Pigła Włodzimierz 145

Pigoń Stanisław 81

Piłsudski Józef 79, 122

Piotrowski Michał Julian 33

Piotrowski Wacław 33, 70, 72, 153, 209, 222, 223

Pirro André 86

Plamenac Dragan 293, 312

Pleuss-Turczynowicz Maria see Turczynowicz Maria

Podoska-Palester Barbara 349

Pogonowski Jerzy 374, 476

Pohorylesowa Zofia 104

Polak Jakub 32 
Poliński Aleksander 21, 23, 41, $43,133,240,245,254,262,273$, 281, 285

Poniatowska Irena 240, 244, 245

Poniatowski Stanislaus Augustus 281

Poraj-Różycka Stefania 62, 63

Porębowiczowa Anna 26

Pośpiech Remigiusz 145

Poulenc Francis 295

Powroźniak Józef 500

Pozdniewa Olga 498

Poźniak Włodzimierz 10, 23 24, $175,211,212,214,215,220,342$, $351,352,366,369,370,375,380$, 397, 399, 430, 447, 450, 465, 466, 479

Prokofiev Sergei 115, 295

Prosnak Jan 352, 376, 397, 414, 438, 467, 468, 469, 479, 480, 492, 500, 505, 507, 510, 511

Prüfer Artur 110

Prus Bolesław 24

Przybylski Henryk 448

Przybylski Tadeusz 16, 43, 210, 211 Przybyszewska-Jarmińska

Barbara 212, 257, 346

Przybyszewski Stanisław 118

Przystański Stanisław 21

Puccini Giacomo 32

Pulikowski Julian (T.K.) 76, 81, $83,96,101,146,147,208,209$, 214, 220, 225, 230-239, 260, 261, 266, 267, 298, 316-318, 327, 328, $341,342,345,352,376,399,447$, 467, 502

Putrament Jerzy 358

Pyrszyński Kasper 207, 341

$\mathbf{R}$

Rachmaninoff Sergei 115 Raczkowski Władysław 95
Raczyński Bolesław 181

Rajchman Aleksander 23-25, 517

Ramert Maria 191, 207

Ravel Maurice 115, 295

Régamey Konstanty (Constantin) 10, 83, 101, 327, $331,332,334,335,370,379,380$, 397, 447, 452-454, 478, 481

Reger Max 28, 33, 110, 253

Reinach Théodore 318

Reiss Józef 26, 29-31, 33, 47, 71, 72, 104-106, 116, 126, 132, 138, 142, $143,153,171,175,180,189,211$, $213,215,219,220,234,239,250$, $251,255,257,262,272,342,352$, $363,365,366,368-370,374,375$, $397,479,503$

Reszke Jan 461

Réti Rudolf 61

Rieger Adam 369, 370, 377, 397

Riemann Hugo 33, 42, 44, 45, 110 , 130, 143, 204, 241, 264, 274, 277, 280, 284, 299, 318, 456

Roger Juliusz 214

Rogowski Ludomir Michał 63

Rolland Romain 119

Romaniszyn Bronisław 10, 205, 210, 300, 302, 303, 316, 350, 420, 447, 461, 499, 503

Ronsard Pierre de 285

Rosenzweig Józef 42

Rossini Gioacchino 212, 310, 510

Rossowski Stanisław 284

Różycka Stefania, see Poraj-Różycka Stefania

Różycki Jacek (Hyacinthus) 28, 94, 95, 372, 446

Różycki Ludomir 29, 44, 62, 116, 118, 182, 225, 290, 416

Rudnicka Hanna 227

Rudnicki Edmund 349, 433

Rudzińska-Kruszewska Hanna 223 
Rudziński Witold 352, 375, 376, 388, 389, 397, 398, 409, 414, 428, 443, 487, 498, 501, 505, 511

Rutkowski Bronisław (Jan Olcha) 51-53, 79, 80, 84-88, 91, 93-98, 100, 146, 155, 156, 161-164, $220,282,312,324,325,327,328$, $331,337,338,343,345,375,376$, $378,379,416,419,422,429,469$, 499, 503

Rydzewski Henryk 234-237

Ryszkiewicz Andrzej 476, 477

Rytel Piotr 32, 50, 51, 54, 85, 86, 296, 373, 469, 478, 503

Rzanna-Szczepaniak Ewa 386, 387, 394, 395, 403

$S$

Sachs Curt 114, 154

Sadkowski Aleksander 344

Sand George 424, 466

Sandberger Adolf 33, 34, 179, 180

Sarnecki Konstanty 17, 39

Scacchi Marco 197, 271, 273

Schaff Adam 360, 389

Schäffer Bogusław 366

Schenker Heinrich 280

Schering Arnold 110, 274, 456, 465

Schiedermeier Ludwig 180

Schiller Leon 85, 499

Schloezer Boris von 154

Schmitz Franz Arnold 465

Schnoor Hans 274

Schönberg Arnold 107, 114, 134, 174, 274, 280, 297, 317, 330

Schopenhauer Arthur 42, 189, 191, 255

Schreker Franz 154, 175

Schreyer Johannes 280

Schubart Christian Friedrich

Daniel 318
Schubert Franz Peter 29, 116, 321, 479

Schumann Robert Alexander 23, 284, 309-311

Scriabin Alexander 106, 116, 193, 207, 280, 296, 315

Sebastian of Felsztyn 140, 161, 192, 278, 279, 281

Seiffert Max 273

Seklucjan Jan 262

Serocki Kazimierz 500

Serwaczyński Stanisław 306

Shaw George Bernard 503

Shostakovich Dmitri 499

Sienkiewicz Henryk 24

Sierakowski Sebastian 341

Sikorski Józef 17, 19, 20-22, 34, 35, $243,62,313,341,378,437,517$

Sikorski Kazimierz 51-55, 59, 93-96, 00, 100, 107, 137, 155, 229, 234, 293, 296, 301, 322, 325, 327, $328,337,350,373,396,419,426$, $428,442,452,467,478,515$

Simon Alicja 10, 26, 33, 41, 56, 57, $60,71,72,114,116,143,154,175$, $200,341,355,364,370,397-399$, 469-471, 479, 492

Sitowski Zygmunt 223, 227

Sivert Tadeusz 511

Skałkowski Adam 435

Skierkowski Władysław 133, 300, 304, 305, 317-319, 341

Skoczek Józef 289

Skoczylas Władysław 122

Skolimowski Mieczysław 41

Skowron Zbigniew 246

Slipyj Josip 204

Słowacki Juliusz 386

Smetana Bedřich 117, 207

Smijers Albert 169, 274

Sobieski Marian 10, 223, 227, 228, 352-354, 359, 361, 369-372, 375, 
$376,397,398,410,426,447,465$, $469,476,492,510$

Sokorski Jerzy 387, 409, 414, 415

Sokorski Włodzimierz 378, 387, 391, 392, 396-398, 401-404, 414, 437, 439

Solczanyk Wołodymyr 204

Solski Leon 176

Sołtys Adam 66, 70-72, 104, 109, $116,127,170,175,177,178,210$, 269, 420

Sołtys Maria Ewa 170

Sołtys Mieczysław 170, 196, 204

Sontag Henrietta 505

Sopoćko Konstanty 382

Sosnowska Joanna 412

Sowiński Wojciech 242, 254

Sperontes (Johann Sigismund Scholze) 41, 143, 469

Spiegel Irena 208

Spiess Stefan 373

Spisak Michał 478

Spodenkiewicz Wiktor 366

Stachowicz P. Damian 95

Stalin Joseph 395, 507

Stanislaus Saint 134

Starczewski Feliks 156, 238, 272, 286, 287, 294, 306, 314, 316, 331, 374,437

Starzyński Juliusz 389, 406-409, $412,413,500,512$

Statkowski Roman 35, 37, 86, 95, 109,510

Stefani Jan 21, 23

Stefani Józef 19, 20

Stefko Kamil 368

Stein Erwin 105

Steinhaus Hugo 166, 368

Stelmachowska Bożena 223

Stempniewicz Mirosława 137

Stevich F. 22

Stęszewski Jan 222, 357
Stieber Zdzisław 233

Stoepel François-DavidChristophe 287

Stoiński Stefan Marian 53, 140, 200, 373, 374

Stolpe Antoni 214, 283

Strauss Richard 30, 115, 174, 179, 253, 333

Stravinsky Igor 115, 174, 175, 295, 296, 330

Stromenger Karol 49, 56, 57, 59, 60, $74,79,80,116,162,201,239,260$, 300, 301, 375, 469, 471, 503

Strumiłło Dobrochna 16, 18

Strumiłło Tadeusz 357, 366, 382, 493, 494, 505, 507

Stumpf Karl 171, 300

Styś Wincenty 368

Suchodolski Bogdan 307

Surzyński Józef 35, 40, 43, 141, 245, 254, 257, 262, 274, 399

Surzyński Mieczysław 35, 43, 86, 109

Swaryczewska Katarzyna, see Morawska Katarzyna

Swatoń Józef 374, 379, 476

Sweelinck Jan Pieterszoon 321

Swolkień Henryk 375, 379

Sychra Antonín 474

Sydow Bronisław Edward 10, 368, 424, 466, 467, 471, 477, 513

Sygietyński Antoni 286

Szabolcsi Benedict 312

Szałowski Antoni 332, 478

Szamotulczyk see Wacław of Szamotuły

Szarlitt Bernard 118

Szarzyński Stanisław Sylwester 91, 92, 94, 95, 489

Szczepańska Maria 68, 70-72, 74, $76,94,95,106,109,116,133$, $134,138,140,141,156,162,163$, 
$169,172,185,187,191,195,196$, 198-201, 207, 209, 210, 212, 270-273, 275, 277, 316-318, 339-341, 352, 354, 369-371, 374, $397,420,424,438,440,449,460$, $479,482,492,494$

Szczepańska-Lange Elżbieta 19, 313

Szczurowski Jacek 207, 341

Szeligowski Tadeusz 66, 95, 101, $118,328,331,351,395,397,478$

Szeluto Apolinary 44, 333

Szembek, family 122

Szmar Adam 66

Szopowicz Henryk 287

Szopski Felicjan 35, 37-39, 42, $52,63,64,88,93,111,116,161$, 179,333

Szpinalski Stanisław 512, 515

Szujski Józef 64

Szuman Stefan 147, 369, 370, 409, 447, 472, 481

Szweykowski Zygmunt M. 354, 357, 366, 505

Szyfers Tomasz 176

Szymanowski Karol 29-31, 44, 52, 61-64, 78, 79, 82, 94, 95, 112, 115, $116,122,128,143,171,175,176$, $182,185,192-195,198,205,208$, 209, 214, 234, 260, 269, 273, 282, 283, 292-295, 304, 310, 315, 316, $319,328,330-332,334,335,340$, $343,345,355,356,360,366,373$, $374,378,380-382,392,393,411$, 420, 421, 440, 446, 457-459, 470, 492, 298, 503, 510, 511

Szymanowski Wacław 119

Śledziński (Śledziński-Lidzki)

Stefan 47, 75, 89, 107, 211, 219, 220, 221, 230, 231, 234-238, 342, $368,370,375,397,500,505$

Śliwiński Józef 85

Świerc Piotr 214
Świeży Władysław 108, 109

Świętosławski Wojciech 168

T

T.K. see Pulikowski Julian

Tacina Jan 47, 218

Tarnowski Stanisław 46

Tartini Giuseppe 269

Tatarkiewicz Władysław 370

Tchaikovsky Pyotr 24, 32

Thun, family 470

Thun-Hohenstein, sisters 471

Tiersot Julien 321

Tołoszniak Natalia 203

Tołwiński Gabriel 156, 228, 234-236, 272, 300-302, 320

Tomaszewski Henryk 501

Tomaszewski Mieczysław 101

Töpfer Wacław 109

Trombini-Kazuro Margerita 88

Tuilly Ludwig 179

Turczynowicz Maria 223, 226, 492

Turczyński Józef 81, 310, 410, 503, 512

Turowicz Jerzy 377

Turski Zbigniew 379, 391

Tuwim Julian 496

Twardowski Kazimierz 166, 193

Tyszkiewicz, family 122

Tyszkowski Kazimierz 341

U

Ugrewicz Adam 362, 363

Urbański Janusz 409

V

Verdi Giuseppe 212

Vidal Paul 294

Vierne Louis 86

Vìtols Jāzeps 312, 317, 319

Voisé Waldemar 379, 440

Volkmann Hans 339

Vomáčka Boleslav 114 


\section{W}

Wacław of Szamotuły 95, 140, 245, 281, 376, 382, 447-449

Wagner Peter 34, 68, 196, 308

Wagner Wilhelm Richard 20, 24, $30,31,33,112,142,173,181,203$, 206, 212, 255, 257, 514

Waldorff Jerzy 114, 334

Walijewski Szymon 107

Wallek-Walewski Bolesław 181, 196

Wański Jan 285

Ważyk Adam 358

Weber Carl Maria von 288, 289

Weinmann Karl 258

Weissmann Adolf 127

Wellesz Egon 61, 114, 146

Wertheim Piotr 39

Wesołowski Franciszek 375

Wędkiewicz Stanisław 237

Węsławski Stanisław 328

Wiechowicz Stanisław 51, 53, 101, 136-138, 229, 328, 331, 349, 377, 395

Wieczorek Antoni 215

Wieczorek Sławomir 358, 409, 417, 455, 456, 475

Wielhorski Aleksander 32

Wieniawski Adam 50, 51, 53-55, $79,82,116,121,122,349$

Wieniawski Henryk 104, 214, 375

Wieniawski Józef 20, 23, 25

Wihtol Joseph, see Vītols Jāzeps

Wilkowska (Wilkowska-Chomińska)

Krystyna 361, 438, 447, 472,

477, 479, 481, 482, 489, 507, 509,

511,515

Willaert Adrian 180

Wilusz Jan 41

Wiłkomirski Kazimierz 85, 335, 361, 395, 500

Windakiewiczowa Helena 48, 71, 72, 208, 209, 275, 300, 303, 304,
$317,318,341,369,370,397$, 476, 492

Winowicz Krystyna 73

Wiślicki Władysław 34

Witkiewicz Stanisław Ignacy 452

Witkowska-Zaremba

Elżbieta 193, 519

Witkowski Leon 397

Włodarczyk Wojciech 394

Wodzicki Ludwik 46

Wojciechowski Tadeusz 166

Wojciechowski Zygmunt 368

Wolf Hugo 173

Wolf Johannes 33, 34, 114, 171, 221, 300, 469

Wolff August Robert 116, 263

Woronczak Jerzy 197

Woronicz Jan Paweł 240

Woytowicz Bolesław 10, 87, 332, 351, 373, 391, 395, 397, 409, 478

Wozaczyńska Antonina 208

Woźna-Stankiewicz

Małgorzata 24, 218

Woźniakowska Anna 302

Wójcik-Keuprulian (Wójcikówna) Bronisława 41, 70-72, 79, 81-83, $104,106,108,116,119,130,134$, $135,141,145,153,155,164,172$, 183-190, 195, 196, 198, 207, 209, $211,213,214,220,222,226,228$, 234, 238, 239, 253, 254, 262, 263, 265-267, 271, 275, 276, 313, 316, $317,319,342,452,462,463$

Wóycicki Kazimierz 307

Wrona Grażyna 108

Wysocki Stanisław 274

Z

Zaborski Bogdan 237

Zagiba Franz (Franciszek, František) 438, 467, 473 
Zahorowski Władysław 118 Zaleski August 78, 81

Zalewski, family 85

Zalewska Elżbieta 39

Zalewski Maciej 501

Zalewski Teodor 51, 84-86, 88, 91-93, 95-98, 100, 155, 157, 228, 294, 298, 300, 301, 322, 327, 328, $334,344,345,419$

Zamoyski Maurycy Klemens 17, 39

Zarębski Juliusz 24, 375

Zarzycki Aleksander 35

Zawiłowski Konrad 33, 180

Zawistowski Władysław 79

Zborowski Juliusz 369
Zetowski Stanisław 224, 225, 288, 289, 465

Zieleński Mikołaj 94, 95, 112, 200, 245, 247, 340, 341, 489, 493

Zieliński Kazimierz 70, 72, 145, 223

Zieliński Zygmunt 145

Zmigryder Stanisław 50

Znaniecki Florian 195

Żakiej Tadeusz see Marek Tadeusz

Żeleński Władysław 23, 24, 116, 176, 210, 214, 375, 416

Żongołłowicz Bronisław 231

Żółkiewski Stefan 388

Żółkowski Alojzy 16

Żurawlew Jerzy 82 



\title{
Eastern European Studies in Musicology
}

\author{
Edited by Maciej Gołąb
}

Vol. 1 Paweł Gancarczyk / Lenka Hlávková-Mráčková / Remigiusz Pośpiech (eds.): The Musical Culture of Silesia before 1742. New Contexts - New Perspectives. 2013.

Vol. 2 Laura Vasiliu/Florin Luchian/Loredana Iaţeşen/Diana-Beatrice Andron (eds.): Musical Romania and the Neighbouring Cultures. Traditions-Influences-Identities. Proceedings of the International Musicological Conference July 4-7, 2013, Iaşi (Romania). 2014.

Vol. 3 Barbara Przybyszewska-Jarmińska: Marcin Mielczewski and Music under the Patronage of the Polish Vasas. Translated by John Comber. 2014.

Vol. 4 Tomasz Jasiński: The Musical Rhetoric of the Polish Baroque. Translated by Wojciech Bońkowski. 2015.

Vol. 5 Bogusław Raba: Between Romanticism and Modernism. Ignacy Jan Paderewski's Compositional CEuvre. Translated by John Comber. 2015.

Vol. 6 Maciej Gołąb: Musical Modernism in the Twentieth Century. Translated by Wojciech Bońkowski. 2015.

Vol. 7 Wojciech Bońkowski: Editions of Chopin's Works in the Nineteenth Century. Aspects of Reception History. 2016.

Vol. 8 Ivana Perković / Franco Fabbri (eds.): Musical Identities and European Perspective. An Interdisciplinary Approach. 2017.

Vol. 9 Bożena Muszkalska (ed.): The Kolbergs of Eastern Europe. 2018.

Vol. 10 Renata Tańczuk / Sławomir Wieczorek (eds.): Sounds of War and Peace. Soundscapes of European Cities in 1945. 2018.

Vol. 11 Tomasz Jeż: The Musical Culture of the Jesuits in Silesia and the Kłodzko County (15811776). 2019.

Vol. 12 Magdalena Walter-Mazur: Musical Culture of Polish Benedictine Nuns in the 17th and 18th Centuries. 2018.

Vol. 13 Danuta Popinigis: Carillons and Carillon Music in Old Gdańsk. 2019

Vol. 14 Andrzej Tuchowski: Nationalism, Chauvinism and Racism as Reflected in European Musical Thought and in Compositions from the Interwar Period. 2019.

Vol. 15 Ludwik Bielawski: Time in Music and Culture. 2019.

Vol. 16 Barbara Literska: Nineteenth-Century Transcriptions of Works by Fryderyk Chopin. Translated by John Comber. 2019

Vol. 17 Barbara Literska: Tadeusz Baird. The Composer, His Work, and Its Reception. 2019

Vol. 18 Slawomir Wieczorek: On the Music Front. Socialist-Realist Discourse on Music in Poland, 1948 to 1955.2020

Vol. 19 Alicja Jarzębska: Strawinski - Thoughts and Music. 2020

Vol. 20 Małgorzata Sieradz: The Beginnings of Polish Musicology. Translated by Lindsay Davidson. 2020.

www.peterlang.com 
